DOC.20050809.0002

QA: QA

ANL-NBS-MD-000001 REV 04

August 2005

\title{
Features, Events, and Processes in UZ Flow and Transport
}

Prepared for:

U.S. Department of Energy

Office of Civilian Radioactive Waste Management

Office of Repository Development

1551 Hillshire Drive

Las Vegas, Nevada 89134-6321

Prepared by:

Bechtel SAIC Company, LLC

1180 Town Center Drive

Las Vegas, Nevada 89144

Under Contract Number

DE-AC28-01RW12101 


\section{DISCLAIMER}

This report was prepared as an account of work sponsored by an agency of the United States Government. Neither the United States Government nor any agency thereof, nor any of their employees, nor any of their contractors, subcontractors or their employees, makes any warranty, express or implied, or assumes any legal liability or responsibility for the accuracy, completeness, or any third party's use or the results of such use of any information, apparatus, product, or process disclosed, or represents that its use would not infringe privately owned rights. Reference herein to any specific commercial product, process, or service by trade name, trademark, manufacturer, or otherwise, does not necessarily constitute or imply its endorsement, recommendation, or favoring by the United States Government or any agency thereof or its contractors or subcontractors. The views and opinions of authors expressed herein do not necessarily state or reflect those of the United States Government or any agency thereof. 
QA: QA

Features, Events, and Processes in UZ Flow and Transport ANL-NBS-MD-000001 REV 04

August 2005 
BSC

SCIENTLEIC ANalysis Signature PAGEl Change History

\begin{tabular}{|c|c|c|c|}
\hline \multicolumn{4}{|c|}{$\begin{array}{l}\text { 2. Scientific Analysis Title } \\
\text { Fearwes. Evenss. and Processes in UZ Flow and Transport }\end{array}$} \\
\hline \multicolumn{4}{|l|}{ 3. DI (Inaluding Rev. No.) } \\
\hline \multicolumn{4}{|c|}{ ANL-ABS-MD-D00001 REV 04} \\
\hline & & Printed Name & Date \\
\hline 4. Originertor & & P. Persoff & $8 / 3 / 05$ \\
\hline 5. Checker & & C. Heukwa & los \\
\hline 6. QER & & P. Buentisje & $8 / 4 / 05$ \\
\hline 7. Respons/ble Manager/ Le & & lame \& hruelvosef & $8 / 4 / 05$ \\
\hline 8. Responsible Manager & for & thogrthe & $8 / 465$ \\
\hline \multicolumn{4}{|c|}{$\begin{array}{l}\text { 9. Remarks } \\
\text { G.X. Zhang and I.E. Houseworth contribunod A.ppendix D. }\end{array}$} \\
\hline \multicolumn{4}{|l|}{ Change Gistory } \\
\hline 10. Revision No. & \multicolumn{3}{|c|}{ 11. Description of Change } \\
\hline REV OO & \multicolumn{3}{|c|}{ Initial Issue } \\
\hline REVO1 & \multicolumn{3}{|c|}{ 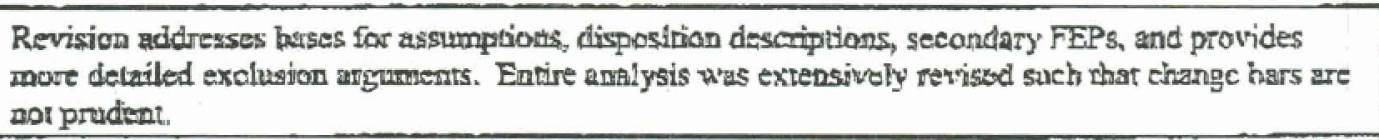 } \\
\hline REV a? & \multicolumn{3}{|c|}{ 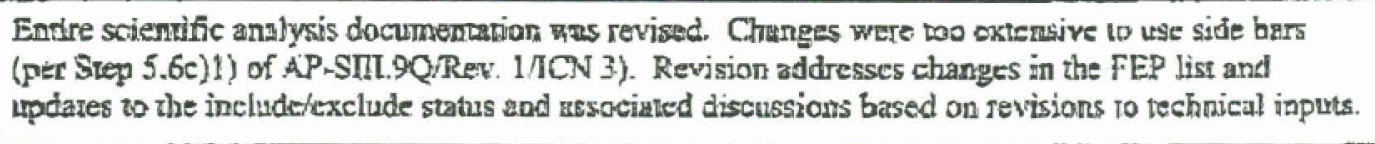 } \\
\hline REV 03 & \multicolumn{3}{|c|}{ 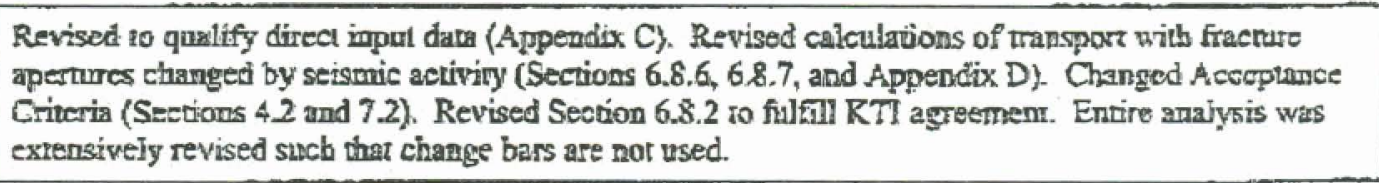 } \\
\hline REV 04 & \multicolumn{3}{|c|}{$\begin{array}{l}\text { Revised to comply with LP.SML } 9 \text { Q-BSC and } 10 \text { minimize reliance upon mountain-scale model. } \\
\text { Adbed Appendix E to documen anaiysis of lateril dispersion of plumes, Clranges in this revision } \\
\text { addtess condition reports } 4615,5600,5757 \text {, and } 5917 \text {. }\end{array}$} \\
\hline
\end{tabular}




\section{INTENTIONALLY LEFT BLANK}




\section{CONTENTS}

ACRONYMS AND ABBREVIATIONS xiii

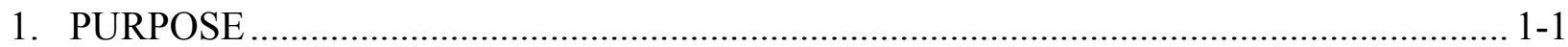

1.1 PLANNING AND DOCUMENTATION …..................................................... 1-1

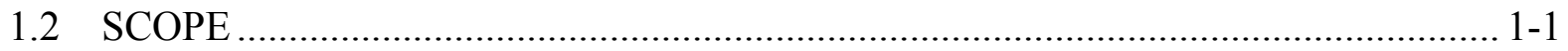

1.3 SCIENTIFIC ANALYSIS AND LIMITATIONS ........................................... 1-5

2. QUALITY ASSURANCE ................................................................................ 2-1

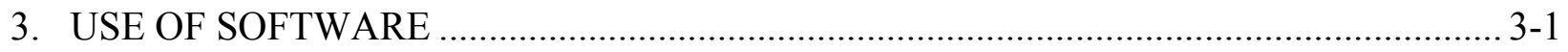

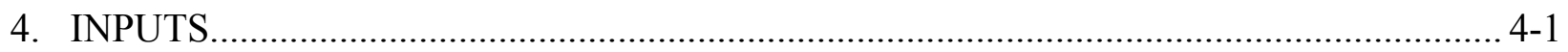

4.1 DIRECT INPUTS .................................................................................... 4-10

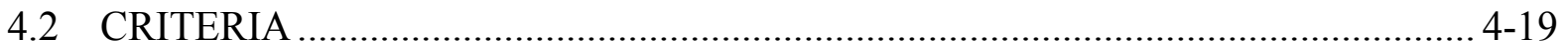

4.2.1 Project Requirements Document ....................................................... 4-20

4.2.2 Yucca Mountain Review Plan ....................................................................... 4-21

4.2.3 FEPs Screening Criteria ......................................................................... 4-22

4.3 CODES, STANDARDS, AND REGULATIONS ............................................. 4-24

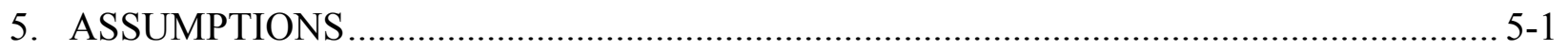

6. SCIENTIFIC ANALYSIS DISCUSSION ................................................................ $6-1$

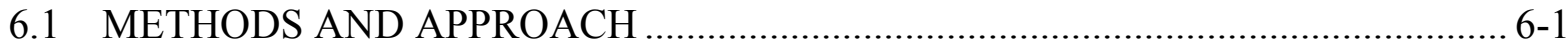

6.1.1 Identification of Features, Events, and Processes........................................... 6-1

6.1.2 Feature, Event, and Process Screening Process .......................................... 6-1

6.1.3 Supporting Reports and Inputs.............................................................. 6-3

6.1.4 Qualification of Unqualified Direct Inputs ............................................. 6-5

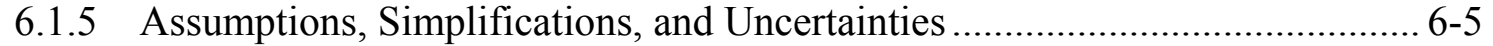

6.1.6 Intended Use and Limitations .............................................................. 6-5

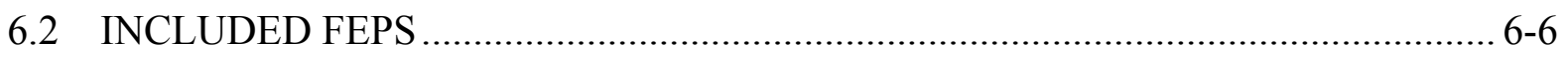

6.2.1 Preclosure Ventilation (1.1.02.02.0A) ....................................................... 6-7

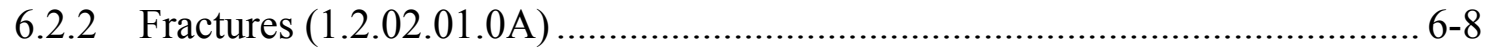

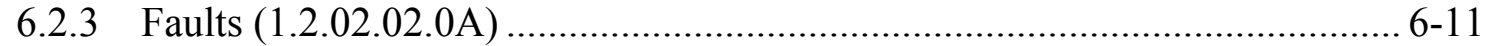

6.2.4 Climate Change (1.3.01.00.0A) .............................................................. 6-12

6.2.5 Water Table Rise Affects UZ (1.3.07.02.0B) ............................................. 6-14

6.2.6 Climate Modification Increases Recharge (1.4.01.01.0A) .......................... 6-15

6.2.7 Water Influx at the Repository (2.1.08.01.0A) ....................................... 6-16

6.2.8 Enhanced Influx at the Repository (2.1.08.02.0A) .................................... 6-18

6.2.9 Mechanical Effects of Excavation and Construction in the Near-Field

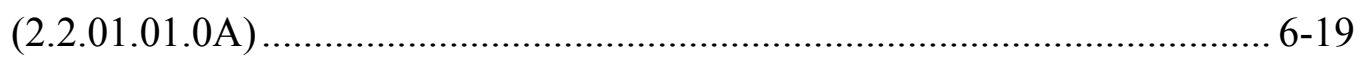

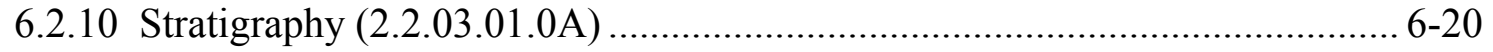

6.2.11 Rock Properties of Host Rock and Other Units (2.2.03.02.0A) ................... 6-22

6.2.12 Locally Saturated Flow at Bedrock/Alluvium Contact (2.2.07.01.0A) ......... 6-24

6.2.13 Unsaturated Groundwater Flow in the Geosphere $(2.2 .07 .02 .0 \mathrm{~A})$............... 6-25 


\section{CONTENTS (Continued)}

6.2.14 Capillary Rise in the UZ (2.2.07.03.0A)..... 6-27

6.2.15 Focusing of Unsaturated Flow (Fingers, Weeps) (2.2.07.04.0A).

6.2.16 Long-Term Release of Radionuclides from the Repository (2.2.07.06.0B) $6-28$

6.2.17 Perched Water Develops (2.2.07.07.0A) 6-29

6.2.18 Fracture Flow in the UZ (2.2.07.08.0A).... 6-30

6.2.19 Matrix Imbibition in the UZ (2.2.07.09.0A) ........................................... 6-32

6.2.20 Condensation Zone Forms around Drifts (2.2.07.10.0A) ............................ 6-34

6.2.21 Resaturation of Geosphere Dry-Out Zone (2.2.07.11.0A) ........................... 6-35

6.2.22 Advection and Dispersion in the UZ (2.2.07.15.0B) ................................. 6-36

6.2.23 Film Flow into the Repository (2.2.07.18.0A) ......................................... 6-36

6.2.24 Lateral Flow from Solitario Canyon Fault Enters Drifts (2.2.07.19.0A)....... 6-37

6.2.25 Flow Diversion around Repository Drifts (2.2.07.20.0A) .......................... 6-37

6.2.26 Chemical Characteristics of Groundwater in the UZ (2.2.08.01.0B) ............ 6-38

6.2.27 Re-dissolution of Precipitates Directs More Corrosive Fluids to Waste Packages (2.2.08.04.0A) .......................................................................... 6-40

6.2.28 Complexation in the UZ (2.2.08.06.0B) ……........................................... 6-40

6.2.29 Matrix Diffusion in the UZ (2.2.08.08.0B) ............................................ 6-42

6.2.30 Sorption in the UZ (2.2.08.09.0B) ...................................................... 6-43

6.2.31 Colloidal Transport in the UZ (2.2.08.10.0B) .......................................... 6-45

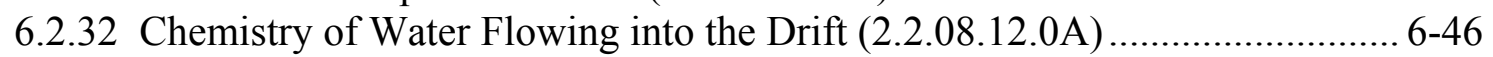

6.2.33 Microbial Activity in the UZ (2.2.09.01.0B) ........................................... 6-49

6.2.34 Natural Geothermal Effects on Flow in the UZ (2.2.10.03.0B) ................... 6-49

6.2.35 Two-Phase Buoyant Flow/Heat Pipes (2.2.10.10.0A) ................................ 6-50

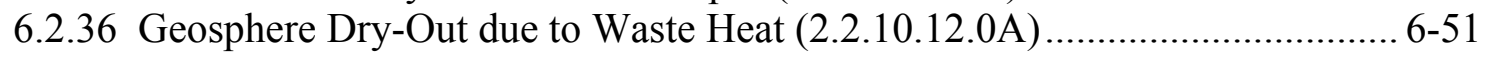

6.2.37 Topography and Morphology (2.3.01.00.0A) ............................................ 6-52

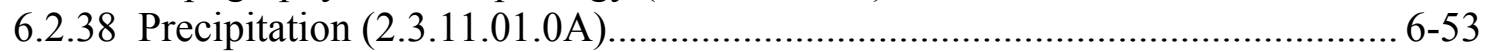

6.2.39 Surface Runoff and Flooding (2.3.11.02.0A) …….................................... 6-54

6.2.40 Infiltration and Recharge (2.3.11.03.0A) .................................................. 6-54

6.2.41 Radioactive Decay and Ingrowth (3.1.01.01.0A) ..................................... 6-55

6.3 BOREHOLE SEALS AND REPOSITORY DRIFT SEALS ………..................... 6-56

6.3.1 Open Site Investigation Boreholes (1.1.01.01.0A) ...................................... 6-57

6.3.2 Influx through Holes Drilled in Drift Wall or Crown (1.1.01.01.0B) ............ 6-60

6.3.3 Site Flooding (During Construction and Operation) (1.1.02.01.0A) ............. 6-61

6.3.4 Incomplete Closure (1.1.04.01.0A)......................................................... 6-61

6.3.5 Monitoring of the Repository (1.1.11.00.0A) .............................................. 6-62

6.3.6 Flow through Seals (Access Ramps and Ventilation Shafts)

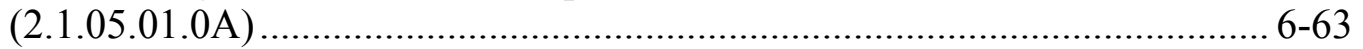

6.3.7 Radionuclide Transport through Seals $(2.1 .05 .02 .0 \mathrm{~A})$................................. 6-64

6.3.8 Degradation of Seals (2.1.05.03.0A) .......................................................... 6-65

6.4 EXTREME CLIMATE/ALTERNATIVE FLOW PROCESSES................................ 6-65

6.4.1 Periglacial Effects (1.3.04.00.0A)........................................................ 6-66

6.4.2 Glacial and Ice Sheet Effect (1.3.05.00.0A) ……..................................... 6-67

6.4.3 Water Table Decline (1.3.07.01.0A) ........................................................ 6-67 


\section{CONTENTS (Continued)}

6.4.4 Transport of Particles Larger Than Colloids in the UZ (2.1.09.21.0C).......... 6-68

6.4.5 Flow in the UZ from Episodic Infiltration (2.2.07.05.0A) ......................... 6-69

6.4.6 Episodic or Pulse Release from Repository (2.2.07.06.0A) .......................... 6-70

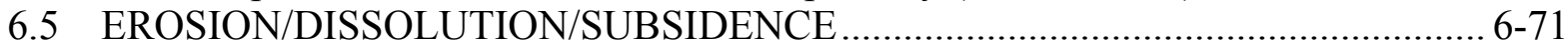

6.5.1 Erosion/Denudation (1.2.07.01.0A) .......................................................... 6-71

6.5.2 Deposition (1.2.07.02.0A) .................................................................. 6-72

6.5.3 Large-Scale Dissolution (1.2.09.02.0A) ………....................................... 6-73

6.5.4 Effects of Subsidence (2.2.06.04.0A) …………....................................... 6-73

6.6 HUMAN INFLUENCES ON CLIMATE AND SOIL ............................................ 6-74

6.6.1 Human Influences on Climate (1.4.01.00.0A) ........................................... 6-75

6.6.2 Greenhouse Gas Effects (1.4.01.02.0A) ………....................................... 6-76

6.6.3 Acid Rain (1.4.01.03.0A) .................................................................... 6-77

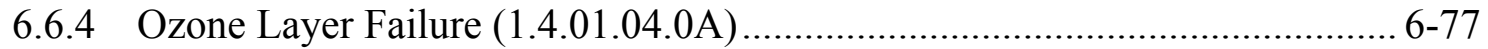

6.6.5 Altered Soil or Surface Water Chemistry (1.4.06.01.0A)............................. 6-77

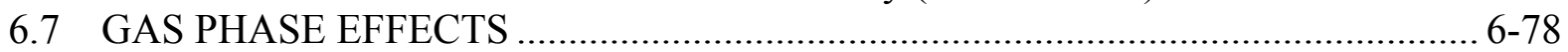

6.7.1 Natural Air Flow in the UZ (2.2.10.11.0A) .............................................. 6-78

6.7.2 Gas Effects in the UZ (2.2.11.02.0A) ……............................................. 6-79

6.7.3 Gas Transport in Geosphere (2.2.11.03.0A) ………………………….... 6-80

6.8 SEISMIC/IGNEOUS/ROCK CHARACTERISTICS ............................................ 6-81

6.8.1 Igneous Activity Changes Rock Properties (1.2.04.02.0A) .......................... 6-82

6.8.2 Hydrothermal Activity (1.2.06.00.0A) ……….......................................... 6-83

6.8.3 Hydrologic Response to Seismic Activity (1.2.10.01.0A)............................. 6-85

6.8.4 Hydrologic Response to Igneous Activity (1.2.10.02.0A)............................ 6-88

6.8.5 Seismic Activity Changes Porosity and Permeability of Rock

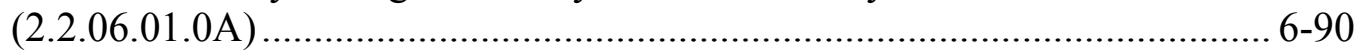

6.8.6 Seismic Activity Changes Porosity and Permeability of Faults $(2.2 .06 .02 .0 \mathrm{~A})$...................................................................................... 6-90

6.8.7 Seismic Activity Changes Porosity and Permeability of Fractures

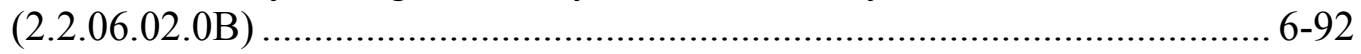

6.8.8 Seismic Activity Alters Perched Water Zones (2.2.06.03.0A) ....................... 6-94

6.8.9 Undetected Features in the UZ (2.2.12.00.0A) ……................................... 6-95

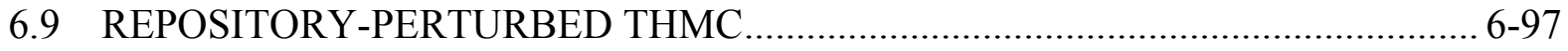

6.9.1 Rind (Chemically Altered Zone) Forms in the Near-Field (2.1.09.12.0A) .... 6-98

6.9.2 Chemical Effects of Excavation and Construction in the Near-Field (2.2.01.01.0B)

6.9.3 Thermally Induced Stress Changes in the Near-Field (2.2.01.02.0A)......... 6-100

6.9.4 Changes in Fluid Saturations in the Excavation Disturbed Zone (2.2.01.03.0A)

6.9.5 Radionuclide Solubility in the Excavation Disturbed Zone (2.2.01.04.0A)

6.9.6 Radionuclide Transport in the Excavation Disturbed Zone (2.2.01.05.0A)

6.9.7 Geochemical Interactions and Evolution in the UZ (2.2.08.03.0B) ............ 6-104

6.9.8 Radionuclide Solubility Limits in the UZ (2.2.08.07.0B) …...................... 6-107 


\section{CONTENTS (Continued)}

Page

6.9.9 Repository-Induced Thermal Effects on Flow in the UZ (2.2.10.01.0A) _.... 6-108

6.9.10 Thermo-Mechanical Stresses Alter Characteristics of Fractures near Repository (2.2.10.04.0A) $6-110$

6.9.11 Thermo-Mechanical Stresses Alter Characteristics of Faults near Repository (2.2.10.04.0B)

6.9.12 Thermo-Mechanical Stresses Alter Characteristics of Rocks above and below the Repository (2.2.10.05.0A)

6.9.13 Thermo-Chemical Alteration in the UZ (Solubility, Speciation, Phase Changes, Precipitation/Dissolution) (2.2.10.06.0A) ................................... 6-113

6.9.14 Thermo-Chemical Alteration of the Calico Hills Unit (2.2.10.07.0A) 6-115

6.9.15 Thermo-Chemical Alteration of the Topopah Spring Basal Vitrophyre (2.2.10.09.0A)

6.9.16 Mineralogic Dehydration Reactions (2.2.10.14.0A)

6.9.17 Diffusion in the UZ (2.2.08.05.0A) $6-120$

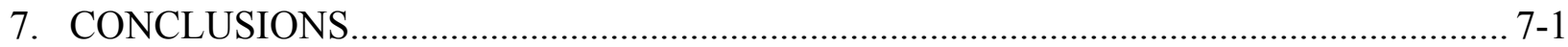

7.1 SATISFACTION OF YMRP ACCEPTANCE CRITERIA...................................... 7-4

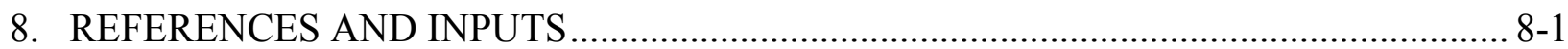

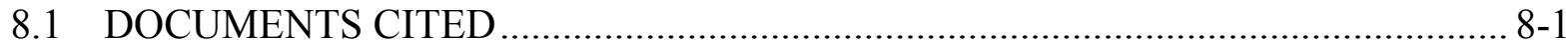

8.2 CODES, STANDARDS, REGULATIONS, AND PROCEDURES .......................... 8-2

8.3 SOURCE DATA, LISTED BY DATA TRACKING NUMBER ……….................. 8-21

8.4 OUTPUT DATA, LISTED BY DATA TRACKING NUMBER ……………......... 8-28

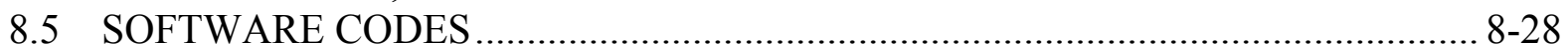

APPENDIX A - PERCHED WATER VOLUME ………................................................ A-1

APPENDIX B - PTN LOCATIONS RELATIVE TO WASTE EMPLACEMENT ................... B-1

APPENDIX C - QUALIFICATION OF UNQUALIFIED DATA ……………………...........

APPENDIX D - ANALYSIS OF SENSITIVITY OF TRANSPORT TO CHANGES IN FRACTURE APERTURE................................................................ D-1

APPENDIX E - ANALYSIS OF LATERAL DISPERSION OF PLUMES............................... 


\section{FIGURES}

Page

6-1. Ternary Diagram of Water Compositions from the PTn and TSw

$6-48$

A-1. Coordinates of UZ Grid Repository Gridblocks Compared with Repository Design

Drift Endpoint Coordinates (Plan View) .....

A-2. Coordinates of UZ Grid Repository Gridblocks Compared with Repository Design

Drift Endpoint Coordinates (Elevation).

B-1. PTn Coverage over the UZ Flow Model and Waste Emplacement Areas

D-1. Comparison of SR And LA Transport Results for an Instantaneous Release of (Nonsorbing) Tracer Mass at the Repository Horizon at Time Zero under Present-Day Climate. a) Cumulative Fractional Breakthrough, b) Normalized Mass Arrival Rate

D-2. Comparison of SR and LA Transport Results for an Instantaneous Release of (Nonsorbing) Tracer Mass at the Repository Horizon at Time Zero under Glacial-Transition Climate. a) Cumulative Fractional Breakthrough, b) Normalized Mass Arrival Rate....

D-3. Conceptual Connection Diagram for a One-Dimensional

Dual-Permeability Model.

D-4. Conceptual Connection Diagram for a Two-Dimensional Dual-Permeability Model.

D-5. Schematic Diagram of a Breakthrough Curve ..................................................... D-19

D-6. Plan View of the Locations of the Two-Dimensional Cross Section and the Nearby Faults within the TSPA-SR UZ Grid.

D-7. Breakthrough Curves under Present-day Infiltration when Fracture Property Changes are Limited to the Fault Fractures.

D-8. Breakthrough Curves under Glacial-Transition Infiltration when Fracture Property Changes are Limited to the Fault Fractures.

D-9. Breakthrough Curves under Present-Day Infiltration with Change in Fracture Properties Throughout the Entire Model Domain.

D-10. Breakthrough Curves under Glacial-Transition Infiltration with Change in Fracture Properties Throughout the Entire Model Domain.

E-1. Plume Spreading with Depth Due to Lateral Dispersion and Molecular Diffusion .... E-4 


\section{INTENTIONALLY LEFT BLANK}




\section{TABLES}

Page

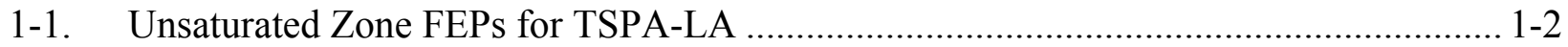

3-1. Qualified Software Used in This Report.................................................................... 3-1

4-1. Inputs Used to Demonstrate Disposition of Included FEPs......................................... 4-1

4-2. Direct Inputs Used for Exclusion of FEPs................................................................ 4-11

4-3. Regulations Used as Direct Inputs.................................................................. 4-18

4-4. Relationships of Regulations to the YMRP Acceptance Criteria ………….................. 4-20

4-5. Relevant YMRP Acceptance Criteria .................................................................... 4-21

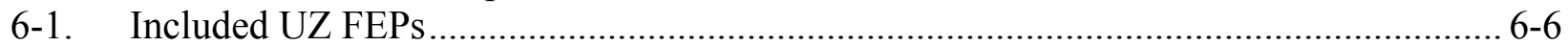

6-2. Infiltration Rates (mm/year) Averaged over the UZ Model Domain ........................... 6-12

6-3. PTn Pore Water Identifications and Chloride Concentration ........................................ 6-47

6-4. Comparison of W0 Pore-Water and PTn Pore-Water Compositions ............................. 6-48

6-5. Excluded FEPs: Repository Seals and Borehole Seals .............................................. 6-57

6-6. Deep Boreholes in or Close to the Repository Block ………….................................. 6-58

6-7. Excluded FEPs: Climate and Episodic Transient Flow ……...................................... 6-66

6-8. Excluded FEPs: Erosion/Dissolution/Subsidence...................................................... 6-71

6-9. Excluded FEPs: Human Influences on Climate and Soil............................................ 6-75

6-10. Excluded FEPs: Natural Gas/Gas Generation Effects ............................................ 6-78

6-11. Excluded FEPs: Seismic/Igneous/Rock Characteristics ............................................... 6-81

6-12. Excluded FEPs: Repository-Perturbed THMC …………………………….............. 6-97

7-1. FEPs Analysis Results ...........................................................................................

7-2. Where YMRP Acceptance Criteria Have Been Addressed in This Report..................... 7-5

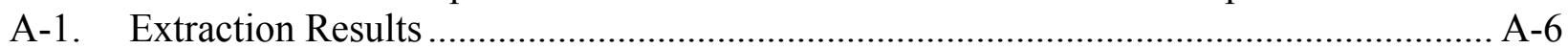


INTENTIONALLY LEFT BLANK 


\section{ACRONYMS AND ABBREVIATIONS}

\section{Acronyms}

DOE

EBS

ECRB

EDZ

ESF

FEHM finite element heat and mass

FEP

LA

NRC

RMEI

RTTF

SR

SZ

$\mathrm{TH}$

THC

THM

THMC

TSPA

UZ

YMP

YMRP

U.S. Department of Energy

engineered barrier system

excavation disturbed zone

Exploratory Studies Facility

feature, event, or process

license application

site recommendation

saturated zone

thermal-hydrologic

unsaturated zone

Yucca Mountain Project
Enhanced Characterization of the Repository Block

U.S. Nuclear Regulatory Commission

reasonably maximally exposed individual

residence time transfer function

thermal-hydrologic-chemical

thermal-hydrologic-mechanical

thermal-hydrologic-mechanical-chemical

total system performance assessment

Yucca Mountain Review Plan, Final Report

\section{Abbreviations}

CHn Calico Hills nonwelded hydrogeologic unit

PTn Paintbrush Tuff nonwelded hydrogeologic unit

TSw Topopah Spring welded hydrogeologic unit 


\section{INTENTIONALLY LEFT BLANK}




\section{PURPOSE}

The purpose of this report is to evaluate and document the inclusion or exclusion of the unsaturated zone (UZ) features, events, and processes (FEPs) with respect to modeling that supports the total system performance assessment (TSPA) for license application (LA) for a nuclear waste repository at Yucca Mountain, Nevada. A screening decision, either Included or Excluded, is given for each FEP, along with the technical basis for the screening decision. This information is required by the U.S. Nuclear Regulatory Commission (NRC) in 10 CFR 63.114 (d, e, and f) [DIRS 173273].

The FEPs deal with UZ flow and radionuclide transport, including climate, surface water infiltration, percolation, drift seepage, and thermally coupled processes. This analysis summarizes the implementation of each FEP in TSPA-LA (that is, how the FEP is included) and also provides the technical basis for exclusion from TSPA-LA (that is, why the FEP is excluded). This report supports TSPA-LA.

\subsection{PLANNING AND DOCUMENTATION}

Development of this report follows the technical work scope, content, and management in Technical Work Plan for Unsaturated Zone Flow, Drift Seepage and Unsaturated Zone Transport Modeling (BSC 2005 [DIRS 173951]).

\subsection{SCOPE}

The scope of this report is to describe, evaluate, and document screening decisions and technical bases for the UZ FEPs for TSPA-LA. TSPA-LA dispositions are provided in Section 6.2 for FEPs that are included in the TSPA-LA. The disposition is a consolidated summary of how each FEP has been included and addressed in the TSPA-LA model, based on supporting reports that describe the inclusion of the FEP. This report also provides, in Section 6.1.3, a list, or reference roadmap, of the specific supporting technical analysis model reports that provide more detailed discussions of the FEP. This report in turn is used as input to MDL-WIS-PA-000004, Total System Performance Assessment Model/Analysis for License Application.

This report provides, in Sections 6.3 through 6.9, a screening argument for each FEP that is excluded from the TSPA-LA, which identifies the basis for the screening decision (that is, low probability, low consequence, or by regulation) and discusses the technical basis that supports that decision. Appropriate references to Yucca Mountain Project (YMP) and non-Project information support the exclusion.

In cases where a FEP covers multiple technical areas and is shared with other FEP reports, only a partial technical basis is provided for the screening decision as it relates to UZ concerns. The full technical basis for these shared FEPs is addressed collectively by all of the sharing FEP reports. This information is provided with the individual FEP discussions in Sections 6.2 through 6.9.

The YMP FEP analysis and scenario development process is explained in The Development of the TSPA-LA Features, Events, and Processes (BSC 2005 [DIRS 173800], Sections 2.4, 3, and 4). As part of that process, the LA FEP list and screening (DTN: MO0501SEPFEPLA.001 
[DIRS 172601]) was developed. This DTN was used as an input to the UZ FEP analysis. The list of UZ TSPA-LA FEPs, which is a subset of the LA FEP list, is presented in Table 1-1, including the designation of shared FEPs. Section 4 lists direct inputs supporting the screening decisions. FEP discussions providing identification (FEP number, name, and description) and screening information (screening decision, screening argument or TSPA disposition) are in Section 6.2 for included FEPs and in Sections 6.3 through 6.9 for excluded FEPs.

Table 1-1. Unsaturated Zone FEPs for TSPA-LA

\begin{tabular}{|c|c|c|c|}
\hline FEP Number & FEP Name & $\begin{array}{l}\text { Addressed in } \\
\text { Section }\end{array}$ & Sharing FEP Report ${ }^{a}$ \\
\hline 1.1.01.01.0A & Open site investigation boreholes & 6.3 .1 & (none) \\
\hline 1.1.01.01.0B & Influx through holes drilled in drift wall or crown & 6.3 .2 & (none) \\
\hline 1.1.02.01.0A & Site flooding (during construction and operation) & 6.3 .3 & (none) \\
\hline 1.1.02.02.0A & Preclosure ventilation & 6.2 .1 & EBS \\
\hline 1.1.04.01.0A & Incomplete closure & 6.3 .4 & (none) \\
\hline 1.1.11.00.0A & Monitoring of the repository & 6.3 .5 & SYS \\
\hline 1.2.02.01.0A & Fractures & 6.2 .2 & Sz \\
\hline 1.2.02.02.0A & Faults & 6.2 .3 & $\mathrm{Sz}$ \\
\hline 1.2.04.02.0A & Igneous activity changes rock properties & 6.8 .1 & $\begin{array}{l}\mathrm{DE} \\
\mathrm{SZ}\end{array}$ \\
\hline 1.2.06.00.0A & Hydrothermal activity & 6.8 .2 & $\mathrm{sz}$ \\
\hline 1.2.07.01.0A & Erosion/denudation & 6.5 .1 & (none) \\
\hline 1.2.07.02.0A & Deposition & 6.5 .2 & (none) \\
\hline 1.2.09.02.0A & Large-scale dissolution & 6.5 .3 & SZ \\
\hline 1.2.10.01.0A & Hydrologic response to seismic activity & 6.8 .3 & $\begin{array}{l}\mathrm{DE} \\
\mathrm{SZ}\end{array}$ \\
\hline 1.2.10.02.0A & Hydrologic response to igneous activity & 6.8 .4 & $\begin{array}{l}\mathrm{DE} \\
\mathrm{SZ}\end{array}$ \\
\hline 1.3.01.00.0A & Climate change & 6.2 .4 & Bio \\
\hline 1.3.04.00.0A & Periglacial effects & 6.4 .1 & Bio \\
\hline 1.3.05.00.0A & Glacial and ice sheet effect & 6.4 .2 & Bio \\
\hline 1.3.07.01.0A & Water table decline & 6.4 .3 & $\mathrm{SZ}$ \\
\hline 1.3.07.02.0B & Water table rise affects $\cup Z$ & 6.2 .5 & (none) \\
\hline 1.4.01.00.0A & Human influences on climate & 6.6 .1 & Bio \\
\hline 1.4.01.01.0A & Climate modification increases recharge & 6.2 .6 & (none) \\
\hline 1.4.01.02.0A & Greenhouse gas effects & 6.6 .2 & Bio \\
\hline 1.4.01.03.0A & Acid rain & 6.6 .3 & Bio \\
\hline 1.4.01.04.0A & Ozone layer failure & 6.6 .4 & Bio \\
\hline 1.4.06.01.0A & Altered soil or surface water chemistry & 6.6 .5 & (none) \\
\hline 2.1.05.01.0A & $\begin{array}{l}\text { Flow through seals (access ramps and ventilation } \\
\text { shafts) }\end{array}$ & 6.3 .6 & (none) \\
\hline 2.1.05.02.0A & Radionuclide transport through seals & 6.3 .7 & (none) \\
\hline 2.1.05.03.0A & Degradation of seals & 6.3 .8 & (none) \\
\hline 2.1.08.01.0A & Water influx at the repository & 6.2 .7 & (none) \\
\hline 2.1.08.02.0A & Enhanced influx at the repository & 6.2 .8 & (none) \\
\hline
\end{tabular}


Table 1-1. Unsaturated Zone FEPs for TSPA-LA (Continued)

\begin{tabular}{|c|c|c|c|}
\hline FEP Number & FEP Name & $\begin{array}{l}\text { Addressed in } \\
\text { Section }\end{array}$ & Sharing FEP Report ${ }^{a}$ \\
\hline 2.1.09.12.0A & $\begin{array}{l}\text { Rind (chemically altered zone) forms in the } \\
\text { near-field }\end{array}$ & 6.9 .1 & (none) \\
\hline 2.1.09.21.0C & $\begin{array}{l}\text { Transport of particles larger than colloids in the } \\
\text { UZ }\end{array}$ & 6.4.4 & (none) \\
\hline 2.2.01.01.0A & $\begin{array}{l}\text { Mechanical effects of excavation and construction } \\
\text { in the near-field }\end{array}$ & 6.2 .9 & (none) \\
\hline 2.2.01.01.0B & $\begin{array}{l}\text { Chemical effects of excavation and construction in } \\
\text { the near-field }\end{array}$ & 6.9 .2 & (none) \\
\hline 2.2.01.02.0A & $\begin{array}{l}\text { Thermally-induced stress changes in the } \\
\text { near-field }\end{array}$ & 6.9 .3 & EBS \\
\hline 2.2.01.03.0A & $\begin{array}{l}\text { Changes in fluid saturations in the excavation } \\
\text { disturbed zone }\end{array}$ & 6.9 .4 & (none) \\
\hline 2.2.01.04.0A & $\begin{array}{l}\text { Radionuclide solubility in the excavation disturbed } \\
\text { zone }\end{array}$ & 6.9 .5 & (none) \\
\hline 2.2.01.05.0A & $\begin{array}{l}\text { Radionuclide transport in the excavation disturbed } \\
\text { zone }\end{array}$ & 6.9 .6 & (none) \\
\hline 2.2.03.01.0A & Stratigraphy & 6.2 .10 & $\mathrm{SZ}$ \\
\hline 2.2.03.02.0A & Rock properties of host rock and other units & 6.2 .11 & $\mathrm{Sz}$ \\
\hline 2.2.06.01.0A & $\begin{array}{l}\text { Seismic activity changes porosity and permeability } \\
\text { of rock }\end{array}$ & 6.8 .5 & $\begin{array}{l}\mathrm{DE} \\
\mathrm{SZ}\end{array}$ \\
\hline 2.2.06.02.0A & $\begin{array}{l}\text { Seismic activity changes porosity and permeability } \\
\text { of faults }\end{array}$ & 6.8 .6 & $\begin{array}{l}\mathrm{DE} \\
\mathrm{SZ}\end{array}$ \\
\hline 2.2.06.02.0B & $\begin{array}{l}\text { Seismic activity changes porosity and permeability } \\
\text { of fractures }\end{array}$ & 6.8 .7 & $\begin{array}{l}\mathrm{DE} \\
\mathrm{SZ}\end{array}$ \\
\hline 2.2.06.03.0A & Seismic activity alters perched water zones & 6.8 .8 & $\mathrm{DE}$ \\
\hline $2.2 .06 .04 .0 \mathrm{~A}$ & Effects of subsidence & 6.5 .4 & (none) \\
\hline 2.2.07.01.0A & Locally saturated flow at bedrock/alluvium contact & 6.2 .12 & (none) \\
\hline 2.2.07.02.0A & Unsaturated groundwater flow in the geosphere & 6.2 .13 & (none) \\
\hline 2.2.07.03.0A & Capillary rise in the UZ & 6.2 .14 & (none) \\
\hline 2.2.07.04.0A & Focusing of unsaturated flow (fingers, weeps) & 6.2 .15 & (none) \\
\hline 2.2.07.05.0A & Flow in the UZ from episodic infiltration & 6.4 .5 & (none) \\
\hline 2.2.07.06.0A & Episodic or pulse release from repository & 6.4 .6 & EBS \\
\hline 2.2.07.06.0B & $\begin{array}{l}\text { Long-term release of radionuclides from the } \\
\text { repository }\end{array}$ & 6.2 .16 & EBS \\
\hline 2.2.07.07.0A & Perched water develops & 6.2 .17 & (none) \\
\hline 2.2.07.08.0A & Fracture flow in the UZ & 6.2 .18 & (none) \\
\hline 2.2.07.09.0A & Matrix imbibition in the UZ & 6.2 .19 & (none) \\
\hline 2.2.07.10.0A & Condensation zone forms around drifts & 6.2 .20 & (none) \\
\hline 2.2.07.11.0A & Resaturation of geosphere dry-out zone & 6.2 .21 & (none) \\
\hline 2.2.07.15.0B & Advection and dispersion in the UZ & 6.2 .22 & (none) \\
\hline 2.2.07.18.0A & Film flow into the repository & 6.2 .23 & (none) \\
\hline 2.2.07.19.0A & $\begin{array}{l}\text { Lateral flow from Solitario Canyon Fault enters } \\
\text { drifts }\end{array}$ & 6.2 .24 & (none) \\
\hline 2.2.07.20.0A & Flow diversion around repository drifts & 6.2 .25 & (none) \\
\hline 2.2.08.01.0B & Chemical characteristics of groundwater in the UZ & 6.2 .26 & (none) \\
\hline 2.2.08.03.0B & Geochemical interactions and evolution in the UZ & 6.9 .7 & (none) \\
\hline
\end{tabular}


Table 1-1. Unsaturated Zone FEPs for TSPA-LA (Continued)

\begin{tabular}{|c|c|c|c|}
\hline FEP Number & FEP Name & $\begin{array}{l}\text { Addressed in } \\
\text { Section }\end{array}$ & Sharing FEP Report ${ }^{a}$ \\
\hline 2.2.08.04.0A & $\begin{array}{l}\text { Re-dissolution of precipitates directs more } \\
\text { corrosive fluids to waste packages }\end{array}$ & 6.2 .27 & EBS \\
\hline 2.2.08.05.0A & Diffusion in the UZ & 6.9.17 & (none) \\
\hline 2.2.08.06.0B & Complexation in the UZ & 6.2 .28 & (none) \\
\hline 2.2.08.07.0B & Radionuclide solubility limits in the UZ & 6.9 .8 & (none) \\
\hline 2.2.08.08.0B & Matrix diffusion in the UZ & 6.2 .29 & (none) \\
\hline 2.2.08.09.0B & Sorption in the UZ & 6.2 .30 & (none) \\
\hline 2.2.08.10.0B & Colloidal transport in the UZ & 6.2 .31 & (none) \\
\hline 2.2.08.12.0A & Chemistry of water flowing into the drift & 6.2 .32 & (none) \\
\hline 2.2.09.01.0B & Microbial activity in the UZ & 6.2 .33 & (none) \\
\hline 2.2.10.01.0A & $\begin{array}{l}\text { Repository-induced thermal effects on flow in the } \\
\text { UZ }\end{array}$ & 6.9 .9 & (none) \\
\hline 2.2.10.03.0B & Natural geothermal effects on flow in the UZ & 6.2 .34 & (none) \\
\hline 2.2.10.04.0A & $\begin{array}{l}\text { Thermo-mechanical stresses alter characteristics } \\
\text { of fractures near repository }\end{array}$ & 6.9 .10 & $\mathrm{SZ}$ \\
\hline 2.2.10.04.0B & $\begin{array}{l}\text { Thermo-mechanical stresses alter characteristics } \\
\text { of faults near repository }\end{array}$ & 6.9 .11 & $\mathrm{SZ}$ \\
\hline 2.2.10.05.0A & $\begin{array}{l}\text { Thermo-mechanical stresses alter characteristics } \\
\text { of rocks above and below the repository }\end{array}$ & 6.9.12 & $\mathrm{SZ}$ \\
\hline $2.2 .10 .06 .0 \mathrm{~A}$ & $\begin{array}{l}\text { Thermo-chemical alteration in the UZ (solubility, } \\
\text { speciation, phase changes, } \\
\text { precipitation/dissolution) }\end{array}$ & 6.9 .13 & (none) \\
\hline 2.2.10.07.0A & Thermo-chemical alteration of the Calico Hills unit & 6.9 .14 & (none) \\
\hline 2.2.10.09.0A & $\begin{array}{l}\text { Thermo-chemical alteration of the Topopah Spring } \\
\text { basal vitrophyre }\end{array}$ & 6.9 .15 & (none) \\
\hline 2.2.10.10.0A & Two-phase buoyant flow/heat pipes & 6.2 .35 & (none) \\
\hline 2.2.10.11.0A & Natural air flow in the UZ & 6.7 .1 & (none) \\
\hline 2.2.10.12.0A & Geosphere dry-out due to waste heat & 6.2 .36 & (none) \\
\hline 2.2.10.14.0A & Mineralogic dehydration reactions & 6.9 .16 & (none) \\
\hline 2.2.11.02.0A & Gas effects in the UZ & 6.7 .2 & (none) \\
\hline 2.2.11.03.0A & Gas transport in geosphere & 6.7 .3 & (none) \\
\hline 2.2.12.00.0A & Undetected features in the UZ & 6.8 .9 & (none) \\
\hline 2.3.01.00.0A & Topography and morphology & 6.2 .37 & (none) \\
\hline 2.3.11.01.0A & Precipitation & 6.2 .38 & Bio \\
\hline 2.3.11.02.0A & Surface runoff and flooding & 6.2 .39 & (none) \\
\hline 2.3.11.03.0A & Infiltration and recharge & 6.2 .40 & (none) \\
\hline 3.1.01.01.0A & Radioactive decay and ingrowth & 6.2 .41 & $\begin{array}{l}\text { WF } \\
\text { SZ } \\
\text { Bio }\end{array}$ \\
\hline
\end{tabular}

${ }^{a}$ Bio=biosphere; DE= disruptive events; EBS=engineered barrier system; FEP=feature, event, or process; LA=license application; SYS=system level FEPs report; SZ=saturated zone; TSPA=total system performance assessment; WF= waste form 


\subsection{SCIENTIFIC ANALYSIS AND LIMITATIONS}

This report provides FEP screening information for the LA project-specific FEP database and promotes traceability and transparency for both included and excluded UZ FEPs. The report is intended for use as the documentation for inclusion or exclusion of UZ FEPs within or from the TSPA-LA model. The following limitations apply to this report:

- Because this report cites other reports and controlled documents as direct input, limitations inherently include any limitations or constraints described in the cited reports or controlled documents.

- In cases where FEPs are shared (that is, where the FEP affects more than one model area), the scope is limited to effects of the FEP on UZ flow and transport. The full technical basis for each shared FEP is addressed, collectively, by this report and all sharing FEP reports.

- For screening purposes, mean values of probabilities, mean amplitude of events, or mean value of consequences (e.g., mean time to waste package degradation) are used as a basis for reaching an include or exclude decision. Mean values are determined based on the range of possible values.

- The results of the FEP screening are specific to the repository design and processes for YMP available at the time of the TSPA-LA. Changes in direct inputs listed in Section 4.1, in baseline conditions used for this evaluation, or in other subsurface conditions, will need to be evaluated to determine whether the changes are within the limits stated in the FEP evaluations. Engineering and design changes are subject to evaluation to determine whether there are any adverse impacts to safety, as codified at 10 CFR 63.73 and in Subparts F and G [DIRS 173273]. See also the requirements at 10 CFR 63.44 [DIRS 173273]. 


\section{INTENTIONALLY LEFT BLANK}




\section{QUALITY ASSURANCE}

Development of this report and the supporting modeling activities are subject to the Yucca Mountain Project quality assurance (QA) program, as indicated in Technical Work Plan for Unsaturated Zone Flow, Drift Seepage and Unsaturated Zone Transport Modeling (BSC 2005 [DIRS 173951], Section 8.1). Approved QA procedures identified in Section 4 of the technical work plan have been used to conduct and document the activities described in this report. Section 8.4 of the technical work plan also identifies applicable controls for the electronic management of data during the analysis and documentation activities. This report was developed under LP-SIII.9Q-BSC, Scientific Analyses.

This report provides information about radionuclide transport through the UZ above and below the repository, which are natural barriers classified in Q-List (BSC 2005 [DIRS 171190]) as "Safety Category" because they are important to waste isolation, as defined in AP-2.22Q, Classification Analyses and Maintenance of the Q-List. The results of this report are important to the demonstration of compliance with the postclosure performance objectives prescribed in 10 CFR 63.113 [DIRS 173273]. The report contributes to the analysis and modeling data used to support postclosure performance assessment; the conclusions do not directly impact engineered features important to safety, as defined in AP-2.22Q. 


\section{INTENTIONALLY LEFT BLANK}




\section{USE OF SOFTWARE}

Calculations to support exclusion arguments presented in Sections 6.8.6 and 6.8.7 and Appendix D used software listed in Table 3-1. These are appropriate for the intended application and were used only within the range of validation. These codes were obtained from software configuration management in accordance with LP-SI.11Q-BSC, Software Management.

Table 3-1. Qualified Software Used in This Report

\begin{tabular}{|c|c|c|c|c|}
\hline Software Name & Version & $\begin{array}{c}\text { Software Tracking } \\
\text { Number }\end{array}$ & $\begin{array}{c}\text { DIRS } \\
\text { Reference } \\
\text { Number }\end{array}$ & Platform/Operating System \\
\hline TOUGH2 & 1.4 & $10007-1.4-01$ & 146496 & SUN / OSF1 V4.0 \\
\hline T2R3D & 1.4 & $10006-1.4-00$ & 146654 & SUN / UNIX \\
\hline
\end{tabular}

TOUGH2 V1.4 (LBNL 2000 [DIRS 146496]) and T2R3D (LBNL 1999 [DIRS 146654]) were used in Appendix D for modeling UZ flow and radionuclide transport in the UZ, respectively. The results of those calculations are the basis for FEP exclusion arguments presented in Sections 6.8.6 and 6.8.7. The selection of TOUGH2 and T2R3D to evaluate UZ flow and transport is based on the fact that these software codes have been developed on the Yucca Mountain Project specifically for this purpose.

Pre- and postprocessing were performed using Microsoft Excel (v. 97-SR-1 and 2000), and visual display graphics were developed using Tecplot v. 7.0-4.0 for Microsoft Windows and RockWare Aq॰QA v. 1.0. No other software requiring qualification in accordance with LP-SI.11Q-BSC was used for the development of this report. Standard functions of Excel (v. 97-SR-1) and visual display graphics programs (Tecplot v. 7.0-4.0 for Microsoft Windows and RockWare Aq•QA v. 1.0) were used. All information required for an independent person to reproduce the work using these standard software programs, including the input, computation, and output, is included in this report. Excel calculations are documented in Appendices A and B. 


\section{INTENTIONALLY LEFT BLANK}




\section{INPUTS}

LP-3.15Q-BSC, Managing Technical Product Inputs, categorizes technical product input usage as either direct input or indirect input. Direct input is used to develop the results or conclusions in a technical product. Indirect input is used to provide additional information, often corroborative, that is not directly used in the development of results or conclusions. Indirect inputs that demonstrate the inclusion of FEPs in the TSPA are listed in Table 4-1; included FEPs are discussed in Section 6.2.

Table 4-1. Inputs Used to Demonstrate Disposition of Included FEPs

\begin{tabular}{|c|c|c|}
\hline Source $^{a}$ & $\begin{array}{l}\text { Used in Section } \\
\text { Number }\end{array}$ & Description \\
\hline $\begin{array}{l}\text { LL000122051021.116 } \\
\text { [DIRS 142973], } \\
\text { MOL.20000131.0348 }\end{array}$ & 6.2 .31 & $\begin{array}{l}\text { Summary of analyses of glass dissolution } \\
\text { filtrates }\end{array}$ \\
\hline $\begin{array}{l}\text { LB0205REVUZPRP.001 } \\
\text { [DIRS 159525], } \\
\text { FRACTURE_PROPERTY.xIs }\end{array}$ & $\begin{array}{l}6.2 .2,6.2 .11,6.2 .14 \\
6.2 .18\end{array}$ & Fracture properties \\
\hline $\begin{array}{l}\text { LB0207REVUZPRP.001 } \\
\text { [DIRS 159526] }\end{array}$ & $6.2 .2,6.2 .11$ & Fracture properties \\
\hline $\begin{array}{l}\text { LB0302DSCPTHCS.002 } \\
\text { [DIRS 161976] }\end{array}$ & $\begin{array}{l}\text { 6.2.1, 6.2.2, 6.2.4, } \\
6.2 .6,6.2 .7,6.2 .10, \\
6.2 .11,6.2 .13,6.2 .15, \\
6.2 .18,6.2 .19,6.2 .20, \\
6.2 .21,6.2 .26,6.2 .27, \\
6.2 .32,6.2 .34,6.2 .35, \\
6.2 .36\end{array}$ & $\begin{array}{l}\text { Drift-scale coupled processes (THC } \\
\text { seepage) model: data summary }\end{array}$ \\
\hline $\begin{array}{l}\text { LB0302SCMREV02.002 } \\
\text { [DIRS 162273] }\end{array}$ & 6.2 .23 & $\begin{array}{l}\text { Seepage calibration model capillary strength } \\
\text { parameter results }\end{array}$ \\
\hline $\begin{array}{l}\text { LB0302PTNTSW9I.001 } \\
\text { [DIRS 162277] }\end{array}$ & $6.2 .4,6.2 .6,6.2 .7$ & PTn/TSw flux maps from UZ flow model \\
\hline $\begin{array}{l}\text { LA0303HV831352.002 } \\
\text { [DIRS 163558] }\end{array}$ & 6.2 .31 & $\begin{array}{l}\text { Colloid retardation factors for the saturated } \\
\text { zone fractured volcanics }\end{array}$ \\
\hline $\begin{array}{l}\text { LB0301DSCPTHSM.002 } \\
\text { [DIRS 163689] }\end{array}$ & $\begin{array}{l}6.2 .1,6.2 .2,6.2 .8 \\
6.2 .11,6.2 .13,6.2 .15 \\
6.2 .18,6.2 .20,6.2 .21 \\
6.2 .25,6.2 .35,6.2 .36\end{array}$ & TH seepage model results \\
\hline $\begin{array}{l}\text { LB0305PTNTSW9I.001 } \\
\text { [DIRS 163690] }\end{array}$ & $6.2 .4,6.2 .6,6.2 .7$ & $\begin{array}{l}\text { PTn/TSw flux maps from UZ flow } \\
\text { model - alternative model }\end{array}$ \\
\hline $\begin{array}{l}\text { SN0306T0504103.006 } \\
\text { [DIRS 164131] }\end{array}$ & $6.2 .30,6.2 .31$ & $\begin{array}{l}\text { Colloid concentration and radionuclide } \\
\text { sorption coefficients onto colloids }\end{array}$ \\
\hline $\begin{array}{l}\text { BSC } 2004 \text { [DIRS 164500], } \\
\text { Appendix A }\end{array}$ & 6.2 .30 & Treatment of sorption in TSPA-LA \\
\hline $\begin{array}{l}\text { BSC } 2004 \text { [DIRS 164500], } \\
\text { Appendix A, Section A4 }\end{array}$ & 6.2 .26 & Treatment of sorption in TSPA-LA \\
\hline $\begin{array}{l}\text { BSC } 2004 \text { [DIRS 164500], } \\
\text { Appendix A, Section A5 }\end{array}$ & $\begin{array}{l}6.2 .26,6.2 .28,6.2 .30 \\
6.2 .33\end{array}$ & Treatment of sorption in TSPA-LA \\
\hline
\end{tabular}


Table 4-1. Inputs Used to Demonstrate Disposition of Included FEPs (Continued)

\begin{tabular}{|c|c|c|}
\hline Source $^{a}$ & $\begin{array}{l}\text { Used in Section } \\
\text { Number }\end{array}$ & Description \\
\hline $\begin{array}{l}\text { BSC } 2004 \text { [DIRS 164500], } \\
\text { Appendix A, Section A8 }\end{array}$ & $\begin{array}{l}6.2 .26,6.2 .28,6.2 .30 \\
6.2 .33\end{array}$ & Treatment of sorption in TSPA-LA \\
\hline $\begin{array}{l}\text { BSC } 2004 \text { [DIRS 164500], } \\
\text { Sections 6.1.3, } 6.18\end{array}$ & 6.2 .28 & Treatment of complexation in TSPA-LA \\
\hline $\begin{array}{l}\text { BSC } 2004 \text { [DIRS 164500], } \\
\text { Sections } 6.1,6.2 .3,6.18\end{array}$ & 6.2 .30 & Treatment of sorption in TSPA-LA \\
\hline $\begin{array}{l}\text { LB0307DSTTHCR2.002 } \\
\text { [DIRS 165541] }\end{array}$ & $\begin{array}{l}\text { 6.2.1, 6.2.2, 6.2.4, } \\
6.2 .6,6.2 .7,6.2 .10, \\
6.2 .11,6.2 .13,6.2 .18, \\
6.2 .19,6.2 .20,6.2 .21 \\
6.2 .26,6.2 .27,6.2 .32 \\
6.2 .34,6.2 .35,6.2 .36\end{array}$ & $\begin{array}{l}\text { Drift-scale coupled processes (DST } \\
\text { seepage) model: Data summary }\end{array}$ \\
\hline $\begin{array}{l}\text { LB0305TSPA18FF.001 } \\
\text { [DIRS 165625] }\end{array}$ & $\begin{array}{l}6.2 .2,6.2 .3,6.2 .4, \\
6.2 .6,6.2 .7,6.2 .10, \\
6.2 .11,6.2 .13,6.2 .15, \\
6.2 .17,6.2 .18,6.2 .19, \\
6.2 .24,6.2 .38,6.2 .39, \\
6.2 .40\end{array}$ & $\begin{array}{l}\text { Flow fields for present-day and future } \\
\text { climates, converted from TOUGH2 to FEHM } \\
\text { format }\end{array}$ \\
\hline $\begin{array}{l}\text { SN0308T0503100.008 } \\
\text { [DIRS 165640] }\end{array}$ & $\begin{array}{l}\text { 6.2.2, 6.2.4, 6.2.11, } \\
6.2 .12,6.2 .18,6.2 .37 \\
6.2 .39,6.2 .40 \\
\end{array}$ & $\begin{array}{l}\text { Frequency distributions for net infiltration and } \\
\text { weighting factors applied to lower, mean, and } \\
\text { upper climates }\end{array}$ \\
\hline $\begin{array}{l}\text { BSC } 2003 \text { [DIRS 165991], } \\
\text { Section } 7.1\end{array}$ & $\begin{array}{l}6.2 .2,6.2 .4,6.2 .11 \\
6.2 .12,6.2 .18,6.2 .37 \\
6.2 .38,6.2 .39 \\
\end{array}$ & $\begin{array}{l}\text { Treatment of infiltration uncertainty in } \\
\text { TSPA-LA }\end{array}$ \\
\hline $\begin{array}{l}\text { BSC } 2003 \text { [DIRS 165991], } \\
\text { Section } 1.1\end{array}$ & 6.2 .40 & $\begin{array}{l}\text { Treatment of infiltration uncertainty in } \\
\text { TSPA-LA }\end{array}$ \\
\hline $\begin{array}{l}\text { BSC } 2003 \text { [DIRS 165991], } \\
\text { Section } 6.1 .2\end{array}$ & $6.2 .38,6.2 .39$ & Model parameters for infiltration analysis \\
\hline $\begin{array}{l}\text { BSC } 2003 \text { [DIRS 165991], } \\
\text { Figure 1-1 }\end{array}$ & 6.2 .40 & Repository footprint \\
\hline $\begin{array}{l}\text { BSC } 2003 \text { [DIRS 165991], } \\
\text { Table 6-1 }\end{array}$ & 6.2 .2 & Model parameters for infiltration analysis \\
\hline $\begin{array}{l}\text { BSC } 2003 \text { [DIRS 165991], } \\
\text { Table 6-2 }\end{array}$ & $6.2 .2,6.2 .11$ & Treatment of infiltration uncertainty \\
\hline $\begin{array}{l}\text { BSC } 2003 \text { [DIRS 165991], } \\
\text { Table 6-3 }\end{array}$ & $\begin{array}{l}\text { 6.2.2, 6.2.11, 6.2.38, } \\
6.2 .39\end{array}$ & Treatment of infiltration uncertainty \\
\hline $\begin{array}{l}\text { LB0311ABSTHCR2.001 } \\
\text { [DIRS 166714] }\end{array}$ & $\begin{array}{l}\text { 6.2.1, 6.2.2, 6.2.4, } \\
6.2 .6,6.2 .7,6.2 .10, \\
6.2 .11,6.2 .13,6.2 .15, \\
6.2 .18,6.2 .19,6.2 .20, \\
6.2 .21,6.2 .26,6.2 .27, \\
6.2 .32,6.2 .34,6.2 .35, \\
6.2 .36\end{array}$ & $\begin{array}{l}\text { Summary statistics of predicted aqueous } \\
\text { species and } \mathrm{CO}_{2} \text { gas concentrations }\end{array}$ \\
\hline $\begin{array}{l}\text { LA0311BR831229.001 } \\
\text { [DIRS 166924] }\end{array}$ & $6.2 .15,6.2 .18,6.2 .29$ & $\begin{array}{l}\text { Transfer function calculation files for UZ } \\
\text { transport abstraction model }\end{array}$ \\
\hline $\begin{array}{l}\text { LA0311AM831341.001 } \\
\text { [DIRS 167015] }\end{array}$ & $6.2 .26,6.2 .28,6.2 .30$ & $\begin{array}{l}\text { Correlation matrix for sampling of sorption } \\
\text { coefficient probability distributions }\end{array}$ \\
\hline $\begin{array}{l}\text { BSC } 2004 \text { [DIRS 167652], } \\
\text { Section } 6.3\end{array}$ & $6.2 .2,6.2 .8$ & $\begin{array}{l}\text { Process model of seepage from fractures } \\
\text { into drift; treatment of enhanced influx at the } \\
\text { repository for drift seepage in TSPA }\end{array}$ \\
\hline
\end{tabular}


Table 4-1. Inputs Used to Demonstrate Disposition of Included FEPs (Continued)

\begin{tabular}{|c|c|c|}
\hline Source $^{a}$ & $\begin{array}{l}\text { Used in Section } \\
\text { Number }\end{array}$ & Description \\
\hline $\begin{array}{l}\text { BSC } 2004 \text { [DIRS 167652], } \\
\text { Section 6.3.6 }\end{array}$ & $6.2 .4,6.2 .6,6.2 .7$ & $\begin{array}{l}\text { Climate change and resulting change in } \\
\text { percolation flux included in drift seepage } \\
\text { model }\end{array}$ \\
\hline $\begin{array}{l}\text { BSC } 2004 \text { [DIRS 167652], } \\
\text { Sections } 6.3 .2,6.4\end{array}$ & 6.2 .9 & $\begin{array}{l}\text { Mechanical effects of excavation are } \\
\text { included in the seepage model }\end{array}$ \\
\hline $\begin{array}{l}\text { BSC } 2004 \text { [DIRS 167652], } \\
\text { Sections 6.3.2, 6.3.3, 6.3.4 }\end{array}$ & $6.2 .10,6.2 .11$ & $\begin{array}{l}\text { Seepage simulated in Tptpmn and Tptpll } \\
\text { layers of TSw }\end{array}$ \\
\hline $\begin{array}{l}\text { BSC } 2004 \text { [DIRS 167652], } \\
\text { Sections } 6.2 .1,6.3\end{array}$ & 6.2 .13 & $\begin{array}{l}\text { Conceptual and numerical model of } \\
\text { unsaturated groundwater flow used for } \\
\text { seepage calculations }\end{array}$ \\
\hline $\begin{array}{l}\text { BSC } 2004 \text { [DIRS 167652], } \\
\text { Section } 6.8\end{array}$ & 6.2 .15 & $\begin{array}{l}\text { Treatment of flow focusing in the seepage } \\
\text { model }\end{array}$ \\
\hline $\begin{array}{l}\text { BSC } 2004 \text { [DIRS 167652], } \\
\text { Sections 6.3.2, 6.3.3 }\end{array}$ & 6.2 .18 & $\begin{array}{l}\text { Treatment of fracture flow in the seepage } \\
\text { model }\end{array}$ \\
\hline $\begin{array}{l}\text { BSC } 2004 \text { [DIRS 167652], } \\
\text { Section } 6.3\end{array}$ & 6.2 .19 & $\begin{array}{l}\text { Matrix imbibition is neglected in the seepage } \\
\text { model }\end{array}$ \\
\hline $\begin{array}{l}\text { BSC } 2004 \text { [DIRS 167652], } \\
\text { Section } 6.3\end{array}$ & 6.2 .23 & Film flow is included in the seepage model. \\
\hline $\begin{array}{l}\text { BSC } 2004 \text { [DIRS 167652], } \\
\text { Sections 6.2.1, 6.3.2, 6.7 }\end{array}$ & 6.2 .25 & $\begin{array}{l}\text { Flow diversion around opening is included in } \\
\text { the seepage model. }\end{array}$ \\
\hline BSC 2004 [DIRS 168489] & 6.2 .1 & Heat output from emplaced waste \\
\hline $\begin{array}{l}\text { BSC } 2004 \text { [DIRS 169131], } \\
\text { Sections 6.4.3.1, 6.5.2 }\end{array}$ & 6.2 .1 & Effect of preclosure ventilation on seepage \\
\hline $\begin{array}{l}\text { BSC } 2004 \text { [DIRS 169131], } \\
\text { Sections } 6.3 .1,6.4,6.6\end{array}$ & 6.2 .2 & $\begin{array}{l}\text { Method of deriving seepage-relevant } \\
\text { parameters, and probability distributions } \\
\text { describing their spatial variability and } \\
\text { uncertainty. Abstraction methodology. } \\
\text { Effects of THC and THM processes on } \\
\text { seepage. }\end{array}$ \\
\hline $\begin{array}{l}\text { BSC } 2004 \text { [DIRS 169131], } \\
\text { Section 6.6.5 }\end{array}$ & $6.2 .4,6.2 .6,6.2 .7$ & $\begin{array}{l}\text { Percolation flux distributions from flow fields } \\
\text { output by UZ flow model }\end{array}$ \\
\hline $\begin{array}{l}\text { BSC } 2004 \text { [DIRS 169131], } \\
\text { Section 6.4.1, 6.4.2, 6.4.3 }\end{array}$ & 6.2 .8 & $\begin{array}{l}\text { Calculation of ambient seepage, using drift } \\
\text { scale model with distributions of } \\
\text { seepage-relevant parameters }\end{array}$ \\
\hline $\begin{array}{l}\text { BSC } 2004 \text { [DIRS 169131], } \\
\text { Sections } 6.6 .2,6.6 .3 ; \\
\text { Tables } 6.6-1 \text { and } 6.6-3\end{array}$ & 6.2 .9 & $\begin{array}{l}\text { Permeability and capillary-strength values, } \\
\text { and their probability distributions, for fracture } \\
\text { continuum }\end{array}$ \\
\hline $\begin{array}{l}\text { BSC } 2004 \text { [DIRS 169131], } \\
\text { Section } 6.4\end{array}$ & 6.2 .10 & Drift-scale seepage process model \\
\hline $\begin{array}{l}\text { BSC } 2004 \text { [DIRS 169131], } \\
\text { Sections 6.4, 6.6.1, 6.6.2, } \\
6.6 .5 .1\end{array}$ & 6.2 .11 & $\begin{array}{l}\text { Rock properties used in seepage calculation } \\
\text { and seepage abstraction }\end{array}$ \\
\hline $\begin{array}{l}\text { BSC } 2004 \text { [DIRS 169131], } \\
\text { Sections } 6.4,6.6 .5 .1\end{array}$ & 6.2 .13 & $\begin{array}{l}\text { Method of calculating seepage. Distribution } \\
\text { of values of seepage-relevant parameters. } \\
\text { Effects of THC and THM processes on } \\
\text { seepage }\end{array}$ \\
\hline $\begin{array}{l}\text { BSC } 2004 \text { [DIRS 169131], } \\
\text { Sections } 6.4,6.6 .5 .2\end{array}$ & 6.2 .15 & $\begin{array}{l}\text { Flow focusing factor distribution and effect of } \\
\text { heterogeneous permeability field }\end{array}$ \\
\hline $\begin{array}{l}\text { BSC } 2004 \text { [DIRS 169131], } \\
\text { Sections 6.3.1, 6.4, 6.5.1.4, } \\
6.5 .2,6.6 .5,6.7 .1\end{array}$ & 6.2 .18 & $\begin{array}{l}\text { Inclusion of fracture-flow processes in } \\
\text { seepage abstraction }\end{array}$ \\
\hline
\end{tabular}


Table 4-1. Inputs Used to Demonstrate Disposition of Included FEPs (Continued)

\begin{tabular}{|c|c|c|}
\hline Source $^{a}$ & $\begin{array}{l}\text { Used in Section } \\
\text { Number }\end{array}$ & Description \\
\hline $\begin{array}{l}\text { BSC } 2004 \text { [DIRS 169131], } \\
\text { Sections } 6.4,6.6 .5 .1\end{array}$ & 6.2 .19 & $\begin{array}{l}\text { Matrix imbibition is not included in calculation } \\
\text { of seepage from fractures, but is included in } \\
\text { calculation of percolation flux. }\end{array}$ \\
\hline $\begin{array}{l}\text { BSC } 2004 \text { [DIRS 169131], } \\
\text { Sections 6.3.2, 6.4.3.3, } \\
6.5 .2\end{array}$ & 6.2 .20 & $\begin{array}{l}\text { Inclusion of condensation zone in seepage } \\
\text { abstraction }\end{array}$ \\
\hline $\begin{array}{l}\text { BSC } 2004 \text { [DIRS 169131], } \\
\text { Sections 6.4.3, 6.5.2 }\end{array}$ & 6.2 .21 & $\begin{array}{l}\text { Inclusion of re-saturation and reflux in } \\
\text { seepage abstraction }\end{array}$ \\
\hline $\begin{array}{l}\text { BSC } 2004 \text { [DIRS 169131], } \\
\text { Section 6.4.1.1, } \\
\text { Table 6.6-1 }\end{array}$ & 6.2 .23 & $\begin{array}{l}\text { Inclusion of film flow in fractures in seepage } \\
\text { abstraction }\end{array}$ \\
\hline $\begin{array}{l}\text { BSC } 2004 \text { [DIRS 169131], } \\
\text { Sections 6.4.1, 6.4.2, } 6.4 .3\end{array}$ & 6.2 .25 & $\begin{array}{l}\text { Inclusion of flow diversion around drifts, and } \\
\text { of drift collapse, in seepage abstraction }\end{array}$ \\
\hline $\begin{array}{l}\text { BSC } 2004 \text { [DIRS 169131], } \\
\text { Sections 6.4.3, 6.4.4 }\end{array}$ & 6.2 .34 & Inclusion of natural geothermal gradient \\
\hline $\begin{array}{l}\text { BSC } 2004 \text { [DIRS 169131], } \\
\text { Sections 6.3.2, 6.4.3.3, } \\
6.5 .2\end{array}$ & 6.2 .35 & Inclusion of heat pipe effect \\
\hline $\begin{array}{l}\text { BSC } 2004 \text { [DIRS 169131], } \\
\text { Sections 6.4.3.3, 6.5.2 }\end{array}$ & 6.2 .36 & Inclusion of geosphere dryout \\
\hline $\begin{array}{l}\text { BSC } 2004 \text { [DIRS 169855], } \\
\text { Entire }\end{array}$ & $\begin{array}{l}\text { 6.2.2, 6.2.3, } 6.2 .10 \\
6.2 .11,6.2 .37\end{array}$ & Stratigraphic sequence \\
\hline $\begin{array}{l}\text { BSC } 2004 \text { [DIRS 169857], } \\
\text { Section } 6.3\end{array}$ & 6.2 .2 & Calibration of fracture properties \\
\hline $\begin{array}{l}\text { BSC } 2004 \text { [DIRS 169857], } \\
\text { Section 6.3.4 }\end{array}$ & 6.2 .3 & Calibration of fault properties \\
\hline $\begin{array}{l}\text { BSC } 2004 \text { [DIRS 169857], } \\
\text { Section } 6.1 .4\end{array}$ & 6.2 .10 & $\begin{array}{l}\text { Treatment of stratigraphy on calibration of } \\
\text { flow model }\end{array}$ \\
\hline $\begin{array}{l}\text { BSC } 2004 \text { [DIRS 169857], } \\
\text { Section } 6.3\end{array}$ & 6.2 .11 & Calibration of rock properties \\
\hline $\begin{array}{l}\text { BSC } 2004 \text { [DIRS 169857], } \\
\text { Section } 6.1 .4,6.3 .2\end{array}$ & 6.2 .15 & $\begin{array}{l}\text { Treatment of flow focusing in model } \\
\text { calibration, calibration of active-fracture } \\
\text { parameter }\end{array}$ \\
\hline $\begin{array}{l}\text { BSC } 2004 \text { [DIRS 169857], } \\
\text { Section } 6.1 .4,6.3\end{array}$ & 6.2 .13 & Calibration of unsaturated flow parameters \\
\hline $\begin{array}{l}\text { BSC } 2004 \text { [DIRS 169857], } \\
\text { Section } 6.1 .4,6.3\end{array}$ & 6.2 .18 & $\begin{array}{l}\text { Calibration of parameters to simulate fracture } \\
\text { flow }\end{array}$ \\
\hline $\begin{array}{l}\text { BSC } 2004 \text { [DIRS 169857], } \\
\text { Section } 6.1 .5\end{array}$ & 6.2 .19 & $\begin{array}{l}\text { Treatment of matrix imbibition in model } \\
\text { calibration }\end{array}$ \\
\hline $\begin{array}{l}\text { BSC } 2004 \text { [DIRS 169858], } \\
\text { Section } 6.2\end{array}$ & 6.2 .20 & $\begin{array}{l}\text { Treatment of condensation zone in post } \\
\text { processing of } \mathrm{THC} \text { simulations }\end{array}$ \\
\hline $\begin{array}{l}\text { BSC } 2004 \text { [DIRS 169858], } \\
\text { Section 6.2.3.1 }\end{array}$ & 6.2 .21 & $\begin{array}{l}\text { Treatment of resaturation of dryout zone in } \\
\text { post processing of THC simulations }\end{array}$ \\
\hline $\begin{array}{l}\text { BSC } 2004 \text { [DIRS 169858], } \\
\text { Section } 6.2 .3\end{array}$ & 6.2 .27 & $\begin{array}{l}\text { Treatment of re-dissolution of precipitates in } \\
\text { post processing of } \mathrm{THC} \text { simulations }\end{array}$ \\
\hline $\begin{array}{l}\text { BSC } 2004 \text { [DIRS 169858], } \\
\text { Section } 6.2\end{array}$ & 6.2 .32 & $\begin{array}{l}\text { Treatment of seepage chemistry in post } \\
\text { processing of THC simulations }\end{array}$ \\
\hline $\begin{array}{l}\text { BSC } 2004 \text { [DIRS 169861], } \\
\text { Sections 6.1.5, 6.2.3 }\end{array}$ & 6.2 .2 & Treatment of fractures in the UZ flow model \\
\hline
\end{tabular}


Table 4-1. Inputs Used to Demonstrate Disposition of Included FEPs (Continued)

\begin{tabular}{|c|c|c|}
\hline Source $^{a}$ & $\begin{array}{l}\text { Used in Section } \\
\text { Number }\end{array}$ & Description \\
\hline $\begin{array}{l}\text { BSC } 2004 \text { [DIRS 169861], } \\
\text { Sections 6.1.5, 6.2.2, 6.3.3, } \\
6.7 .3\end{array}$ & 6.2 .3 & $\begin{array}{l}\text { Treatment of faults, water influx at the } \\
\text { repository, and diffusion in the UZ flow model }\end{array}$ \\
\hline $\begin{array}{l}\text { BSC } 2004 \text { [DIRS 169861], } \\
\text { Sections 6.1.4, } 6.2 .5\end{array}$ & 6.2 .4 & $\begin{array}{l}\text { Treatment of climate change in UZ flow } \\
\text { model }\end{array}$ \\
\hline $\begin{array}{l}\text { BSC } 2004 \text { [DIRS 169861], } \\
\text { Section 6.6.3 }\end{array}$ & 6.2 .5 & Effects of water table rise on UZ flow \\
\hline $\begin{array}{l}\text { BSC } 2004 \text { [DIRS 169861], } \\
\text { Section } 6.6\end{array}$ & 6.2 .6 & $\begin{array}{l}\text { Treatment of climate modification and } \\
\text { increased recharge in the UZ flow model }\end{array}$ \\
\hline $\begin{array}{l}\text { BSC } 2004 \text { [DIRS 169861], } \\
\text { Section 6.6.3 }\end{array}$ & 6.2 .7 & $\begin{array}{l}\text { Development of flow fields representing } \\
\text { water influx at repository }\end{array}$ \\
\hline $\begin{array}{l}\text { BSC } 2004 \text { [DIRS 169861], } \\
\text { Section 6.1.1, 6.1.2 }\end{array}$ & 6.2 .10 & $\begin{array}{l}\text { Treatment of stratigraphy in the UZ flow } \\
\text { model }\end{array}$ \\
\hline $\begin{array}{l}\text { BSC } 2004 \text { [DIRS 169861], } \\
\text { Section } 6.1 .5\end{array}$ & 6.2 .11 & $\begin{array}{l}\text { Treatment of rock properties in the UZ flow } \\
\text { model }\end{array}$ \\
\hline $\begin{array}{l}\text { BSC } 2004 \text { [DIRS 169861], } \\
\text { Sections 6.1.3, 6.1.4 }\end{array}$ & 6.2 .12 & $\begin{array}{l}\text { Effects of infiltration are linked to UZ flow } \\
\text { model }\end{array}$ \\
\hline $\begin{array}{l}\text { BSC } 2004 \text { [DIRS 169861], } \\
\text { Sections } 6.2,6.6,6.7\end{array}$ & 6.2 .13 & $\begin{array}{l}\text { Treatment of unsaturated groundwater flow } \\
\text { in the UZ flow model }\end{array}$ \\
\hline $\begin{array}{l}\text { BSC } 2004 \text { [DIRS 169861], } \\
\text { Section } 6.2 .5\end{array}$ & 6.2 .14 & $\begin{array}{l}\text { Treatment of capillary rise in the UZ flow } \\
\text { model }\end{array}$ \\
\hline $\begin{array}{l}\text { BSC } 2004 \text { [DIRS 169861], } \\
\text { Sections 6.1.2, 6.6.3, 6.7.3 }\end{array}$ & 6.2 .15 & $\begin{array}{l}\text { Treatment of flow focusing in the UZ flow } \\
\text { model }\end{array}$ \\
\hline $\begin{array}{l}\text { BSC } 2004 \text { [DIRS 169861], } \\
\text { Sections } 6.2 .2,6.2 .3,6.2 .5 \\
6.6 .2,6.6 .3\end{array}$ & 6.2 .17 & $\begin{array}{l}\text { Treatment of perched water in the UZ flow } \\
\text { model }\end{array}$ \\
\hline $\begin{array}{l}\text { BSC } 2004 \text { [DIRS 169861], } \\
\text { Section } 6.6 .3\end{array}$ & 6.2 .18 & $\begin{array}{l}\text { Fracture-continuum flow fields output by the } \\
\text { UZ flow model }\end{array}$ \\
\hline $\begin{array}{l}\text { BSC } 2004 \text { [DIRS 169861], } \\
\text { Section } 6.6\end{array}$ & 6.2 .19 & $\begin{array}{l}\text { Treatment of matrix imbibition in the UZ flow } \\
\text { model }\end{array}$ \\
\hline $\begin{array}{l}\text { BSC } 2004 \text { [DIRS 169861], } \\
\text { Section } 6.6 .3\end{array}$ & 6.2 .24 & $\begin{array}{l}\text { Treatment of lateral flow from Solitario } \\
\text { Canyon Fault }\end{array}$ \\
\hline $\begin{array}{l}\text { BSC } 2004 \text { [DIRS 169861], } \\
\text { Section } 6.3\end{array}$ & 6.2 .34 & $\begin{array}{l}\text { Treatment of natural geothermal effects in } \\
\text { the UZ flow model }\end{array}$ \\
\hline $\begin{array}{l}\text { BSC } 2004 \text { [DIRS 169861], } \\
\text { Section } 6.1 .1\end{array}$ & 6.2 .37 & $\begin{array}{l}\text { Incorporation of topography and morphology } \\
\text { in UZ flow model through the grid. }\end{array}$ \\
\hline $\begin{array}{l}\text { BSC } 2004 \text { [DIRS 169861], } \\
\text { Sections } 6.1 .3,6.1 .4\end{array}$ & 6.2 .38 & $\begin{array}{l}\text { Treatment of precipitation through the } \\
\text { infiltration model in the UZ flow model }\end{array}$ \\
\hline $\begin{array}{l}\text { BSC } 2004 \text { [DIRS 169861], } \\
\text { Sections } 6.1 .3,6.1 .4\end{array}$ & 6.2 .39 & $\begin{array}{l}\text { Treatment of surface runoff and flooding } \\
\text { through the infiltration model in the UZ flow } \\
\text { model }\end{array}$ \\
\hline $\begin{array}{l}\text { BSC } 2004 \text { [DIRS 169861], } \\
\text { Section } 6.1 .4\end{array}$ & 6.2 .40 & $\begin{array}{l}\text { Treatment of infiltration and recharge in the } \\
\text { UZ flow model }\end{array}$ \\
\hline $\begin{array}{l}\text { BSC } 2004 \text { [DIRS 170002], } \\
\text { Section } 6.6\end{array}$ & 6.2 .4 & Treatment of climate change \\
\hline $\begin{array}{l}\text { BSC } 2004 \text { [DIRS 170004], } \\
\text { Section } 6.1,6.2\end{array}$ & $6.2 .2,6.2 .13$ & $\begin{array}{l}\text { Data used to derive seepage-relevant } \\
\text { parameters }\end{array}$ \\
\hline $\begin{array}{l}\text { BSC } 2004 \text { [DIRS 170004], } \\
\text { Section } 6.6\end{array}$ & 6.2 .2 & Data describing fracture-matrix interaction \\
\hline
\end{tabular}


Table 4-1. Inputs Used to Demonstrate Disposition of Included FEPs (Continued)

\begin{tabular}{|c|c|c|}
\hline Source $^{a}$ & $\begin{array}{l}\text { Used in Section } \\
\text { Number }\end{array}$ & Description \\
\hline $\begin{array}{l}\text { BSC } 2004 \text { [DIRS 170004], } \\
\text { Section } 6.1\end{array}$ & 6.2 .9 & $\begin{array}{l}\text { Measurements that include the effects of } \\
\text { construction }\end{array}$ \\
\hline $\begin{array}{l}\text { BSC } 2004 \text { [DIRS 170004], } \\
\text { Sections } 6.1,6.2\end{array}$ & 6.2 .13 & Data describing unsaturated flow \\
\hline $\begin{array}{l}\text { BSC } 2004 \text { [DIRS 170004], } \\
\text { Section } 6.4\end{array}$ & 6.2 .19 & Data from matrix imbibition tests \\
\hline $\begin{array}{l}\text { BSC } 2004 \text { [DIRS 170004], } \\
\text { Section } 6.2\end{array}$ & $6.2 .23,6.2 .25$ & $\begin{array}{l}\text { Measurements that demonstrate flow } \\
\text { diversion around niches and include the } \\
\text { effects of film flow into niches }\end{array}$ \\
\hline $\begin{array}{l}\text { BSC } 2004 \text { [DIRS 170004], } \\
\text { Section } 6.12\end{array}$ & 6.2 .40 & Infiltration test data \\
\hline $\begin{array}{l}\text { BSC } 2004 \text { [DIRS 170006], } \\
\text { Section } 6.4 .3\end{array}$ & 6.2 .31 & Colloid retardation factors \\
\hline $\begin{array}{l}\text { BSC } 2004 \text { [DIRS 170007], } \\
\text { Section 6.1, Appendix B }\end{array}$ & 6.2 .2 & Treatment of fractures in infiltration model \\
\hline $\begin{array}{l}\text { BSC } 2004 \text { [DIRS 170007], } \\
\text { Section } 6.9\end{array}$ & 6.2 .4 & $\begin{array}{l}\text { Inclusion of future climate states in infiltration } \\
\text { model }\end{array}$ \\
\hline $\begin{array}{l}\text { BSC } 2004 \text { [DIRS 170007], } \\
\text { Section 6.3.4 }\end{array}$ & 6.2 .12 & $\begin{array}{l}\text { Treatment of saturated flow at } \\
\text { bedrock/alluvium contact in infiltration model }\end{array}$ \\
\hline $\begin{array}{l}\text { BSC } 2004 \text { [DIRS 170007], } \\
\text { Section } 6.11\end{array}$ & $6.2 .6,6.2 .7$ & $\begin{array}{l}\text { Percolation flux and increased percolation } \\
\text { due to climate change in infiltration model }\end{array}$ \\
\hline $\begin{array}{l}\text { BSC } 2004 \text { [DIRS 170007], } \\
\text { Section } 6.6\end{array}$ & 6.2 .10 & Treatment of stratigraphy in infiltration model \\
\hline $\begin{array}{l}\text { BSC } 2004 \text { [DIRS 170007], } \\
\text { Section 6.6.4, Appendix B }\end{array}$ & 6.2 .11 & $\begin{array}{l}\text { Treatment of rock properties in infiltration } \\
\text { model }\end{array}$ \\
\hline $\begin{array}{l}\text { BSC } 2004 \text { [DIRS 170007], } \\
\text { Sections 6.1.2, } 6.11\end{array}$ & 6.2 .13 & $\begin{array}{l}\text { Treatment of unsaturated flow in infiltration } \\
\text { model }\end{array}$ \\
\hline $\begin{array}{l}\text { BSC } 2004 \text { [DIRS 170007], } \\
\text { Sections } 6.1 .2,6.3 .4\end{array}$ & 6.2 .18 & Treatment of fracture flow in infiltration model \\
\hline $\begin{array}{l}\text { BSC } 2004 \text { [DIRS 170007], } \\
\text { Sections 6.5.3, 6.6.1, } \\
\text { Appendix D }\end{array}$ & 6.2 .37 & $\begin{array}{l}\text { Treatment of topography and morphology in } \\
\text { infiltration model }\end{array}$ \\
\hline $\begin{array}{l}\text { BSC } 2004 \text { [DIRS 170007], } \\
\text { Sections } 6.4,6.9\end{array}$ & 6.2 .38 & Treatment of precipitation in infiltration model \\
\hline $\begin{array}{l}\text { BSC } 2004 \text { [DIRS 170007], } \\
\text { Section } 6.4\end{array}$ & 6.2 .39 & $\begin{array}{l}\text { Treatment of surface runoff and flooding in } \\
\text { infiltration model }\end{array}$ \\
\hline $\begin{array}{l}\text { BSC } 2004 \text { [DIRS 170007], } \\
\text { Section } 6.11\end{array}$ & 6.2 .40 & $\begin{array}{l}\text { Treatment of infiltration and recharge in } \\
\text { infiltration model }\end{array}$ \\
\hline $\begin{array}{l}\text { BSC } 2004 \text { [DIRS 170035], } \\
\text { Section 6.2.2 }\end{array}$ & 6.2 .29 & Scale dependency of matrix diffusion \\
\hline $\begin{array}{l}\text { BSC } 2004 \text { [DIRS 170035], } \\
\text { Sections } 6.3,7\end{array}$ & 6.2 .13 & Active-fracture model \\
\hline $\begin{array}{l}\text { BSC } 2004 \text { [DIRS 170035], } \\
\text { Sections 6.1.7, 6.3.7, } 7\end{array}$ & 6.2 .15 & Treatment of focusing of unsaturated flow \\
\hline $\begin{array}{l}\text { BSC } 2004 \text { [DIRS 170035], } \\
\text { Section } 6.3\end{array}$ & 6.2 .18 & Treatment of fracture flow \\
\hline $\begin{array}{l}\text { BSC } 2004 \text { [DIRS 170035], } \\
\text { Section } 6.2 .3\end{array}$ & 6.2 .30 & Treatment of sorption \\
\hline
\end{tabular}


Table 4-1. Inputs Used to Demonstrate Disposition of Included FEPs (Continued)

\begin{tabular}{|c|c|c|}
\hline Source $^{a}$ & $\begin{array}{l}\text { Used in Section } \\
\text { Number }\end{array}$ & Description \\
\hline $\begin{array}{l}\text { BSC } 2004 \text { [DIRS 170035], } \\
\text { Section 6.2.4 }\end{array}$ & 6.2 .31 & Treatment of colloid transport \\
\hline $\begin{array}{l}\text { LB0406U0075FCS.002 } \\
\text { [DIRS 170712] }\end{array}$ & 6.2 .7 & Distribution of flow-focusing factor \\
\hline $\begin{array}{l}\text { LA0407BR831371.001 } \\
\text { [DIRS 170806] }\end{array}$ & $\begin{array}{l}6.2 .2,6.2 .11,6.2 .15 \\
6.2 .18,6.2 .29,6.2 .30\end{array}$ & $\begin{array}{l}\text { UZ transport abstraction model, transport } \\
\text { parameters and base case simulation results }\end{array}$ \\
\hline $\begin{array}{l}\text { LA0408AM831341.001 } \\
\text { [DIRS 171584] }\end{array}$ & $6.2 .26,6.2 .28,6.2 .30$ & $\begin{array}{l}\text { UZ distribution coefficients }\left(\mathrm{K}_{d} \mathrm{~S}\right) \text { for } \mathrm{U}, \mathrm{Np} \text {, } \\
\mathrm{Pu}, \mathrm{Am}, \mathrm{Pa}, \mathrm{Cs}, \mathrm{Sr}, \mathrm{Ra} \text {, and } \mathrm{Th}\end{array}$ \\
\hline $\begin{array}{l}\text { BSC } 2004 \text { [DIRS 171764], } \\
\text { Sections } 6.3,6.5\end{array}$ & 6.2 .2 & $\begin{array}{l}\text { Development of seepage relevant } \\
\text { parameters for fracture continuum }\end{array}$ \\
\hline $\begin{array}{l}\text { BSC } 2004 \text { [DIRS 171764], } \\
\text { Sections } 6.3,6.6,6.8\end{array}$ & 6.2 .8 & $\begin{array}{l}\text { Treatment of enhanced influx in the seepage } \\
\text { calibration model }\end{array}$ \\
\hline $\begin{array}{l}\text { BSC } 2004 \text { [DIRS 171764], } \\
\text { Sections } 6.3,6.5 .2,6.6\end{array}$ & 6.2 .9 & $\begin{array}{l}\text { Mechanical effects of construction are } \\
\text { included in the seepage calibration model }\end{array}$ \\
\hline $\begin{array}{l}\text { BSC } 2004 \text { [DIRS 171764], } \\
\text { Section } 6.5 .2\end{array}$ & 6.2 .11 & $\begin{array}{l}\text { Location-specific rock properties are included } \\
\text { in seepage calibration model }\end{array}$ \\
\hline $\begin{array}{l}\text { BSC } 2004 \text { [DIRS 171764], } \\
\text { Sections 6.3.2, 6.6.1.1 }\end{array}$ & 6.2 .13 & $\begin{array}{l}\text { Unsaturated flow processes are accounted } \\
\text { for in the seepage calibration model }\end{array}$ \\
\hline $\begin{array}{l}\text { BSC } 2004 \text { [DIRS 171764], } \\
\text { Sections } 6.3,6.6\end{array}$ & 6.2 .15 & Flow focusing developed from heterogeneity \\
\hline $\begin{array}{l}\text { BSC } 2004 \text { [DIRS 171764], } \\
\text { Sections } 6.3,6.6\end{array}$ & 6.2 .18 & $\begin{array}{l}\text { Fracture flow is included in the seepage } \\
\text { calibration model }\end{array}$ \\
\hline $\begin{array}{l}\text { BSC } 2004 \text { [DIRS 171764], } \\
\text { Sections 6.3.3.2 }\end{array}$ & 6.2 .19 & $\begin{array}{l}\text { Matrix imbibition is neglected in the seepage } \\
\text { calibration model }\end{array}$ \\
\hline $\begin{array}{l}\text { BSC } 2004 \text { [DIRS 171764], } \\
\text { Sections } 6.1 .2,6.3 .3,6.6 .3\end{array}$ & 6.2 .23 & $\begin{array}{l}\text { Film flow is included in the seepage } \\
\text { calibration model }\end{array}$ \\
\hline $\begin{array}{l}\text { BSC } 2004 \text { [DIRS 171764], } \\
\text { Sections } 6.3,6.6,6.8\end{array}$ & 6.2 .25 & $\begin{array}{l}\text { Flow diversion is included in the seepage } \\
\text { calibration model }\end{array}$ \\
\hline $\begin{array}{l}\text { BSC } 2005 \text { [DIRS 172232], } \\
\text { Sections } 6.1 .1,6.2 .1 .4\end{array}$ & 6.2 .8 & $\begin{array}{l}\text { Grid for simulation of thermal seepage } \\
\text { includes drift geometry }\end{array}$ \\
\hline $\begin{array}{l}\text { BSC } 2005 \text { [DIRS 172232] } \\
\text { Sections 4.1.1.3, 6.2.1.3.3 }\end{array}$ & 6.2 .1 & $\begin{array}{l}\text { Simulation of thermal seepage includes heat } \\
\text { removal by preclosure ventilation }\end{array}$ \\
\hline $\begin{array}{l}\text { BSC } 2005 \text { [DIRS 172232], } \\
\text { Section } 6.2\end{array}$ & $6.2 .4,6.2 .20,6.2 .21$ & $\begin{array}{l}\text { Simulation of thermal seepage includes } \\
\text { condensation zone and changes in } \\
\text { percolation flux resulting from climate change }\end{array}$ \\
\hline $\begin{array}{l}\text { BSC } 2005 \text { [DIRS 172232], } \\
\text { Section 6.2.2.2 }\end{array}$ & 6.2 .7 & $\begin{array}{l}\text { Refluxing condensate contributes to } \\
\text { percolation flux }\end{array}$ \\
\hline $\begin{array}{l}\text { BSC } 2005 \text { [DIRS 172862], } \\
\text { Section 4.1.7, } 6.5\end{array}$ & 6.2 .1 & $\begin{array}{l}\text { Treatment of preclosure ventilation in THC } \\
\text { modeling }\end{array}$ \\
\hline $\begin{array}{l}\text { BSC } 2005 \text { [DIRS 172862], } \\
\text { Sections } 6.2 .1,6.4 .3,6.4 .4 \\
6.4 .7\end{array}$ & $6.2 .2,6.2 .18$ & Treatment of fracture flow in THC modeling \\
\hline $\begin{array}{l}\text { BSC } 2005 \text { [DIRS 172862], } \\
\text { Sections } 6.2 .1 .3,6.5 .2 \\
\end{array}$ & $6.2 .4,6.2 .6$ & $\begin{array}{l}\text { Treatment of climate change in THC } \\
\text { modeling }\end{array}$ \\
\hline $\begin{array}{l}\text { BSC } 2005 \text { [DIRS 172862], } \\
\text { Sections } 6.2 .1,6.2 .1 .3 \\
6.5 .2,6.5 .5 .2\end{array}$ & 6.2 .7 & $\begin{array}{l}\text { Percolation flux increases caused by climate } \\
\text { change and by contribution of reflux to } \\
\text { percolation flux }\end{array}$ \\
\hline $\begin{array}{l}\text { BSC } 2005 \text { [DIRS 172862], } \\
\text { Sections 4.1.2, } 6.5 .1\end{array}$ & 6.2 .10 & Treatment of stratigraphy in THC modeling \\
\hline
\end{tabular}


Table 4-1. Inputs Used to Demonstrate Disposition of Included FEPs (Continued)

\begin{tabular}{|c|c|c|}
\hline Source $^{a}$ & $\begin{array}{c}\text { Used in Section } \\
\text { Number }\end{array}$ & Description \\
\hline $\begin{array}{l}\text { BSC } 2005 \text { [DIRS 172862], } \\
\text { Sections 6.4.7, 6.5.5.3, } \\
\text { Table 6.4-1 }\end{array}$ & 6.2 .11 & $\begin{array}{l}\text { Treatment of rock properties for THC } \\
\text { modeling }\end{array}$ \\
\hline $\begin{array}{l}\text { BSC } 2005 \text { [DIRS 172862], } \\
\text { Section 6.2.1 }\end{array}$ & 6.2 .13 & $\begin{array}{l}\text { Treatment of unsaturated flow and matrix } \\
\text { imbibition in THC modeling }\end{array}$ \\
\hline $\begin{array}{l}\text { BSC } 2005 \text { [DIRS 172862], } \\
\text { Section } 6.3\end{array}$ & 6.2 .15 & $\begin{array}{l}\text { Treatment of matrix imbibition in } \mathrm{THC} \\
\text { modeling }\end{array}$ \\
\hline $\begin{array}{l}\text { BSC } 2005 \text { [DIRS 172862], } \\
\text { Section 6.2.1; Figure 6.2.3 }\end{array}$ & 6.2 .19 & $\begin{array}{l}\text { Treatment of matrix imbibition in THC } \\
\text { modeling }\end{array}$ \\
\hline $\begin{array}{l}\text { BSC } 2005 \text { [DIRS 172862], } \\
\text { Sections } 6.2,6.5,6.6\end{array}$ & 6.2 .20 & Treatment of condensation in THC modeling \\
\hline $\begin{array}{l}\text { BSC } 2005 \text { [DIRS 172862], } \\
\text { Sections 6.2.1, 6.5.5 }\end{array}$ & 6.2 .21 & $\begin{array}{l}\text { Treatment of resaturation of the rock } \\
\text { following dryout in THC modeling }\end{array}$ \\
\hline $\begin{array}{l}\text { BSC } 2005 \text { [DIRS 172862], } \\
\text { Sections 6.2.2, 6.5.5; Table } \\
6.2-1\end{array}$ & 6.2 .26 & $\begin{array}{l}\text { Treatment of variability of groundwater } \\
\text { chemistry in THC modeling }\end{array}$ \\
\hline $\begin{array}{l}\text { BSC } 2005 \text { [DIRS 172862], } \\
\text { Sections 6.4.4, 6.4.5, } \\
6.5 .5 .2\end{array}$ & 6.2 .27 & $\begin{array}{l}\text { Treatment of redissolution of precipitates in } \\
\text { THC modeling }\end{array}$ \\
\hline $\begin{array}{l}\text { BSC } 2005 \text { [DIRS 172862], } \\
\text { Sections 6.2.1.2, 6.2.2.1, } \\
6.2 .2 .2 ; \text { Table } 6.2-1\end{array}$ & 6.2 .32 & $\begin{array}{l}\text { Treatment of THC processes leading to } \\
\text { simulation of seepage chemistry }\end{array}$ \\
\hline $\begin{array}{l}\text { BSC } 2005 \text { [DIRS 172862], } \\
\text { Section 6.5.2 }\end{array}$ & 6.2 .34 & $\begin{array}{l}\text { Treatment of natural geothermal gradient in } \\
\text { THC modeling }\end{array}$ \\
\hline $\begin{array}{l}\text { BSC } 2005 \text { [DIRS 172862], } \\
\text { Sections 6.2.1.1, 6.2.1.2, } \\
6.5 .5 .2 .2\end{array}$ & 6.2 .35 & $\begin{array}{l}\text { Treatment of heat pipes and buoyant flow in } \\
\text { THC modeling }\end{array}$ \\
\hline $\begin{array}{l}\text { BSC } 2005 \text { [DIRS 172862], } \\
\text { Sections 6.2.1, 6.5.5.1 }\end{array}$ & 6.2 .36 & $\begin{array}{l}\text { Treatment of geosphere dryout in THC } \\
\text { modeling }\end{array}$ \\
\hline $\begin{array}{l}\text { BSC } 2005 \text { [DIRS 172862], } \\
\text { Table 6.2-1, Fig. 6.2-4 }\end{array}$ & 6.2 .40 & $\begin{array}{l}\text { Treatment of infiltration and recharge in THC } \\
\text { modeling }\end{array}$ \\
\hline $\begin{array}{l}\text { LB0407AMRU0120.001 } \\
\text { [DIRS 173280] }\end{array}$ & $\begin{array}{l}\text { 6.2.2, 6.2.8, 6.2.11, } \\
6.2 .13,6.2 .15,6.2 .18 \\
6.2 .25\end{array}$ & Seepage model lookup tables for TSPA \\
\hline $\begin{array}{l}\text { LB0407AMRU0120.002 } \\
\text { [DIRS 173308] }\end{array}$ & $\begin{array}{l}\text { 6.2.2, 6.2.8, 6.2.11, } \\
6.2 .13,6.2 .15,6.2 .18 \\
6.2 .25\end{array}$ & Seepage results for collapsed drift scenario \\
\hline $\begin{array}{l}\text { BSC } 2004 \text { [DIRS 173871], } \\
\text { Entire }\end{array}$ & 6.9 .7 & $\begin{array}{l}\text { Use of cementitious materials for ground } \\
\text { support }\end{array}$ \\
\hline $\begin{array}{l}\text { BSC } 2005 \text { [DIRS 173944], } \\
\text { Section 5.1.4 }\end{array}$ & 6.2 .4 & Timing of climate change for TSPA \\
\hline $\begin{array}{l}\text { BSC } 2005 \text { [DIRS 173980], } \\
\text { Sections 6.4, 6.4.1, 6.4.2, } \\
6.5 .1\end{array}$ & 6.2 .22 & Particle-tracking methodology \\
\hline $\begin{array}{l}\text { BSC } 2005 \text { [DIRS 173980], } \\
\text { Sections 6.4.3, 6.5.4, 6.5.8, } \\
6.5 .12\end{array}$ & 6.2 .30 & $\begin{array}{l}\text { Treatment of sorption in particle-tracking } \\
\text { model }\end{array}$ \\
\hline $\begin{array}{l}\text { BSC } 2005 \text { [DIRS 173980], } \\
\text { Section 6.4.4 }\end{array}$ & 6.2 .41 & $\begin{array}{l}\text { Treatment of radioactive decay and ingrowth } \\
\text { in particle-tracking model }\end{array}$ \\
\hline
\end{tabular}


Table 4-1. Inputs Used to Demonstrate Disposition of Included FEPs (Continued)

\begin{tabular}{|c|c|c|}
\hline Source $^{a}$ & $\begin{array}{c}\text { Used in Section } \\
\text { Number }\end{array}$ & Description \\
\hline $\begin{array}{l}\text { BSC } 2005 \text { [DIRS 173980], } \\
\text { Section 6.5.1 }\end{array}$ & $\begin{array}{l}6.2 .3,6.2 .6,6.2 .10 \\
6.2 .13,6.2 .17,6.2 .18 \\
6.2 .19\end{array}$ & $\begin{array}{l}\text { Use of pregenerated flow fields output by UZ } \\
\text { flow model for particle-tracking simulations }\end{array}$ \\
\hline $\begin{array}{l}\text { BSC } 2005 \text { [DIRS 173980], } \\
\text { Sections 6.5.1, 6.5.7 }\end{array}$ & $6.2 .2,6.2 .3$ & $\begin{array}{l}\text { Treatment of fractures for radionuclide } \\
\text { transport in the rock }\end{array}$ \\
\hline $\begin{array}{l}\text { BSC } 2005 \text { [DIRS 173980], } \\
\text { Sections } 6.4 .6,6.4 .7\end{array}$ & 6.2 .16 & Treatment of radionuclide transport in TSPA \\
\hline $\begin{array}{l}\text { BSC } 2005 \text { [DIRS 173980], } \\
\text { Entire }\end{array}$ & $\begin{array}{l}6.2 .2,6.2 .5,6.2 .11 \\
6.2 .17,6.2 .30,6.2 .31\end{array}$ & $\begin{array}{l}\text { Treatment of perched water, diffusion and } \\
\text { radioactive decay for radionuclide transport } \\
\text { in the rock }\end{array}$ \\
\hline $\begin{array}{l}\text { BSC } 2005 \text { [DIRS 173980], } \\
\text { Section 6.5.15 }\end{array}$ & 6.2 .7 & $\begin{array}{l}\text { Tracked-particle releases dependent upon } \\
\text { percolation flux }\end{array}$ \\
\hline $\begin{array}{l}\text { BSC } 2005 \text { [DIRS 173980], } \\
\text { Section } 6.4 .5\end{array}$ & $6.2 .29,6.2 .30,6.2 .31$ & $\begin{array}{l}\text { Treatment of colloid-facilitated radionuclide } \\
\text { transport in the rock }\end{array}$ \\
\hline $\begin{array}{l}\text { BSC } 2005 \text { [DIRS 173980], } \\
\text { Entire }\end{array}$ & 6.2 .22 & $\begin{array}{l}\text { Treatment of advection and dispersion for } \\
\text { radionuclide transport in the rock }\end{array}$ \\
\hline $\begin{array}{l}\text { BSC } 2005 \text { [DIRS 173980], } \\
\text { Sections 6.4.4, 6.5.1.4 }\end{array}$ & 6.2 .41 & Treatment of radioactive decay and ingrowth \\
\hline $\begin{array}{l}\text { BSC } 2005 \text { [DIRS 173980], } \\
\text { Sections 6.5.4 }\end{array}$ & $6.2 .26,6.2 .28,6.2 .33$ & $\begin{array}{l}\text { Matrix adsorption coefficient used in particle } \\
\text { tracking model for TSPA }\end{array}$ \\
\hline $\begin{array}{l}\text { BSC } 2005 \text { [DIRS 173980], } \\
\text { Sections } 6.4 .5,6.5 .9\end{array}$ & 6.2 .31 & Fraction of unretarded colloids \\
\hline
\end{tabular}

a Sources are listed in order of DIRS number

DST=Drift Scale Test; FEHM=finite element heat and mass; LA=license application; $\mathrm{TH}=$ themalhydrologic; THC=themal-hydrologic-chemical; $\mathrm{THM}=$ thermal-hydrologic-mechanical; TSPA=total system performance assessment; UZ=unsaturated zone.

Section 4.1 identifies all direct inputs used in this FEP report. The direct inputs were obtained from controlled source documents and other appropriate sources in accordance with the controlling procedure LP-3.15Q-BSC. Section 4.2 identifies the FEP screening criteria described in 10 CFR Part 63 [DIRS 173273] along with the FEP screening criteria derived directly from 10 CFR Part 63 [DIRS 173273].

The direct inputs listed in Section 4.1 are appropriate for use, as discussed below:

Established facts: Richards (1931 [DIRS 104252], pp. 319-321) presents the commonly used conservation law for unsaturated single-phase flow based on the fact that for air and water in the unsaturated zone, capillary forces dominate the liquid pressure and the gas phase rapidly equilibrates such that a constant gas-phase pressure is suitable.

Perry and Chilton (1973 [DIRS 104946], Equation 5-215) present Stokes' law, which is the standard relationship used for settling of particles for which the Reynolds number is less than 0.1 (Vanoni 1977 [DIRS 164901], p. 23). The Reynolds number is sufficiently small for particles on the order of $1 \mu \mathrm{m}$ in diameter, as used in Section 6.4.4 (Vanoni 1977 [DIRS 164901], Figure 2.2). 
Bird et al. (1960 [DIRS 103524], Equation 16.5-4) present the Stokes-Einstein equation, which describes the diffusion of colloidal particles.

Repository design information: Repository design information is presented in controlled design drawings and requirements (BSC 2004 [DIRS 168370]; BSC 2004 [DIRS 168489]; BSC 2005 [DIRS 173498]; BSC 2004 [DIRS 172801]; BSC 2005 [DIRS 173871]; BSC 2005 [DIRS 174514], Sections 2.2, 3.1.1.13.1 through 3.1.1.13.3, and 3.1.1.16.6 through 3.1.1.16.8), which represent the best available information concerning repository system characteristics.

Site characterization information: Information on site characterization boreholes are provided in input DTNs: SNF40060298001.001 [DIRS 107372], MO9906GPS98410.000 [DIRS 109059], MO0004QGFMPICK.000 [DIRS 152554], and MO0010CPORGLOG.003 [DIRS 155959]. This is the best available information pertaining to location, stratigraphic units encountered and contact depths, and total borehole depth for the site characterization boreholes evaluated in Section 6.3.1.

Data qualified within this report: Unqualified data used as direct input for this report are qualified in Appendix C, where their appropriateness for the intended purpose is documented.

All remaining direct inputs: All remaining direct inputs are from model and analysis reports qualified for use to support the Yucca Mountain license application. The information used as inputs from these reports pertain directly to the TSPA dispositions or screening arguments presented in Sections 6.2 through 6.9 and, therefore, are suitable for their intended use.

\subsection{DIRECT INPUTS}

The LA FEP list and screening (DTN: MO0501SEPFEPLA.001 [DIRS 172601]) was used as a direct input to provide the list of UZ FEPs for screening in this report. The LA FEP list and screening identifies a FEP report or a set of sharing FEP reports for each FEP. Direct inputs used for the exclusion of FEPs in Sections 6.3 through 6.9 are listed in Table 4-2. Several direct inputs in Table 4-2 have been qualified for use in accordance with LP-SIII.2Q-BSC, Qualification of Unqualified Data, or LP-SIII.9Q-BSC; the qualification reports are presented in Appendix C. 
Table 4-2. Direct Inputs Used for Exclusion of FEPs

\begin{tabular}{|c|c|c|c|}
\hline Source $^{a}$ & Type & $\begin{array}{l}\text { Used in } \\
\text { Section } \\
\text { Number }\end{array}$ & Description \\
\hline $\begin{array}{l}\text { DOE } 1988 \text { [DIRS 100282], } \\
\text { Section 1.1.3.3.2 }\end{array}$ & $\begin{array}{l}\text { Data qualified in accordance } \\
\text { with LP-SIII.2Q-BSC; see } \\
\text { Appendix C, Section C10. }\end{array}$ & 6.5 .1 & Mass wasting at Yucca Mountain \\
\hline $\begin{array}{l}\text { YMP } 1993 \text { [DIRS 100520], } \\
\text { Section } 3.4\end{array}$ & $\begin{array}{l}\text { Data qualified in accordance } \\
\text { with LP-SIII.2Q-BSC; see } \\
\text { Appendix C, Section C10. }\end{array}$ & $6.4 .1,6.5 .1$ & Erosion rate \\
\hline $\begin{array}{l}\text { YMP } 1993 \text { [DIRS 100520], } \\
\text { Section } 3.4\end{array}$ & $\begin{array}{l}\text { Data qualified in accordance } \\
\text { with LP-SIII.2Q-BSC; see } \\
\text { Appendix C, Section C10. }\end{array}$ & 6.5 .2 & Deposition rate \\
\hline $\begin{array}{l}\text { Carrigan et al. } 1991 \\
\text { [DIRS 100967], p. 1,159 }\end{array}$ & $\begin{array}{l}\text { Data qualified in accordance } \\
\text { with LP-SIII.2Q-BSC; see } \\
\text { Appendix C, Section C2. }\end{array}$ & 6.8 .3 & $\begin{array}{l}\text { Water table excursions due to a } \\
\text { fault slip }\end{array}$ \\
\hline $\begin{array}{l}\text { Stock and Healy } 1988 \\
\text { [DIRS 101022], pp. 87-92 }\end{array}$ & $\begin{array}{l}\text { Data qualified in accordance } \\
\text { with LP-SIII.2Q-BSC; see } \\
\text { Appendix C, Section C1. }\end{array}$ & 6.8 .3 & $\begin{array}{l}\text { Interpretation of stress } \\
\text { measurements at Yucca Mountain }\end{array}$ \\
\hline $\begin{array}{l}\text { Stock et al. } 1985 \\
\text { [DIRS 101027], } \\
\text { pp. 8691-8706 }\end{array}$ & $\begin{array}{l}\text { Data qualified in accordance } \\
\text { with LP-SIII.2Q-BSC; see } \\
\text { Appendix C, Section C1. }\end{array}$ & 6.8 .3 & $\begin{array}{l}\text { Residual stress field at Yucca } \\
\text { Mountain }\end{array}$ \\
\hline $\begin{array}{l}\text { YMP } 1995 \text { [DIRS 102215], } \\
\text { Sections } 2.5 .2 \text { and } 4.2\end{array}$ & $\begin{array}{l}\text { Data qualified in accordance } \\
\text { with LP-SIII.2Q-BSC; see } \\
\text { Appendix C, Section C10. }\end{array}$ & 6.5 .1 & $\begin{array}{l}\text { Effects of debris flows on erosion } \\
\text { processes }\end{array}$ \\
\hline $\begin{array}{l}\text { Bird et al. } 1960 \text { [DIRS } \\
\text { 103524], Equation 16.5-4 }\end{array}$ & Established fact & 6.4 .4 & Stokes-Einstein Equation \\
\hline $\begin{array}{l}\text { CRWMS M\&O } 1999 \\
\text { [DIRS 103618], Figure } 30\end{array}$ & $\begin{array}{l}\text { Data qualified in accordance } \\
\text { with LP-SIII.2Q-BSC; see } \\
\text { Appendix C, Section C5. }\end{array}$ & 6.9 .9 & Thermal effects on vegetation \\
\hline $\begin{array}{l}\text { Richards 1931 } \\
\text { [DIRS 104252], pp. } \\
319-321\end{array}$ & Established fact & 6.7 .1 & $\begin{array}{l}\text { Unsaturated flow mathematical } \\
\text { approximation }\end{array}$ \\
\hline $\begin{array}{l}\text { Perry and Chilton } 1973 \\
\text { [DIRS 104946], } \\
\text { Equation 5-215 }\end{array}$ & Established Fact & 6.4 .4 & Stokes' law \\
\hline $\begin{array}{l}\text { LB990701233129.001 } \\
\text { [DIRS 106785], file } \\
\text { 3d2kpa_pc1.mesh }\end{array}$ & Data & Appendix D & $\begin{array}{l}\text { Grid for calculations of transport } \\
\text { sensitivity to fracture aperture }\end{array}$ \\
\hline $\begin{array}{l}\text { SNF40060298001.001 } \\
\text { [DIRS 107372], Table } \\
\text { S98430_001 }\end{array}$ & Data & Table 6-6 & Stratigraphic contact depths \\
\hline $\begin{array}{l}\text { MO9906GPS98410.000 } \\
\text { [DIRS 109059], file } \\
\text { MO9906GPS98410.xls }\end{array}$ & Data & $\begin{array}{l}\text { 6.3.1; } \\
\text { Table 6-6 }\end{array}$ & Surface borehole coordinates \\
\hline
\end{tabular}


Table 4-2. Direct Inputs Used for Exclusion of FEPs (Continued)

\begin{tabular}{|c|c|c|c|}
\hline Source & Type & $\begin{array}{l}\text { Used in } \\
\text { Section } \\
\text { Number }\end{array}$ & Description \\
\hline $\begin{array}{l}\text { LA9908JC831321.001 } \\
\text { [DIRS 113495], files } \\
\text { G1.well, G2.well, G3.well, } \\
\text { G4.well, H3.well, H4.well, } \\
\text { H5.well, H6.well, } \\
\text { NRG6.well, NRG7.well, } \\
\text { SD12.well, SD6.well, } \\
\text { SD7.well, SD9.well, } \\
\text { UZ14.well, UZ16.well, } \\
\text { UZN31_32,well, WT1.well, } \\
\text { WT2.well, WT24.well }\end{array}$ & Data & 6.5 .3 & $\begin{array}{l}\text { Bulk mineral composition of Yucca } \\
\text { Mountain }\end{array}$ \\
\hline $\begin{array}{l}\text { LB990801233129.009 } \\
\text { [DIRS 118717], file } \\
\text { pa_glam1.dat }\end{array}$ & Data & Appendix D & $\begin{array}{l}\text { Fracture continuum hydraulic } \\
\text { properties }(\mathrm{k} \text { and } \alpha)\end{array}$ \\
\hline $\begin{array}{l}\text { Valentine et al. } 1998 \\
\text { [DIRS 119132], Chapter } 5\end{array}$ & $\begin{array}{l}\text { Data qualified in accordance } \\
\text { with LP-SIII.2Q-BSC; see } \\
\text { Appendix C, Section C3 }\end{array}$ & $6.8 .1,6.8 .4$ & $\begin{array}{l}\text { Mineral alteration resulting from } \\
\text { hydrothermal activity }\end{array}$ \\
\hline $\begin{array}{l}\text { MO9910MWDISMMM.003 } \\
\text { [DIRS 119199], file } \\
\text { rev3-results.txt }\end{array}$ & Data & 6.9 .16 & Location of zeolites in the UZ \\
\hline $\begin{array}{l}\text { Smyth } 1982 \\
\text { [DIRS 119483], p. } 201\end{array}$ & $\begin{array}{l}\text { Data qualified in accordance } \\
\text { with LP-SIII.2Q-BSC; see } \\
\text { Appendix C, Section C8 }\end{array}$ & 6.9 .16 & Zeolitic alteration temperature \\
\hline $\begin{array}{l}\text { LB990801233129.003 } \\
\text { [DIRS 122757], file } \\
\text { pa_pchm1.dat }\end{array}$ & Data & Appendix D & $\begin{array}{l}\text { Fracture continuum hydraulic } \\
\text { properties }(\mathrm{k} \text { and } \alpha)\end{array}$ \\
\hline $\begin{array}{l}\text { GS000308311221.004. } \\
\text { [DIRS 146853], file } \\
\text { GeoK.xls }\end{array}$ & Data & 6.8 .4 & Soil and bedrock permeability \\
\hline $\begin{array}{l}\text { LB9908T1233129.001 } \\
\text { [DIRS 147115], files } \\
\text { pchm1_tr1.out, } \\
\text { glam1_tr1.out }\end{array}$ & Data & Appendix D & SR transport breakthrough curves \\
\hline $\begin{array}{l}\text { GS000308311221.005 } \\
\text { [DIRS 147613], files } \\
\text { glaciall.dat, glacialm.dat, } \\
\text { glacialu.dat, modernl.dat, } \\
\text { modernm.dat, } \\
\text { modernu.dat, } \\
\text { monsoonl.dat, } \\
\text { monsoonm.dat, } \\
\text { monsoonu.dat }\end{array}$ & Data & 6.9 .17 & Infiltration flux \\
\hline $\begin{array}{l}\text { GS000308315121.003 } \\
\text { [DIRS 151139], file } \\
\text { MOL.20000316.0566 }\end{array}$ & Data & $6.4 .1,6.4 .2$ & $\begin{array}{l}\text { Identification of climate analogue } \\
\text { stations representing } \\
\text { glacial-transition climate }\end{array}$ \\
\hline $\begin{array}{l}\text { MO0004QGFMPICK.000 } \\
\text { [DIRS 152554], } \\
\text { Table S00214_001 }\end{array}$ & Data & $\begin{array}{l}6.3 .1 ; \\
\text { Table 6-6 }\end{array}$ & $\begin{array}{l}\text { Stratigraphic contact depths in } \\
\text { boreholes }\end{array}$ \\
\hline
\end{tabular}


Table 4-2. Direct Inputs Used for Exclusion of FEPs (Continued)

\begin{tabular}{|c|c|c|c|}
\hline Source & Type & $\begin{array}{l}\text { Used in } \\
\text { Section } \\
\text { Number }\end{array}$ & Description \\
\hline $\begin{array}{l}\text { CRWMS M\&O } 2000 \\
\text { [DIRS 153246], } \\
\text { Figure } 4.1-7\end{array}$ & $\begin{array}{l}\text { Output from canceled } \\
\text { document qualified in } \\
\text { accordance with } \\
\text { LP-SIII.9Q-BSC; see } \\
\text { Appendix C, Section C14 }\end{array}$ & 6.7 .3 & Aqueous-phase dose for ${ }^{14} \mathrm{C}$ \\
\hline $\begin{array}{l}\text { CRWMS M\&O } 2000 \\
\text { [DIRS 153246], } \\
\text { Figures } 4.1-5 \text { and } 4.1-7\end{array}$ & $\begin{array}{l}\text { Output from canceled } \\
\text { document qualified in } \\
\text { accordance with } \\
\text { LP-SIII.9Q-BSC; see } \\
\text { Appendix C, Section C14 }\end{array}$ & 6.9 .6 & $\begin{array}{l}\text { Change in dose rates over } 10,000 \\
\text { years }\end{array}$ \\
\hline $\begin{array}{l}\text { CRWMS M\&O } 2000 \\
\text { [DIRS 153246], } \\
\text { Figure } 4.1-9\end{array}$ & $\begin{array}{l}\text { Output from canceled } \\
\text { document qualified in } \\
\text { accordance with } \\
\text { LP-SIII.9Q-BSC; see } \\
\text { Appendix C, Section C14 }\end{array}$ & 6.9 .6 & $\begin{array}{l}\text { Waste package failures as a } \\
\text { function of time }\end{array}$ \\
\hline $\begin{array}{l}\text { LA0010JC831341.007 } \\
\text { [DIRS 153319], Table } \\
\text { S00426_001 }\end{array}$ & Data & 6.9 .13 & $\begin{array}{l}\text { Effects of temperature on } \\
\text { neptunium sorption }\end{array}$ \\
\hline $\begin{array}{l}\text { LA0010JC831341.002 } \\
\text { [DIRS 153321], Table } \\
\text { S00421_001 }\end{array}$ & Data & 6.9 .13 & $\begin{array}{l}\text { Effects of temperature on cesium } \\
\text { sorption }\end{array}$ \\
\hline $\begin{array}{l}\text { LA0010JC831341.003 } \\
\text { [DIRS 153322], Table } \\
\text { S00422_001 }\end{array}$ & Data & 6.9 .13 & $\begin{array}{l}\text { Effects of temperature on strontium } \\
\text { sorption }\end{array}$ \\
\hline $\begin{array}{l}\text { Wu et al., } 2000 \\
\text { [DIRS 154918] } \\
\text { Section } 4.1\end{array}$ & $\begin{array}{l}\text { Data qualified in accordance } \\
\text { with LP-SIII.2Q-BSC; see } \\
\text { Appendix C, Section C16 }\end{array}$ & 6.4 .5 & $\begin{array}{l}\text { Damping effect of PTn on episodic } \\
\text { infiltration }\end{array}$ \\
\hline $\begin{array}{l}\text { BSC } 2001 \text { [DIRS 155950], } \\
\text { Section 5.3.2.4.4 }\end{array}$ & $\begin{array}{l}\text { Output from cancelled } \\
\text { document qualified in } \\
\text { accordance with } \\
\text { LP-SIII.9Q-BSC; see } \\
\text { Appendix C, Section C13 }\end{array}$ & 6.9 .4 & $\begin{array}{l}\text { Sensitivity of temperature to } \\
\text { preclosure ventilation }\end{array}$ \\
\hline $\begin{array}{l}\text { MO0010CPORGLOG.003 } \\
\text { [DIRS 155959], } \\
\text { Table S00418_013 }\end{array}$ & Data & Table 6-6 & $\begin{array}{l}\text { Borehole design information for } \\
\text { USW UZ-7a }\end{array}$ \\
\hline $\begin{array}{l}\text { DOE } 2002 \text { [DIRS 155970], } \\
\text { Section I.7 }\end{array}$ & $\begin{array}{l}\text { Data qualified in accordance } \\
\text { with LP-SIII.2Q-BSC; see } \\
\text { Appendix C, Section C9 }\end{array}$ & 6.7 .3 & Gas-phase dose for ${ }^{14} \mathrm{C}$ \\
\hline $\begin{array}{l}\text { BSC } 2001 \text { [DIRS 158726], } \\
\text { Sections } 6.2 .2,6.2 .5, \text { and } \\
6.2 .6\end{array}$ & $\begin{array}{l}\text { Output from superseded } \\
\text { document qualified in } \\
\text { accordance with LP-SIII.9Q- } \\
\text { BSC; see Appendix C, } \\
\text { Section C12. }\end{array}$ & $\begin{array}{l}6.8 .9,6.9 .14 \\
6.9 .15\end{array}$ & Alternative perched water models \\
\hline $\begin{array}{l}\text { BSC } 2001 \text { [DIRS 158726], } \\
\text { Sections } 6.2 .6 \text { and } 6.7 .2 ; \\
\text { Figures } 6-54 \text { through } 6-56\end{array}$ & $\begin{array}{l}\text { Output from superseded } \\
\text { document qualified in } \\
\text { accordance with LP-SIII.9Q- } \\
\text { BSC; see Appendix C, } \\
\text { Section C12. }\end{array}$ & $\begin{array}{l}6.8 .9,6.9 .14 \\
6.9 .15\end{array}$ & $\begin{array}{l}\text { Transport sensitivity to perched } \\
\text { water models }\end{array}$ \\
\hline $\begin{array}{l}\text { LB0205REVUZPRP.001 } \\
\text { [DIRS 159525], file } \\
\text { FRACTURE_PROPERTY.xIs }\end{array}$ & Data & $\begin{array}{l}6.9 .3 \\
6.9 .16\end{array}$ & $\begin{array}{l}\text { Fracture properties, } \\
\text { Fracture spacing and aperture in } \\
\text { zeolitic Calico Hills unit }\end{array}$ \\
\hline
\end{tabular}


Table 4-2. Direct Inputs Used for Exclusion of FEPs (Continued)

\begin{tabular}{|c|c|c|c|}
\hline Source & Type & $\begin{array}{l}\text { Used in } \\
\text { Section } \\
\text { Number }\end{array}$ & Description \\
\hline $\begin{array}{l}\text { UN0201SPA021SS.007 } \\
\text { [DIRS 161588], file table } \\
\text { 6-3.doc }\end{array}$ & Data & $6.4 .1,6.4 .2$ & $\begin{array}{l}\text { Mean annual temperatures for } \\
\text { glacial-transition climate }\end{array}$ \\
\hline $\begin{array}{l}\text { UN0201SPA021SS.007 } \\
\text { [DIRS 161588], file table } \\
\text { 6-3.doc }\end{array}$ & Data & 6.4 .3 & $\begin{array}{l}\text { Mean annual precipitation for future } \\
\text { climate states }\end{array}$ \\
\hline $\begin{array}{l}\text { BSC } 2003 \text { [DIRS 161727], } \\
\text { Entire }\end{array}$ & $\begin{array}{l}\text { Output from superseded } \\
\text { document qualified in } \\
\text { accordance with LP-SIII.9Q- } \\
\text { BSC; see Appendix C, } \\
\text { Section C15 }\end{array}$ & Appendix A & $\begin{array}{l}\text { Emplacement drift end point } \\
\text { coordinates }\end{array}$ \\
\hline $\begin{array}{l}\text { MO0209EBSPMFSD.029 } \\
\text { [DIRS 161845], Table } \\
\text { S02250_001/mo0209ebsp } \\
\text { mfsd_029.zip/F18 Flood } \\
\text { Inund High Sed.pdf }\end{array}$ & Data & 6.3 .3 & $\begin{array}{l}\text { Flooding at Yucca Mountain: Map } \\
\text { of flood-prone areas on the site } \\
\text { surface near North Portal }\end{array}$ \\
\hline $\begin{array}{l}\text { LB0302DSCPTHCS.002 } \\
\text { [DIRS 161976], files } \\
\text { thc6_w*_r.xls }\end{array}$ & Data & 6.7 .2 & $\begin{array}{l}\text { Drift-scale coupled processes (THC } \\
\text { seepage) model: Data summary }\end{array}$ \\
\hline $\begin{array}{l}\text { LB0302DSCPTHCS.002 } \\
\text { [DIRS 161976], files } \\
\text { thc6_w*_r.xls }\end{array}$ & Data & $6.9 .7,6.9 .13$ & $\begin{array}{l}\text { Effects of THC processes on } \mathrm{pH} \\
\text { and water composition }\end{array}$ \\
\hline $\begin{array}{l}\text { Zhou et al. } 2003 \\
\text { [DIRS 162133], Section } 5.2\end{array}$ & $\begin{array}{l}\text { Data qualified in accordance } \\
\text { with LP-SIII.2Q-BSC; see } \\
\text { Appendix C, Section C11 }\end{array}$ & 6.8 .4 & $\begin{array}{l}\text { Effects of small-scale heterogeneity } \\
\text { on flow and transport }\end{array}$ \\
\hline $\begin{array}{l}\text { LA0010JC831341.001 } \\
\text { [DIRS 162476], Table } \\
\text { S00420_001 }\end{array}$ & Data & 6.9 .13 & $\begin{array}{l}\text { Effects of temperature on barium } \\
\text { sorption }\end{array}$ \\
\hline $\begin{array}{l}\text { LB03023DSSCP9I.001 } \\
\text { [DIRS 163044], files } \\
\text { glaq_IA.tar.gz, } \\
\text { glaq_mA.tar.gz, } \\
\text { glaq_uA.tar.gz, } \\
\text { monq_IA.tar.gz, } \\
\text { monq_mA.tar.gz, } \\
\text { monq_uA.tar.gz, } \\
\text { preq_IA.tar.gz, } \\
\text { preq_mA.tar.gz, } \\
\text { preq_uA.tar.gz }\end{array}$ & Data & $\begin{array}{l}\text { Appendix A, } \\
\text { Appendix B, } \\
\text { Figures A-1, } \\
\text { A-2, B-1 }\end{array}$ & $\begin{array}{l}\text { Fracture and matrix saturation in } \\
\text { gridblocks where perched water } \\
\text { occurs; used to estimate potential } \\
\text { quick release of perched water and } \\
\text { to calculate how many years of flux } \\
\text { this corresponds to; also to confirm } \\
\text { that the PTn overlies the entire } \\
\text { repository }\end{array}$ \\
\hline $\begin{array}{l}\text { LB03023DSSCP9I.001 } \\
\text { [DIRS 163044], files } \\
\text { glaq_IA.tar.gz, } \\
\text { glaq_mA.tar.gz, } \\
\text { glaq_uA.tar.gz, } \\
\text { monq_IA.tar.gz, } \\
\text { monq_mA.tar.gz, } \\
\text { monq_uA.tar.gz, } \\
\text { preq_IA.tar.gz, } \\
\text { preq_mA.tar.gz, } \\
\text { preq_uA.tar.gz }\end{array}$ & Data & 6.9 .17 & $\begin{array}{l}\text { Fraction of flux in fractures and } \\
\text { faults }\end{array}$ \\
\hline
\end{tabular}


Table 4-2. Direct Inputs Used for Exclusion of FEPs (Continued)

\begin{tabular}{|c|c|c|c|}
\hline Source & Type & $\begin{array}{l}\text { Used in } \\
\text { Section } \\
\text { Number }\end{array}$ & Description \\
\hline $\begin{array}{l}\text { Wilson et al. 2003 } \\
\text { [DIRS 163589], Section } 8\end{array}$ & $\begin{array}{l}\text { Data qualified in accordance } \\
\text { with LP-SIII.2Q-BSC; see } \\
\text { Appendix C, Section C7. }\end{array}$ & 6.8 .2 & Two-phase fluid inclusions \\
\hline $\begin{array}{l}\text { LB0304SMDCREV2.004 } \\
\text { [DIRS 163691], files } \\
\text { Fig6-22.wmf, Fig6-22.xls }\end{array}$ & Data & $\begin{array}{l}\text { 6.9.3, 6.9.10 } \\
6.9 .11\end{array}$ & $\begin{array}{l}\text { Effect of thermo-mechanical } \\
\text { stresses on seepage }\end{array}$ \\
\hline $\begin{array}{l}\text { LB0302DSCPTHCS.001 } \\
\text { [DIRS 164744], file } \\
\text { thc6_w0_rerun.tar.gz }\end{array}$ & Data & 6.9 .1 & $\begin{array}{l}\text { Effect of chemically altered zone } \\
\text { (rind) on seepage }\end{array}$ \\
\hline $\begin{array}{l}\text { LB0302DSCPTHCS.001 } \\
\text { [DIRS 164744], files } \\
\text { thc6_w0_rerun.tar.gz, } \\
\text { thc6_w5_rerun.tar.gz }\end{array}$ & Data & $\begin{array}{l}\text { 6.9.1, 6.9.7 } \\
6.9 .13\end{array}$ & $\begin{array}{l}\text { Effects of mineral precipitation near } \\
\text { waste emplacement drifts and } \\
\text { changes in hydrologic properties } \\
\text { due to THC processes }\end{array}$ \\
\hline $\begin{array}{l}\text { Vanoni } 1977 \\
\text { [DIRS 164901], Figure } 2.51\end{array}$ & $\begin{array}{l}\text { Data qualified in accordance } \\
\text { with LP-SIII.9Q-BSC; see } \\
\text { Appendix C, Section C4 }\end{array}$ & 6.4 .4 & $\begin{array}{l}\text { Entrainment of cohesive sediments } \\
\text { in flowing water }\end{array}$ \\
\hline $\begin{array}{l}\text { LB0307FMRADTRN.001 } \\
\text { [DIRS 165451], file } \\
\text { Free-Water Diffusion } \\
\text { Coefficient.xls }\end{array}$ & Data & 6.9.17 & Mean value of diffusion coefficient \\
\hline $\begin{array}{l}\text { LB0307DSTTHCR2.002 } \\
\text { [DIRS 165541], files } \\
\text { LB0307DSTTHCR2.002.zip, } \\
\text { LB0307DSTTHCR2.002sup } \\
\text { plemental.zip }\end{array}$ & Data & $6.9 .7,6.9 .13$ & $\begin{array}{l}\text { Effects of THC processes on } \mathrm{pH} \\
\text { and water composition }\end{array}$ \\
\hline $\begin{array}{l}\text { BSC } 2003 \text { [DIRS 165572], } \\
\text { Section 7.1.8 }\end{array}$ & Data & 6.5 .1 & Overburden thickness \\
\hline $\begin{array}{l}\text { LB0304RDTRNSNS.001 } \\
\text { [DIRS 165992], files } \\
\text { basecase_loporosity.tar.gz, } \\
\text { reducedAFPforTSw.tar.gz, } \\
\text { Underrep.tar.gz }\end{array}$ & Data & 6.9.14 & $\begin{array}{l}\text { Sensitivity of transport to fracture } \\
\text { porosity and active fracture } \\
\text { parameter }\end{array}$ \\
\hline $\begin{array}{l}\text { MO0401MWDRPSHA.000 } \\
\text { [DIRS 166962], file } \\
\text { displ/tot_haz/s2.frac_mean }\end{array}$ & Data & 6.8 .6 & $\begin{array}{l}\text { Future fault movement for Solitario } \\
\text { Canyon Fault }\end{array}$ \\
\hline $\begin{array}{l}\text { BSC } 2004 \text { [DIRS 168180], } \\
\text { Figures } 4 \text { and 5, Table } 9\end{array}$ & Data & $\begin{array}{l}\text { 6.3.1, Table } \\
6-6\end{array}$ & $\begin{array}{l}\text { Borehole location relative to waste } \\
\text { emplacement }\end{array}$ \\
\hline $\begin{array}{l}\text { BSC } 2004 \text { [DIRS 168370], } \\
\text { Figure 3, Table } 8\end{array}$ & Data & $\begin{array}{l}\text { 6.3.1, Table } \\
6-6\end{array}$ & Repository layout information \\
\hline $\begin{array}{l}\text { BSC } 2004 \text { [DIRS 168370], } \\
\text { Figure 3, Table } 8\end{array}$ & Data & 6.8 .8 & Waste emplacement area \\
\hline $\begin{array}{l}\text { LB0402THRMLPRP.001 } \\
\text { [DIRS 168481], file } \\
\text { thermal_prop_model_layer } \\
\text { s_0204.xls }\end{array}$ & Data & 6.9.16 & $\begin{array}{l}\text { Bulk density of zeolitic Calico Hills } \\
\text { unit }\end{array}$ \\
\hline $\begin{array}{l}\text { BSC } 2004 \text { [DIRS 168489], } \\
\text { Figure 1, Table } 1\end{array}$ & Data & 6.5 .4 & Drift diameter and spacing \\
\hline
\end{tabular}


Table 4-2. Direct Inputs Used for Exclusion of FEPs (Continued)

\begin{tabular}{|c|c|c|c|}
\hline Source & Type & $\begin{array}{l}\text { Used in } \\
\text { Section } \\
\text { Number }\end{array}$ & Description \\
\hline $\begin{array}{l}\text { LB0306DRSCLTHM.001 } \\
\text { [DIRS 169733], files } \\
\text { Fmn1_0.sav, Fll1_0.sav }\end{array}$ & Data & 6.5 .4 & $\begin{array}{l}\text { Subsidence calculations for drifts in } \\
\text { Tptpmn and Tptpll }\end{array}$ \\
\hline $\begin{array}{l}\text { BSC } 2004 \text { [DIRS 169864], } \\
\text { Section } 8.1\end{array}$ & Data & 6.5 .4 & Effects of drift subsidence \\
\hline $\begin{array}{l}\text { BSC } 2004 \text { [DIRS 169864], } \\
\text { Section } 8.2\end{array}$ & Data & 6.8 .5 & $\begin{array}{l}\text { The dominant mode of stress- } \\
\text { induced permeability change is } \\
\text { elastic fracture opening or closing } \\
\text { caused by changes in stress normal } \\
\text { to the fractures. }\end{array}$ \\
\hline $\begin{array}{l}\text { BSC } 2004 \text { [DIRS 169864], } \\
\text { Section } 8.1\end{array}$ & Data & 6.8 .6 & $\begin{array}{l}\text { Effect of drift collapse on } \\
\text { permeability and capillary strength } \\
\text { at the drift crown }\end{array}$ \\
\hline $\begin{array}{l}\text { BSC } 2004 \text { [DIRS 169980], } \\
\text { Table } 7.1\end{array}$ & Data & 6.8 .4 & $\begin{array}{l}\text { Range of violent Strombolian } \\
\text { eruption grain sizes }\end{array}$ \\
\hline $\begin{array}{l}\text { BSC } 2004 \text { [DIRS 169989], } \\
\text { Table 7-1 }\end{array}$ & Data & $\begin{array}{l}\text { 6.8.1, 6.8.2, } \\
6.8 .4\end{array}$ & Probability of a volcanic event \\
\hline $\begin{array}{l}\text { BSC } 2004 \text { [DIRS 170037], } \\
\text { Section } 6.4 .5\end{array}$ & Data & 6.8 .8 & Water table rise \\
\hline $\begin{array}{l}\text { LB0310MTSCLTH3.001 } \\
\text { [DIRS 170270], files } \\
\text { th_v16.out, th_v16.out_2, } \\
\text { th_v16_2.out, } \\
\text { th_v16_3.out_1, } \\
\text { th_v16_3.out_2 }\end{array}$ & Data & 6.9 .16 & $\begin{array}{l}\text { Temperature at the top of the Calico } \\
\text { Hills }\end{array}$ \\
\hline $\begin{array}{l}\text { LB03033DUZTRAN.001 } \\
\text { [DIRS 170372], files } \\
\text { output_glaq3I_AB_nptc.tar. } \\
\text { gz, } \\
\text { output_preq3I_AB_nptc.tar. } \\
\text { gz }\end{array}$ & Data & 6.8 .7 & $\begin{array}{l}\text { Effects of infiltration uncertainty on } \\
\text { transport }\end{array}$ \\
\hline $\begin{array}{l}\text { LB0310MTSCLTH2.001 } \\
\text { [DIRS 170714], files } \\
\text { th_2dt.out_1, th_600y.out, } \\
\text { th_2000y.out_1, } \\
\text { th_2000y.out_2 }\end{array}$ & Data & 6.9 .16 & $\begin{array}{l}\text { Temperature at the top of the Calico } \\
\text { Hills }\end{array}$ \\
\hline $\begin{array}{l}\text { LB0310MTSCLTHC.001 } \\
\text { [DIRS 170715], files } \\
\text { TEC_CONC.DAT for } \\
\text { present day, monsoon, and } \\
\text { glacial-transition time } \\
\text { periods }\end{array}$ & Data & 6.9 .13 & $\begin{array}{l}\text { Magnitude and duration of water } \\
\text { composition changes due to THC } \\
\text { processes }\end{array}$ \\
\hline $\begin{array}{l}\text { LB0310MTSCLTHM.002 } \\
\text { [DIRS 170718], files } \\
\text { Tmo2_100y.tec, } \\
\text { Tmo2_100y_m.tec, } \\
\text { Tmo2_1ky.tec, } \\
\text { Tmo2_1ky_m.tec, } \\
\text { Tmo2_10ky.tec, } \\
\text { Tmo2_10ky_m.tec, } \\
\text { Fk_prof.tec, Fk_prof2.tec }\end{array}$ & Data & 6.9.12 & $\begin{array}{l}\text { Effects of THM processes on flux } \\
\text { through repository and fracture } \\
\text { permeability }\end{array}$ \\
\hline
\end{tabular}


Table 4-2. Direct Inputs Used for Exclusion of FEPs (Continued)

\begin{tabular}{|c|c|c|c|}
\hline Source & Type & $\begin{array}{l}\text { Used in } \\
\text { Section } \\
\text { Number }\end{array}$ & Description \\
\hline $\begin{array}{l}\text { LB0308DRSCLTHM.001, } \\
\text { file Fll1c1_001Y.SAV }\end{array}$ & Data & 6.5 .4 & $\begin{array}{l}\text { Subsidence calculations for drift } \\
\text { inTptpll low-quality rock }\end{array}$ \\
\hline $\begin{array}{l}\text { LB0408CMATUZFT.003 } \\
\text { [DIRS 171705], file } \\
\text { dispersion2.xls }\end{array}$ & $\begin{array}{l}\text { Data qualified in accordance } \\
\text { with LP-SIII.2Q-BSC; see } \\
\text { Appendix C, Section C6 }\end{array}$ & 6.9 .2 & $\begin{array}{l}\text { Chemistry of leachate from altered } \\
\text { cementitious materials }\end{array}$ \\
\hline $\begin{array}{l}\text { LB0408CMATUZFT.004 } \\
\text { [DIRS 171706], file } \\
\text { LB0408CMATUZFT.004.doc }\end{array}$ & $\begin{array}{l}\text { Data qualified in accordance } \\
\text { with LP-SIII.2Q-BSC; see } \\
\text { Appendix C, Section C6 }\end{array}$ & 6.9 .2 & $\begin{array}{l}\text { Diffusion and dispersion of plumes } \\
\text { of leachate from altered } \\
\text { cementitious materials. }\end{array}$ \\
\hline $\begin{array}{l}\text { BSC } 2004 \text { [DIRS 172452], } \\
\text { Sections 3.3.1.4, 3.3.2 }\end{array}$ & Data & 6.3 .5 & $\begin{array}{l}\text { Effects of monitoring activities on } \\
\text { repository performance }\end{array}$ \\
\hline $\begin{array}{l}\text { BSC } 2004 \text { [DIRS 172801], } \\
\text { Entire }\end{array}$ & Data & $\begin{array}{l}\text { 6.3.1, Table } \\
6-6\end{array}$ & Repository layout information \\
\hline $\begin{array}{l}\text { MO0408EG831811.008 } \\
\text { [DIRS 173078], files Heat } \\
\text { Conduction - Dry } \\
\text { TPTPLL.xls, Heat } \\
\text { Conduction - Wet } \\
\text { TPTPLL.xls }\end{array}$ & Data & $6.8 .1,6.8 .4$ & Spatial extent of boiling near dikes \\
\hline $\begin{array}{l}\text { LB0304SMDCREV2.001 } \\
\text { [DIRS 173235], files } \\
\text { Irockbolt_analysis } \\
\text { rockboltsreadme.doc, } \\
\text { Irockbolt_analysis|*0cm_di } \\
\text { screte_fracture_simulations } \\
\text { It21.5df*|vh_aX2*.out, } \\
\text { Irockbolt_analysisISCM } \\
\text { simulations } \\
\text { It } 21.5^{\star} \mid \text { IVh_aX2*.out }\end{array}$ & Data & $\begin{array}{l}\text { 6.3.2, 6.3.5, } \\
6.9 .2\end{array}$ & $\begin{array}{l}\text { Effects of boreholes on drift } \\
\text { seepage }\end{array}$ \\
\hline $\begin{array}{l}\text { BSC } 2005 \text { [DIRS 173433], } \\
\text { Sections 6.3.3, 6.6.1 }\end{array}$ & Data & 6.4 .6 & $\begin{array}{l}\text { Treatment of release from } \\
\text { repository }\end{array}$ \\
\hline $\begin{array}{l}\text { BSC } 2005 \text { [DIRS 173498], } \\
\text { Figs. 1, } 2,3\end{array}$ & Data & $6.5 .4,6.9 .2$ & $\begin{array}{l}\text { Drift diameter; ground support } \\
\text { materials }\end{array}$ \\
\hline $\begin{array}{l}\text { BSC } 2005 \text { [DIRS 173871], } \\
\text { Tables } 3,4,5\end{array}$ & Data & 6.9 .2 & $\begin{array}{l}\text { Use of cementitious materials for } \\
\text { ground support }\end{array}$ \\
\hline $\begin{array}{l}\text { BSC } 2005 \text { [DIRS 173873], } \\
\text { Section } 8.1\end{array}$ & Data & 6.9 .8 & $\begin{array}{l}\text { Solubility of actinides at elevated } \\
\text { temperature }\end{array}$ \\
\hline $\begin{array}{l}\text { BSC } 2005 \text { [DIRS 173980], } \\
\text { Table 8-1 }\end{array}$ & Data & 6.9.17 & $\begin{array}{l}\text { Values for dispersivity and fracture } \\
\text { porosity }\end{array}$ \\
\hline $\begin{array}{l}\text { BSC } 2005 \text { [DIRS 173980], } \\
\text { Table 8-1 }\end{array}$ & Data & 6.8 .8 & $\begin{array}{l}\text { Minimum average water content of } \\
\text { rock in the UZ within } 100 \mathrm{~m} \text { of the } \\
\text { water table. }\end{array}$ \\
\hline $\begin{array}{l}\text { BSC } 2005 \text { [DIRS 174290], } \\
\text { Section } 8.1\end{array}$ & Data & $6.9 .5,6.9 .8$ & $\begin{array}{l}\text { Formation of true colloids from } \\
\text { waste form }\end{array}$ \\
\hline $\begin{array}{l}\text { SN0312T0510102.013 } \\
\text { [DIRS 174488], } \\
\text { file 316ss-base.xls }\end{array}$ & Data & 6.9 .2 & $\begin{array}{l}\text { Effects of stainless steel on water } \\
\text { composition }\end{array}$ \\
\hline
\end{tabular}


Table 4-2. Direct Inputs Used for Exclusion of FEPs (Continued)

\begin{tabular}{|c|c|c|c|}
\hline Source & Type & $\begin{array}{l}\text { Used in } \\
\text { Section } \\
\text { Number }\end{array}$ & Description \\
\hline $\begin{array}{l}\text { LB0310MR0060R1.010 } \\
\text { [DIRS 174489], files } \\
\text { np_pm_chv.out, } \\
\text { np_pm_chz.out, } \\
\text { np_pm_tsw.out }\end{array}$ & Data & 6.9 .14 & Sensitivity of transport to sorption \\
\hline $\begin{array}{l}\text { LB0306DRSCLTHM.002 } \\
\text { [DIRS 174490], files } \\
{ }^{* 001 y . t e c}\end{array}$ & Data & 6.9 .6 & Effects of stress relief \\
\hline $\begin{array}{l}\text { LB0306DRSCLTHM.002 } \\
\text { [DIRS 174490], files *0y.tec } \\
\text { and *ky.tec }\end{array}$ & Data & $6.9 .3,6.9 .10$ & $\begin{array}{l}\text { Effects of temperature-induced } \\
\text { stress changes on permeability and } \\
\text { flow }\end{array}$ \\
\hline $\begin{array}{l}\text { LB0306DRSCLTHM.002 } \\
\text { [DIRS 174490], files *0y.tec } \\
\text { and *ky.tec }\end{array}$ & Data & 6.9 .9 & $\begin{array}{l}\text { Effects of temperature on flow; } \\
\text { creation of shadow zone beneath } \\
\text { drift }\end{array}$ \\
\hline $\begin{array}{l}\text { LB0208HYDSTRAT.001 } \\
\text { [DIRS 174491], } \\
\text { files tsw39_vitric_pw.ply, } \\
\text { ch*_vit.ply }\end{array}$ & Data & 6.9 .16 & Location of zeolites in the UZ \\
\hline $\begin{array}{l}\text { BSC } 2005 \text { [DIRS 174514], } \\
\text { Sections 2.2, 3.1.1.13.1 } \\
\text { through 3.1.1.13.3, and } \\
\text { 3.1.1.16.6 through } \\
\text { 3.1.1.16.8 }\end{array}$ & Data & $\begin{array}{l}\text { 6.3.3, 6.3.6, } \\
6.3 .7,6.3 .8\end{array}$ & $\begin{array}{l}\text { Design requirement concerning } \\
\text { surface water inundation of the } \\
\text { subsurface facilities }\end{array}$ \\
\hline
\end{tabular}

a Sources are listed in order of DIRS number.

$\mathrm{LA}=$ license application; $\mathrm{TH}=$ thermal hydrologic; $\mathrm{THC}=$ thermal-hydrologic-chemical;

THM = thermal-hydrologic-mechanical; TSPA = total system performance assessment; UZ = unsaturated zone.

Table 4-3. Regulations Used as Direct Inputs

\begin{tabular}{|l|l|l|l|}
\hline \multicolumn{1}{|c|}{$\begin{array}{c}\text { Section } \\
\text { Number }\end{array}$} & \multicolumn{1}{|c|}{ Input } & \multicolumn{1}{c|}{ Type } & \multicolumn{1}{c|}{ Description } \\
\hline $\begin{array}{l}6.6 .1,6.6 .2, \\
6.6 .3,6.6 .4\end{array}$ & $\begin{array}{l}\text { 10 CFR 63.305(b) and (c) [DIRS } \\
\text { 173273] }\end{array}$ & $\begin{array}{l}\text { Established } \\
\text { Fact }\end{array}$ & $\begin{array}{l}\text { Regulatory exclusion of human effects on } \\
\text { climate }\end{array}$ \\
\hline $\begin{array}{l}6.6 .1,6.6 .2, \\
6.6 .3,6.6 .4\end{array}$ & $\begin{array}{l}\text { 66 FR 55732 [DIRS 156671], } \\
\text { p. 55,757 }\end{array}$ & $\begin{array}{l}\text { Established } \\
\text { fact }\end{array}$ & $\begin{array}{l}\text { Rationale for regulatory position excluding } \\
\text { human influences on climate }\end{array}$ \\
\hline 6.6 .1 & 67 FR 62628 [DIRS 162317] & $\begin{array}{l}\text { Established } \\
\text { fact }\end{array}$ & $\begin{array}{l}\text { Rationale for regulatory position excluding } \\
\text { human influences on climate }\end{array}$ \\
\hline $\begin{array}{l}6.3 .4 \\
6.6 .5\end{array}$ & 10 CFR 63.305(b) [DIRS 173273] & $\begin{array}{l}\text { Established } \\
\text { fact }\end{array}$ & $\begin{array}{l}\text { Rationale for regulatory position excluding } \\
\text { human influences on soil and water }\end{array}$ \\
\hline
\end{tabular}


Regulation 10 CFR Part 63 [DIRS 173273] and a portion of the Federal Register containing the preamble to 10 CFR Part 63 [DIRS 173273], 66 FR 55732 [DIRS 156671], and 67 FR 62628 [DIRS 162317], provide the regulatory requirements and the background information for licensing and operating the repository. These requirements and definitions were used throughout Section 6.6 to construct FEP exclusion arguments. Information from 10 CFR Part 63 [DIRS 173273] and the background information can be considered established fact and is appropriate for use in this analysis. In particular, human influences on climate are excluded on the basis of requirements of 10 CFR 63.305(b) [DIRS 173273]. The licensing rule and the supplemental information (66 FR 55732 [DIRS 156671]) indicate that only natural evolution of the reference biosphere is to be included in the performance assessment and that the changes caused by the future human behaviors are not to be included. Furthermore, 10 CFR 63.305(b) [DIRS 173273] states that "DOE should not project changes in society, the biosphere (other than climate), human biology, or increases or decreases in human knowledge or technology. In all analyses done to demonstrate compliance with this part, the DOE must assume that all of those factors remain constant as they are at the time of submission of the license application." Therefore, human activities (changes in the social and institutional attributes of society, lifestyle, land use, and water use) that would alter soil or surface water chemistry are excluded on the basis of the regulatory requirements (10 CFR 63.305(b) [DIRS 173273]). The NRC has indicated that the natural systems of the biosphere should be allowed to vary consistent with the geologic records, which provide a basis for predicting future biosphere changes (66 FR 55732 [DIRS 156671], p. 55,757). Because human behavior cannot be similarly predicted, such an approach cannot be used for the reasonably maximally exposed individual (66 FR 55732 [DIRS 156671], p. 55,757) and, extending this reasoning, for the human-induced changes to the environment. Therefore, the geological, hydrological and climatological factors that the U.S. Department of Energy (DOE) must vary under 10 CFR 63.305(b) [DIRS 173273], are limited to naturally occurring FEPs. Following similar reasoning, 10 CFR 63.305 (c) [DIRS 173273] also restricts the range of conditions investigated for future climate. The text of 10 CFR 63.305 (c) [DIRS 173273] states that "DOE must vary factors related to the geology, hydrology, and climate based upon cautious, but reasonable assumptions consistent with present knowledge of factors that could affect the Yucca Mountain disposal system over the next 10,000 years." Given that human behavior cannot be predicted, the development of climate scenarios accounting for human effects on climate would require going beyond "cautious, but reasonable assumptions consistent with present knowledge of factors that could affect the Yucca Mountain disposal system over the next 10,000 years."

\subsection{CRITERIA}

This section addresses the criteria relevant to the FEP screening process. These criteria stem from the applicable regulations at 10 CFR Part 63 [DIRS 173273], as identified in Project Requirements Document (PRD) (Canori and Leitner 2003 [DIRS 166275]). These criteria find expression as specific acceptance criteria presented by the NRC in Yucca Mountain Review Plan, Final Report (NRC 2003 [DIRS 163274], Sections 2.2.1.2.1.3 and 2.2.1.2.2.3). The correlation of the regulations and Yucca Mountain Review Plan (YMRP) acceptance criteria are shown in Table 4-4. Satisfaction of the criteria is discussed in Section 7.1. 
Table 4-4. Relationships of Regulations to the YMRP Acceptance Criteria

\begin{tabular}{|c|c|c|c|}
\hline \multirow[b]{2}{*}{$\begin{array}{l}\text { Description of the Applicable Regulatory } \\
\text { Requirement or Acceptance Criterion }\end{array}$} & $\begin{array}{l}10 \text { CFR Part } 63 \\
\text { [DIRS 173273] }\end{array}$ & $\begin{array}{c}\text { Canori and Leitner } \\
2003 \\
\text { [DIRS 166275] } \\
\end{array}$ & \multirow{2}{*}{$\begin{array}{l}\text { Associated } \\
\text { Criteria } \\
\text { in the YMRP } \\
\text { [DIRS 163274] }\end{array}$} \\
\hline & Regulatory Citation & $\begin{array}{l}\text { Associated } \\
\text { PRD }\end{array}$ & \\
\hline \multicolumn{4}{|c|}{ General Requirements and Scope Pertinent to FEP Screening } \\
\hline $\begin{array}{l}\text { Include data related to geology, hydrology, } \\
\text { geochemistry, and geophysics }\end{array}$ & $63.114(a)$ & PRD-002/T-015 & $\begin{array}{l}\text { 2.2.1.2.1.3 } \\
\text { Acceptance } \\
\text { Criterion } 1 \\
\end{array}$ \\
\hline $\begin{array}{l}\text { Include information of the design of the } \\
\text { engineered barrier system used to define } \\
\text { parameters and conceptual models }\end{array}$ & $63.114(a)$ & PRD-002/T-015 & $\begin{array}{l}2.2 .1 .2 .1 .3 \\
\text { Acceptance } \\
\text { Criterion } 1 \\
\end{array}$ \\
\hline $\begin{array}{l}\text { Account for uncertainties and variabilities in } \\
\text { parameter values and provide the technical } \\
\text { basis for parameter ranges, probability } \\
\text { distributions, or bounding values }\end{array}$ & 63.114(b) & PRD-002/T-015 & $\begin{array}{l}2.2 .1 .2 .2 .3 \\
\text { Acceptance } \\
\text { Criteria } \\
2 \text { and } 3\end{array}$ \\
\hline \multicolumn{4}{|c|}{ FEP Screening Criteria } \\
\hline $\begin{array}{l}\text { Provide the justification and technical basis } \\
\text { for excluding FEPs specifically excluded by } \\
\text { regulation. }\end{array}$ & Not Applicable & Not Applicable & $\begin{array}{l}2.2 .1 .2 .1 .3 \\
\text { Acceptance } \\
\text { Criterion } 2 \\
\end{array}$ \\
\hline $\begin{array}{l}\text { Provide the technical basis for either } \\
\text { inclusion or exclusion of FEPs. Provide the } \\
\text { justification and technical basis for those } \\
\text { excluded based on probability. }\end{array}$ & $\begin{array}{c}63.114(d) \\
63.342\end{array}$ & $\begin{array}{l}\text { PRD-002/T-015 } \\
\text { PRD-002/T-034 }\end{array}$ & $\begin{array}{l}\text { 2.2.1.2.1.3 } \\
\text { Acceptance } \\
\text { Criterion } 2 \\
\text { 2.2.1.2.2.3 } \\
\text { Acceptance } \\
\text { Criteria } \\
1 \text { and } 2\end{array}$ \\
\hline $\begin{array}{l}\text { Provide the technical basis for either } \\
\text { inclusion or exclusion of FEPs. Provide the } \\
\text { justification and the technical basis for } \\
\text { those excluded based on lack of significant } \\
\text { change in resulting radiological exposure or } \\
\text { release to the accessible environment. }\end{array}$ & $63.114(\mathrm{e}$ and $\mathrm{f})$ & PRD-002/T-015 & $\begin{array}{l}\text { 2.2.1.2.1.3 } \\
\text { Acceptance } \\
\text { Criterion } 2 \\
\text { 2.2.1.2.2.3 } \\
\text { Acceptance } \\
\text { Criteria } \\
1 \text { and } 2\end{array}$ \\
\hline
\end{tabular}

FEPs = features, events, and processes, PRD = Project Requirements Document, YMRP = Yucca Mountain Review Plan

\subsubsection{Project Requirements Document}

Project Requirements Document (PRD) (Canori and Leitner 2003 [DIRS 166275]) documents and categorizes the regulatory requirements and other project requirements and provides a crosswalk to the various YMP organizations that are responsible for ensuring that the criteria have been addressed in the LA. The regulatory requirements include criteria relevant to performance assessment activities, in general, and to FEP-related activities as they pertain to performance assessment, in particular. Table 4-4 provides a crosswalk between the regulatory requirements, the PRD (Canori and Leitner 2003 [DIRS 166275]), and the acceptance criteria provided in Yucca Mountain Review Plan, Final Report (YMRP) (NRC 2003 [DIRS 163274], Sections 2.2.1.2.1.3 and 2.2.1.2.2.3). 


\subsubsection{Yucca Mountain Review Plan}

The acceptance criteria for the NRC review of the LA are described in Yucca Mountain Review Plan, Final Report (YMRP) (NRC 2003 [DIRS 163274], Section 2.2.1.2). In Table 4-4, YMRP acceptance criteria are correlated to the corresponding regulations as they pertain to FEP-related criteria.

The cited YMRP (NRC 2003 [DIRS 163274]) criteria are provided in Table 4-5. The YMRP acceptance criteria for FEP screening echo the regulatory screening criteria of low probability and low consequence, but also allow for exclusion of a FEP if the process is specifically excluded by the regulations (Section 4.2.3).

Table 4-5. Relevant YMRP Acceptance Criteria

\begin{tabular}{|c|c|c|}
\hline YMRP Section & $\begin{array}{c}\text { Acceptance } \\
\text { Criterion }\end{array}$ & Description \\
\hline \multirow{4}{*}{$\begin{array}{l}\text { Scenario Analysis } \\
\text { and Event } \\
\text { Probability: } \\
\text { Scenario Analysis } \\
\text { (from } \\
\text { Section 2.2.1.2.1.3 } \\
\text { NUREG-1804 } \\
\text { [DIRS 163274]) }\end{array}$} & $\begin{array}{l}\text { 1. The } \\
\text { Identification of } \\
\text { a List of FEPs } \\
\text { Is Adequate }\end{array}$ & $\begin{array}{l}\text { The safety analysis report contains a complete list of FEPs related to the } \\
\text { geologic setting or the degradation, deterioration, or alteration of engineered } \\
\text { barriers (including those processes that would affect the performance of } \\
\text { natural barriers) that have the potential to influence repository performance. } \\
\text { The list is consistent with the site characterization data. Moreover, the } \\
\text { comprehensive features, events, and processes list includes, but is not limited } \\
\text { to, potentially disruptive events related to igneous activity (extrusive and } \\
\text { intrusive); seismic shaking (high-frequency-low magnitude, and rare } \\
\text { large-magnitude events); tectonic evolution (slip on existing faults and } \\
\text { formation of new faults); climatic change (change to pluvial conditions); and } \\
\text { criticality. }\end{array}$ \\
\hline & \multirow{3}{*}{$\begin{array}{l}\text { 2. Screening } \\
\text { of the Initial } \\
\text { List of } \\
\text { Features, } \\
\text { Events, and } \\
\text { Processes Is } \\
\text { Appropriate }\end{array}$} & $\begin{array}{l}\text { (1) The DOE has identified all FEPs related to either the geologic setting or to } \\
\text { the degradation, deterioration, or alteration of engineered barriers (including } \\
\text { those processes that would affect the performance of natural barriers) that } \\
\text { have been excluded. }\end{array}$ \\
\hline & & $\begin{array}{l}\text { (2) The DOE has provided justification for those FEPs that have been } \\
\text { excluded. An acceptable justification for excluding FEPS is that either the FEP } \\
\text { is specifically excluded by regulation; probability of the FEP (generally an } \\
\text { event) falls below the regulatory criterion; or omission of the feature, and } \\
\text { process does not significantly change the magnitude and time of the resulting } \\
\text { radiological exposures to the reasonably maximally exposed individual, or } \\
\text { radionuclide releases to the accessible environment. }\end{array}$ \\
\hline & & $\begin{array}{l}\text { (3) The DOE has provided an adequate technical basis for each FEP, } \\
\text { excluded from the performance assessment, to support the conclusion that } \\
\text { either the FEP is specifically excluded by regulation; the probability of the FEP } \\
\text { falls below the regulatory criterion; or omission of the FEP does not } \\
\text { significantly change the magnitude and time of the resulting radiological } \\
\text { exposures to the reasonably maximally exposed individual, or radionuclide } \\
\text { releases to the accessible environment. }\end{array}$ \\
\hline
\end{tabular}


Table 4-5. Relevant YMRP Acceptance Criteria (Continued)

\begin{tabular}{|c|c|c|}
\hline YMRP Section & $\begin{array}{c}\text { Acceptance } \\
\text { Criterion }\end{array}$ & Description \\
\hline \multirow{2}{*}{$\begin{array}{l}\text { Scenario Analysis } \\
\text { and Event } \\
\text { Probability: } \\
\text { Identification of } \\
\text { Events with } \\
\text { Probability Greater } \\
\text { than } 10^{-8} \text { per Year } \\
\text { (from } \\
\text { Section 2.2.1.2.2.3 } \\
\text { NUREG-1804 } \\
\text { [DIRS 163274]) }\end{array}$} & $\begin{array}{l}\text { 2. Probability } \\
\text { Estimates for } \\
\text { Future Events } \\
\text { Are Supported } \\
\text { by Appropriate } \\
\text { Technical } \\
\text { Bases }\end{array}$ & $\begin{array}{l}\text { (1) Probabilities for future natural events are based on past patterns of the } \\
\text { natural events in the Yucca Mountain region, considering the likely future } \\
\text { conditions and interactions of the natural and engineered repository system. } \\
\text { These probability estimates have specifically included igneous events, faulting } \\
\text { and seismic events, and criticality events. }\end{array}$ \\
\hline & $\begin{array}{l}\text { 3. Probability } \\
\text { Model Support } \\
\text { is Adequate }\end{array}$ & $\begin{array}{l}\text { (1) Probability models are justified through comparison with output from } \\
\text { detailed process level models and/or empirical observations (e.g., laboratory } \\
\text { testing, field measurements, or natural analogs, including Yucca Mountain site } \\
\text { data). Specifically: } \\
\text { (a) For infrequent events, the U.S. Department of Energy justifies, to the } \\
\text { extent appropriate, proposed probability models with data from } \\
\text { reasonably analogous systems. Analog systems should contain } \\
\text { significantly more events than the Yucca Mountain system, to provide } \\
\text { reasonable evaluations of probability model performance; } \\
\text { (b) The U.S. Department of Energy justifies, to the extent appropriate, } \\
\text { the ability of probability models to produce results consistent with the } \\
\text { timing and characteristics (e.g., location and magnitude) of successive } \\
\text { past events in the Yucca Mountain system; and } \\
\text { (c) The U.S. Department of Energy probability models for natural events } \\
\text { use underlying geologic bases (e.g., tectonic models) that are consistent } \\
\text { with other relevant features, events, and processes evaluated. }\end{array}$ \\
\hline
\end{tabular}

DOE = U.S. Department of Energy; FEP=feature, event, and process; YMRP=Yucca Mountain Review Plan, Final Report

\subsubsection{FEPs Screening Criteria}

The criteria for determining exclusions for low probability, low consequence, or by regulation are described below.

\section{Low Probability}

The low-probability criterion is stated in 10 CFR 63.114(d) [DIRS 173273]:

Consider only events that have at least one chance in 10,000 of occurring over 10,000 years.

and supported by 10 CFR 63.342 [DIRS 173273]:

The Department of Energy's (DOE) performance assessments shall not include consideration of very unlikely features, events, or processes, i.e., those that are estimated to have less than one chance in 10,000 of occurring within 10,000 years of disposal.

As noted in Section 5 (Assumption 5.1), the low-probability criterion for very unlikely events corresponds to an annual-exceedance probability of $10^{-8}$. 


\section{Low Consequence}

The low consequence criterion is stated in 10 CFR 63.114 (e and f) [DIRS 173273]:

(e) Provide the technical basis for either inclusion or exclusion of specific features, events, and processes in the performance assessment. Specific features, events, and processes must be evaluated in detail if the magnitude and time of the resulting radiological exposures to the reasonably maximally exposed individual, or radionuclide releases to the accessible environment, would be significantly changed by their omission.

(f) Provide the technical basis for either inclusion or exclusion of degradation, deterioration, or alteration processes of engineered barriers in the performance assessment, including those processes that would adversely affect the performance of natural barriers. Degradation, deterioration, or alteration processes of engineered barriers must be evaluated in detail if the magnitude and time of the resulting radiological exposures to the reasonably maximally exposed individual, or radionuclide releases to the accessible environment, would be significantly changed by their omission.

and supported by 10 CFR 63.342 [DIRS 173273]:

DOE's performance assessments need not evaluate the impacts resulting from any features, events, and processes or sequences of events and processes with a higher chance of occurrence if the results of the performance assessments would not be changed significantly.

Some FEPs have a beneficial effect on the TSPA, as opposed to an adverse effect. As identified in 10 CFR 63.102(j) [DIRS 173273], the concept of a performance assessment includes:

The features, events, and processes considered in the performance assessment should represent a wide range of both beneficial and potentially adverse effects on performance (e.g., beneficial effects of radionuclide sorption; potentially adverse effects of fracture flow or a criticality event). Those features, events, and processes expected to materially affect compliance with [10 CFR] 63.113(b) or be potentially adverse to performance are included, while events (event classes or scenario classes) that are very unlikely (less than one chance in 10,000 over 10,000 years) can be excluded from the analysis. ...

Yucca Mountain Review Plan, Final Report (NRC 2003 [DIRS 163274], Section 2.2.1) states:

In many regulatory applications, a conservative approach can be used to decrease the need to collect additional information or to justify a simplified modeling approach. Conservative estimates for the dose to the reasonably maximally exposed individual may be used to demonstrate that the proposed repository meets U.S. Nuclear Regulatory Commission regulations and provides adequate protection of public health and safety. ...The total system performance assessment is a complex analysis with many parameters, and the U.S. Department 
of Energy may use conservative assumptions to simplify its approaches and data collection needs. However, a technical basis ... must be provided.

On the basis of these statements, those FEPs that are demonstrated to have only beneficial effects on the radiological exposures to the reasonably maximally exposed individual, or radionuclide releases to the accessible environment, can be excluded on the basis of low consequence because they have no adverse effects on performance.

\section{By Regulation}

Yucca Mountain Review Plan, Final Report (NRC 2003 [DIRS 163274], Section 2.2.1.2.1.3, Acceptance Criterion 2) allows for exclusion of a FEP if the process is specifically excluded by the regulations. To wit:

The DOE has provided justification for those FEPs that have been excluded. An acceptable justification for excluding FEPs is that either the FEP is specifically excluded by regulation; probability of the FEP (generally an event) falls below the regulatory criterion; or omission of the feature, and process does not significantly change the magnitude and time of the resulting radiological exposures to the reasonably maximally exposed individual (RMEI), or radionuclide releases to the accessible environment.

\subsection{CODES, STANDARDS, AND REGULATIONS}

No codes, standards, or regulations, other than those identified in Project Requirements Documents (Canori and Leitner 2003 [DIRS 166275], Table 2-3) and determined to be applicable in Table 4-5, were used in this report. 


\section{ASSUMPTIONS}

Assumption 5.1-A regulation expressed as a probability criterion also can be expressed as an annual exceedance probability, which is defined as "the probability that a specified value will be exceeded during one year." More specifically, a stated probability screening criterion for very unlikely FEPs of one chance in 10,000 in 10,000 years $\left(10^{-4} / 10^{4} \mathrm{yr}\right)$ is assumed equivalent to a $10^{-8}$ annual exceedance probability or annual exceedance frequency.

Justification-The assumption of equivalence of annual exceedance probability is appropriate if the possibility of an event is equal for any given year (10 CFR 63.114(d) [DIRS 173273]). Geologic events such as earthquakes are considered independent events with regard to size, time, and location. Consequently, assuming annual equivalence is reasonable. No further confirmation is required.

Use-This assumption is used in FEPs 2.2.06.02.0A and 2.2.06.02.0B.

Assumption 5.2-It is assumed that the repository will be constructed, operated, and closed according to the regulatory requirements applicable to the construction operation and closure period. Deviations from design will be detected and corrected.

Justification-Inherent in the FEPs evaluation approach is the assumption that the repository will be constructed, operated, and closed according to the design used as the basis for the FEP screening and in accordance with NRC license requirements. This is inherent in performance evaluation of any engineering project, and design verification and performance confirmation are required as part of the construction and operation processes. Therefore, no further confirmation of the assumption is required.

Engineering and design changes are subject to evaluation to determine if there are any adverse manner impacts to safety as codified at 10 CFR 63.73 and in Subparts F and G [DIRS 173273]. See also the requirements at 10 CFR 63.32, 10 CFR 63.44, and 10 CFR 63.131 [DIRS 173273].

These requirements require the periodic and special reports regarding:

(1) Progress of construction

(2) Any data about the site, obtained during construction, that are not within the predicted limits on which the facility design was based

(3) Any deficiencies in design and construction that, if uncorrected, could adversely affect safety at any future time

(4) Results of research and development programs being conducted to resolve safety questions.

Use-Any changes in direct inputs listed in Section 4.1, in baseline conditions used for this evaluation, or in other subsurface conditions, will need to be evaluated to determine if the changes are within the limits stated in the FEP evaluations. This assumption is specifically used in FEPs 1.1.04.01.0A and 1.1.11.00.0A. 


\section{INTENTIONALLY LEFT BLANK}




\section{SCIENTIFIC ANALYSIS DISCUSSION}

The following sections discuss the UZ FEP analyses. Section 6.1 of this report discusses the methods and approach used for the FEP screening. Section 6.2 provides the screening documentation for included FEPs (those that are screened into TSPA) and Sections 6.3 through 6.9 provide the screening documentation for excluded FEPs (those that are screened out of TSPA).

\subsection{METHODS AND APPROACH}

The identification and screening process of a comprehensive list of FEPs potentially relevant to the postclosure performance of the Yucca Mountain repository is an ongoing, iterative process based on site-specific information, design, and regulations. FEP analysis uses the following definitions from Yucca Mountain Review Plan, Final Report (NRC 2003 [DIRS 163274], Glossary):

- Feature An object, structure, or condition that has a potential to affect disposal system performance.

- Event A natural or human-caused phenomenon that has a potential to affect disposal system performance and that occurs during an interval that is short compared to the period of performance.

- Process A natural or human-caused phenomenon that has a potential to affect disposal system performance and that operates during all or a significant part of the period of performance.

FEP analysis for TSPA-LA is described in The Development of the TSPA-LA Features, Events, and Processes (BSC 2005 [DIRS 173800]), which is summarized in the following sections.

\subsubsection{Identification of Features, Events, and Processes}

The first step of FEP analysis is the FEP identification and classification process, which addresses Acceptance Criterion 1 of the YMRP (NRC 2003 [DIRS 163274], Section 2.2.1.2.1.3). The TSPA-LA FEP identification and classification process is described in Section 3 of The Development of the TSPA-LA Features, Events, and Processes (BSC 2005 [DIRS 173800]). This classification process resulted in the LA FEP list and screening (DTN: MO0501SEPFEPLA.001 [DIRS 172601]), which was used as input in this UZ FEP analysis. This report addresses the 93 FEPs that are identified as UZ FEPs for TSPA-LA as noted and derived from the YMP FEPs database.

\subsubsection{Feature, Event, and Process Screening Process}

The second step of FEP analysis is FEP screening, which addresses Acceptance Criterion 2 of the YMRP (NRC 2003 [DIRS 163274], Section 2.2.1.2.1.3). The TSPA-LA FEP screening process is described in Section 4 of The Development of the TSPA-LA Features, Events, and Processes (BSC 2005 [DIRS 173800]). 
For the purposes of this report, the FEPs are divided into two broad categories: included and excluded FEPs. Each FEP is screened against the specified exclusion criteria (Section 4.2.1) summarized in the following FEP screening statements:

- FEPs having less than one chance in 10,000 of occurring over 10,000 years may be excluded (screened out) from the TSPA on the basis of low probability (as per 10 CFR 63.114(d) [DIRS 173273])

- FEPs whose omission would not significantly change the magnitude and time of the resulting radiological exposures to the reasonably maximally exposed individual, or radionuclide releases to the accessible environment, may be excluded (screened out) from the TSPA on the basis of low consequence (as per 10 CFR 63.114(e) and (f) [DIRS 173273])

- FEPs that are inconsistent with the characteristics, concepts, and definitions specified in 10 CFR Part 63 [DIRS 173273] may be excluded (screened out) from the TSPA by regulation.

A FEP need only satisfy one of the exclusion screening criteria to be excluded from TSPA. A FEP that does not satisfy any of the exclusion screening criteria must be included (screened in) in the TSPA-LA model.

This report documents the screening decisions for the UZ FEPs. In cases where a FEP covers multiple technical areas and is shared with other FEP reports, this report provides only a partial technical basis for the screening decision as it relates to UZ issues. The full technical basis for these shared FEPs is addressed, collectively, by all of the sharing FEP reports.

For UZ Flow and Transport, there are 41 included FEPs and 52 excluded FEPs. Included FEPs are those directly (or, in some cases, implicitly) represented in TSPA-LA models. Included FEPs are identified and the method for inclusion is summarized, with reference to the reports that document how the FEP is represented in TSPA-LA. Section 6.2 discusses FEPs that are included in TSPA-LA.

Excluded FEPs are those excluded due to low probability, low consequence, or by regulation and therefore not modeled in TSPA-LA. In particular, low probability means that the occurrence of a FEP has a probability lower than $10^{-4}$ in $10^{4}$ years. Low-consequence arguments in this analysis are based on the UZ subsystem performance. UZ subsystem performance is defined by the release of radionuclides at the water table for saturated zone (SZ) radionuclide transport, or water seepage into waste emplacement drifts. A UZ subsystem low-consequence argument for exclusion is always conservative with respect to a total system argument, because the other components that contribute to performance are not amplified by changes in UZ performance. The performance of the waste package outer barrier and drip shield over 10,000 years depends on temperature, relative humidity, and water chemistry derived from seepage water chemistry, but is not a strong function of drift seepage quantity (BSC 2004 [DIRS 169984], Figure 6-1; BSC 2004 [DIRS 169845], Figure 1). Seepage water chemistry is determined mainly by water-rock interaction and evaporative concentration in the near-field, and the uncertainty in seepage water chemistry determined by the uncertainty in initial water chemistry, as discussed in 
Drift-Scale THC Seepage Model (BSC 2005 [DIRS 172862]), Section 6.6.2). In addition, the rate of radionuclide transport in the saturated zone is independent of the source-term strength. Therefore, some FEPs may have a significant effect on radionuclide transport or drift seepage in the UZ and yet have an insignificant effect on total system performance, because of the contributions of the other system components to total system performance. Thus, if a FEP can be shown to have minimal consequence on the UZ subsystem performance, and is not included by any other FEP report, then it will also have a minimal consequence on total system performance in terms of the time or magnitude of the resulting radiological exposures to the reasonably maximally exposed individual, or radionuclide releases to the accessible environment. The rationale for exclusion is given in the screening argument presented for each excluded FEP. Sections 6.3 through 6.9 discuss FEPs that are excluded from TSPA-LA.

The following standardized format is used to present the status of each FEP as presented in the third-order subsections of this chapter. Documentation of the screening for each FEP is provided in Sections 6.2 through 6.9. The following standardized format is used.

Third-Order Subsection Heading: FEP Name (FEP Number)

FEP Description: This field describes the nature and scope of the FEP under consideration.

Screening Decision: Identifies the screening decision as one of:

- "Included"

- "Excluded-Low Probability"

- "Excluded-Low Consequence"

- "Excluded-By Regulation."

A few FEPs are excluded by a combination of two criteria (e.g., Low Probability and Low Consequence).

Screening Argument: This field is used only for excluded FEPs. It provides the discussion for why a FEP has been excluded from TSPA-LA.

TSPA Disposition: This field is used only for included FEPs. It provides the consolidated discussion of how a FEP has been included in TSPA-LA, making reference to more detailed documentation in other supporting technical reports, as applicable.

Supporting Reports: This field is only used for included FEPs. It provides the list of supporting technical reports that identified the FEP as an included FEP and contain information relevant to the implementation of the FEP within the TSPA-LA model. This list of supporting technical reports provides traceability of the FEP through the document hierarchy. For excluded FEPs, it is indicated as "Not applicable."

\subsubsection{Supporting Reports and Inputs}

For included FEPs, the model reports develop the models or parameters. These are passed to abstraction reports and then to the TSPA model. In some cases, process model reports pass outputs directly to the TSPA model (e.g., in the flow fields that are output from UZ Flow Models 
and Submodels (BSC 2004 [DIRS 169861])). Reports that discuss the subject matter of a FEP, but do not develop any input that is eventually used in, or abstracted for use in, the TSPA model are not listed as supporting reports in the disposition of included FEPs. Supporting reports are listed below.

- Abstraction of Drift Seepage

(BSC 2004 [DIRS 169131])

- Analysis of Hydrologic Properties Data

(BSC 2004 [DIRS 170038])

- Analysis of Infiltration Uncertainty

(BSC 2004 [DIRS 165991])

- Calibrated Properties Model

(BSC 2004 [DIRS 169857])

- Conceptual Model and Numerical Approaches for UZ (BSC 2004 [DIRS 170035]) Flow and Transport

- Development of Numerical Grids for UZ Flow and (BSC 2004 [DIRS 169855]) Transport Modeling

- Drift Scale THM Model

(BSC 2004 [DIRS 169864])

- Drift-Scale Coupled Processes (DST and TH Seepage)

(BSC 2005 [DIRS 172232]) Models

- Drift-Scale THC Seepage Model

(BSC 2005 [DIRS 172862])

- Future Climate Analysis

(BSC 2004 [DIRS 170002])

- In Situ Field Testing of Processes

(BSC 2004 [DIRS 170004])

- Particle Tracking Model and Abstraction of Transport

(BSC 2005 [DIRS 173980]) Processes

- Post-Processing Analysis for THC Seepage

(BSC 2004 [DIRS 169858])

- Radionuclide Transport Models Under Ambient (BSC 2004 [DIRS 164500]) Conditions

- Saturated Zone Colloid Transport

(BSC 2004 [DIRS 170006])

- Seepage Calibration Model and Seepage Testing Data

(BSC 2004 [DIRS 171764])

- Seepage Model for PA Including Drift Collapse

(BSC 2004 [DIRS 167652])

- Simulation of Net Infiltration for Present-Day and (BSC 2004 [DIRS 170007]) Potential Future Climates

- UZ Flow Models and Submodels

(BSC 2004 [DIRS 169861]) 
Direct inputs to this report are listed in Table 4-2. Indirect inputs are cited within the discussions of individual FEPs; those indirect inputs that demonstrate the inclusion of FEPs in TSPA are also listed in Table 4-1.

\subsubsection{Qualification of Unqualified Direct Inputs}

Direct inputs are listed in Section 4.1, which identifies several inputs that are qualified in this report in accordance with LP-SIII.2Q-BSC or LP-SIII.9Q-BSC. The qualification reports for those inputs are included in Appendix C.

\subsubsection{Assumptions, Simplifications, and Uncertainties}

For included FEPs, the TSPA dispositions may include statements regarding assumptions made to implement the FEP within the TSPA-LA model. Such statements are descriptive of the manner in which the FEP has been included and are not used as the basis of the screening decision to include the FEP with the TSPA-LA model.

Because the individual FEPs are specific in nature, any discussion of applicable mathematical formulations, equations, algorithms, numerical methods, idealizations, or simplifications are provided within the individual FEP discussions in Sections 6.2 through 6.9.

For included FEPs, uncertainty is captured in the treatment of the processes as implemented in TSPA-LA. Therefore, uncertainty from the standpoint of the FEPs evaluation is concerned only with uncertainty in the exclusion of FEPs. Because there is no mechanism to capture uncertainty in the FEPs analysis in TSPA-LA, uncertainty leads to conservatism in the FEPs exclusion analyses (i.e., exclusions are based on conservative arguments that are unlikely to change with more detailed or accurate input information). The only restrictions for subsequent use that result from this approach is that worst-case or conservative analyses may overemphasize the importance of FEPs included on that basis.

\subsubsection{Intended Use and Limitations}

The intended use of this report is to provide FEP screening information for a project-specific FEP database and to promote traceability and transparency regarding FEP screening. This report is the documentation for the FEP database described in The Development of the Total System Performance Assessment License Application Features, Events, and Processes (BSC 2005 [DIRS 173800]). For included FEPs, this document summarizes and consolidates the method of implementation of the FEP in TSPA-LA in the form of TSPA disposition statements, based on more detailed implementation information in the listed supporting technical reports. For excluded FEPs, this document provides the technical basis for exclusion in the form of screening arguments.

The results of the FEP screening are specific to the repository design evaluated in this report for TSPA-LA, as presented in several reports (BSC 2004 [DIRS 168489]; BSC 2004 [DIRS 168180]; BSC 2005 [DIRS 173498]; BSC 2005 [DIRS 173871]). Any changes in direct inputs listed in Section 4.1, in baseline conditions used for this evaluation, or in other subsurface conditions, will need to be evaluated to determine whether the changes are within the limits stated in the FEP evaluations. 


\subsection{INCLUDED FEPS}

Table 6-1 gives the section numbers, FEP numbers, and names of Included FEPs. For FEP 3.1.01.01.0A, the FEP description in Section 6.2.41 is changed slightly from the description given in DTN: MO0501SEPFEPLA.001 [DIRS 172601]. The difference is editorial in nature.

Table 6-1. Included UZ FEPs

\begin{tabular}{|c|c|c|}
\hline $\begin{array}{l}\text { Section } \\
\text { Number }\end{array}$ & FEP Number & FEP Name \\
\hline 6.2 .1 & 1.1.02.02.0A & Preclosure ventilation \\
\hline 6.2 .2 & 1.2.02.01.0A & Fractures \\
\hline 6.2 .3 & 1.2.02.02.0A & Faults \\
\hline 6.2 .4 & 1.3.01.00.0A & Climate change \\
\hline 6.2 .5 & 1.3.07.02.0B & Water table rise affects UZ \\
\hline 6.2 .6 & 1.4.01.01.0A & Climate modification increases recharge \\
\hline 6.2 .7 & 2.1.08.01.0A & Water influx at the repository \\
\hline 6.2 .8 & 2.1.08.02.0A & Enhanced influx at the repository \\
\hline 6.2 .9 & 2.2.01.01.0A & Mechanical effects of excavation and construction in the near-field \\
\hline 6.2 .10 & 2.2.03.01.0A & Stratigraphy \\
\hline 6.2 .11 & 2.2.03.02.0A & Rock properties of host rock and other units \\
\hline 6.2 .12 & 2.2.07.01.0A & Locally saturated flow at bedrock/alluvium contact \\
\hline 6.2 .13 & 2.2.07.02.0A & Unsaturated groundwater flow in the geosphere \\
\hline 6.2 .14 & 2.2.07.03.0A & Capillary rise in the UZ \\
\hline 6.2 .15 & 2.2.07.04.0A & Focusing of unsaturated flow (fingers, weeps) \\
\hline 6.2 .16 & 2.2.07.06.0B & Long-term release of radionuclides from the repository \\
\hline 6.2.17 & 2.2.07.07.0A & Perched water develops \\
\hline 6.2 .18 & 2.2.07.08.0A & Fracture flow in the UZ \\
\hline 6.2 .19 & 2.2.07.09.0A & Matrix imbibition in the UZ \\
\hline 6.2 .20 & 2.2.07.10.0A & Condensation zone forms around drifts \\
\hline 6.2 .21 & 2.2.07.11.0A & Resaturation of geosphere dry-out zone \\
\hline 6.2 .22 & 2.2.07.15.0B & Advection and dispersion in the UZ \\
\hline 6.2 .23 & 2.2.07.18.0A & Film flow into the repository \\
\hline 6.2 .24 & 2.2.07.19.0A & Lateral flow from Solitario Canyon fault enters drifts \\
\hline 6.2 .25 & 2.2.07.20.0A & Flow diversion around repository drifts \\
\hline 6.2 .26 & 2.2.08.01.0B & Chemical characteristics of groundwater in the UZ \\
\hline 6.2 .27 & 2.2.08.04.0A & Re-dissolution of precipitates directs more corrosive fluids to waste packages \\
\hline 6.2 .28 & 2.2.08.06.0B & Complexation in the UZ \\
\hline 6.2 .29 & 2.2.08.08.0B & Matrix diffusion in the UZ \\
\hline 6.2 .30 & 2.2.08.09.0B & Sorption in the UZ \\
\hline 6.2 .31 & 2.2.08.10.0B & Colloidal transport in the UZ \\
\hline 6.2 .32 & 2.2.08.12.0A & Chemistry of water flowing into the drift \\
\hline 6.2 .33 & 2.2.09.01.0B & Microbial activity in the UZ \\
\hline 6.2 .34 & 2.2.10.03.0B & Natural geothermal effects on flow in the UZ \\
\hline 6.2 .35 & 2.2.10.10.0A & Two-phase buoyant flow/heat pipes \\
\hline 6.2 .36 & 2.2.10.12.0A & Geosphere dry-out due to waste heat \\
\hline
\end{tabular}


Table 6-1. Included UZ FEPs (Continued)

\begin{tabular}{|l|l|l|}
\hline $\begin{array}{c}\text { Section } \\
\text { Number }\end{array}$ & FEP Number & \multicolumn{1}{|c|}{ FEP Name } \\
\hline 6.2 .37 & $2.3 .01 .00 .0 \mathrm{~A}$ & Topography and morphology \\
\hline 6.2 .38 & $2.3 .11 .01 .0 \mathrm{~A}$ & Precipitation \\
\hline 6.2 .39 & $2.3 .11 .02 .0 \mathrm{~A}$ & Surface runoff and flooding \\
\hline 6.2 .40 & $2.3 .11 .03 .0 \mathrm{~A}$ & Infiltration and recharge \\
\hline 6.2 .41 & $3.1 .01 .01 .0 \mathrm{~A}$ & Radioactive decay and ingrowth \\
\hline
\end{tabular}

Source: DTN: MO0501SEPFEPLA.001 [DIRS 172601].

\subsubsection{Preclosure Ventilation (1.1.02.02.0A)}

FEP Description: The duration of preclosure ventilation acts together with waste package spacing (as per design) to control the extent of the boiling front (zone of reduced water content).

Screening Decision: Included.

TSPA Disposition: Preclosure ventilation in drifts will remove a considerable amount of the heat output from the waste canisters. The ventilation period following emplacement is 50 years, during which, for an 800 -m-long drift, $86 \% \pm 3 \%$ of the heat energy supplied to the rock by the waste is removed from the drifts by ventilation (BSC 2004 [DIRS 169862], Table 8-2). This effect of preclosure ventilation on the thermal load provided to the rock is explicitly simulated in Drift-Scale Coupled Processes (DST and TH Seepage) Models (BSC 2005 [DIRS 172232], Sections 4.1.1.3 and 6.2.1.3.3), which bases its simulations on $86.3 \%$ heat removal by ventilation. Those results are incorporated into the seepage abstraction by using time-dependent boundary conditions for the thermal load (BSC 2004 [DIRS 169131], Section 6.4.3.1). These boundary conditions reflect the current emplacement design (waste package spacing, average heat output of waste canisters, etc.), as provided in design drawing $D \& E / P A / C$ IED Emplacement Drift Configuration and Environment (BSC 2004 [DIRS 168489]). Thus, the thermal-hydrologic (TH) modeling results from the $\mathrm{TH}$ seepage model (DTN: LB0301DSCPTHSM.002 [DIRS 163689]) directly account for the impact of preclosure ventilation and waste package spacing on two-phase flow and the TH conditions in the near-drift rock. As discussed in Abstraction of Drift Seepage (BSC 2004 [DIRS 169131], Section 6.5.2), the abstraction of thermal seepage utilizes these modeling results to develop an appropriate thermal seepage abstraction methodology. Preclosure ventilation also causes initial rock drying in the drift vicinity because of evaporation effects. The reduced relative humidity in the emplacement drifts leads to evaporation of water at the drift surfaces and development of a small zone of reduced saturation in the drift vicinity. This early dryout because of evaporation is neglected in the TH seepage model because seepage into ventilated drifts is highly unlikely (BSC 2004 [DIRS 169131], Section 6.5.2). The effects of preclosure ventilation on dryout of the rock are the same for the thermal-hydrologic-chemical (THC) model as for the TH model.

The effect of preclosure ventilation on the thermal load provided to the rock is also explicitly simulated with the THC seepage model that feeds into the drift-scale coupled processes abstraction model, by using time-dependent boundary conditions for the thermal load (BSC 2005 
[DIRS 172862], Sections 4.1.7 and 6.5). These boundary conditions reflect the current emplacement design (waste package spacing, average heat output of waste canisters, etc.), provided in the design drawings (BSC 2004 [DIRS 168489]).

The results from the THC seepage model, and their abstraction (BSC 2004 [DIRS 169858], Section 6.2), account for the impact of preclosure ventilation and waste package spacing on the THC conditions in the near-drift rock. Summary tables of concentrations through time are presented in DTNs: LB0302DSCPTHCS.002 [DIRS 161976] and LB0307DSTTHCR2.002 [DIRS 165541], and summary statistics through time are presented in DTN: LB0311ABSTHCR2.001 [DIRS 166714]. These data are used to feed and/or provide technical basis for Engineered Barrier System: Physical and Chemical Environment (BSC 2005 [DIRS 173727]), which generates lookup tables used in the TSPA-LA model.

Supporting Reports: Abstraction of Drift Seepage (BSC 2004 [DIRS 169131]); Drift-Scale THC Seepage Model (BSC 2005 [DIRS 172862]); Drift-Scale Coupled Processes (DST and TH Seepage) Models (BSC 2005 [DIRS 172232]).

\subsubsection{Fractures (1.2.02.01.0A)}

FEP Description: Groundwater flow in the Yucca Mountain region and transport of any released radionuclides may take place along fractures. The rate of flow and the extent of transport in fractures are influenced by characteristics such as orientation, aperture, asperity, fracture length, connectivity, and the nature of any linings or infills.

Screening Decision: Included.

TSPA Disposition: This FEP on "Fractures" is included in process models for UZ flow and transport. The UZ flow model is based on a dual-permeability concept, with fractures and matrix each represented by a continuum in the dual permeability mesh (BSC 2004 [DIRS 169855]). The fracture continuum represents the spatially averaged flow through discrete fractures. The fracture continuum interacts with the matrix continuum, which represents matrix blocks separated by fractures.

Fracture continuum properties include permeability, porosity, interface area per unit volume, van Genuchten $\alpha$ and $m$ parameters for the saturation-capillary pressure and relative permeability functions, and an active fracture parameter. These parameters and the associated ranges of values are obtained as described in UZ Flow Models and Submodels (BSC 2004 [DIRS 169861], Section 6.1.5) and adjusted as described in UZ Flow Models and Submodels (BSC 2004 [DIRS 169861], Section 6.2.3) for each UZ model layer (DTNs: LB0205REVUZPRP.001 [DIRS 159525] and LB0209DSSCFPR.002 [DIRS 162128]).

Fracture permeability is based on field measurements, which integrate the discrete fracture characteristics such as orientation, aperture, asperity, fracture length, connectivity, and the nature of any linings or infills. Permeabilities and other properties are further calibrated as described in Calibrated Properties Model (BSC 2004 [DIRS 169857], Section 6.3) and Analysis of Hydrologic Properties Data (BSC 2004 [DIRS 170038]). The fracture continuum properties are used as inputs to the UZ flow model, and their effects are incorporated into the output flow fields 
developed for use in TSPA-LA (output flow fields are in DTN: LB0305TSPA18FF.001 [DIRS 165625]).

The permeability of bedrock (either unfractured PTn or fractured TCw depending on location) is a major contributor to the simulation of net infiltration (BSC 2004 [DIRS 170007], Section 6.1.2). Simulation of Net Infiltration for Present-Day and Potential Future Climates (BSC 2004 [DIRS 170007], Section 6.1) discusses conceptual treatment of fractures in the infiltration model and numerical values used (BSC 2004 [DIRS 170007], Appendix B).

The influence of fractures on radionuclide transport through the UZ is investigated through the dual permeability model (BSC 2005 [DIRS 173980], Section 6.4.3). The influences of fracture characteristics on UZ flow are included through the pregenerated flow fields (BSC 2005 [DIRS 173980], Section 6.5.1; DTN: LB0305TSPA18FF.001 [DIRS 165625]). Fracture aperture, porosity, and frequency (DTNs: LB0205REVUZPRP.001 [DIRS 159525] and LB0207REVUZPRP.001 [DIRS 159526]) affecting UZ radionuclide transport are summarized in Particle Tracking Model and Abstraction of Transport Processes (BSC 2005 [DIRS 173980], Section 6.5.7). Fracture porosity and frequency data will be statistically sampled during TSPA-LA multirealization runs using the distribution given in DTN: LA0407BR831371.001 [DIRS 170806].

Flow processes in fractures or other channels are important for seepage because the amount of seepage is determined by the diversion capacity of the fracture flow in the drift vicinity. This process is modeled in Seepage Model for PA Including Drift Collapse (BSC 2004 [DIRS 167652], Section 6.3). Seepage-relevant parameters are determined in Seepage Calibration Model and Seepage Testing Data (BSC 2004 [DIRS 171764], Sections 6.3 and 6.5), based upon data acquired in In Situ Field Testing of Processes (BSC 2004 [DIRS 170004], Sections 6.1 and 6.2). Data relevant to modeling of fracture-matrix interaction are acquired in $I n$ Situ Field Testing of Processes (BSC 2004 [DIRS 170004], Section 6.6). The seepage simulation results in Seepage Model for PA Including Drift Collapse (BSC 2004 [DIRS 167652] are abstracted for use in Abstraction of Drift Seepage (BSC 2004 [DIRS 169131], Section 6.3.1). These flow processes are influenced by fracture characteristics such as orientation, aperture, asperity, length, connectivity, and fillings. All seepage process models that feed into seepage abstraction explicitly simulate the flow processes in fractures, using appropriate continuum properties that represent these characteristics (BSC 2004 [DIRS 169131], Section 6.4).

For ambient seepage, the relevant continuum properties are the continuum permeability and the effective fracture capillary-strength in the drift vicinity. For seepage abstraction, probability distributions describing the spatial variability and uncertainty of these parameters have been developed in Abstraction of Drift Seepage (BSC 2004 [DIRS 169131], Section 6.6), based on air-permeability measurements and liquid-release tests combined with inverse modeling (BSC 2004 [DIRS 169131], Sections 6.6 and 6.4). Ambient seepage calculations will be conducted within the TSPA-LA by sampling from these probability distributions and interpolating seepage rates from the lookup tables given in DTNs: LB0407AMRU0120.001 [DIRS 173280] and LB0407AMRU0120.002 [DIRS 173308]. During the thermal period, the ambient seepage rates will be adjusted based on the TH-modeling results from Drift-Scale Coupled Processes (DST and TH Seepage) Models (BSC 2005 [DIRS 172232]), which explicitly simulates the thermally perturbed fracture flow conditions. Results are given in 
DTN: LB0301DSCPTHSM.002 [DIRS 163689]. Thermal-hydrologic-mechanical (THM) and THC effects on fracture characteristics are evaluated with process models that explicitly account for fracture flow affected by THM and THC parameter alterations (BSC 2004 [DIRS 169131], Section 6.4.4; see FEPs 2.1.09.12.0A and 2.2.10.04.0A). It was demonstrated that these potential alterations could be neglected in the TSPA-LA, because the expected changes would lead to less seepage (BSC 2004 [DIRS 169131], Section 6.5.1.4), and therefore would result in predictions that underestimate repository performance.

Flow processes in fractures or other channels affect modeled THC coupled processes because of (1) their strong effect on TH behavior (BSC 2004 [DIRS 169131], Sections 6.4.4.1 and 6.4.4.2), and (2) their strong effect on water and gas chemistry (BSC 2005 [DIRS 172862], Section 6.2.1). The latter is primarily due to volatilization of steam and $\mathrm{CO}_{2}$ from the rock matrix-water and subsequent transport and condensation in fractures. The amount of mobilized $\mathrm{CO}_{2}$ with steam directly affects the $\mathrm{pH}$ of the condensate, which in turn affects the degree of water-rock interaction and water chemistry. These THC processes are influenced by the fracture characteristics, such as orientation, aperture, asperity, length, connectivity, and fillings. The THC seepage model that feeds into the drift-scale coupled processes abstraction model explicitly simulates the flow processes in fractures using appropriate continuum properties that represent these characteristics (BSC 2005 [DIRS 172862], Sections 6.4.3, 6.4.4, and 6.4.7).

Thus, the results from the THC seepage model and their abstraction (BSC 2004 [DIRS 169858], Section 6.2), and tables of concentrations and summary statistics through time, implicitly account for the effect of climate change on THC processes. Summary tables of concentrations through time are presented in DTNs: LB0302DSCPTHCS.002 [DIRS 161976] and LB0307DSTTHCR2.002 [DIRS 165541], and summary statistics through time are presented in DTN: LB0311ABSTHCR2.001 [DIRS 166714]. These data are used to feed and/or provide technical basis for Engineered Barrier System: Physical and Chemical Environment (BSC 2005 [DIRS 173727]), which generates lookup tables used in the TSPA-LA model.

The effects of fractures are also included in the treatment of infiltration uncertainty for TSPA-LA (BSC 2003 [DIRS 165991]). Infiltration uncertainty is represented through three discrete infiltration scenarios (lower, mean, and upper), which are sampled in TSPA-LA according to weighting factors (BSC 2003 [DIRS 165991], Section 7.1). Fractures are included in the infiltration uncertainty analysis by incorporation of the fracture parameters for bedrock permeability (BRPERM) and bedrock porosity (BRPOROS) that are included implicitly in the determination of the weighting factors. Analysis of Infiltration Uncertainty (BSC 2003 [DIRS 165991], Table 6-1) defines these fracture parameters and their uncertainties (BSC 2003 [DIRS 165991], Tables 6-2 and 6-3). These uncertainties are propagated through the infiltration numerical model and so are implicitly included in the output (weighting factors) that is passed to TSPA-LA (BSC 2003 [DIRS 165991]; DTN: SN0308T0503100.008 [DIRS 165640]).

Supporting Reports: Simulation of Net Infiltration for Present-Day and Potential Future Climates (BSC 2004 [DIRS 170007]); Development of Numerical Grids for UZ Flow and Transport Modeling (BSC 2004 [DIRS 169855]); In Situ Field Testing of Processes (BSC 2004 [DIRS 170004]); Calibrated Properties Model (BSC 2004 [DIRS 169857]); UZ Flow Models and Submodels (BSC 2004 [DIRS 169861]); Particle Tracking Model and Abstraction of Transport Processes (BSC 2005 [DIRS 173980]); Seepage Model for PA Including Drift 
Collapse (BSC 2004 [DIRS 167652]); Seepage Calibration Model and Seepage Testing Data (BSC 2004 [DIRS 171764]); Analysis of Hydrologic Properties Data (BSC 2004 [DIRS 170038]), Drift-Scale THC Seepage Model (BSC 2005 [DIRS 172862]), Abstraction of Drift Seepage (BSC 2004 [DIRS 169131], Drift-Scale Coupled Processes (DST and TH Seepage) Models (BSC 2005 [DIRS 172232]), Analysis of Infiltration Uncertainty (BSC 2003 [DIRS 165991].

\subsubsection{Faults (1.2.02.02.0A)}

FEP Description: Numerous faults of various sizes have been noted in the Yucca Mountain region and specifically in the repository area. Faults may represent an alteration of the rock permeability and continuity of the rock mass, an alteration or short-circuiting of the flow paths and flow distributions close to the repository, and/or unexpected pathways through the repository.

Screening Decision: Included

TSPA Disposition: The stratigraphic units or layers and fault geometries are defined in Geological Framework Model (GFM2000) (BSC 2004 [DIRS 170029]) and DTN: MO0012MWDGFM02.002 [DIRS 153777]). This provides the basis the UZ model grid in Development of Numerical Grids for UZ Flow and Transport Modeling (BSC 2004 [DIRS 169855]). Major displacement, dip-slip, strike-slip, and detachment faults within the model domain are explicitly discretized in the mountain-scale UZ flow and transport models described in UZ Flow Models and Submodels (BSC 2004 [DIRS 169861], Sections 6.1.5, 6.2.2, 6.6.3, and 6.7.3) and Development of Numerical Grids for UZ Flow and Transport Modeling (BSC 2004 [DIRS 169855], Sections 6.4 and 6.6.1). These faults are represented in the UZ model grid developed in Development of Numerical Grids for UZ Flow and Transport Modeling (BSC 2004 [DIRS 169855] as vertical or inclined discrete zones $30 \mathrm{~m}$ wide, and include existing displacements that affect the relative geometry of the hydrogeologic model units. Specific hydrogeologic properties are assigned to the fault zones. Fault properties (matrix and fracture parameters) are in DTN: LB02092DSSCFPR.002 [DIRS 162128] and in UZ Flow Models and Submodels (BSC 2004 [DIRS 169861], Table 4.1-1). These properties have been calibrated as described in Calibrated Properties Model (BSC 2004 [DIRS 169857], Section 6.3.4) and Analysis of Hydrologic Properties Data (BSC 2004 [DIRS 170038]). The fault properties are used as inputs to the UZ flow model, and their effects are incorporated into the output flow fields developed for use in TSPA-LA (output flow fields are in DTN: LB0305TSPA18FF.001 [DIRS 165625]).

The influence of faults on radionuclide transport is implicitly included through the use of a dual permeability model, the use of pregenerated flow fields that include the faults in the three-dimensional model in Particle Tracking Model and Abstraction of Transport Processes (BSC 2005 [DIRS 173980], Section 6.5.1; DTN: LB0305TSPA18FF.001 [DIRS 165625]), and the characteristics of fractures within the faults (BSC 2005 [DIRS 173980], Section 6.5.7). In TSPA-LA runs, the influence of faults is included through the use of fault properties and the pregenerated flow fields under different climate conditions as described in Particle Tracking Model and Abstraction of Transport Processes (BSC 2005 [DIRS 173980], Sections 6.5.1 and 6.5.7). 
Supporting Reports: Development of Numerical Grids for UZ Flow and Transport Modeling (BSC 2004 [DIRS 169855]); Analysis of Hydrologic Properties Data (BSC 2004 [DIRS 170038]); Calibrated Properties Model (BSC 2004 [DIRS 169857]); UZ Flow Models and Submodels (BSC 2004 [DIRS 169861]); Particle Tracking Model and Abstraction of Transport Processes (BSC 2005 [DIRS 173980]).

\subsubsection{Climate Change (1.3.01.00.0A)}

FEP Description: Climate change may affect the long-term performance of the repository. This includes the effects of long-term change in global climate (e.g., glacial/interglacial cycles) and shorter-term change in regional and local climate. Climate is typically characterized by temporal variations in precipitation and temperature.

Screening Decision: Included.

TSPA Disposition: Global climate change is addressed in TSPA-LA, using a climate analysis based on paleoclimate information. That is, the record of climate changes in the past is used to predict the expected changes in climate for the future. Future climates are described in terms of discrete climate states that are used to approximate continuous variations in climate. The effects of seasonality are included in the climate analysis through the use of climate analogues with specific seasonal meteorological records. Climate analyses are incorporated into TSPA-LA through the UZ flow fields that have different surface water infiltration as a result of different climates corresponding to three distinct different climates (climate change timing in parentheses): present day (from 0 to 600 years after present), monsoon (from 600 to 2,000 years after present), and glacial transition (from 2,000 years after present to the end of the period simulated) (BSC 2005 [DIRS 173944], Section 5.1.4). The nine infiltration rates are summarized in Table 6-2 for average values over the model domain.

Table 6-2. Infiltration Rates (mm/year) Averaged over the UZ Model Domain

\begin{tabular}{|l|c|c|c|}
\hline \multicolumn{1}{|c|}{ Scenario } & Lower-Bound Infiltration & Mean Infiltration & Upper-Bound Infiltration \\
\hline Present-Day/Modern & 1.25 & 4.43 & 10.74 \\
\hline Monsoon & 4.43 & 11.83 & 19.23 \\
\hline Glacial Transition & 2.35 & 17.02 & 31.69 \\
\hline
\end{tabular}

NOTE: Values averaged from DTN: GS000308311221.005 [DIRS 147613].

Future climate conditions are addressed in the infiltration model (BSC 2004 [DIRS 170007], Section 6.9) through the selection of analogues at other locations with present day climates that are representative of the range of future climate conditions at Yucca Mountain (BSC 2004 [DIRS 170002], Section 6.6). The meteorological data from these analogues are then used for modeling infiltration under future climate conditions at Yucca Mountain. A description of the modeling methods used for infiltration, and of how infiltration is affected by climate, is given in Simulation of Net Infiltration for Present-Day and Potential Future Climates (BSC 2004 [DIRS 170007], Section 6.9). The results of the infiltration model are then used for computing UZ flow throughout the UZ flow-model domain, which includes the repository waste emplacement zone. The UZ flow model uses the infiltration results as top boundary conditions for UZ flow calculations (BSC 2004 [DIRS 169861], Section 6.1.4). The UZ flow fields are 
used directly in TSPA-LA (BSC 2004 [DIRS 169861], Section 6.2.5). The output flow fields are in DTN: LB0305TSPA18FF.001 [DIRS 165625], developed for use in performance assessment (BSC 2003 [DIRS 166296]); the conversion of flow fields to the format needed for use in TSPA is documented in UZ Flow Models and Submodels (BSC 2004 [DIRS 169861], Appendix D).

Climate change is implicitly included in the treatment of radionuclide transport for TSPA-LA as discussed in Particle Tracking Model and Abstraction of Transport Processes (BSC 2005 [DIRS 173980], Section 6.4.8). The effect of climate change on repository performance was studied by using pregenerated flow fields under different climates (DTN: LB0305TSPA18FF.001 [DIRS 165625]). For TSPA-LA, the pregenerated flow fields are used by the finite element heat and mass (FEHM) model as described in Particle Tracking Model and Abstraction of Transport Processes (BSC 2005 [DIRS 173980], Section 6.4.9).

Potential effects of climate change on the amount of infiltration and percolation at Yucca Mountain are taken implicitly into account in the THC seepage model by considering different climate stages and climate scenarios when setting infiltration rates at the top model boundary (BSC 2005 [DIRS 172862], Sections 6.2.1.3 and 6.5.2). Thus, the results from the THC seepage model and their abstraction (BSC 2004 [DIRS 169858], Section 6.2), and tables of concentrations and summary statistics through time, implicitly account for the effect of climate change on THC processes. Summary tables of concentrations through time are presented in DTNs: LB0302DSCPTHCS.002 [DIRS 161976], LB0307DSTTHCR2.002 [DIRS 165541], and summary statistics through time are presented in DTN: LB0311ABSTHCR2.001 [DIRS 166714]. These data are used to feed and/or provide technical basis for Engineered Barrier System: Physical and Chemical Environment (BSC 2005 [DIRS 173727]), which generates lookup tables used in the TSPA-LA model. Note that seepage is calculated in the TSPA-LA using percolation flux distributions based on results from the UZ flow and transport model (BSC 2004 [DIRS 169131], Section 6.6.5.1) given in DTNs: LB0302PTNTSW9I.001 [DIRS 162277] and LB0305PTNTSW9I.001 [DIRS 163690]. These flux distributions are based on the same varying climate stages and scenarios identified and used in the THC seepage model.

Potential effects of climate change on the amount of infiltration and percolation at Yucca Mountain are taken into account in the seepage abstraction by considering different climate stages and climate scenarios in Abstraction of Drift Seepage (BSC 2004 [DIRS 169131], Section 6.6.5) and in Drift-Scale Coupled Processes (DST and TH Seepage) Models (BSC 2005 [DIRS 172232], Section 6.2). Seepage is calculated in the TSPA-LA using percolation flux distributions based on results from the UZ flow and transport model (BSC 2004 [DIRS 169131], Section 6.6.5.1) given in DTNs: LB0302PTNTSW9I.001 [DIRS 162277] and LB0305PTNTSW9I.001 [DIRS 163690]. These flux distributions include different climate stages and scenarios.

The effects of climate change are also included in the treatment of infiltration uncertainty for TSPA-LA (BSC 2003 [DIRS 165991]). Infiltration uncertainty is represented through three discrete infiltration scenarios (lower, mean, and upper), which are sampled in TSPA-LA according to weighting factors (BSC 2003 [DIRS 165991], Section 7.1). Climate change is incorporated through the use of the analogue climate (lower-bound, mean, and upper-bound) infiltration rate maps (BSC 2003 [DIRS 165991], Table 6-7; DTN: GS000308311221.005 [DIRS 147613]) developed in Simulation of Net Infiltration for Present-Day and Potential 
Future Climates (BSC 2004 [DIRS 170007]) by using the climate analogue data as direct input. It is incorporated implicitly by inclusion of the spatial average analogue net infiltration rate maps in the calculation of the weighting factors passed to TSPA-LA (BSC 2003 [DIRS 165991]; DTN: SN0308T0503100.008 [DIRS 165640]).

The effects of climate change are also included in the treatment of seepage in Seepage Model for PA Including Drift Collapse (BSC 2004 [DIRS 167652], Section 6.3.6) and Drift-Scale Coupled Processes (DST and TH Seepage) Models (BSC 2005 [DIRS 172232]) through the use of percolation fluxes taken from flow fields calculated for present and future climate states; and in Drift-Scale Coupled Processes (DST and TH Seepage) Models (BSC 2005 [DIRS 172232]) through the use of varying flux boundary conditions applied at the top of the model.

Supporting Reports: Future Climate Analysis (BSC 2004 [DIRS 170002]); Simulation of Net Infiltration for Present-Day and Potential Future Climates (BSC 2004 [DIRS 170007]); UZ Flow Models and Submodels (BSC 2004 [DIRS 169861]); Abstraction of Drift Seepage (BSC 2004 [DIRS 169131]); Drift-Scale Coupled Processes (DST and TH Seepage) Models (BSC 2005 [DIRS 172232]); Particle Tracking Model and Abstraction of Transport Processes (BSC 2005 [DIRS 173980]); Seepage Model for PA Including Drift Collapse (BSC 2004 [DIRS 167652]); Drift-Scale THC Seepage Model (BSC 2005 [DIRS 172862]); Analysis of Infiltration Uncertainty (BSC 2003 [DIRS 165991]).

\subsubsection{Water Table Rise Affects UZ (1.3.07.02.0B)}

FEP Description: Climate change could produce increased infiltration, leading to a rise in the regional water table, possibly affecting radionuclide release from the repository by altering flow and transport pathways in the UZ. A regionally higher water table and change in UZ flow patterns might flood the repository.

Screening Decision: Included.

TSPA Disposition: The water table will be higher in future climates with greater infiltration (see Table 6-2). To include this water table rise in TSPA-LA calculations, the water table elevation is instantaneously increased by $120 \mathrm{~m}$ when the climate changes from present-day to monsoon climate. The same water table elevation is also used for glacial-transition climate. This is conservative and is consistent with the instantaneous change of UZ flow fields (see FEP 1.3.01.00.0A).

Water table changes are implemented in the TSPA-LA by allowing the water table to change elevation instantaneously upon change in climate, concurrent with changes in infiltration (implemented by the postprocessor software WTRISE (V2.0, STN: 105372.000) (LBNL 2003 [DIRS 163453]) for radionuclide transport), thus affecting the unsaturated flow and pathways in the UZ. WTRISE allows the user to specify a water table location and removes all the particles in the gridblocks below the specified water table instantaneously by setting full saturation to the submerged gridblocks (BSC 2004 [DIRS 169861], Section 6.6.3). The particles removed from the UZ gridblocks enter the SZ transport model. WTRISE is implemented in the TSPA-LA model. 
Paleoclimate data indicates that the historical water table has never risen to the level of the repository (Forester et al. 1999 [DIRS 109425], pp. 46 and 56). Based on analysis of mineralogic alteration (zeolitization and tridymite distribution) and strontium isotope ratios, and groundwater flow modeling, the water table for future climates (both monsoon and glacial transition) is specified in Particle Tracking Model and Abstraction of Transport Processes (BSC 2005 [DIRS 173980], Section 6.4.8). Future climate flow fields, implemented in the UZ transport abstraction model (BSC 2004 [DIRS 169861], Section 6.4.8), have been generated using WTRISE for three monsoon and three glacial-transition climate flow fields, which are given in DTN: LB0312TSPA06FF.001 [DIRS 166671].

The effect of water table rise on the thermal regime is not included in the TSPA because the exact boundary condition values for temperature, gas pressure, and saturation are not important for TH seepage model results. The temperature and gas pressure values that define the initial temperature and pressure fields, respectively, are soon significantly altered in the near-field rock once the drifts are heated up. The thermal perturbation of the temperature and pressure fields is so strong in the near field that the initial distribution of these parameters has little effect (BSC 2005 [DIRS 172232], Section 4.1.1.2).

Supporting Reports: UZ Flow Models and Submodels (BSC 2004 [DIRS 169861]); Particle Tracking Model and Abstraction of Transport Processes (BSC 2005 [DIRS 173980]).

\subsubsection{Climate Modification Increases Recharge (1.4.01.01.0A)}

FEP Description: Climate modification causes an increase in recharge in the Yucca Mountain region. Increased recharge might lead to increased flux through the repository, perched water, or water table rise.

Screening Decision: Included.

TSPA Disposition: The effects of climate changes (BSC 2003 [DIRS 166296], Section 5.2) on UZ flux through the repository are incorporated through the explicit simulations of UZ flow fields corresponding to the upper-bound, mean, and lower-bound infiltrations of three distinct different climates: present-day, monsoon, and glacial transition. The flow boundary conditions at the top of the UZ flow model are set by nine infiltration maps developed in Simulation of Net Infiltration for Present-Day and Potential Future Climates (BSC 2004 [DIRS 170007], Section 6.11). The nine base-case flow fields and nine alternative flow fields are presented in UZ Flow Models and Submodels (BSC 2004 [DIRS 169861], Section 6.6). The output flow fields are in DTN: LB0305TSPA18FF.001 [DIRS 165625], developed for use in performance assessment (BSC 2003 [DIRS 166296]); the conversion of flow fields to the format needed for use in TSPA is documented in UZ Flow Models and Submodels (BSC 2004 [DIRS 169861], Appendix D).

Above the repository, perched water bodies were neither observed in the field nor predicted by the UZ flow model. The potential effect of perched water above the repository is indirectly related to lateral diversion of percolation flux in the PTn above the repository. PTn effects on the flow field are discussed in UZ Flow Models and Submodels (BSC 2004 [DIRS 169861], Section 6.6). The potential for water table rise caused by climate change is included in 
TSPA-LA calculations by adjusting the flow fields to the higher water tables, implemented by software WTRISE (LBNL 2003 [DIRS 163453]).

The effect of climate changes in the form of increased recharge is implicitly included in the transport model for TSPA-LA through the use of pregenerated flow fields (BSC 2005 [DIRS 173980], Section 6.5.1; DTN: LB0305TSPA18FF.001 [DIRS 165625]). In multirealization TSPA-LA runs, different climate patterns are applied and the effect of climate change is included through FEHM's use of pregenerated flow fields for the corresponding climates as described in Particle Tracking Model and Abstraction of Transport Processes (BSC 2005 [DIRS 173980], Section 6.5.1).

Potential effects of climate change on the amount of infiltration and percolation at Yucca Mountain are taken into account in the THC seepage model by implicitly considering different climate stages and climate scenarios when setting infiltration rates at the top model boundary (BSC 2005 [DIRS 172862], Sections 6.2.1.3 and 6.5.2).

Thus, the results from the THC seepage model, and their abstraction in Post-Processing Analysis for THC Seepage (BSC 2004 [DIRS 169858], Section 6.2), implicitly account for the effect of climate change on predicted water and gas chemistry. Summary tables of concentrations through time are presented in DTNs: LB0302DSCPTHCS.002 [DIRS 161976] and LB0307DSTTHCR2.002 [DIRS 165541], and summary statistics through time are presented in DTN: LB0311ABSTHCR2.001 [DIRS 166714]. These data are used to feed and/or provide technical basis for Engineered Barrier System: Physical and Chemical Environment (BSC 2005 [DIRS 173727]), which generates lookup tables used in the TSPA-LA model. Potential effects of climate change on the amount of flux through the repository are taken into account in the seepage modeling and abstraction by considering different climate stages and climate scenarios (BSC 2004 [DIRS 169131], Section 6.6.5). The method for calculating seepage in the TSPA-LA (BSC 2004 [DIRS 167652], Section 6.3.6; BSC 2005 [DIRS 172232]; BSC 2004 [DIRS 169131], Section 6.6.5.1) uses percolation flux distributions based on results from $U Z$ Flow Model and Submodels (BSC 2004 [DIRS 169861]), as given in DTNs: LB0302PTNTSW9I.001 [DIRS 162277] and LB0305PTNTSW9I.001 [DIRS 163690]. These flux distributions are based on the same varying climate stages and scenarios as identified and used in the THC seepage model.

Supporting Reports: UZ Flow Models and Submodels (BSC 2004 [DIRS 169861]); Seepage Model for PA Including Drift Collapse (BSC 2004 [DIRS 167652]); Drift-Scale THC Seepage Model (BSC 2005 [DIRS 172862]); Abstraction of Drift Seepage (BSC 2004 [DIRS 169131]); Drift-Scale Coupled Processes (DST and TH Seepage) Models (BSC 2005 [DIRS 172232]); Simulation of Net Infiltration for Present-Day and Potential Future Climates (BSC 2004 [DIRS 170007]); Particle Tracking Model and Abstraction of Transport Processes (BSC 2005 [DIRS 173980]).

\subsubsection{Water Influx at the Repository (2.1.08.01.0A)}

FEP Description: An increase in the unsaturated water flux at the repository may affect thermal, hydrologic, chemical, and mechanical behavior of the system. Increases in flux could result from climate change, but the cause of the increase is not an essential part of the FEP. 
Screening Decision: Included.

TSPA Disposition: This FEP is considered to be included implicitly in the TSPA-LA. Changes in UZ flow in response to climate changes are incorporated in the infiltration maps developed in Simulation of Net Infiltration for Present-Day and Future Climates (BSC 2004 [DIRS 170007], Section 6.11) and in output flow fields developed for use in the TSPA-LA by UZ Flow Models and Submodels (BSC 2004 [DIRS 169861], Section 6.6.3; the output flow fields are in DTN: LB0305TSPA18FF.001 [DIRS 165625]). Furthermore, the outputs from UZ Flow Models and Submodels (BSC 2004 [DIRS 169861]) are also used by other models and evaluations that are intermediate between the UZ flow model and the TSPA-LA model. For example, the flow fields are used to calculate seepage flux in Seepage Model for PA Including Drift Collapse (BSC 2004 [DIRS 167652], Section 6.3.6) and Abstraction of Drift Seepage (BSC 2004 [DIRS 169131]).

In TSPA-LA multirealization runs, climate changes and the change of water influx at the repository on radionuclide transport are addressed through the use of corresponding pregenerated flow fields. Release of tracked particles (the transport modeling method used for TSPA-LA) is related to the percolation flux at the repository as described in Particle Tracking Model and Abstraction of Transport Processes (BSC 2005 [DIRS 173980], Section 6.5.15).

The thermal model output from UZ Flow Models and Submodels (BSC 2004 [DIRS 169861]) is used for setting initial conditions for the downstream mountain-scale coupled process evaluation. The effects of transient flow driven by thermal-hydrologic processes are also included in TSPA-LA calculations for drift seepage in Abstraction of Drift Seepage (BSC 2004 [DIRS 169131]). The effects of THC and THM on seepage are also addressed in the seepage abstraction report.

The potential increase in the magnitude of percolation flux at the repository, as a result of climate changes or flow-focusing effects, is accounted for in the seepage abstraction by considering different climate stages, climate scenarios, and introducing flow-focusing factors (BSC 2004 [DIRS 169131], Section 6.6.5). Seepage is calculated in the TSPA-LA using percolation flux distributions based on results from the UZ flow and transport model (BSC 2004 [DIRS 169131], Section 6.6.5.1) given in DTNs: LB0302PTNTSW9I.001 [DIRS 162277] and LB0305PTNTSW9I.001 [DIRS 163690]. These flux distributions include different climate stages and scenarios. The potential focusing of flow towards individual drift sections is accounted for by a distribution of flow-focusing factors, as discussed in Abstraction of Drift Seepage (BSC 2004 [DIRS 169131], Section 6.6.5.2). This distribution is given in DTN: LB0406U0075FCS.002 [DIRS 170712]. The local percolation flux distribution used for the seepage calculations in the TSPA-LA is derived by multiplying the percolation flux values from the site-scale model with the randomly sampled flow-focusing factors (BSC 2004 [DIRS 169131], Section 6.7.1).

The potential increase in the magnitude of percolation flux at the repository, as a result of climate changes, is accounted for in the THC seepage model by implicitly considering different climate stages, and climate scenarios when setting infiltration rates at the top model boundary (BSC 2005 [DIRS 172862], Sections 6.2.1.3 and 6.5.2). In addition, flux increases caused by reflux of water upon boiling are explicitly accounted for by the modeling of coupled THC 
processes (BSC 2005 [DIRS 172862], Sections 6.2.1 and 6.5.5.2). Therefore, these effects are directly accounted for in results from the THC seepage model and their abstraction (BSC 2004 [DIRS 169858], Section 6.2). Summary tables of concentrations through time are presented in DTNs: LB0302DSCPTHCS.002 [DIRS 161976] and LB0307DSTTHCR2.002 [DIRS 165541], and summary statistics through time are presented in DTN: LB0311ABSTHCR2.001 [DIRS 166714]. DTNs: LB0302DSCPTHCS.002 [DIRS 161976] and LB0311ABSTHCR2.001 [DIRS 166714] are used to feed and/or provide technical basis for Engineered Barrier System: Physical and Chemical Environment (BSC 2005 [DIRS 173727]), which generates lookup tables used in the TSPA-LA model. Note that seepage is calculated in the TSPA-LA using percolation flux distributions that are based on results from the UZ flow and transport model (BSC 2004 [DIRS 169131], Section 6.6.5.1) given in DTNs: LB0302PTNTSW9I.001 [DIRS 162277] and LB0305PTNTSW9I.001 [DIRS 163690]. These flux distributions include the same climate stages and scenarios as used in the THC seepage model.

Waste heat causes water to boil and move as vapor to a cooler region where it condenses. This condensation is then available to increase the percolation flux. The effect of this increased percolation flux at the repository as a result of this refluxing flow was examined in Drift-Scale Coupled Processes (DST and TH Seepage) Models (BSC 2005 [DIRS 172232], Section 6.2.2.2). Despite the refluxing of condensate, no seepage into intact drifts was found to occur as long as the temperature at the drift wall remains above $100^{\circ} \mathrm{C}$. The thermal seepage abstraction for TSPA-LA consists of setting the thermal seepage for intact drifts equal to zero for the period of above-boiling temperatures at the drift wall. (For collapsed drifts and intact drifts with wall temperatures below $100^{\circ} \mathrm{C}$, seepage is set equal to the estimated ambient seepage.)

Supporting Reports: Simulation of Net Infiltration for Present-Day and Future Climates (BSC 2004 [DIRS 170007]); UZ Flow Models and Submodels (BSC 2004 [DIRS 169861]); Seepage Model for PA Including Drift Collapse (BSC 2004 [DIRS 167652]); Drift-Scale THC Seepage Model (BSC 2005 [DIRS 172862]); Abstraction of Drift Seepage BSC 2004 [DIRS 169131]); Particle Tracking Model and Abstraction of Transport Processes (BSC 2005 [DIRS 173980]); Drift-Scale Coupled Processes (DST and TH Seepage) Models (BSC 2005 [DIRS 172232]).

\subsubsection{Enhanced Influx at the Repository (2.1.08.02.0A)}

FEP Description: An opening in unsaturated rock may alter the hydraulic potential, affecting local saturation around the opening and redirecting flow. Some of the flow may be directed to the opening where it is available to seep into the opening.

Screening Decision: Included.

TSPA Disposition: The impact of an underground opening on the unsaturated flow field (including capillary barrier effect and flow diversion around the drifts) and its relevance for seepage is explicitly captured in the seepage process models used for the seepage abstraction, which are described in Seepage Model for PA Including Drift Collapse (BSC 2004 [DIRS 167652], Section 6.3), Abstraction of Drift Seepage (BSC 2004 [DIRS 169131], Sections 6.4.1, 6.4.2, and 6.4.3); and Drift-Scale Coupled Processes (DST and TH Seepage) Models (BSC 2005 [DIRS 172232], Sections 6.1.1 and 6.2.1.4). Parameters used in the process 
models are developed from inverse modeling in Seepage Calibration Model and Seepage Testing Data (BSC 2004 [DIRS 171764], Sections 6.3, 6.6, and 6.8). From these model simulations, seepage predictions are available in the form of lookup tables in DTNs: LB0407AMRU0120.001 [DIRS 173280] and LB0407AMRU0120.002 [DIRS 173308]. These will be used in the TSPA-LA to calculate ambient seepage, by sampling parameter cases of seepage-relevant parameters from the probability distributions that are defined in Abstraction of Drift Seepage (BSC 2004 [DIRS 169131], Section 6.7.1). These seepage-relevant parameters are the effective capillary-strength parameter, the permeability, and the local percolation flux. The percolation flux distributions include flow-focusing effects, as discussed in Abstraction of Drift Seepage (BSC 2004 [DIRS 169131], Section 6.6.5.2). During the thermal period, the ambient seepage rates will be adjusted based on the TH-modeling results from DTN: LB0301DSCPTHSM.002 [DIRS 163689], using the abstraction methodology developed in Abstraction of Drift Seepage (BSC 2004 [DIRS 169131], Sections 6.5.2 and 6.5.3).

Supporting Reports: Seepage Model for PA Including Drift Collapse (BSC 2004 [DIRS 167652]); Seepage Calibration Model and Seepage Testing Data (BSC 2004 [DIRS 171764]); Abstraction of Drift Seepage (BSC 2004 [DIRS 169131]); Drift-Scale Coupled Processes (DST and TH Seepage) Models (BSC 2005 [DIRS 172232]).

\subsubsection{Mechanical Effects of Excavation and Construction in the Near-Field (2.2.01.01.0A)}

FEP Description: Excavation will produce some disturbance of the rocks surrounding the drifts due to stress relief. Stresses associated directly with excavation (e.g., boring and blasting operations) may also cause some changes in rock properties. Properties that may be affected include rock strength, fracture spacing and block size, and hydrologic properties such as permeability.

Screening Decision: Included.

TSPA Disposition: Excavation effects, including mechanical effects of excavation on excavation-disturbed zone (EDZ) fractures, near-field fractures, and seepage, are taken into account in the fracture permeability measurements reported in In Situ Field Testing of Processes (BSC 2004 [DIRS 170004], Section 6.1). Seepage-relevant parameters are derived from those measurements in Seepage Calibration Model and Seepage Testing Data (BSC 2004 [DIRS 171764], Sections 6.3, 6.5.2, and 6.6) and used in Seepage Model for PA Including Drift Collapse (BSC 2004 [DIRS 167652], Sections 6.3.2 and 6.4). These results are included in the seepage abstraction through the use of postexcavation air-permeability data (BSC 2004 [DIRS 169131], Section 6.6.3 and Table 6.6-3) and the estimation of a capillary-strength parameter determined from seepage tests (BSC 2004 [DIRS 169131], Section 6.6.2 and Table 6.6-1). These data reflect the impact of excavation around a large opening (niche or drift). The THM modeling results are supported by the measured postexcavation air-permeability data (BSC 2004 [DIRS 169131], Section 6.6.3.1). The statistics for permeability and capillary strength that are presented in Abstraction of Drift Seepage (BSC 2004 [DIRS 169131], Tables 6.6-3 and 6.6-1, respectively) therefore include the effects of excavation. They provide the basis for the probability distributions that are presented in Abstraction of Drift Seepage (BSC 2004 [DIRS 169131], Section 6.7.1). These distributions will be used in the TSPA-LA to calculate seepage from the seepage lookup tables, using the methodology defined in Abstraction of Drift 
Seepage (BSC 2004 [DIRS 169131], Section 6.7.1). Simulation results presented in Drift-Scale Coupled Processes (DST and TH Seepage) Models (BSC 2005 [DIRS 172232], Sections 6.2.2 and 6.2.3) also incorporate the effects of excavation. The seepage abstraction model also captures the effects of drift collapse (BSC 2004 [DIRS 169131], Sections 6.4.2.4 and 6.7.1.2) in terms of the larger drift profile that results.

Supporting Reports: In Situ Field Testing of Processes (BSC 2004 [DIRS 170004]); Seepage Model for PA Including Drift Collapse (BSC 2004 [DIRS 167652]); Seepage Calibration Model and Seepage Testing Data (BSC 2004 [DIRS 171764]); Abstraction of Drift Seepage (BSC 2004 [DIRS 169131]); Drift-Scale Coupled Processes (DST and TH Seepage) Models (BSC 2005 [DIRS 172232]).

\subsubsection{Stratigraphy $(2 \cdot 2.03 .01 .0 A)$}

FEP Description: Stratigraphic information is necessary information for the performance assessment. This information should include identification of the relevant rock units, soils and alluvium, and their thickness, lateral extents, and relationships to each other. Major discontinuities should be identified.

Screening Decision: Included.

TSPA Disposition: This FEP is included in the UZ flow model (BSC 2004 [DIRS 169861], Sections 6.1.1 and 6.1.2) by use of the grids developed with the information contained in Geologic Framework Model (GFM2000) (BSC 2004 [DIRS 170029]) and DTN: MO0012MWDGFM02.002 [DIRS 153777]. The stratigraphic unit and layers are developed into a model grid in Development of Numerical Grids for UZ Flow and Transport Modeling (BSC 2004 [DIRS 169855]). Because the assignment of hydrologic properties is associated with the grid used for the UZ flow model, the stratigraphy information is implicitly embedded in the TSPA-LA through the output flow fields. Aspects that affect hydrogeologic properties for flow are further discussed in Development of Numerical Grids for UZ Flow and Transport Modeling (BSC 2004 [DIRS 169855], Section 6) and Calibrated Properties Model (BSC 2004 [DIRS 169857], Section 6.1.4). See also FEP 2.2.03.02.0A.

This FEP is also implicitly included for radionuclide transport in the UZ through the use of pregenerated flow fields (DTN: LB0305TSPA18FF.001 [DIRS 165625]) as used by FEHM in TSPA-LA UZ multirealization runs as described in Particle Tracking Model and Abstraction of Transport Processes (BSC 2005 [DIRS 173980], Section 6.5.1).

Ambient seepage as a result of incomplete flow diversion around drifts is a local process simulated by drift-scale seepage process models (BSC 2004 [DIRS 169131], Section 6.4). In these models, the stratigraphy below and above the repository unit can be neglected. In contrast, the UZ flow and transport model (which provides the percolation flux distributions used for seepage calculations) explicitly accounts for the various geological units and major faults in the UZ (BSC 2004 [DIRS 169861], Sections 6.1.1 and 6.1.2). This is because the overall distribution of percolation flux at the repository horizon is influenced by stratigraphic layering and by major discontinuities. For example, the PTn unit overlying the Topopah Spring welded tuff units can divert a fraction of percolating water to intercepting faults and fault zones, thereby 
changing the spatial distribution of fluxes (BSC 2004 [DIRS 169861], Section 6.6.3), which could affect water-rock interaction and seepage water chemistry. The drift-scale process models addressing TH, THM, and THC processes (BSC 2004 [DIRS 169131], Sections 6.4.3.1, 6.4.4.1, and 6.4.4.2) also represent the stratigraphy in the UZ at Yucca Mountain in an explicit manner. This is needed because the thermal perturbation of the unsaturated rock extends far into the overlying and underlying geological units. Thus, the stratigraphy information is inherently embedded in the respective model results from the UZ flow and transport model and the TH, THM, and THC drift-scale models. In addition, the mineralogy of stratigraphic intervals affects seepage water chemistry. For example, the presence of fluorite in the Tptpll hydrogeologic unit may affect fluoride concentrations in pore waters in this unit (BSC 2005 [DIRS 172862], Section 6.5.5.2). Finally, the thermal perturbation of the unsaturated rock extends far into the geologic units overlying and underlying the emplacement drifts. For these reasons, the THC seepage model includes explicitly the Yucca Mountain stratigraphy (BSC 2005 [DIRS 172862], Sections 4.1.2 and 6.5.1), using stratigraphic information from DTN: LB990501233129.004 [DIRS 111475] and mineralogical information from DTNs: LA9908JC831321.001 [DIRS 113495], LA9912SL831151.001 [DIRS 146447], LA9912SL831151.002 [DIRS 146449], and LA0009SL831151.001 [DIRS 153485]. Therefore, the results from the THC seepage model, and their abstraction in Post-Processing Analysis for THC Seepage (BSC 2004 [DIRS 169858], Section 6.2), explicitly account for the effect of stratigraphy on predicted water and gas chemistry. Summary tables of concentrations through time are presented in DTNs: LB0302DSCPTHCS.002 [DIRS 161976] and LB0307DSTTHCR2.002 [DIRS 165541], and summary statistics through time are presented in DTN: LB0311ABSTHCR2.001 [DIRS 166714]. These data are used to feed and/or provide technical basis for Engineered Barrier System: Physical and Chemical Environment (BSC 2005 [DIRS 173727]), which generates lookup tables used in the TSPA-LA model.

The bases for the UZ and SZ stratigraphic models are different. The UZ uses the geologic framework model, GFM2000 (BSC 2004 [DIRS 170029]; DTN: MO0012MWDGFM02.002 [DIRS 153777]) and the SZ uses the hydrogeologic framework model, HFM (BSC 2005 [DIRS 174109]; DTN: GS030208312332.001 [DIRS 163087]). These different models for stratigraphy are used as a result of the different domains treated by the UZ and SZ models. The UZ model encompasses rock above the water table over a region around the repository that is roughly $5 \mathrm{~km}$ $\times 9 \mathrm{~km}$ (BSC 2004 [DIRS 169861], Figure 6.1-1). The SZ model encompasses rock below the water table over an area that is roughly $30 \mathrm{~km} \times 45 \mathrm{~km}$ (BSC 2004 [DIRS 170037], Figure 6-1).

Stratigraphy is implicitly incorporated in the output from reports that develop different data sets for drifts in the Tptpll and Tptpmn. This includes Drift-Scale Coupled Processes (DST and TH Seepage) Models (BSC 2005 [DIRS 172232]) and Seepage Model for PA Including Drift Collapse (BSC 2004 [DIRS 167652], Sections 6.3.2 through 6.3.4). Stratigraphy is also explicitly incorporated in Analysis of Hydrologic Properties Data (BSC 2004 [DIRS 170038]). Stratigraphy is implicitly incorporated in Simulation of Net Infiltration for Present-Day and Future Climates (BSC 2004 [DIRS 170007], Section 6.6) because different strata form the bedrock at different locations.

Supporting Reports: Development of Numerical Grids for UZ Flow and Transport Modeling (BSC 2004 [DIRS 169855]); Calibrated Properties Model (BSC 2004 [DIRS 169857]); UZ Flow Models and Submodels (BSC 2004 [DIRS 169861]); Seepage Model for PA Including Drift 
Collapse (BSC 2004 [DIRS 167652]); Analysis of Hydrologic Properties Data (BSC 2004 [DIRS 170038]); Drift-Scale THC Seepage Model (BSC 2005 [DIRS 172862]); Abstraction of Drift Seepage (BSC 2004 [DIRS 169131]); Drift-Scale Coupled Processes (DST and TH Seepage) Models (BSC 2005 [DIRS 172232]); Simulation of Net Infiltration for Present-Day and Potential Future Climate (BSC 2004 [DIRS 170007]); Particle Tracking Model and Abstraction of Transport Processes (BSC 2005 [DIRS 173980]).

\subsubsection{Rock Properties of Host Rock and Other Units (2.2.03.02.0A)}

FEP Description: Physical properties such as porosity and permeability of the relevant rock units, soils, and alluvium are necessary for the performance assessment. Possible heterogeneities in these properties should be considered. Questions concerning events and processes that may cause these physical properties to change over time are considered in other FEPs.

Screening Decision: Included.

TSPA Disposition: This FEP is similar to FEP 2.2.03.01.0A, Stratigraphy (Section 6.2.10). Rock properties used are defined for each of the stratigraphic units/layers classified in the geological framework model (GFM2000; DTN: MO0012MWDGFM02.002 [DIRS 153777]), which is further developed into model grid in Development of Numerical Grids for UZ Flow and Transport Modeling (BSC 2004 [DIRS 169855]). However, rock properties are not developed in the grid development report. For the UZ flow model, rock properties are modeled in terms of the sequence of hydrogeologic units and discrete faults (BSC 2004 [DIRS 169861], Section 6.1.5). Therefore, rock properties are implicitly embedded in the TSPA-LA through the output flow fields, with site-scale layering and faults explicitly taken into account. Rock properties used as input for UZ Flow Models and Submodels (BSC 2004 [DIRS 169861]) are developed in Calibrated Properties Model (BSC 2004 [DIRS 169857], Section 6.3). On the drift scale, the effects of rock heterogeneity on seepage are discussed in Abstraction of Drift Seepage (BSC 2004 [DIRS 169131]). Percolation-flux distributions provided by UZ Flow Models and Submodels (BSC 2004 [DIRS 169861]) are used in Abstraction of Drift Seepage (BSC 2004 [DIRS 169131], Section 6.6.5.1), which accounts for rock properties and their variation on a larger scale (e.g., stemming from stratigraphy effects).

Rock properties of host rock and other units are included and used in the simulations of radionuclide transport through the UZ. Particle Tracking Model and Abstraction of Transport Processes (BSC 2005 [DIRS 173980], Sections 6.5.3 and 6.5.7) documents the matrix porosity, rock density, fracture porosity, fracture spacing, and aperture data (DTNs: LB0305TSPA18FF.001 [DIRS 165625], LB0210THRMLPRP.001 [DIRS 160799], LB0205REVUZPRP.001 [DIRS 159525], and LB0207REVUZPRP.001 [DIRS 159526]). The generated distributions of fracture porosity and fracture frequency are given in DTN: LA0407BR831371.001 [DIRS 170806] and will be used by TSPA-LA in multirealization runs as described in Particle Tracking Model and Abstraction of Transport Processes (BSC 2005 [DIRS 173980], Sections 6.5.3 and 6.5.7).

All the seepage process models that feed into seepage abstraction explicitly represent the physical properties of the unsaturated rock and their heterogeneity (BSC 2004 [DIRS 169131], Section 6.4). Small-scale heterogeneity is accounted for by a stochastic continuum 
representation of fracture permeability. Thus, heterogeneity on this scale is implicitly embedded in the model output from the seepage calibration model (BSC 2004 [DIRS 171764], Section 6.5.2), the seepage model for performance assessment (BSC 2004 [DIRS 167652], Sections 6.3.2 through 6.3.4), and the TH seepage model (BSC 2005 [DIRS 172232]) provided respectively in DTNs: LB0407AMRU0120.001 [DIRS 173280]; LB0407AMRU0120.002 [DIRS 173308]; and LB0301DSCPTHSM.002 [DIRS 163689]. The intermediate-scale spatial variability and uncertainty of seepage-relevant rock properties are accounted for by appropriate probability distributions that were developed in Abstraction of Drift Seepage (BSC 2004 [DIRS 169131], Sections 6.6.1 and 6.6.2). Potential alterations of these properties, as a result of THM or THC processes, have been assessed using drift-scale process models (BSC 2004 [DIRS 169131], Sections 6.4.4.1 and 6.4.4.2). It was demonstrated that these potential alterations can be neglected in the TSPA-LA, because the expected changes would lead to less seepage (BSC 2004 [DIRS 169131], Section 6.5.1.4; see FEPs 2.1.09.12.0A and 2.2.10.04.0A). The THC seepage model feeding into the drift-scale coupled process abstraction model explicitly represents the physical properties of the unsaturated rock (BSC 2005 [DIRS 172862], Section 6.4.7 and Table 6.4-1). Therefore, these effects are explicitly accounted for in the results from the THC seepage model, and their abstraction in Post-Processing Analysis for THC Seepage (BSC 2004 [DIRS 169858], Section 6.2). Summary tables of concentrations through time are presented in DTNs: LB0302DSCPTHCS.002 [DIRS 161976] and LB0307DSTTHCR2.002 [DIRS 165541], and summary statistics through time are presented in DTN: LB0311ABSTHCR2.001 [DIRS 166714]. These data are used to feed and/or provide technical basis for Engineered Barrier System: Physical and Chemical Environment (BSC 2005 [DIRS 173727]), which generates lookup tables used in the TSPA-LA model. Small-scale fracture permeability heterogeneity was also investigated and determined not to significantly affect seepage water chemistry (BSC 2005 [DIRS 172862], Section 6.3). The THC seepage model includes rock properties from DTNs: LB0205REVUZPRP.001 [DIRS 159525], LB0208UZDSCPMI.002 [DIRS 161243], LB0207REVUZPRP.002 [DIRS 159672] and LB0210THRMLPRP.001 [DIRS 160799]. Potential alterations of these properties as a result of THC processes are explicitly accounted for by the modeling of coupled THC processes, and result in reducing fracture permeability (BSC 2005 [DIRS 172862], Section 6.5.5.3). The effects of rock properties are also included in the treatment of infiltration uncertainty for TSPA-LA (BSC 2003 [DIRS 165991]). Infiltration uncertainty is represented through three discrete infiltration scenarios (lower, mean, and upper), which are sampled in TSPA-LA according to weighting factors (BSC 2003 [DIRS 165991], Section 7.1). Rock properties are included through the fracture parameters bedrock permeability (BRPERM) and bedrock porosity (BRPOROS). The uncertainties for these parameters are described in Analysis of Infiltration Uncertainty (BSC 2003 [DIRS 165991], Tables 6-2 and 6-3). These uncertainties are propagated through the infiltration numerical model and so are implicitly included in the output (weighting factors) that is passed to TSPA-LA (BSC 2003 [DIRS 165991]; DTN: SN0308T0503100.008 [DIRS 165640]). Heterogeneities in these properties are included in the input used in the analysis reported in Simulation of Net Infiltration for Present-Day and Potential Future Climates (BSC 2004 [DIRS 170007], Section 6.6.4 and Appendix B).

Rock properties are implicitly incorporated in the output from reports that develop different data sets for drifts in the Tptpll and Tptpmn. This includes Drift-Scale Coupled Processes (DST and TH Seepage) Models (BSC 2005 [DIRS 172232]) and Seepage Model for PA Including Drift Collapse (BSC 2004 [DIRS 167652], Sections 6.3.2 through 6.3.4). Rock properties are also 
explicitly incorporated in Analysis of Hydrologic Properties Data (BSC 2004 [DIRS 170038]). Rock properties are implicitly incorporated in Simulation of Net Infiltration for Present-Day and Potential Future Climate (BSC 2004 [DIRS 170007], Section 6.6.4 and Appendix B) and Analysis of Infiltration Uncertainty (BSC 2003 [DIRS 165991]) because different rocks form the bedrock at different locations.

Supporting Reports: UZ Flow Models and Submodels (BSC 2004 [DIRS 169861]); Simulation of Net Infiltration for Present-Day and Potential Future Climates (BSC 2004 [DIRS 170007]); Calibrated Properties Model (BSC 2004 [DIRS 169857]); Abstraction of Drift Seepage (BSC 2004 [DIRS 169131]); Particle Tracking Model and Abstraction of Transport Processes (BSC 2005 [DIRS 173980]); Seepage Model for PA Including Drift Collapse (BSC 2004 [DIRS 167652]); Seepage Calibration Model and Seepage Testing Data (BSC 2004 [DIRS 171764]); Analysis of Hydrologic Properties Data (BSC 2004 [DIRS 170038]); Drift-Scale THC Seepage Model (BSC 2005 [DIRS 172862]); Drift-Scale Coupled Processes (DST and TH Seepage) Models (BSC 2005 [DIRS 172232]); Analysis of Infiltration Uncertainty (BSC 2003 [DIRS 165991]).

\subsubsection{Locally Saturated Flow at Bedrock/Alluvium Contact (2.2.07.01.0A)}

FEP Description: In washes in arid areas, infiltration can descend to the alluvium/bedrock interface and then proceed down the wash at that interface as a saturated flow system distinct from the surface and distinct from the local water table.

Screening Decision: Included.

TSPA Disposition: The phenomenon of infiltration resulting in a saturated condition at the bedrock/alluvium contact, with water then either infiltrating into fractures or contributing to lateral drainage, is indirectly included in the infiltration model. Although not explicitly modeled, runoff at the bedrock/alluvium contact is accounted for in the overall model water balance through the calibration process (using runoff measurements). The assumptions underlying this calibration are given in Simulation of Net Infiltration for Present-Day and Potential Future Climates (BSC 2004 [DIRS 170007], Section 6.3.4). The impacts of runoff processes on preferential flow and percolation in the UZ is incorporated into the TSPA-LA through the UZ flow fields in DTNs: LB0305TSPA18FF.001 [DIRS 165625] and LB0312TSPA06FF.001 [DIRS 166671]. These flow fields are developed by the UZ Flow Model, which uses the infiltration model results (DTN: GS000308311221.005 [DIRS 147613]) as upper-boundary conditions (BSC 2004 [DIRS 169861], Sections 6.1.3 and 6.1.4).

The effects of locally saturated flow at bedrock/alluvium contact are also included in the treatment of infiltration uncertainty for TSPA-LA in Analysis of Infiltration Uncertainty (BSC 2003 [DIRS 165991]), which derives weighting factors used by TSPA-LA to sample from the flow fields developed by the UZ Flow Model. Flow through the alluvium-bedrock interface is incorporated into this uncertainty analysis using the uncertain parameters such as soil depth (SOILDEPM), the soil permeability (SOILPERM), and the effective bedrock permeability (BRPERM). Infiltration uncertainty is represented through three discrete flow fields, which are calculated in UZ Flow Models and Submodels (BSC 2004 [DIRS 169861]) with boundary conditions that represent the lower bound, mean, and upper bound infiltration. These flow fields 
are sampled in TSPA-LA according to weighting factors in DTN: SN0308T0503100.008 [DIRS 165640]).

Supporting Reports: Simulation of Net Infiltration for Present-Day and Potential Future Climates (BSC 2004 [DIRS 170007]); Analysis of Infiltration Uncertainty (BSC 2003 [DIRS 165991]); UZ Flow Models and Submodels (BSC 2004 [DIRS 169861]).

\subsubsection{Unsaturated Groundwater Flow in the Geosphere (2.2.07.02.0A)}

FEP Description: Groundwater flow occurs in unsaturated rocks in most locations above the water table at Yucca Mountain, including at the location of the repository. See related FEPs for discussions of specific issues related to unsaturated flow.

Screening Decision: Included.

TSPA Disposition: This FEP is included in the UZ process models for mountain-scale flow, drift seepage, mountain-scale radionuclide transport, drift-scale radionuclide transport, and seepage chemistry. The flow model is for three-dimensional, steady flow in a heterogeneous dual-permeability system that includes discrete fault zones (BSC 2004 [DIRS 169861], Sections 6.2, 6.6, and 6.7), which allow for a realistic description of flow pathways in the UZ. The flow fields (DTN: LB0305TSPA18FF.001 [DIRS 165625]) generated by the UZ flow model are used directly by the TSPA-LA and are also implicitly included in the TSPA-LA via the abstractions for drift seepage (BSC 2004 [DIRS 169131], Section 6.6.5.1) and radionuclide transport simulations (BSC 2005 [DIRS 173980], Section 6.5.1). The infiltration model provides the flux boundary condition at the top of the UZ flow model (BSC 2004 [DIRS 170007], Section 6.11) and includes the effects of soil depth on UZ flow at Yucca Mountain (BSC 2004 [DIRS 170007], Section 6.1.2).

Unsaturated groundwater flow in the UZ is the driving force for radionuclide transport through the UZ. This FEP is implicitly addressed through the use of pregenerated flow fields (BSC 2005 [DIRS 173980], Section 6.5.1; DTN: LB0305TSPA18FF.001 [DIRS 165625]) in TSPA-LA multirealization runs. The pregenerated flow fields are directly used by FEHM as described in Particle Tracking Model and Abstraction of Transport Processes (BSC 2005 [DIRS 173980], Section 6.5.1).

Parameter values needed to describe unsaturated flow are developed in supporting reports. Data input for model calibration is developed in Analysis of Hydrologic Properties Data (BSC 2004 [DIRS 170038]). The van Genuchten $\alpha$ and $m$ values and the active-fracture parameter $\gamma$ value for each model layer of the fracture and matrix continua are developed in Calibrated Properties Model (BSC 2004 [DIRS 169857], Sections 6.1.4 and 6.3). The active fracture model is described and validated in Conceptual Model and Numerical Approaches for UZ Flow and Transport (BSC 2004 [DIRS 170035], Sections 6.3 and 7). Seepage-relevant parameters for the drift-scale seepage model are based on measurements reported in In Situ Field Testing of Processes (BSC 2004 [DIRS 170004, Sections 6.1 and 6.2) and developed in Seepage Calibration Model and Seepage Testing Data (BSC 2004 [DIRS 171764], Sections 6.3.2 and 6.6.1.1). Unsaturated flow processes are accounted for in the seepage abstraction by using results from process models that explicitly account for various relevant aspects of unsaturated 
groundwater flow. All the seepage process models that feed into seepage abstraction simulate groundwater flow processes in unsaturated rock (BSC 2004 [DIRS 169131], Section 6.4). For ambient seepage, the fracture flow processes in the drift vicinity and the resulting seepage rates are predicted by model simulations from the seepage model for performance assessment (BSC 2004 [DIRS 167652], Sections 6.2.1 and 6.3.4), and abstracted in Abstraction of Drift Seepage (BSC 2004 [DIRS 169131], Section 6.4.2). Results are available as lookup tables in DTNs: LB0407AMRU0120.001 [DIRS 173280] and LB0407AMRU0120.002 [DIRS 173308]. These will be used in the TSPA-LA to calculate ambient seepage, by sampling parameter cases of seepage-relevant parameters from the probability distributions defined in Abstraction of Drift Seepage (BSC 2004 [DIRS 169131], Section 6.7.1). During the thermal period, the ambient seepage rates will be adjusted based on the TH-modeling results from Drift-Scale Coupled Processes (DST and TH Seepage) Models (BSC 2005 [DIRS 172232]), which explicitly simulates thermally perturbed groundwater flow processes. Results are given in DTN: LB0301DSCPTHSM.002 [DIRS 163689]. THM and THC effects on fracture flow processes are evaluated with process models that explicitly account for groundwater flow processes affected by THM and THC parameter alterations (BSC 2004 [DIRS 169131], Sections 6.4.4.1 and 6.4.4.2). It was demonstrated that these potential alterations can be neglected in the TSPA-LA, as the expected changes would lead to less seepage (BSC 2004 [DIRS 169131], Section 6.5.1.4). See also FEPs 2.1.09.12.0A and 2.2.10.04.0A. Percolation flux distributions are provided by the UZ flow model (BSC 2004 [DIRS 169131], Section 6.6.5.1), which accounts for groundwater flow on a larger scale, influenced by climate changes, infiltration variability, and stratigraphy effects.

The THC seepage model that feeds into the drift-scale coupled processes abstraction model simulates groundwater flow and water-gas-rock interactions in unsaturated rock and explicitly accounts for various relevant aspects of unsaturated groundwater flow (BSC 2005 [DIRS 172862], Section 6.2.1). Therefore, the results from the THC seepage model, and their abstraction in Post-Processing Analysis for THC Seepage (BSC 2004 [DIRS 169858], Section 6.2), explicitly account for the effect of unsaturated groundwater flow on predicted water and gas chemistry. Summary tables of concentrations through time are presented in DTNs: LB0302DSCPTHCS.002 [DIRS 161976] and LB0307DSTTHCR2.002 [DIRS 165541]), and summary statistics through time are presented in DTN: LB0311ABSTHCR2.001 [DIRS 166714]. These data are used to feed and/or provide technical basis for Engineered Barrier System: Physical and Chemical Environment (BSC 2005 [DIRS 173727]), which generates lookup tables used in the TSPA-LA model.

Supporting Reports: In Situ Field Testing of Processes (BSC 2004 [DIRS 170004]); Simulation of Net Infiltration for Present-Day and Potential Future Climates (BSC 2004 [DIRS 170007]); UZ Flow Models and Submodels (BSC 2004 [DIRS 169861]); Conceptual Model and Numerical Approaches for UZ Flow and Transport (BSC 2004 [DIRS 170035]); Calibrated Properties Model (BSC 2004 [DIRS 169857]); Seepage Model for PA Including Drift Collapse (BSC 2004 [DIRS 167652]); Seepage Calibration Model and Seepage Testing Data (BSC 2004 [DIRS 171764]); Analysis of Hydrologic Properties Data (BSC 2004 [DIRS 170038]); Drift-Scale THC Seepage Model (BSC 2005 [DIRS 172862]); Abstraction of Drift Seepage (BSC 2004 [DIRS 169131]); Drift-Scale Coupled Processes (DST and TH Seepage) Models (BSC 2005 [DIRS 172232]; Particle Tracking Model and Abstraction of Transport Processes (BSC 2005 [DIRS 173980]). 


\subsubsection{Capillary Rise in the UZ (2.2.07.03.0A)}

FEP Description: Capillary rise involves the drawing up of water, above the water table or above locally saturated zones, in continuous pores of the unsaturated zone until the suction gradient is balanced by the gravitational pull downward.

Screening Decision: Included.

TSPA Disposition: Capillary forces are included in the UZ flow model. These forces affect the distribution of water in the UZ through capillary effects on water flow, also known as capillary wicking. Parameters used for capillarity modeling are incorporated within the matrix properties (DTN: LB02091DSSCP3I.002 [DIRS 161433]) and fracture properties (DTN: LB0205REVUZPRP.001 [DIRS 159525]), as described in UZ Flow Models and Submodels (BSC 2004 [DIRS 169861], Section 6.2.5). These parameters are used as direct input to the UZ flow model and are implicitly incorporated into the output flow fields used in the TSPA-LA (output flow fields are in DTN: LB0305TSPA18FF.001 [DIRS 165625]).

\section{Supporting Reports: UZ Flow Models and Submodels (BSC 2004 [DIRS 169861]).}

\subsubsection{Focusing of Unsaturated Flow (Fingers, Weeps) (2.2.07.04.0A)}

FEP Description: Unsaturated flow can differentiate into zones of greater and lower saturation (fingers) that may persist as preferential flow paths. Heterogeneities in rock properties, including fractures and faults, may contribute to focusing. Focused flow may become locally saturated.

Screening Decision: Included.

TSPA Disposition: The UZ flow fields represent the redistribution of infiltration through UZ layers, with faults explicitly taken into account (BSC 2004 [DIRS 169861], Sections 6.1.2, 6.6.3, and 6.7.3). The flux redistribution is based on tuff layer properties including fracture and matrix interaction. Faults are included in the UZ flow model as discrete features; therefore, flow in faults is also included in the UZ flow model (BSC 2004 [DIRS 169861]). Flow model results indicate that as flow moves downward through the UZ, the flow tends to focus into fault zones, with the fraction of flow in the faults increasing from about $30-40 \%$ at the repository to about $60 \%$ at the water table (BSC 2004 [DIRS 169861], Section 6.6.3).

For radionuclide transport, the effect of focusing unsaturated flow is implicitly included through the use of pregenerated flow fields contained in DTN: LB0305TSPA18FF.001 [DIRS 165625] for simulations (BSC 2005 [DIRS 173980], Sections 6.5.1, 6.6.2). In TSPA-LA runs, pregenerated flow fields are used directly by the transport model FEHM (LANL 2003 [DIRS 165741]). Particle Tracking Model and Abstraction of Transport Processes (BSC 2005 [DIRS 173980]) provides transport parameters in DTN: LA0407BR831371.001 [DIRS 170806] for use in TSPA-LA, and provides transfer function data for the particle tracking algorithm for use in TSPA-LA in DTN: LA0311BR831229.001 [DIRS 166924].

Intermediate-scale focusing of flow from the site scale to the drift scale is accounted for in the seepage abstraction by using appropriate flow-focusing factors (BSC 2004 [DIRS 169131], 
Section 6.6.5.2). The distribution of flow-focusing factors used for seepage calculations is developed in Seepage Calibration Model and Seepage Testing Data (BSC 2004 [DIRS 171764], Sections 6.3 and 6.6), using property values calibrated in Calibrated Properties Model (BSC 2004 [DIRS 169857], Sections 6.1.4 and 6.3.2). Small-scale preferential flow is explicitly simulated in the seepage process model, developed in Seepage Model for PA Including Drift Collapse (BSC 2004 [DIRS 167652], Section 6.8) that feeds into the abstraction by use of heterogeneous fracture-permeability fields (BSC 2004 [DIRS 169131], Sections 6.4.1.1, 6.4.2.1, and 6.4.3.1). Thus, preferential flow is inherently embedded in the seepage lookup tables for ambient seepage given in DTNs: LB0407AMRU0120.001 [DIRS 173280] and LB0407AMRU0120.002 [DIRS 173308], and in the thermal seepage results provided in DTN: LB0301DSCPTHSM.002 [DIRS 163689]. The abstraction methodology for both ambient and thermal seepage is described in Abstraction of Drift Seepage (BSC 2004 [DIRS 169131], Section 6.7.1). The possibility of episodic finger flow is accounted for with an alternative conceptual model analyzed in the thermal seepage model report (BSC 2005 [DIRS 172232], Section 6.3). Results from this alternative conceptual model are consistent with results from the TH seepage model used for this abstraction (BSC 2004 [DIRS 169131], Section 6.4.3.2).

Intermediate-scale focusing of flow from the site scale to the drift scale is implicitly accounted for in Drift-Scale Coupled Processes (DST and TH Seepage) Models (BSC 2005 [DIRS 172232] by using appropriate flow-focusing factors (BSC 2004 [DIRS 169131], Section 6.6.5.2). However, flow focusing is not taken into account in the THC seepage model results or their abstraction (BSC 2004 [DIRS 169858], Section 6.2). This is because fracture permeability heterogeneity was determined to not significantly affect seepage water chemistry (BSC 2005 [DIRS 172862], Section 6.3). DTNs: LB0302DSCPTHCS.002 [DIRS 161976] and LB0311ABSTHCR2.001 [DIRS 166714] are used to feed and/or provide technical basis for Engineered Barrier System: Physical and Chemical Environment (BSC 2005 [DIRS 173727]), which generates lookup tables used in the TSPA-LA model. Another aspect of flow focusing is the channeling of fracture flow into a relatively few fractures. This is captured in the active fracture model described and validated in Conceptual Model and Numerical Approaches for UZ Flow and Transport (BSC 2004 [DIRS 170035], Sections 6.1.7 and 6.3.7, description; Section 7, validation). The active-fracture parameter values for different model layers are calibrated in the Calibrated Properties Model (BSC 2004 [DIRS 169857], Tables 6-8, 6-9, 6-10, and 6-14).

Supporting Reports: Conceptual Model and Numerical Approaches for UZ Flow and Transport (BSC 2004 [DIRS 170035]); Calibrated Properties Model (BSC 2004 [DIRS 169857]); UZ Flow Models and Submodels (BSC 2004 [DIRS 169861]); Seepage Model for PA Including Drift Collapse (BSC 2004 [DIRS 167652]); Seepage Calibration Model and Seepage Testing Data (BSC 2004 [DIRS 171764]); Drift-Scale Coupled Processes (DST and TH Seepage) Models (BSC 2005 [DIRS 172232]); Abstraction of Drift Seepage (BSC 2004 [DIRS 169131]); Particle Tracking Model and Abstraction of Transport Processes (BSC 2005 [DIRS 173980]); Drift-Scale THC Seepage Model (BSC 2005 [DIRS 172862]).

\subsubsection{Long-Term Release of Radionuclides from the Repository (2.2.07.06.0B)}

FEP Description: The release of radionuclides from the repository may occur over a long period of time, as a result of the timing and magnitude of the waste packages and drip shield failures, waste form degradation, and radionuclide transport through the invert. 
Screening Decision: Included.

TSPA Disposition: The effects of long-term waste package failures over a long period of time are included in the source term model for TSPA-LA (BSC 2003 [DIRS 166296], Section 5.1). This is done by modeling the environmental conditions of the waste packages in different parts of the repository and by modeling corrosion processes under these environmental conditions that lead to waste package failure. Releases from the waste package and engineered barrier system serve as a time-dependent boundary condition to the mountain-scale radionuclide transport model, which allows for a general time-dependent radionuclide source term that accounts for long-term releases (BSC 2005 [DIRS 173980], Section 6.4.7). For each GoldSim-FEHM run, GoldSim passes radionuclide mass releases to FEHM and FEHM simulates the transport process through the UZ. Long-term radionuclide release because of the failure of waste packages in the repository is implicitly included in Particle Tracking Model and Abstraction of Transport Processes (BSC 2005 [DIRS 173980], Sections 6.4.6 and 6.4.7).

Supporting Reports: Particle Tracking Model and Abstraction of Transport Processes (BSC 2005 [DIRS 173980]).

\subsubsection{Perched Water Develops (2.2.07.07.0A)}

FEP Description: Zones of perched water may develop above the water table. If these zones occur above the repository, they may affect UZ flow between the surface and the waste packages. If they develop below the repository, e.g., at the base of the Topopah Spring welded unit, they may affect flow pathways and radionuclide transport between the waste packages and the saturated zone.

Screening Decision: Included.

TSPA Disposition: The seepage abstraction model contains a wide range of seepage possibilities, including flow focusing and spatial variability (BSC 2004 [DIRS 169131], Section 6). Therefore, the potential for effects of perched water above the repository are indirectly captured in the seepage abstraction model through cases with high percolation flux (DTN: LB0305TSPA18FF.001 [DIRS 165625]), as described in Abstraction of Drift Seepage (BSC 2004 [DIRS 169131], Section 6). However, above the repository, no perched water bodies were observed in the fields predicted by the UZ flow model. The effects of existing perched water zones below the repository are also included, and potential changes in these perched-water zones caused by climate changes are also included in the mountain-scale UZ flow model (BSC 2004 [DIRS 169861], Sections 6.2.2, 6.2.3, 6.2.5, 6.6.2, and 6.6.3). The potential for this effect is captured in the output flow fields developed for use in TSPA-LA (output flow fields are in DTN: LB0305TSPA18FF.001 [DIRS 165625]).

This FEP is also implicitly included through the use of pregenerated flow fields (DTN: LB0305TSPA18FF.001 [DIRS 165625]) for radionuclide transport in the UZ. In TSPA-LA runs, pregenerated flow fields are used by FEHM and used in UZ transport simulations as described in Particle Tracking Model and Abstraction of Transport Processes (BSC 2005 [DIRS 173980], Section 6.5.1). 
Supporting Reports: UZ Flow Models and Submodels (BSC 2004 [DIRS 169861]); Particle Tracking Model and Abstraction of Transport Processes (BSC 2005 [DIRS 173980]).

\subsubsection{Fracture Flow in the UZ (2.2.07.08.0A)}

FEP Description: Fractures or other analogous channels may act as conduits for fluids to move into the subsurface to interact with the repository and as conduits for fluids to leave the vicinity of the repository and be conducted to the SZ. Water may flow through only a portion of the fracture network, including flow through a restricted portion of a given fracture plane.

Screening Decision: Included.

TSPA Disposition: The UZ flow model is based on the dual-permeability concept, with the fractures represented by a continuum (BSC 2004 [DIRS 169861], Section 6.1.2). The fracture continuum represents the spatially averaged flow through discrete fractures. The fracture continuum interacts with the matrix continuum, which represents matrix blocks separated by fractures. Fracture continuum properties, including permeability, porosity, interface area per unit volume, van Genuchten $\alpha$ and $m$ parameters for the saturation-capillary pressure and relative permeability functions, and active fracture parameter $\gamma$, for each UZ model layer are used as input to the UZ flow model (DTN: LB0205REVUZPRP.001 [DIRS 159525]) listed in UZ Flow Models and Submodels (BSC 2004 [DIRS 169861], Table 4.1-1). Permeabilities and other properties are calibrated as described in Analysis of Hydrologic Properties Data (BSC 2004 [DIRS 170038]) and Calibrated Properties Model (BSC 2004 [DIRS 169857], Sections 6.1.4 and 6.3). The fracture-continuum properties are used as inputs to the UZ flow model, and their effects are incorporated into the output flow fields developed for use in TSPA-LA (output flow fields are in DTN: LB0305TSPA18FF.001 [DIRS 165625]). Output flow fields for the fracture continuum are presented in UZ Flow Models and Submodels (BSC 2004 [DIRS 169861], Section 6.6.3)

The top boundary condition for the UZ flow model is set by the infiltration maps output by Simulation of Net Infiltration for Present-Day and Potential Future Climates (BSC 2004 [DIRS 170007], Section 6.11). When the soil/bedrock contact reaches near-saturated conditions, fracture flow is initiated in the bedrock (BSC 2004 [DIRS 170007] Sections 6.1.2 and 6.3.4). Channeling in the UZ fracture continuum is captured as discussed for FEP 2.2.07.04.0A, including the use of the active fracture model in Conceptual Model and Numerical Approaches for UZ Flow and Transport (BSC 2004 [DIRS 170035], Section 6.3); and the development of the distribution of flow-focusing factors in Seepage Calibration Model and Seepage Testing Data (BSC 2004 [DIRS 171764], Sections 6.3 and 6.6).

In the UZ, fracture flow plays an important role in the transport of radionuclides. In TSPA-LA runs, the effect of fracture flow on radionuclide transport (advection) is implicitly included through FEHM's use of pregenerated flow fields (DTN: LB0305TSPA18FF.001 [DIRS 165625]) in UZ transport simulations as described in Particle Tracking Model and Abstraction of Transport Processes (BSC 2005 [DIRS 173980], Section 6.5.1). Particle Tracking Model and Abstraction of Transport Processes (BSC 2005 [DIRS 173980]) provides transport parameters in DTN: LA0407BR831371.001 [DIRS 170806] for use in TSPA-LA, and 
provides transfer function data for the particle tracking algorithm for use in TSPA-LA in DTN: LA0311BR831229.001 [DIRS 166924].

Flow processes in fractures or other channels are important for the seepage abstraction, because the amount of seepage is determined by the capacity of the fracture network to divert flow around the drifts as a result of capillary forces (BSC 2004 [DIRS 169131], Section 6.3.1). All the seepage process models that feed into seepage abstraction simulate flow processes in fractured rock (BSC 2004 [DIRS 169131], Section 6.4). Spatial variability in the fracture flow, potentially leading to water flow through only a portion of the fracture network, is accounted for by using a stochastic continuum representation. For ambient seepage, the fracture flow processes in the drift vicinity and the resulting seepage rates are predicted by model simulations from the seepage model for PA (BSC 2004 [DIRS 167652], Sections 6.3.2 and 6.3.3) and abstracted in Abstraction of Drift Seepage (BSC 2004 [DIRS 169131], Section 6.4.2). Results are available as lookup tables in DTNs: LB0407AMRU0120.001 [DIRS 173280] and LB0407AMRU0120.002 [DIRS 173308]. These will be used in the TSPA-LA to calculate ambient seepage, by sampling parameter cases of seepage-relevant parameters from the probability distributions defined in Section 6.7.1 of Abstraction of Drift Seepage (BSC 2004 [DIRS 169131]). During the thermal period, the ambient seepage rates will be adjusted based on the TH-modeling results from Drift-Scale Coupled Processes (DST and TH Seepage) Models (BSC 2005 [DIRS 172232]), which explicitly simulates thermally perturbed fracture flow conditions. Results are given in DTN: LB0301DSCPTHSM.002 [DIRS 163689]. The abstraction methodology for thermal seepage is developed in Abstraction of Drift Seepage (BSC 2004 [DIRS 169131]), Section 6.5.2). THM and THC effects on fracture flow processes are evaluated with process models that explicitly account for fracture flow affected by THM and THC parameter alterations (BSC 2004 [DIRS 169131], Section 6.4.4). It was demonstrated that these potential alterations can be neglected in the TSPA-LA, because the expected changes would lead to less seepage (BSC 2004 [DIRS 169131], Section 6.5.1.4); see also Sections 6.9.1 (FEP 2.1.09.12.0A) and 6.9.10 (FEP 2.2.10.04.0A) of the current report. Percolation flux distributions are provided by the UZ flow model for use in the seepage abstraction model (BSC 2004 [DIRS 169131], Section 6.6.5.1), which accounts for fracture flow on a larger scale (influenced by climate changes), infiltration variability, and stratigraphy effects. Flow-focusing effects (channeling) are included as discussed in Abstraction of Drift Seepage (BSC 2004 [DIRS 169131], Section 6.6.5.2).

Flow processes in fractures or other channels affect modeled THC coupled processes because of (1) their strong effect on TH behavior (BSC 2004 [DIRS 169131], Section 6.4.4) and (2) their strong effect on water and gas chemistry (BSC 2005 [DIRS 172862], Section 6.2.1). The latter is primarily due to volatilization of steam and $\mathrm{CO}_{2}$ from the rock matrix-water and subsequent transport and condensation in fractures. The amount of mobilized $\mathrm{CO}_{2}$ with steam directly affects the $\mathrm{pH}$ of the condensate, which in turn affects the degree of water-rock interaction and water chemistry. These THC processes are influenced by the fracture characteristics, such as orientation, aperture, asperity, length, connectivity, and fillings. The THC seepage model that feeds into the drift-scale coupled processes abstraction model explicitly simulates the flow processes in fractures using appropriate continuum properties that represent these characteristics as shown in Drift-Scale THC Seepage Model (BSC 2005 [DIRS 172862], Sections 6.4.3, 6.4.4, and 6.4.7). Thus, the results from the THC seepage model and their abstraction (BSC 2004 [DIRS 169858], Section 6.2), and tables of concentrations and summary statistics through time, 
implicitly account for the effect of climate change on THC processes. Summary tables of concentrations through time are presented in DTNs: LB0302DSCPTHCS.002 [DIRS 161976] and LB0307DSTTHCR2.002 [DIRS 165541], and summary statistics through time are presented in DTN: LB0311ABSTHCR2.001 [DIRS 166714]. These data are used to feed and/or provide technical basis for Engineered Barrier System: Physical and Chemical Environment (BSC 2005 [DIRS 173727]), which generates lookup tables used in the TSPA-LA model. The effects of fracture flow are also included in the treatment of infiltration uncertainty for TSPA-LA (BSC 2003 [DIRS 165991]). Infiltration uncertainty is represented through three discrete infiltration scenarios (lower, mean, and upper), which are sampled in TSPA-LA according to weighting factors (BSC (2003 [DIRS 165991], Section 7.1). This FEP is implicitly included in the determination of the weighting factors fed to TSPA-LA (BSC 2003 [DIRS 165991]; DTN: SN0308T0503100.008 [DIRS 165640]). This FEP is incorporated in the uncertain parameters describing the bedrock permeability multiplier (BRPERM) and bedrock porosity (BRPOROS).

Supporting Reports: In Situ Field Testing of Processes (BSC 2004 [DIRS 170004]); Simulation of Net Infiltration for Present-Day and Potential Future Climates (BSC 2004 [DIRS 170007]); Conceptual Model and Numerical Approaches for UZ Flow and Transport (BSC 2004 [DIRS 170035]); Analysis of Hydrologic Properties Data (BSC 2004 [DIRS 170038]); Calibrated Properties Model (BSC 2004 [DIRS 169857]); UZ Flow Models and Submodels (BSC 2004 [DIRS 169861]); Seepage Model for PA Including Drift Collapse (BSC 2004 [DIRS 167652]); Seepage Calibration Model and Seepage Testing Data (BSC 2004 [DIRS 171764]); Drift-Scale THC Seepage Model (BSC 2005 [DIRS 172862]); Abstraction of Drift Seepage (BSC 2004 [DIRS 169131]); Drift-Scale Coupled Processes (DST and TH Seepage) Models (BSC 2005 [DIRS 172232]); Analysis of Infiltration Uncertainty (BSC 2003 [DIRS 165991]); Particle Tracking Model and Abstraction of Transport Processes (BSC 2005 [DIRS 173980]).

\subsubsection{Matrix Imbibition in the UZ (2.2.07.09.0A)}

FEP Description: Water flowing in fractures or other channels in the unsaturated zone may be imbibed into the surrounding rock matrix. This may occur during steady flow, episodic flow, or into matrix pores that have been dried out during the thermal period.

Screening Decision: Included.

TSPA Disposition: Matrix imbibition is included in the process model for UZ flow at the mountain scale (BSC 2004 [DIRS 169861], Section 6.1.2). Matrix imbibition refers to the movement of water into the matrix as a result of capillary forces. This process affects the distribution of flow between fractures and matrix in a dual-permeability flow model for fractured rock. The flow simulations in UZ Flow Models and Submodels (BSC 2004 [DIRS 169861], Section 6.6) are for steady-state flow. Imbibition is captured in the UZ flow model through capillarity modeling, which uses matrix and fracture properties as model input. Therefore, the effect of imbibition is implicitly incorporated in the output flow fields (DTN: LB0305TSPA18FF.001 [DIRS 165625]) used in the TSPA-LA. Matrix imbibition is implicit in the increase in matrix saturation that is simulated when changing to a wetter climate state. Matrix imbibition is also important in damping the effect of episodic infiltration, as 
discussed in UZ Flow Models and Submodels (BSC 2004 [DIRS 169861], Appendix G). Also see FEP 2.2.07.05.0A, Flow in the UZ from episodic infiltration.

For TSPA-LA runs, the pregenerated flow fields (DTN: LB0305TSPA18FF.001 [DIRS 165625]) are used by FEHM in UZ transport simulations as described in Particle Tracking Model and Abstraction of Transport Processes (BSC 2005 [DIRS 173980], Section 6.5.1). Therefore, the effects of matrix imbibition are implicitly included in the treatment of $\mathrm{UZ}$ radionuclide transport.

The THC seepage model similarly explicitly accounts for matrix imbibition using appropriate dual-permeability modeling concepts as reported in Drift-Scale THC Seepage Model (BSC 2005 [DIRS 172862], Section 6.2.1). This is needed because heating and dryout of the unsaturated rock transfers liquid and gas from the matrix into the fractures; upon rewetting water and solutes are imbibed from fracture to matrix (see, for example, BSC 2005 [DIRS 172862], Figure 6.2-3). Therefore, these effects are directly accounted for in the results from the THC seepage model, and in their abstraction in Post-Processing Analysis for THC Seepage (BSC 2004 [DIRS 169858], Section 6.2). Summary tables of concentrations through time are presented in DTNs: LB0302DSCPTHCS.002 [DIRS 161976] and LB0307DSTTHCR2.002 [DIRS 165541], and summary statistics through time are presented in DTN: LB0311ABSTHCR2.001 [DIRS 166714. These data are used to feed and/or provide technical basis for Engineered Barrier System: Physical and Chemical Environment (BSC 2005 [DIRS 173727]), which generates lookup tables used in the TSPA-LA model.

Ambient seepage is mainly governed by flow in the fractures, as discussed in Abstraction of Drift Seepage (BSC 2004 [DIRS 169131], Section 6.4). Thus, in the predictive model for ambient seepage, that is, the seepage calibration model (BSC 2004 [DIRS 171764], Section 6.3.3.2) and the seepage model for PA (BSC 2004 [DIRS 167652], Section 6.3), matrix imbibition is neglected. In contrast, the drift-scale process models addressing TH, THM, and THC processes, including Drift-Scale Coupled Processes (DST and TH Seepage) Models (BSC 2005 [DIRS 172232]), Drift-Scale THC Seepage Model (BSC 2005 [DIRS 172862]), and Abstraction of Drift Seepage (BSC 2004 [DIRS 169131], Sections 6.4.3.1, 6.4.4.1, and 6.4.4.2), explicitly account for matrix imbibition using appropriate dual-permeability modeling concepts. This is needed because the thermal perturbation of the unsaturated rock results in significant transfer of liquid and gas from the matrix into the fractures and vice versa. The UZ flow model (which provides the percolation flux distributions used for seepage calculations) also accounts for the impact of matrix imbibition in an explicit manner (BSC 2004 [DIRS 169131], Section 6.6.5.1). Thus, matrix imbibition effects are inherently embedded in the respective model results used for this abstraction.

Matrix imbibition tests are reported in In Situ Field Testing of Processes (BSC 2004 [DIRS 170004], Section 6.4). The matrix properties used to simulate matrix imbibition are developed in Calibrated Properties Model (BSC 2004 [DIRS 169857], Section 6.1.5).

Supporting Reports: In Situ Field Testing of Processes (BSC 2004 [DIRS 170004]); Calibrated Properties Model (BSC 2004 [DIRS 169857]); UZ Flow Models and Submodels (BSC 2004 [DIRS 169861]); Seepage Model for PA Including Drift Collapse (BSC 2004 [DIRS 167652]); Seepage Calibration Model and Seepage Testing Data (BSC 2004 
[DIRS 171764]); Drift-Scale THC Seepage Model (BSC 2005 [DIRS 172862]); Abstraction of Drift Seepage (BSC 2004 [DIRS 169131]); Drift-Scale Coupled Processes (DST and TH Seepage) Models (BSC 2005 [DIRS 172232]); Particle Tracking Model and Abstraction of Transport Processes (BSC 2005 [DIRS 173980]).

\subsubsection{Condensation Zone Forms around Drifts (2.2.07.10.0A)}

FEP Description: Condensation of the two-phase flow generated by repository heat may form in the rock where the temperature drops below the local vaporization temperature. Waste package emplacement geometry and thermal loading may affect the scale at which condensation caps form (over waste packages, over panels, or over the entire repository), and the extent to which "shedding" will occur as water flows from the region above one drift to the region above another drift or into the rock between drifts.

Screening Decision: Included.

TSPA Disposition: The coupled processes of vapor condensation forming a condensation zone (or "condensation cap") in the fractured rock above the drifts are explicitly simulated with the TH seepage model (BSC 2005 [DIRS 172232], Sections 6.2 and 7.4) that feeds into the seepage abstraction. Using this model, the impact of condensation and shedding on seepage is assessed for various simulation cases (BSC 2004 [DIRS 169131], Section 6.4.3.3). Thus, the TH-modeling results from DTN: LB0301DSCPTHSM.002 [DIRS 163689] inherently include these effects. As discussed in Abstraction of Drift Seepage (BSC 2004 [DIRS 169131], Section 6.5.2), the abstraction of thermal seepage uses these modeling results to develop an appropriate thermal-seepage abstraction methodology.

The coupled processes of vapor condensation forming a condensation cap above the drifts and occurrence of "shedding" between drifts (that is, diversion of vapor to cooler regions and drainage of condensation through the cooler region between drifts) are explicitly simulated with the THC seepage model (BSC 2005 [DIRS 172862], Sections 6.2.1, 6.5.5.1, 6.5.5.3, and 6.5.5.2.2). Using this model, the impact of condensation and drainage on seepage water chemistry is assessed for various simulation cases (BSC 2005 [DIRS 172862], Sections 6.2, 6.5, and 6.6). Therefore, the results from the THC seepage model, and their abstraction in Post-Processing Analysis for THC Seepage (BSC 2004 [DIRS 169858], Section 6.2), explicitly include these effects. Summary tables of concentrations through time are presented in DTNs: LB0302DSCPTHCS.002 [DIRS 161976] and LB0307DSTTHCR2.002 [DIRS 165541], and summary statistics through time are presented in DTN: LB0311ABSTHCR2.001 [DIRS 166714]. These data are used to feed and/or provide technical basis for Engineered Barrier System: Physical and Chemical Environment (BSC 2005 [DIRS 173727]), which generates lookup tables used in the TSPA-LA model.

Supporting Reports: Drift-Scale THC Seepage Model (BSC 2005 [DIRS 172862]); Abstraction of Drift Seepage (BSC 2004 [DIRS 169131]); Post-Processing Analysis for THC Seepage (BSC 2004 [DIRS 169858]); Drift-Scale Coupled Processes (DST and TH Seepage) Models (BSC 2005 [DIRS 172232]). 


\subsubsection{Resaturation of Geosphere Dry-Out Zone (2.2.07.11.0A)}

FEP Description: Following the peak thermal period, water in the condensation cap may flow downward into the drifts. Influx of cooler water from above, such as might occur from episodic flow, may accelerate return flow from the condensation cap by lowering temperatures below the condensation point. Percolating groundwater will also contribute to resaturation of the dry-out zone. Vapor flow, as distinct from liquid flow by capillary processes, may also contribute.

Screening Decision: Included.

TSPA Disposition: Resaturation of the dryout zone around drifts, and the potential of return flow from the condensation zone back to the drifts, are explicitly simulated with the TH seepage model (BSC 2005 [DIRS 172232], Section 6.2), which feeds into seepage abstraction. Using this model, the impact of resaturation and reflux on seepage is assessed for various simulation cases (BSC 2004 [DIRS 169131], Section 6.4.3.3). Thus, the TH-modeling results from DTN: LB0301DSCPTHSM.002 [DIRS 163689] inherently include these effects. As discussed in Abstraction of Drift Seepage (BSC (2004 [DIRS 169131], Section 6.5.2), the abstraction of thermal seepage utilizes these modeling results to develop an appropriate thermal-seepage abstraction methodology. The impact of potential episodic flow was addressed with an alternative conceptual model for thermal seepage, as discussed in Abstraction of Drift Seepage (BSC 2004 [DIRS 169131], Section 6.4.3). It was shown that results from this alternative conceptual model are consistent with the process model results from the TH seepage model used for this abstraction.

Resaturation of the dryout zone around drifts, and the potential of return flow from the condensation zone back to the drifts, are explicitly simulated with the THC seepage model (BSC 2005 [DIRS 172862], Sections 6.2.1 and 6.5.5). Using this model, the impact of resaturation on reflux chemistry is assessed as part of the abstraction methodology (that is, the compositions of abstracted "FRONT" waters reflect concentration increases because of the dissolution of salts precipitated during dryout; see Post-Processing Analysis for THC Seepage (BSC 2004 [DIRS 169858], Section 6.2.3.1). Therefore, the results from the THC seepage model, and their abstraction in Post-Processing Analysis for THC Seepage (BSC 2004 [DIRS 169858], Section 6.2), explicitly include these effects. Summary tables of concentrations through time are presented in DTNs: LB0302DSCPTHCS.002 [DIRS 161976] and LB0307DSTTHCR2.002 [DIRS 165541], and summary statistics through time are presented in DTN: LB0311ABSTHCR2.001 [DIRS 166714]. These data are used to feed and/or provide technical basis for Engineered Barrier System: Physical and Chemical Environment (BSC 2005 [DIRS 173727]), which generates lookup tables used in the TSPA-LA model.

Supporting Reports: Drift-Scale THC Seepage Model (BSC 2005 [DIRS 172862]); Abstraction of Drift Seepage (BSC 2004 [DIRS 169131]); Post-Processing Analysis for THC Seepage (BSC 2004 [DIRS 169858]); Drift-Scale Coupled Processes (DST and TH Seepage) Models (BSC 2005 [DIRS 172232]). 


\subsubsection{Advection and Dispersion in the UZ (2.2.07.15.0B)}

FEP Description: Advection and dispersion processes may affect radionuclide transport in the UZ.

Screening Decision: Included.

TSPA Disposition: Radionuclide transport through the UZ by advection is simulated using the Residence Time Transfer Function (RTTF) method documented in Particle Tracking Model and Abstraction of Transport Processes (BSC 2005 [DIRS 173980], Section 6.4.1). Dispersion is incorporated into the RTTF algorithm through the use of a transfer function based on an analytical solution to the advection-dispersion equation (BSC 2005 [DIRS 173980], Section 6.4.2). In TSPA-LA runs, advection and dispersion are implicitly included through the use of FEHM RTTF model and the pregenerated flow fields as described in Particle Tracking Model and Abstraction of Transport Processes (BSC 2005 [DIRS 173980], Sections 6.4 and 6.5.1).

Supporting Reports: Particle Tracking Model and Abstraction of Transport Processes (BSC 2005 [DIRS 173980]).

\subsubsection{Film Flow into the Repository (2.2.07.18.0A)}

FEP Description: Water may enter waste emplacement drifts by a film flow process. This differs from the traditional view of flow in a capillary network where the wetting phase exclusively occupies capillaries with apertures smaller than some level defined by the capillary pressure. A film flow process could allow water to enter a waste emplacement drift at non-zero capillary pressure. Dripping into the drifts could also occur through collection of the film flow on the local minima of surface roughness features along the crown of the drift.

Screening Decision: Included.

TSPA Disposition: The potential impact of film flow is represented in the data acquired in In Situ Field Testing of Processes (BSC 2004 [DIRS 170004], Section 6.2), and developed by Seepage Calibration Model and Seepage Testing Data (BSC 2004 [DIRS 171764], Sections 6.1.2, 6.3.3, and 6.6.3) into results that are used for the seepage abstraction; that is, the calibrated values of the capillary-strength parameter given in Abstraction of Drift Seepage (BSC 2004 [DIRS 169131], Table 6.6-1) and DTN: LB0302SCMREV02.002 [DIRS 162273]. If water originating from film flow seeps into the opening during a liquid-release test, it is reflected in the corresponding seepage data point used for model calibration. Film flow is thus inherently accounted for in the estimated seepage-related capillary-strength parameter from the seepage calibration model (BSC 2004 [DIRS 171764]), and thus in the prediction of seepage into waste emplacement drifts in Seepage Model for PA Including Drift Collapse (BSC 2004 [DIRS 167652], Section 6.3) and the abstraction in Abstraction of Drift Seepage (BSC 2004 [DIRS 169131], Section 6.4.1.1). In theory, film-flow behavior may be influenced by the elevated temperatures in the drift vicinity during the first several thousand years after emplacement. This effect is not included in the ambient liquid-release tests. However, the potential changes in film flow as a result of temperature increase are not expected to be significant for drift seepage. 
Supporting Reports: In Situ Field Testing of Processes (BSC 2004 [DIRS 170004]); Abstraction of Drift Seepage (BSC 2004 [DIRS 169131]); Seepage Calibration Model and Seepage Testing Data (BSC 2004 [DIRS 171764]); Seepage Model for PA Including Drift Collapse (BSC 2004 [DIRS 167652]).

\subsubsection{Lateral Flow from Solitario Canyon Fault Enters Drifts (2.2.07.19.0A)}

FEP Description: Water movement down Solitario Canyon Fault could enter waste emplacement drifts through lateral flow mechanisms in the Topopah Spring welded hydrogeologic unit. This percolation pathway is more likely to transmit episodic transient flow to waste emplacement locations due to the major fault pathway through the overlying units.

Screening Decision: Included.

TSPA Disposition: The UZ flow model contains potential hydrogeologic connections between the Solitario Canyon Fault and the waste emplacement horizon. The potential connection is captured using a property set of the PTn unit with calibrated fracture-matrix properties that favor lateral flow (BSC 2004 [DIRS 169861], Sections 6.2.2.1 and 6.2.3). Therefore, flow from this fault to waste emplacement locations is addressed. This water may seep into waste emplacement drifts if the flux is sufficient to overcome the capillary barrier represented in the drift seepage model (BSC 2004 [DIRS 169131]); however, this FEP is not explicitly represented in that report. The lateral flow effect is implicitly incorporated in the output flow fields developed in UZ Flow Models and Submodels (BSC 2004 [DIRS 169861], Section 6.6.3) and submitted to the TDMS (DTN: LB0305TSPA18FF.001 [DIRS 165625]) for use in TSPA-LA. Other aspects of flow focusing in faults (preferential flow in faults) are discussed in FEP 2.2.07.04.0A. Perched water is discussed in FEP 2.2.07.07.0A.

Supporting Reports: UZ Flow Models and Submodels (BSC 2004 [DIRS 169861]).

\subsubsection{Flow Diversion around Repository Drifts (2.2.07.20.0A)}

FEP Description: Flow in unsaturated rock tends to be diverted by openings such as waste emplacement drifts due to the effects of capillary forces. The resulting diversion of flow could have an effect on seepage into the repository. Flow diversion around the drift openings could also lead to the development of a zone of lower flow rates and low saturation beneath the drift, known as the drift shadow.

Screening Decision: Included.

TSPA Disposition: The impact of flow diversion around the drifts and its relevance for seepage is explicitly captured in the data acquired in In Situ Field Testing of Processes (BSC 2004 [DIRS 170004], Section 6.2) and in the seepage process models (BSC 2004 [DIRS 171764], Sections 6.3, 6.6, and 6.8; BSC 2004 [DIRS 167652], Sections 6.2.1, 6.3.2, and 6.7; BSC 2005 [DIRS 172232]; BSC 2005 [DIRS 172862]) and the seepage abstractions (BSC 2004 [DIRS 169131], Sections 6.4.1, 6.4.2, and 6.4.3). From these model simulations, seepage predictions are available in the form of lookup tables in DTNs: LB0407AMRU0120.001 [DIRS 173280] and LB0407AMRU0120.002 [DIRS 173308]. These will be used in the TSPA-LA to calculate ambient seepage, by sampling parameter cases of seepage-relevant 
parameters from the probability distributions defined in Abstraction of Drift Seepage (BSC 2004 [DIRS 169131], Section 6.7.1). These seepage-relevant parameters are the effective capillary-strength parameter permeability and local percolation flux. During the thermal period, the ambient rates will be adjusted based on the TH-modeling results from DTN: LB0301DSCPTHSM.002 [DIRS 163689], using the abstraction methodology developed in Abstraction of Drift Seepage (BSC 2004 [DIRS 169131], Section 6.5.2.1). The drift seepage model also captures the effects of drift collapse (BSC 2004 [DIRS 169131], Sections 6.4.2.4 and 6.7.1.2) in terms of the larger drift profile that results.

Supporting Reports: In Situ Field Testing of Processes (BSC 2004 [DIRS 170004]); Seepage Model for PA Including Drift Collapse (BSC 2004 [DIRS 167652]); Seepage Calibration Model and Seepage Testing Data (BSC 2004 [DIRS 171764]); Drift-Scale THC Seepage Model (BSC 2005 [DIRS 172862]); Abstraction of Drift Seepage (BSC 2004 [DIRS 169131]); Drift-Scale Coupled Process (DST and TH Seepage) Models (BSC 2005 [DIRS 172232]).

\subsubsection{Chemical Characteristics of Groundwater in the UZ (2.2.08.01.0B)}

FEP Description: Chemistry and other characteristics of groundwater in the unsaturated zone may affect groundwater flow and radionuclide transport of dissolved and colloidal species. Groundwater chemistry and other characteristics, including temperature, $\mathrm{pH}, \mathrm{Eh}$, ionic strength, and major ionic concentrations, may vary spatially throughout the system as a result of different rock mineralogy.

Screening Decision: Included.

TSPA Disposition: THC seepage model simulations feeding the drift scale coupled processes abstraction were run explicitly using five different input water compositions representing the range of compositions at Yucca Mountain (BSC 2005 [DIRS 172862], Table 6.2-1, Sections 6.2.2 and 6.5.5). This variability of pore-water compositions in repository host units implicitly reflects spatial variations in rock mineralogy and infiltration rates. Therefore, the results from the THC seepage model, and their abstraction in Post-Processing Analysis for THC Seepage (BSC 2004 [DIRS 169858], Section 6.2), explicitly reflect the natural variability of pore-water compositions and implicitly reflect the natural variability of rock mineralogy. Summary tables of concentrations through time are presented in DTNs: LB0302DSCPTHCS.002 [DIRS 161976] and LB0307DSTTHCR2.002 [DIRS 165541], and summary statistics through time are presented in DTN: LB0311ABSTHCR2.001 [DIRS 166714]. These data are used to feed and/or provide technical basis for Engineered Barrier System: Physical and Chemical Environment (BSC 2005 [DIRS 173727]), which generates lookup tables used in the TSPA-LA model to define the chemical environment inside the drift.

The effects of groundwater chemical characteristics are included in the radionuclide sorption coefficients under ambient conditions. The sorption coefficient data on which the distributions are based are obtained in laboratory experiments in which crushed rock samples from the Yucca Mountain site are contacted with groundwaters (or simulated groundwaters) representative of the site, spiked with one or more of the elements of interest (BSC 2004 [DIRS 164500], Sections A4 and A5). The chemistry of pore waters and perched waters in the UZ along potential flowpaths to the accessible environment is discussed in Yucca Mountain Site Description (BSC 2004 
[DIRS 169734]). In the UZ, two distinct water types exist in the ambient system. One is perched water and the other is pore water. Perched water is generally more dilute than pore water. The J-13 and UE p\#1 waters were used in sorption experiments as end-member compositions intended to bracket the impact of water composition on sorption coefficients (BSC 2004 [DIRS 164500], Appendix A, Section A4). Some spatial trends in water composition through the TSw and CHn geologic units have been noted (BSC 2003 [DIRS 169734], Section 5.2.2.4.2). However, the uncertainty in these spatial variations (BSC 2005 [DIRS 172862], Section 6.2.2.1) and the uncertainty with respect to the effects of the bounding water compositions on sorption (BSC 2004 [DIRS 164500], Appendix A, Sections A8.3, A8.4, and A8.9) have led to the treatment of natural variability in water composition as uncertainty. Sorption experiments have been carried out as a function of time, element concentration, atmospheric composition, particle size, and temperature. In some cases, the solids remaining from sorption experiments were contacted with unspiked groundwater in desorption experiments. The experimental data used to determine the sorption $\mathrm{K}_{d} \mathrm{~S}$ are provided in the following DTNs: LA0305AM831341.001 [DIRS 163789], LA0407AM831341.001 [DIRS 170623], LA0407AM831341.002 [DIRS 170621], LA0407AM831341.004 [DIRS 170622], LA0407AM831341.005 [DIRS 170625], LA0407AM831341.003 [DIRS 170626], LA0407AM831341.006 [DIRS 170628], and LA0310AM831341.001 [DIRS 165865]. The sorption and desorption experiments together provide information on the equilibration rates of the forward and backward sorption reactions. For elements that sorb primarily through surface complexation reactions, the experimental data are augmented with the results of modeling calculations using PHREEQC (V2.3, STN: 10068-2.3-00) (BSC 2001 [DIRS 155323]). The inputs for the modeling calculations include groundwater compositions, surface areas, binding constants for the elements of interest, and thermodynamic data for solution species. These modeling calculations provide a basis for interpolation and extrapolation of the experimentally derived sorption coefficient dataset. The effects of nonlinear sorption are approximated by capturing the effective $\mathrm{K}_{\mathrm{d}}$ range (BSC 2004 [DIRS 164500], Appendix A, Section A8).

The effects of groundwater composition with respect to sorption coefficients are provided in terms of probability distributions for the sorption coefficient of each element of interest among the three major rock types (devitrified, zeolitic, and vitric) found in the UZ. The influence of expected variations in water chemistry, radionuclide concentrations, and variations in rock surface properties within one of the major rock types are incorporated into these probability distributions. These distributions are specified for each radionuclide-rock type combination (BSC 2004 [DIRS 164500], Appendix A, Section A8) and are sampled in the TSPA-LA to account for the effects of natural variations in pore-water chemistry and mineral surfaces on sorption. Correlations for sampling sorption coefficient probability distributions have been derived for the elements investigated (BSC 2004 [DIRS 164500], Appendix B). To derive the correlations, a rating system was first developed to rate the impact of six different variables on the sorption coefficient for a given element in each of the three major rock types. The six variables are $\mathrm{pH}$, Eh, water chemistry, rock composition, rock surface area, and radionuclide concentration. Water chemistry refers to the major ion concentrations and silica. Rock composition refers to both the mineralogical composition of the rocks and the chemical composition of the minerals (for example, zeolite compositions). The output DTNs for the sorption $\mathrm{K}_{d} \mathrm{~S}$ and correlations are LA0408AM831341.001 [DIRS 171584] and LA0311AM831341.001 [DIRS 167015]. These $\mathrm{K}_{d} \mathrm{~S}$, which include the effects of the chemical characteristics of groundwater, are used in the simulation of radionuclide transport for 
TSPA-LA, as described in Particle Tracking Model and Abstraction of Transport Processes (BSC 2005 [DIRS 173980], Section 6.5.4).

Supporting Reports: Radionuclide Transport Models Under Ambient Conditions (BSC 2004 [DIRS 164500]); Particle Tracking Model and Abstraction of Transport Processes (BSC 2005 [DIRS 173980]); Drift-Scale THC Seepage Model (BSC 2005 [DIRS 172862]).

\subsubsection{Re-dissolution of Precipitates Directs More Corrosive Fluids to Waste Packages (2.2.08.04.0A)}

FEP Description: Re-dissolution of precipitates that have plugged pores as a result of evaporation of groundwater in the dry-out zone, may produce a pulse of fluid reaching the waste packages when gravity-driven flow resumes, which is more corrosive than the original fluid in the rock.

Screening Decision: Included.

TSPA Disposition: The THC seepage model simulations feeding Post-Processing Analysis for THC Seepage (BSC 2004 [DIRS 169858]) explicitly consider the formation of salt precipitates upon dryout (BSC 2005 [DIRS 172862], Sections 6.4.5 and 6.5.5.2), their dissolution during rewetting around drifts (BSC 2005 [DIRS 172862], Section 6.5.5.2), and the resulting effect on percolation water chemistry (BSC 2004 [DIRS 169858], Section 6.2.3; BSC 2005 [DIRS 172862], Section 6.4.4). Therefore, the results from the THC seepage model, and their abstraction in Post-Processing Analysis for THC Seepage (BSC 2004 [DIRS 169858], Section 6.2), explicitly reflect the effect of salt redissolution upon rewetting. The effect results in an increase in both salinity and variability (BSC 2004 [DIRS 169858], Section 6.2.3). Summary tables of concentrations through time are presented in DTNs: LB0302DSCPTHCS.002 [DIRS 161976] and LB0307DSTTHCR2.002 [DIRS 165541], and summary statistics through time are presented in DTN: LB0311ABSTHCR2.001 [DIRS 166714]. These data are used to feed and/or provide technical basis for Engineered Barrier System: Physical and Chemical Environment (BSC 2005 [DIRS 173727]), which generates lookup tables used in the TSPA-LA model.

Supporting Reports: Drift-Scale THC Seepage Model (BSC 2005 [DIRS 172862]); Post-Processing Analysis for THC Seepage (BSC 2004 [DIRS 169858]).

\subsubsection{Complexation in the UZ (2.2.08.06.0B)}

FEP Description: Complexing agents such as humic and fulvic acids present in natural groundwaters could affect radionuclide transport in the UZ.

Screening Decision: Included.

TSPA Disposition: Complexation on mobile complexing agents such as humic and fulvic acids is treated as part of colloid transport in Radionuclide Transport Models Under Ambient Conditions (BSC 2004 [DIRS 164500], Sections 6.1.3 and 6.18). Complexation on mineral surfaces is treated as part of sorption in Radionuclide Transport Models Under Ambient Conditions (BSC 2004 [DIRS 164500], Appendix A, Section A7). Therefore, the effects of 
complexation are implicitly included in the radionuclide sorption coefficients under ambient conditions. For TSPA-LA, radionuclide transport is simulated by a particle-tracking model that includes the effects of complexation, as described in Particle Tracking Model and Abstraction of Transport Processes (BSC 2005 [DIRS 173980], Section 6.5.4).

The sorption coefficient data on which the distributions are based are obtained in laboratory experiments in which crushed rock samples from the Yucca Mountain site are contacted with groundwaters (or simulated groundwaters) representative of the site (BSC 2004 [DIRS 164500], Appendix A, Section A4), spiked with one or more of the elements of interest (BSC 2004 [DIRS 164500], Appendix A, Section A5). As such, the sorption experiments contain representative ligands responsible for complex formation, such as carbonates (Triay et al. 1997 [DIRS 100422], p. 85, 133). Sorption experiments have been carried out as a function of time, element concentration, atmospheric composition, particle size, and temperature. In some cases, the solids remaining from sorption experiments were contacted with unspiked groundwater in desorption experiments. The experimental data used to determine the sorption $\mathrm{K}_{\mathrm{d}} \mathrm{S}$ are provided in the following DTNs: LA0305AM831341.001 [DIRS 163789], LA0407AM831341.001 [DIRS 170623], LA0407AM831341.002 [DIRS 170621], LA0407AM831341.004 [DIRS 170622], LA0407AM831341.005 [DIRS 170625], LA0407AM831341.003 [DIRS 170626], LA0407AM831341.006 [DIRS 170628], and LA0310AM831341.001 [DIRS 165865]. The sorption and desorption experiments together provide information on the equilibration rates of the forward and backward sorption reactions. For elements that sorb primarily through surface complexation reactions, the experimental data are augmented with the results of modeling calculations using PHREEQC V2.3 (BSC 2001 [DIRS 155323]). The inputs for the modeling calculations include groundwater compositions, surface areas, binding constants for the elements of interest, and thermodynamic data for solution species. These modeling calculations provide a basis for interpolation and extrapolation of the experimentally derived sorption coefficient dataset. The effects of nonlinear sorption are approximated by capturing the effective $\mathrm{K}_{d}$ range (BSC 2004 [DIRS 164500], Appendix A, Section A8).

The effects of organics on sorption were also investigated by Triay et al. (1997 [DIRS 100422], Section IV.B). Their experiments tested the effects of organic materials (dihydroxyphenylalanine and Nordic Aquatic Fulvic Acid) on the sorption of Pu and $\mathrm{Np}$ on tuff materials. The results of these tests showed very little effect of the organic materials for sorption of these radionuclides in tuffs. The effects of complexation with respect to sorption coefficients are provided in terms of probability distributions for the sorption coefficient of each element of interest among the three major rock types (devitrified, zeolitic, and vitric) found in the UZ. The influence of expected variations in water chemistry, radionuclide concentrations, and variations in rock surface properties within one of the major rock types are incorporated into these probability distributions. These distributions are specified for each radionuclide-rock type combination (BSC 2004 [DIRS 164500], Appendix A, Section A8) and are sampled in the TSPA-LA to account for the effects of natural variations in pore-water chemistry and mineral surfaces on sorption. Correlations for sampling sorption coefficient probability distributions have been derived for the elements investigated (BSC 2004 [DIRS 164500], Appendix B). To derive the correlations, a rating system was first developed to rate the impact of six different variables on the sorption coefficient for a given element in each of the three major rock types. The six variables are $\mathrm{pH}$, Eh, water chemistry, rock composition, rock surface area, and radionuclide concentration. Water chemistry refers to the major ion concentrations and silica. 
Rock composition refers to both the mineralogic composition of the rocks and the chemical composition of the minerals (for example, zeolite compositions). The output DTNs for the sorption $\mathrm{K}_{\mathrm{d}} \mathrm{S}$ and correlations are LA0408AM831341.001 [DIRS 171584] and LA0311AM831341.001 [DIRS 167015].

Supporting Reports: Radionuclide Transport Models Under Ambient Condition (BSC 2004 [DIRS 164500]); Particle Tracking Model and Abstraction of Transport Processes (BSC 2005 [DIRS 173980]).

\subsubsection{Matrix Diffusion in the UZ (2.2.08.08.0B)}

FEP Description: Matrix diffusion is the process by which radionuclides and other species transported in the UZ by advective flow in fractures or other pathways move into the matrix of the porous rock by diffusion. This includes osmotic processes in response to chemical gradients. Matrix diffusion can be a very efficient retarding mechanism, especially for strongly sorbed radionuclides, due to the increase in rock surface accessible to sorption.

Screening Decision: Included.

TSPA Disposition: Migration of radionuclides from fast flow fracture into surrounding slow flow matrix blocks by diffusion could play an important role in delaying the transport process of radionuclides in fractures. Matrix diffusion is identified in Conceptual Model and Numerical Approaches for UZ Flow and Transport (BSC 2004 [DIRS 170035], Section 6.2.2) as a process to be included in transport modeling. The role of matrix diffusion is included through the development of the particle tracking approach as described in Particle Tracking Model and Abstraction of Transport Processes (BSC 2005 [DIRS 173980], Section 6.4.3). Transfer function curves (DTN: LA0311BR831229.001 [DIRS 166924]) that are generated are fed directly to TSPA-LA. These curves are used by FEHM in simulating the effect of matrix diffusion on radionuclide transport in TSPA-LA runs as described in Particle Tracking Model and Abstraction of Transport Processes (BSC 2005 [DIRS 173980], Section 6.4.3 and Appendix C). This particle tracking approach was used to simulate matrix diffusion of dissolved radionuclides. This treatment of matrix diffusion includes the effects of partial saturation of the matrix, radionuclide sorption in the matrix, and finite spacing of fractures. Osmosis would tend to cause water from fractures to flow into the matrix, if the matrix presents a suitable barrier to the migration of dissolved salts. Matrix diffusion of colloids was assumed not to occur because its effects would be small and would only retard transport (BSC 2005 [DIRS 173980], Section 6.4.5). Therefore, the approximation of no diffusion for colloids results in predictions that underestimate repository performance. One important factor affecting the strength of matrix diffusion is matrix diffusion coefficient. Matrix diffusion coefficient is related to matrix water content and matrix effective permeability through the relationship developed by Reimus et al. (2002 [DIRS 163008], Eq. 2.5). The distributions of matrix water content and matrix effective permeability are outputs from Particle Tracking Model and Abstraction of Transport Processes (BSC 2005 [DIRS 173980], Section 6.5.5 and Table 6-6; DTN: LA0407BR831371.001 [DIRS 170806]). TSPA-LA uses these distributions in multiple realization runs to randomly generate matrix diffusion coefficients (DTN: LA0407BR831371.001 [DIRS 170806]). Related FEP 2.1.09.08.0A, Diffusion of dissolved radionuclides in EBS, is discussed in Engineered Barrier System Features, Events, and Processes (BSC 2005 [DIRS 173781], Section 6.2.51). 
Supporting Reports: Conceptual Model and Numerical Approaches for UZ Flow and Transport (BSC 2004 [DIRS 170035]); Particle Tracking Model and Abstraction of Transport Processes (BSC 2005 [DIRS 173980]).

\subsubsection{Sorption in the UZ (2.2.08.09.0B)}

FEP Description: Sorption of dissolved and colloidal radionuclides in the UZ can occur on the surfaces of both fractures and matrix in rock or soil along the transport path. Sorption may be reversible or irreversible, and it may occur as a linear or nonlinear process. Sorption kinetics and the availability of sites for sorption should be considered. Sorption is a function of the radioelement type, mineral type, and groundwater composition.

Screening Decision: Included.

TSPA Disposition: Sorption is identified in Conceptual Model and Numerical Approaches for UZ Flow and Transport (BSC 2004 [DIRS 170035], Section 6.2.3) as a process to be included in transport modeling. It is included in the TSPA-LA model for mountain-scale UZ radionuclide transport as a linear equilibrium sorption $\left(\mathrm{K}_{\mathrm{d}}\right)$ model in Radionuclide Transport Models Under Ambient Conditions (BSC 2004 [DIRS 164500], Section 6.1); $\mathrm{K}_{\mathrm{d}}$ values and their basis in experimental data are presented in Radionuclide Transport Models Under Ambient Conditions (BSC 2004 [DIRS 164500], Appendix A). In TSPA-LA runs, sorption coefficients are sampled and fed into FEHM. Sorption onto fracture surfaces is neglected because of few data available in supporting such a retardation mechanism in the UZ. Thus, a fracture surface retardation factor of one is set for use in TSPA-LA runs (BSC 2005 [DIRS 173980], Section 6.5.8; DTN: LA0407BR831371.001 [DIRS 170806]).

Sorption is only accounted for in the matrix continuum; there is no sorption modeled in the fracture continuum. Sorption characteristics of the rock minerals are assumed to be static in time. Sorption $\mathrm{K}_{\mathrm{d}} \mathrm{S}$ have been derived for the elements americium, cesium, neptunium, protactinium, plutonium, radium, strontium, thorium, and uranium as dissolved radionuclides; other dissolved radionuclide elements treated by TSPA-LA (for example, technetium) are modeled as nonsorbing.

The sorption coefficient data on which the distributions are based are obtained in laboratory experiments in which crushed rock samples from the Yucca Mountain site are contacted with groundwaters (or simulated groundwaters) representative of the site, spiked with one or more of the elements of interest (BSC 2004 [DIRS 164500], Appendix A, Sections A4 and A5). Sorption experiments have been carried out as a function of time, element concentration, atmospheric composition, particle size, and temperature. In some cases, the solids remaining from sorption experiments were contacted with unspiked groundwater in desorption experiments. The experimental data used to determine the sorption $\mathrm{K}_{\mathrm{d}} \mathrm{S}$ are provided in the following DTNs: LA0305AM831341.001 [DIRS 163789], LA0309AM83341.002 [DIRS 170623], LA0309AM83341.003 [DIRS 170621], LA0309AM83341.004 [DIRS 170622], LA0309AM83341.005 [DIRS 170625], LA0309AM83341.006 [DIRS 170626], LA0309AM83341.007 [DIRS 170628], and LA0310AM831341.001 [DIRS 165865]. The sorption and desorption experiments together provide information on the equilibration rates of the forward and backward sorption reactions. For elements that sorb primarily through surface 
complexation reactions, the experimental data are augmented with the results of modeling calculations using PHREEQC V2.3 (BSC 2001 [DIRS 155323]). The inputs for the modeling calculations include groundwater compositions, surface areas, binding constants for the elements of interest, and thermodynamic data for solution species. These modeling calculations provide a basis for interpolation and extrapolation of the experimentally derived sorption coefficient dataset. The effects of nonlinear sorption are approximated by capturing the effective $\mathrm{K}_{\mathrm{d}}$ range (BSC 2004 [DIRS 164500], Appendix A, Section A8).

Sorption coefficients are provided in terms of probability distributions for the sorption coefficient of each element of interest among the three major rock types (devitrified, zeolitic, and vitric) found in the UZ. The influence of expected variations in water chemistry, radionuclide concentrations, and variations in rock surface properties within one of the major rock types are incorporated into these probability distributions. These distributions are specified for each radionuclide-rock type combination (BSC 2004 [DIRS 164500], Appendix A, Section A8) and are sampled in the TSPA-LA to account for the effects of natural variations in pore-water chemistry and mineral surfaces on sorption. Correlations for sampling sorption coefficient probability distributions have been derived for the elements investigated (BSC 2004 [DIRS 164500], Appendix B). To derive the correlations, a rating system was first developed to rate the impact of six different variables on the sorption coefficient for a given element in each of the three major rock types. The six variables are $\mathrm{pH}$, Eh, water chemistry, rock composition, rock surface area, and radionuclide concentration. Water chemistry refers to the major ion concentrations and silica. Rock composition refers to both the mineralogic composition of the rocks and the chemical composition of the minerals (for example, zeolite compositions). The output DTNs for the sorption $\mathrm{K}_{\mathrm{d}} \mathrm{S}$ and correlations are LA0408AM831341.001 [DIRS 171584] and LA0311AM831341.001 [DIRS 167015].

Sorption in the UZ is treated as a linear process in the radionuclide transport abstraction model (BSC 2005 [DIRS 173980], Section 6.5.4). In the matrix, sorption is incorporated in the generation of transfer function curves and expressed as part of the defined dimensionless parameters (BSC 2005 [DIRS 173980], Section 6.4.3). For colloid facilitated radionuclide transport, radionuclide sorption onto colloids and its effect on transport are simulated through the colloid $\mathrm{K}_{\mathrm{c}}$ factor (BSC 2005 [DIRS 173980], Section 6.4.5). The $\mathrm{K}_{\mathrm{c}}$ factor is the product of the radionuclide sorption coefficient onto colloids and the colloid concentration (BSC 2005 [DIRS 173980], Section 6.5.12). Radionuclide sorption coefficients that were used in the simulation of radionuclide transport in the UZ are documented in Radionuclide Transport Models Under Ambient Conditions (BSC 2005 [DIRS 173980], Section 6.5.4); the data are presented in DTN: LA0408AM831341.001 [DIRS 171584]. Colloid concentration and radionuclide sorption coefficients onto colloids are documented in Waste Form and In-Drift Colloids-Associated Radionuclide Concentrations: Abstraction and Summary (BSC 2005 [DIRS 174290], Section 6.3) and used in Radionuclide Transport Models Under Ambient Conditions (BSC 2005 [DIRS 173980], Section 6.5.12); the data are presented in DTNs: SN0306T0504103.005 [DIRS 164132] and SN0306T0504103.006 [DIRS 164131]). Sorption on colloids and resulting colloid transport are addressed in Radionuclide Transport Models Under Ambient Conditions (BSC 2004 [DIRS 164500], Sections 6.1.3 and 6.2.3), with simulation results presented in Section 6.18 of that report. 
Supporting Reports: Conceptual Model and Numerical Approaches for UZ Flow and Transport (BSC 2004 [DIRS 170035]); Radionuclide Transport Models Under Ambient Conditions (BSC 2004 [DIRS 164500]); Particle Tracking Model and Abstraction of Transport Processes (BSC 2005 [DIRS 173980]).

\subsubsection{Colloidal Transport in the UZ (2.2.08.10.0B)}

FEP Description: Radionuclides may be transported in groundwater in the UZ as colloidal species. Types of colloids include true colloids, pseudo colloids, and microbial colloids.

Screening Decision: Included.

TSPA Disposition: Colloidal transport of radionuclides is identified in Conceptual Model and Numerical Approaches for UZ Flow and Transport (BSC 2004 [DIRS 170035], Section 6.2.4) as a process to be included in transport modeling. The influence of colloid transport on radionuclide migration through the UZ is implicitly included and discussed in Particle Tracking Model and Abstraction of Transport Processes (BSC 2005 [DIRS 173980], Section 6.4.5). Parameters that can impact colloid transport in the UZ include colloid size (DTN: LL000122051021.116 [DIRS 142973]), colloid concentration (DTN: SN0306T0504103.005 [DIRS 164132]), radionuclide sorption coefficient onto colloid (DTN: SN0306T0504103.006 [DIRS 164131]), and colloid retardation factors (DTN: LA0303HV831352.002 [DIRS 163558]). The colloid concentration data and sorption-onto-colloid data are documented in Waste Form and In-Drift Colloids-Associated Radionuclide Concentrations: Abstraction and Summary (BSC 2005 [DIRS 174290], Section 6.3). Colloid retardation factors are documented in Saturated Zone Colloid Transport (BSC 2004 [DIRS 170006], Section 6.4.3). These data are used in Particle Tracking Model and Abstraction of Transport Processes (BSC 2005 [DIRS 173980], Sections 6.5.9 through 6.5.13). Colloid transport processes include advection and dispersion. In addition, colloids that undergo reversible filtration in fractures (BSC 2005 [DIRS 173980], Sections 6.4.5 and 6.5.9) are simulated through the use of the colloid retardation factor, $R_{c}$, which is evaluated based on field experiments in the C-Wells complex using microspheres as analogues. Field experiments have also shown that a small percentage of colloidal particles are transported through the groundwater system essentially unretarded (BSC 2004 [DIRS 170006], Section 6.6). The fractions of unretarded colloids have been developed based on field data (BSC 2004 [DIRS 170006]). Sorption of colloids is addressed in FEP 2.2.08.09.0B. Colloid matrix diffusion was assumed not to occur because its effect would be small and would only retard transport (BSC 2005 [DIRS 173980], Section 6.5.5). Therefore, the approximation of no diffusion for colloids will result in predictions that underestimate repository performance. In TSPA-LA runs, colloid facilitated radionuclide transport is investigated through the FEHM colloid transport model and variations of colloid transport parameters.

Supporting Reports: Conceptual Model and Numerical Approaches for UZ Flow and Transport (BSC 2004 [DIRS 170035]); Particle Tracking Model and Abstraction of Transport Processes (BSC 2005 [DIRS 173980]); Saturated Zone Colloid Transport (BSC 2004 [DIRS 170006]) (While FEP 2.2.08.10.0B is not explicitly identified in this report (BSC 2004 [DIRS 170006], Table 6-1), the FEP is addressed in the report.) 


\subsubsection{Chemistry of Water Flowing into the Drift (2.2.08.12.0A)}

FEP Description: Inflowing water chemistry may be used in analysis or modeling that requires initial water chemistry in the drift. Chemistry of water flowing into the drift is affected by initial water chemistry in the rock, mineral and gas composition in the rock, and thermal-hydrologic-chemical processes in the rock.

Screening Decision: Included.

TSPA Disposition: The THC seepage model was designed specifically to investigate the effect of thermal-hydrologic-chemical processes in the host rock (BSC 2005 [DIRS 172862], Section 6.2.1.2), including the effects of initial water chemistry (BSC 2005 [DIRS 172862], Section 6.2.2.1), and mineral and gas compositions in the rock (BSC 2005 [DIRS 172862], Section 6.2.2.2). Therefore, these effects are explicitly accounted for in the results from the THC seepage model, and their abstraction in Post-Processing Analysis for THC Seepage (BSC 2004 [DIRS 169858], Section 6.2). Summary tables of concentrations through time are presented in DTNs: LB0302DSCPTHCS.002 [DIRS 161976] and LB0307DSTTHCR2.002 [DIRS 165541], and summary statistics through time are presented in DTN: LB0311ABSTHCR2.001 [DIRS 166714]. These data are used to feed and/or provide technical basis for Engineered Barrier System: Physical and Chemical Environment (BSC 2005 [DIRS 173727]), which generates lookup tables used in the TSPA-LA model. Because in the analysis of seepage water chemistry no water is predicted to actually seep into the modeled drift, the abstraction method was specifically designed to consider waters deemed most representative of potential in-drift seepage (BSC 2004 [DIRS 169858], Section 6.2.1; DTN: LB0311ABSTHCR2.001 [DIRS 166714]). The evaluation of seepage flow rates into the drifts is discussed in FEP 2.2.07.20.0A.

Mixing of waters from the PTn into the TSw may affect the chemistry of water entering the drifts. Seepage water compositions can have a significant impact on the resulting water compositions that contact engineered barrier materials. The base-case seepage water chemistry is based on five initial pore water compositions, denoted by W0, W4, W5, W6, and W7, as discussed in Drift-Scale THC Seepage Model (BSC 2005 [DIRS 172862], Table 6.2-1). Nine pore-water compositions from the PTn have been analyzed for $\mathrm{pH}, \mathrm{Na}^{+}, \mathrm{K}^{+}, \mathrm{Ca}^{2+}, \mathrm{Mg}^{2+}, \mathrm{SiO}_{2}$, $\mathrm{Cl}^{-}, \mathrm{SO}_{4}{ }^{2-}, \mathrm{HCO}_{3}{ }^{-}, \mathrm{NO}_{3}{ }^{-}$, and $\mathrm{F}^{-}$. The nine selected PTn pore-water compositions were selected from the available data (Table 6-3), based on completeness of the chemical analyses. Many available PTn pore water analyses were not used because they were incomplete within available qualified DTNs. Originally, eleven PTn pore water analyses were found to include the necessary analytes $\left(\mathrm{Na}^{+}, \mathrm{K}^{+}, \mathrm{Ca}^{2+}, \mathrm{Mg}^{2+}, \mathrm{SO}_{4}{ }^{2-}, \mathrm{Cl}^{-}, \mathrm{NO}_{3}{ }^{-}\right.$, and carbonate alkalinity) but two were eliminated because of large charge imbalances (samples ESF-SR-MS\#22/4.3-4.5/UC and ESF-NR-MS\#10/4.9-5.1/UC from DTN: GS031008312272.008 [DIRS 166570]).

A ternary water composition plot for PTn water and TSw water is given in Figure 6-1. This figure shows the range of water composition used as initial water compositions for thermalhydrological-chemical seepage water chemistry analyses. The figure also shows the nine pore water compositions from the PTn. The plot shows that the W0 composition for TSw water roughly representative of the PTn water compositions, although some PTn waters are more concentrated in $\mathrm{Ca}^{2+}$ and $\mathrm{SO}_{4}{ }^{2-}$, and lower in $\mathrm{HCO}_{3}{ }^{-}$. These waters tend to be higher in chloride concentration (see Table 6-3) and may not be as significant for water compositions entering the 
TSw. The higher chloride concentration waters are believed to be correlated with areas of high evapotranspiration and low infiltration flux, whereas lower concentration waters are correlated with lower evapotranspiration and higher infiltration flux (Sonnenthal and Bodvarsson 1999 [DIRS 117127], Section 4). Observations of chloride content versus depth in borehole SD-9 (water samples SD9-93, SD9-134, and SD9-252 in Table 6-3) show substantial reductions in chloride content with depth in the PTn. Furthermore, areas of higher flux are more likely to lead to conditions of drift seepage (BSC 2004 [DIRS 169131], Section 6.6.5). Therefore, the compositions of water entering the TSw from the PTn that are more likely to ultimately seep into drifts are biased toward the lower-concentration compositions from the PTn.

The average, maximum, and minimum concentrations for the PTn pore waters are compared with the W0 water from Drift-Scale THC Seepage Model (BSC 2005 [DIRS 172862], Table 6.2-1) in Table 6-4. The compositional comparison shows that, with the exception of $\mathrm{pH}$ and $\mathrm{NO}_{3}{ }^{-}$, the average values for the PTn water composition differ by less than $50.6 \%$ with the W0 water composition and the W0 compositions lie within the range of values identified for the $\mathrm{PTn}$. The variations in $\mathrm{pH}$ are not large, although the range found for $\mathrm{PTn}$ waters is $0.6 \mathrm{pH}$ units lower than the value for $\mathrm{W} 0$ water. The mean $\mathrm{PTn} \mathrm{NO}_{3}{ }^{-}$concentration is more than $200 \%$ larger than the value for W0 water and the minimum value is larger than the value found for W0. However, the main effect of $\mathrm{NO}_{3}^{-}$on performance is to inhibit localized corrosion, as documented in General Corrosion and Localized Corrosion of Waste Package Outer Barrier (BSC 2004 [DIRS 169984], Section 8.3.1). Therefore, higher $\mathrm{NO}_{3}{ }^{-}$concentrations in the PTn pore water may be conservatively represented by the lower concentrations in the W0 pore water composition.

Table 6-3. PTn Pore Water Identifications and Chloride Concentration

\begin{tabular}{|c|c|c|}
\hline $\begin{array}{l}\text { Abbreviated } \\
\text { Water Name }\end{array}$ & $\begin{array}{l}\text { Starting Water Composition } \\
\text { Sample Identification } \\
\text { (Source DTN: GS031008312272.008) }\end{array}$ & $\begin{array}{c}\text { Chloride } \\
\text { (mg/L) }\end{array}$ \\
\hline SD6-501 & SD-6/501.3-501.6/UC & 27 \\
\hline SD9-93 & SD-9/93.3-93.4/UC & 234 \\
\hline SD9-134 & SD-9/134.2-134.4/UC & 143 \\
\hline SD9-252 & SD-9/252.9-253.0/UC & 27 \\
\hline ESF-58 ${ }^{a}$ & ESF-SR-MS\#22/5.8-6.0/UC & 134 \\
\hline ESF-60 & ESF-SR-MS\#22/6.0-6.3/UC & 113 \\
\hline ESF-63 ${ }^{a}$ & ESF-SR-MS\#23/6.3-6.7/UC & 176 \\
\hline ESF-145 ${ }^{a}$ & ESF-SR-MS\#23/14.5-14.6/UC & 119 \\
\hline ESF-146 & ESF-SR-MS\#23/14.6-14.9/UC & 109 \\
\hline $\mathrm{ESF}-43^{\mathrm{b}}$ & ESF-SR-MS\#22/4.3-4.5/UC & NA \\
\hline ESFNR-49 ${ }^{b}$ & ESF-NR-MS\#10/4.9-5.1/UC & NA \\
\hline \multicolumn{3}{|c|}{ DTN: GS031008312272.008 [DIRS 166570] } \\
\hline \multicolumn{3}{|c|}{ a Starting water $\mathrm{pH}$ value not reported in source DTN. } \\
\hline \multicolumn{3}{|c|}{$\begin{array}{l}\text { PTn waters ESF-SR-MS\#22/4.3-4.5/UC and ESF-NR-MS\#10/4. } \\
\text { 9-5.1/UC meet the criteria for use stated above but were not used in } \\
\text { the analysis due to large charge imbalances. }\end{array}$} \\
\hline
\end{tabular}


Table 6-4. Comparison of WO Pore-Water and PTn Pore-Water Compositions

\begin{tabular}{|c|c|c|c|c|c|c|c|}
\hline \multirow{2}{*}{$\begin{array}{c}\text { Compositional } \\
\text { Variables }\end{array}$} & \multirow[t]{2}{*}{ Units } & \multirow{2}{*}{$\begin{array}{l}\text { TSw water } \\
\text { (W0) }^{\mathrm{a}}\end{array}$} & \multicolumn{3}{|c|}{ PTn waters ${ }^{\text {b }}$} & \multirow{2}{*}{$\begin{array}{l}\text { Percent delta PTn } \\
\text { mean \& W0 }\end{array}$} & \multirow{2}{*}{$\begin{array}{c}\text { Wo in the range } \\
\text { for the PTn? }\end{array}$} \\
\hline & & & Mean & Max & Min & & \\
\hline $\mathrm{pH}$ & $\mathrm{pH}$ & 8.3 & 7.5 & 7.7 & 7.3 & $9 \%$ & No \\
\hline $\mathrm{Na}^{+}$ & $\mathrm{mg} / \mathrm{L}$ & 61.5 & 58.1 & 125 & 36 & $5.5 \%$ & Yes \\
\hline $\mathrm{K}^{+}$ & $\mathrm{mg} / \mathrm{L}$ & 8 & 9.7 & 23.6 & 1.5 & $21.8 \%$ & Yes \\
\hline $\mathrm{Ca}^{2+}$ & $\mathrm{mg} / \mathrm{L}$ & 101 & 108.7 & 199 & 33 & $7.6 \%$ & Yes \\
\hline $\mathrm{Mg}^{2+}$ & $\mathrm{mg} / \mathrm{L}$ & 17 & 22.8 & 41.6 & 6.1 & $33.9 \%$ & Yes \\
\hline $\mathrm{SiO}_{2}$ & $\mathrm{mg} / \mathrm{L}$ & 70.5 & 67.6 & 81 & 55 & $4.2 \%$ & Yes \\
\hline $\mathrm{Cl}^{-}$ & $\mathrm{mg} / \mathrm{L}$ & 117 & 120.2 & 234 & 27 & $2.8 \%$ & Yes \\
\hline $\mathrm{SO}_{4}{ }^{2-}$ & $\mathrm{mg} / \mathrm{L}$ & 116 & 159.6 & 393 & 49 & $37.5 \%$ & Yes \\
\hline $\mathrm{HCO}_{3}^{-}$ & $\mathrm{mg} / \mathrm{L}$ & 200 & 163.0 & 511 & 50 & $18.5 \%$ & Yes \\
\hline $\mathrm{NO}_{3}^{-}$ & $\mathrm{mg} / \mathrm{L}$ & 6.5 & 20.6 & 37 & 8.6 & $217.3 \%$ & No \\
\hline $\mathrm{F}^{-}$ & $\mathrm{mg} / \mathrm{L}$ & 0.86 & 1.3 & 3.7 & 0.61 & $50.6 \%$ & Yes \\
\hline
\end{tabular}

a DTN: MO0005PORWATER.000 [DIRS 150930]

b DTN: GS031008312272.008 [DIRS 166570]

\section{Equivalents \%}
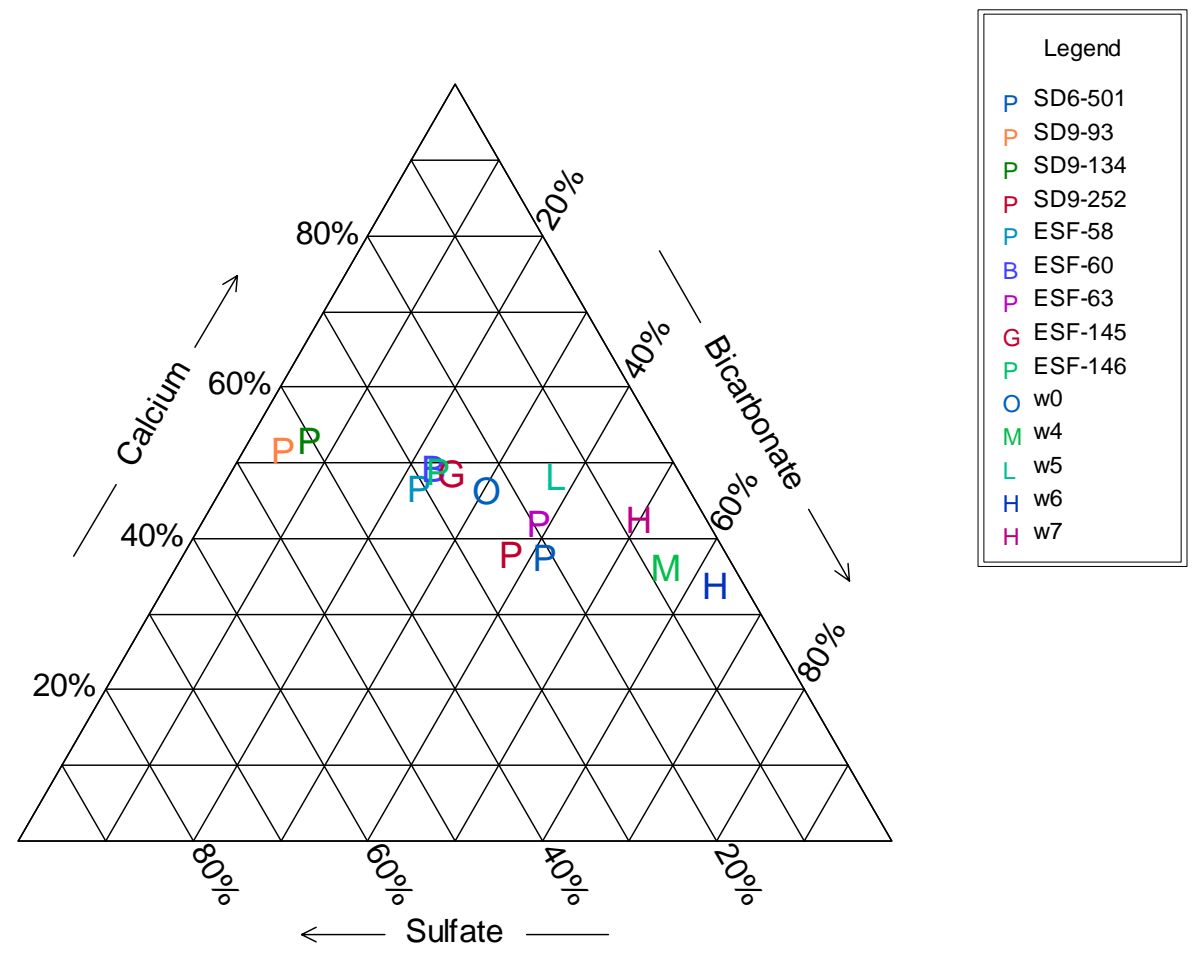

Source: DTNS: GS031008312272.008 [DIRS 166570] and MO0005PORWATER.000 [DIRS 150930].

Figure 6-1. Ternary Diagram of Water Compositions from the Ptn and Tsw

Supporting Reports: Drift-Scale THC Seepage Model (BSC 2005 [DIRS 172862]); Post-Processing Analysis for THC Seepage (BSC 2004 [DIRS 169858]). 


\subsubsection{Microbial Activity in the UZ (2.2.09.01.0B)}

FEP Description: Microbial activity in the UZ may affect radionuclide mobility in rock and soil through colloidal processes, by influencing the availability of complexing agents, or by influencing groundwater chemistry. Changes in microbial activity could be caused by the response of the soil zone to changes in climate.

Screening Decision: Included.

TSPA Disposition: The effects of microbes on sorption are included in the distributions for sorption coefficients used in TSPA-LA. The sorption coefficient data on which the distributions are based are obtained in laboratory experiments in which crushed rock samples from the Yucca Mountain site are contacted with groundwaters (or simulated groundwaters) representative of the site, spiked with one or more of the elements of interest (BSC 2004 [DIRS 164500], Appendix A, Section A5). These $\mathrm{K}_{\mathrm{d}}$ values, which include the effects of microbial activity, are used in Particle Tracking Model and Abstraction of Transport Processes (BSC 2005 [DIRS 173980], Section 6.5.4).

The basic technique for the laboratory determination of sorption coefficients involved the contact of a groundwater sample, spiked with the radionuclide of interest, with a crushed sample of tuff or alluvium. The rock sample was generally obtained as a core sample. The rock and water samples were not sterilized and, therefore, contain representative microbial biota from the UZ. Sorption experiments have been carried out as a function of time, element concentration, atmospheric composition, particle size, and temperature. In some cases, the solids remaining from sorption experiments were contacted with unspiked groundwater in desorption experiments. The effects of microbial activity with respect to sorption coefficients are provided in terms of probability distributions for the sorption coefficient of each element of interest among the three major rock types (devitrified, zeolitic, and vitric) found in the UZ. The influence of expected variations in water chemistry, radionuclide concentrations, and variations in rock surface properties within one of the major rock types are incorporated into these probability distributions. These distributions are specified for each radionuclide-rock type combination (BSC 2004 [DIRS 164500], Appendix A, Section A8) and are sampled in the TSPA-LA to account for the effects of natural variations in pore-water chemistry and mineral surfaces on sorption. Correlations for sampling sorption coefficient probability distributions have been derived for the elements (BSC 2004 [DIRS 164500], Appendix B).

Supporting Reports: Particle Tracking Model and Abstraction of Transport Processes (BSC 2005 [DIRS 173980]); Radionuclide Transport Models Under Ambient Conditions (BSC 2004 [DIRS 164500]).

\subsubsection{Natural Geothermal Effects on Flow in the UZ (2.2.10.03.0B)}

FEP Description: The existing geothermal gradient, and spatial or temporal variability in that gradient, may affect groundwater flow in the UZ.

Screening Decision: Included. 
TSPA Disposition: The natural geothermal gradient at Yucca Mountain is explicitly included in boundary conditions for the TH seepage model in Drift-Scale Coupled Processes (DST and TH Seepage) Models (BSC 2005 [DIRS 172232], Section 6.5.2) and thereby included in Abstraction of Drift Seepage (BSC 2004 [DIRS 169131], Section 6.4.3). The natural geothermal gradient is also included in the THC seepage model in Drift-Scale THC Seepage Model (BSC 2005 [DIRS 172862]), and in the abstraction of drift seepage (BSC 2004 [DIRS 169131], Section 6.4.4), by setting the ground surface temperature (top model boundary) and the temperature at the water table (bottom boundary) to measured values (BSC 2005 [DIRS 172862], Section 6.5.2). The effect of this temperature gradient on flow is explicitly accounted for by the coupled heat-flow transport algorithms implemented in the THC simulator (TOUGHREACT V3.0 LBNL 2002 [DIRS 161256]). Therefore, this effect is explicitly taken into account in the results of the THC seepage model; summary tables of concentrations through time submitted under DTNs: LB0302DSCPTHCS.002 [DIRS 161976] and LB0307DSTTHCR2.002 [DIRS 165541], and tables of concentrations and summary statistics through time submitted under DTN: LB0311ABSTHCR2.001 [DIRS 166714]). DTNs: LB0302DSCPTHCS.002 [DIRS 161976] and LB0311ABSTHCR2.001 [DIRS 166714] are used to feed and/or provide technical basis for Engineered Barrier System: Physical and Chemical Environment (BSC 2005 [DIRS 173727]), which generates lookup tables used in the TSPA-LA model.

Natural geothermal effects on unsaturated flow in the absence of repository thermal effects have been investigated in the models of natural thermal processes in the UZ (BSC 2004 [DIRS 169861], Section 6.3). The results of these models indicate that the effects of the natural temperature gradient on UZ flow are insignificant.

Supporting Reports: Drift-Scale THC Seepage Model (BSC 2005 [DIRS 172862]); Abstraction of Drift Seepage (BSC 2004 [DIRS 169131]); Drift-Scale Coupled Processes (DST and TH Seepage) Models (BSC 2005 [DIRS 172232]); UZ Flow Models and Submodels (BSC 2004 [DIRS 169861]).

\subsubsection{Two-Phase Buoyant Flow/Heat Pipes (2.2.10.10.0A)}

FEP Description: Heat from waste can generate two-phase buoyant flow. The vapor phase (water vapor) could escape from the mountain. A heat pipe consists of a system for transferring energy between a hot and a cold region (source and sink respectively) using the heat of vaporization and movement of the vapor as the transfer mechanism. Two-phase circulation continues until the heat source is too weak to provide the thermal gradients required to drive it. Alteration of the rock adjacent to the drift may include dissolution that maintains the permeability necessary to support the circulation (as inferred for some geothermal systems).

Screening Decision: Included.

TSPA Disposition: The coupled processes causing heat-pipe behavior (BSC 2004 [DIRS 169131], Section 6.3.2) are explicitly simulated with the TH seepage model (BSC 2005 [DIRS 172232]) that feeds into the seepage abstraction. Using this model, the impact of heat-pipe behavior on seepage is assessed for various simulation cases (BSC 2004 [DIRS 169131], Section 6.4.3.3) Thus, the TH-modeling results from DTN: LB0301DSCPTHSM.002 [DIRS 163689] inherently include the effect of heat pipes. As 
discussed in Abstraction of Drift Seepage (BSC 2004 [DIRS 169131], Section 6.5.2), the abstraction of thermal seepage utilizes these modeling results to develop an appropriate thermal-seepage abstraction methodology.

The coupled processes causing heat-pipe behavior are explicitly simulated with the THC seepage model (BSC 2005 [DIRS 172862], Section 6.2.1.1). The continuous boiling and refluxing of water in this zone affects water-rock interactions (BSC 2005 [DIRS 172862], Section 6.2.1.2). The resulting water chemistry in the heat pipe is captured by the HISAT waters (BSC 2004 [DIRS 169858], Section 6.2.3; BSC 2005 [DIRS 172862], Section 6.5.5.2.2). Therefore, the effect of heat pipes on predicted water and gas chemistries is explicitly taken into account in the results of the THC seepage model and their abstraction (BSC 2004 [DIRS 169858], Section 6.2; summary tables of concentrations through time are presented in DTNs: LB0302DSCPTHCS.002 [DIRS 161976], LB0307DSTTHCR2.002 [DIRS 165541]; and tables of concentrations and summary statistics through time are presented in DTN: LB0311ABSTHCR2.001 [DIRS 166714]). DTNs: LB0302DSCPTHCS.002 [DIRS 161976] and LB0311ABSTHCR2.001 [DIRS 166714] are used to feed and/or provide technical basis for Engineered Barrier System: Physical and Chemical Environment (BSC 2005 [DIRS 173727]), which generates lookup tables used in the TSPA-LA model to define the chemical environment inside the drift.

Supporting Reports: Drift-Scale THC Seepage Model (BSC 2005 [DIRS 172862]); Abstraction of Drift Seepage (BSC 2004 [DIRS 169131]); Drift-Scale Coupled Processes (DST and TH Seepage) Models (BSC 2005 [DIRS 172232]).

\subsubsection{Geosphere Dry-Out due to Waste Heat (2.2.10.12.0A)}

FEP Description: Repository heat evaporates water from the UZ rocks near the drifts as the temperature exceeds the vaporization temperature. This zone of reduced water content (reduced saturation) migrates outward during the heating phase (about the first 1000 years) and then migrates back to the waste packages as heat diffuses throughout the mountain and the radioactive sources decay. This FEP addresses the effects of dry-out within the rocks.

Screening Decision: Included.

TSPA Disposition: The coupled processes of vaporization, dryout, and resaturation are explicitly simulated with the TH seepage model (BSC 2005 [DIRS 172232]) that feeds into the seepage abstraction. Using this model, the impact of such coupled processes on seepage is assessed for various simulation cases (BSC 2004 [DIRS 169131], Section 6.4.3.3). Thus, the TH-modeling results from DTN: LB0301DSCPTHSM.002 [DIRS 163689] inherently include these effects. As discussed in Abstraction of Drift Seepage (BSC 2004 [DIRS 169131], Section 6.5.2), the abstraction of thermal seepage utilizes these modeling results to develop an appropriate thermal-seepage abstraction methodology.

The coupled processes of vaporization, dryout, and resaturation are explicitly simulated with the THC seepage model, including the formation of a dry (or nearly dry) zone around drifts, expanding and then receding through time following the pulse of heat released from the waste packages (BSC 2005 [DIRS 172862], Sections 6.2.1 and 6.5.5.1). Therefore, these effects are 
explicitly accounted for in the results from the THC seepage model, and in their abstraction in Post-Processing Analysis for THC Seepage (BSC 2004 [DIRS 169858], Section 6.2). Summary tables of concentrations through time are presented in DTNs: LB0302DSCPTHCS.002 [DIRS 161976], LB0307DSTTHCR2.002 [DIRS 165541], and summary statistics through time are presented in DTN: LB0311ABSTHCR2.001 [DIRS 166714]. These data are used to feed and/or provide technical basis for Engineered Barrier System: Physical and Chemical Environment (BSC 2005 [DIRS 173727]), which generates lookup tables used in the TSPA-LA model. The effects of dryout on surface infiltration are discussed in FEP 2.2.10.01.0A.

Supporting Reports: Drift-Scale THC Seepage Model (BSC 2005 [DIRS 172862]) (Note that while FEP 2.2.10.12.0A is listed as an excluded FEP in this report (BSC 2004 [DIRS 172862], Table 6.1-2), the FEP is included and is addressed in the report.); Abstraction of Drift Seepage (BSC 2004 [DIRS 169131]); Drift-Scale Coupled Processes (DST and TH Seepage) Models (BSC 2005 [DIRS 172232].

\subsubsection{Topography and Morphology (2.3.01.00.0A)}

FEP Description: This FEP is related to the topography and surface morphology of the disposal region. Topographical features include outcrops and hills, water-filled depressions, wetlands, recharge areas and discharge areas. Topography, precipitation, and surficial permeability distribution in the system will determine the flow boundary conditions (i.e., location and amount of recharge and discharge in the system).

Screening Decision: Included.

TSPA Disposition: Topographical features (such as hillslopes, washes, and ridges), precipitation, and surficial permeability distribution are included in Simulation of Net Infiltration for Present-Day and Potential Future Climates (BSC 2004 [DIRS 170007] Sections 6.5 .3 and 6.6.1 and Appendix D), and are incorporated into the INFIL V2.0 (USGS 2001 [DIRS 139422]) model. Precipitation and surficial permeability distribution are also incorporated into the uncertainty analysis (Analysis of Infiltration Uncertainty (BSC 2003 [DIRS 165991]). Topography is also captured in INFIL V2.0 (USGS 2001 [DIRS 139422]; BSC 2004 [DIRS 170007]) model using data from the digital elevation model (DEM). The impacts of topography and morphology on preferential flow/percolation in the UZ is incorporated into the TSPA-LA through the UZ flow fields that use the infiltration model results (DTN: GS000308311221.005 [DIRS 147613]) as upper boundary conditions (BSC 2004 [DIRS 169861], Section 6.1.4). Topographical features from GFM2000 [DIRS 153777] are captured in the UZ model grid developed in Development of Numerical Grids for UZ Flow and Transport Modeling (BSC 2004 [DIRS 169855]) and used in UZ Flow Models and Submodels (BSC 2004 [DIRS 169861], Section 6.1.1). The incorporation of UZ flow fields into the TSPA-LA is described in UZ Flow Models and Submodels (BSC 2004 [DIRS 169861], Section 6.2.5).

The effects of topography and morphology are also included in the treatment of infiltration uncertainty for TSPA-LA (BSC 2003 [DIRS 165991]). Infiltration uncertainty is represented through three discrete infiltration scenarios (lower, mean, and upper), which are sampled in TSPA-LA according to weighting factors (BSC 2003 [DIRS 165991], Section 7.1). Precipitation 
and the surficial permeability distributions are captured in the uncertainty analysis using the precipitation multiplier (PRECIPM), the soil permeability multiplier (SOILPERM), and the effective bedrock permeability multiplier (BRPERM). They are incorporated implicitly by inclusion of uncertainty in the precipitation multiplier, soil permeability multiplier, and effective bedrock permeability multiplier in the calculation of the weighting factors, which are passed to TSPA-LA (BSC 2003 [DIRS 165991], DTN: SN0308T0503100.008 [DIRS 165640]).

Supporting Reports: Development of Numerical Grids for UZ Flow and Transport Modeling (BSC 2004 [DIRS 169855]); Simulation of Net Infiltration for Present-Day and Potential Future Climates (BSC 2004 [DIRS 170007]); Analysis of Infiltration Uncertainty (BSC 2003 [DIRS 165991]); UZ Flow Models and Submodels (BSC 2004 [DIRS 169861]).

\subsubsection{Precipitation (2.3.11.01.0A)}

FEP Description: Precipitation is an important control on the amount of recharge. It transports solutes with it as it flows downward through the subsurface or escapes as runoff. Precipitation influences agricultural practices of the receptor. The amount of precipitation depends on climate.

Screening Decision: Included.

TSPA Disposition: Precipitation affects the net infiltration. Water balance, climate, and snowpack are included in Simulation of Net Infiltration for Present-Day and Potential Future Climate (BSC 2004 [DIRS 170007], Section 6.4), and precipitation under future climates is represented in Simulation of Net Infiltration for Present-Day and Potential Future Climate (BSC 2004 [DIRS 170007], Section 6.9). The net infiltration map outputs (DTN: GS000308311221.005 [DIRS 147613]) are used as a boundary condition for the UZ flow model (BSC 2004 [DIRS 169861], Sections 6.1.3 and 6.1.4). Flow fields developed for use in TSPA-LA (DTN: LB0305TSPA18FF.001 [DIRS 165625]) using the UZ flow model, therefore, include the effects of precipitation and changes of precipitation under future climate conditions, including low, mean, and upper bounds of infiltrations in glacial, monsoon, and present-day (or modern) climatic scenarios.

The effects of precipitation are also included in the treatment of infiltration uncertainty for TSPA-LA (Analysis of Infiltration Uncertainty, BSC 2003 [DIRS 165991]). Infiltration uncertainty is represented through three discrete infiltration scenarios (lower, mean, and upper), which are sampled in TSPA-LA according to weighting factors (BSC 2003 [DIRS 165991], Section 7.1). Precipitation is incorporated in the infiltration uncertainty analysis through the precipitation-rate multiplier (PRECIPM) (BSC 2003 [DIRS 165991], Table 6-3 and Section 6.1.2). PRECIPM operates on the precipitation rate, as prescribed in the input file TULELAKE.INP, which contains the precipitation record for the selected "mean glacial transition-climate" analogue site, within the infiltration model software, INFIL VA_2.a1 (SNL 2001 [DIRS 147608]) and INFIL V2.0 (USGS 2001 [DIRS 139422]).

Supporting Reports: Simulation of Net Infiltration for Present-Day and Potential Future Climates (BSC 2004 [DIRS 170007]); Analysis of Infiltration Uncertainty (BSC 2003 [DIRS 165991]); UZ Flow Models and Submodels (BSC 2004 [DIRS 169861]). 


\subsubsection{Surface Runoff and Flooding (2.3.11.02.0A)}

FEP Description: Surface runoff and evapotranspiration are components in the water balance, together with precipitation and infiltration. Surface runoff produces erosion, and can feed washes, arroyos, and impoundments, where flooding may lead to increased recharge.

Screening Decision: Included.

TSPA Disposition: Evapotranspiration and surface runoff affect the net infiltration, as discussed in Simulation of Net Infiltration for Present-Day and Potential Future Climates (BSC 2004 [DIRS 170007], Section 6.4). The net infiltration map outputs (DTN: GS000308311221.005 [DIRS 147613]) are used as a boundary condition for the UZ flow model (BSC 2004 [DIRS 169861], Sections 6.1.3 and 6.1.4). Flow fields developed for use in TSPA-LA (DTN: LB0305TSPA18FF.001 [DIRS 165625]) using the UZ flow model, therefore, include the effects of precipitation and changes of precipitation under future climate conditions, including low, mean, and upper bounds of infiltrations in glacial, monsoon, and present-day (or modern) climatic scenarios.

The effects of evapotranspiration are included in the treatment of infiltration uncertainty for TSPA-LA (BSC 2003 [DIRS 165991]). Infiltration uncertainty is represented through three discrete infiltration scenarios (lower, mean, and upper), which are sampled in TSPA-LA according to weighting factors in Analysis of Infiltration Uncertainty (BSC 2003 [DIRS 165991], Section 7.1). Evapotranspiration is incorporated in the infiltration uncertainty analysis through the two evapotranspiration coefficient-rate multipliers ETCOEFFA and ETCOEFFB (BSC 2003 [DIRS 165991], Table 6-3 and Section 6.1.2.). The evapotranspiration-rate multiplier POTETMUL operates on the evapotranspiration rate, as calculated within the infiltration model software, INFIL VA_2.a1 (SNL 2001 [DIRS 147608]) (and also INFIL V2.0; USGS 2001 [DIRS 139422]). Surface runoff is incorporated through the inclusion of a parameter (FLAREA) that defines the fraction of each grid cell in the infiltration model that is affected by overland flow and channel flow during the routing of runoff. It is incorporated implicitly by inclusion of uncertainty in the fraction of each grid cell in the infiltration model that is affected by overland flow and channel flow during the routing of runoff in the calculation of the weighting factors that are passed to TSPA-LA (BSC 2003 [DIRS 165991] and DTN: SN0308T0503100.008 [DIRS 165640]).

Supporting Reports: Simulation of Net Infiltration for Present-Day and Potential Future Climates (BSC 2004 [DIRS 170007]); Analysis of Infiltration Uncertainty (BSC 2003 [DIRS 165991]); UZ Flow Models and Submodels (BSC 2004 [DIRS 169861]).

\subsubsection{Infiltration and Recharge (2.3.11.03.0A)}

FEP Description: Infiltration into the subsurface provides a boundary condition for groundwater flow. The amount and location of the infiltration influences the hydraulic gradient and the height of the water table. Different sources of recharge water could change the composition of groundwater passing through the repository. Mixing of these waters with other groundwaters could result in precipitation, dissolution, and altered chemical gradients.

Screening Decision: Included. 
TSPA Disposition: The hydrological effects of infiltration and recharge are included in the infiltration model (FEP 1.3.01.00.0A). This model includes the effects of seasonal and climate variations, climate change, surface-water runoff, and site topography such as hillslopes and washes to simulate the spatial distribution of infiltration as described in Simulation of Net Infiltration for Present-Day and Potential Future Climates (BSC 2004 [DIRS 170007], Section 6.11). The time dependence of infiltration results is linked to the timing of climate change as discussed in Section 6.2.4; FEP 1.3.01.00.0A. This is incorporated into the TSPA-LA through the UZ flow fields that use the infiltration model results (DTN: GS000308311221.005 [DIRS 147613]) as upper boundary conditions (BSC 2004 [DIRS 169861], Section 6.1.4). Flow fields for TSPA-LA are in DTN: LB0305TSPA18FF.001 [DIRS 165625]. Data for calibrating the infiltration model were acquired in experiments at Alcove 1, as reported in In Situ Field Testing of Processes (BSC 2004 [DIRS 170004], Section 6.12).

The effects of present-day water composition infiltrating from the ground surface are accounted for in the analysis of seepage-water chemistry by using the measured pore-water chemistry in the UZ (BSC 2005 [DIRS 172862], Table 6.2-1). However, pore-water chemistry varies by hydrologic unit (BSC 2005 [DIRS 172862], Figure 6.2-4). Variation in the quality of infiltrating water is dominated by rock-water interaction.

Infiltration uncertainty, as it applies to the determination of weighting factors used in TSPA-LA (DTN: SN0308T0503100.008 [DIRS 165640]), is documented in Analysis of Infiltration Uncertainty (BSC 2003 [DIRS 165991]). The way it is handled is summarized in Analysis of Infiltration Uncertainty (BSC 2003 [DIRS 165991], Section 1.1). TSPA-LA has included three distinct climate regimes in the comprehensive repository performance analysis for Yucca Mountain: present-day, monsoon, and glacial-transition. Each climate regime was characterized using three infiltration-rate maps, including a lower- and upper-bound and a mean value (equal to the average of the two boundary values). For each of these maps, which were obtained based on analogue site climate data, a spatially averaged value was also calculated. For a more detailed discussion of these infiltration-rate maps, see Simulation of Net Infiltration for Present-Day and Potential Future Climates (BSC 2004 [DIRS 170007]). Spatially averaged values were calculated for the lower-bound, mean, and upper-bound climate analogues only for the glacial transition climate regime, within the simulated multirectangular region approximating the repository footprint, shown in Analysis of Infiltration Uncertainty (BSC 2003 [DIRS 165991], Figure 1-1).

Supporting Reports: Simulation of Net Infiltration for Present-Day and Potential Future Climates (BSC 2004 [DIRS 170007]); Analysis of Infiltration Uncertainty (BSC 2003 [DIRS 165991]); UZ Flow Models and Submodels (BSC 2004 [DIRS 169861]); In Situ Field Testing of Processes (BSC 2004 [DIRS 170004]).

\subsubsection{Radioactive Decay and Ingrowth (3.1.01.01.0A)}

FEP Description: Radioactivity is the spontaneous disintegration of an unstable atomic nucleus that results in the emission of subatomic particles. Radioactive species (isotopes) of a given element are known as radionuclides. Radioactive decay of the fuel in the repository changes the radionuclide content in the fuel with time and generates heat. Radionuclide quantities in the system at any time are the result of the radioactive decay and the ingrowth of decay products as a 
consequence of that decay. Over a 10,000-year performance period, these processes will produce decay products that need to be considered in order to adequately evaluate the release and transport of radionuclides to the accessible environment.

Screening Decision: Included.

TSPA Disposition: Decay and ingrowth are implicitly included through the development of an effective integration algorithm described in Particle Tracking Model and Abstraction of Transport Processes (BSC 2005 [DIRS 173980], Section 6.4.4). This algorithm can handle multiple species decay and ingrowth processes. Radionuclide half lives and daughter products considered in the UZ transport abstraction model are documented in Particle Tracking Model and Abstraction of Transport Processes (BSC 2005 [DIRS 173980], Section 6.5.14). In TSPA-LA runs, 36 species of radionuclides are simulated through the UZ using the FEHM (V2.21; LANL 2003 [DIRS 165741]) decay/ingrowth model over a specified time period as described in Particle Tracking Model and Abstraction of Transport Processes (BSC 2005 [DIRS 173980], Sections 6.4.4 and 6.5.14). The output of the UZ radionuclide transport model is a boundary condition for the SZ radionuclide transport model, which accounts for decay and ingrowth during radionuclide transport as described in Saturated Zone Flow and Transport Model Abstraction (BSC 2005 [DIRS 174012], Section 6.3).

Supporting Reports: Particle Tracking Model and Abstraction of Transport Processes (BSC 2005 [DIRS 173980]).

\subsection{BOREHOLE SEALS AND REPOSITORY DRIFT SEALS}

These excluded FEPs concern the effects of boreholes and repository drifts as pathways for fluid and radionuclide migration. The implicit treatment of boreholes in the TSPA-LA is that boreholes are sealed so that the borehole region is indistinguishable from the natural rock in terms of fluid flow and radionuclide transport. However, the specific properties of the seals and their evolution over time are not accounted for in the flow and transport modeling. Similarly, repository drifts will be assumed to be sealed such that liquids or gases cannot migrate between emplacement drifts (other than through geosphere pathways). Arguments are presented here to demonstrate that the potential effects of borehole seal or repository seal leakage have a negligible effect on the potential performance of the repository. Therefore, these FEPs are excluded from the TSPA-LA calculation, based on low consequence.

Table 6-5 gives the FEP numbers and names categorized under borehole and repository seals. 
Table 6-5. Excluded FEPs: Repository Seals and Borehole Seals

\begin{tabular}{|l|l|l|}
\hline Section Number & FEP Number & \multicolumn{1}{c|}{ FEP Name } \\
\hline 6.3 .1 & $1.1 .01 .01 .0 \mathrm{~A}$ & Open site investigation boreholes \\
\hline 6.3 .2 & $1.1 .01 .01 .0 \mathrm{~B}$ & Influx through holes drilled in drift wall or crown \\
\hline 6.3 .3 & $1.1 .02 .01 .0 \mathrm{~A}$ & Site flooding (during construction and operation) \\
\hline 6.3 .4 & $1.1 .04 .01 .0 \mathrm{~A}$ & Incomplete closure \\
\hline 6.3 .5 & $1.1 .11 .00 .0 \mathrm{~A}$ & Monitoring of the repository \\
\hline 6.3 .6 & $2.1 .05 .01 .0 \mathrm{~A}$ & Flow through seals (access ramps and ventilation shafts) \\
\hline 6.3 .7 & $2.1 .05 .02 .0 \mathrm{~A}$ & Radionuclide transport through seals \\
\hline 6.3 .8 & $2.1 .05 .03 .0 \mathrm{~A}$ & Degradation of seals \\
\hline
\end{tabular}

Source: DTN: MO0501SEPFEPLA.001 [DIRS 172601].

\subsubsection{Open Site Investigation Boreholes (1.1.01.01.0A)}

FEP Description: Site investigation boreholes that have been left open, degraded, improperly sealed, or reopened, could modify flow and transport properties and produce enhanced pathways between the surface and the repository.

Screening Decision: Excluded-Low Consequence

Screening Argument: The implicit treatment of boreholes in the TSPA-LA is that boreholes are sealed so that the borehole region is indistinguishable from the natural rock in terms of fluid flow and radionuclide transport. However, the specific properties of the seals and their evolution over time are not accounted for in the flow and transport modeling. Similarly, repository drifts will be assumed to be sealed such that liquids or gases cannot migrate between emplacement drifts (other than through geosphere pathways).

The consequence of site-investigation boreholes depends on several factors, such as location and depth of the boreholes. The following arguments demonstrate that, based on a number of factors and considerations, the existing test boreholes will not have a significant impact on either radionuclide transport or the performance of the repository.

Only boreholes within or close to the repository block are important to the performance of the UZ. Boreholes well outside the footprint of the repository block will not influence water movement to the waste emplacement drifts or radionuclide transport from the waste emplacement drifts to the water table. Table 6-6 lists eight deep boreholes in the repository block and seven deep boreholes near the repository block. The definition for deep borehole in the repository block is a borehole that penetrates the TSw. The definition for deep borehole near the repository block is a borehole that penetrates below the elevation of waste emplacement (DTNs: MO9906GPS98410.000 [DIRS 109059], MO0004QGFMPICK.000 [DIRS 152554], and D\&E/RIT IED Subsurface Facilities (BSC 2004 [DIRS 172801]). Boreholes that terminate in or above the PTn will have a negligible effect on percolation flux at the repository because flow through these boreholes will tend to be homogenized by matrix flow in the underlying Paintbrush nonwelded hydrogeologic unit (UZ Flow Models and Submodels, BSC 2004 [DIRS 169861], Appendix G; CRWMS M\&O 1998 [DIRS 100356], Section 2.4.2.8; Wu et al. 2000 [DIRS 154918], Section 4.1). The locations of the boreholes listed in Table 6-6 relative to waste emplacement locations are shown in D\&E/PA/C IED Subsurface Facilities (BSC 2004 [DIRS 168180]). 
Many of the boreholes penetrate the UZ entirely and terminate at or below the water table. Based on the design layout (BSC 2004 [DIRS 172801]) and borehole locations in Table 6-6, none of the existing boreholes will intersect with a waste emplacement drift. Therefore, water entering these boreholes would continue to flow through these boreholes to the water table, bypassing waste emplacement locations. One of the deep boreholes within the waste emplacement footprint, USW UZ-1, only partially penetrates the UZ. USW UZ-1 has a total depth of 1,270 ft, but terminates near the TSw vitrophyre beneath waste emplacement locations. Therefore, none of the deep boreholes in the repository block terminates above potential waste emplacement locations. In the event that a drift unexpectedly encounters a borehole during repository construction, such boreholes will either be sealed or waste packages will have a stand-off distance from the location of the borehole penetration into the waste emplacement drift, or both.

The other aspect of this problem is the movement of dissolved radionuclides and radionuclides associated with mobile colloids between the repository and the water table. Fractures and faults represent continuous rapid-transport pathways from the repository to the water table. Any significant lateral flow beneath the repository eventually finds one of these high-permeability pathways to the water table. The principal difference between these high-permeability pathways and boreholes is that the cross-sectional area of the boreholes available to intercept lateral flow is much smaller than the area associated with fractures and faults. The 15 boreholes in Table 6-6 with depths greater than $1,000 \mathrm{ft}$ present a total cylindrical area (available to intercept lateral flow) per unit depth that may be calculated by the product of the borehole diameter times the number of boreholes. The average borehole diameter is bounded by a value of $1 \mathrm{~m}$ (Table 6-6), given that borehole diameters can exceed the size of the drill bit. This gives a total borehole sidewall area per unit depth of $15 \pi \mathrm{m}^{2} / \mathrm{m}$. The fractured rock between the repository and the water table has a fracture area per unit volume of 0.1 per meter or more (BSC 2004 [DIRS 170038], Table 6-5). Multiplying this by the $5 \times 10^{6} \mathrm{~m}^{2}$ footprint of the repository (BSC 2004 [DIRS 168370]) gives a minimum fracture area per unit depth of about $5 \times 10^{5} \mathrm{~m}^{2} / \mathrm{m}$. Therefore, the contribution of boreholes to the steady state flow and transport pattern between the repository and the water table is negligible. A potential scenario that could lead to greater radionuclide releases is the migration of perched water through the borehole pathways if a borehole seal should fail.

Table 6-6. Deep Boreholes in or Close to the Repository Block

\begin{tabular}{|c|c|c|c|c|c|c|}
\hline Borehole Identifier & $\begin{array}{l}\text { Surface } \\
\text { Elevation } \\
\text { (feet) }\end{array}$ & $\begin{array}{c}\text { Lowest } \\
\text { Stratigraphic } \\
\text { Contact } \\
\text { Depth (feet) } \\
\text { (except as }^{16} \\
\text { noted) }\end{array}$ & $\begin{array}{l}\text { Tptpv3 }^{\ddagger} \\
\text { Depth } \\
\text { (feet) }^{16} \\
\text { (except } \\
\text { as noted) }\end{array}$ & $\begin{array}{l}\text { Nominal } \\
\text { Borehole } \\
\text { Diameter } \\
\text { (inches) }\end{array}$ & $\begin{array}{c}\text { NSP } \\
\text { Easting } \\
\text { (feet) }\end{array}$ & $\begin{array}{c}\text { NSP } \\
\text { Northing } \\
\text { (feet) }\end{array}$ \\
\hline UE-25 WT \#18** & 4,384 & 1,620 & 1,501 & $8.75^{1}$ & 564,854 & 771,167 \\
\hline USW G-1* & 4,350 & 3,558 & 1,287 & $3.875^{2}$ & 561,001 & 770,502 \\
\hline USW G-4** & 4,166 & 2,950 & 1,317 & $12.25^{3}$ & 563,082 & 765,808 \\
\hline USW H-1* & 4,274 & 3,661 & 1,410 & $13.25^{4}$ & 562,388 & 770,255 \\
\hline USW H-5* & 4,851 & 3,422 & 1,582 & $14.75^{5}$ & 558,908 & 766,634 \\
\hline USW NRG-7a** & 4,207 & 1,498 & 1,415 & $5.5^{6}$ & 562,984 & 768,880 \\
\hline USW SD-7* & 4,472 & 2,612 & 1,182 & $8.75^{7}$ & 561,240 & 758,950 \\
\hline
\end{tabular}


Table 6-6. Deep Boreholes in or Close to the Repository Block (Continued)

\begin{tabular}{|c|c|c|c|c|c|c|}
\hline Borehole Identifier & $\begin{array}{c}\text { Surface } \\
\text { Elevation } \\
\text { (feet) }\end{array}$ & $\begin{array}{c}\text { Lowest } \\
\text { Stratigraphic } \\
\text { Contact } \\
\text { Depth (feet) } \\
\text { (except as }^{16} \\
\text { noted) } \\
\end{array}$ & $\begin{array}{c}\text { Tptpv3 }^{\ddagger} \\
\text { Depth } \\
\text { (feet) } \\
\text { (except } \\
\text { as noted) }\end{array}$ & $\begin{array}{l}\text { Nominal } \\
\text { Borehole } \\
\text { Diameter } \text { (inches) }^{\dagger}\end{array}$ & $\begin{array}{c}\text { NSP } \\
\text { Easting } \\
\text { (feet) }\end{array}$ & $\begin{array}{c}\text { NSP } \\
\text { Northing } \\
\text { (feet) }\end{array}$ \\
\hline USW SD-9* & 4,273 & 2,016 & 1,358 & $8.5^{8}$ & 561,818 & 767,998 \\
\hline USW SD-12* & 4,343 & 2,138 & 1,278 & $12.25^{9}$ & 561,606 & 761,957 \\
\hline USW UZ-1* & 4,425 & 1,145 & $979^{17}$ & $17.5^{10}$ & 560,222 & 771,277 \\
\hline USW UZ-6** & 4,925 & 1,829 & 1,333 & $17.5^{11}$ & 558,325 & 759,730 \\
\hline USW UZ-7a** & 4,228 & $759^{18}$ & $629^{17}$ & $12.25^{12}$ & 562,270 & 760,693 \\
\hline USW UZ-14* & 4,425 & 2,072 & 1,279 & $12.25^{13}$ & 560,142 & 771,310 \\
\hline USW WT-2** & 4,268 & 1,794 & 1,179 & $8.75^{14}$ & 561,924 & 760,662 \\
\hline USW SD-6** & $4,905^{20}$ & $2,506^{19}$ & $1,456^{19}$ & $12.25^{15}$ & $558,608^{20}$ & $762,421^{20}$ \\
\hline
\end{tabular}

NOTE: DTN: MO9906GPS98410.000 [DIRS 109059] except where other source noted; NSP easting and northing and elevation values have been rounded to the nearest foot.

NSP = Nevada State Plane.

*In repository block.

${ }^{\star *}$ close to repository block.

${ }^{\dagger}$ based on drill bit size used to create borehole in the repository host rock .

${ }^{\ddagger}$ Top contact of Tptpv3, or lower contact of Tptpln (BSC 2004 [DIRS 169855]). Tptpln is the lowest stratigraphic unit that was identified for waste emplacement (BSC 2004 [DIRS 168370]).

${ }^{1}$ Fenix and Scisson (1986 [DIRS 101238], p. 63).

${ }^{2}$ Fenix and Scisson (1987 [DIRS 103102], p. 3).

${ }^{3}$ Fenix and Scisson (1987 [DIRS 103102], p. 109).

${ }^{4}$ Fenix and Scisson (1987 [DIRS 126415], p. 3).

${ }^{5}$ Fenix and Scisson (1987 [DIRS 126415], p. 51).

${ }^{6}$ DTN: TMUSWNRG7A0096.002 ([DIRS 166424], MOL.19971023.0323, Attachment VII).

${ }^{7}$ CRWMS M\&O (1996 [DIRS 129957], p. 13).

${ }^{8}$ CRWMS M\&O (1996 [DIRS 114799], p. 11).

9 DTN: TM000000SD12RS.012 ([DIRS 105627], p. 9).

${ }^{10}$ Fenix and Scisson (1987 [DIRS 165939], p. 3).

${ }^{11}$ Fenix and Scisson (1987 [DIRS 165939], p. 35).

${ }^{12}$ CRWMS M\&O (1996 [DIRS 130425], p. 2).

${ }^{13}$ CRWMS M\&O (1996 [DIRS 130429], p. 9).

${ }^{14}$ Fenix and Scisson (1986 [DIRS 101238], p. 75).

${ }^{15}$ YMP (1999 [DIRS 166080], Attachment 8).

${ }^{16}$ DTN: MO0004QGFMPICK.000 [DIRS 152554], note that borehole UE-25 WT\#18 is designated as USW WT\#18 in this DTN.

${ }^{17}$ nearest repository waste emplacement depth, also uses information from BSC 2004 [DIRS 172801] and 800-IED-WIS0-00104-000-00A (BSC 2004 [DIRS 168180]).

18 maximum depth of borehole data, DTN: MO0010CPORGLOG.003 [DIRS 155959].

19 DTN: SNF40060298001.001 [DIRS 107372].

${ }^{20}$ DTN: MO9912GSC99492.000 [DIRS 165922]. 
A bounding calculation was performed that assessed the potential for radionuclides in the perched water to be suddenly released to the water table (Appendix A of this report; FEP 2.2.06.03.0A). The calculation considers the volume of perched water contained in the fractures to be available for rapid release. This volume is restricted to fractures with permeability greater than one millidarcy. In no case (of the nine UZ flow scenarios) does this volume represent more than three months of percolation flux. Therefore, the potential effects of these boreholes on flow and percolation in the UZ or as preferential pathways for radionuclide transport, even if the borehole seals should fail completely, are negligible. It follows that any effects on repository performance are negligible, given that these are the factors associated with boreholes that could affect repository performance.

Test boreholes drilled in the underground facility are all relatively short (they remain within the TSw hydrogeologic unit) and are only present in access and observation drifts, not in the waste emplacement drifts (FEP 1.1.01.01.0B). Therefore, these boreholes will not have any significant effect on radionuclide transport between the repository and the water table. This FEP is therefore excluded because it will not significantly change radiological exposures to the RMEI or radiological releases to the accessible environment. Section 6.1.2 explains why low consequence for specific elements of the UZ system leads to low consequence for total system performance.

Supporting Reports: Not applicable.

\subsubsection{Influx through Holes Drilled in Drift Wall or Crown (1.1.01.01.0B)}

FEP Description: Holes may be drilled through the drift walls or crown for a variety of reasons including, but not limited to, rock bolt and ground support, monitoring and testing, or construction related activities. These openings may promote flow or seepage into the drifts and onto the waste packages.

Screening Decision: Excluded-Low Consequence.

Screening Argument: Detailed simulations were made using the predictive seepage model for PA (Seepage Model for PA Including Drift Collapse, BSC 2004 [DIRS 167652], Section 6.5) to study the effect of rock bolts in the drift crown. In a sensitivity analysis, several combinations of capillarity and permeability were examined, including cases representing both grouted and ungrouted rock bolts and an open hole. These features were found to have only a minor effect on seepage, less than 2\% according to Seepage Model for PA Including Drift Collapse (BSC 2004 [DIRS 167652], Table 6-4; DTN: LB0304SMDCREV2.001 [DIRS 173235]), due to the small area for water to enter the boreholes from the surrounding formation (BSC 2004 [DIRS 169131], Section 6.4.2.5). These conclusions are not dependent on the activity that creates a hole in the drift wall or crown (that is, ground support, monitoring, testing, or construction activities). From these results, the presence of holes drilled in drift wall or crown is not considered significant for seepage into drifts. This FEP is therefore excluded because it will not significantly change radiological exposures to the RMEI or radiological releases to the accessible environment. Section 6.1.2 explains why low consequence for specific elements of the UZ system leads to low consequence for total system performance.

Supporting Reports: Not applicable. 


\subsubsection{Site Flooding (During Construction and Operation) (1.1.02.01.0A)}

FEP Description: Flooding of the site during construction and operation could introduce water into the underground tunnels, which could affect the long-term performance of the repository.

Screening Decision: Excluded-Low Consequence.

Screening Argument: This FEP describes an issue related to preclosure operations. Design requirements also address the issue of surface water inundation of subsurface facilities (BSC 2005 [DIRS 174514], Sections 3.1.1.13.1 through 3.1.1.13.3).

Areas that would be inundated in the probable maximum flood in the vicinity of the North Portal pad were calculated in Preliminary Hydrologic Engineering Studies for the North Portal Pad and Vicinity (BSC 2002 [DIRS 157928], Figures 17 through 19), and presented in DTN: MO0209EBSPMFSD.029 [DIRS 161845]. These maps show that flooding is not expected to reach the main portals of the Exploratory Studies Facility or the intake and exhaust shafts.

Areas that would be inundated in the maximum potential flood for the Yucca Mountain area have also been calculated (DTN: MO0004YMP98132.004 [DIRS 149806]). Very little of the flood zone overlies waste emplacement zones. A small region of the expected flood zone overlies the repository footprint in the upper part of Drill Hole Wash. Boreholes USW NRG-7a, USW G-1, and USW H-1 lie close to or within the potential flood zone of Drill Hole Wash, which overlies the repository footprint (DTN: MO0011YMP00114.000 [DIRS 171565]). As discussed for FEP 1.1.01.01.0A (Section 6.3.1), if water should enter these boreholes, it is not expected to enter waste emplacement locations.

Flooding during storm events is not unusual and leads to infiltration and runoff. The effects of flooding are addressed in the infiltration model (FEP 2.3.11.02.0A). This FEP is therefore excluded because it will not significantly change radiological exposures to the RMEI or radiological releases to the accessible environment. Section 6.1.2 explains why low consequence for specific elements of the UZ system leads to low consequence for total system performance.

Supporting Reports: Not applicable.

\subsubsection{Incomplete Closure (1.1.04.01.0A)}

FEP Description: Disintegration of society could result in incomplete closure, sealing, and decommissioning of the disposal vault.

Screening Decision: Excluded - Low Consequence and By Regulation

Screening Argument: This FEP is similar in content to the ones discussed in Sections 6.3.1 (FEP 1.1.01.01.0A) and 6.3.6 (FEP 2.1.05.01.0A). In these FEPs, the effects of boreholes on water movement between the surface and the repository and transport of radionuclides between the repository and the water table were argued to be negligible. In addition, the effects of short test boreholes drilled in the underground test facility were found (FEP 1.1.01.01.0A) to be negligible with respect to repository performance. The effects of drift seals on water or gas movement through the drifts were also assessed (FEP 2.1.05.01.0A) to have a negligible effect 
on repository performance under nominal case performance modeling. With regard to sealing of the access portals, Preliminary Hydrologic Engineering Studies for the North Portal Pad and Vicinity (BSC 2002 [DIRS 157928], Figures 17 through 19) shows that flooding is not expected to reach the main portals of the Exploratory Studies Facility or the intake and exhaust shafts (at least under present-day climate), even if not sealed. This FEP is therefore excluded because it will not significantly change radiological exposures to the RMEI or radiological releases to the accessible environment. Section 6.1.2 explains why low consequence for specific elements of the UZ system leads to low consequence for total system performance. 10 CFR 63.305(b) [DIRS 173273] specifies that "DOE should not project changes to society..." This FEP is predicated on an assumption of a disintegration of society (i.e., a projected change) and is therefore also excluded by regulation.

Supporting Reports: Not applicable.

\subsubsection{Monitoring of the Repository (1.1.11.00.0A)}

FEP Description: Monitoring that is carried out during or after operations, for either operational safety or verification of long-term performance, has the potential to detrimentally affect long-term performance. For example, monitoring boreholes could provide enhanced pathways between the surface and the repository.

Screening Decision: Excluded-Low Consequence.

Screening Argument: This FEP is similar to the ones discussed in Sections 6.3.1 (FEP 1.1.01.01.0A), 6.3.2 (FEP 1.1.01.01.0B), and 6.3.6 (FEP 2.1.05.01.0A). The effect of rock-bolt boreholes drilled in the drift wall or crown was analyzed (BSC 2004 [DIRS 167652], Section 6.5) and found to increase seepage less than 2\% (DTN: LB0304SMDCREV2.001 [DIRS 173235]; BSC 2004 [DIRS 167652], Table 6-4). The effects of repository drift seals on water or gas movement through the drifts were also assessed (FEP 2.1.05.01.0A) to have a negligible effect on repository performance. Therefore, this FEP is excluded on the basis of low consequence. These conclusions are not dependent on the activity that creates a hole in the drift wall or crown (i.e., ground support, monitoring, testing, or construction activities).

Planned UZ monitoring activities, including testing of transport properties and field sorptive properties of the host rock, are described in Performance Confirmation Plan (BSC 2004 [DIRS 172452], Section 3.3.1.4). These activities began during site characterization and will continue during construction and emplacement. They are not expected to adversely affect the ability of the repository to meet performance objectives because the construction of alcoves and drilling to obtain samples is very limited and occurs in a very small portion of the repository. Planned geotechnical and construction effects monitoring activities, including subsurface mapping, and instrumenting mined openings to detect construction deformation, are described in Performance Confirmation Plan (BSC 2004 [DIRS 172452], Section 3.3.2). These activities also are not expected to adversely affect the ability of the repository to meet performance objectives because the instrumentation is very small and covers an insignificant portion of the rock in the repository. This FEP is therefore excluded because it will not significantly change radiological exposures to the RMEI or radiological releases to the accessible environment. Other activities associated with performance confirmation are given in Performance Confirmation Plan 
(BSC 2004 [DIRS 172452], Section 5). These include air permeability and gas and liquid tracer tests prior to waste emplacement and monitoring, sampling, and laboratory testing of condensation water quantities, composition, and ionic characteristics, including microbial effects, from a thermally accelerated emplacement drift. These activities do not present any disturbance greater than the creation of test boreholes or other similar activities conducted during site characterization. Section 6.1.2 explains why low consequence for specific elements of the UZ system leads to low consequence for total system performance.

Supporting Reports: Not applicable.

\subsubsection{Flow through Seals (Access Ramps and Ventilation Shafts) (2.1.05.01.0A)}

FEP Description: Long-term fluid flow through the shaft seal system, and uncertainty about long-term properties of the shaft seal system, may influence cumulative radionuclide releases from the disposal system.

Screening Decision: Excluded-Low Consequence.

Screening Argument: The host rock in the repository is highly fractured; hence seals for repository access drifts are of little consequence for water movement in the repository environment. There is only a small driving force for water to move along the relatively horizontal access drifts or emplacement drifts. Water is expected to move in a general vertical flow pattern through the waste emplacement horizon relative to the length scale of these drifts, with some flow diversion around the drifts caused by the capillary barrier effect. This flow pattern is consistent with the drift-scale seepage model having no-flow lateral boundary conditions (BSC 2004 [DIRS 167652], Section 6.3.1). The ventilation shafts connect to access drifts at the waste emplacement level and, therefore, represent pathways for water to enter the waste emplacement drifts. For postclosure, the ventilation shafts will be backfilled. The hydrogeologic effects of ventilation shafts provide high-permeability pathways similar to smaller fault features with respect to flow from the surface to the repository. The design for the shafts will account for the effects of flooding (BSC 2005 [DIRS 174514], Sections 3.1.1.13.1 through 3.1.1.13.3). Therefore, the quantity of water available to flow through the ventilation shafts is limited to rainfall and should not exceed infiltration that occurs in smaller fault features. Although fault features are suspected pathways for rapid migration of water from the surface to the repository (as observed from ${ }^{36} \mathrm{Cl}$ measurements), the amount of water that can bypass matrix flow in the Paintbrush nonwelded hydrogeologic unit is a only a small fraction (generally less than $5 \%$ in fault zones) of the total infiltration, based on transport calculations for ${ }^{36} \mathrm{Cl}$ between the ground surface and the repository horizon, which show 5\% breakthrough at several hundred years (BSC 2004 [DIRS 169861], Figure H-2). Similarly, flow through the backfilled ventilation shafts is expected to have a large component of matrix flow, greatly reducing the amount of transient water pulses penetrating from the surface to the waste emplacement drifts, regardless of the specific characteristics or evolution of the backfill over time (BSC 2005 [DIRS 174514], Sections 2.2 and 3.1.1.16.6 through 3.1.1.16.8). Therefore, the effect of the ventilation shafts on flow from the surface to the repository is negligible. Gas flow could potentially move through the drifts, so drift seals could affect the nature of this flow. However, the fractured nature of the host rock ensures that gas will be able to move between drifts if there is a driving force for this flow pattern. Given these conditions, the seals in the repository access drifts and ventilation 
shafts are expected to have very little effect on the movement of gas or water in the repository environment and therefore to have little effect on repository performance. This FEP is, therefore, excluded because it will not significantly change radiological exposures to the RMEI or radiological releases to the accessible environment. Section 6.1.2 explains why low consequence for specific elements of the UZ system leads to low consequence for total system performance.

The effects of borehole seal failure can also be excluded on the basis of low consequence, as discussed in FEP 1.1.01.01.0A.

Supporting Reports: Not applicable.

\subsubsection{Radionuclide Transport through Seals (2.1.05.02.0A)}

FEP Description: Groundwater flow through seals in the access ramps, ventilation shafts, and exploratory boreholes could affect long-term performance of the disposal system. Radionuclide transport through seals should be considered.

Screening Decision: Excluded-Low Consequence.

Screening Argument: This FEP is similar in content to the ones discussed in Sections 6.3.1 (FEP 1.1.01.01.0A) and 6.3.6 (FEP 2.1.05.01.0A). The host rock in the repository is highly fractured; hence, seals for ramps, ventilation shafts, and exploratory boreholes are of little consequence for water movement in the repository environment. The ventilation shafts connect to access drifts at the waste emplacement level and, therefore, represent pathways for water to enter the waste emplacement drifts. For postclosure, the ventilation shafts will be backfilled. The hydrogeologic effects of ventilation shafts provide high-permeability pathways similar to smaller fault features with respect to flow from the surface to the repository. The design for the shafts will account for the effects of flooding (BSC 2005 [DIRS 174514], Sections 3.1.1.13.1 through 3.1.1.13.3). Therefore, the quantity of water available to flow through the ventilation shafts is limited to rainfall and should not exceed infiltration that occurs in smaller fault features. Although fault features are suspected pathways for rapid migration of water from the surface to the repository (as observed from ${ }^{36} \mathrm{Cl}$ measurements), the amount of water that can bypass matrix flow in the Paintbrush nonwelded hydrogeologic unit is a only a small fraction (generally less than $5 \%$ in fault zones) based on transport calculations for ${ }^{36} \mathrm{Cl}$ between the ground surface and the repository horizon, which show 5\% breakthrough at several hundred years (BSC 2004 [DIRS 169861], Figure H-2). Similarly, flow through the backfilled ventilation shafts is expected to have a large component of matrix flow, greatly reducing the amount of transient water pulses penetrating from the surface to the waste emplacement drifts, regardless of the specific characteristics or evolution of the backfill over time (BSC 2005 [DIRS 174514], Sections 2.2 and 3.1.1.16.6 through 3.1.1.16.8). Therefore, the effect of radionuclide transport through seals is negligible. This FEP is therefore excluded because it will not significantly change radiological exposures to the RMEI or radiological releases to the accessible environment. Section 6.1.2 explains why low consequence for specific elements of the UZ system leads to low consequence for total system performance.

Supporting Reports: Not applicable. 


\subsubsection{Degradation of Seals (2.1.05.03.0A)}

FEP Description: Degradation of seals in the access ramps, ventilation shafts, and exploratory boreholes could modify flow and transport properties. Physical properties of the seals emplaced in the access ramps, ventilation shafts, and exploratory boreholes may affect the long-term performance of the disposal system. These properties include the location of the seals (and the openings they seal), and the physical and chemical characteristics of the sealing materials. Possible mechanisms for seal degradation include: chemical alteration from water interactions, wetting associated with condensation, and thermally-induced stress-strain changes.

Screening Decision: Excluded-Low Consequence.

Screening Argument: The host rock in the repository is highly fractured; hence seals for ramps, ventilation shafts, and exploratory boreholes, whether intact or degraded, are of little consequence for water movement in the repository environment. The ventilation shafts connect to access drifts at the waste emplacement level and therefore represent pathways for water to enter the waste emplacement drifts. For postclosure, the ventilation shafts will be backfilled. The hydrogeologic effects of ventilation shafts provide high-permeability pathways similar to smaller fault features with respect to flow from the surface to the repository. The design for the shafts will account for the effects of flooding (BSC 2005 [DIRS 174514], Sections 3.1.1.13.1 through 3.1.1.13.3). Therefore, the quantity of water available to flow through the ventilation shafts in case of degraded seals is limited to rainfall and should not exceed infiltration that occurs in smaller fault features. Although fault features are suspected pathways for rapid migration of water from the surface to the repository (as observed from ${ }^{36} \mathrm{Cl}$ measurements), the amount of water that can bypass matrix flow in the Paintbrush nonwelded hydrogeologic unit is a only a small fraction (generally less than $5 \%$ in fault zones) of the total infiltration based on transport calculations for ${ }^{36} \mathrm{Cl}$ between the ground surface and the repository horizon, which show 5\% breakthrough at several hundred years (BSC 2004 [DIRS 169861], Figure H-2). Similarly, flow through the backfilled ventilation shafts is expected to have a large component of matrix flow, greatly reducing the amount of transient water pulses penetrating from the surface to the waste emplacement drifts, regardless of the specific characteristics or evolution of the backfill over time (BSC 2005 [DIRS 174514], Sections 2.2 and 3.1.1.16.6 through 3.1.1.16.8). Therefore, the effect of radionuclide transport through seals is negligible. This FEP is therefore excluded because it will not significantly change radiological exposures to the RMEI or radiological releases to the accessible environment. Section 6.1.2 explains why low consequence for specific elements of the UZ system leads to low consequence for total system performance.

Supporting Reports: Not applicable.

\subsection{EXTREME CLIMATE/ALTERNATIVE FLOW PROCESSES}

These excluded FEPs concern the effects of climate and alternative flow processes on hydrological conditions, flow, and radionuclide transport in the UZ. Episodic (or short duration) transient flows are found to have a negligible effect and an average steady flow is used to represent the effects of flow. The rationale for this approximation is discussed below. Longer-term changes in climate are addressed in TSPA-LA using a quasi-steady flow approximation; in other words, the flow fields instantaneously adjust to steady conditions for a 
given climate (infiltration). However, certain aspects of climate discussed in this section are excluded based on low probability and others on low consequence.

Table 6-7 gives the FEP numbers and names categorized under extreme climate/alternative flow processes.

Table 6-7. Excluded FEPs: Climate and Episodic Transient Flow

\begin{tabular}{|l|l|l|}
\hline Section Number & \multicolumn{1}{|c|}{ FEP Number } & \multicolumn{1}{c|}{ FEP Name } \\
\hline 6.4 .1 & $1.3 .04 .00 .0 \mathrm{~A}$ & Periglacial effects \\
\hline 6.4 .2 & $1.3 .05 .00 .0 \mathrm{~A}$ & Glacial and ice sheet effect \\
\hline 6.4 .3 & $1.3 .07 .01 .0 \mathrm{~A}$ & Water table decline \\
\hline 6.4 .4 & $2.1 .09 .21 .0 \mathrm{C}$ & Transport of particles larger than colloids in the UZ \\
\hline 6.4 .5 & $2.2 .07 .05 .0 \mathrm{~A}$ & Flow in the UZ from episodic infiltration \\
\hline 6.4 .6 & $2.2 .07 .06 .0 \mathrm{~A}$ & Episodic or pulse release from repository \\
\hline
\end{tabular}

Source: DTN: MO0501SEPFEPLA.001 [DIRS 172601].

\subsubsection{Periglacial Effects (1.3.04.00.0A)}

FEP Description: This FEP addresses the physical processes and associated landforms in cold but ice-sheet-free environments. Permafrost and seasonal freeze/thaw cycles are characteristic of periglacial environments. These effects could include erosion and deposition.

Screening Decision: Excluded-Low Consequence and Low Probability.

Screening Argument: This FEP refers to climate conditions that could produce a cold, but glacier-free environment. Results of such a climate could include permafrost (permanently frozen ground). Paleoclimate records indicate that the climate conditions necessary to form permafrost are not credible at Yucca Mountain over the next 10,000 years (BSC 2004 [DIRS 170002], Section 6.6.2). The glacial-transition climate (identified as "intermediate" in Sharpe 2003 [DIRS 161591], Table 6-6) has the lowest predicted mean annual temperatures for the 10,000-year period (BSC 2004 [DIRS 170002], Section 6.6.2; Sharpe 2003 [DIRS 161591], Section 6.3.2). For the glacial-transition climate, analogue sites are identified in DTN: GS000308315121.003 [DIRS 151139]; the estimated range of mean annual temperatures is $8.3^{\circ} \mathrm{C}$ to $10.1^{\circ} \mathrm{C}$ (DTN: UN0201SPA021SS.007 [DIRS 161588], Sharpe 2003 [DIRS 161591], Table 6-3), which is too warm to sustain permafrost. Only the coldest scenario for the full glacial climate (Oxygen Isotope Stage 6/16) is expected to have a mean annual temperature of $0^{\circ} \mathrm{C}$ (Sharpe 2003 [DIRS 161591], Table 6-3). The expected return for such a climate is 200,000 years after present (Sharpe 2003 [DIRS 161591], Table 6-5). Therefore, soil erosion and deposition at Yucca Mountain as a result of permafrost are not credible. Freeze-thaw mechanical erosion will likely increase as the climate cools. However, the magnitude of erosion will not likely be significant even during the cooler climate condition. The time-averaged erosion over a 10,000-year period is expected to be less than $10 \mathrm{~cm}$ (YMP 1993 [DIRS 100520], Section 3.4), which is within the range of existing surface irregularities. This is based on estimates for erosion rates that have occurred at Yucca Mountain over the last 12 million years (YMP 1993 [DIRS 100520], Section 3.4) and therefore includes the effects of cooler climates. This FEP is therefore excluded because it will not significantly change radiological exposures to 
the RMEI or radiological releases to the accessible environment. Section 6.1.2 explains why low consequence for specific elements of the UZ system leads to low consequence for total system performance. This FEP is also excluded because climate conditions necessary to form permafrost are not credible at Yucca Mountain over the next 10,000 years.

Supporting Reports: Not applicable.

\subsubsection{Glacial and Ice Sheet Effect (1.3.05.00.0A)}

FEP Description: This FEP addresses the effects of glaciers and ice sheets occurring within the region of the repository, including direct geomorphologic effects and hydrologic effects. These effects include changes in topography (due to glaciation and melt water), changes in flow fields, and isostatic depression and rebound. These effects could include erosion and deposition.

Screening Decision: Excluded-Low Probability.

Screening Argument: This FEP refers to the local effects of glaciers and ice sheets. Paleoclimate records indicate that during the next 10,000 years, the existence of glaciers or ice sheets at Yucca Mountain is not credible (BSC 2004 [DIRS 170002], Section 6.6). The glacial-transition climate (identified as "intermediate" in Sharpe 2003 [DIRS 161591], Table 6-6) has the lowest predicted mean annual temperatures for the 10,000-year period (BSC 2004 [DIRS 170002], Section 6.6.2; Sharpe 2003 [DIRS 161591], Section 6.3.2). For the glacial-transition climate, analogue sites are identified in DTN: GS000308315121.003 [DIRS 151139]; the estimated range of mean annual temperatures is $8.3^{\circ} \mathrm{C}$ to $10.1^{\circ} \mathrm{C}$ (DTN: UN0201SPA021SS.007 [DIRS 161588], Sharpe 2003 [DIRS 161591], Table 6-3), which is too warm to sustain permafrost. Only the coldest scenario for the full glacial climate (Oxygen Isotope Stage 6/16) is expected to have a mean annual temperature of $0^{\circ} \mathrm{C}$ (Sharpe 2003 [DIRS 161591], Table 6-3). The expected return for such a climate is 200,000 years after present (Sharpe 2003 [DIRS 161591], Table 6-5). Therefore, glacial and ice sheet effects at Yucca Mountain are not credible.

The closest alpine glaciers to Yucca Mountain during the Pleistocene were in the White Mountains in California and possibly the Spring Range near Las Vegas (BSC 2004 [DIRS 169734], Section 6.4.1.4), too far from Yucca Mountain to have any effect on site geomorphology or hydrology. Given the relatively low elevation of Yucca Mountain, there is no credible mechanism by which a glacier could form at the site over the next 10,000 years. The geomorphologic and hydrological effects associated with glaciers, such as changes in topography resulting from erosion, deposition, and glacial transport, changes in flow fields, and isostatic depression and rebound, are not credible processes at Yucca Mountain. Therefore, this FEP is excluded from TSPA-LA on the basis of low probability.

Supporting Reports: Not applicable.

\subsubsection{Water Table Decline (1.3.07.01.0A)}

FEP Description: Climate change could produce decreased infiltration (e.g., an extended drought), leading to a decline in the water table in the saturated zone, which would affect the release and exposure pathways from the repository. 
Screening Decision: Excluded-Low Consequence.

Screening Argument: This FEP refers to the effects of a climate change that leads to much drier climate conditions. Some of the consequences of this type of climate change are a decrease in infiltration rate over time, water table decline, and desertification of the surface environment. However, the Yucca Mountain region is already a desert environment, and future climates are only expected to have increased precipitation (BSC 2004 [DIRS 170002], Section 6.6, DTN: UN0112SPA021SS.004 [DIRS 161588]). Paleoclimate records indicate that arid conditions are short compared to wetter conditions. Investigations of proxy climate records (Forester et al. 1996 [DIRS 100148], p. 52) indicate that climatic conditions during the past two million years were wetter than current climatic conditions $70 \%$ to $80 \%$ of the time (Szabo et al. 1994 [DIRS 100088], Fig 6). Analysis of Searles Lake deposits indicate that extremely dry conditions have occurred only twice within the past 600,000 years: once about 290,000 years ago and again in the past 10,000 years. (Jannik et al. 1991 [DIRS 109434], p. 1146 and Fig. 10). Therefore, water table decline below its present level is unlikely to occur during the regulatory period.

In any case, a decline in the water table and lower infiltration rates would increase the distance, and reduce the velocity of transport, from the repository to the water table and, therefore, would only enhance the UZ as a barrier to radionuclide movement. This FEP is, therefore, excluded because it will have no adverse affects on the radiological exposures to the RMEI, or radionuclide release to the accessible environment. Section 6.1.2 explains why low consequence for specific elements of the UZ system leads to low consequence for total system performance.

Supporting Reports: Not applicable.

\subsubsection{Transport of Particles Larger Than Colloids in the UZ (2.1.09.21.0C)}

FEP Description: Particles of radionuclide-bearing material larger than colloids could be entrained in suspension and then be transported in water flowing through the UZ.

Screening Decision: Excluded - Low Consequence.

Screening Argument: Particles larger than colloids are not expected to show much mobility in the UZ because of the large gravitational settling that occurs relative to diffusive movement for such particles. A relevant velocity scale for particle diffusion is the particle diffusion coefficient divided by the particle diameter. The colloid diffusion coefficient is given by the Stokes-Einstein equation (Bird et al. 2004 [DIRS 103524], Equation 16.5-4). The gravitational settling velocity for a colloid may be computed from Stokes' law (Perry and Chilton 1973 [DIRS 104946], Equation 5-215). The particle diameter, $d_{p}$, at which these velocities are equal is given by:

$$
d_{p}=\left[\frac{6 k T}{\pi g\left(\rho_{c}-\rho_{w}\right)}\right]^{\frac{1}{4}}
$$


where $k$ is the Boltzmann constant $\left(1.38 \times 10^{-23} \mathrm{~J} / \mathrm{K}\right), T$ is the temperature in Kelvin $(300 \mathrm{~K})$, $g$ is the gravitational acceleration $\left(9.81 \mathrm{~m} / \mathrm{s}^{2}\right), \rho_{c}$ is the colloid grain density $\left(2,650 \mathrm{~kg} / \mathrm{m}^{3}\right)$, and $\rho_{w}$ is the density of water $\left(1,000 \mathrm{~kg} / \mathrm{m}^{3}\right)$. This equation indicates that for a value of $d_{p}$ equal to $0.836 \mu \mathrm{m}$, gravitational settling and diffusion will be roughly in balance. For particles larger than colloids (greater than $1 \mu \mathrm{m}$ ), gravitational settling will dominate particle movement. Therefore, particles larger than colloids are not mobile.

The effects of perturbed TH conditions or other perturbed flow conditions (e.g., "groundwater rinse") on colloid movement (or movement of particles larger than colloids) are expected to be negligible because of the limited entrainment expected. Tests with fine, cohesive sediments presented by Vanoni (1977 [DIRS 164901], Figure 2.51) show that although entrainment does occur, for a wide variety of conditions this appears to be a very limited transient response. Entrainment is observed for a few days, and then the system stabilizes with no further initiation of motion, compared with unretarded colloid transport, which has a $10 \%$ breakthrough in about five years (BSC 2004 [DIRS 164500], Section 6.18.4). The limited time frame for enhanced colloid movement is negligible with respect to the time frames for waste release and transport. This FEP is therefore excluded because it will not significantly change radiological exposures to the RMEI or radiological releases to the accessible environment. Section 6.1.2 explains why low consequence for specific elements of the UZ system leads to low consequence for total system performance.

Supporting Reports: Not applicable.

\subsubsection{Flow in the UZ from Episodic Infiltration (2.2.07.05.0A)}

FEP Description: Episodic flow could occur in the UZ as a result of episodic infiltration. Episodic flow may affect radionuclide transport.

Screening Decision: Excluded-Low Consequence.

Screening Argument: The process that drives infiltration in the UZ is precipitation, which is clearly episodic in nature. Studies of episodic infiltration and percolation have found, however, that matrix-dominated flow in the Paintbrush Tuff nonwelded hydrogeologic unit (PTn) damps out the transient nature of the percolation such that UZ flow below the PTn is essentially steady (BSC 2004 [DIRS 169861], Appendix G).

The PTn primarily consists of nonwelded to partially welded tuffs and extends from the base of the densely to moderately welded Tiva Canyon welded tuff (TCw) to the top of the densely welded Topopah Spring welded (TSw) hydrogeologic unit. Within the repository area, the thickness of the PTn unit ranges from approximately 30 to $60 \mathrm{~m}$. As a whole, the PTn unit exhibits different hydrogeologic properties than the TCw and TSw units that bound it above and below. Both the $\mathrm{TCw}$ and the TSw units display the low porosity and intense fracturing typical of the densely welded tuffs at Yucca Mountain. In contrast, with its high porosity and low fracture intensity, the matrix of the PTn has a large capacity for storing groundwater and effectively damps percolation flux at the base of the TCw unit. Water imbibing into the PTn matrix from rapid fracture flow of the $\mathrm{TCw}$ results in a more uniform distribution of flux at the base of the PTn after traveling through the entire PTn unit. 
The effects of transient infiltration events were tested for average infiltration rates of $5 \mathrm{~mm} / \mathrm{yr}$ and $20 \mathrm{~mm} / \mathrm{yr}$, which are representative of present-day climate and glacial-transition climate, respectively. Calculations with both of these average infiltration rates (BSC 2004 [DIRS 169861], Figures G-11 and G-12) show the flow damping effect. This conclusion is supported by additional calculations (Wu et al. 2000 [DIRS 154918], Section 4.1; Wu et al. 2002 [DIRS 161058]). Furthermore, the PTn overlies the entire repository block (Appendix B of this report). This damping of transient flow is due to capillary forces and high matrix permeability in the PTn that lead to matrix imbibition of water from fractures to the matrix. This is also supported by carbon-14 data collected in bedded tuffs of the PTn unit (BSC 2004 [DIRS 169861], Appendix G) as well as by results of a water-release test at Alcove 4 and the results of line surveys of fracture minerals in the Exploratory Studies Facility (ESF) and Enhanced Characterization of the Repository Block (ECRB) Cross-Drift (BSC 2004 [DIRS 170004], Sections 6.7 and 6.14.1). Therefore, this FEP is excluded on the basis that the UZ flow is steady at the repository and along radionuclide transport pathways.

Very small amounts of fracture flow do appear to penetrate as fast pathways through fault zones between the ground surface and the repository elevation as evidenced by high ${ }^{36} \mathrm{Cl}$ concentrations in samples taken from the ESF. Higher concentrations of this isotope found in the ESF can only be explained through surface deposition of ${ }^{36} \mathrm{Cl}$ from nuclear weapons testing and subsequent aqueous transport to certain ESF sampling locations in a period of approximately 50 years. The flow responsible for rapid transport could occur either as steady flow or as episodic transient flow. In either case, the key to fast transport through the PTn is for solute to move through fractures and bypass transport through the rock matrix. However, the flow and transport models indicate that the quantity of water and dissolved constituents that do penetrate the PTn as a result of fast pathways (generally less than $1 \%$ of the total infiltration) is negligible with respect to repository performance (CRWMS M\&O 1998 [DIRS 100356], Section 2.4.2.8). This FEP is therefore excluded because it will not significantly change radiological exposures to the RMEI or radiological releases to the accessible environment. Section 6.1.2 explains why low consequence for specific elements of the UZ system leads to low consequence for total system performance.

Supporting Reports: Not applicable.

\subsubsection{Episodic or Pulse Release from Repository (2.2.07.06.0A)}

FEP Description: Episodic or pulse release of radionuclides from the repository and radionuclide transport in the UZ may occur both because of episodic flow into the repository, and because of pulse releases from failed waste packages.

Screening Decision: Excluded-Low Consequence.

Screening Argument: Precipitation and infiltration are episodic, but percolation flux in the UZ at the repository horizon (below the PTn) is steady, as discussed in the screening argument for FEP 2.2.07.05.0A. Seepage, if it occurs, will also be steady. Radionuclide release from failed waste packages is modeled in EBS Radionuclide Transport Abstraction (BSC 2005 [DIRS 173433], Section 6.3.3) as a "flow-through" process, where, for any waste package that has been breached by corrosion, the geometry of the openings does not present any barrier to flow. 
Section 6.6.1 of that report also examines an alternative "bathtub flow" model, where an opening at the top of a waste package allows water to enter, but the package retains mobilized radionuclides until either it overflows or a second opening is formed below the water line, suddenly releasing water with mobilized radionuclides. Waste packages also fail at different times in the TSPA model, resulting in step increases of release rate. Transport would then proceed with matrix imbibition, diffusion, and retardation by sorption.

The analysis in EBS Radionuclide Transport Abstraction (BSC 2005 [DIRS 173433], Section 6.6.1) also examined the effect of step changes in seepage chemistry, such that the solubility of radionuclides might increase or decrease. The conclusion is that the effect of episodic or pulse releases from waste packages is not significant because of the potential mitigation from sorption and diffusion and because the variability of corrosion rates provides large uncertainty in radionuclide release rates from the waste package. This treatment of episodic release is inherent in the base case EBS transport model and is included in product output from (BSC 2005 [DIRS 173433]). This FEP is therefore excluded because it will not significantly change radiological exposures to the RMEI or radiological releases to the accessible environment. Section 6.1.2 explains why low consequence for specific elements of the UZ system leads to low consequence for total system performance.

Supporting Reports: Not applicable.

\subsection{EROSION/DISSOLUTION/SUBSIDENCE}

These excluded FEPs concern the effects of surface erosion, mineral dissolution, and subsidence on hydrological conditions, flow, and radionuclide transport in the UZ. All of these processes are expected to occur at Yucca Mountain at low rates. These FEPs are all excluded on the basis of low consequence given conservative bounds on the extent that these processes can affect the hydrogeologic system at Yucca Mountain in a 10,000-year period.

Table 6-8 gives the FEP numbers and names categorized under Erosion/Dissolution/Subsidence.

Table 6-8. Excluded FEPs: Erosion/Dissolution/Subsidence

\begin{tabular}{|l|l|l|}
\hline \multicolumn{1}{|c|}{ Section Number } & FEP Number & \multicolumn{1}{c|}{ FEP Name } \\
\hline 6.5 .1 & $1.2 .07 .01 .0 \mathrm{~A}$ & Erosion/denudation \\
\hline 6.5 .2 & $1.2 .07 .02 .0 \mathrm{~A}$ & Deposition \\
\hline 6.5 .3 & $1.2 .09 .02 .0 \mathrm{~A}$ & Large-scale dissolution \\
\hline 6.5 .4 & $2.2 .06 .04 .0 \mathrm{~A}$ & Effects of subsidence \\
\hline
\end{tabular}

Source: DTN: MO0501SEPFEPLA.001 [DIRS 172601].

\subsubsection{Erosion/Denudation (1.2.07.01.0A)}

FEP Description: Erosion and denudation are processes which cause significant changes in the present-day topography and thus affect local and regional hydrology. Erosion of surficial materials can occur by a variety of means, including physical weathering (including glacial and fluvial erosion), chemical weathering, erosion by wind (aeolian erosion), and mass wasting (e.g., landslide) processes. The extent of erosion depends to a large extent on climate and uplift. 
Screening Decision: Excluded-Low Consequence.

Screening Argument: Erosion is a process that will be ongoing at Yucca Mountain over the 10,000 -year performance period. The time-averaged erosion due to various processes (e.g., fluvial erosion, aeolian erosion, chemical weathering) over a 10,000-year period is expected to be less than $10 \mathrm{~cm}$ (YMP 1993 [DIRS 100520], Section 3.4), even in high-erosion rate environments such as canyons. Erosion of $10 \mathrm{~cm}$ is within the range of existing surface irregularities (or surface roughness) and is negligible compared to the distance of $215 \mathrm{~m}$ from the ground surface to the repository emplacement areas (BSC 2003 [DIRS 165572], Section 7.1.8). Denudation, the rate of lowering of the earth's surface, includes mechanisms other than erosion, in particular dissolution and glaciation. The effects of dissolution are discussed in Section 6.5.3 (FEP 1.2.09.02.0A) and the effects of glaciation are discussed in Section 6.4.2 (FEP 1.3.05.00.0A). Site Characterization Plan, Yucca Mountain Site, Nevada Research and Development Area, Nevada (DOE 1988 [DIRS 100282], Section 1.1.3.3.2) indicates that mass wasting, such as landslides, does not play a significant role in the present erosional regime at Yucca Mountain.

Debris flows are the primary mechanism for hillslope erosion of unconsolidated deposits in the Yucca Mountain region (YMP 1995 [DIRS 102215], Section 2.5.2). However, the effects of debris flows are generally restricted to channelized areas (YMP 1995 [DIRS 102215], Section 4.2) and are not an effective erosion mechanism for unweathered bedrock. Therefore, debris flows have a limited influence on the evolution of surficial materials at Yucca Mountain. The effects of debris flows, over a 10,000-year period, are captured within the maximum expected erosion of $10 \mathrm{~cm}$ or less and are, therefore, insignificant.

The effects of surface construction and characterization activities at the ground surface on future erosion will also be negligible because of the planned reclamation of the site ground surface. As stated in Reclamation Implementation Plan (YMP 2001 [DIRS 154386], Section 5.2.2.1), "Recontouring and erosion control practices include backfilling spoil material and grading disturbed sites, so that a stable land form is created that blends with the surrounding topography. Following site decommissioning, disturbed areas will be graded such that the natural drainage pattern (predisturbance drainage) is restored. The sites will be stabilized and recontoured to blend into the natural topography of the area." This FEP is therefore excluded because it will not significantly change radiological exposures to the RMEI or radiological releases to the accessible environment. Section 6.1.2 explains why low consequence for specific elements of the UZ system leads to low consequence for total system performance.

Supporting Reports: Not applicable.

\subsubsection{Deposition (1.2.07.02.0A)}

FEP Description: Deposition is a process that causes significant changes in the present-day topography and thus affects local and regional hydrology. Deposition of surficial materials can occur by a variety of means, including fluvial, aeolian, and lacustrine deposition and redistribution of soil through weathering and mass wasting processes.

Screening Decision: Excluded-Low Consequence. 
Screening Argument: Like erosion, deposition is a process that will be ongoing at Yucca Mountain over the 10,000-year performance period. However, given the topographic relief of Yucca Mountain, erosion is expected to dominate over deposition. Deposition is believed to be a dominant process in Fortymile Wash (YMP 1993 [DIRS 100520], Section 3.4). However, this drainage channel has no effect on UZ flow and transport at Yucca Mountain due to its lateral offset. This FEP is therefore excluded because it will not significantly change radiological exposures to the RMEI or radiological releases to the accessible environment. Section 6.1.2 explains why low consequence for specific elements of the UZ system leads to low consequence for total system performance. The effects of igneous disruptive events and possible ash deposition are addressed in FEP 1.2.10.02.0A.

Supporting Reports: Not applicable

\subsubsection{Large-Scale Dissolution (1.2.09.02.0A)}

FEP Description: Dissolution can occur when any soluble mineral is removed by flowing water. Large-scale dissolution is a potentially important process in rocks that are composed predominantly of water-soluble evaporite minerals, such as salt.

Screening Decision: Excluded-Low Consequence.

Screening Argument: This FEP is principally concerned with the dissolution of highly soluble evaporite rocks such as halite or carbonates. Evaporitic minerals are present, but the UZ at Yucca Mountain is primarily composed of high-silica minerals such as quartz, feldspar, and glass (DTN: LA9908JC831321.001 [DIRS 113495]; BSC 2004 [DIRS 169734], Section 3.3.2). Solubilities of these minerals are too low to produce large dissolution cavities, breccia pipes, or solution chimneys over the time scales of interest and expected water flow rates. Local dissolution processes, for example those that affect fracture-filling minerals, are discussed in FEP 2.2.08.03.0B. This FEP is therefore excluded because it will not significantly change radiological exposures to the RMEI or radiological releases to the accessible environment. Section 6.1.2 explains why low consequence for specific elements of the UZ system leads to low consequence for total system performance.

Supporting Reports: Not applicable.

\subsubsection{Effects of Subsidence (2.2.06.04.0A)}

FEP Description: Subsidence above the mined underground facility or other openings may affect the properties of the overlying rocks and surface topography. Changes in rock properties, such as enhanced permeability, may alter flow paths from the surface to the repository. Changes in surface topography may alter run-off and infiltration, and may perhaps create impoundments.

Screening Decision: Excluded-Low Consequence.

Screening Argument: Subsidence can occur as a result of underground excavations. Subsidence calculations for Yucca Mountain were done as the first step in analysis of drift-scale THM effects (BSC 2004 [DIRS 169864]). The model domain extends upward to the ground surface (BSC 2004 [DIRS 169864], Tables 4.1-3c and 4.1-3d). The simulation was conducted 
by first excavating the drift and then implementing a thermal line load into the drift opening (BSC 2004 [DIRS 169864], Section 6.5.1). Subsidence at the drift crown and at the ground surface directly above the drift were extracted from model results in DTNs: LB0306DRSCLTHM.001 [DIRS 169733] and LB0308DRSCLTHM.001 [DIRS 171567]. These results show that the simulated subsidence from excavation of a single drift, without input of heat, is greater at the drift crown than at the ground surface. The maximum subsidence predicted was $1.4 \mathrm{~cm}$ at the drift crown and $0.7 \mathrm{~mm}$ at the ground surface, for a drift in Tptpll low-quality rock. These calculated subsidence distances are too small to affect run-off or infiltration, or to create impoundments. Therefore, subsidence is expected to have a negligible impact on large-scale UZ flow or surface topography, and is excluded from TSPA-LA modeling.

Corroborative evidence comes from mining experience. In coal mining, subsidence has been found to occur when more than 50\% of the coal bed was removed (Keller 1992 [DIRS 146831], p. 142). In the case of Yucca Mountain, the percentage of earth removal is very small. The emplacement drift diameter $(5.5 \mathrm{~m})$ is less than $10 \%$ of the drift spacing of $(81 \mathrm{~m}$ between center lines, BSC 2004 [DIRS 168489]; BSC 2005 [DIRS 173498]).

Brady and Brown (1985 [DIRS 126811], Figure 16.18) present an empirical correlation of maximum subsidence $S$ with width $w$ of a rectangular opening, the extraction thickness $m$ (height of the opening), and depth $d$. A circular drift, being smaller, will be less likely to cause subsidence; that is, the empirical correlation represents an upper bound. For repository drifts, $w=m=5.5 \mathrm{~m}$ and $d=300 \mathrm{~m}$. For this combination of variables, the maximum subsidence is off the chart on the low side; that is, $S / m$ is less than $1 \%$, or less than $5.5 \mathrm{~cm}$.

Further corroboration comes from modeling of drift collapse (BSC 2004 [DIRS 166107], Appendix R). Collapse, separation of blocks from the roof of the drift, is distinct from subsidence, which is downward displacement without separation. A typical realization of drift collapse is shown in Drift Degradation Analysis (BSC 2004 [DIRS 166107], Figure 6-173). This figure shows collapse extending about $7 \mathrm{~m}$ above the original elevation of the drift crown, with uncollapsed rock above the drift being displaced downward 6 to $10 \mathrm{~cm}$ (subsidence at the ground surface is not shown).

The effects of changes to fracture characteristics around emplacement drifts caused by stress relief have been found to be small to moderate and to have no adverse effects on seepage (BSC 2004 [DIRS 169864], Section 8.1). Therefore, subsidence is expected to have a negligible impact on large-scale UZ flow or surface topography. This FEP is therefore excluded because it will not significantly change radiological exposures to the RMEI or radiological releases to the accessible environment. Section 6.1.2 explains why low consequence for specific elements of the UZ system leads to low consequence for total system performance.

Supporting Reports: Not applicable.

\subsection{HUMAN INFLUENCES ON CLIMATE AND SOIL}

This group of FEPs is excluded from the TSPA-LA calculation because they postulate a human influence on climatic effects. The licensing rule and supplemental information (66 FR 55732 [DIRS 156671]) indicate that only natural evolution of the reference biosphere is to be included 
in the performance assessment. Naturally occurring climate change effects are addressed in the TSPA-LA through climate modeling and ranges of parameters used to characterize UZ water chemistry.

Table 6-9 gives the FEP numbers and names categorized under Human Influences on Climate and Soil.

Table 6-9. Excluded FEPs: Human Influences on Climate and Soil

\begin{tabular}{|l|l|l|}
\hline Section Number & FEP Number & \multicolumn{1}{|c|}{ FEP Name } \\
\hline 6.6 .1 & $1.4 .01 .00 .0 \mathrm{~A}$ & Human influences on climate \\
\hline 6.6 .2 & $1.4 .01 .02 .0 \mathrm{~A}$ & Greenhouse gas effects \\
\hline 6.6 .3 & $1.4 .01 .03 .0 \mathrm{~A}$ & Acid rain \\
\hline 6.6 .4 & $1.4 .01 .04 .0 \mathrm{~A}$ & Ozone layer failure \\
\hline 6.6 .5 & $1.4 .06 .01 .0 \mathrm{~A}$ & Altered soil or surface water chemistry \\
\hline
\end{tabular}

Source: DTN: MO0501SEPFEPLA.001 [DIRS 172601].

\subsubsection{Human Influences on Climate (1.4.01.00.0A)}

FEP Description: Future human actions, either intentional or accidental, could influence global, regional, or local climate.

Screening Decision: Excluded-By Regulation.

Screening Argument: Human influences on climate are excluded on the basis of requirements of 10 CFR 63.305(b) and (c) [DIRS 173273]. The licensing rule and the supplemental information (66 FR 55732 [DIRS 156671]) indicate that only natural evolution of the reference biosphere is to be included in the performance assessment and that the changes caused by the future human behaviors are not to be included. In response to comments on climate change (66 FR 55732 [DIRS 156671], p. 55,757), the NRC emphasized the importance of including "climate change in both the geosphere and biosphere performance assessment calculations to ensure that the conceptual model of the environment is consistent with our scientific understanding of reasonably anticipated natural events [emphasis added]." Similarly, in the background discussion of the 2002 amendment to the rule the NRC stated "DOE's performance assessments are required to consider the naturally occurring features, events and processes that could affect the performance of a geologic repository...[emphasis added]" (67 FR 62628 [DIRS 162317]). As the part of the response to the comments, the NRC also stated that considering future economic growth trends and human behaviors would add inappropriate speculation into the requirements and would lead to problems deciding which alternative futures are credible and which are unrealistic (66 FR 55732 [DIRS 156671], p. 55,757). The NRC stated further that the natural systems of the biosphere should be allowed to vary consistent with the geologic records, which provide basis for predicting future biosphere changes (66 FR 55732 [DIRS 156671], p. 55,757). Because human behavior cannot be similarly predicted, such an approach cannot be used for the reasonably maximally exposed individual (66 FR 55732 [DIRS 156671], p. 55,757) and, extending this reasoning, for the human-induced changes to the environment. Prediction of the human-induced climate changes would not only involve speculations about the local population, but also introduce inherently large uncertainties in 
prediction of the global population behaviors and their consequences. In their discussion of consideration of future economic growth trends the NRC concluded that inclusion of such future predictions would not only add inappropriate speculation, but also would not enhance public safety and would likely be inconsistent with the Environmental Protection Agency standards. Based on these statements, the FEPs associated with the characteristics of the reference biosphere and their change are limited to naturally occurring FEPs and exclude those related to human activities. Likewise, the geological, hydrological and climatological factors that the DOE must vary under $10 \mathrm{CFR}$ 63.305(b) and (c) [DIRS 173273], are also limited to naturally occurring FEPs. Present-day climate as discussed in Section 6.2.4 (FEP 1.3.01.00.0A ) is based on recent climate records that implicitly include any effects of modern society over the duration of the historical record implemented. However, future climate predictions using this data and other paleoclimate data does not encompass potential changes that may occur as a result of future human actions. In general, the exclusion of anthropogenic effects on future climate is believed to be conservative, because global warming would increase temperature and reduce precipitation in the Yucca Mountain region (NRC 2004 [DIRS 170243], Section 4.3.5.1).

Supporting Reports: Not applicable.

\subsubsection{Greenhouse Gas Effects (1.4.01.02.0A)}

FEP Description: The greenhouse effect refers to the presence in the atmosphere of carbon dioxide and other gases that tend to allow solar radiation through to the earth's surface and reflect heat back. Thus, these gases act much as the glass of a greenhouse, with the earth as the greenhouse. Human activities, such as burning fossil fuels, clearing forests, and industrial processes, produce these greenhouse gases. The greenhouse effect could increase concentrations of carbon dioxide and other gases in the atmosphere, and lead to changes in climate such as global warming.

Screening Decision: Excluded-By Regulation.

Screening Argument: Human influences on climate are excluded on the basis of requirements of 10 CFR 63.305(b) and (c) [DIRS 173273]. The licensing rule and the supplemental information (66 FR 55732 [DIRS 156671]) indicate that only natural evolution of the reference biosphere is to be included in the performance assessment and that the changes caused by the future human behaviors are not to be included (FEP 1.4.01.00.0A). Present-day climate as discussed in Section 6.2.4 (FEP 1.3.01.00.0A ) is based on recent climate records that implicitly include any effects of modern society over the duration of the historical record implemented. However, future climate predictions using this data and other paleoclimate data does not encompass potential changes that may occur as a result of future human actions. In general, the exclusion of anthropogenic effects on climate is believed to be conservative, because global warming would increase temperature and reduce precipitation in the Yucca Mountain region (NRC 2004 [DIRS 170243], Section 4.3.5.1).

Supporting Reports: Not applicable. 


\subsubsection{Acid Rain (1.4.01.03.0A)}

FEP Description: Human actions may result in acid rain on a local to regional scale. Acid rain can detrimentally affect aquatic and terrestrial life by interfering with the growth, reproduction, and survival of organisms. It can influence the behavior and transport of contaminants in the biosphere, particularly by affecting surface water and soil chemistry.

Screening Decision: Excluded-By Regulation.

Screening Argument: Human influences on climate are excluded on the basis of requirements of 10 CFR 63.305(b) and (c) [DIRS 173273]. The licensing rule and the supplemental information (66 FR 55732 [DIRS 156671]) indicate that only natural evolution of the reference biosphere is to be included in the performance assessment and that the changes caused by the future human behaviors are not to be included (FEP 1.4.01.00.0A). Present-day climate as discussed in Section 6.2.4 (FEP 1.3.01.00.0A ) is based on recent climate records that implicitly include any effects of modern society over the duration of the historical record implemented. However, future climate predictions using this data and other paleoclimate data does not encompass potential changes that may occur as a result of future human actions.

Supporting Reports: Not applicable.

\subsubsection{Ozone Layer Failure (1.4.01.04.0A)}

FEP Description: Human actions (i.e., the use of certain industrial chemicals) may lead to destruction or damage to the earth's ozone layer. This may lead to significant changes to the climate, affecting properties of the geosphere such as groundwater flow patterns.

Screening Decision: Excluded-By Regulation.

Screening Argument: Human influences on climate are excluded on the basis of requirements of 10 CFR 63.305(b) and (c) [DIRS 173273]. The licensing rule and the supplemental information (66 FR 55732 [DIRS 156671]) indicate that only natural evolution of the reference biosphere is to be included in the performance assessment and that the changes caused by the future human behaviors are not to be included (FEP 1.4.01.00.0A). Present-day climate as discussed in Section 6.2.4 (FEP 1.3.01.00.0A ) is based on recent climate records that implicitly include any effects of modern society over the duration of the historical record implemented. However, future climate predictions using this data and other paleoclimate data does not encompass potential changes that may occur as a result of future human actions.

Supporting Reports: Not applicable.

\subsubsection{Altered Soil or Surface Water Chemistry (1.4.06.01.0A)}

FEP Description: Human activities (e.g., industrial pollution, agricultural chemicals) may produce local changes to the soil chemistry or to the chemistry of water infiltrating Yucca Mountain and could provide a plume of unspecified nature to interact with the repository and possibly with waste packages. 
Screening Decision: Excluded-By Regulation.

Screening Argument: Human activities may affect soil and surface water chemistry because of agricultural activities or pollution from industrial activities. Current land use at Yucca Mountain does not include activities such as these that may lead to large-scale changes in soil or water chemistry. It is not credible that such activities would occur at Yucca Mountain, because the site does not offer known mineral resources (BSC 2004 [DIRS 169734], Section 3.6), commercial or industrial land uses (BSC 2004 [DIRS 169734], Section 3.2), or land that is suitable for agricultural development due to the rough terrain, thin soils, low rainfall, and deep water table. The nearest agriculture to the repository site is currently well outside the footprint of the UZ model (CRWMS M\&O 1997 [DIRS 101090], Tables 3-10 through 3-12, Figure 3-10, Appendix A). Furthermore, 10 CFR 63.305(b) [DIRS 173273] states that "DOE should not project changes in society, the biosphere (other than climate), human biology, or increases or decreases in human knowledge or technology. In all analyses done to demonstrate compliance with this part, the DOE must assume that all of those factors remain constant as they are at the time of submission of the license application." Therefore, human activities (changes in the social and institutional attributes of society, lifestyle, land use, and water use) that would alter soil or surface water chemistry are excluded on the basis of the regulatory requirements (10 CFR 63.305(b) [DIRS 173273]).

Supporting Reports: Not applicable.

\subsection{GAS PHASE EFFECTS}

This group of FEPs is excluded from the TSPA-LA calculation. These FEPs concern the effects of gas generation caused by chemical reactions in the repository, the intrusion of naturally occurring gases such as methane, gas-phase radionuclide transport, and natural airflow. These FEPs are all excluded on the basis of low consequence to performance.

Table 6-10 gives the FEP numbers and names categorized under Natural Gas/Gas Generation Effects.

Table 6-10. Excluded FEPs: Natural Gas/Gas Generation Effects

\begin{tabular}{|l|l|l|}
\hline Section Number & \multicolumn{1}{|c|}{ FEP Number } & \multicolumn{1}{c|}{ FEP Name } \\
\hline 6.7 .1 & $2.2 .10 .11 .0 \mathrm{~A}$ & Natural air flow in the UZ \\
\hline 6.7 .2 & $2.2 .11 .02 .0 \mathrm{~A}$ & Gas effects in the UZ \\
\hline 6.7 .3 & $2.2 .11 .03 .0 \mathrm{~A}$ & Gas transport in geosphere \\
\hline
\end{tabular}

Source: DTN: MO0501SEPFEPLA.001 [DIRS 172601].

\subsubsection{Natural Air Flow in the UZ (2.2.10.11.0A)}

FEP Description: Natural convective air circulation has been observed at a borehole at the top of the mountain. Repository heat may increase this flow.

Screening Decision: Excluded-Low Consequence. 
Screening Argument: Natural airflow is expected to have a negligible impact on TH processes, owing to the large volume of thermally generated flow, including water vapor. The effects of natural airflow have little consequence on water movement in the UZ because of the high mobility of the gas phase; hence, little dynamic interaction occurs between the phases. The standard practice when modeling unsaturated liquid flow is to neglect the effects resulting from flow in the gas phase (Richards 1931 [DIRS 104252], pp. 319-321). All unsaturated zone flow results supporting TSPA-LA were performed using the EOS9 module of TOUGH2 V1.4 (LBNL 2000 [DIRS 146496]), which solves Richards' equation for unsaturated flow calculations (BSC 2004 [DIRS 169861], Section 6.2.4). In this method, gas flow dynamics are ignored by using a constant gas-phase pressure in an isothermal system. This simplified two-phase flow solution for the three-dimensional model calibrations and TSPA flow field simulations is the most computationally efficient approach, while giving accurate results for isothermal two-phase flow. Two-phase flow problems are solved with one equation per gridblock instead of solving two or three equations, as required by the EOS3 module. Numerical tests have shown that for unsaturated flow at steady state, the EOS9 solutions are nearly identical to EOS3, "true two-phase" flow solutions (BSC 2004 [DIRS 169861], Section 6.2.4).

The effects of natural air flow due to barometric pumping and the associated removal of water through vapor transport has been investigated. Estimates of the rate of water removal from Yucca Mountain through this mechanism range from $0.001 \mathrm{~mm} / \mathrm{yr}$ to an upper limit of $0.1 \mathrm{~mm} / \mathrm{yr}$ (Tsang and Pruess, 1990, [DIRS 172018], p. iii; Martinez and Nilson, 1994, [DIRS 174095], p.106). These rates are negligible in comparison with the estimates for average infiltration at Yucca Mountain, which range from 1.25 to $31.69 \mathrm{~mm} / \mathrm{yr}$ (BSC 2004 [DIRS 169861], Table 6.1-2), and would likely be even smaller under future climate scenarios. Regardless of magnitude, excluding this effect of natural airflow will not result in an underestimation of dose in TSPA.

Repository heat affects gas-phase flow. Gas flow for thermally-perturbed conditions are incorporated in models for thermal-hydrological (BSC 2005 [DIRS 172232], Section 6.2.1.1.3) and thermal-hydrological-chemical processes (BSC 2005 [DIRS 172862], Section 6.4.1). Various aspects of the effects gas-phase flow under thermally-perturbed conditions are discussed in Sections 6.2.20 (FEP 2.2.07.10.0A), 6.2.21 (FEP 2.2.07.11.0A), 6.2.35 (FEP 2.2.10.10.0A), and 6.2.36 (FEP 2.2.10.12.0A).

This FEP is therefore excluded because it will not significantly change radiological exposures to the RMEI or radiological releases to the accessible environment. Section 6.1.2 explains why low consequence for specific elements of the UZ system leads to low consequence for total system performance.

Supporting Reports: Not applicable.

\subsubsection{Gas Effects in the UZ (2.2.11.02.0A)}

FEP Description: Pressure variations due to gas generation may affect flow patterns and contaminant transport in the UZ or may intrude into the repository. Degassing could affect flow and transport of gaseous contaminants. Gases could also affect other contaminants if water flow is driven by large gas bubbles forming in the repository. Potential gas sources include 
degradation of repository components and naturally occurring gases from clathrates, microbial degradation of organic material, or deep gases in general.

Screening Decision: Excluded-Low Consequence.

Screening Argument: In the Yucca Mountain UZ, the build-up of any significant gas pressure is unlikely, because of the permeable fracture pathways (BSC 2004 [DIRS 169861], Appendix A). Gas-phase pressures in fractures for $\mathrm{TH}$ calculations (no mineral precipitation) were compared with those for THC calculations (mineral precipitation included) (DTN: LB0302DSCPTHCS.002 [DIRS 161976]; BSC 2005 [DIRS 172862]). These analyses included the effects the phase change of water to vapor under the higher temperatures caused by waste heat from the repository. A comparison of these pressures showed that sealing of fractures due to precipitation in the thermally perturbed repository environment has a negligible effect on hydrogeologic properties of the fractures relative to gas pressure effects. This FEP also addresses the effects of gas bubbles. Because the repository at Yucca Mountain is located in the UZ with high aqueous to gas-phase contact, bubbles would quickly be absorbed into the gas phase and could not drive substantial water flow. Therefore, the bubble-release mechanism is negligible. This argument is valid regardless of the specific potential sources of gas generation (e.g., degradation of repository components or microbial degradation of organic matter). This FEP is therefore excluded because it will not significantly change radiological exposures to the RMEI or radiological releases to the accessible environment. Section 6.1.2 explains why low consequence for specific elements of the UZ system leads to low consequence for total system performance.

Supporting Reports: Not applicable.

\subsubsection{Gas Transport in Geosphere (2.2.11.03.0A)}

FEP Description: Gas released from the drifts and gas generated in the near-field rock will flow through fracture systems in the near-field rock and in the geosphere. Certain gaseous or volatile radionuclides may be able to migrate through the far-field faster than the groundwater advection rate.

Screening Decision: Excluded-Low Consequence.

Screening Argument: All radionuclides in the nominal scenario for TSPA-LA are transported from the repository to the accessible environment into the aqueous phase (DOE 2002 [DIRS 155970], Section I.7). This is expected to bound any dose effects of gas-phase transport in the geosphere. The only radionuclides that would have a potential for gas transport are ${ }^{14} \mathrm{C}$ and ${ }^{222} \mathrm{Rn} .{ }^{129} \mathrm{I}$ can exist in a gas phase, but it is highly soluble and, therefore, would be more likely to dissolve in groundwater rather than migrate as a gas. Other gas-phase isotopes have been eliminated in a screening analysis (DOE 2002 [DIRS 155970], Section I.3.3), usually because they have short half-lives and are not decay products of long-lived isotopes. Note that for ${ }^{14} \mathrm{C}$ and ${ }^{222} \mathrm{Rn}$, the process of inhalation dose in the biosphere model is included (BSC 2005 [DIRS 174107], Section 6.2.45)

An analysis of the potential dose from gas-phase geosphere transport of carbon-14 shows that the individual maximum radiological dose rate was found to be $1.8 \times 10^{-10}$ mrem per year 
(DOE 2002 [DIRS 155970], Section I.7). This may be compared with doses from ${ }^{14} \mathrm{C}$ in Total System Performance Assessment for the Site Recommendation (TSPA-SR) CRWMS M\&O 2000 [DIRS 153246], Figure 4.1-7), which found peak doses from aqueous ${ }^{14} \mathrm{C}$ release to be in excess of $10^{-4} \mathrm{mrem} / \mathrm{yr}$. Because gas-phase releases comprise approximately $2 \%$ of the ${ }^{14} \mathrm{C}$ inventory (DOE 2002 [DIRS 155970], Section I.7), this fraction should result in a maximum dose rate of about $10^{-6} \mathrm{mrem} / \mathrm{yr}$, given aqueous release. Therefore, the dose from aqueous geosphere transport of carbon-14 bounds the dose from gas-phase geosphere transport pathways.

Radon is a decay product of uranium and would be generated for as long as any uranium remained in the repository. Based on gas flow studies, radon released from the repository in the gas phase is expected to decay before reaching the ground surface (DOE 2002 [DIRS 155970], Section I.7.3). Therefore, aqueous geosphere transport pathway will also bound the dose from ${ }^{222} \mathrm{Rn}$, primarily through aqueous transport of the parent uranium radionuclide and generation of ${ }^{222} \mathrm{Rn}$ as a decay product at the accessible environment.

In summary, all radionuclides are transported in the aqueous phase between the repository and the accessible environment for the nominal scenario. The effects of gas phase geosphere transport on radiological exposures and radionuclide releases are bounded by aqueous phase geosphere transport. Therefore, this FEP is excluded because including gas-phase radionuclide transport in the geosphere would result in lower predicted doses in TSPA. Section 6.1.2 explains why low consequence for specific elements of the UZ system leads to low consequence for total system performance.

Supporting Reports: Not applicable.

\subsection{SEISMIC/IGNEOUS/ROCK CHARACTERISTICS}

This group of FEPs is excluded from the TSPA-LA calculation. These FEPs concern the potential effects of seismic and igneous events and processes on existing rock properties and characteristics. Table 6-11 gives the FEP numbers and names categorized under Seismic/ Igneous/Rock Characteristics.

Table 6-11. Excluded FEPs: Seismic/Igneous/Rock Characteristics

\begin{tabular}{|l|l|l|}
\hline Section Number & FEP Number & \multicolumn{1}{c|}{ FEP Name } \\
\hline 6.8 .1 & $1.2 .04 .02 .0 \mathrm{~A}$ & Igneous activity changes rock properties \\
\hline 6.8 .2 & $1.2 .06 .00 .0 \mathrm{~A}$ & Hydrothermal activity \\
\hline 6.8 .3 & $1.2 .10 .01 .0 \mathrm{~A}$ & Hydrologic response to seismic activity \\
\hline 6.8 .4 & $1.2 .10 .02 .0 \mathrm{~A}$ & Hydrologic response to igneous activity \\
\hline 6.8 .5 & $2.2 .06 .01 .0 \mathrm{~A}$ & Seismic activity changes porosity and permeability of rock \\
\hline 6.8 .6 & $2.2 .06 .02 .0 \mathrm{~A}$ & Seismic activity changes porosity and permeability of faults \\
\hline 6.8 .7 & $2.2 .06 .02 .0 \mathrm{~B}$ & Seismic activity changes porosity and permeability of fractures \\
\hline 6.8 .8 & $2.2 .06 .03 .0 \mathrm{~A}$ & Seismic activity alters perched-water zones \\
\hline 6.8 .9 & $2.2 .12 .00 .0 \mathrm{~A}$ & Undetected features in the UZ \\
\hline
\end{tabular}

Source: DTN: MO0501SEPFEPLA.001 [DIRS 172601]. 


\subsubsection{Igneous Activity Changes Rock Properties (1.2.04.02.0A)}

FEP Description: Igneous activity near the underground facility may cause extreme changes in rock stress and the thermal regime, and may lead to rock deformation, including activation, creation, and sealing of faults and fractures. This may cause changes in the rock hydrologic and mineralogic properties. Permeabilities of dikes and sills and the heated regions immediately around them can differ from those of country rock. Mineral alterations can also change the chemical response of the host rock to contaminants.

Screening Decision: Excluded-Low Consequence.

Screening Argument: Volcanism and igneous activity in the Yucca Mountain region was principally silicic until about $11 \mathrm{Ma}$ (million years ago); since then the igneous activity has been basaltic, at a much lower level of activity (BSC 2004 [DIRS 169989], Section 6.2). The extent of alteration or other damage caused by basalt magma intruding rock of the repository block can be assessed from basalt dike contacts in comparable settings. Such studies constrain the type and spatial scale of alteration that would accompany a basaltic intrusion into the repository. Two sites provided good analogues for the various rocks in the vadose zone at Yucca Mountain: (1) Grants Ridge, New Mexico, where a thick sequence of rhyolite ignimbrite, fallout, and reworked volcaniclastic deposits were intruded by a basaltic plug. Erosion of the Grants Ridge site has since produced a natural cross section through the scoria cone, its feeding system, and the pyroclastic host rocks; and (2) the Slanted Buttes area of Paiute Ridge, eastern Nevada Test Site, where variably vitric and zeolitized silicic tuffs (some of which correlate to those at Yucca Mountain, some $40 \mathrm{~km}$ away) were intruded by basaltic dikes and sills (BSC 2004 [DIRS 169734], Section 4.2.3.5). The basaltic intrusions at Grants Ridge and Paiute Ridge show limited alteration caused by hydrothermal circulation, no brecciation or other deformation related to basaltic intrusion into the vitric and zeolitized tuffs. Field and analytical evidence from the localized contact metamorphic aureoles and devitrification of the silicic tuffs adjacent to the intrusion, minimal hydrothermal alteration, and presence of low-temperature minerals close to the intrusions also suggest insignificant thermal and chemical effects of the shallow basaltic intrusions on the vitric and zeolitized tuffs (CRWMS M\&O 1998 [DIRS 123201], p. 5-57).

Dikes are expected to range between about $0.5 \mathrm{~m}$ to $4.5 \mathrm{~m}$ in thickness, with an average of $1.5 \mathrm{~m}$ (BSC 2004 [DIRS 169980], Section 6.3.1). A dike intersecting a drift would bleed magma into the drift. A simple conduction-only cooling model indicates that if a drift is instantaneously and entirely filled with basaltic magma $1150^{\circ} \mathrm{C}$, it (and the surrounding rock) will cool to sub-boiling in less than three years, with boiling temperatures no more than $10 \mathrm{~m}$ from the drift (BSC 2004 [DIRS 170028], Figures 6-98 and 6-99; DTN: MO0408EG831811.008 [DIRS 173078]). A period of 200 to 300 years to cool to $500^{\circ} \mathrm{C}$ was estimated by Ratcliff et al. (1994 [DIRS 106634] for the 150-m-thick Paiute Ridge lopolith, but long, thin intrusions (such as a drift filled with magma) would cool much faster. Contact metamorphism resulting from dikes at a vadose-zone analogue site, Paiute Ridge, is confined to distances of a few meters from the dike (Valentine et al. 1998 [DIRS 119132], Chapter 5). With significant thermal perturbations limited to less than 100 years and alteration limited to zones of a few meters around the dike, the effects of basaltic magmatism on transport pathways, advective velocities, and sorption coefficients $\left(K_{d} S\right)$ is negligible. 
On the basis of these confined and short-duration features and processes, this FEP is therefore excluded because it will not significantly change radiological exposures to the RMEI or radiological releases to the accessible environment. Furthermore, the probability for the occurrence of a volcanic event at Yucca Mountain is $1.7 \times 10^{-8}$ per year (BSC 2004 [DIRS 169989], Table 7-1), which results in a greatly reduced expected consequence from a probability-weighted perspective. Section 6.1.2 explains why low consequence for specific elements of the UZ system leads to low consequence for total system performance.

Supporting Reports: Not applicable

\subsubsection{Hydrothermal Activity (1.2.06.00.0A)}

FEP Description: Naturally-occurring high-temperature groundwater may induce hydrothermal alteration of minerals in the rocks through which the high-temperature groundwater flows.

Screening Decision: Excluded-Low Consequence.

Screening Argument: The earliest volcanism in the Yucca Mountain region, a primary source for hydrothermal activity, was dominated by a major episode of caldera-forming, silicic volcanism that occurred primarily between approximately 15 and 11 million years ago (Ma), forming the southwestern Nevada volcanic field (Sawyer et al. 1994 [DIRS 100075]). Silicic volcanism was approximately coincident with a major period of extension, which occurred primarily between 13 and 9 Ma (Sawyer et al. 1994 [DIRS 100075], Figure 4). The southwestern Nevada volcanic field ceased silicic eruptive activity about 7.5 Ma (BSC 2004 [DIRS 169989], Section 6.2). The commencement of basaltic volcanism occurred during the latter part of the caldera-forming phase, as extension rates waned, and small-volume basaltic volcanism has continued into the Quaternary (BSC 2004 [DIRS 169989], Section 6.2). The focus of igneous-related FEPs is on the potential for small-scale basaltic volcanism and the mean probability of a basaltic dike intersecting the repository footprint has been calculated to be $1.7 \times 10^{-8}$ per year (BSC 2004 [DIRS 169989], Table 7-1)

Yucca Mountain is an uplifted, erosional remnant of voluminous ash-flow tuff deposits formed during the early phase of silicic volcanism (BSC 2004 [DIRS 169989], Section 6.2). Hydrothermal alteration and mineralization that followed the deposition of the Paintbrush Group are present within a few kilometers of the Yucca Mountain site in the Calico Hills and in Claim Canyon. However, no clear evidence for hydrothermal activity exists in the repository area (BSC 2004 [DIRS 169734], Section 3.6.2). Yucca Mountain is located outside the caldera margin (BSC 2004 [DIRS 169989], Figure 6-1), and the level of heating at Yucca Mountain associated with the Timber Mountain volcanic center (and its associated hydrothermal system) was relatively minor, with peak fluid inclusion temperatures of around $80^{\circ} \mathrm{C}$ to $90^{\circ} \mathrm{C}$ occurring at around 9 to $10 \mathrm{Ma}$, so that the heating event at Yucca Mountain did not result in pervasive hydrothermal alteration of the tuffs. Studies of secondary minerals at Yucca Mountain using petrography, fluid-inclusion thermometry, and uranium-lead dating indicate that temperatures have remained close to the current ambient values over the past two to five million years (Wilson et al. 2003 [DIRS 163589], Section 8). 
Mineral coatings composed primarily of calcite, opal, chalcedony, and quartz provide evidence of the thermal-hydrothermal history of Yucca Mountain. The minerals were deposited under unsaturated conditions, because they are found only on fracture footwalls and lithophysal cavity bottoms (Marshall and Whelan 2000 [DIRS 154415]). Various lines of evidence, including (1) stable isotope oxygen data of calcite, which indicates the temperature of mineral precipitation (2) homogenization temperatures of fluid inclusions which indicates the temperature at which the inclusions were trapped (3) uranium and lead isotope ratios in opal associated with the calcite (Neymark et al. 2003 [DIRS 163681]), which constrain the age of deposited minerals, combine to indicate that temperatures in the UZ decreased over time from approximately $90^{\circ} \mathrm{C}$ at $10 \mathrm{Ma}$ to near ambient temperatures at $2 \mathrm{Ma}$. These secondary minerals were interpreted to have been deposited from downward percolating meteoric water, and not from upwelling groundwaters (Whelan et al. 2003 [DIRS 163590]).

Marshall and Whelan (2001 [DIRS 163591]) present a conceptual model of heat transfer from the Timber Mountain magma chamber to explain the temperature history of Yucca Mountain that was inferred from geological evidence. This was implemented in a numerical model using the program HEAT (Wohletz et al. 1999 [DIRS 164597], Appendix B); model results are presented in Marshall and Whelan (2001 [DIRS 171061]). In a sensitivity study, the conditions above the magma chamber were varied: $5 \mathrm{~km}$ or $2.5 \mathrm{~km}$ distance from the top of the magma chamber to the ground surface (shallower depth causes faster cooling of the magma), presence or absence of an UZ (with a UZ the magma cools slower because saturated rock is more thermally conductive), and presence or absence of a hydrothermal regime, which would allow heat loss by convection (Ziegler 2004 [DIRS 171590], Section H.4.2). Conditions that caused the magma to cool off more rapidly also caused a target location $4 \mathrm{~km}$ from the edge of the magma chamber and $250 \mathrm{~m}$ deep (approximately representing the near edge of the repository location) to get hot sooner and to reach a higher maximum temperature. That is, applying conditions of convective heat transfer and shallow burial resulted in more heat transfer to the target location. The simulations presented by Marshall and Whelan (2001 [DIRS 171061]) agree with the temperature history inferred from the geologic evidence (Whelan et al. 2003 [DIRS 163590], Figure 4) since 5 Ma, but before that time, the geologic evidence indicates hotter temperatures than predicted by the model.

In simulations conducted by Marshall and Whelan (2001 [DIRS 171061]), the magma chamber is maintained at constant magmatic temperature from $15 \mathrm{Ma}$ to $11 \mathrm{Ma}$. One way to possibly reconcile the model and data would be to extend the magmatic activity of the Timber Mountain system beyond $11 \mathrm{Ma}$ (Ziegler 2004 [DIRS 171590], Section H.4.2). While only minor volcanic activity is associated with Timber Mountain after $11.4 \mathrm{Ma}$, it is possible that the system received continued injections of mantle-derived mafic magmas that would have provided additional heating to the region (Farmer et al. 1991 [DIRS 153024]). Continuing silicic volcanism at the Black Mountain caldera (9.4 Ma) and Stonewall Mountain volcanic center (7.5 Ma), both located northwest of the Timber Mountain caldera, indicates that regional silicic magmatism and associated heating persisted beyond 11 Ma (Sawyer et al. 1994 [DIRS 100075]).

The Long Valley caldera in California provides a natural analogue to test the caldera-heating model proposed by Marshall and Whelan (2001 [DIRS 163591]). This is a younger caldera than Timber Mountain, so that the thermal gradient away from the caldera is still detectable. Data presented by Lachenbruch et al. (1976 [DIRS 171203], Table 1) show a horizontal thermal 
gradient decreasing with distance from the caldera, analogous to the results provided by Marshall and Whelan (2001 [DIRS 171061]).

Additional evidence of elevated paleotemperatures at Yucca Mountain may be provided by observations of thick twinned calcite samples in discrete narrow faults $(2 \mathrm{~cm}$ to $20 \mathrm{~cm})$ (Gray et al. 2000 [DIRS 171202]). Thick twinned calcite was interpreted to indicate deformation at temperature above $170^{\circ} \mathrm{C}$ (Ferrill et al 2004, [DIRS 171196], which is higher than the temperatures indicated by calcite fluid inclusions reported by Whelan et al. (2003 [DIRS 163590]) and by Wilson et al. (2003 [DIRS 163589], Section 8). If the higher temperatures indicated by thick twins (which have not been confirmed by studies of fluid inclusions in the same samples) are correct, they may indicate that the twinned calcite was formed during a very early, higher-temperature event. Such temperatures would most likely have occurred shortly after emplacement of the ash-flow tuff deposits at Yucca Mountain, when degassing and cooling of the ash-flow tuff can result in devitrification, vapor-phase alteration, and development of localized meteoric-hydrothermal activity in the upper parts of ash-flow sheets (Holt 2002 [DIRS 162326]). Gray et al. (2000 [DIRS 171202]) note that the calcite mineralization observed in the narrow faults is not encountered in the intrablock and block-bounding faults, which would be likely candidates for fluid flow and mineralization in the event of widespread hydrothermal alteration. The absence of pervasive hydrothermal mineralization of the Yucca Mountain tuffs is consistent with the interpretation that large-scale hydrothermal activity has not occurred in the Yucca Mountain area.

Since the cessation of silicic magmatism about $11.4 \mathrm{Ma}$, basaltic igneous activity has been characteristic of the Yucca Mountain region. Silicic volcanism during the regulatory period is, therefore, not credible and analysis of this FEP is focused on the probability and consequence of basaltic magmatism (Reamer 1999 [DIRS 119693], p. 5). Although basaltic magmatism could occur during the regulatory period, the effects of any related hydrothermal system would be of limited scale as described in Section 6.8.1 (FEP 1.2.04.02.0A) where the effects of basaltic magmatism are addressed. Due to the limited scale of effects from basaltic dikes, the potential effects of hydrothermal alteration are excluded based on low consequence because they will not significantly change radiological exposures to the RMEI or radiological releases to the accessible environment. With significant thermal perturbations limited to less than 100 years and alteration limited to zones of a few meters around the dike, the effects of basaltic magmatism on transport pathways, advective velocities, and sorption coefficients $\left(\mathrm{K}_{d} \mathrm{~s}\right)$ is also negligible. Section 6.1.2 explains why low consequence for specific elements of the UZ system leads to low consequence for total system performance.

Supporting Reports: Not applicable.

\subsubsection{Hydrologic Response to Seismic Activity (1.2.10.01.0A)}

FEP Description: Seismic activity, associated with fault movement, may create new or enhanced flow pathways and/or connections between stratigraphic units, or it may change the stress (and, therefore, fluid pressure) within the rock. These responses have the potential to significantly change the surface and groundwater flow directions, water level, water chemistry, and temperature. 
Screening Decision: Excluded-Low Consequence and Low Probability.

Screening Argument: This FEP addresses the effects of seismic activity on UZ flow and transport at the mountain scale and for drift seepage. It also addresses the possible water table rise in response to seismic activity. The aspects of this FEP related to flow and transport are addressed in Sections 6.8.5 (FEP 2.2.06.01.0A), 6.8.6 (FEP 2.2.06.02.0A), and 6.8.7 (FEP 2.2.06.02.0B). This FEP assesses the effects of seismically induced water table rise caused by seismic pumping and changes in the large hydraulic gradient. The effect of seismic activity on transport is addressed in a sensitivity study in Sections 6.8.5, 6.8.6, 6.8.7, and in Appendix D of this report.

Seismic pumping (Szymanski 1989 [DIRS 106963], pp. 3 through 22) is the temporary increase in height of the water table caused by fault movement. This movement of the water table is caused by the opening and closing of fractures during an earthquake cycle. Longer-term changes result from complex strain adjustments, but these changes are dissipated under the influence of regional stress field, which brings the state of the SZ fracture network back to an ambient, preseismic state as postseismic relaxation occurs.

Numerical simulations by Carrigan et al. (1991 [DIRS 100967]) of seismic pumping involving earthquakes typical of the Basin and Range province (approximately $1 \mathrm{~m}$ slip) produced $2 \mathrm{~m}$ to $3 \mathrm{~m}$ excursions of a water table $500 \mathrm{~m}$ below the ground surface. Extrapolation to an event of about 4-m slip would result in a transient rise of $17 \mathrm{~m}$ near the fault (Carrigan et al. 1991 [DIRS 100967], p. 1,159). As discussed in Section 6.8.6, seismic activity can also change fault permeability. Carrigan et al. (1991 [DIRS 100967]) modeled a 100-m-wide fracture zone centered on a vertical fault, with vertical permeability increased by a factor of 1,000 . Water level excursions in the fracture zone were twice as great as in the adjacent block. For a fault-fracture zone with 1-m slip, transient excursions of about $12 \mathrm{~m}$ can occur.

An investigation of seismic pumping was performed by the National Research Council (1992 [DIRS 105162], Chapter 5). This group estimated the maximum changes in water table elevations over a 10,000-year period in response to seismic activity, which presumes some degree of fault displacement. They estimated fault displacement using two modeling approaches: (1) a dislocation approach, where zones of extension on one side of a fault are balanced by compression across the fault; and (2) the more realistic 'changes in the regional stress' approach caused by normal fault slippage in regions of extension. The regional stress approach evaluated the effect of stress on pore pressure, which is dependent on the elastic properties of the bulk rock and the mineral grains. Both models resulted in a transient change in water table elevation given a seismic event in the Yucca Mountain region. However, the extent of the rise differed for both models. Adopting the dislocation model, the maximum rise in the water table is approximately $10 \mathrm{~m}$. Results from the regional stress approach resulted in a maximum water table rise of $50 \mathrm{~m}$. The later approach assumes realistically conservative rock and mineral elastic properties. The panel concluded that regardless of which approach is taken, the maximum water table rise given a seismic event would be less than $50 \mathrm{~m}$. Given the National Research Council's study, it is inferred that a 10-m slip along Solitario Canyon fault would result in no more than a 50-m rise in the water table. 
An analysis of seismic pumping performed by Gauthier et al. (1996 [DIRS 100447], pp. 163 to 164) indicates that the greatest strain-induced changes in water table elevation occur with strike-slip faults. Simulations of the timing, magnitude, and duration of water table rise indicate a maximum rise of $50 \mathrm{~m}$ within an hour of the simulated event. The simulated system returns to steady-state conditions within six months. Gauthier et al. (1996 [DIRS 100447]) concluded that seismically induced water table excursions caused by poroelastic coupling would not influence model predictions of long-term repository performance.

The significance of a rise in the water table is that it reduces the barrier capability of the UZ by shortening the flow path from the repository to the SZ. Regardless, data and modeling results indicate that changes in water table elevation at Yucca Mountain are not likely to exceed several meters and are likely to be transient. What seems most reasonable is that the water table excursions caused by earthquakes do not cause sufficient water table level fluctuations to threaten, even temporarily, the repository horizon, which in the current design is approximately $300 \mathrm{~m}$ above the water table. Given this limited water table movement, changes to surface- and groundwater-flow directions, water level, water chemistry, and temperature would also be negligible. Therefore, the seismic effects on water table rise resulting from seismic pumping are excluded because they will not significantly change radiological exposures to the RMEI or radiological releases to the accessible environment.

Another aspect of the water-table rise issue concerns the large hydraulic gradient that exists north of the repository. North of the repository, the water table elevation decreases by about $250 \mathrm{~m}$ as one moves from north to south towards the repository. If this gradient were to migrate southward, the resulting water table below the repository could be much higher than present-day conditions.

The work of Davies and Archambeau (1997 [DIRS 103180], p. 28) presents a hypothesis that the gradient is a result of stress variations in the rock that are residual stress effects induced by the Timber Mountain caldera. Furthermore, they suggest that moderate earthquakes in this area could induce a sufficient change in geomechanical strain downstream of the current large hydraulic gradient to induce a similar gradient downstream of the repository. This would result in a large $(150 \mathrm{~m}$ to $250 \mathrm{~m})$ rise in the water table beneath the repository. However, the hypothesis regarding the residual stress effects of the 10 Ma Timber Mountain caldera contradicts extensive previous experience in the region of the Nevada Test Site (Stock et al. 1985 [DIRS 101027]). This composite experience is compiled from 14 sources reporting results from diverse methods, including hydraulic fracturing, overcoring stress measurements, earthquake focal mechanisms, borehole breakouts, orientations of explosion-produced fractures, and study of Quaternary faults and cinder-cone alignments. These studies show a reasonably uniform direction of extension between northwest and west, with a mixed potential-slip regime of normal faulting (mainly for shallow indicators) and strike-slip faulting (mainly for deep indicators). The Davies and Archambeau discussion is also inconsistent with actual stress measurements in G-2 as reported by Stock and Healy (1988 [DIRS 101022]), which is cited, though erroneously, as a source of "slug-test" data. Stock and Healy (1988 [DIRS 101022]) characterize G-2 as being within the same ("combined normal and strike-slip") faulting regime as that indicated by the results from the three holes that they tested south of the large gradient. Based on the stress measurements in the four holes, the tendency for strike-slip faulting is greatest in the 
southeastern hole, UE-25p\#1, not in the northern Yucca Mountain area where G-2 is located, as Davies and Archambeau propose.

The available data (Stock et al. 1985 [DIRS 101027]; Stock and Healy (1988 [DIRS 101022]) do not support a residual stress effect from the Timber Mountain caldera, do not support a modern stress field changing from strike-slip in northern Yucca Mountain to normal south of the hydraulic gradient, and do not support a southward decrease of the least principal stress. Although it is reasonable that the area of the large hydraulic gradient is less transmissive than the area to the south-southeast, a more reasonable explanation for this lower transmissivity is that durable differences of lithology, alteration history, and structural deformation have affected this region, rather than a transient state of stress. This mechanism is inconsistent with the existing data of Stock et al. (1985 [DIRS 101027]) and Stock and Healy (1988 [DIRS 101022]). In the Basin and Range Province, which includes the Yucca Mountain region, seismic and tectonic activity are in a waning phase with the focal point moving westward (BSC 2005 [DIRS 173981], Section 6.2.1.1). Therefore, any large changes to surface- and groundwater-flow directions, water level, water chemistry, and temperature due to the seismic activity are not credible. Therefore, the seismic effects on water table rise caused by seismic activity, or by migration of the large hydraulic gradient induced by seismic activity, are excluded from TSPA-LA on the basis of low probability.

Supporting Reports: Not applicable.

\subsubsection{Hydrologic Response to Igneous Activity (1.2.10.02.0A)}

FEP Description: Igneous activity includes magmatic intrusions, which may alter groundwater flow pathways, and thermal effects which may heat up groundwater and rock. Igneous activity may change the groundwater flow directions, water level, water chemistry, and temperature. Eruptive and extrusive phases may change the topography, surface drainage patterns, and surface soil conditions. This may affect infiltration rates and locations.

Screening Decision: Excluded-Low Consequence.

Screening Argument: Intrusion of a basalt dike at or near the repository block could locally alter the hydrological properties of the host rock. However, analogue studies show that alteration is quite limited, typically only found within a few meters of intrusions (Valentine et al. 1998 [DIRS 119132], p. 5-74). The effects of local-scale heterogeneity on unsaturated flow and transport at Yucca Mountain were investigated by Zhou et al. (2003 [DIRS 162133]). The conclusions reached in this study were that local heterogeneity in fracture permeability had a negligible effect on flow (Zhou et al., 2003 [DIRS 162133], Section 5.2). Effects on transport were found to be more significant, but the uncertainty in transport behavior caused by local heterogeneity was less than that caused by uncertainty in matrix diffusion. Therefore, local variations in properties caused by dike intrusions would result in only minor changes to the flow patterns. Other aspects related to the effects of igneous intrusions, such as mineral alteration, are discussed in Sections 6.8.1 (FEP 1.2.04.02.0A) and 6.8.2 (FEP 1.2.06.00.0A). These aspects were also found to be limited in extent and duration. 
Dikes are expected to range between about $0.5 \mathrm{~m}$ and $4.5 \mathrm{~m}$ in thickness, with an average of $1.5 \mathrm{~m}$ (BSC 2004 [DIRS 169980], Section 6.3.1). A dike intersecting a drift would bleed magma into the drift. A simple conduction-only cooling model indicates that if a drift is instantaneously and entirely filled with basaltic magma at $1150^{\circ} \mathrm{C}$, it (and the surrounding rock) will cool to sub-boiling in less than three years, with boiling temperatures no more than $10 \mathrm{~m}$ from the drift (BSC 2004 [DIRS 170028], Figures 6-98 and 6-99; DTN: MO0408EG831811.008 [DIRS 173078]). Contact metamorphism caused by dikes appears to be confined to distances of less than $5 \mathrm{~m}$ from the dike (BSC 2004 [DIRS 169734], Section 4.2.3.5). With significant thermal perturbations limited to less than 100 years and alteration limited to zones of a few meters around the dike, the thermal and chemical effects of basaltic magmatism on UZ processes are negligible.

Igneous activity could also affect the ground surface of the repository through eruptions of lava or ash. If lava were to dam one or more washes that drain the repository block, the dam would not produce a large surface-water impoundment relative to the repository emplacement area. Such lava dams would probably not be effective in any case, as the lava would consist of clinker or aa (aa is a lava flow with a surface typified by angular, jagged blocks). Another potential effect would be the deposition of an ash cover on the repository block. The range of mean particle size erupted during violent Strombolian eruptions is described by a log-triangular distribution with a minimum of $0.01 \mathrm{~mm}$, a mode of $0.1 \mathrm{~mm}$, and a maximum of $1.0 \mathrm{~mm}$. (BSC 2004 [DIRS 169980], Table 7-1). These values are typical of median grain sizes in silt, fine sand, and coarse sand, which typically have porosities of $40 \%, 35 \%$, and $30 \%$, respectively. (Bear 1972 [DIRS 156269], pp. 40 and 46). Using these porosity and grain size ranges and the modified Kozeny-Carmen equation for permeability (Bear 1972 [DIRS 156269], p. 166):

$$
k=\frac{d_{m}^{2}}{180} \frac{n^{3}}{(1-n)^{2}}
$$

where $k$ is permeability, $d_{m}$ is grain size, and $n$ is porosity, the estimated permeability of the ash deposit ranges from $4 \times 10^{-14}$ to $2 \times 10^{-10} \mathrm{~m}^{2}$. Bedrock saturated hydraulic conductivity in the infiltration model ranges from 0.01 to $500 \mathrm{~mm} / \mathrm{d}$, corresponding to a permeability range of $1 \times 10^{-17}$ to $6 \times 10^{-13} \mathrm{~m}^{2}$, and soil saturated hydraulic conductivity ranges from $5.6 \times 10^{-6}$ to $3.8 \times 10^{-5} \mathrm{~m} / \mathrm{s}$, corresponding to a permeability range of $6 \times 10^{-13}$ to $4 \times 10^{-12} \mathrm{~m}^{2}$ (BSC 2004 [DIRS 170007], Tables B-3 and B-4; DTN: GS000308311221.004 [DIRS 146853]). Therefore, an ash deposit is expected to similar in permeability to the underlying bedrock and soil.

As an additional consideration, the mean probability for the occurrence of a volcanic intrusion at Yucca Mountain is $1.7 \times 10^{-8}$ per year (BSC 2004 [DIRS 169989], Table 7-1). This results in a greatly reduced expected consequence from a probability-weighted perspective. This FEP is therefore excluded because it will not significantly change radiological exposures to the RMEI or radiological releases to the accessible environment. Section 6.1.2 explains why low consequence for specific elements of the UZ system leads to low consequence for total system performance.

Supporting Reports: Not applicable. 


\subsubsection{Seismic Activity Changes Porosity and Permeability of Rock (2.2.06.01.0A)}

FEP Description: Seismic activity (fault displacement or vibratory ground motion) has a potential to change rock stresses and result in strains that affect flow properties in rock outside the excavation-disturbed zone. It could result in strains that alter the permeability in the rock matrix. These effects may decrease the transport times for potentially released radionuclides.

Screening Decision: Excluded-Low Consequence.

Screening Argument: This argument is directed towards the effects of seismic activity (fault displacement and vibratory ground motion) on the rock matrix. For effects of seismic activity on the rock fractures, see FEPs 2.2.06.02.0A and 2.2.06.02.0B. The effects of stress changes on flow in the UZ have been investigated in Drift Scale THM Model (BSC 2004 [DIRS 169864]). In this model, the effects of thermal stress are evaluated in terms of changes to rock fracture properties, but not rock matrix (BSC 2004 [DIRS 169864], Section 6.2). This modeling approach is based on the approximation that the effects of changes to the rock matrix porosity and permeability caused by changes in rock stress are negligible compared with changes to the fracture porosity and permeability. The basis for this approximation is that the matrix, being approximately $10 \%$ pore space and $90 \%$ solid, is stronger than the fractures, which are $100 \%$ pore space. The fractures are, therefore, more sensitive to mechanical strain; when a volume of fractured rock is subjected to a stress, most of the resulting strain occurs in the fractures. Furthermore, the fracture volume is only about $1 \%$ of the bulk volume. Therefore, when a small mechanical strain in the rock is mostly taken up by change in fracture volume, the change in fracture volume (and, therefore, fracture aperture) is relatively large, with a corresponding large change in fracture permeability. This should be true not only for thermal stress, but also for other sources of mechanical stress, such as seismic activity.

The drift-scale THM model was validated by comparing its simulations to experimental data (BSC 2004 [DIRS 169864], Section 7) and the dominant mode of stress-induced permeability change was found to be elastic fracture opening or closing caused by changes in stress normal to the fractures (BSC 2004 [DIRS 169864], Section 8.2). Therefore, changes to the rock matrix characteristics due to seismic activity are excluded from TSPA-LA because they will not significantly change radiological exposures to the RMEI or radiological releases to the accessible environment. Section 6.1.2 explains why low consequence for specific elements of the UZ system leads to low consequence for total system performance.

Supporting Reports: Not applicable.

\subsubsection{Seismic Activity Changes Porosity and Permeability of Faults (2.2.06.02.0A)}

FEP Description: Seismic activity (fault displacement or vibratory ground motion) has a potential to produce jointed-rock motion and change stress and strains that alter the permeability along faults. This could result in reactivation of preexisting faults or generation of new faults, which could significantly change the flow and transport paths, alter or short-circuit the flow paths and flow distributions close to the repository, and/or create new pathways through the repository. These effects may decrease the transport times for potentially released radionuclides.

Screening Decision: Excluded-Low Consequence. 
Screening Argument: This FEP is similar in content to the one discussed in Section 6.8.7 (FEP 2.2.06.02.0B). Like fractures, faulting is a characteristic feature of Yucca Mountain geology. The present-day faults are addressed in the flow and transport models of the UZ (FEP 1.2.02.02.0A). Fault movements can affect the fracture properties through changes in rock stress. This aspect of the problem is discussed in Section 6.8.7 (FEP 2.2.06.02.0B). Fault movements can also change the properties of the faults themselves, and this aspect has been investigated with a sensitivity study reported in Appendix D of this report.

Movements produced by a fault displacement will result in changes in the rock stress in the vicinity of the fault. The change in rock stress will decrease with distance from any given fault that does move. However, the magnitude of the changes in rock stress as a function of distance from the fault depends on the specific details of the fault displacement (e.g., magnitude of fault motion, direction of fault movement, extent of the fault that participates in the movement) and the mechanical properties of the surrounding rock (e.g., fracture spacing, fracture stiffness, geomechanical properties of the rock matrix). Given some change in rock stress, the fractured rock mass will respond to the change in stress through deformation, or strain, in the rock. Note that this induced strain can affect the geometry of fractures in the rock. The effects of stress changes on flow in the UZ have been investigated in Drift Scale THM Model (BSC 2004 [DIRS 169864]). In this model, the effects of thermal stress are evaluated in terms of changes to rock fracture properties, but not rock matrix (BSC 2004 [DIRS 169864], Section 6.2); see FEP 2.2.06.01.0A. This modeling approach is used because the effects of changes to the rock matrix porosity and permeability caused by changes in rock stress are negligible compared with changes to the fracture porosity and permeability. It is reasonable to expect that this should be true for other sources of mechanical stress, such as seismic activity. In theory, the effects of a given fault displacement could be evaluated using process-level calculations for the effects of the induced stress and strain on fracture geometry. However, this direct approach was not further used to specifically evaluate seismic effects because of the large uncertainty in the specification of the seismic event and complexity of translating seismic motion along faults into imposed stresses. An alternative bounding approach was used to assess the potential effects of fault displacement on repository performance as described in Appendix D of this report.

The approach used to investigate the effects of fault displacements was to evaluate the sensitivity of radionuclide transport in the UZ to changes in fracture apertures. (Appendix D, Section D3.2.6 of this report). This is investigated over a wide enough range to bound the potential changes in fracture aperture that could result from any fault displacement at Yucca Mountain with an annual exceedance probability greater than $10^{-8}$ (Section 5). The largest fault movement close to the repository is likely to be along the Solitario Canyon fault (Appendix D, Section D2.1.1 of this report). The general topic of seismic hazard at Yucca Mountain has been investigated in detail in Probabilistic Seismic Hazard Analyses for Fault Displacement and Vibratory Ground Motion at Yucca Mountain, Nevada (CRWMS 1998 [DIRS 103731]). For the Solitario Canyon fault, the hazard analysis shows fault displacement of approximately $10 \mathrm{~m}$ (CRWMS 1998 [DIRS 103731], Figure 8-3; DTN: MO0401MWDRPSHA.000 [DIRS 166962]) at an annual exceedance probability of $10^{-8}$ (Section 5). An approximately $10 \mathrm{~m}$ fault movement was used as the fault displacement for these analyses. The results of geomechanical models suggest that a factor of 10 change in aperture would bound the effects of tensile strain from such a fault movement (Appendix D, Section D3.2.6 of this report). Based on the cubic law for fracture permeability, a factor of 10 change in aperture leads to a factor of 1,000 change in 
permeability. Fracture permeabilities reduced by a factor of 1,000 were found to be inconsistent with infiltration rates. Therefore, reductions in aperture were limited to factors of 0.2 , and in the case of a wetter climate, the lowest value that could be used was a factor of 0.5 , leading to permeability reductions of 125 and 8 , respectively.

The sensitivity study considered the effects of changes in fracture aperture on porosity, permeability, and capillary pressure (Appendix D, Section D3.2.7 of this report). Calculations were then performed for unsaturated flow and transport using the modified fracture properties (Appendix D, Section D3.3 of this report). A subset of these sensitivity calculations considered changes to these hydrological properties restricted to faults specifically identified in the UZ Flow Model for present-day and glacial transition climates (Appendix D, Section D3.3.1, Figures D-7 and D-8 of this report). The results showed almost no change in transport behavior between the repository and the water table for a range in fracture apertures affected by factors of 0.2 to 10 when only fault fractures are altered. This study concluded that radionuclide transport in the UZ is highly insensitive to the fault properties.

The results presented in Appendix D, Section D3.3 are supported by scientific notebook YMP-LBNL-GJM-GZ-1 (Zhang and Moridis 2004 [DIRS 171212], pp. 41-49). These results are also corroborated by an earlier study (CRWMS M\&O (2000 [DIRS 151953], Section 6.2).

The analysis in Appendix D of this report, as summarized in the preceding paragraphs, considers the effects of altering the hydrologic properties of fractures in faults on transport. The effects on seepage have also been studied in Abstraction of Drift Seepage (BSC 2004 [DIRS 169131], Sections 6.4.4.1.2 and 6.5.1.5). Dilation of fractures, resulting from seismic activity, increases the fracture aperture and permeability, allowing greater flow capacity to divert seepage around drifts; however, the increase in fracture aperture also reduces the capillary strength of the fractures, which acts to prevent water that percolates to the drift crown from seeping. For a collapsed drift scenario, the permeability in the host rock outside a rubble-filled collapsed drift is estimated to increase by one to two orders of magnitude and the capillary pressure is estimated to decrease by less than a factor of 0.5 in the drift crown (BSC 2004 [DIRS 169864], Section 8.1). These two effects counteract each other, resulting in effectively no increase in seepage. Therefore, changes to fault properties due to seismic activity are excluded because they will not significantly change radiological exposures to the RMEI or radiological releases to the accessible environment. Section 6.1.2 explains why low consequence for specific elements of the UZ system leads to low consequence for total system performance.

Supporting Reports: Not applicable.

\subsubsection{Seismic Activity Changes Porosity and Permeability of Fractures (2.2.06.02.0B)}

FEP Description: Seismic activity (fault displacement or vibratory ground motion) has a potential to change stress and strains that alter the permeability along fractures. This could result in reactivation of pre-existing fractures or generation of new fractures, which could significantly change the flow and transport paths, alter or short-circuit the flow paths and flow distributions close to the repository, and/or create new pathways through the repository. These effects may decrease the transport times for potentially released radionuclides. 
Screening Decision: Excluded-Low Consequence.

Screening Argument: Movements produced by a fault displacement will result in changes in the rock stress in the vicinity of the fault. The change in rock stress will decrease with distance from any given fault that does move. However, the magnitude of the changes in rock stress as a function of distance from the fault depends on the specific details of the fault displacement (e.g., magnitude of fault motion, direction of fault movement, extent of the fault that participates in the movement) and the mechanical properties of the surrounding rock (e.g., fracture spacing, fracture stiffness, geomechanical properties of the rock matrix). Given some change in rock stress, the fractured rock mass will respond to the change in stress through deformation, or strain, in the rock. This induced strain can affect the geometry of fractures in the rock.

The effects of stress changes on flow in the UZ have been investigated in Drift Scale THM Model (BSC 2004 [DIRS 169864]). In this model, the effects of thermal stress are evaluated in terms of changes to rock fracture properties, but not rock matrix (BSC 2004 [DIRS 169864], Section 6.2; see FEP 2.2.06.01.0A). This modeling approach is used because the effects of changes to the rock matrix porosity and permeability caused by changes in rock stress are negligible compared with changes to the fracture porosity and permeability. It is reasonable to expect that this should be true for other sources of mechanical stress, such as seismic activity. In theory, the effects of a given fault displacement could be evaluated using process-level calculations for the effects of the induced stress and strain on fracture geometry. However, this direct approach was not further used to specifically evaluate seismic effects because of the large uncertainty in the specification of the seismic event and complexity of translating seismic motion along faults into imposed stresses. An alternative bounding approach was used to assess the potential effects of fault displacement on repository performance (Appendix D of this report).

The sensitivity of radionuclide transport in the UZ to changes in fracture apertures was studied to investigate the effects of fault displacements (Appendix D, Section D3.2.6 of this report). This is investigated over a wide enough range to bound the potential changes in fracture aperture that could result from any fault displacement at Yucca Mountain, with an annual exceedance probability of greater than $10^{-8}$ (Section 5). The largest fault movement close to the repository is likely to be along the Solitario Canyon fault (Appendix D, Section D2.1.1 of this report). The general topic of seismic hazard at Yucca Mountain has been investigated in detail in Probabilistic Seismic Hazard Analyses for Fault Displacement and Vibratory Ground Motion at Yucca Mountain, Nevada (CRWMS 1998 [DIRS 103731]). For the Solitario Canyon fault, the hazard analysis shows fault displacement of 10 m (CRWMS 1998 [DIRS 103731], Figure 8-3; DTN: MO0401MWDRPSHA.000 [DIRS 166962]) at an annual exceedance probability of $10^{-8}$ (Section 5). A 10-m fault movement was used as the fault displacement for these analyses. The results of geomechanical models suggest that a factor of ten change in aperture would bound the effects of tensile strain from a 10-m fault movement (Appendix D of this report). Based on the cubic law for fracture permeability, a factor of ten-change in aperture leads to a factor of 1,000 change in permeability. Fracture permeabilities reduced by a factor of 1,000 were found to be inconsistent with infiltration rates. Therefore, reductions in aperture were limited to factors of 0.2 , and in the case of a wetter climate, the lowest value that could be used was a factor of 0.5 , leading to permeability reductions of 125 and 8 , respectively. 
The sensitivity study considered the effects of changes in fracture aperture on porosity, permeability, and capillary pressure (Appendix D, Section D3.2.7 of this report). Calculations were then performed for unsaturated flow and transport using the modified fracture properties (Appendix D of this report).

In the context of the TSPA-SR three-dimensional UZ flow and transport model, sensitivity studies for UZ flow and transport presented in this analysis suggest that transport between the repository and the water table is only weakly coupled to changes in fracture aperture. Overall, insignificant changes in transport behavior are found for large changes in fracture aperture. Breakthrough at some points is found to be at most only about one order of magnitude earlier than the base case (under the present-day or the glacial transition climate), for an extremely conservative ten-fold increase in fracture aperture applied over the entire UZ domain. Effects of such magnitude on travel time are less significant than those caused by some of the other uncertainties. For example, infiltration uncertainties (DTN: LB03033DUZTRAN.001 [DIRS 170372]; BSC 2004 [DIRS 169861], Figure 6.7-1) result in breakthrough curve uncertainties with more than three orders of magnitude variation. Therefore, changes to fracture properties due to seismic activity are excluded because they will not significantly change radiological exposures to the RMEI or radiological releases to the accessible environment. Section 6.1.2 explains why low consequence for specific elements of the UZ system leads to low consequence for total system performance.

The results presented in Appendix D, Section D3.3 are supported by scientific notebook YMP-LBNL-GJM-GZ-1, pp. 41-49 (Zhang and Moridis 2004 [DIRS 171212]). These results are also corroborated by an earlier study (CRWMS M\&O 2000 [DIRS 151953], Section 6.2).

Supporting Reports: Not applicable.

\subsubsection{Seismic Activity Alters Perched Water Zones (2.2.06.03.0A)}

FEP Description: Strain caused by stress changes from tectonic or seismic events could alter the rock permeabilities that allow formation and persistence of perched-water zones.

Screening Decision: Excluded-Low Consequence.

Screening Argument: Perched water zones below the elevation of the repository have been found in site characterization boreholes. The potential release of perched water (that might contain released radionuclides) as a result of stress changes and fracture openings driven by seismic activity was evaluated using a bounding scenario in which all perched water was suddenly released. Although this may only have a small effect on the ultimate cumulative releases of radionuclides to the $\mathrm{SZ}$, it could focus the radionuclide releases in a relatively sharp "pulse" when the perched water is allowed to drain. This possibility was investigated by considering the volume of perched water in the fracture domain below the repository. The perched water in high-permeability fracture domains is the relevant feature because it is this volume that could potentially be quickly released to the saturated zone. Perched water in the matrix or low-permeability fractures would also ultimately desaturate, but this would be a much slower process and unlikely to cause any temporal pulses of radionuclide flux at the water table. The UZ flow model shows that the volume of perched water in the high-permeability fracture 
domain below the repository ranges from about $466 \mathrm{~m}^{3}$ to $1,190 \mathrm{~m}^{3}$ (Appendix A of this report). This volume may be compared with the water flux entering the repository footprint (i.e., the average infiltration rate times the area of the repository footprint), which ranges from $2,000 \mathrm{~m}^{3} / \mathrm{yr}$ to $192,000 \mathrm{~m}^{3} / \mathrm{yr}$ (Appendix A of this report). As shown in Appendix A of this report, the perched-water volume is seen to represent about 0.006 to 0.2 years of water flux. Thus, the perched-water volume in high-permeability fractures is small compared to the water flux through the repository horizon for one year. The sudden release of radionuclides that could be contained in this water volume would not cause a significant "pulse" in radionuclide mass flux at the water table. Therefore, the effects of changes in perched water due to seismic or tectonic effects are excluded from TSPA-LA because they will not significantly change radiological exposures to the RMEI or radiological releases to the accessible environment. For comparison, note that water table rise caused by climate change in the nominal performance assessment calculations instantly releases radionuclides from a much larger quantity of water in the UZ - on the order of $10^{8} \mathrm{~m}^{3}$ of water (Section 6.2.5, FEP 1.3.07.02.0B). (This is an order of magnitude estimate based on the following data: Repository footprint approximately equals $10^{7} \mathrm{~m}^{2}\left(5 \times 10^{6} \mathrm{~m}^{2}\right)$ (BSC 2004 [DIRS 168370]); Water table rise approximately equals $100 \mathrm{~m}$ (BSC 2004 [DIRS 170037], Sections 6.4.5 and 8.4); Water content of rock approximately equals 0.1 (range from 0.1 to 0.3 BSC 2005 [DIRS 173980], Table 6-6). Section 6.1.2 explains why low consequence for specific elements of the UZ system leads to low consequence for total system performance.

Supporting Reports: Not applicable.

\subsubsection{Undetected Features in the UZ (2.2.12.00.0A)}

FEP Description: Undetected features in the UZ portion of the geosphere can affect long-term performance of the disposal system. Undetected but important features may be present, and may have significant impacts. These features include unknown active fracture zones, inhomogeneities, faults and features connecting different zones of rock, different geometries for fracture zones, and induced fractures due to the construction or presence of the repository.

Screening Decision: Excluded-Low Consequence.

Screening Argument: Two kinds of undetected features are of concern: (1) features which, on the basis of previous investigations, could be thought to be present, (2) features totally unexpected. Features that could be present include buried Plio-Pleistocene basaltic intrusions; such features may be the cause of unresolved anomalies in existing geophysical mapping and investigations of such anomalies are ongoing. As discussed in Section 6.8.4, FEP 1.2.10.02.0A, the effects of small intrusions, or more generally, any heterogeneous features approximating meter scale intrusions (or smaller) are expected to have a negligible effect on flow and transport behavior in the UZ. The scenario that a major, critical feature in the vicinity of Yucca Mountain, such as a large seismogenic fault zone, has been overlooked is not expected, given the extensive site characterization conducted at Yucca Mountain (DOE 2004 [DIRS 169734], p. 1-1).

Unexpected features encountered in waste emplacement drifts will be assessed in terms of potential standoffs for waste package emplacement. The design criterion for standoff between 
Type I faults and repository openings is $60 \mathrm{~m}$ (Doraswamy 2004 [DIRS 167101], Section 4.11.2). By way of corroboration and clarification, the following standoff requirements have been identified in Underground Layout Configuration (BSC 2003 [DIRS 165572], Sections 7.1.3 and 7.3.1):

It is conservatively estimated that a 60-meter (197-foot) standoff from the trace of any Type I fault is adequate to reduce the impact of potential fault movement. This standoff considers potential fractured ground in proximity of the Type I fault and uncertainty as to where the fault is located at depth. The use of a 60-meter (197-foot) standoff for a LA design is conservatively applied.

In the event that the standoff from repository openings to a Type I fault is waived following a site impact analysis, a standoff must be maintained between Type I faults and any waste package. A standoff must be maintained between splays associated with Type I faults and any waste package. Areas that contain Type I faults should be avoided, but if unavoidable, they must be allowed for in engineering design. It is conservatively estimated that a standoff from the edge of the Type I fault or fault zone by 15 meters ( 49 feet) is adequate to reduce the impact of potential fault movement. Using a 15-meter (49-foot) standoff to establish useable drift length for the LA design is conservatively applied.

Induced fractures may occur near waste emplacement drifts due to the disturbance of the rock stress field caused by the presence of the drift openings. Induced fractures are not unexpected features and are included by default in underground testing of drift seepage as discussed in Section 6.2.9 (FEP 2.2.01.01.0A)

The major effect of fault features and fracture zones on flow and transport patterns below the repository is to allow downward pathways for flow that has been diverted laterally (BSC 2004 [DIRS 169861], Sections 6.2.2.1 and 6.6.3). The effects of the fault properties have been found to be much less important in terms of radionuclide transport behavior (Appendix D of this report). Lateral diversion beneath the repository is affected significantly by the presence of perched water bodies, which are postulated to exist as a result of permeability barriers (BSC 2004 [DIRS 169861], Sections 6.2.2.2 and 6.6.3). The effects of flow path diversion on transport may be evaluated based on the alternative perched water models presented in UZ Flow Models and Submodels (BSC 2001 [DIRS 158726], Section 6.2.2). Perched water models \#1 and \#2 are named the "flow-through" perched water model and "by-passing" perched water model, respectively (BSC 2001 [DIRS 158726], Section 6.2.2). For model \#1, the minimum permeability barriers are introduced to produce the known perched water bodies. For model \#2, all zeolitic units are modeled as unfractured and result in more extensive perched water. As the names imply, there is less lateral diversion in model \#1 than in model \#2 (BSC 2001 [DIRS 158726], Section 6.2.5). An extreme case is "no perched water" model \#3, which does not introduce any permeability barrier, leading to minimal lateral flow. However, this model is not supported by the data, because it does not predict perched water where such features are known to exist.

Comparisons for transport between the repository and the water table for the three perched water models were performed using sorbing and nonsorbing radionuclides (BSC 2001 [DIRS 158726], 
Section 6.7.2). The transport results for perched water models $\# 1$ and $\# 2$ have only minor differences (BSC 2001 [DIRS 158726], Figures 6-54 through 6-56). Although early breakthroughs are more substantial for model \#3, transport times are about the same or longer after 1,000 years for both sorbing and nonsorbing radionuclides. Furthermore, the effect of a finite number of undetected fault features that could potentially act as pathways to the water table necessarily has less impact on flow pathways than model \#3, as evidenced by the existence of large perched water bodies. Therefore, this FEP is excluded because it will not significantly change radiological exposures to the RMEI or radiological releases to the accessible environment. Section 6.1.2 explains why low consequence for specific elements of the UZ system leads to low consequence for total system performance.

Supporting Reports: Not applicable.

\subsection{REPOSITORY-PERTURBED THMC}

This group of FEPs is excluded from the TSPA-LA calculation. These FEPs concern the effects of changes to the thermal-hydrological-mechanical-chemical (THMC) environment as a result of repository excavations, heat, and materials, and the effects of these changes on hydrological, geochemical, and geomechanical processes.

Table 6-12 gives the FEP numbers and names categorized under Repository-Perturbed THMC.

Table 6-12. Excluded FEPs: Repository-Perturbed THMC

\begin{tabular}{|l|l|l|}
\hline Section Number & FEP Number & \multicolumn{1}{|c|}{ FEP Name } \\
\hline 6.9 .1 & $2.1 .09 .12 .0 \mathrm{~A}$ & Rind (chemically altered zone) forms in the near-field \\
\hline 6.9 .2 & $2.2 .01 .01 .0 \mathrm{~B}$ & Chemical effects of excavation and construction in the near-field \\
\hline 6.9 .3 & $2.2 .01 .02 .0 \mathrm{~A}$ & Thermally-induced stress changes in the near-field \\
\hline 6.9 .4 & $2.2 .01 .03 .0 \mathrm{~A}$ & Changes in fluid saturations in the excavation disturbed zone \\
\hline 6.9 .5 & $2.2 .01 .04 .0 \mathrm{~A}$ & Radionuclide solubility in the excavation disturbed zone \\
\hline 6.9 .6 & $2.2 .01 .05 .0 \mathrm{~A}$ & Radionuclide transport in the excavation disturbed zone \\
\hline 6.9 .7 & $2.2 .08 .03 .0 \mathrm{~B}$ & Geochemical interactions and evolution in the UZ \\
\hline 6.9 .8 & $2.2 .08 .07 .0 \mathrm{~B}$ & Radionuclide solubility limits in the UZ \\
\hline 6.9 .9 & $2.2 .10 .01 .0 \mathrm{~A}$ & Repository-induced thermal effects on flow in the UZ \\
\hline 6.9 .10 & $2.2 .10 .04 .0 \mathrm{~A}$ & Thermo-mechanical stresses alter characteristics of fractures near repository \\
\hline 6.9 .11 & $2.2 .10 .04 .0 \mathrm{~B}$ & Thermo-mechanical stresses alter characteristics of faults near repository \\
\hline 6.9 .12 & $2.2 .10 .05 .0 \mathrm{~A}$ & $\begin{array}{l}\text { Thermo-mechanical stresses alter characteristics of rocks above and below the } \\
\text { repository }\end{array}$ \\
\hline 6.9 .13 & $2.2 .10 .06 .0 \mathrm{~A}$ & $\begin{array}{l}\text { Thermo-chemical alteration in the UZ (solubility, speciation, phase changes, } \\
\text { precipitation/dissolution) }\end{array}$ \\
\hline 6.9 .14 & $2.2 .10 .07 .0 \mathrm{~A}$ & Thermo-chemical alteration of the Calico Hills unit \\
\hline 6.9 .15 & $2.2 .10 .09 .0 \mathrm{~A}$ & Thermo-chemical alteration of the Topopah Spring basal vitrophyre \\
\hline 6.9 .16 & $2.2 .10 .14 .0 \mathrm{~A}$ & Mineralogic dehydration reactions \\
\hline 6.9 .17 & $2.2 .08 .05 .0 \mathrm{~A}$ & Diffusion in the UZ \\
\hline
\end{tabular}

DTN: MO0501SEPFEPLA.001 [DIRS 172601].

UZ=unsaturated zone 


\subsubsection{Rind (Chemically Altered Zone) Forms in the Near-Field (2.1.09.12.0A)}

FEP Description: Thermal-chemical processes involving precipitation, condensation, and re-dissolution could alter the properties of the adjacent rock. These alterations may form a rind, or altered zone, in the rock, with hydrological, thermal, and mineralogical properties different from the initial conditions.

Screening Decision: Excluded-Low Consequence.

Screening Argument: The thermal-chemical interactions that will occur in the repository environment have been studied with respect to effects on the seepage water entering the waste emplacement drifts using the THC seepage model (BSC 2005 [DIRS 172862]). This model, which explicitly captures the effects of changes in temperature, $\mathrm{pH}$, Eh, ionic strength (and other compositional variables), time dependency, precipitation or dissolution effects, and effects of resaturation, was used to examine near-field and drift seepage flow and chemistry (BSC 2005 [DIRS 172862], Section 6.2). Changes in fracture permeabilities resulting from mineral precipitation or dissolution were found to be on the order of the natural variation in these properties (DTN: LB0302DSCPTHCS.001 [DIRS 164744]; BSC 2005 [DIRS 172862], Section 6.5.5.3; BSC 2004 [DIRS 170038], Table 6-5), with most of the substantial effects limited to regions above and to the side of the drift within about a drift diameter (BSC 2005 [DIRS 172862], Figures 6.5-39 and 6.5-40). The predicted mineral precipitation reduces permeability in the affected regions and leads to a reduction in flow around the drift. THC effects on fracture characteristics have been evaluated with the THC seepage model that explicitly accounts for fracture flow affected by THC parameter alterations (BSC 2004 [DIRS 169131], Section 6.4.4.2). It was demonstrated that the effects of these potential alterations on near-field and drift seepage flow can be neglected in the TSPA-LA, because the expected changes would lead to less seepage (DTN: LB0302DSCPTHCS.001 [DIRS 164744]; BSC 2004 [DIRS 169131], Section 6.5.1.4). Consequently, neglect of this effect is likely to result in slightly conservative model predictions for both drift seepage and radionuclide transport phenomena. Therefore, this FEP is excluded because it will have no adverse affects on the radiological exposure to the RMEI, or radionuclide release to the accessible environment. Section 6.1.2 explains why low consequence for specific elements of the UZ system leads to low consequence for total system performance.

Supporting Reports: Not applicable.

\subsubsection{Chemical Effects of Excavation and Construction in the Near-Field (2.2.01.01.0B)}

FEP Description: Excavation may result in chemical changes to the incoming groundwater and to the rock in the excavation disturbed zone.

Screening Decision: Excluded-Low Consequence.

Screening Argument: This FEP concerns the changes in the host rock environment immediately surrounding the waste emplacement drifts. Related FEP 1.1.02.00.0A (Chemical effects of excavation and construction in the EBS) is discussed in Engineered Barrier System Features, Events, and Processes (BSC 2005 [DIRS 173781, Section 6.2.1]). Changes are expected in the rock fracture properties from excavation disturbance, stress relief around the 
opening, and ground support. However, these changes will not affect water chemistry. Excavation will introduce water (for dust control), but this should not have any significant effect on water chemistry. This is based on the limited volumes of water that are typically lost during underground excavation (for example, for ESF construction the average was required to be less than $7.4 \mathrm{~m}^{3}$ per meter of tunnel length, with a projected tunnel width of $7.6 \mathrm{~m}$, or approximately $1 \mathrm{~m}^{3} / \mathrm{m}^{2}$ of the projected horizontal area of an excavation (BSC 2002 [DIRS 160689], Section 13.2.16). Furthermore, any water that remains local to the emplacement drifts will be more strongly affected by ventilation and thermal dryout. Any construction water that penetrates the UZ deeply through fractures is not likely to have any significant interaction with released radionuclides. The ground support for the emplacement drifts can affect water flow patterns in the immediate vicinity of the drift and can affect the aqueous geochemistry in the drift environment and along flow pathways from the drift to the water table. However, detailed simulations were made using the predictive seepage model for performance assessment (BSC 2004 [DIRS 167652], Section 6.5) to study the effect of rock bolts in the drift crown on seepage into drifts. These features were found to have only a minor effect on seepage, less than 2\% (DTN: LB0304SMDCREV2.001 [DIRS 173235]; BSC 2004 [DIRS 167652], Table 6-4), owing to the small area for water to enter the rock-bolt boreholes from the surrounding formation (BSC 2004 [DIRS 169131], Section 6.4.2.5). From these results, the presence of rock bolts is not considered a relevant factor for seepage into drifts. Based on this finding, only a minor quantity of the total water intercepting a drift is likely to move through rock-bolt pathways. Other ground-support materials will not affect flow patterns in the rock, because these materials are entirely within the emplacement drift.

The principal ground support in the emplacement drifts is expected to be SS 316L rock bolts and steel sheets (BSC 2005 [DIRS 173498]). A model of the effects of steel ground support on aqueous chemistry has been developed (BSC 2005 [DIRS 173727], Section 6.8). The model considered the interaction of "Bin 11" water with SS 316L ground support materials. Interaction with the abstracted "Bin 11" seepage water was chosen, because this is the most likely water to be present, occurring in almost 40\% of the abstracted periods (BSC 2005 [DIRS 173727], Table 6.6-5). In addition, this Bin 11 water is seen to occur during the relevant period for the corrosion of 316L stainless steel, in the range of approximately 500 to 5,000 years for four of the five seepage water compositions shown in Engineered Barrier System: Physical and Chemical Environment (BSC 2005 [DIRS 173727], Tables 6.6-9 through 6.6-13). The effect of dissolving the abstracted SS316L steel species into Bin 11 water was found to be negligible (BSC 2005 [DIRS 173727], Table 6.8-5; DTN: SN0312T0510102.013 [DIRS 174488]). The Bin 11 water with and without the $4.7 \times 10^{-3}$ moles of SS316L added was found to only have two differences in the water chemistries at the 6th significant figure for ionic strength and $\mathrm{C}$ total molality (BSC 2005 [DIRS 173727], Section 6.8.4.3). Use of "Bin 7" seepage water was selected as an uncertainty case and is described in Engineered Barrier System: Physical and Chemical Environment (BSC 2005 [DIRS 173727], Section 6.12.4.1). There is effectively no change in the aqueous water chemistry caused by abstracted stainless steel corrosion and corrosion product formation in this case, as with the basecase Bin 11 seepage water (BSC 2005 [DIRS 173727], Section 6.12.4.1.3). This FEP is, therefore, excluded because it will not significantly change radiological exposures to the RMEI or radiological releases to the accessible environment. Section 6.1.2 explains why low consequence for specific elements of the UZ system leads to low consequence for total system performance. 
Supporting Reports: Not applicable.

\subsubsection{Thermally Induced Stress Changes in the Near-Field (2.2.01.02.0A)}

FEP Description: Changes in host rock properties may result from thermal effects or other factors related to emplacement of the waste. Properties that may be affected include rock strength, fracture spacing and block size, and hydrologic properties such as permeability and sorption.

Screening Decision: Excluded-Low Consequence.

Screening Argument: The results of the coupled drift-scale THM model presented in Drift Scale THM Model (BSC 2004 [DIRS 169864], Sections 6.5, 6.6, and 6.9) shows that the impact of time-dependent THM processes will last for well over 10,000 years, but these processes have a small or moderate impact on the drift scale $\mathrm{TH}$ behavior, including a negligible impact on the temperature evolution and small impact on the percolation flux. The model accounts for rock strength and fracture spacing. Rock strength is modeled as independent of temperature (BSC 2004 [DIRS 169864], Table 6.4.5-1). Similarly, fracture frequency (or spacing) is also modeled as independent of temperature (DTN: LB0205REVUZPRP.001 [DIRS 159525]; BSC 2004 [DIRS 169864], Table 4.1-3a). The THM model, including these parameterizations, were found to compare well with measured rock mechanical behavior in the drift-scale test (BSC 2004 [DIRS 169864], Section 7.4.2). These model results were obtained for a conservative estimate of input THM properties (thermal expansion coefficient and stress versus permeability function), which is sufficient for bounding the possible impact of the THM processes on permeability and percolation flux.

The THM simulations discussed in Drift Scale THM Model (BSC 2004 [DIRS 169864], Sections 6.5 through 6.7) suggest that temperature-induced stress decreases the vertical fracture permeability in the vicinity of waste emplacement drifts, especially in the Tptpmn unit (BSC 2004 [DIRS 169864], Figure 6.5.4-1). The vertical fracture permeability changes more than the horizontal fracture permeability because thermal expansion in the horizontal direction is constrained by surrounding rock, while expansion in the vertical direction is not constrained (that is, the ground surface can rise). However, these permeability changes do not result in significant changes in the flow fields (BSC 2004 [DIRS 169864], Sections 6.5.5 and 6.6.2). In particular, the seepage rates calculated for a permeability field including THM permeability changes were similar to, but slightly smaller than, those calculated for a permeability field representative of the initial postexcavation conditions. (DTN: LB0304SMDCREV2.004 [DIRS 163691]; BSC 2004 [DIRS 169131], Section 6.4.4.1). Therefore, the impact of THM property changes is neglected in the seepage abstraction.

Thermal effects on sorption are evaluated in Section 6.9.13 (FEP 2.2.10.06.0A). Thermal effects on rockfall and drift degradation are included in the analysis of drift degradation (BSC 2004 [DIRS 166107], Sections 6.3 and 6.4).

Note that rockfall and drift collapse are discussed in FEPs 2.2.01.01.0A and 2.2.07.20.0A. Changes in rock strength and block size have no other impacts on UZ flow and transport 
processes. Fracture spacing in the Drift Degradation Analysis (BSC 2004 [DIRS 166107], Sections 6.4.1.1 and 6.4.2.2.2.1) is fixed and is not affected by thermal effects.

The overall effect of THM coupled processes on drift-scale radionuclide transport may also be excluded, because the primary effect of THM processes leads to enhanced seepage diversion and reduced drift seepage, reduced water saturations beneath the drift and, therefore, greater partitioning of radionuclide releases to the rock matrix. This FEP is, therefore, excluded because it will have no adverse affects on the radiological exposures to the RMEI, or radionuclide release to the accessible environment. Section 6.1.2 explains why low consequence for specific elements of the UZ system leads to low consequence for total system performance.

Supporting Reports: Not applicable.

\subsubsection{Changes in Fluid Saturations in the Excavation Disturbed Zone (2.2.01.03.0A)}

FEP Description: Fluid flow in the region near the repository may be affected by the presence of the excavation, waste, and EBS. Some dry-out will occur during excavation and operations.

Screening Decision: Excluded-Low Consequence.

Screening Argument: Inclusion of preclosure dryout is not significant for thermal seepage (BSC 2005 [DIRS 172232], Section 6.2.1.3.3). The overall effect of ventilation dryout on drift-scale radionuclide transport may also be excluded, because thermal dryout and rewetting will erase nearly any effect of the ventilation dryout. Sensitivity studies in FY 01 Supplemental Science and Performance Analyses, Volume 1: Scientific Bases and Analyses (BSC 2001 [DIRS 155950], Section 5.3.2.4.4) indicate that inclusion of preclosure dryout gives rise to slightly higher temperatures during the heating period compared to a model that ignores the influence of preclosure dryout. Therefore, this FEP is excluded based on low consequence. Section 6.1.2 explains why low consequence for specific elements of the UZ system leads to low consequence for total system performance.

Other aspects of this FEP are discussed elsewhere. For the effects of the excavation on fluid flow, see FEP 2.2.07.20.0A; for the effects of waste heat on fluid flow, see FEPs 2.2.10.10.0A and 2.2.10.12.0A; for the effects of the engineered barrier system (EBS) (rock bolt holes) on fluid flow, see FEP 1.1.01.01.0B.

Supporting Reports: Not applicable.

\subsubsection{Radionuclide Solubility in the Excavation Disturbed Zone (2.2.01.04.0A)}

FEP Description: Radionuclide solubility limits in the excavation-disturbed zone may differ from those in the EBS.

Screening Decision: Excluded-Low Consequence.

Screening Argument: If solubility limits are lower in the EDZ than in the emplacement drifts, then some dissolved radionuclides will precipitate as water flows out of the drifts. In this case, exclusion of the FEP would not result in an underestimation of radionuclide transport. The 
magnitude of this conservative approximation may be qualitatively evaluated through a comparison of the different ranges of chemical environments estimated for the engineered barrier system, compared with the EDZ and $\mathrm{UZ}$ in general. The $\mathrm{pH}$ of waters inside the drift range from less than five to more than ten (BSC 2005 [DIRS 173727], Figures 6.13-2 through 6.13-12). The evolution of water chemistry in the UZ, however, is not so broad. Near the drift, the $\mathrm{pH}$ ranges from roughly 7 to 8.5 (BSC 2005 [DIRS 172862], Figures 6.5-12, 6.5-25, 6.5-58).-17). Given the much larger range of $\mathrm{pH}$ inside the drift, equilibrium solution concentrations for radionuclides inside the drift could be significantly larger than equilibrium solution concentrations in the UZ. See also Section 6.9.6 (FEP 2.2.01.05.0A) for additional information on this subject. If solubility limits are higher in the EDZ than in the emplacement drifts, then radionuclides entering the EDZ will remain in solution and there will be no effect on radionuclide transport.

Solubility limits could also affect the formation of certain kinds of true colloids, such as polymeric forms of plutonium oxide (BSC 2005 [DIRS 174290], Section 6.3.1). However, only small quantities have been observed to form in experiments on waste form degradation (BSC 2005 [DIRS 174290], Sections 6.3.1 and 8.1). Furthermore, these colloids are expected to undergo formation of pseudocolloids in the near-field aquifer system (BSC 2005 [DIRS 174290], Section 6.3.1) and are, therefore, excluded.

Therefore, the effects of different solubility limits in the EDZ are excluded because they will have no adverse affects on the radiological exposures to the RMEI, or radionuclide release to the accessible environment. Section 6.1.2 explains why low consequence for specific elements of the UZ system leads to low consequence for total system performance.

Supporting Reports: Not applicable.

\subsubsection{Radionuclide Transport in the Excavation Disturbed Zone (2.2.01.05.0A)}

FEP Description: Radionuclide transport through the excavation disturbed zone may differ from transport in the EBS and the undisturbed host rock. Transport processes such as dissolution and precipitation, sorption, and colloid filtration should be considered.

Screening Decision: Excluded-Low Consequence.

Screening Argument: This FEP refers to the effects of altered fracture properties in the disturbed zone immediately surrounding the waste emplacement drifts on radionuclide transport. The effects of changes in fracture aperture on radionuclide transport were investigated at the mountain scale (FEP 2.2.06.02.0B and Appendix D of this report). The results of this analysis indicate that transport behavior is relatively insensitive to changes in fracture aperture by as much as a factor of ten. Investigations on the effects of stress relief on fracture permeability in the EDZ have found that the vertical permeability beneath the drift is affected over a very narrow zone, on the order of one to two meters for changes in permeability more than a factor of two (DTN: LB0306DRSCLTHM.002 [DIRS 174490]; BSC 2004 [DIRS 169864], Sections 6.5 .1 and 6.6.1).

The drift-scale radionuclide transport analyses have shown that the main factor affecting radionuclide transport immediately below the waste emplacement drift is the partitioning of 
radionuclides exiting the drift between rock fractures and matrix (BSC 2004 [DIRS 170040], Section 6.4). Aperture affects this partitioning through its influence on fracture water content (BSC 2004 [DIRS 170040], Section 6.4.2). Fracture water content is calculated as the product of fracture water saturation and fracture porosity. The uncertainty in this parameter is primarily a result of uncertainty in fracture water residual saturation which has a broad range, from 0.001 to 0.1 , based on experimental data for capillary materials that cover a wide range in effective apertures (BSC 2004 [DIRS 170040], Section 6.4.5). Fracture porosity in the waste emplacement zones is on the order of 1\% (DTN: LB0205REVUZPRP.001 [DIRS 159525]), and its theoretical maximum is one but because of the presence of matrix blocks its maximum possible value is less than one. On the other hand, fracture porosity can be reduced by a much larger factor because it can approach zero. Large reductions in fracture aperture will lead to large reductions in fracture porosity and water content. However, reducing fracture water content increases the partitioning of radionuclides from the waste emplacement drift to the rock matrix, which can only result in reduced rates of radionuclide transport. Increases in fracture aperture are limited in terms of the effect on fracture water content because of limitations on the increase in fracture porosity and the trend for residual saturation to decrease with an increase in aperture or permeability (Dombrowski and Brownell 1954 [DIRS 163222], Figure 7). Due to limited information regarding functional dependencies between fracture aperture and residual saturation, residual saturation is not treated in the model as a function of fracture aperture. Given the wide range of uncertainty in fracture residual saturation already included in the radionuclide transport model (BSC 2005 [DIRS 173433], Section 6.5.2.5.7) and the limited potential range for increases in fracture aperture (i.e. porosity), the effects of the EDZ on fracture water content, and hence on fracture aperture, may be neglected.

Therefore, the effects of altered fracture properties in the EDZ are excluded because they will not significantly change radiological exposures to the RMEI or radiological releases to the accessible environment. Section 6.1.2 explains why low consequence for specific elements of the UZ system leads to low consequence for total system performance.

The effects of precipitation of aqueous radionuclides on transport in the EDZ also are excluded (FEP 2.2.01.04.0A). The precipitation of radionuclides as a solid phase slows the progress of the radionuclide transport, which occurs in the aqueous phase. If the radionuclide remains as a solid precipitate long enough for the radionuclide to decay, then precipitation prevents the radionuclide from reaching the accessible environment. Therefore, excluding precipitation for radionuclides that undergo simple decay is conservative because precipitation delays radionuclide transport. For radionuclides that undergo chain decay, excluding precipitation will be conservative because the radionuclide source is not significantly depleted within the 10,000 -year regulatory time. In the latest total-system performance assessment, dose rates for all radionuclides are predicted to increase over tens of thousands of years (CRWMS M\&O 2000 [DIRS 153246], Figures 4.1-5 and 4.1-7). This is a result of the spread of waste package failures over time (CRWMS M\&O 2000 [DIRS 153246], Figure 4.1-9) and the slow release of radionuclides from the waste emplacement drifts. Therefore, during the 10,000-year period, the highest concentration for any radionuclide at the receptor is expected to occur under conditions giving the greatest transport rates. Reduced solubilities for neptunium, americium, plutonium, thorium, and uranium were investigated as a sensitivity in TSPA-SR (CRWMS M\&O 2000 [DIRS 153246], Sections 3.5.5, 4.1.3, and Figures 4.1-19a and 4.1-20). The dose rates for radionuclides affected by the lower solubilities (including decay products such as ${ }^{226} \mathrm{Ra}$ ) were 
found to be lower in the reduced-solubility case. This leads to the conclusion that suppressing precipitation of radionuclides in the TSPA-LA model results in higher calculated dose rates. Therefore, precipitation of radionuclides is excluded; this exclusion leads to underestimation of repository performance.

The principal effects of the near-field environment on transport are temperature and geochemical environment. Thermal effects on sorption are evaluated in Section 6.9.13 (FEP 2.2.10.06.0A), where increased temperatures are found to slightly increase sorption. Compositional variations found at the base of the drift in Drift-Scale THC Seepage Model (BSC 2005 [DIRS 172862], Figures 6.5-12 to 6.5-20) lie within the range of compositional variations expected in the unsaturated zone and accounted for in terms of radionuclide sorption (BSC 2004 [DIRS 164500], Appendix A, Section A4).

Supporting Reports: Not applicable.

\subsubsection{Geochemical Interactions and Evolution in the UZ (2.2.08.03.0B)}

FEP Description: Groundwater chemistry and other characteristics, including temperature, $\mathrm{pH}$, Eh, ionic strength, and major ionic concentrations, may change through time, as a result of the evolution of the disposal system or from mixing with other waters. Geochemical interactions may lead to dissolution and precipitation of minerals along the groundwater flow path, affecting groundwater flow, rock properties, and sorption of radionuclides. Effects on hydrologic flow properties of the rock, radionuclide solubilities, sorption processes, and colloidal transport are relevant. Kinetics of chemical reactions should be considered in the context of the time scale of concern.

Screening Decision: Excluded-Low Consequence.

Screening Argument: The thermal-chemical interactions that will occur in the repository environment have been studied with respect to effects on the seepage water entering the waste emplacement drifts using the THC seepage model (BSC 2005 [DIRS 172862]). This model, which explicitly captures the effects of changes in temperature, $\mathrm{pH}$, Eh, ionic strength (and other compositional variables), time dependency, precipitation or dissolution effects, and effects of resaturation, was used to examine near-field and drift seepage flow and chemistry (BSC 2005 [DIRS 172862], Section 6.2). Changes in fracture permeabilities resulting from mineral precipitation or dissolution were found to be on the order of the natural variation in these properties (DTN: LB0302DSCPTHCS.001 [DIRS 164744]; BSC 2005 [DIRS 172862], Section 6.5.5.3 and BSC 2004 [DIRS 170038], Table 6-5), with most of the substantial effects limited to regions above and to the side of the drift within about a drift diameter (BSC 2005 [DIRS 172862], Figures 6.5-39, 6.5-40). The predicted mineral precipitation reduces the permeability in the affected regions, and leads to a reduction in flow around the drift. These effects may be excluded because including such changes in fracture permeability would result in lower predicted doses in TSPA. Note that the effects of mineral precipitation on fracture permeability as it relates to near-field and drift seepage chemistry was also evaluated with the THC seepage model. A discussion is provided in Section 6.2.11, FEP 2.2.03.02A. The effects of mixing of waters are discussed in Section 6.2.32, FEP 2.2.08.12.0A, in connection with the THC seepage model. 
The representation of geochemistry in the THC Seepage Model includes the major solid phases (minerals and glass) encountered in geological units at Yucca Mountain, together with a range of possible reaction product minerals, $\mathrm{CO}_{2}$ gas, and the aqueous species necessary to include these solid phases and the pore-water composition within the THC model (BSC 2005 [DIRS 172862], Table 6.2-2). Compositional changes were only calculated near the drift boundary for the Drift-Scale THC Seepage Model (BSC 2005 [DIRS 172862]). Results from these simulations show most compositional variations returning to unperturbed conditions in 10,000 years or less. Variations in $\mathrm{pH}$ (DTN: LB0302DSCPTHCS.002 [DIRS 161976] and DTN: LB0307DSTTHCR2.002 [DIRS 165541]; BSC 2005 [DIRS 172862], Figures 6.5-12 and 6.5-25), a key compositional variable for sorption of some radionuclides (BSC 2004 [DIRS 164500], Appendix A), roughly lie within the range of variability investigated for initial pore-water compositions (BSC 2005 [DIRS 172862], Table 6.2-1). Bicarbonate is found to be depressed in concentration upon water resaturation at the drift wall, as expected based on the reduced $\mathrm{pH}$ values for the same time period.

Results were investigated for the THC Seepage Model applied to the Tptpll (TSw lower lithophysal unit) unit considering a range of initial pore-water compositions. In this model, five different initial pore-water compositions were investigated (BSC 2005 [DIRS 172862], Table 6.2-1). Peak concentrations usually found at the time of rewetting reflect mostly the small values of the first nonzero liquid-saturation output. In any case, elevated concentrations are predicted only for small liquid saturations that are not subject to significant fluid movement. The improved treatment of mineral precipitation at the boiling front used in the most recent THC model for the Tptpll also results in the prediction of lower, more realistic aqueous silica concentrations than in earlier models (DTN: LB0302DSCPTHCS.002 [DIRS 161976] and DTN: LB0307DSTTHCR2.002 [DIRS 165541]; BSC 2005 [DIRS 172862], Figure 6.5-16). This model also predicts, upon rewetting, more rapid return to near-ambient conditions for aqueous $\mathrm{Ca}$, $\mathrm{Na}$, and $\mathrm{Cl}$. The findings indicate that at the drift wall, most of the significant compositional variations resulting from thermal-chemical processes are limited to low-saturation conditions over time periods that are short relative to the 10,000-year performance period. Similar magnitudes of variation in chloride and $\mathrm{pH}$ were found in the mountain-scale THC model results (BSC 2005 [DIRS 174101], Section 6.4.3.3.2).

The effects of colloid formation are accounted for in the colloid source term (BSC 2005 [DIRS 174290], Section 6.5.2.3). Colloids are formed from the degradation of the high-level waste and spent nuclear fuel waste forms, EBS materials, and rock (BSC 2005 [DIRS 174290], Section 6.3.1). Radionuclides associated with colloids are modeled as either irreversibly or reversibly attached to colloids to encompass the broadest range of potential radionuclide-colloid interactions (BSC 2005 [DIRS 173980], Section 6.4.5). Elevated temperatures are expected to lead to fewer colloids due to the decrease in colloid stability. This is due to the greater energy of colloid motion at higher temperatures, which allows colloids to overcome the energy barrier associated with coagulation (BSC 2005 [DIRS 174290], Section 6.3.2). Boiling results in evaporation and this tends to increase the ionic strengths of colloid suspensions. This also leads to colloid instability due to compression of the electric double layer surrounding colloids (BSC 2005 [DIRS 174290], Section 6.3.2). Therefore, colloid entrainment as a result of boiling is not expected. 
In addition to natural materials, introduced materials may take part in geochemical interactions. Cementitious material (shotcrete) is planned for use as part of the ground support for the turnout intersections of the main access drifts and for the turnouts and intersections of the exhaust drifts with the emplacement drifts (BSC 2004 [DIRS 173871]). The incorporation of cementitious materials in the repository poses two concerns. The first is that the leaching of cementitious materials, particularly the shotcrete supporting the turnout intersections in the main access drifts and the intersections of the exhaust main drifts with the emplacement drifts, will affect repository performance by modifying the hydrologic properties of the surrounding rock and diverting the flow of water entering the drifts. The second concern is that an alkaline plume resulting from leaching of the cementitious material could enhance radionuclide transport to the accessible environment, either through the complexation of radionuclides or through the presence of pseudocolloids.

No cementitious material will be used in the emplacement drifts (BSC 2005 [DIRS 173498]). In nonemplacement drifts, all cementitious material (concrete invert and shotcrete used in shafts) will be removed prior to closure except that necessary for ground support (BSC 2005 [DIRS 174514], Section 3.1.1.15.1). The only significant cementitious materials remaining in the repository will be shotcrete supports and grout for rock bolt placement in nonemplacement drifts and turnout intersections. These materials can result in changes in water composition, particularly alkalinity and sulfate concentration (Hardin 1998 [DIRS 100123], Section 6.3.4).

The scientific and technical basis for the impact of shotcrete support structures and rock-bolt grout on repository performance, in relation to potential modifications to the hydrology and the effect of cementitious leachates on radionuclide migration, is presented by Ziegler (2004 [DIRS 171694]). Several factors, including direct carbonation of the cement itself due to $\mathrm{CO}_{2}$ gas diffusion and carbonation of any hyperalkaline plume that is generated as a result of cement-water interaction, act to minimize the effect of cementitious leachates. Direct carbonation of the cement consumes portlandite and other high-pH phases, rendering it benign. Diffusion of $\mathrm{CO}_{2}$ gas into the hyperalkaline plume, if generated, reduces the $\mathrm{pH}$ and calcium concentration in solution through acidification and calcite precipitation. These processes will result in leachate from the cementitious materials and their reaction products being similar in water quality to ambient pore water (DTN: LB0408CMATUZFT.004 [DIRS 171706]). Therefore, the presence of cementitious materials will not significantly change the transport of radionuclides. Plumes of leachate from cementitious materials, where not completely neutralized by interaction with $\mathrm{CO}_{2}$, may intersect radionuclide transport plumes from failed waste packages as they spread by diffusion and dispersion (DTN: LB0408CMATUZFT.003 [DIRS 171705]), but because the cementitious materials are only used in the turnouts (that is, at the ends) of emplacement drifts, and flow is mainly vertical in the UZ, such contact is somewhat limited, and as mentioned above, would not significantly affect radionuclide transport. Water is expected to move generally vertically through the waste emplacement horizon relative to the length scale of these drifts, with some flow diversion around the drifts resulting from the capillary barrier effect. This flow pattern is consistent with the drift-scale seepage model having no-flow lateral-boundary conditions (BSC 2004 [DIRS 167652], Section 6.3.1). The potential interaction of a plume of leachate from cementitious material with a radionuclide transport plume, by diffusion or dispersion, is discussed in Ziegler (2004 [DIRS 171694]) and in Appendix E of this report. 
According to the arguments presented in this section and in Appendix E of this report, the effects of geochemical interaction due to both natural and introduced materials are excluded from TSPA because they will not significantly change radiological releases to the accessible environment or radiological exposures to the RMEI. Section 6.1.2 explains why low consequence for specific elements of the UZ system leads to low consequence for total system performance.

Supporting Reports: Not applicable.

\subsubsection{Radionuclide Solubility Limits in the UZ (2.2.08.07.0B)}

FEP Description: Solubility limits for radionuclides may be different in unsaturated zone groundwater than in the water in the waste and EBS.

Screening Decision: Excluded-Low Consequence.

Screening Argument: In general the conditions that control the solubility of radionuclides will be different in the invert of the EBS and in the UZ, and may vary in the UZ with location and time. The argument for exclusion is presented here in two parts. First, because actinides are less soluble at higher temperature and the drift will be hotter than the surrounding rock, actinides will be less soluble in the invert than in the UZ below the invert. Therefore, transport away from the drift will be limited by the relatively low solubility in the invert, compared to the UZ. Despite the greater solubility away from the invert, there will be no source of actinides to increase the concentration to the greater limit. Second, even if solubility in the UZ were less than in the invert (that is, the opposite case), the result would be precipitation, reducing the concentration and transport of radionuclides. Therefore, the expected difference in solubility limit between the invert and the UZ will have no effect on the release of radionuclides to the accessible environment, and if the difference were in the opposite direction than expected, the effect would be to reduce the rate of release.

The conditions that control radionuclide solubility are identified in Dissolved Concentration Limits of Radioactive Elements (BSC 2005 [DIRS 173873]) and include $\mathrm{pH}$, fugacity of $\mathrm{CO}_{2}$, concentration of fluoride ion, and temperature. These variables are not all independent: at higher temperature, $\mathrm{CO}_{2}$ gas is less soluble. This reduces the solubility of carbonate complexes, which at high $\mathrm{pH}$ are the species that contribute the most to actinide solubilities. The result is that actinides are less soluble at higher temperatures (BSC 2005 [DIRS 173873, Section 6.3.3.3, but note that only solubility limits at $25^{\circ} \mathrm{C}$ are used for TSPA). Non-actinide radionuclides that may be released include carbon, cesium, iodine, strontium, and technetium. The concentrations of these elements are controlled by release rate, not solubility; therefore, any change in their solubility limit is of no consequence (BSC 2005 [DIRS 173873, Section 8.1).

The drifts will be hotter than the UZ below (or above) the repository because of heat released by the emplaced radioactive waste. When the invert has cooled enough to allow liquid water to exist, water flowing through or past the drift will transport heat advectively, but not fast enough to reverse the thermal gradient below the drift. Eventually the entire system will return to a geothermal gradient so the emplaced waste, by now effectively completely decayed, is cooler than the rock beneath it. This argument is qualitative, but sufficient to justify the exclusion of changes in radionuclide solubility from the TSPA, especially because even the reverse situation 
(drift cooler than the surrounding UZ) results in no increase in release rate. Therefore, exclusion of this FEP is conservative.

If solubility limits are greater in the geosphere than in the emplacement drifts, then there is no effect on transport because all available radionuclides that were transported from the emplacement drift are already aqueous species.

If solubility limits are lower in the geosphere than in the emplacement drifts, then some dissolved radionuclides will precipitate there. This would reduce the amount of dissolved radionuclides available for transport in the geosphere. Subsequent cooling may increase the solubility, restoring the precipitated radionuclides to the aqueous phase; in this case precipitation would delay, but not prevent, transport of radionuclides. It is, therefore, conservative to neglect precipitation.

Solubility limits could also affect the formation of certain kinds of true colloids, such as polymeric forms of plutonium oxide (BSC 2005 [DIRS 174290], Section 6.3.1). However, only small quantities have been observed to form in experiments on waste form degradation (BSC 2005 [DIRS 174290], Sections 6.3.1 and 8.1). Furthermore, these colloids are expected to undergo formation of pseudocolloids in the near- or far-field aquifer system (BSC 2005 [DIRS 174290], Section 6.3.1) and are, therefore, excluded.

Analysis of coupled THC effects indicates that only small changes in hydrologic properties and mineralogy a result from these coupled processes (BSC 2005 [DIRS 172862], Section 6). Therefore, far-field changes are likewise expected to be small, including mineral precipitation or dissolution and alteration of minerals such as zeolites and clays. Therefore, coupled thermal-hydrologic-chemical effects on radionuclide transport properties and the effects of different solubility limits in the geosphere are excluded because they will have no adverse affects on the radiological exposures to the RMEI, or radionuclide release to the accessible environment. Section 6.1.2 explains why low consequence for specific elements of the UZ system leads to low consequence for total system performance.

Supporting Reports: Not applicable.

\subsubsection{Repository-Induced Thermal Effects on Flow in the UZ (2.2.10.01.0A)}

FEP Description: Thermal effects in the geosphere could affect the long-term performance of the disposal system, including effects on groundwater flow (e.g., density-driven flow), mechanical properties, and chemical effects in the UZ.

Screening Decision: Excluded-Low Consequence.

Screening Argument: Heat from each emplacement drift dries out the rock surrounding the drift, and the resulting "vaporization barrier" diverts water around the drift. This thermal effect on flow is of limited spatial extent, and is distinct from the capillary barrier (see Section 6.2.25), which does not depend on dryout or heat, and becomes effective after the surrounding rock is rewetted. Thermal-hydrologic modeling at the drift scale has been performed using a two-dimensional cross-sectional dual-permeability model in Drift-Scale Coupled Processes (DST and TH Seepage) Models (BSC 2005 [DIRS 172232]). Simulations by the TH seepage model 
(BSC 2005 [DIRS 172232], Figures 6.2.2.1-3 through 6.2.2.1-6) show that during the heating period TH processes, including vaporization of percolating water near hot emplacement drifts with condensation in cooler zones, redistribute moisture, forming a dry-out zone around the drift, with a condensation cap above it. As a result of this vaporization and condensation, downward-percolating water above the drift is diverted laterally. This flow-field disturbance extends upward only about $9 \mathrm{~m}$ above the drift. Above that elevation the vertical percolation flux is the same as imposed at the top boundary (BSC 2005 ([DIRS 172232], Figure 6.2.2.1-7). Additional 2-D TH simulation results in Drift Scale THM Model (BSC 2004 [DIRS 169864, Figures 6.5.5-3(b), 6.5.5-4(b), and 6.5.5-5(b)) (DTN: LB0306DRSCLTHM.002 [DIRS 174490]) also show redistribution of percolating water around heated drifts.

Two-dimensional TH simulations in Mountain-Scale Coupled Processes (TH/THC/THM) Models (BSC 2005 [DIRS 174101], Figures 6.5.13-1(a) through 6.5.13-6(a)) show the flow redistribution, with vertical percolation flux reduced beneath the drifts and increased around each drift. The limited extent of flow redistribution found in the mountain-scale is consistent with drift-scale results discussed above (DTN: LB0306DRSCLTHM.002 [DIRS 174490]; BSC 2004 [DIRS 169864, Figures 6.5.5-3(b), 6.5.5-4(b), and 6.5.5-5(b)).

Drift-scale modeling (BSC 2005 ([DIRS 172232], Figure 6.2.2.1-7; DTN: LB0306DRSCLTHM.002 [DIRS 174490]; BSC 2004 [DIRS 169864, Figures 6.5.5-3(b), 6.5.5-4(b), and 6.5.5-5(b)) shows that the flow changes resulting from $\mathrm{TH}$ processes are much smaller than those that result from climate change at 600 and 2,000 years, which are included in the flow and transport models (Section 6.2.4, FEP 1.3.01.00.0A).

Numerical simulations of flow at 100 years and 500 years after emplacement show reduced fracture saturation and diversion of percolating water around the dryout zone (BSC 2005 [DIRS 172232], Section 6.2.2.1). Because of the flow diversion, the dryout is more extensive and longer lasting beneath the drift; this is called the "drift shadow" effect. Note that there is no water flux inside the dryout region, because fracture saturation is zero. After resaturation in 1,000 to 2,000 years, saturations below the drift remain smaller than above, because of the "shadow zone" created by the diversion of flow around the drift (BSC 2005 [DIRS 172232], Section 6.2.2.1; DTN: LB0306DRSCLTHM.002 [DIRS 174490]; BSC 2004 [DIRS 169864, Figures 6.5.5-3(b), 6.5.5-4(b), and 6.5.5-5(b)). In general, the TH dryout and associated coupled processes will lead to an environment where radionuclide transport in the vicinity of the drift is less likely (BSC 2005 [DIRS 172232], Section 6.2.2.1.1; BSC 2005 [DIRS 172862], Section 6.5.5.3; DTN: LB0306DRSCLTHM.002 [DIRS 174490]; BSC 2004 [DIRS 169864, Figures 6.5.5-3(b), 6.5.5-4(b), and 6.5.5-5(b)).

The effects of repository heat and the associated dryout on shallow infiltration at the surface of Yucca Mountain were investigated in CRWMS M\&O (1999 [DIRS 105031]). The primary issue for thermal effects at the ground surface is the change in temperature and its associated effect on vegetation. Based on the detailed analysis of soil temperature changes documented in CRWMS M\&O (1999 [DIRS 103618], Figure 30), the temperature rise will have a negligible effect on vegetation, and hence on surface infiltration.

This FEP is, therefore, excluded because it will not significantly change radiological exposures to the RMEI or radiological releases to the accessible environment. Section 6.1.2 explains why 
low consequence for specific elements of the UZ system leads to low consequence for total system performance.

For thermal effects on chemical processes, see FEPs 2.2.08.03.0B, 2.2.10.06.0A, 2.2.10.07.0A, and 2.2.10.09.0A. For thermal effects on mechanical processes, see FEPs 2.2.10.04.0A, 2.2.10.04.0B, and 2.2.10.05.0A. Note that the effects of thermal-hydrologic processes on drift seepage and seepage water chemistry are addressed in FEPs 2.2.07.10.0A, 2.2.07.11.0A, 2.2.08.12.0A, 2.2.10.10.0A, and 2.2.10.12.0A.

Supporting Reports: Not applicable.

\subsubsection{Thermo-Mechanical Stresses Alter Characteristics of Fractures near Repository (2.2.10.04.0A)}

FEP Description: Heat from the waste causes thermal expansion of the surrounding rock, generating changes in the stress field that may change the properties (both hydrologic and mechanical) of fractures in the rock. Cooling following the peak thermal period will also change the stress field, further affecting fracture properties near the repository.

Screening Decision: Excluded-Low Consequence.

Screening Argument: The results of the coupled drift-scale thermal-hydrological-mechanical (THM) model presented in Drift Scale THM Model (BSC 2004 [DIRS 169864], Sections 6.5 and 6.6) show that the impact of time-dependent, THM processes will last for well over 10,000 years. These processes have a small or moderate impact on the drift scale $\mathrm{TH}$ behavior, including a negligible impact on the temperature evolution and small impact on the percolation flux (BSC 2004 [DIRS 169864], Section 6.9). These model results were obtained for a conservative estimate of input THM properties (thermal expansion coefficient and stress versus permeability function), which is sufficient for bounding the possible impact of the THM processes on permeability and percolation flux.

The THM simulations discussed in Abstraction of Drift Seepage (BSC 2004 [DIRS 169131], Section 6.4.4.1) suggest that temperature-induced stress changes give rise to changes in the vertical fracture permeability in the vicinity of waste emplacement drifts, particularly in the Tptpmn unit (BSC 2004 [DIRS 169131], Section 6.5.1.4). However, these permeability changes do not result in significant changes in the flow fields (BSC 2004 [DIRS 169864], Sections 6.5.5 and 6.6.2). In particular, the seepage rates calculated for a permeability field including THM permeability changes were similar to, but slightly smaller than, those calculated for a permeability field representative of the initial postexcavation conditions (DTN: LB0304SMDCREV2.004 [DIRS 163691]; BSC 2004 [DIRS 169131], Section 6.4.4.1). Therefore, the impact of THM property changes is neglected in the seepage abstraction.

Changes in fracture properties in the vicinity of the drift may also affect radionuclide transport near the drift. The overall effect of THM coupled processes on drift-scale radionuclide transport may also be excluded because the primary effect of THM processes leads to enhanced seepage diversion and reduced drift seepage, reduced water saturations beneath the drift, and therefore, greater partitioning of radionuclide releases to the rock matrix. Therefore, this FEP is excluded based on low consequence because it has no adverse effects on the radiological exposures to the 
RMEI, or radionuclide release to the accessible environment. Section 6.1.2 explains why low consequence for specific elements of the UZ system leads to low consequence for total system performance.

Supporting Reports: Not applicable.

\subsubsection{Thermo-Mechanical Stresses Alter Characteristics of Faults near Repository (2.2.10.04.0B)}

FEP Description: Heat from the waste causes thermal expansion of the surrounding rock, generating changes to the stress field that may change the properties (both hydrologic and mechanical) in and along faults. Cooling following the peak thermal period will also change the stress field, further affecting fault properties near the repository.

Screening Decision: Excluded-Low Consequence.

Screening Argument: The primary differences represented by faults, as compared with the general fractured rock mass, for flow, transport, drift seepage, and coupled processes, are the greater permeability and potential continuity of high-permeability pathways through the UZ. Thermal-mechanical effects on fault-fractures are expected to be qualitatively similar to rock-mass fractures in the sense that THM processes lead to reductions in vertical permeabilities, but increased horizontal permeability above the drift. Faults may be viewed as a specific type of heterogeneity in the fractured rock mass. From this viewpoint, Drift Scale THM Model (BSC 2004 [DIRS 169864], Section 6.10.5) indicates that the main effect of THM processes is on the mean permeability, and that it is appropriate to apply the mean permeability changes to a seepage analysis that considers either the homogenous or heterogeneous permeability field. This is the approach that is presented in FEP 2.2.10.04.0A. In that FEP, the effects of THM processes were found to result in slightly lower seepage rates than the unperturbed condition (DTN: LB0304SMDCREV2.004 [DIRS 163691]). See also Section 6.9.3 (FEP 2.2.01.02.0A) concerning the thermal-hydrological-mechanical effects of rockfall, rock strength, block size, and fracture spacing. Therefore, the screening arguments used in FEP 2.2.10.04.0A also apply here, and consequently this FEP is excluded because it does not significantly change radiological exposures to the RMEI or radiological releases to the accessible environment. Section 6.1.2 explains why low consequence for specific elements of the UZ system leads to low consequence for total system performance.

Supporting Reports: Not applicable.

\subsubsection{Thermo-Mechanical Stresses Alter Characteristics of Rocks above and below the Repository (2.2.10.05.0A)}

FEP Description: Thermal-mechanical compression at the repository may produce tension fracturing in the Paintbrush non-welded tuff and other units above the repository. These fractures may alter unsaturated zone flow between the surface and the repository. Extreme fracturing may propagate to the surface, affecting infiltration. Thermal fracturing in rocks below the repository may affect flow and radionuclide transport to the saturated zone.

Screening Decision: Excluded-Low Consequence. 
Screening Argument: The mountain-scale THM model (BSC 2005 [DIRS 174101], Section 6.5) assesses the magnitude and distribution of changes in hydrological properties and analyzes the impact of such changes on the mountain-scale vertical percolation flux through the repository horizon. The result shows that a maximum THM-induced change in hydrological properties occurs at around 1,000 years after emplacement, when the average temperature in the mountain is maximal. Near the repository level, thermal-elastic stresses tend to tighten vertical fractures to smaller apertures, leading to reduced permeability and increased capillary. At the ground surface, in a zone extending about $100 \mathrm{~m}$ deep, compressive stresses are completely relieved from tension. In this zone, fractures will open elastically, and fracturing or shear-slip along preexisting fractures is possible.

Using a conservative estimate of input THM properties, changes in permeability by elastic closure or opening of preexisting fractures are within a factor of 0.3 to 5 , whereas calculated changes in capillary pressure are within a factor of 0.7 to 1.2 . In addition, a conservative three-order-of-magnitude increase in permeability and one-order-of-magnitude reduction in capillary strength were imposed for the zone of possible fracturing and shear slip near the ground surface. Despite these conservative estimates of potential changes in hydrological properties, the main conclusion from the results documented in Mountain-Scale Coupled Processes (TH/THC/THM) (DTN: LB0310MTSCLTHM.002 [DIRS 170718]; BSC 2005 [DIRS 174101], Sections 6.5 .10 to 6.5 .14 ) is that THM-induced changes in the mountain-scale hydrological properties have no significant impact on the vertical percolation flux through the repository horizon. Again, these results were obtained for conservative estimates of the input THM properties, which is sufficient for bounding the possible impact of the THM processes on permeability and percolation flux on the mountain scale.

The effects of mechanical disturbance of fractures along radionuclide transport pathways are discussed in Section 6.8.7, FEP 2.2.06.02.0B. The conclusion reached in that section is that the effects of changes to fracture aperture or spacing on radionuclide transport are expected to be negligible over a wide range of permeability variation. In this case, the disturbance is caused by thermal-mechanical effects rather than by a seismic event. However, the conclusions reached in Section 6.8.7, FEP 2.2.06.02.0B are also applicable here because the analysis supporting the conclusions in Section 6.8.7, FEP 2.2.06.02.0B are based on a general sensitivity study of how fracture properties affect radionuclide transport. Furthermore, the general effects of thermal stresses on fracture permeability due to repository heating are evaluated in Mountain-Scale Coupled Processes (TH/THC/THM) (BSC 2005 [DIRS 174101], Section 6.5.12) and in DTN: LB0310MTSCLTHM.002 ([DIRS 170718]). This analysis indicates that in the zones near the repository and below the repository, the fracture permeability is either reduced or unaffected. Thus, it is conservative to not include thermal effects on fracture permeability because radionuclide transport is slower with reduced permeability (Appendix D, Section D3.3.1 of this report). Therefore, this FEP is excluded based on low consequence because it has no adverse effects on the radiological exposures to the RMEI, or radionuclide release to the accessible environment. Section 6.1.2 explains why low consequence for specific elements of the UZ system leads to low consequence for total system performance.

Supporting Reports: Not applicable. 


\subsubsection{Thermo-Chemical Alteration in the UZ (Solubility, Speciation, Phase Changes, Precipitation/Dissolution) (2.2.10.06.0A)}

FEP Description: Thermal effects may affect radionuclide transport directly, by causing changes in radionuclide speciation and solubility in the UZ, or indirectly, by causing changes in the host rock mineralogy that affect the flow path. Relevant processes include volume effects associated with silica phase changes, precipitation and dissolution of fracture-filling minerals (including silica and calcite), and alteration of zeolites and other minerals to clays.

Screening Decision: Excluded-Low Consequence.

Screening Argument: This FEP raises some issues already addressed in Section 6.9.7, FEP 2.2.08.03.0B and Section 6.9.8, FEP 2.2.08.07.0B. If solubility limits decrease in the geosphere so that they are lower than in the waste emplacement drifts, then some dissolved radionuclides will precipitate as water flows out of the drifts. This limits the dissolved radionuclides available for transport into the geosphere, which results in no adverse effect on performance. See also Section 6.9.6 (FEP 2.2.01.05.0A) for additional information on this subject. If solubility limits increase in the geosphere compared with the waste emplacement drift, there is no effect on transport because all available radionuclides from the source at the waste emplacement drift are already aqueous species. The effects of colloid formation are accounted for in the colloid source term (BSC 2005 [DIRS 174290], Section 6.5.2.3). Colloids are formed from the degradation of the high-level waste and spent nuclear fuel waste forms, EBS materials, and rock (BSC 2005 [DIRS 174290], Section 6.3.1). Radionuclides associated with colloids are modeled as either irreversibly or reversibly attached to colloids to encompass the broadest range of potential radionuclide-colloid interactions (BSC 2005 [DIRS 173980], Section 6.4.5). Elevated temperatures are expected to lead to fewer colloids due to the decrease in colloid stability. This is due to the greater energy of colloid motion at higher temperatures, which allows colloids to overcome the energy barrier associated with coagulation (BSC 2005 [DIRS 174290], Section 6.3.2). Boiling results in evaporation and this tends to increase the ionic strengths of colloid suspensions. This also leads to colloid instability due to compression of the electric double layer surrounding colloids (BSC 2005 [DIRS 174290], Section 6.3.2). Therefore, colloid entrainment as a result of boiling is not expected.

Measurements at various temperatures of $\mathrm{K}_{\mathrm{d}}$ for sorption of barium (a proxy for radium), cesium, strontium, and neptunium, on Yucca Mountain tuff are reported, respectively, in DTNs: LA0010JC831341.001 [DIRS 162476], LA0010JC831341.002 [DIRS 153321], LA0010JC831341.003 [DIRS 153322], and LA0010JC831341.007 [DIRS 153319]. Plots of these data, showing that $K_{d}$ values for these elements are either unaffected by temperature or increase slightly with temperature, are presented in BSC 2004 ([DIRS 164500], Figure I-1). These data were combined with additional measurements of these elements, plus plutonium, americium, uranium, and europium and cerium (proxies for trivalent actinides), and analyzed in BSC 2004 ([DIRS 164500], Appendix I) to estimate enthalpy of sorption, $\Delta \mathrm{H}_{\mathrm{r}} ; \Delta \mathrm{H}_{\mathrm{r}}$ greater than zero indicates that sorption increases with increasing temperature. The results of that analysis are shown in BSC 2004 ([DIRS 164500], Figure I-5). For cesium, barium, cerium, europium, plutonium, and americium, the value of $\Delta \mathrm{H}_{\mathrm{r}}$ was not statistically different from zero; that is, no dependence of $\mathrm{K}_{\mathrm{d}}$ upon temperature could be inferred. For uranium, strontium, and neptunium, $\Delta \mathrm{H}_{\mathrm{r}}$ was greater than zero. Therefore the effect of temperature on radionuclide transport is 
excluded on the basis of low consequence because it has no adverse effects on performance; for uranium, strontium, and neptunium, exclusion of this FEP is conservative.

The thermal-chemical interactions that will occur in the repository environment have been studied with respect to effects on the seepage water entering the waste emplacement drifts in Drift-Scale THC Seepage Model (BSC 2005 [DIRS 172862]). This model explicitly captures the effects of changes in temperature, $\mathrm{pH}$, Eh, ionic strength (and other compositional variables), time dependency, precipitation or dissolution effects, and effects of resaturation (BSC 2005 [DIRS 172862], Section 6.2). Changes in fracture permeabilities resulting from mineral precipitation or dissolution were found to be on the order of the natural variation in these properties (DTN: LB0302DSCPTHCS.001 [DIRS 164744]; BSC 2005 [DIRS 172862], Section 6.5.5.3 and BSC 2004 [DIRS 170038], Table 6-5), with most of the substantial effects limited to regions above and to the side of the drift within about a drift diameter (BSC 2005 [DIRS 172862], Figures 6.5-39 and 6.5-40). The predicted mineral precipitation decreases permeability in the affected regions, and leads to a reduction in flow around the drift. This is conservative for both drift seepage and radionuclide transport phenomena and this FEP is, therefore, excluded because it will have no adverse affects on the radiological exposures to the RMEI, or radionuclide release to the accessible environment.

The geochemical model includes the major solid phases (minerals and glass) encountered in geological units at Yucca Mountain, together with a range of possible reaction product minerals, $\mathrm{CO}_{2}$ gas, and the aqueous species necessary to include these solid phases and the pore-water composition within the THC model (BSC 2005 [DIRS 172862], Table 6.2-2). Compositional changes were only calculated at the drift boundary for the drift-scale THC seepage model (BSC 2005 [DIRS 172862]). Results from these simulations show most compositional variations returning to unperturbed conditions in 10,000 years or less. Variations in $\mathrm{pH}$ (DTN: LB0302DSCPTHCS.002 [DIRS 161976] and DTN: LB0307DSTTHCR2.002 [DIRS 165541]; BSC 2005 [DIRS 172862], Figures 6.5-12 and 6.5-25), a key compositional variable for sorption of some radionuclides (BSC 2004 [DIRS 164500], Appendix A), roughly lie within the range of variability investigated for initial pore-water compositions (BSC 2005 [DIRS 172862], Table 6.2-1). Bicarbonate is found to be depressed in concentration upon water resaturation at the drift wall, as expected based on the reduced $\mathrm{pH}$ values at the same time period.

Results were also investigated for the Tptpll (lower lithophysal unit) model considering a range of initial pore-water compositions. In this model, five different initial pore-water compositions were investigated (BSC 2005 [DIRS 172862], Table 6.2-1). Peak concentrations found at the time of rewetting in both models reflect mostly the small values of the first, nonzero, liquid-saturation output. In any case, elevated concentrations are predicted only for small liquid saturations that are not subject to significant fluid movement. The improved treatment of mineral precipitation at the boiling front used in the most recent THC model for the Tptpll also results in the prediction of lower, more realistic aqueous silica concentrations than in earlier models (DTN: LB0302DSCPTHCS.002 [DIRS 161976] and DTN: LB0307DSTTHCR2.002 [DIRS 165541]; BSC 2005 [DIRS 172862], Figure 6.5-16). This model also predicts, upon rewetting, more rapid return to near-ambient conditions for aqueous $\mathrm{Ca}, \mathrm{Na}$, and $\mathrm{Cl}$. 
The findings indicate that at the drift wall, most of the significant compositional variations resulting from thermal-chemical processes are limited to low-saturation conditions over time periods that are short relative to the 10,000-year performance period. Similar magnitudes of variation in chloride and $\mathrm{pH}$ were found in the mountain-scale THC model results (BSC 2005 [DIRS 174101], Section 6.4.3.3.2). As for the drift-scale study, variations in chloride are driven mainly by evaporation and are found to return to near-ambient values upon rewetting (DTN: LB0310MTSCLTHC.001 [DIRS 170715]; BSC 2005 [DIRS 174101], Section 6.4.3.3.2). Variations in $\mathrm{pH}$ also were found to be similar to the results for the drift-scale THC model (DTN: LB0302DSCPTHCS.002 [DIRS 161976] and DTN: LB0307DSTTHCR2.002 [DIRS 165541]; BSC 2005 [DIRS 172862], Figures 6.5-12 and 6.5-25). Therefore, the effects of these changes are excluded because they will not significantly change radiological exposures to the RMEI or radiological releases to the accessible environment. Section 6.1.2 explains why low consequence for specific elements of the UZ system leads to low consequence for total system performance.

Supporting Reports: Not applicable

\subsubsection{Thermo-Chemical Alteration of the Calico Hills Unit (2.2.10.07.0A)}

FEP Description: Fracture pathways in the Calico Hills may be altered by the thermal and chemical properties of the water flowing out of the repository.

Screening Decision: Excluded-Low Consequence.

Screening Argument: Thermo-chemical alteration of fracture pathways in the Calico Hills unit might affect UZ flow and transport by (1) mineral dissolution and precipitation, which would change the fracture porosity or permeability of the fracture network, (2) by changing the $\gamma$ value for the active fracture model (Liu et al. 1998 [DIRS 105729]), or (3) by changing the sorptive properties of minerals lining the fracture walls, which would change the sorptive capacity, represented by $\mathrm{K}_{\mathrm{d}}$. Sensitivity studies to examine these effects have shown that none of them significantly increases the transport to the accessible environment or the dose to the RMEI.

Sensitivity of tracer transport to fracture porosity was studied by calculating breakthrough curves using the calibrated fracture porosity for each unit, and with fracture porosity reduced by a factor of ten everywhere (DTN: LB0304RDTRNSNS.001 [DIRS 165992]; BSC 2004 [DIRS 169861], Section 6.8.2.2). BSC 2004 ([DIRS 169861], Figure 6.8-4) shows that with reduced fracture porosity the fractional mass breakthrough of the tracer arriving at the water table is larger only during the first 50 years. However, in both cases less than $15 \%$ of the released mass arrives during this period. After 100 years, both simulation cases give similar results: almost 50 percent of the tracer mass arrives at the groundwater table at 3,400 years, and the two breakthrough curves are not distinguishable. Increasing the fracture porosity was not considered in that sensitivity study, because it would retard tracer breakthrough and would therefore not be conservative. Comparison of the cases studied shows that transport is not sensitive to fracture porosity.

Sensitivity of tracer transport to the permeability of the fracture network in the Calico Hills was studied in UZ Flow Models and Submodels (BSC 2001 [DIRS 158726], Sections 6.2.2, 6.2.5, 
and 6.2.6; Figures 6-64 through 6-56). Radionuclide breakthrough curves were evaluated for alternative perched water models presented in BSC 2001 ([DIRS 158726], Section 6.2.2). Perched water models \#1 and \#2 are named the "flow-through" perched water model and "by-passing" perched water model, respectively (BSC 2001 [DIRS 158726], Section 6.2.2). For model \#1, fracture permeability in some layers of the Calico Hills is set ten times as great as matrix permeability; this property set produces the known perched water. For model \#2, fracture permeability is set equal to matrix permeability in all zeolitic units, effectively removing the fractures; this represents the case of fracture sealing. Comparisons for transport between the repository and the water table for the two perched water models (and one other not discussed here) were performed using sorbing and nonsorbing radionuclides (BSC 2001 [DIRS 158726], Section 6.7.2). The transport results for perched water models \#1 and \#2 have only minor differences (BSC 2001 [DIRS 158726], Figures 6-54 through 6-56). Transport is therefore not sensitive to fracture permeability in the zeolitic Calico Hills.

Additional sensitivity studies concerning the effects of fracture permeability on radionuclide transport were conducted in Particle Tracking Model and Abstraction of Transport Processes (BSC 2004 [DIRS 173980], Figures 6-29 and 6-30). Two sensitivity cases were investigated for aqueous ${ }^{99} \mathrm{Tc},{ }^{237} \mathrm{~Np}$, and ${ }^{242} \mathrm{Pu}$, and colloidal ${ }^{242} \mathrm{Pu}$. In one case the fracture permeabilities were increased throughout the domain by one standard deviation and in the other case the fracture permeabilities were decreased by one standard deviation. The effects of these variations in fracture permeability on transport behavior are relatively small compared with the effects of uncertainties associated with infiltration (BSC 2004 [DIRS 164500], Figures 6-34, 6-39, and 6-43), and appear to impact conservative, sorbing, and colloidal species in an equivalent way.

Reducing $\gamma$ increases the fraction of active fractures, and allows more fracture-matrix interaction. Sensitivity of flow and transport to the active fracture parameter $\gamma$ was studied by calculating flow fields and breakthrough curves for three cases: "base case" using the calibrated $\gamma$ for each unit, "TSw" with $\gamma$ reduced by half in the TSw units above and below the repository, including the repository layer, and "UnderRepo" with $\gamma$ reduced by half in the TSw units below the repository, including the repository layer, and in all units below the TSw (DTN: LB0304RDTRNSNS.001 [DIRS 165992]; BSC 2004 [169861], Table 6.8-1). The flow field was not sensitive to these changes in $\gamma$. Fracture fluxes at the repository layer and at the water table varied less than 2.5\% from the base case (BSC 2004 [169861], Table 6.8-2).

In the study of transport sensitivity to $\gamma$, the breakthrough curve for case "TSw" showed delayed tracer breakthrough compared to the base case. When a tracer is released as a pulse from the repository gridblocks, it travels faster in the fractures than in the matrix, causing a temporary concentration gradient between the fracture and matrix. Decreasing $\gamma$ allows more tracer to diffuse into the matrix, where its transport is delayed (no sorption was modeled). In the base case, $20 \%$ of the total input mass arrives at the water table at (approximately) 150 years, and $50 \%$ of the total mass arrives at the water table at (approximately) 3,400 years. For case "TSw," $20 \%$ mass arrival at 1,900 years and $50 \%$ at (approximately) 7,100 years, (BSC 2004 [DIRS 169861], Figure 6.8-3).

The breakthrough curve for case "UnderRepo" was indistinguishable from that for case "TSw" (BSC 2004 [DIRS 169861], Figure 6.8-3). This indicates that increasing the fracture-matrix 
interaction in the Calico Hills does not further delay tracer breakthrough, that is, fracture-matrix interaction in the TSw is more important in delaying transport than fracture-matrix interaction in the Calico Hills.

Additional sensitivity studies concerning the effects of the active-fracture parameter on radionuclide transport were conducted in Particle Tracking Model and Abstraction of Transport Processes (BSC 2004 [DIRS 173980], Figures 6-33 through 6-36). Five sensitivity cases were investigated for aqueous ${ }^{99} \mathrm{Tc},{ }^{237} \mathrm{~Np}$, and ${ }^{242} \mathrm{Pu}$. The active fracture parameter $\gamma$ in the TSw was set to values of $0.6,0.5,0.4,0.3$, and 0.2 , with the base case values for hydrogeologic units in and below the repository for the $\mathrm{TSw}$ (tsw33 through tsw38) ranging from 0.569 to 0.6 (BSC 2004 [DIRS 169861], Table A-1). This uncertainty range for $\gamma$ is discussed in Conceptual and Numerical Approaches for Unsaturated Zone Flow and Transport (BSC 2004 [DIRS 170035] Sections 7.4.1 and 7.4.2). The results show that transport is sensitive to $\gamma$ only for the TSw; changes in $\gamma$ for hydrogeologic units below the TSw had almost no effect on transport behavior (BSC 2004 [DIRS 173980], Figures 6-36).

Sensitivity of transport to $K_{d}$ values was studied in (DTN: LB0310MR0060R1.010 [DIRS 174489]; BSC 2004 [DIRS 164500], Section 6.9.1.5). In this study, transport of ${ }^{237} \mathrm{~Np}$ was simulated for a base case and three alternative cases. For the base case, non-zero $K_{d}$ values (presented in BSC (2004 [DIRS 164500], Table 6-3) were used for TSw, CHv, and CHz. In the alternative cases $K_{d}$ for $\mathrm{TSw}, \mathrm{CHv}$, or $\mathrm{CHz}$ was set to zero, leaving the others unchanged. Breakthrough curves for a mean present-day infiltration scenario are shown in (BSC 2004 [DIRS 164500], Figure 6-37). Eliminating sorption in the TSw caused ${ }^{237} \mathrm{~Np}$ to arrive at the water table significantly earlier, but eliminating sorption in the $\mathrm{CHz}$ or $\mathrm{CHv}$ had little effect on the breakthrough curve. This indicates that TSw is the most important unit in the transport and retardation of ${ }^{237} \mathrm{~Np}$.

These sensitivity studies show that alteration of fracture pathways in the Calico Hills does not significantly change the rate of radionuclide transport. Therefore, the effects of these changes are excluded because they will not significantly change radiological exposures to the RMEI or radiological releases to the accessible environment. Section 6.1.2 explains why low consequence for specific elements of the UZ system leads to low consequence for total system performance.

Supporting Reports: Not applicable.

\subsubsection{Thermo-Chemical Alteration of the Topopah Spring Basal Vitrophyre (2.2.10.09.0A)}

FEP Description: Heating the Topopah Spring basal vitrophyre with available water may cause alteration of the glasses to clays and zeolites. Possible effects include volume increases that plug fractures, changes in flow paths, creation of perched water zones, and an increase in the sorptive properties of the unit.

Screening Decision: Excluded-Low Consequence

Screening Argument: The Topopah Spring basal vitrophyre is densely welded glassy tuff extending downward from the base of the lower nonlithophysal zone into the crystal-poor vitric 
zone through a stratigraphic interval ranging from about $3 \mathrm{~m}$ to $30 \mathrm{~m}$. Alteration of this material to zeolitized tuff would increase its sorptive capacity for radionuclides, and therefore would retard transport. The effect of this change in sorptive properties can therefore be excluded from TSPA, because the base case (without alteration) gives a more conservative, i.e. faster, transport time.

The other effect of thermo-chemical alteration of the Topopah Spring basal vitrophyre is the increase in mineral volume, which would reduce permeability and could result in the creation of perched water zones. The effect of perched water zones on transport was examined in a sensitivity study in UZ Flow Models and Submodels (BSC 2001 [DIRS 158726], Sections 6.2.2, 6.2.5, and 6.2.6; Figures 6-54 through 6-56). In that sensitivity study, simulations using model \#1 (so-called "flow through" model) reproduced observed locations of perched water at the base of the Topopah Spring formation with a small fracture permeability in the zeolitic portion of the Calico Hills. Model \#2 (so-called "bypassing" model) eliminated fracture permeability, resulting in more perched water and greater lateral diversion (BSC 2001 [DIRS 158726], Sections 6.2.2 and 6.2.5). Loss of fracture permeability in the basal vitrophyre would be expected to have an effect similar to model \#2. Transport between the repository and the water table was simulated for these two perched water models were performed using sorbing and nonsorbing radionuclides (BSC 2001 [DIRS 158726], Section 6.7.2). The transport results for perched water models \#1 and \#2 have only minor differences (BSC 2001 [DIRS 158726], Figures 6-54 through 6-56). Therefore flow diversion and perched water resulting from alteration of the vitrophyre would not significantly affect transport.

Transport simulations in (BSC 2004 [DIRS 164500], Figure 6-37), as discussed above for FEP 2.2.10.07.0A, (Thermo-chemical alteration of the Calico Hills unit) showed that the TSw is the most important unit in the transport and retardation of ${ }^{237} \mathrm{~Np}$. Sealing of fractures in the vitrophyre would slow access to its adsorptive capacity. However the thickness of the vitrophyre, ranging from $3 \mathrm{~m}$ to $30 \mathrm{~m}$, accounts for only one-third or less of the TSw thickness beneath the repository. Flow that is laterally diverted through perched water in the TSw will have a longer flow path, and therefore greater access to the adsorptive capacity of the TSw.

Therefore, this FEP is excluded because it will not significantly change radiological exposures to the RMEI or radiological releases to the accessible environment. Section 6.1.2 explains why low consequence for specific elements of the UZ system leads to low consequence for total system performance.

Supporting Reports: Not applicable.

\subsubsection{Mineralogic Dehydration Reactions (2.2.10.14.0A)}

FEP Description: Mineralogic dehydration reactions release water affecting hydrologic conditions. Dehydration of zeolites below the repository may lead to large-scale volume changes affecting flow and/or drift stability.

Screening Decision: Excluded-Low Consequence. 
Screening Argument: The predominant zone of zeolite-bearing minerals is at the base of the TSw (tsw39) and in the Calico Hills nonwelded unit (ch1, ch2, ch3, ch4, ch5, and ch6) (DTN: MO9910MWDISMMM.003 [DIRS 119199]; DTN: LB0208HYDSTRAT.001 [DIRS 174491]; BSC 2004 [DIRS 169855], Section 5.2). Dehydration of zeolites below the repository could occur if temperatures in the zeolitic units exceed the estimated minimum alteration temperature of $85^{\circ} \mathrm{C}$ (Smyth 1982 [DIRS 119483], p. 201). Such dehydration reactions could affect geohydrologic conditions two ways: by release of water of hydration and by the resulting shrinkage of the zeolites. At high temperatures $\left(200^{\circ} \mathrm{C}\right.$ to $300^{\circ} \mathrm{C}$ for I-phase clinoptilolite), more water of hydration can be released, with up to 10\% shrinkage (Boles 1972 [DIRS 174526]; Smyth and Caporuscio 1981 [DIRS 174060], p. 10). Phase change from clinoptilolite to analcime could also occur, with greater shrinkage (Smyth and Caporuscio 1981 [DIRS 174060], p. 12). Shrinkage could lead to formation of new fractures or expansion of existing fractures.

The amount of water lost and shrinkage of the zeolites can be bounded by considering the data presented in Smyth and Caporuscio 1981 ([DIRS 174060], Table B-1), which records the volume and weight changes observed for a cylindrical sample from the zeolitized Calico Hills formation as it was heated from $25^{\circ} \mathrm{C}$ to $500^{\circ} \mathrm{C}$ stepwise in increments of $75^{\circ} \mathrm{C}$ and $100^{\circ} \mathrm{C}$. The sample, which originally weighed $25.0519 \mathrm{~g}$ and had a volume of $15.2242 \mathrm{~cm}^{3}$ at $25^{\circ} \mathrm{C}$, lost $4.4 \%$ of its weight and $0.0263 \%$ of its volume when heated to $100^{\circ} \mathrm{C}$. When heated to $500^{\circ} \mathrm{C}$, it lost $10.2 \%$ of its weight and $1.79 \%$ of its volume. Weight loss was greatest between $25^{\circ} \mathrm{C}$ and $100^{\circ} \mathrm{C}$; above $100^{\circ} \mathrm{C}$ the weight lost decreased in each successive increment of temperature. Volume loss was least between $25^{\circ} \mathrm{C}$ and $100^{\circ} \mathrm{C}$ and greatest between $100^{\circ} \mathrm{C}$ and $200^{\circ} \mathrm{C}$. A conservative estimate of the fraction of mass lost as water of hydration upon heating to $85^{\circ} \mathrm{C}$ is $2 \%$ (Smyth 1982 [DIRS 119483], p. 201). It is also conservative to bound the shrinkage due to this water loss by using the ratio of shrinkage and water loss observed in the heating experiment; $2 \%$ water loss would lead to shrinkage of $(2 / 4.4) \times(0.026 \%)$, or $0.012 \%$.

This calculated shrinkage can be used to estimate the increase in fracture permeability. The greatest mean fracture spacing in the zeolitic Calico Hills is $0.14 \mathrm{~m}$, and the greatest mean aperture is $0.0002 \mathrm{~m}$ (DTN: LB0205REVUZPRP.001 [DIRS 159525]). Linear shrinkage of $0.14 \mathrm{~m}$ of zeolitic tuff would expand the aperture by $(0.012 / 100) \times 0.14 \mathrm{~m}$, or $17 \mu \mathrm{m}$. This increase in fracture aperture would have an insignificant effect on the fracture permeability. (Because the hydraulic conductivity of individual fractures varies with the cube of the aperture, the effect of increased fracture volume is greater if the increased fracture volume is accrued to existing fractures than if it forms new fractures of similar spacing.) The effect of fracture expansion on transport is also discussed in a sensitivity study in Appendix D of this report, which shows that changes in fracture aperture (by factors of two and larger) have no significant effect on radiological exposures to the RMEI or radiological releases to the accessible environment.

Results of the two-dimensional mountain-scale TH calculations suggest that temperatures at the base of the TSw will remain below $77^{\circ} \mathrm{C}$ (DTN: LB 0310MTSCLTH2.001 [DIRS 170714]; BSC 2005 [DIRS 174101], Figure 6.2-6c). Note, however, that the highest temperatures occur in the southern portion of the repository (BSC 2005 [DIRS 174101], Figure 6.2-6c), where the percentage of zeolitic alteration is low (BSC 2004 [DIRS 169855], Figures 6-6 through 6-8). Peak temperatures in the northern portion of the repository remain below $74^{\circ} \mathrm{C}$. Furthermore, 
peak temperatures in the three-dimensional mountain-scale $\mathrm{TH}$ calculations predict a peak temperature of less than $75^{\circ} \mathrm{C}$ at the TSw-CHn interface (DTN: LB 0310MTSCLTH3.001 [DIRS 170270]; BSC 2005 [DIRS 174101], Section 6.3.1). Therefore, the temperature changes induced by the repository are not high enough to cause significant zeolite dehydration or volume changes in the zeolitic rock. Dehydration absorbs energy, so whatever dehydration does occur would tend to cool the rock (Carey and Bish 1996 [DIRS 105200], p. 960).

The volume of water released by this amount of dehydration can be compared to the volume of pore water initially present in the zeolitic Calico Hills matrix. The mean porosity is 0.322 , with 0.96 saturation (DTN: LB0207REVUZPRP.002 [DIRS 159672]). For each cubic meter of zeolitic Calico Hills matrix rock, this amounts to $0.309 \mathrm{~m}^{3}$ of pore water. The bulk density of the zeolitic Calico Hills unit is $1.67 \times 10^{3} \mathrm{~kg} / \mathrm{m}^{3}$ (DTN: LB0402THRMLPRP.001 [DIRS 168481]). The water released by dehydration at $85^{\circ} \mathrm{C}, 2 \%$ of the rock mass, is therefore estimated at $(1.67$ $\times 10^{3} \times 0.02$ ), or $33.4 \mathrm{~kg} / \mathrm{m}^{3}$. That is, it is approximately one-ninth of the initial pore water. This release of water by dehydration is not significant compared to the pore water initially present.

Therefore, this FEP is excluded as low consequence because it will not significantly change radiological exposures to the RMEI or radiological releases to the accessible environment. Section 6.1.2 explains why low consequence for specific elements of the UZ system leads to low consequence for total system performance.

Supporting Reports: Not applicable.

\subsubsection{Diffusion in the UZ (2.2.08.05.0A)}

FEP Description: Molecular diffusion processes may affect radionuclide transport in the UZ. This includes osmotic processes in response to chemical gradients.

Screening Decision: Excluded-Low Consequence.

Screening Argument: When radionuclides are present in fractures or faults, they can be transported by advection, dispersion, and diffusion. Transport by advection and dispersion are included in FEP 2.2.07.15.0B, advection and dispersion in the UZ. Transport by diffusion is neglected because it is mathematically similar to dispersion (that is, flux is proportional to concentration gradient) and under all scenarios, it is much smaller than transport by dispersion.

The mean value of the $\log _{10}$ of molecular diffusion coefficient is 4.69 , giving a diffusion coefficient of $4.9 \times 10^{4} \mathrm{~mm}^{2} / \mathrm{yr}$ (DTN: LB0307FMRADTRN.001 [DIRS 165451]; BSC 2004 [DIRS 170040], Table E-2). The corresponding value of dispersion coefficient is the product of the flow velocity and the dispersivity; the dispersivity has a fixed value of $10 \mathrm{~m}$ (BSC 2005 [DIRS 173980], Table 6-2). The smaller the flow velocity, the greater the ratio of diffusion coefficient to dispersion coefficient.

The flow velocity $v$ depends upon the overall percolation flux $q$, the fraction of the flux, which flows in fractures or faults (that is, not in the matrix) $f$, and the fracture porosity $\phi$ :

$$
v=(q f) / \phi
$$


Both $q$ and $f$ depend upon the flow field; that is, upon the climate (present, monsoon, or glacial transition) and whether the lower bound, mean, or upper bound infiltration is imposed as a boundary condition. Values of $q$ and $f$ are found in UZ Flow Models and Submodels (DTN: GS000308311221.005 [DIRS 147613]; DTN: DTN: LB03023DSSCP9I.001 [DIRS 163044]; BSC 2004 [DIRS 169861], Tables 6.1-2 and 6.6-3, respectively). Porosity $\phi$ varies with the model layer, as shown in Particle Tracking Model and Abstraction of Transport Processes (BSC 2005 [DIRS 173980], Table 6-13). To minimize $v$ and, therefore, maximize the importance of diffusion relative to dispersion, take $q$ from the slowest flow field, and take $f$ at the horizon where the greatest fraction of flow is through the matrix continuum. These are the lower bound for present-day climate, with $f$ taken at the water table. This is the lower-bound present-day flow field (preq 1A) for which $q=1.25 \mathrm{~mm} / \mathrm{yr}$ (BSC 2004 [DIRS 169861], Table 6.1-2), and $f=0.43$ (BSC 2004 [DIRS 169861], Table 6.6-3). For model layers below the repository, the greatest $\phi$, giving the slowest $v$, is 0.025 (layer tswf, BSC 2005 [DIRS 173980], Table 6-13). Substituting these values, minimum $v=21.6 \mathrm{~mm} / \mathrm{yr}$ and minimum dispersion coefficient $=2.16 \times 10^{5} \mathrm{~mm}^{2} / \mathrm{yr}$. This minimum is still 4.4 times larger than the diffusion coefficient. For the lower bound monsoon and glacial-transition flow fields, the ratios are 20 and 9.2 respectively, and the ratios are higher still for the mean and upper bound flow fields. These values all assume that the fractures are $100 \%$ saturated and, therefore, they represent lower bounds for velocity and dispersion coefficient. Therefore, under all flow scenarios diffusion in the UZ (other than matrix diffusion) is excluded because it will not significantly change radiological exposures to the RMEI or radiological releases to the accessible environment. Related FEPs 2.1.09.08.0A (Diffusion of dissolved radionuclides in EBS), and 2.1.09.24.0A (Diffusion of colloids in EBS) are treated in Engineered Barrier System Features, Events, and Processes (BSC 2005 [DIRS 173781], Sections 6.2.51 and 6.2.58).

Supporting Reports: Not applicable. 


\section{INTENTIONALLY LEFT BLANK}




\section{CONCLUSIONS}

This document presents the 93 FEPs associated with UZ flow and transport processes. The 41 FEPs identified in Section 6.2 are included in TSPA-LA. The remaining 52 FEPs are excluded from TSPA-LA, based on arguments presented in Sections 6.3 through 6.9. The FEPs analysis results are given in Table $7-1$.

The conclusions from this document (FEP Screening Decision, TSPA Disposition for included FEPs, or Screening Argument for excluded FEPs) will be incorporated in the Yucca Mountain TSPA-LA FEP database. Because this is the only subsequent use for the conclusions of this report, there are no restrictions on this use. Any uncertainties or limitations are generally related to input documents and repository design and have been previously described in Section 1.3. The FEP database will contain all Yucca Mountain FEPs considered for TSPA-LA with FEP number, name, description, and relevant FEP analysis reports where the documentation of the screening of specific FEPs is summarized. The FEP database will also contain screening decisions (Include or Exclude), screening arguments, and TSPA dispositions quoted from this and all other FEP analysis reports.

All FEP information, including the unsaturated zone FEPs considered in this report, will be submitted to Technical Data Management System by the Yucca Mountain FEP database team as a final LA FEP list and screening represented by a Data Tracking Number (DTN).

The output DTN: LB0310FEPS0170.001 contains the sequence of calculations used to evaluate perched water as discussed in Appendix A of this report. This DTN is intended only to provide information on the calculations carried out for this report. These data are not intended to be used as a source of input for other analyses.

The output DTN: LB0408U0170FEP.001 contains the input and output files used to evaluate transport with fracture apertures increased or decreased as a result of seismic activity, as discussed in Appendix D. A summary of that output DTN is presented in DTN: LB0408U0170FEP.002. These DTNs are intended only to provide information on the calculations carried out for this report. They are not intended to be used as a source of input for other analyses. 
Table 7-1. FEPs Analysis Results

\begin{tabular}{|c|c|c|c|c|}
\hline $\begin{array}{l}\text { FEP } \\
\text { Number }\end{array}$ & FEP Name & $\begin{array}{l}\text { Screening } \\
\text { Decision }\end{array}$ & $\begin{array}{l}\text { Screening Basis for } \\
\text { Excluded FEPs }\end{array}$ & $\begin{array}{l}\text { Section } \\
\text { Number }\end{array}$ \\
\hline 1.1.01.01.0A & Open site investigation boreholes & Excluded & Low Consequence & 6.3 .1 \\
\hline 1.1.01.01.0B & $\begin{array}{l}\text { Influx through holes drilled in drift wall or } \\
\text { crown }\end{array}$ & Excluded & Low Consequence & 6.3 .2 \\
\hline 1.1.02.01.0A & $\begin{array}{l}\text { Site flooding (during construction and } \\
\text { operation) }\end{array}$ & Excluded & Low Consequence & 6.3 .3 \\
\hline 1.1.02.02.0A & Preclosure ventilation & Included & & 6.2 .1 \\
\hline 1.1.04.01.0A & Incomplete closure & Excluded & $\begin{array}{l}\text { Low Consequence and } \\
\text { by Regulation }\end{array}$ & 6.3 .4 \\
\hline 1.1.11.00.0A & Monitoring of the repository & Excluded & Low Consequence & 6.3 .5 \\
\hline 1.2.02.01.0A & Fractures & Included & & 6.2 .2 \\
\hline 1.2.02.02.0A & Faults & Included & & 6.2 .3 \\
\hline 1.2.04.02.0A & Igneous activity changes rock properties & Excluded & Low Consequence & 6.8 .1 \\
\hline 1.2.06.00.0A & Hydrothermal activity & Excluded & Low Consequence & 6.8 .2 \\
\hline 1.2.07.01.0A & Erosion/denudation & Excluded & Low Consequence & 6.5 .1 \\
\hline 1.2.07.02.0A & Deposition & Excluded & Low Consequence & 6.5 .2 \\
\hline 1.2.09.02.0A & Large-scale dissolution & Excluded & Low Consequence & 6.5 .3 \\
\hline 1.2.10.01.0A & Hydrologic response to seismic activity & Excluded & $\begin{array}{l}\text { Low Consequence and } \\
\text { Low Probability }\end{array}$ & 6.8 .3 \\
\hline 1.2.10.02.0A & Hydrologic response to igneous activity & Excluded & Low Consequence & 6.8 .4 \\
\hline 1.3.01.00.0A & Climate change & Included & & 6.2 .4 \\
\hline 1.3.04.00.0A & Periglacial effects & Excluded & $\begin{array}{l}\text { Low Consequence and } \\
\text { Low Probability }\end{array}$ & 6.4 .1 \\
\hline 1.3.05.00.0A & Glacial and ice sheet effect & Excluded & Low Probability & 6.4 .2 \\
\hline 1.3.07.01.0A & Water table decline & Excluded & Low Consequence & 6.4 .3 \\
\hline 1.3.07.02.0B & Water table rise affects UZ & Included & & 6.2 .5 \\
\hline 1.4.01.00.0A & Human influences on climate & Excluded & By Regulation & 6.6 .1 \\
\hline 1.4.01.01.0A & Climate modification increases recharge & Included & & 6.2 .6 \\
\hline 1.4.01.02.0A & Greenhouse gas effects & Excluded & By Regulation & 6.6 .2 \\
\hline 1.4.01.03.0A & Acid rain & Excluded & By Regulation & 6.6 .3 \\
\hline 1.4.01.04.0A & Ozone layer failure & Excluded & By Regulation & 6.6 .4 \\
\hline 1.4.06.01.0A & Altered soil or surface water chemistry & Excluded & By Regulation & 6.6 .5 \\
\hline 2.1.05.01.0A & $\begin{array}{l}\text { Flow through seals (access ramps and } \\
\text { ventilation shafts) }\end{array}$ & Excluded & Low Consequence & 6.3 .6 \\
\hline 2.1.05.02.0A & Radionuclide transport through seals & Excluded & Low Consequence & 6.3 .7 \\
\hline 2.1.05.03.0A & Degradation of seals & Excluded & Low Consequence & 6.3 .8 \\
\hline 2.1.08.01.0A & Water influx at the repository & Included & & 6.2 .7 \\
\hline 2.1.08.02.0A & Enhanced influx at the repository & Included & & 6.2 .8 \\
\hline 2.1.09.12.0A & $\begin{array}{l}\text { Rind (chemically altered zone) forms in } \\
\text { the near-field }\end{array}$ & Excluded & Low Consequence & 6.9 .1 \\
\hline 2.1.09.21.0C & $\begin{array}{l}\text { Transport of particles larger than colloids } \\
\text { in the UZ }\end{array}$ & Excluded & Low Consequence & 6.4 .4 \\
\hline
\end{tabular}


Table 7-1. FEPs Analysis Results (Continued)

\begin{tabular}{|c|c|c|c|c|}
\hline $\begin{array}{c}\text { FEP } \\
\text { Number }\end{array}$ & FEP Name & $\begin{array}{c}\text { Screening } \\
\text { Decision }\end{array}$ & $\begin{array}{c}\text { Screening Basis } \\
\text { for Excluded } \\
\text { FEPs } \\
\end{array}$ & $\begin{array}{l}\text { Section } \\
\text { Number }\end{array}$ \\
\hline 2.2.01.01.0A & $\begin{array}{l}\text { Mechanical effects of excavation and construction in } \\
\text { the near-field }\end{array}$ & Included & & 6.2 .9 \\
\hline 2.2.01.01.0B & $\begin{array}{l}\text { Chemical effects of excavation and construction in } \\
\text { the near-field }\end{array}$ & Excluded & Low Consequence & 6.9 .2 \\
\hline 2.2.01.02.0A & Thermally-induced stress changes in the near-field & Excluded & Low Consequence & 6.9 .3 \\
\hline 2.2.01.03.0A & $\begin{array}{l}\text { Changes in fluid saturations in the excavation } \\
\text { disturbed zone }\end{array}$ & Excluded & Low Consequence & 6.9 .4 \\
\hline 2.2.01.04.0A & $\begin{array}{l}\text { Radionuclide solubility in the excavation disturbed } \\
\text { zone }\end{array}$ & Excluded & Low Consequence & 6.9 .5 \\
\hline 2.2.01.05.0A & $\begin{array}{l}\text { Radionuclide transport in the excavation disturbed } \\
\text { zone }\end{array}$ & Excluded & Low Consequence & 6.9 .6 \\
\hline 2.2.03.01.0A & Stratigraphy & Included & & 6.2 .10 \\
\hline 2.2.03.02.0A & Rock properties of host rock and other units & Included & & 6.2 .11 \\
\hline 2.2.06.01.0A & $\begin{array}{l}\text { Seismic activity changes porosity and permeability of } \\
\text { rock }\end{array}$ & Excluded & Low Consequence & 6.8 .5 \\
\hline 2.2.06.02.0A & $\begin{array}{l}\text { Seismic activity changes porosity and permeability of } \\
\text { faults }\end{array}$ & Excluded & Low Consequence & 6.8 .6 \\
\hline 2.2.06.02.0B & $\begin{array}{l}\text { Seismic activity changes porosity and permeability of } \\
\text { fractures }\end{array}$ & Excluded & Low Consequence & 6.8 .7 \\
\hline 2.2.06.03.0A & Seismic activity alters perched water zones & Excluded & Low Consequence & 6.8 .8 \\
\hline 2.2.06.04.0A & Effects of subsidence & Excluded & Low Consequence & 6.5 .4 \\
\hline 2.2.07.01.0A & Locally saturated flow at bedrock/alluvium contact & Included & & 6.2 .12 \\
\hline 2.2.07.02.0A & Unsaturated groundwater flow in the geosphere & Included & & 6.2 .13 \\
\hline 2.2.07.03.0A & Capillary rise in the UZ & Included & & 6.2 .14 \\
\hline 2.2.07.04.0A & Focusing of unsaturated flow (fingers, weeps) & Included & & 6.2 .15 \\
\hline 2.2.07.05.0A & Flow in the UZ from episodic infiltration. & Excluded & Low Consequence & 6.4 .5 \\
\hline 2.2.07.06.0A & Episodic/pulse release from repository & Excluded & Low Consequence & 6.4 .6 \\
\hline 2.2.07.06.0B & $\begin{array}{l}\text { Long-term release of radionuclides from the } \\
\text { repository }\end{array}$ & Included & & 6.2 .16 \\
\hline 2.2.07.07.0A & Perched water develops & Included & & 6.2 .17 \\
\hline 2.2.07.08.0A & Fracture flow in the UZ & Included & & 6.2 .18 \\
\hline 2.2.07.09.0A & Matrix imbibition in the UZ & Included & & 6.2 .19 \\
\hline 2.2.07.10.0A & Condensation zone forms around drifts & Included & & 6.2 .20 \\
\hline 2.2.07.11.0A & Resaturation of geosphere dry-out zone & Included & & 6.2 .21 \\
\hline 2.2.07.15.0B & Advection and dispersion in the UZ & Included & & 6.2 .22 \\
\hline 2.2.07.18.0A & Film flow into the repository & Included & & 6.2 .23 \\
\hline 2.2.07.19.0A & Lateral flow from Solitario Canyon Fault enters drifts & Included & & 6.2 .24 \\
\hline 2.2.07.20.0A & Flow diversion around repository drifts & Included & & 6.2 .25 \\
\hline 2.2.08.01.0B & Chemical characteristics of groundwater in the UZ & Included & & 6.2 .26 \\
\hline 2.2.08.03.0B & Geochemical interactions and evolution in the UZ & Excluded & Low Consequence & 6.9 .7 \\
\hline 2.2.08.04.0A & $\begin{array}{l}\text { Re-dissolution of precipitates directs more corrosive } \\
\text { fluids to waste packages }\end{array}$ & Included & & 6.2 .27 \\
\hline 2.2.08.05.0A & Diffusion in the UZ & Excluded & Low Consequence & 6.9.17 \\
\hline
\end{tabular}


Table 7-1. FEPs Analysis Results (Continued)

\begin{tabular}{|c|c|c|c|c|}
\hline $\begin{array}{c}\text { FEP } \\
\text { Number } \\
\end{array}$ & FEP Name & $\begin{array}{l}\text { Screening } \\
\text { Decision }\end{array}$ & $\begin{array}{c}\text { Screening Basis } \\
\text { for Excluded } \\
\text { FEPs } \\
\end{array}$ & $\begin{array}{l}\text { Section } \\
\text { Number }\end{array}$ \\
\hline 2.2.08.06.0B & Complexation in the UZ & Included & & 6.2 .28 \\
\hline 2.2.08.07.0B & Radionuclide solubility limits in the UZ & Excluded & Low Consequence & 6.9 .8 \\
\hline 2.2.08.08.0B & Matrix diffusion in the UZ & Included & & 6.2 .29 \\
\hline 2.2.08.09.0B & Sorption in the UZ & Included & & 6.2 .30 \\
\hline 2.2.08.10.0B & Colloidal transport in the UZ & Included & & 6.2 .31 \\
\hline 2.2.08.12.0A & Chemistry of water flowing into the drift & Included & & 6.2 .32 \\
\hline 2.2.09.01.0B & Microbial activity in the UZ & Included & & 6.2 .33 \\
\hline 2.2.10.01.0A & Repository-induced thermal effects on flow in the UZ & Excluded & Low Consequence & 6.9 .9 \\
\hline 2.2.10.03.0B & Natural geothermal effects on flow in the UZ & Included & & 6.2 .34 \\
\hline 2.2.10.04.0A & $\begin{array}{l}\text { Thermo-mechanical stresses alter characteristics of } \\
\text { fractures near repository }\end{array}$ & Excluded & Low Consequence & 6.9 .10 \\
\hline 2.2.10.04.0B & $\begin{array}{l}\text { Thermo-mechanical stresses alter characteristics of } \\
\text { faults near repository }\end{array}$ & Excluded & Low Consequence & 6.9 .11 \\
\hline 2.2.10.05.0A & $\begin{array}{l}\text { Thermo-mechanical stresses alter characteristics of } \\
\text { rocks above and below the repository }\end{array}$ & Excluded & Low Consequence & 6.9 .12 \\
\hline 2.2.10.06.0A & $\begin{array}{l}\text { Thermo-chemical alteration in the UZ (solubility, } \\
\text { speciation, phase changes, precipitation/dissolution) }\end{array}$ & Excluded & Low Consequence & 6.9 .13 \\
\hline 2.2.10.07.0A & Thermo-chemical alteration of the Calico Hills unit & Excluded & Low Consequence & 6.9 .14 \\
\hline 2.2.10.09.0A & $\begin{array}{l}\text { Thermo-chemical alteration of the Topopah Spring } \\
\text { basal vitrophyre }\end{array}$ & Excluded & Low Consequence & 6.9 .15 \\
\hline 2.2.10.10.0A & Two-phase buoyant flow/heat pipes & Included & & 6.2 .35 \\
\hline 2.2.10.11.0A & Natural air flow in the UZ & Excluded & Low Consequence & 6.7 .1 \\
\hline 2.2.10.12.0A & Geosphere dry-out due to waste heat & Included & & 6.2 .36 \\
\hline 2.2.10.14.0A & Mineralogic dehydration reactions & Excluded & Low Consequence & 6.9 .16 \\
\hline 2.2.11.02.0A & Gas effects in the UZ & Excluded & Low Consequence & 6.7 .2 \\
\hline 2.2.11.03.0A & Gas transport in geosphere & Excluded & Low Consequence & 6.7 .3 \\
\hline 2.2.12.00.0A & Undetected features in the UZ & Excluded & Low Consequence & 6.8 .9 \\
\hline 2.3.01.00.0A & Topography and morphology & Included & & 6.2 .37 \\
\hline 2.3.11.01.0A & Precipitation & Included & & 6.2 .38 \\
\hline 2.3.11.02.0A & Surface runoff and flooding & Included & & 6.2 .39 \\
\hline 2.3.11.03.0A & Infiltration and recharge & Included & & 6.2 .40 \\
\hline 3.1.01.01.0A & Radioactive decay and ingrowth & Included & & 6.2 .41 \\
\hline
\end{tabular}

\subsection{SATISFACTION OF YMRP ACCEPTANCE CRITERIA}

The satisfaction of acceptance criteria identified in Section 4.2 are summarized in Table 7-2. 
Table 7-2. Where YMRP Acceptance Criteria Have Been Addressed in This Report

\begin{tabular}{|c|c|c|c|}
\hline YMRP Section & $\begin{array}{l}\text { Acceptance } \\
\text { Criterion }\end{array}$ & Subcriteria & How and Where addressed \\
\hline \multirow[t]{4}{*}{$\begin{array}{l}\text { Scenario Analysis } \\
\text { and Event } \\
\text { Probability: } \\
\text { Scenario Analysis } \\
\text { (from Section } \\
2.2 .1 .2 .1 .3 \text { of } \\
\text { NUREG-1804 } \\
\text { [DIRS 163274]) }\end{array}$} & $\begin{array}{l}\text { 1. The } \\
\text { Identification of a } \\
\text { List of Features, } \\
\text { Events, and } \\
\text { Processes is } \\
\text { Adequate }\end{array}$ & $\begin{array}{l}\text { The Safety Analysis Report contains a complete } \\
\text { list of features, events, and processes, related to } \\
\text { the geologic setting or the degradation, } \\
\text { deterioration, or alteration of engineered barriers } \\
\text { (including those processes that would affect the } \\
\text { performance of natural barriers), that have the } \\
\text { potential to influence repository performance. } \\
\text { The list is consistent with the site } \\
\text { characterization data. Moreover, the } \\
\text { comprehensive features, events, and processes } \\
\text { list includes, but is not limited to, potentially } \\
\text { disruptive events related to igneous activity } \\
\text { (extrusive and intrusive); seismic shaking (high } \\
\text { frequency-low magnitude, and rare } \\
\text { large-magnitude events); tectonic evolution (slip } \\
\text { on existing faults and formation of new faults); } \\
\text { climatic change (change to pluvial conditions); } \\
\text { and criticality. }\end{array}$ & $\begin{array}{l}\text { See Section } 6.1 .1 \text { of this report for a } \\
\text { description and origin of the UZ } \\
\text { FEP list and descriptions. The list } \\
\text { of UZ FEPs is provided in } \\
\text { Table 1-1. Included FEP } \\
\text { descriptions and TSPA dispositions } \\
\text { are provided in Section } 6.2 \text {. See } \\
\text { Section } 6.1 .1 \text { of this report for a } \\
\text { description and origin of the UZ } \\
\text { FEP list and descriptions. }\end{array}$ \\
\hline & \multirow[t]{3}{*}{$\begin{array}{l}\text { 2. Screening of } \\
\text { the List of } \\
\text { Features, } \\
\text { Events, and } \\
\text { Processes is } \\
\text { Appropriate }\end{array}$} & $\begin{array}{l}\text { (1) The U.S. Department of Energy has identified } \\
\text { all features, events, and processes related to } \\
\text { either the geologic setting or to the degradation, } \\
\text { deterioration, or alteration of engineered barriers } \\
\text { (including those processes that would affect the } \\
\text { performance of natural barriers) that have been } \\
\text { excluded; }\end{array}$ & $\begin{array}{l}\text { See the method and approach } \\
\text { discussion provided in Section } \\
6.1 .2 \text {. Excluded FEPs are identified } \\
\text { in Sections } 6.3 \text { through } 6.9\end{array}$ \\
\hline & & $\begin{array}{l}\text { (2) The U.S. Department of Energy has provided } \\
\text { justification for those features, events, and } \\
\text { processes that have been excluded. An } \\
\text { acceptable justification for excluding features, } \\
\text { events, and processes is that either the feature, } \\
\text { event, and process is specifically excluded by } \\
\text { regulation; probability of the feature, event, and } \\
\text { process (generally an event) falls below the } \\
\text { regulatory criterion; or omission of the feature, } \\
\text { event, and process does not significantly change } \\
\text { the magnitude and time of the resulting } \\
\text { radiological exposures to the reasonably } \\
\text { maximally exposed individual, or radionuclide } \\
\text { releases to the accessible environment; }\end{array}$ & $\begin{array}{l}\text { The justification for exclusion of } \\
\text { each excluded FEP (by regulation, } \\
\text { low probability, low consequence) is } \\
\text { presented in Sections } 6.3 \text { through } \\
6.9 \text {. }\end{array}$ \\
\hline & & $\begin{array}{l}\text { (3) The U.S. Department of Energy has provided } \\
\text { an adequate technical basis for each feature, } \\
\text { event, and process, excluded from the } \\
\text { performance assessment, to support the } \\
\text { conclusion that either the feature, event, or } \\
\text { process is specifically excluded by regulation; } \\
\text { the probability of the feature, event, and process } \\
\text { falls below the regulatory criterion; or omission of } \\
\text { the feature, event, and process does not } \\
\text { significantly change the magnitude and time of } \\
\text { the resulting radiological exposures to the } \\
\text { reasonably maximally exposed individual, or } \\
\text { radionuclide releases to the accessible } \\
\text { environment. }\end{array}$ & $\begin{array}{l}\text { The technical basis for each } \\
\text { excluded FEP is presented in } \\
\text { Sections } 6.3 \text { through } 6.9 \text {. }\end{array}$ \\
\hline
\end{tabular}


Table 7-2. Where YMRP Acceptance Criteria Have Been Addressed in this Report (Continued)

\begin{tabular}{|c|c|c|c|}
\hline YMRP Section & $\begin{array}{c}\text { Acceptance } \\
\text { Criterion }\end{array}$ & Subcriteria & How and Where addressed \\
\hline \multirow[t]{2}{*}{$\begin{array}{l}\text { Identification of } \\
\text { Events with } \\
\text { Probabilities } \\
\text { Greater than } 10^{-8} \\
\text { per Year Event } \\
\text { Probability } \\
\text { (from Section } \\
2.2 .1 .2 .2 .3 \text { of } \\
\text { NUREG-1804 } \\
\text { [DIRS 163274]) }\end{array}$} & $\begin{array}{l}\text { 2. Probability } \\
\text { Estimates for } \\
\text { Future Events } \\
\text { are Supported } \\
\text { by Appropriate } \\
\text { Technical Bases }\end{array}$ & $\begin{array}{l}\text { (1) Probabilities for future natural events have } \\
\text { considered past patterns of the natural events in } \\
\text { the Yucca Mountain region, considering the } \\
\text { likely future conditions and interactions of the } \\
\text { natural and engineered repository system. } \\
\text { These probability estimates have specifically } \\
\text { included igneous events, faulting and seismic } \\
\text { events, and criticality events. }\end{array}$ & $\begin{array}{l}\text { FEPs are excluded on the basis of } \\
\text { low probability in sections } 6.4 .2 \text {, and } \\
\text { on the basis of low consequence } \\
\text { and low probability in Sections } 6.4 .1 \\
\text { and } 6.8 .3 \text {. In Sections } 6.4 .1 \text { and } \\
6.4 .2 \text {, the exclusion is based on } \\
\text { future climate predictions, } \\
\text { specifically that glacial conditions } \\
\text { will not occur during the regulatory } \\
\text { period. In Section } 6.8 .3 \text {, the } \\
\text { exclusion is based on a lack of } \\
\text { credible evidence for any } \\
\text { mechanism by which a seismic } \\
\text { event could cause the water table to } \\
\text { rise to the elevation of the } \\
\text { repository. }\end{array}$ \\
\hline & $\begin{array}{l}\text { 3. Probability } \\
\text { Model Support is } \\
\text { Adequate }\end{array}$ & $\begin{array}{l}\text { (1) Probability models are justified through } \\
\text { comparison with output from detailed process } \\
\text { level models and/or empirical observations (e.g., } \\
\text { laboratory testing, field measurements, or } \\
\text { natural analogs, including Yucca Mountain site } \\
\text { data). Specifically: } \\
\text { (a) For infrequent events, the U.S. Department } \\
\text { of Energy justifies, to the extent appropriate, } \\
\text { proposed probability models with data from } \\
\text { reasonably analogous systems. Analog systems } \\
\text { should contain significantly more events than the } \\
\text { Yucca Mountain system, to provide reasonable } \\
\text { evaluations of probability model performance; } \\
\text { (b) The U.S. Department of Energy justifies, to } \\
\text { the extent appropriate, the ability of probability } \\
\text { models to produce results consistent with the } \\
\text { timing and characteristics (e.g., location and } \\
\text { magnitude) of successive past events in the } \\
\text { Yucca Mountain system; and } \\
\text { (c) The U.S. Department of Energy probability } \\
\text { models for natural events use underlying } \\
\text { geologic bases (e.g., tectonic models) that are } \\
\text { consistent with other relevant features, events, } \\
\text { and processes evaluated. }\end{array}$ & $\begin{array}{l}\text { The prediction that glacial conditions } \\
\text { will not occur at Yucca Mountain } \\
\text { during the regulatory period is } \\
\text { based upon a combination of a } \\
\text { process model (Milankovich forcing) } \\
\text { and the analogue climate stations } \\
\text { that correspond to the data (oxygen } \\
\text { isotope data and fossil data) from } \\
\text { sites near Yucca mountain. Climate } \\
\text { predictions are cited in the exclusion } \\
\text { arguments in Section } 6.4 \text {. } \\
\text { The prediction that no seismic event } \\
\text { will cause the water table to rise to } \\
\text { the elevation of the repository } \\
\text { (Section } 6.8 .3 \text { ), is based on a lack of } \\
\text { credible evidence for any } \\
\text { mechanism to cause such a rise. }\end{array}$ \\
\hline
\end{tabular}




\section{REFERENCES AND INPUTS}

\subsection{DOCUMENTS CITED}

The following is a list of the references cited in this document. Column 2 represents the unique six digit numerical identifier (the Document Input Reference System number), which is placed in the text following the reference callout (e.g., BSC 2002 [DIRS 157928]). The purpose of these numbers is to assist in locating a specific reference. Within the reference list, multiple sources by the same author (e.g., BSC 2002) are sorted alphabetically by title.

Anderson, R.E.; Bucknam, R.C.; Crone, A.J.; Haller, K.M.; Machette, M.N.;

101422

Personius, S.F.; Barnhard, T.P.; Cecil, M.J.; and Dart, R.L. 1995. Characterization of Quaternary and Suspected Quaternary Faults, Regional Studies, Nevada and

California. Open-File Report 95-599. Denver, Colorado: U.S. Geological Survey.

ACC: MOL.19960924.0562.

Barnard, R.W.; Wilson, M.L.; Dockery, H.A.; Gauthier, J.H.; Kaplan, P.G.; Eaton, R.R.; Bingham, F.W.; and Robey, T.H. 1992. TSPA 1991: An Initial Total-System Performance Assessment for Yucca Mountain. SAND91-2795. Albuquerque, New Mexico: Sandia National Laboratories. ACC: NNA.19920630.0033.

Bear, J. 1972. Dynamics of Fluids in Porous Media. Environmental Science Series. Biswas, A.K., ed. New York, New York: Elsevier. TIC: 217356.

Bish, D.L. and Aronson, J.L. 1993. "Paleogeothermal and Paleohydrologic Conditions in Silicic Tuff from Yucca Mountain, Nevada." Clays and Clay Minerals, 41, (2), 148-161. Long Island City, New York: Pergamon Press. TIC: 224613.

Boles, James R. 1972. "Composition, Optical Properties, Cell Dimensions, and Thermal Stability of Some Heulandite Group Zeolites." American Mineralogist, 57, (NA), 1463-1493. Washington D.C., District of Columbia: Mineralogical Society of America. TIC: 218573.

Brady, B.H.G. and Brown, E.T. 1985. Rock Mechanics for Underground Mining. London, United Kingdom: George Allen and Unwin. TIC: 226226.

Bredehoeft, J.D. 1992. "Response of the Ground-Water System at Yucca Mountain to 101122 an Earthquake." Appendix D of Ground Water at Yucca Mountain: How High Can It Rise?. Washington, D.C.: National Academy Press. TIC: 233195.

BSC (Bechtel SAIC Company) 2001. FY 01 Supplemental Science and Performance 155950 Analyses, Volume 1: Scientific Bases and Analyses. TDR-MGR-MD-000007 REV 00 ICN 01. Las Vegas, Nevada: Bechtel SAIC Company. ACC: MOL.20010801.0404; MOL.20010712.0062; MOL.20010815.0001.

BSC 2001. UZ Flow Models and Submodels. MDL-NBS-HS-000006 REV 00 ICN 01. Las Vegas, Nevada: Bechtel SAIC Company. ACC: MOL.20020417.0382.

100309 
BSC 2002. Determination of Importance Evaluation for the Subsurface Exploratory

160689 Studies Facility. BAB000000-01717-2200-00005 REV 07 ICN 04. Las Vegas,

Nevada: Bechtel SAIC Company. ACC: MOL.20021028.0126.

BSC 2002. Preliminary Hydrologic Engineering Studies for the North Portal Pad and 157928

Vicinity. ANL-EBS-MD-000060 REV 00. Las Vegas, Nevada: Bechtel SAIC

Company. ACC: MOL.20021028.0123.

BSC 2003. Analysis of Infiltration Uncertainty. ANL-NBS-HS-000027 REV 01. Las Vegas, Nevada: Bechtel SAIC Company. ACC: DOC.20031030.0003.

BSC 2003. Repository Design, Repository/PA IED Subsurface Facilities.

161727 800-IED-EBS0-00402-000-00B. Las Vegas, Nevada: Bechtel SAIC Company. ACC: MOL.20030109.0146.

BSC 2003. Total System Performance Assessment-License Application Methods and 166296 Approach. TDR-WIS-PA-000006 REV 00 ICN 01. Las Vegas, Nevada: Bechtel SAIC Company. ACC: DOC.20031215.0001.

BSC 2003. Underground Layout Configuration. 800-P0C-MGR0-00100-000-00E. Las Vegas, Nevada: Bechtel SAIC Company. ACC: ENG.20031002.0007.

BSC 2004. Abstraction of Drift Seepage. MDL-NBS-HS-000019 REV 01. Las Vegas, Nevada: Bechtel SAIC Company. ACC: DOC.20041103.0003.

BSC 2004. Analysis of Hydrologic Properties Data. ANL-NBS-HS-000042 REV 00.170038 Las Vegas, Nevada: Bechtel SAIC Company. ACC: DOC.20041005.0004.

BSC 2004. Calibrated Properties Model. MDL-NBS-HS-000003 REV 02. Las Vegas, Nevada: Bechtel SAIC Company. ACC: DOC.20041006.0004.

BSC 2004. Characterize Eruptive Processes at Yucca Mountain, Nevada. 165572 ANL-MGR-GS-000002 REV 02. Las Vegas, Nevada: Bechtel SAIC Company. ACC: DOC.20041004.0006.

BSC 2004. Characterize Framework for Igneous Activity at Yucca Mountain, Nevada. ANL-MGR-GS-000001 REV 02. Las Vegas, Nevada: Bechtel SAIC Company. ACC: DOC.20041015.0002.

BSC 2004. Conceptual Model and Numerical Approaches for Unsaturated Zone Flow and Transport. MDL-NBS-HS-000005 REV 01. Las Vegas, Nevada: Bechtel SAIC Company. ACC: DOC.20040922.0006.

BSC 2004. D\&E / PA/C IED Emplacement Drift Configuration and Environment. 800-IED-MGR0-00201-000-00B. Las Vegas, Nevada: Bechtel SAIC Company. ACC: ENG.20040326.0001. 
BSC 2004. D\&E / PA/C IED Subsurface Facilities. 800-IED-WIS0-00104-000-00A. 168180 Las Vegas, Nevada: Bechtel SAIC Company. ACC: ENG.20040309.0029.

BSC 2004. D\&E / PA/C IED Subsurface Facilities. 800-IED-WIS0-00103-000-00A. 168370 Las Vegas, Nevada: Bechtel SAIC Company. ACC: ENG.20040309.0028.

BSC 2004. D\&E/RIT IED Subsurface Facilities Sheet 1 of 4. 800-IED-WIS0-00101-000-00B. Las Vegas, Nevada: Bechtel SAIC Company. ACC: ENG.20041130.0002.

BSC 2004. Data Qualification Plan, Qualification of Chemical Evidence for LongTerm Temperature Stability at Yucca Mountain. Las Vegas, Nevada: Bechtel SAIC Company. ACC: MOL.20041214.0119.

BSC 2004. Data Qualification Plan, Qualification of Dehydration Temperature of 174781 Zeolitic Minerals. Las Vegas, Nevada: Bechtel SAIC Company. ACC: MOL.20041214.0118.

BSC 2004. Data Qualification Plan, Qualification of Effect of Local FractureContinuum Heterogeneity on Transport. Las Vegas, Nevada: Bechtel SAIC Company. ACC: MOL.20041214.0115.

BSC 2004. Data Qualification Plan, Qualification of Effect of Radioactive Waste Heat on Soil Temperature. Las Vegas, Nevada: Bechtel SAIC Company. ACC:

MOL.20041214.0111.

BSC 2004. Data Qualification Plan, Qualification of Erosion Rate at Yucca Mountain. 174783 Las Vegas, Nevada: Bechtel SAIC Company. ACC: MOL.20041214.0114.

BSC 2004. Data Qualification Plan, Qualification of Potential Dose from Gas-Phase 174782 Release of Carbon-14. Las Vegas, Nevada: Bechtel SAIC Company. ACC: MOL.20041214.0113.

BSC 2004. Data Qualification Plan, Qualification of Simulations of the Composition of Plumes Formed by Leaching of Cementitius Materials in Drifts. Las Vegas, Nevada: Bechtel SAIC Company. ACC: MOL.20041214.0120.

BSC 2004. Data Qualification Plan, Qualification of Stress Field at Yucca Mountain as Reported by Stock and Healy 1998 [DIRS 101022] and Stock et al. 1985 [DIRS 101027]. La Vegas, Nevada: Bechtel SAIC Company. ACC: MOL.20041214.0117.

BSC 2004. Data Qualification Plan, Qualification of Valentine et al. 1998 [119132], p. 5-74) Observations of Contact Metamorphism Resulting from Igneous Intrusion. Las Vegas, Nevada: Bechtel SAIC Company. ACC: MOL.20041214.0112. 
BSC 2004. Data Qualification Plan, Qualification of Water Table Rise Due to Seismic

174776 Activity, as Simulated by Carrigan et al. (1991 [DIRS 100967]). Las Vegas, Nevada:

Bechtel SAIC Company. ACC: MOL.20041214.0116.

BSC 2004. Development of Numerical Grids for UZ Flow and Transport Modeling. 169855 ANL-NBS-HS-000015 REV 02. Las Vegas, Nevada: Bechtel SAIC Company. ACC: DOC.20040901.0001.

BSC 2004. Dike/Drift Interactions. MDL-MGR-GS-000005 REV 01. Las Vegas, 170028 Nevada: Bechtel SAIC Company. ACC: DOC.20041124.0002.

BSC 2004. Drift Degradation Analysis. ANL-EBS-MD-000027 REV 03. Las Vegas, 166107 Nevada: Bechtel SAIC Company. ACC: DOC.20040915.0010; DOC.20050419.0001.

BSC 2004. Drift Scale THM Model. MDL-NBS-HS-000017 REV 01. Las Vegas, Nevada: Bechtel SAIC Company. ACC: DOC.20041012.0001.

BSC 2004. Drift-Scale Radionuclide Transport. MDL-NBS-HS-000016 REV 01. Las Vegas, Nevada: Bechtel SAIC Company. ACC: DOC.20040927.0031.

BSC 2004. Future Climate Analysis. ANL-NBS-GS-000008 REV 01. Las Vegas, Nevada: Bechtel SAIC Company. ACC: DOC.20040908.0005.

BSC 2004. General Corrosion and Localized Corrosion of the Drip Shield. ANL-EBS-MD-000004 REV 02. Las Vegas, Nevada: Bechtel SAIC Company. ACC: DOC.20040921.0002.

BSC 2004. General Corrosion and Localized Corrosion of Waste Package Outer Barrier. ANL-EBS-MD-000003 REV 02. Las Vegas, Nevada: Bechtel SAIC Company. ACC: DOC.20041004.0001.

BSC 2004. Geologic Framework Model (GFM2000). MDL-NBS-GS-000002 REV 170029 02. Las Vegas, Nevada: Bechtel SAIC Company. ACC: DOC.20040827.0008.

BSC 2004. In Situ Field Testing of Processes. ANL-NBS-HS-000005 REV 03. Las Vegas, Nevada: Bechtel SAIC Company. ACC: DOC.20041109.0001.

BSC 2004. Performance Confirmation Plan. TDR-PCS-SE-000001 REV 05. Las Vegas, Nevada: Bechtel SAIC Company. ACC: DOC.20041122.0002.

169864

170040 170002 169845 BSC 2004. Post-Processing Analysis for THC Seepage. ANL-NBS-HS-000045 REV 00. Las Vegas, Nevada: Bechtel SAIC Company. ACC: DOC.20040929.0002; DOC.20050606.0006. 
BSC 2004. Radionuclide Transport Models Under Ambient Conditions.

164500 MDL-NBS-HS-000008 REV 02. Las Vegas, Nevada: Bechtel SAIC Company. ACC: DOC.20041101.0002.

BSC 2004. Repository Subsurface Turnout Drift 1-8 Interface.

167736 800-KM0-SSD0-00301-000-00A. Las Vegas, Nevada: Bechtel SAIC Company. ACC: ENG.20040220.0009.

BSC 2004. Saturated Zone Colloid Transport. ANL-NBS-HS-000031 REV 02. Las 170006 Vegas, Nevada: Bechtel SAIC Company. ACC: DOC.20041008.0007.

BSC 2004. Saturated Zone Site-Scale Flow Model. MDL-NBS-HS-000011 REV 02. Las Vegas, Nevada: Bechtel SAIC Company. ACC: DOC.20041122.0001.

BSC 2004. Seepage Calibration Model and Seepage Testing Data.

MDL-NBS-HS-000004 REV 03. Las Vegas, Nevada: Bechtel SAIC Company. ACC: DOC.20040922.0003.

BSC 2004. Seepage Model for PA Including Drift Collapse. MDL-NBS-HS-000002 REV 03. Las Vegas, Nevada: Bechtel SAIC Company. ACC: DOC.20040922.0008.

BSC 2004. Simulation of Net Infiltration for Present-Day and Potential Future Climates. MDL-NBS-HS-000023 REV 00. Las Vegas, Nevada: Bechtel SAIC Company. ACC: DOC.20041109.0004.

BSC 2004. Turnout Drift Operations Configuration. 800-KMC-SSD0-00100-000-00A. Las Vegas, Nevada: Bechtel SAIC Company. ACC: ENG.20040209.0010.

BSC 2004. UZ Flow Models and Submodels. MDL-NBS-HS-000006 REV 02. Las 169861 Vegas, Nevada: Bechtel SAIC Company. ACC: DOC.20041101.0004; DOC.20050629.0003.

BSC 2004. Ventilation Model and Analysis Report. ANL-EBS-MD-000030 REV 04.169862 Las Vegas, Nevada: Bechtel SAIC Company. ACC: DOC.20041025.0002.

BSC 2004. Yucca Mountain Site Description. TDR-CRW-GS-000001 REV 02 ICN 169734 01. Two volumes. Las Vegas, Nevada: Bechtel SAIC Company.

ACC: DOC.20040504.0008.

BSC 2005. Data Qualification Plan, Qualification of calculations showing that the PTn effectively damps out the transient effects of episodic infiltration. Las Vegas, NV: Bechtel SAIC Company. ACC: MOL.20050729.0003.

BSC 2005. Dissolved Concentration Limits of Radioactive Elements. ANL-WIS-MD-000010 REV 04. Las Vegas, Nevada: Bechtel SAIC Company. ACC: DOC.20050525.0003. 
BSC 2005. Drift-Scale Coupled Processes (DST and TH Seepage) Models.

172232 MDL-NBS-HS-000015 REV 02. Las Vegas, Nevada: Bechtel SAIC Company. ACC: DOC.20050114.0004.

BSC 2005. Drift-Scale THC Seepage Model. MDL-NBS-HS-000001 REV 04. Las 172862 Vegas, Nevada: Bechtel SAIC Company. ACC: DOC.20050218.0001.

BSC 2005. EBS Radionuclide Transport Abstraction. ANL-WIS-PA-000001 REV 173433 02. Las Vegas, Nevada: Bechtel SAIC Company.

BSC 2005. Engineered Barrier System Features, Events, and Processes.

173781 ANL-WIS-PA-000002 REV 04. Las Vegas, Nevada: Bechtel SAIC Company.

BSC 2005. Engineered Barrier System: Physical and Chemical Environment. ANL-EBS-MD-000033 REV 04. Las Vegas, Nevada: Bechtel SAIC Company.

173727

BSC 2005. Evaluation of Features, Events, and Processes (FEP) for the Biosphere Model. ANL-MGR-MD-000011 REV 05. Las Vegas, Nevada: Bechtel SAIC Company.

BSC 2005. Features, Events, and Processes: Disruptive Events.

173981 ANL-WIS-MD-000005 REV 03. Las Vegas, Nevada: Bechtel SAIC Company.

BSC 2005. Hydrogeologic Framework Model for the Saturated.

MDL-NBS-HS-000024 REV 01. Las Vegas, Nevada: Bechtel SAIC Company.

BSC 2005. IED Subsurface Facilities Committed Materials Sheet 1 of 1. 800-IED-WIS0-01501-000-00A. Las Vegas, Nevada: Bechtel SAIC Company. ACC: ENG.20050406.0002.

BSC 2005. IED Subsurface Facilities Ground Support Configuration Sheet 1 of 1. 173498 800-IED-WIS0-01601-000-00A. Las Vegas, Nevada: Bechtel SAIC Company. ACC: ENG.20050406.0003.

BSC 2005. Mountain-Scale Coupled Processes (TH/THC/THM) Models.

MDL-NBS-HS-000007 REV 03. Las Vegas, Nevada: Bechtel SAIC Company.

BSC 2005. Multiscale Thermohydrologic Model. ANL-EBS-MD-000049 REV 03. 173944 Las Vegas, Nevada: Bechtel SAIC Company. ACC: DOC.20050711.0001.

BSC 2005. Particle Tracking Model and Abstraction of Transport Processes. 173980 MDL-NBS-HS-000020 REV 02. Las Vegas, Nevada: Bechtel SAIC Company.

BSC 2005. Q-List. 000-30R-MGR0-00500-000-001. Las Vegas, Nevada: Bechtel 171190 SAIC Company. ACC: ENG.20050217.0010. 
BSC 2005. Saturated Zone Flow and Transport Model Abstraction.

174012

MDL-NBS-HS-000021 REV 03. Las Vegas, Nevada: Bechtel SAIC Company.

BSC 2005. Subsurface Facility Description Document.

174514

800-3YD-SS00-00100-000-002. Las Vegas, Nevada: Bechtel SAIC Company.

ACC: ENG.20050714.0015.

BSC 2005. Technical Work Plan for Unsaturated Zone Flow, Drift Seepage and

Unsaturated Zone Transport Modeling. TWP-MGR-HS-000004 REV 01. Las Vegas,

Nevada: Bechtel SAIC Company. ACC: DOC.20050523.0003.

BSC 2005. The Development of the Total System Performance Assessment-License

173800

Application Features, Events, and Processes. TDR-WIS-MD-000003 REV 02. Las

Vegas, Nevada: Bechtel SAIC Company.

BSC 2005. Waste Form and In-Drift Colloids-Associated Radionuclide

Concentrations: Abstraction and Summary. MDL-EBS-PA-000004 REV 02. Las

Vegas, Nevada: Bechtel SAIC Company.

Bird, R.B.; Stewart, W.E.; and Lightfoot, E.N. 1960. Transport Phenomena. New

York, New York: John Wiley \& Sons. TIC: 208957.

Carey, J.W. and Bish, D.L. 1996. "Equilibrium in the Clinoptilolite- $\mathrm{H}_{2} \mathrm{O}$ System."

105200

American Mineralogist, 81, 952-962. Washington, D.C.: Mineralogical Society of

America. TIC: 233145.

Carrigan, C.R.; King, G.C.P.; Barr, G.E.; and Bixler, N.E. 1991. "Potential for

Water-Table Excursions Induced by Seismic Events at Yucca Mountain, Nevada."

Geology, 19, (12), 1157-1160. Boulder, Colorado: Geological Society of America.

TIC: 242407.

CRWMS (Civilian Radioactive Waste Management System) M\&O (Management and

Operating Contractor) 1992. Erosion Rates at Yucca Mountain, Technical Assessment, Qualification of Data. Las Vegas, Nevada: CRWMS M\&O.

ACC: NNA.19921007.0095.

CRWMS M\&O 1996. Forensic Evaluation of Geophysical Log Data for Borehole USW SD-9 in Support of the Yucca Mountain Site Characterization Project. BAAA00000-01717-0200-00005 REV 00. Las Vegas, Nevada: CRWMS M\&O. ACC: MOL.19970606.0345.

CRWMS M\&O 1996. Forensic Evaluation of Geophysical Log Data for Borehole USW SD-7 in Support of the Yucca Mountain Site Characterization Project. BAAA00000-01717-0200-00007 REV 00. Las Vegas, Nevada: CRWMS M\&O. ACC: MOL.19971023.0133. 
CRWMS M\&O 1996. Forensic Evaluation of Geophysical Log Data for Borehole

ACC: MOL.19960517.0080.

CRWMS M\&O 1996. Forensic Evaluation of Geophysical Log Data for Borehole USW UZ-14 in Support of the Yucca Mountain Site Characterization Project. BAAA00000-01717-0200-00012 REV 00. Las Vegas, Nevada: CRWMS M\&O. ACC: MOL.19960522.0169.

CRWMS M\&O 1997. Yucca Mountain Site Characterization Project Summary of 101090 Socioeconomic Data Analyses Conducted in Support of the Radiological Monitoring Program First Quarter 1996 to First Quarter 1997. Las Vegas, Nevada: CRWMS M\&O. ACC: MOL.19971117.0460.

CRWMS M\&O 1998. “Geology.” Book 1 - Section 3 of Yucca Mountain Site 100126 Description. B00000000-01717-5700-00019 REV 00. Las Vegas, Nevada: CRWMS M\&O. ACC: MOL.19980729.0049.

CRWMS M\&O 1998. "Physical Processes of Magmatism and Effects on the Potential 123201 Repository: Synthesis of Technical Work through Fiscal Year 1995." Chapter 5 of Synthesis of Volcanism Studies for the Yucca Mountain Site Characterization Project. Deliverable 3781MR1. Las Vegas, Nevada: CRWMS M\&O.

ACC: MOL.19990511.0400.

CRWMS M\&O 1998. Probabilistic Seismic Hazard Analyses for Fault Displacement and Vibratory Ground Motion at Yucca Mountain, Nevada. Milestone SP32IM3, September 23, 1998. Three volumes. Las Vegas, Nevada: CRWMS M\&O. ACC: MOL.19981207.0393

CRWMS M\&O 1998. "Unsaturated Zone Hydrology Model.” Chapter 2 of Total 100356 System Performance Assessment-Viability Assessment (TSPA-VA) Analyses Technical Basis Document. B00000000-01717-4301-00002 REV 01. Las Vegas, Nevada: CRWMS M\&O. ACC: MOL.19981008.0002.

CRWMS M\&O 1998. "Unsaturated Zone Radionuclide Transport." Chapter 7 of Total System Performance Assessment-Viability Assessment (TSPA-VA) Analyses Technical Basis Document. B00000000-01717-4301-00007 REV 01. Las Vegas, Nevada: CRWMS M\&O. ACC: MOL.19981008.0007.

CRWMS M\&O 1998. Cross Drift Geotechnical Predictive Report: Geotechnical Baseline Report. BABEA0000-01717-5705-00002 REV 1. Las Vegas, Nevada: CRWMS M\&O. ACC: MOL.19980806.0219. 
CRWMS M\&O 1999. Final Report: Plant and Soil Related Processes Along a 105031 Natural Thermal Gradient at Yucca Mountain, Nevada. B00000000-01717-5705-00109 REV 00. Las Vegas, Nevada: CRWMS M\&O. ACC: MOL.19990513.0037.

CRWMS M\&O 1999. Impact of Radioactive Waste Heat on Soil Temperatures. 103618 BA0000000-01717-5700-00030 REV 0. Las Vegas, Nevada: CRWMS M\&O. ACC: MOL.19990309.0403.

CRWMS M\&O 2000. Analysis of Base-Case Particle Tracking Results of the 134732 Base-Case Flow Fields (ID: U0160). ANL-NBS-HS-000024 REV 00. Las Vegas, Nevada: CRWMS M\&O. ACC: MOL.20000207.0690.

CRWMS M\&O 2000. Analysis of Hydrologic Properties Data. ANL-NBS-HS-000002 REV 00. Las Vegas, Nevada: CRWMS M\&O. ACC: MOL.19990721.0519.

CRWMS M\&O 2000. Calibrated Properties Model. MDL-NBS-HS-000003 REV 00. Las Vegas, Nevada: CRWMS M\&O. ACC: MOL.19990721.0520.

CRWMS M\&O 2000. Fault Displacement Effects on Transport in the Unsaturated 151953 Zone. ANL-NBS-HS-000020 REV 01. Las Vegas, Nevada: CRWMS M\&O. ACC: MOL.20001002.0154.

CRWMS M\&O 2000. Total System Performance Assessment for the Site 153246 Recommendation. TDR-WIS-PA-000001 REV 00 ICN 01. Las Vegas, Nevada: CRWMS M\&O. ACC: MOL.20001220.0045.

CRWMS M\&O 2000. Unsaturated Zone Flow and Transport Model Process Model 150824 Report. TDR-NBS-HS-000002 REV 00 ICN 1. Las Vegas, Nevada: CRWMS M\&O. ACC: MOL.20000629.0915.

CRWMS M\&O 2000. UZ Flow Models and Submodels. MDL-NBS-HS-000006 REV 00. Las Vegas, Nevada: CRWMS M\&O. ACC: MOL.19990721.0527.

Davies, J.B. and Archambeau, C.B. 1997. "Geohydrological Models and Earthquake 103180 Effects at Yucca Mountain, Nevada." Environmental Geology, 32, (1), 23-35. New York, New York: Springer-Verlag. TIC: 237118.

Day, W.C.; Dickerson, R.P.; Potter, C.J.; Sweetkind, D.S.; San Juan, C.A.; Drake, 100027 R.M., II; and Fridrich, C.J. 1998. Bedrock Geologic Map of the Yucca Mountain Area, Nye County, Nevada. Geologic Investigations Series I-2627. Denver, Colorado: U.S. Geological Survey. ACC: MOL.19981014.0301. 
Day, W.C.; Potter, C.J.; Sweetkind, D.S.; Dickerson, R.P.; and Keefer, W.R. 1996.

124302

"Structural Geology of the Central Block of Yucca Mountain." Chapter 2-I of

Seismotectonic Framework and Characterization of Faulting at Yucca Mountain,

Nevada. Whitney, J.W., ed. Milestone 3GSH100M. Denver, Colorado:

U.S. Geological Survey. TIC: 237980. ACC: MOL.19970129.0041.

Day, W.C.; Potter, C.J.; Sweetkind, D.S.; Dickerson, R.P.; and San Juan, C.A. 1998.

Bedrock Geologic Map of the Central Block Area, Yucca Mountain, Nye County,

Nevada. Miscellaneous Investigations Series Map I-2601. Washington, D.C.:

U.S. Geological Survey. ACC: MOL.19980611.0339.

DOE (U.S. Department of Energy) 1988. Site Characterization Plan Yucca Mountain

100282

Site, Nevada Research and Development Area, Nevada. DOE/RW-0199. Nine volumes. Washington, D.C.: U.S. Department of Energy, Office of Civilian

Radioactive Waste Management. ACC: HQO.19881201.0002.

DOE 2002. Final Environmental Impact Statement for a Geologic Repository for the

Disposal of Spent Nuclear Fuel and High-Level Radioactive Waste at Yucca

Mountain, Nye County, Nevada. DOE/EIS-0250. Washington, D.C.:

U.S. Department of Energy, Office of Civilian Radioactive Waste Management.

ACC: MOL.20020524.0314; MOL.20020524.0315; MOL.20020524.0316;

MOL.20020524.0317; MOL.20020524.0318; MOL.20020524.0319;

MOL.20020524.0320.

Dombrowski, H.S. and Brownell, L.E. 1954. "Residual Equilibrium Saturation of

Porous Media." Industrial \& Engineering Chemistry, 46, (6), 1207-1219. Easton,

Pennsylvania: American Chemical Society. TIC: 254309.

Doraswamy, N. 2004. Project Design Criteria Document.

000-3DR-MGR0-00100-000-002. Las Vegas, Nevada: Bechtel SAIC Company.

ACC: ENG.20040721.0003.

Dudley, W.W., Jr. 1990. "Multidisciplinary Hydrologic Investigations at Yucca

Mountain, Nevada." High Level Radioactive Waste Management, Proceedings of the International Topical Meeting, Las Vegas, Nevada April 8-12, 1990. 1, 1-9. La Grange Park, Illinois: American Nuclear Society. TIC: 202058.

Dyer, J.R. 1999. "Revised Interim Guidance Pending Issuance of New U.S. Nuclear Regulatory Commission (NRC) Regulations (Revision 01, July 22, 1999), for Yucca Mountain, Nevada." Letter from J.R. Dyer (DOE/YMSCO) to D.R. Wilkins (CRWMS M\&O), September 3, 1999, OL\&RC:SB-1714, with enclosure, "Interim Guidance Pending Issuance of New NRC Regulations for Yucca Mountain (Revision 01).” ACC: MOL.19990910.0079. 
Farmer, G.L.; Broxton, D.E.; Warren, R.G.; and Pickthorn, W. 1991. "Nd, Sr, and O 153024 Isotopic Variations in Metaluminius Ash-Flow Tuffs and Related Volcanic Rocks at the Timber Mountain/Oasis Valley Caldera, Complex, SW Nevada: Implications for the Origin and Evolution of Large-Volume Silicic Magma Bodies." Contributions to Mineralogy and Petrology, 109, 53-68. New York, New York: Springer-Verlag. TIC: 249053.

Fenix \& Scisson. 1986. NNWSI Hole Histories, UE-25 WT \#3, UE-25 WT \#4, UE-25 WT \#5, UE-25 WT \#6, UE-25 WT \#12, UE-25 WT \#13, UE-25 WT \#14, UE-25 WT \#15, UE-25 WT \#16, UE-25 WT \#17, UE-25 WT \#18, USW WT-1, USW WT-2, USW WT-7, USW WT-10, USW WT-11. DOE/NV/10322-10. Mercury, Nevada: Fenix \& Scisson. ACC: NNA.19870317.0155.

Fenix \& Scisson. 1987. NNWSI Hole Histories, USW G-1, USW G-2, USW G-3, USW 103102 G-4, USW GA-1, USW GU-3. DOE/NV/10322-19. Mercury, Nevada: Fenix \& Scisson. ACC: HQS.19880517.1194.

Fenix \& Scisson. 1987. NNWSI Hole Histories, USW H-1, USW H-3, USW H-4, USW 126415 H-5, USW H-6. DOE/NV/10322-18. Washington, D.C.: U.S. Department of Energy, Office of Civilian Radioactive Waste Management. ACC: NNA.19871006.0069.

Fenix \& Scisson. 1987. NNWSI Hole Histories, USW UZ-1, UE-25 UZ \#4, UE-25 UZ \#5, USW UZ-6, USW UZ-6s, USW UZ-7, USW UZ-8, USW UZ-13.

DOE/NV/10322-20. Washington, D.C.: U.S. Department of Energy, Office of Civilian Radioactive Waste Management. ACC: HQS.19880517.1193.

Ferrill, D.A.; Morris, A.P.; Evans, M.A.; Burkhard, M.; Groshong,R.H.,Jr.; and 171196 Onasch, C.M. 2004. "Calcite Twin Morphology: A Low-Temperature Deformation Geothermometer." Journal of Structural Geology, 26, (8), 1521-1529. New York, New York: Elsevier. TIC: 256408.

Flint, L.E. 1998. Characterization of Hydrogeologic Units Using Matrix Properties, Yucca Mountain, Nevada. Water-Resources Investigations Report 97-4243. Denver, Colorado: U.S. Geological Survey. ACC: MOL.19980429.0512.

Forester, R.M.; Bradbury, J.P.; Carter, C.; Elvidge, A.B.; Hemphill, M.L.; Lundstrom, S.C.; Mahan, S.A.; Marshall, B.D.; Neymark, L.A.; Paces, J.B.; Sharpe, S.E.; Whelan, J.F.; and Wigand, P.E. 1996. Synthesis of Quaternary Response of the Yucca Mountain Unsaturated and Saturated Zone Hydrology to Climate Change. Milestone 3GCA102M. Las Vegas, Nevada: U.S. Geological Survey.

ACC: MOL.19970211.0026.

Forester, R.M.; Bradbury, J.P.; Carter, C.; Elvidge-Tuma, A.B.; Hemphill, M.L.; 109425 Lundstrom, S.C.; Mahan, S.A.; Marshall, B.D.; Neymark, L.A.; Paces, J.B.; Sharpe, S.E.; Whelan, J.F.; and Wigand, P.E. 1999. The Climatic and Hydrologic History of Southern Nevada During the Late Quaternary. Open-File Report 98-635. Denver, Colorado: U.S. Geological Survey. TIC: 245717. 
Freeze, R.A. and Cherry, J.A. 1979. Groundwater. Englewood Cliffs, New Jersey:

101173 Prentice-Hall. TIC: 217571.

Gauthier, J.H.; Wilson, M.L.; Borns, D.J.; and Arnold, B.W. 1995. Impacts of

103258 Seismic Activity on Long-Term Repository Performance at Yucca Mountain. SAND95-1917C. Albuquerque, New Mexico: Sandia National Laboratories. ACC: MOL.19960327.0356.

Gauthier, J.H.; Wilson, M.L.; Borns, D.J.; and Arnold, B.W. 1996. "Impacts of Seismic Activity on Long-Term Repository Performance at Yucca Mountain." Proceedings of the Topical Meeting on Methods of Seismic Hazards Evaluation, Focus '95, September 18-20, 1995, Las Vegas, Nevada. Pages 159-168. La Grange Park, Illinois: American Nuclear Society. TIC: 232628.

Gray, M.B.; Stamatakos, J.A.; and Ferrill, D.A. 2000. "Polygenetic Secondary Calcite Mineralization in Yucca Mountain, NV." Abstracts with Programs Geological Society of America, 32, (7), A-260. Boulder, Colorado: Geological Society of America. TIC: 249113.

Hardin, E.L. 1998. Near-Field/Altered-Zone Models Report. UCRL-ID-129179. 100123 Livermore, California: Lawrence Livermore National Laboratory. ACC: MOL.19980630.0560.

Harrington, C.D. and Whitney, J.W. 1987. "Scanning Electron Microscope Method for Rock-Varnish Dating." Geology, 15, 967-970. Boulder, Colorado: Geological Society of America. TIC: 203298.

Hawley, J.W. 1989. Peer Review Report on Rock-Varnish Studies within the Yucca Mountain Project--LANL, ESS-1 Group. Letter from J.W. Hawley (New Mexico Bureau of Mines \& Mineral Resources) to W.A. Morris (LANL), September 6, 1989, TWS-ESS-1-6-89-6, with enclosure. ACC: NNA.19921125.0009.

Holt, E.W. 2002. ${ }^{، 18} 0 /{ }^{16} 0$ Evidence for an Early, Short-Lived ( $\left.\sim 10 \mathrm{yr}\right)$, Fumarolic 162326 Event in the Topopah Spring Tuff Near the Proposed High-Level Nuclear Waste Repository Within Yucca Mountain, Nevada, USA." Earth and Planetary Science Letters, 201, (3-4), 559-573. New York, New York: Elsevier. TIC: 255127.

Jannik, N.O.; Phillips, F.M.; Smith, G.I.; and Elmore, D. 1991. "A 36Cl Chronology 109434 of Lacustrine Sedimentation in the Pleistocene Owens River System." Geological Society of America Bulletin, 103, 1146-1159. Boulder, Colorado: Geological Society of America. TIC: 245705.

Keller, E.A. 1992. Environmental Geology. Sixth Edition. New York, New York: Macmillan Publishing. TIC: 247330. 
Lachenbruch, A.H.; Sass, J.H.; Munroe, R.J.; and Moses, T.H., Jr. 1976.

171203

"Geothermal Setting and Simple Heat Conduction Models for the Long Valley Caldera." Journal of Geophysical Research, 81, (5), 769-784. Washington, D.C.: American Geophysical Union. TIC: 223532.

Liu, H.H.; Doughty, C.; and Bodvarsson, G.S. 1998. "An Active Fracture Model for 105729 Unsaturated Flow and Transport in Fractured Rocks." Water Resources Research, 34, (10), 2633-2646. Washington, D.C.: American Geophysical Union. TIC: 243012.

Liu, H-H.; Haukwa, C.B.; Ahlers, C.F.; Bodvarsson, G.S.; Flint, A.L.; and Guertal, W.B. 2003. "Modeling Flow and Transport in Unsaturated Fractured Rock: An Evaluation of the Continuum Approach." Journal of Contaminant Hydrology, 62-63, 173-188. New York, New York: Elsevier. TIC: 254205.

Marshall, B.D. and Whelan, J.F. 2000. "Isotope Geochemistry of Calcite Coatings and the Thermal History of the Unsaturated Zone at Yucca Mountain, Nevada." Abstracts with Programs - Geological Society of America, 32, (7), A-259. Boulder, Colorado: Geological Society of America. TIC: 249113.

Marshall, B.D. and Whelan, J.F. 2001. "Simulating the Thermal History of the Unsaturated Zone at Yucca Mountain, Nevada." Abstracts with Programs Geological Society of America, 33, (6), A-375. Boulder, Colorado: Geological Society of America. TIC: 252701.

Marshall, B.D. and Whelan, J.F. 2001. Simulating the Thermal History of the 171061 Unsaturated Zone at Yucca Mountain, Nevada. Denver, Colorado: U.S. Geological Survey. ACC: MOL.20040505.0491.

Martinez M.J. and Nilson, R.H. 1999. "Estimates of Barometric Pumping of Moisture 174095 through Unsaturated Fractured Rock." Transport in Porous Media, 36, (1), 85-119. Dordrecht, The Netherlands: Kluwer Academic Publishers. TIC: 257394.

Menges, C.M. and Whitney, J.W. 1996. "Summary of Quaternary Faulting on the Paintbrush Canyon, Stagecoach Road, and Bow Ridge Faults." Chapter 4.4 of Seismotectonic Framework and Characterization of Faulting at Yucca Mountain, Nevada. Whitney, J.W., ed. Milestone 3GSH100M. Denver, Colorado: U.S. Geological Survey. TIC: 237980. ACC: MOL.19970129.0041.

Menges, C.M.; Taylor, E.M.; Vadurro, G.; Oswald, J.A.; Cress, R.; Murray, M.; Lundstrom, S.C.; Paces, J.B.; and Mahan, S.A. 1997. Logs and Paleoseismic Interpretations from Trenches $14 C$ and 14D on the Bow Ridge Fault, Northeastern Yucca Mountain, Nye County, Nevada. Miscellaneous Field Studies Map MF-2311. Denver, Colorado: U.S. Geological Survey. ACC: MOL.19980226.0591. 
National Research Council. 1992. Ground Water at Yucca Mountain, How High Can 105162 It Rise? Final Report of the Panel on Coupled Hydrologic/Tectonic/Hydrothermal Systems at Yucca Mountain. Washington, D.C.: National Academy Press.

TIC: 204931.

Neymark, L.A.; Paces, J.B.; and Amelin, Y.V. 2003. "Reliability of U-Th-Pb Dating 163681 of Secondary Silica at Yucca Mountain, Nevada." Proceedings of the 10th International High-Level Radioactive Waste Management Conference (IHLRWM), March 30-April 2, 2003, Las Vegas, Nevada. Pages 1-12. La Grange Park, Illinois: American Nuclear Society. TIC: 254559.

NRC (U.S. Nuclear Regulatory Commission) 2003. Yucca Mountain Review Plan, 163274 Final Report. NUREG-1804, Rev. 2. Washington, D.C.: U.S. Nuclear Regulatory Commission, Office of Nuclear Material Safety and Safeguards. TIC: 254568.

NRC 2004. Risk Insights Baseline Report. Washington, D.C.: U.S. Nuclear 170243 Regulatory Commission, Office of Nuclear Material Safety and Safeguards. ACC: MOL.20040629.0235.

Oversby, V.M. 1987. "Spent Fuel as a Waste Form - Data Needs to Allow Long Term Performance Assessment under Repository Disposal Conditions." Scientific Basis for Nuclear Waste Management X, Symposium held December 1-4, 1986, Boston, Massachusetts. Bates, J.K. and Seefeldt, W.B., eds. 84, 87-101. Pittsburgh, Pennsylvania: Materials Research Society. TIC: 203663.

Papadakis, V.G. 2000. "Effect of Supplementary Cementing Materials on Concrete 172019 Resistance Against Carbonation and Chloride Ingress." Cement and Concrete Research, 30, 291-299. New York, New York: Pergamon. TIC: 256071.

Perry, R.H. and Chilton, C.H., eds. 1973. Chemical Engineers' Handbook. 5th Edition. New York, New York: McGraw-Hill. TIC: 242591.

Piety, L.A. 1996. Compilation of Known or Suspected Quaternary Faults Within 100 106540 km of Yucca Mountain, Nevada and California. Open-File Report 94-112. Denver, Colorado: U.S. Geological Survey. ACC: MOL.19971009.0003.

Potter, C.J.; Day, W.C.; and Sweetkind, D.S. 1996. "Structural Evolution of the Potential High-Level Nuclear Waste Repository Site at Yucca Mountain, Nevada." Abstracts with Programs - Geological Society of America, 28, (7), A-191. Boulder, Colorado: Geological Society of America. TIC: 233271.

Potter, C.J.; Day, W.C.; Sweetkind, D.S.; and Dickerson, R.P. 1996. "Fault Styles 106583 and Strain Accommodation in the Tiva Canyon Tuff, Yucca Mountain, Nevada." Eos, Transactions (Supplement), 77, (17), S265. Washington, D.C.: American Geophysical Union. TIC: 234819. 
Potter, C.J.; Dickerson, R.P.; and Day, W.C. 1999. Nature and Continuity of the 107259 Sundance Fault. Open-File Report 98-266. Denver, Colorado: U.S. Geological Survey. TIC: 246609.

Pruess, K. 1987. TOUGH User's Guide. NUREG/CR-4645. Washington, D.C.: 100684 U.S. Nuclear Regulatory Commission. TIC: 217275.

Pruess, K. 1991. TOUGH2-A General-Purpose Numerical Simulator for 100413 Multiphase Fluid and Heat Flow. LBL-29400. Berkeley, California: Lawrence Berkeley Laboratory. ACC: NNA.19940202.0088.

Pruess, K. 1996. "Effective Parameters, Effective Processes: From Porous Flow Physics to In Situ Remediation Technology." Groundwater and Subsurface Remediation: Research Strategies for In-Situ Technologies VEGAS International Symposium, Stuttgart, Federal Republic of Germany, September 26-27, 1995. Kobus, H.; Barczewski, B.; and Koschitzky, H-P.; eds. 183-193. New York, New York: Springer. TIC: 238489.

Pruess, K.; Oldenburg, C.; and Moridis, G. 1999. TOUGH2 User's Guide, Version 2.0. LBNL-43134. Berkeley, California: Lawrence Berkeley National Laboratory. TIC: 253038.

Ramelli, A.R.; Oswald, J.A.; Vadurro, G.; Menges, C.M.; and Paces, J.B. 1996. "Quaternary Faulting on the Solitario Canyon Fault." Chapter 4.7 of Seismotectonic Framework and Characterization of Faulting at Yucca Mountain, Nevada. Whitney, J.W., ed. Milestone 3GSH100M. Denver, Colorado: U.S. Geological Survey. TIC: 237980. ACC: MOL.19970129.0041.

Raney, R.G. 1988. Reported Effects of Selected Earthquakes in the Western North 147173 America Intermontane Region, 1852-1983, on Underground Workings and Local and Regional Hydrology: A Summary. NRC FIN D1018. Spokane, Washington:

U.S. Department of the Interior, Bureau of Mines. TIC: 217278.

Ratcliff, C.D.; Geissman, J.W.; Perry, F.V.; Crowe, B.M.; and Zeitler, P.K. 1994. 106634 "Paleomagnetic Record of a Geomagnetic Field Reversal from Late Miocene Mafic Intrusions, Southern Nevada." Science, 266, 412-416. Washington, D.C.: American Association for the Advancement of Science. TIC: 234818.

Reamer, C.W. 1999. "Issue Resolution Status Report (Key Technical Issue: Igneous 119693 Activity, Revision 2)." Letter from C.W. Reamer (NRC) to Dr. S. Brocoum (DOE/YMSCO), July 16, 1999, with enclosure. ACC: MOL.19990810.0639.

Reimus, P.W.; Ware, S.D.; Benedict, F.C.; Warren, R.G.; Humphrey, A.; Adams, A.; Wilson, B.; and Gonzales, D. 2002. Diffusive and Advective Transport of ${ }^{3} \mathrm{H},{ }^{14} \mathrm{C}$, and ${ }^{99}$ Tc in Saturated, Fractured Volcanic Rocks from Pahute Mesa, Nevada. LA-13891-MS. Los Alamos, New Mexico: Los Alamos National Laboratory. TIC: 253905. 
Richards, L.A. 1931. "Capillary Conduction of Liquids Through Porous Mediums.” 104252 Physics, 1, 318-333. New York, New York: American Physical Society.

TIC: 225383.

Sawyer, D.A.; Fleck, R.J.; Lanphere, M.A.; Warren, R.G.; Broxton, D.E.; and Hudson, 100075 M.R. 1994. "Episodic Caldera Volcanism in the Miocene Southwestern Nevada Volcanic Field: Revised Stratigraphic Framework, ${ }^{40} \mathrm{Ar} /{ }^{39} \mathrm{Ar}$ Geochronology, and Implications for Magmatism and Extension." Geological Society of America Bulletin, 106, (10), 1304-1318. Boulder, Colorado: Geological Society of America.

TIC: 222523.

Scott, R.B. 1990. "Tectonic Setting of Yucca Mountain, Southwest Nevada." 106751 Chapter 12 of Basin and Range Extensional Tectonics Near the Latitude of Las Vegas, Nevada. Wernicke, B.P., ed. Memoir 176. Boulder, Colorado: Geological Society of America. TIC: 222540.

Scott, R.B. and Bonk, J. 1984. Preliminary Geologic Map of Yucca Mountain, Nye 104181 County, Nevada, with Geologic Sections. Open-File Report 84-494. Denver, Colorado: U.S. Geological Survey. ACC: HQS.19880517.1443.

Sharpe, S. 2003. Future Climate Analysis-10,000 Years to 1,000,000 Years After Present. MOD-01-001 REV 01. Reno, Nevada: Desert Research Institute. ACC: MOL.20030407.0055.

Simonds, F.W.; Whitney, J.W.; Fox, K.F.; Ramelli, A.R.; Yount, J.C.; Carr, M.D.; 101929 Menges, C.M.; Dickerson, R.P.; and Scott, R.B. 1995. Map Showing Fault Activity in the Yucca Mountain Area, Nye County, Nevada. Miscellaneous Investigations Series Map I-2520. Denver, Colorado: U.S. Geological Survey. TIC: 232483.

Smyth, J.R. 1982. "Zeolite Stability Constraints on Radioactive Waste Isolation in Zeolite-Bearing Volcanic Rocks.” Journal of Geology, 90, (2), 195-201. Chicago, Illinois: University of Chicago Press. TIC: 221104.

Smyth, J.R. and Caporuscio, F.A. 1981. Review of the Thermal Stability and Cation Exchange Properties of the Zeolite Minerals Clinoptilolite, Mordenite, and Analcime: Applications to Radioactive Waste Isolation in Silicic Tuff. LA-8841-MS. Los Alamos, New Mexico: Los Alamos Scientific Laboratory. ACC: HQS.19880517.2065.

Sonnenthal, E.L. and Bodvarsson, G.S. 1999. "Constraints on the Hydrology of the Unsaturated Zone at Yucca Mountain, NV from Three-Dimensional Models of Chloride and Strontium Geochemistry." Journal of Contaminant Hydrology, 38, (1-3), 107-156. New York, New York: Elsevier. TIC: 244160. 
Sonnenthal, E.L.; DePaolo, D.J.; and Bodvarsson, G.S. 1997. "Modeling the

Strontium Geochemistry and Isotopic Ratio in the Unsaturated Zone." Chapter 17 of The Site-Scale Unsaturated Zone Model of Yucca Mountain, Nevada, for the Viability Assessment. Bodvarsson, G.S.; Bandurraga, T.M.; and Wu, Y.S., eds. LBNL-40376. Berkeley, California: Lawrence Berkeley National Laboratory.

ACC: MOL.19971014.0232.

Stock, J.M. and Healy, J.H. 1988. "Stress Field at Yucca Mountain, Nevada." 101022 Chapter 6 of Geologic and Hydrologic Investigations of a Potential Nuclear Waste Disposal Site at Yucca Mountain, Southern Nevada. Carr, M.D. and Yount, J.C., eds. Bulletin 1790. Denver, Colorado: U.S. Geological Survey. TIC: 203085.

Stock, J.M.; Healy, J.H.; Hickman, S.H.; and Zoback, M.D. 1985. "Hydraulic 101027 Fracturing Stress Measurements at Yucca Mountain, Nevada, and Relationship to the Regional Stress Field." Journal of Geophysical Research, 90, (B10), 8691-8706. Washington, D.C.: American Geophysical Union. TIC: 219009.

Sweetkind, D.S. and Williams-Stroud, S.C. 1996. Characteristics of Fractures at 100182 Yucca Mountain, Nevada: Synthesis Report. Administrative Report. Denver, Colorado: U.S. Geological Survey. ACC: MOL.19961213.0181.

Sweetkind, D.S.; Barr, D.L.; Polacsek, D.K.; and Anna, L.O. 1997. Administrative Report: Integrated Fracture Data in Support of Process Models, Yucca Mountain, Nevada. Milestone SPG32M3. Las Vegas, Nevada: U.S. Geological Survey. ACC: MOL.19971017.0726.

Sweetkind, D.S.; Potter, C.J.; and Verbeek, E.R. 1996. "Interaction Between Faults and the Fracture Network at Yucca Mountain, Nevada." Eos Transactions, S266. Washington, D.C.: American Geophysical Union. TIC: 236789.

Szabo, B.J.; Kolesar, P.T.; Riggs, A.C.; Winograd, I.J.; and Ludwig, K.R. 1994.

100088 "Paleoclimatic Inferences from a 120,000-Yr Calcite Record of Water-Table Fluctuation in Browns Room of Devils Hole, Nevada." Quaternary Research, 41, (1), 59-69. New York, New York: Academic Press. TIC: 234642.

Szymanski, J.S. 1989. Conceptual Considerations of the Yucca Mountain 106963 Groundwater System with Special Emphasis on the Adequacy of This System to Accommodate a High-Level Nuclear Waste Repository. Three volumes. Las Vegas, Nevada: U.S. Department of Energy, Nevada Operations Office.

ACC: NNA.19890831.0152.

Triay, I.R.; Meijer, A.; Conca, J.L.; Kung, K.S.; Rundberg, R.S.; Strietelmeier, B.A.; 100422 and Tait, C.D. 1997. Summary and Synthesis Report on Radionuclide Retardation for the Yucca Mountain Site Characterization Project. Eckhardt, R.C., ed. LA-13262-MS. Los Alamos, New Mexico: Los Alamos National Laboratory. ACC: MOL.19971210.0177. 
Tsang, Y.W. and Pruess, K. 1990. Further Modeling Studies of Gas Movement and Moisture Migration at Yucca Mountain, Nevada. LBL-29127. Berkeley, California: Lawrence Berkeley Laboratory. ACC: NNA.19910405.0037.

Valentine, G.A.; WoldeGabriel, G.; Rosenberg, N.D.; Carter Krogh, K.E.; Crowe, B.M.; Stauffer, P.; Auer, L.H.; Gable, C.W.; Goff, F.; Warren, R.; and Perry, F.V. 1998. "Physical Processes of Magmatism and Effects on the Potential Repository: Synthesis of Technical Work Through Fiscal Year 1995." Chapter 5 of Volcanism Studies: Final Report for the Yucca Mountain Project. Perry, F.V.; Crowe, B.M.; Valentine, G.A.; and Bowker, L.M., eds. LA-13478. Los Alamos, New Mexico: Los Alamos National Laboratory. TIC: 247225.

van Genuchten, M.T. 1980. "A Closed-Form Equation for Predicting the Hydraulic 100610 Conductivity of Unsaturated Soils." Soil Science Society of America Journal, 44, (5), 892-898. Madison, Wisconsin: Soil Science Society of America. TIC: 217327.

Vanoni, V.A., ed. 1977. "Sediment Transportation Mechanics.” Sedimentation Engineering. Pages 17-315. New York, New York: American Society of Civil Engineers. TIC: 255225.

Whelan, J.F.; Neymark, L.A.; Roedder, E.; and Moscati, R.J. 2003.

"Thermochronology of Secondary Minerals from the Yucca Mountain Unsaturated Zone." Proceedings of the 10th International High-Level Radioactive Waste Management Conference (IHLRWM), March 30-April 2, 2003, Las Vegas, Nevada. Pages 357-366. La Grange Park, Illinois: American Nuclear Society. TIC: 254368.

Whelan, J.F.; Paces, J.B.; and Peterman, Z.E. 2002. "Physical and Stable-Isotope Evidence for Formation of Secondary Calcite and Silica in the Unsaturated Zone, Yucca Mountain, Nevada." Applied Geochemistry, 17, (6), 735-750. New York, New York: Elsevier. TIC: 253462.

Whitney, J.W. and Harrington, C.D. 1993. "Relict Colluvial Boulder Deposits as Paleoclimatic Indicators in the Yucca Mountain Region, Southern Nevada." Geological Society of America Bulletin, 105, 1008-1018. Boulder, Colorado: Geological Society of America. TIC: 208099.

Wilson, N.S.F.; Cline, J.S.; and Amelin, Y.V. 2003. "Origin, Timing, and Temperature of Secondary Calcite-Silica Mineral Formation at Yucca Mountain, Nevada." Geochimica et Cosmochimica Acta, 67, (6), 1145-1176. New York, New York: Pergamon. TIC: 254369.

Wohletz, K.; Civetta, L.; and Orsi, G. 1999. "Thermal Evolution of the Phlegraean Magmatic System." Journal of Volcanology and Geothermal Research, 91, (2-4), 381-414. New York, New York: Elsevier. TIC: 254719. 
WoldeGabriel, G.; Keating, G.N.; and Valentine, G.A. 1999. "Effects of Shallow Basaltic Intrusion into Pyroclastic Deposits, Grants Ridge, New Mexico, USA.” Journal of Volcanology and Geothermal Research, 92, (3), 389-411. New York, New York: Elsevier. TIC: 246037.

Wu, Y-S. and Pruess, K. 2000. "Numerical Simulation of Non-Isothermal Multiphase 153972 Tracer Transport in Heterogeneous Fractured Porous Media." Advances in Water Resources, 23, (7), 699-723. New York, New York: Elsevier. TIC: 249626.

Wu, Y-S.; Zhang, W.; Pan, L.; Hinds, J.; and Bodvarsson, G.S. 2000. Capillary Barriers in Unsaturated Fractured Rocks of Yucca Mountain, Nevada. LBNL-46876. Berkeley, California: Lawrence Berkeley National Laboratory. TIC: 249912.

Wu, Y-S.; Zhang, W.; Pan, L.; Hinds, J.; and Bodvarsson, G.S. 2002. "Modeling Capillary Barriers in Unsaturated Fractured Rock." Water Resources Research, 38, (11), 35-1 through 35-12. Washington, D.C.: American Geophysical Union. TIC: 253854.

YMP (Yucca Mountain Site Characterization Project) 1993. Evaluation of the 100520 Potentially Adverse Condition "Evidence of Extreme Erosion During the Quaternary Period" at Yucca Mountain, Nevada. Topical Report YMP/92-41-TPR. Las Vegas, Nevada: Yucca Mountain Site Characterization Office. ACC: NNA.19930316.0208.

YMP 1995. Technical Basis Report for Surface Characteristics, Preclosure 102215 Hydrology, and Erosion. YMP/TBR-001, Rev. 0. Las Vegas, Nevada: Yucca Mountain Site Characterization Office. ACC: MOL.19951201.0049.

YMP 1999. Borehole USW SD-6. Field Work Package FWP-SB-97-002, Rev. 2. Las Vegas, Nevada: Yucca Mountain Site Characterization Office.

ACC: MOL.19990414.0267.

YMP 2001. Reclamation Implementation Plan. YMP/91-14, Rev. 2. Las Vegas, 154386 Nevada: Yucca Mountain Site Characterization Office. ACC: MOL.20010301.0238.

Zhang, G. and Moridis, G. 2004. YMP-LBNL-GJM-GZ-1, Unsaturated Zone Synthesis and Modeling. Scientific Notebook SN-LBNL-SCI-235-V1 partial submittal. Pages TOC-3, Pages 6-37 ACC: MOL.20030505.0156;

MOL.20040420.0248.

Zhou, Q.; Liu, H-H.; Bodvarsson, G.S.; and Oldenburg, C.M. 2003. "Flow and Transport in Unsaturated Fractured Rock: Effects of Multiscale Heterogeneity of Hydrogeologic Properties." Journal of Contaminant Hydrology, 60, (1-2), 1-30. New York, New York: Elsevier. TIC: 253978. 
Ziegler, J.D. 2004. "Transmittal of Appendix D of the Technical Basis Document No.

171694

10: Unsaturated Zone Transport Addressing Key Technical Issue (KTI) Agreement Evolution of Near-Field Environment (ENFE) 1.04.” Letter from J.D. Ziegler (DOE/ORD) to the NRC, August 31, 2004, 0902043035, OLA\&S: JCP-1434 with enclosure. ACC: MOL.20041027.0242.

Ziegler, J.D. 2004. "Transmittal of Appendix H, Technical Basis Document No. 2: 171590 Unsaturated Zone Flow Addressing Key Technical Issue (KTI) Agreements Evolution of the Near-Field Environment (ENFE) 2.03 and Total System Performance Assessment and Integration (TSPAI) 2.02, Comments 3, 4, 12, and J-23." Letter from J.D. Ziegler (DOE/ORD) to the NRC, July 1, 2004, 0702042234, OLA\&S: JCP-1386 with enclosure. ACC: MOL.20040922.0225. 


\subsection{CODES, STANDARDS, REGULATIONS, AND PROCEDURES}

10 CFR 63. 2005 Energy: Disposal of High-Level Radioactive Wastes in a Geologic

Repository at Yucca Mountain, Nevada. ACC: MOL.20050405.0118.

66 FR 55732. Disposal of High-Level Radioactive Wastes in a Proposed Geologic

Repository at Yucca Mountain, NV, Final Rule. 10 CFR Parts 2, 19, 20, 21, 30, 40,

51, 60, 61, 63, 70, 72, 73, and 75. ACC: MOL.20050324.0102.

67 FR 62628. Specification of a Probability for Unlikely Features, Events and

Processes. Readily available.

Canori, G.F. and Leitner, M.M. 2003. Project Requirements Document.

TER-MGR-MD-000001 REV 02. Las Vegas, Nevada: Bechtel SAIC Company.

ACC: DOC.20031222.0006.

AP-2.22Q, Rev. 1, ICN 1. Classification Analyses and Maintenance of the Q-List. Washington, D.C.: U.S. Department of Energy, Office of Civilian Radioactive Waste Management. ACC: DOC.20040714.0002.

LP-3.15Q-BSC, Rev0, ICN 1. Managing Technical Product Inputs. Washington, D.C.: U.S. Department of Energy, Office of Civilian Radioactive Waste Management. ACC: DOC.20050622.0003.

LP-SI.11Q-BSC, Rev. 0, ICN 1. Software Management. Washington, D.C.: U.S. Department of Energy, Office of Civilian Radioactive Waste Management. ACC: DOC.20041005.0008.

LP-SIII.2Q-BSC, Rev. 0, ICN 0. Qualification of Unqualified Data. Washington, D.C.: U.S. Department of Energy, Office of Civilian Radioactive Waste Management. ACC: DOC.20050119.002.

LP-SIII.9Q-BSC, Rev. 0, ICN 1. Scientific Analyses. Washington, D.C.: U.S. Department of Energy, Office of Civilian Radioactive Waste Management. ACC: DOC.20050622.0004.

\subsection{SOURCE DATA, LISTED BY DATA TRACKING NUMBER}

GS000308311221.004. Geospatial Input Data for Infil V2.0 FY99. Submittal date: 146853 03/01/2000.

GS000308311221.005. Net Infiltration Modeling Results for 3 Climate Scenarios 147613 for FY99. Submittal date: 03/01/2000.

GS000308315121.003. Meteorological Stations Selected to Represent Future Climate States at Yucca Mountain, Nevada. Submittal date: 03/14/2000. 
GS030208312332.001. HFM Final Output - Hydrogeologic Framework Model for 163087 the Saturated-Zone Site-Scale Flow and Transport Model. Submittal date:

02/10/2003.

GS031008312272.008. Analysis of Pore Water and Miscellaneous Water Samples 166570 for the Period from December 2002 to July 2003. Submittal date: 11/13/2003.

GS990408314224.001. Detailed Line Survey Data for Stations 00+00.89 to 14+95.18, ECRB Cross Drift. Submittal date: 09/09/1999.

GS990408314224.002. Detailed Line Survey Data for Stations $15+00.85$ to 26+63.85, ECRB Cross Drift. Submittal date: 09/09/1999.

GS990408314224.003. Full-Periphery Geologic Maps for Station -0+10 to 10+00, 108404 ECRB Cross Drift. Submittal date: 09/09/1999.

GS990408314224.006. Full-Periphery Geologic Maps for Station 20+00 to 26+81, ECRB Cross Drift. Submittal date: 09/09/1999.

LA0009SL831151.001. Fracture Mineralogy of the ESF Single Heater Test Block, 153485 Alcove 5. Submittal date: 09/28/2000.

LA0010JC831341.001. Radionuclide Retardation Measurements of Sorption 162476 Distribution Coefficients for Barium. Submittal date: 10/19/2000.

LA0010JC831341.002. Radionuclide Retardation Measurements of Sorption 153321 Distribution Coefficients for Cesium. Submittal date: 10/19/2000.

LA0010JC831341.003. Radionuclide Retardation Measurements of Sorption Distribution Coefficients for Strontium. Submittal date: 10/19/2000.

LA0010JC831341.007. Radionuclide Retardation Measurements of Sorption 153319 Distribution Coefficients for Neptunium. Submittal date: 10/19/2000.

LA0303HV831352.002. Colloid Retardation Factors for the Saturated Zone Fractured Volcanics. Submittal date: 03/31/2003.

LA0305AM831341.001. 1977 to 1987 Sorption Measurements of AM, BA, CS, 163789 NP, PU, PA, SR, TH, and U with Yucca Mountain Tuff Samples. Submittal date: 05/21/2003.

LA0310AM831341.001. Sorption/Desorption Measurements of Cesium on Yucca Mountain Tuff. Submittal date: 10/21/2003.

165865

LA0311AM831341.001. Correlation Matrix for Sampling of Sorption Coefficient 167015 Probability Distributions. Submittal date: 11/06/2003. 
LA0311BR831229.001. UZ Transport Abstraction Model, Transfer Function

LA0407AM831341.001. Batch Sorption Coefficient Data for Barium on Yucca

Mountain Tuffs in Representative Water Compositions. Submittal date:

07/12/2004.

LA0407AM831341.002. Batch Sorption Coefficient Data for Cesium on Yucca

Mountain Tuffs in Representative Water Compositions. Submittal date:

07/12/2004.

LA0407AM831341.003. Batch Sorption Coefficient Data for Strontium on Yucca

170626

Mountain Tuffs in Representative Water Compositions. Submittal date:

07/12/2004.

LA0407AM831341.004. Batch Sorption Coefficient Data for Neptunium on Yucca

170622 Mountain Tuffs in Representative Water Compositions. Submittal date:

07/12/2004.

LA0407AM831341.005. Batch Sorption Coefficient Data for Plutonium on Yucca

170625

Mountain Tuffs in Representative Water Compositions. Submittal date:

07/12/2004.

LA0407AM831341.006. Batch Sorption Coefficient Data for Uranium on Yucca

170628 Mountain Tuffs in Representative Water Compositions. Submittal date:

07/12/2004.

LA0407BR831371.001. UZ Transport Abstraction Model, Transport Parameters

and Base Case Simulation Results. Submittal date: 07/13/2004.

LA0408AM831341.001. Unsaturated Zone Distribution Coefficients (Kds) for U,

171584 $\mathrm{Np}, \mathrm{Pu}, \mathrm{Am}, \mathrm{Pa}, \mathrm{Cs}, \mathrm{Sr}, \mathrm{Ra}$, and Th. Submittal date: 08/24/2004.

LA9908JC831321.001. Mineralogic Model "MM3.0" Version 3.0. Submittal date: 08/16/1999.

LA9912SL831151.001. Fracture Mineralogy of Drill Core ESF-HD-TEMP-2.

Submittal date: 01/05/2000.

LA9912SL831151.002. Percent Coverage by Fracture-Coating Minerals in Core ESF-HD-TEMP-2. Submittal date: 01/05/2000.

LB0205REVUZPRP.001. Fracture Properties for UZ Model Layers Developed 159525 from Field Data. Submittal date: 05/14/2002. date: $07 / 03 / 2002$. 
LB0207REVUZPRP.002. Matrix Properties for UZ Model Layers Developed from 159672 Field and Laboratory Data. Submittal date: 07/15/2002.

LB0208HYDSTRAT.001. 2002 UZ Model Grid Components. Submittal date:

174491 $08 / 26 / 2002$.

LB0208UZDSCPMI.002. Drift-Scale Calibrated Property Sets: Mean Infiltration 161243 Data Summary. Submittal date: 08/26/2002.

LB02091DSSCP3I.002. 1-D Site Scale Calibrated Properties: Data Summary. Submittal date: 09/18/2002.

LB02092DSSCFPR.002. 2-D Site Scale Calibrated Fault Properties: Data 162128 Summary. Submittal date: 09/18/2002.

LB0210THRMLPRP.001. Thermal Properties of UZ Model Layers: Data 160799 Summary. Submittal date: 10/25/2002.

LB0301DSCPTHSM.002. Drift-Scale Coupled Process Model for 163689 Thermohydrologic Seepage: Data Summary. Submittal date: 01/29/2003.

LB03023DSSCP9I.001. 3-D Site Scale UZ Flow Field Simulations for 9 Infiltration 163044 Scenarios. Submittal date: 02/28/2003.

LB0302DSCPTHCS.001. Drift-Scale Coupled Processes (THC Seepage) Model: Simulations. Submittal date: 02/11/2003.

LB0302DSCPTHCS.002. Drift-Scale Coupled Processes (THC Seepage) Model: Data Summary. Submittal date: 02/11/2003.

LB0302PTNTSW9I.001. PTN/TSW Interface Percolation Flux Maps for 9 162277 Infiltration Scenarios. Submittal date: 02/28/2003.

LB0302SCMREV02.002. Seepage-Related Model Parameters K and 1/A: Data 162273 Summary. Submittal date: 02/28/2003.

LB03033DUZTRAN.001. TC and NP Distributions/Transport in UZ Flow-Fields. 170372 Submittal date: 03/28/2003.

LB0304RDTRNSNS.001. Supporting Files of 3D Flow and Transport Sensitivity 165992 Analyses. Submittal date: 04/29/2003.

LB0304SMDCREV2.001. Seepage Modeling for Performance Assessment, 173235 Including Drift Collapse: Input/Output Files. Submittal date: 04/11/2003.

LB0304SMDCREV2.004. Impact of Thermal-Hydrologic-Mechanical Effects on 163691 Seepage: Summary Plot Files and Tables. Submittal date: 04/23/2003. 
LB0305PTNTSW9I.001. PTN/TSW Interface Percolation Flux Maps for 9

163690

Alternative Infiltration Scenarios. Submittal date: 05/12/2003.

LB0305TSPA18FF.001. Eighteen 3-D Site Scale UZ Flow Fields Converted from 165625

TOUGH2 to T2FEHM Format. Submittal date: 05/09/2003.

LB0306DRSCLTHM.001. Drift Scale THM Model Predictions: Simulations.

169733

Submittal date: 06/26/2003.

LB0306DRSCLTHM.002. Drift Scale THM Model Predictions: Summary Plots. Submittal date: 06/26/2003.

174490

LB0307DSTTHCR2.002. Drift-Scale Coupled Processes (DST Seepage) Model:

165541

Data Summary. Submittal date: 07/24/2003.

LB0307FMRADTRN.001. Fracture-Matrix Partitioning Model: Spreadsheet

165451

Calculations. Submittal date: 07/31/2003.

LB0308DRSCLTHM.001. Drift Scale THM Model Predictions for Poor Quality

Rock in Tptpll: Simulations. Submittal date: 08/29/2003.

LB0310MR0060R1.010. Supplemental Radionuclide Transport Simulations:

174489 Input/Output Files. Submittal date: 10/23/2003.

LB0310MTSCLTH2.001. Mountain Scale 2D TH Predictions: Simulations.

170714

Submittal date: 10/21/2003.

LB0310MTSCLTH3.001. Mountain Scale 3D TH Predictions: Simulations.

Submittal date: 10/21/2003.

LB0310MTSCLTHC.001. Mountain Scale THC Predictions: Simulations.

170715

Submittal date: 10/21/2003.

LB0310MTSCLTHM.002. Mountain Scale THM Predictions: Summary Plots.

Submittal date: 10/21/2003.

LB0311ABSTHCR2.001. Drift Scale Coupled Process Abstraction Model (for

166714 Intact-Drift Case). Submittal date: 11/07/2003.

LB0312TSPA06FF.001. Six Flow Fields with Raised Water Tables. Submittal 166671 date: $12 / 23 / 2003$.

LB0402THRMLPRP.001. Thermal Properties of UZ Model Layers: Data 168481 Summary. Submittal date: 02/20/2004.

LB0406U0075FCS.002. Flow Focusing in Heterogeneous Fractured Rock: 170712 Summaries. Submittal date: 06/30/2004. 
LB0407AMRU0120.001. Supporting Calculations and Analysis for Seepage

173280 Abstraction and Summary of Abstraction Results. Submittal date: 07/29/2004.

LB0407AMRU0120.002. Mathcad 11 Spreadsheets for Probabilistic Seepage

173308

Evaluation. Submittal date: 07/29/2004.

LB0408CMATUZFT.002. Carbonation - Papadakis Model Calculations for

172022

Carbonation Distances. Submittal date: 08/31/2004.

LB0408CMATUZFT.003. Leaching of Altered Cementitious Materials - Estimates

171705 of Molecular Diffusion/Dispersion in Cementitious Material Transport. Submittal date: $08 / 31 / 2004$.

LB0408CMATUZFT.004. Leaching of Altered Cementitious Materials - EQ3/6

171706

Simulations for Cementitious Material Transport. Submittal date: 08/31/2004.

LB990501233129.004. 3-D UZ Model Calibration Grids for AMR U0000,

"Development of Numerical Grids of UZ Flow and Transport Modeling". Submittal date: $09 / 24 / 1999$.

LB990701233129.001. 3-D UZ Model Grids for Calculation of Flow Fields for PA

106785 for AMR U0000, "Development of Numerical Grids for UZ Flow and Transport Modeling”. Submittal date: 09/24/1999.

LB990801233129.003. TSPA Grid Flow Simulations for AMR U0050, "UZ Flow Models and Submodels" (Flow Field \#3). Submittal date: 11/29/1999.

122757

LB990801233129.009. TSPA Grid Flow Simulations for AMR U0050, "UZ Flow

Models and Submodels" (Flow Field \#9). Submittal date: 11/29/1999.

LB9908T1233129.001. Transport Simulations for the Low, Mean, and Upper

147115 Infiltration Scenarios of the Present-Day, Monsoon, and Glacial Transition Climates for AMR U0050, "UZ Flow Models and Submodels". Submittal date: 03/11/2000.

LL000122051021.116. Summary of Analyses of Glass Dissolution Filtrates.

142973

Submittal date: $01 / 27 / 2000$.

LL020711323125.001. Pre-Test Calculations for Grout Carbonation Experiments.

172026

Submittal date: 08/13/2002.

LL030211423125.005. Cementitious Grout-Seepage Water Interaction. Submittal date: $02 / 02 / 2004$.

LL030211523125.006. EQ3/6 Modeling of Grout-Reacted Liquid Carbonation

172021

Experiments. Submittal date: 07/01/2003. 
MO0004QGFMPICK.000. Lithostratigraphic Contacts from

152554

MO9811MWDGFM03.000 to be Qualified Under the Data Qualification Plan,

TDP-NBS-GS-000001. Submittal date: 04/04/2000.

MO0004YMP98132.004. Flood Inundation Areas in the Vicinity of Yucca

149806

Mountain. Submittal date: 03/31/2000.

MO0005PORWATER.000. Perm-Sample Pore Water Data. Submittal date: 05/04/2000.

MO0010CPORGLOG.003. Calculated Porosity Values at Depth Derived from 155959 Qualified Geophysical Log Data from Modern Boreholes. Submittal date: $10 / 16 / 2000$.

MO0011YMP00114.000. Potential Repository Site. Submittal date: 11/21/2000.

MO0012MWDGFM02.002. Geologic Framework Model (GFM2000). Submittal 153777 date: $12 / 18 / 2000$.

MO0209EBSPMFSD.029. Probable Maximum Flood Study Data. Submittal date: 161845 09/18/2002.

MO0401MWDRPSHA.000. Results of the Yucca Mountain Probabilistic Seismic 166962 Hazard Analysis (PSHA). Submittal date: 01/21/2004.

MO0408EG831811.008. Magma Cooling and Solidification. Submittal date: 09/13/2004.

MO0501SEPFEPLA.001. LA FEP List and Screening. Submittal date: $01 / 17 / 2005$.

MO9906GPS98410.000. Yucca Mountain Project (YMP) Borehole Locations. Submittal date: 06/23/1999.

MO9910MWDISMMM.003. ISM3.1 Mineralogic Models. Submittal date: 10/01/1999.

MO9912GSC99492.000. Surveyed USW SD-6 As-Built Location. Submittal date: 165922 12/21/1999.

SN0306T0504103.005. Revised Groundwater Colloid Mass Concentration 164132 Parameters for TSPA (Total System Performance Assessment). Submittal date: 06/30/2003.

SN0306T0504103.006. Revised Sorption Partition Coefficients (Kd Values) for Selected Radionuclides Modeled in the TSPA (Total System Performance Assessment). Submittal date: 06/30/2003. 
SN0308T0503100.008. Revised Frequency Distributions for Net Infiltrations and Weighting Factors Applied to Lower, Mean, and Upper Climates. Submittal date: 08/28/2003.

SN0310T0505503.004. Initial Radionuclide Inventories for TSPA-LA. Submittal 168761 date: $10 / 27 / 2003$.

SN0312T0510102.013. EBS P\&CE Model Stainless Steel Abstraction. Submittal date: $12 / 15 / 2003$.

SNF40060298001.001. Unsaturated Zone Lithostratigraphic Contacts in Borehole 107372 USW SD-6. Submittal date: 10/15/1998.

TM000000SD12RS.012. USW SD-12 Composite Borehole Log (0.0'-1435.3') and 105627 Weight Logs (1,438.8-2,151.7'). Submittal date: 09/08/1995.

TMUSWNRG7A0096.002. Geophysical Logs for Borehole USW NRG-7/7A. Submittal date: 11/27/1996.

UN0201SPA021SS.007. Mean Annual Temperature and Precipitation for Select Western Regional Climate Locations. Submittal date: 01/11/2002.

\subsection{OUTPUT DATA, LISTED BY DATA TRACKING NUMBER}

LB0310FEPS0170.001. Computations of Perched Water Volume in Repository Footprint and Flux through Repository. Submittal date: 10/31/2003.

LB0408U0170FEP.001. T2R3D transport calculations for flow fields with fracture apertures increased or decreased due to seismic activity. Submittal date: 09/01/2004.

LB0408U0170FEP.002. Summary of transport calculations for flow fields with fracture apertures increased or decreased due to seismic activity. Submittal date: $09 / 01 / 2004$.

\subsection{SOFTWARE CODES}

BSC (Bechtel SAIC Company) 2001. Software Code: PHREEQC. V2.3. PC, 
LBNL 2002. Software Code: TOUGHREACT. V3.0. DEC ALPHA/OSF1 V5.1, 161256 DEC ALPHA/OSF1 V5.0, Sun UltraSparc/Sun OS 5.5.1, PC/Linux Redhat 7.2. 10396-3.0-00.

LBNL 2003. Software Code: WTRISE. V2.0. PC/WINDOWS 2000/98; DEC 163453 ALPHA/OSF1 V5.1. 10537-2.0-00.

LLNL (Lawrence Livermore National Laboratory) 1999. Software Code: NUFT 127906 V3.0s. V3.0s. 10088-3.0s-00.

SNL (Sandia National Laboratories) 2001. Software Code: Infil. VA_2.a1. DEC 147608 Alpha, VMS AXP V7.2-1. 10253-A_2.a1-00.

USGS (U.S. Geological Survey) 2001. Software Code: INFIL. V2.0. PC, 139422 Windows NT 4.0. 10307-2.0-00. 


\section{INTENTIONALLY LEFT BLANK}


APPENDIX A

PERCHED WATER VOLUME 


\section{A1. COMPUTING PERCHED WATER VOLUME IN REPOSITORY FOOTPRINT AND FLUX THROUGH REPOSITORY}

Perched water volumes and flux through the repository are evaluated here to support arguments concerning the potential effects of boreholes on drainage of perched water as discussed in Section 6.3.1 and seismic effects on perched water in Section 6.8.8. Perched water volumes and flux through the repository are extracted from the UZ flow model output data set contained in DTN: LB03023DSSCP9I.001 [DIRS 163044]. The files used are: the out files contained within the zipped files glaq_lA.tar.gz, glaq_mA.tar.gz, glaq_uA.tar.gz, monq_lA.tar.gz, monq_mA.tar.gz, monq_uA.tar.gz, preq_lA.tar.gz, preq_mA.tar.gz, and preq_uA.tar.gz. (Here glaq, monq, and preq refer to the glacial-transition, monsoon, and present climate states, and $l A$, $u A$, and $m A$ refer to flow fields with boundary conditions imposed by the lower, upper and mean infiltration maps.)

To assess the flux through the proposed repository horizon, the flux represented in the first 241,914 connections in the flux output are searched for flux through repository cells. The first 237,338 connections in the TOUGH2 output file are the vertical connections for the interior cells (not including the boundary cells), as can be seen in the mesh file. However, the additional 4,576 (horizontal) connections do not involve any of the 469 repository cells and, therefore, do not contribute to the calculations of vertical flux through the proposed repository.

The cells are first checked against the list of 469 repository cells. The first 62,000 connections are copied as text from the flow field output file (a text file created in Microsoft Word) to Microsoft Excel. The text in the Excel file is converted to column data using the "Text to Columns" function. The spreadsheet is then sorted in ascending order on Column 1. This sorts the fracture and matrix cells and also sorts the header information, which is deleted. The matrix cells are cut and pasted onto the second worksheet in the file. Columns F, G, H, and I are redundant and deleted. The 469 repository cell names are pasted into Column L. The following formulas are used to check which site-scale-model cells in Columns A and B are in the repository:

$F r n=\operatorname{MATCH}($ Arn,L\$1:L\$469,0)

Grn $=$ MATCH $(B r n, L \$ 1: L \$ 469,0)$

(Here Frn means any cell in column F of the worksheet, with $r n$ representing the same row number on both sides of the equation, and similarly for other letter-designated columns). The list of gridblock names is needed for extracting the vertical flux through the repository zone from the file total_rep_q.dat. There are a total of 469 blocks within the repository zone; their names are listed in the file $R E P O \_Z$. Both these files are found in the attached compact disc for UZ Flow Models and Submodels (BSC 2004 [DIRS 169861], Appendix C) titled, C.2/files in table C.2.5-1/.

These are used for both the fracture and matrix worksheets. These expressions return the index number of Column L if the cell names match and return the error message \#N/A if the cell names do not match. Similar manipulations are used for the flux output from TOUGH2, connections 62001-124000, 124001-186000, and 186001-241914. (Data from each of the nine flow fields is 
divided into three segments to fit within the row-number limit of Microsoft Excel.) Once the cell identifications have been made for the glacial transition upper case, the same results for Columns $\mathrm{F}$ and $\mathrm{G}$ are copied onto the files generated for the other infiltration and climate scenarios. The manipulations are carried out for each of the nine flow fields. These files are saved as:

gt upper flux 1-62000.xls

gt upper flux 62001-124000.xls

gt upper flux 124001-186000.xls

gt upper flux 186001-241914.xls

gt mean flux 1-62000.xls

gt mean flux 62001-124000.xls

gt mean flux 124001-186000.xls

gt mean flux 186001-241914.xls

gt lower flux 1-62000.xls

gt lower flux 62001-124000.xls

gt lower flux 124001-186000.xls

gt lower flux 186001-241914.xls

ms upper flux 1-62000.xls

ms upper flux 62001-124000.xls

ms upper flux 124001-186000.xls

ms upper flux 186001-241914.xls

ms mean flux 1-62000.xls

ms mean flux 62001-124000.xls

ms mean flux 124001-186000.xls

ms mean flux 186001-241914.xls

ms lower flux 1-62000.xls

ms lower flux 62001-124000.xls

ms lower flux 124001-186000.xls

ms lower flux 186001-241914.xls

pd upper flux 1-62000.xls

pd upper flux 62001-124000.xls

pd upper flux 124001-186000.xls

pd upper flux 186001-241914.xls

pd mean flux 1-62000.xls

pd mean flux 62001-124000.xls

pd mean flux 124001-186000.xls

pd mean flux 186001-241914.xls 
pd lower flux 1-62000.xls

pd lower flux 62001-124000.xls

pd lower flux 124001-186000.xls

pd lower flux 186001-241914.xls

For each case (1-62000, 620001-124000, 124001-186000, and 186001-241914), Columns A through $\mathrm{G}$ for the repository cells are copied and pasted into a summary file for the given climate scenario. The same operations are performed for the fractures and matrix on separate worksheets in the summary file. The data are then sorted by Columns $\mathrm{G}$ and F, respectively, in ascending order. Each cell has two vertical fluxes representing inflow and outflow. The second set of values ordered through Column G are cut and pasted into Columns I through O. Columns B, G, $\mathrm{H}$, and $\mathrm{M}$ are not needed and deleted. "Duplicate" cells are identified in 24 instances due to the cells having the same name except for the case of one of the letters (that is, upper case vs. lower case), which are not distinguished by the MATCH command. The "duplicate" cells are identified manually in Column L by marking them with a "1." The other cells are marked with a "0" in Column L. The summary files with marked duplicates are stored in the following files (for each of the nine flow fields):

Repository cells with vertical flux and marked duplicates gt upper.xls Repository cells with vertical flux and marked duplicates gt mean.xls Repository cells with vertical flux and marked duplicates gt lower.xls Repository cells with vertical flux and marked duplicates ms upper.xls Repository cells with vertical flux and marked duplicates ms mean.xls Repository cells with vertical flux and marked duplicates ms lower.xls Repository cells with vertical flux and marked duplicates pd upper.xls Repository cells with vertical flux and marked duplicates pd mean.xls Repository cells with vertical flux and marked duplicates pd lower.xls

The worksheet is then sorted on Column L in descending order and the 24 "duplicates" are deleted. Column L is deleted, and Column A is copied into Column M. The larger of the two vertical fluxes is found through the following formula:

Orn $=\operatorname{IF}(\mathrm{Crn}>\mathrm{Irn}, \mathrm{Crn}, \mathrm{Irn})$

The total flux for each continuum is summed in Cell O470, and then the fracture and matrix flux are summed on the fracture worksheet in Cell O471. The total flux in $\mathrm{kg} / \mathrm{s}$ is converted to $\mathrm{kg} / \mathrm{yr}$ in Cell O473, using the following formula on the fracture worksheet:

$\mathrm{O} 472=\mathrm{O} 471 * 3600 * 24 * 365.25$

This flux is converted to $\mathrm{m}^{3} / \mathrm{yr}$ by dividing by the density $\left(997 \mathrm{~kg} / \mathrm{m}^{3}\right)$ in Cell $\mathrm{O} 473$ on the fracture worksheet. These results are saved in the following files:

Repository cells with vertical flux - gt upper.xls

Repository cells with vertical flux - gt mean.xls

Repository cells with vertical flux - gt lower.xls 
Repository cells with vertical flux - ms upper.xls Repository cells with vertical flux - ms mean.xls Repository cells with vertical flux - ms lower.xls

Repository cells with vertical flux - pd upper.xls Repository cells with vertical flux - pd mean.xls

Repository cells with vertical flux - pd lower.xls

Perched water volumes are extracted from the summary files described in Section A2. These summary files contain the capillary pressure, saturation, and volume information needed to determine perched water volumes. Only perched water within the fractures of the repository footprint is considered. For each climate-infiltration scenario, the segments are 61000-122000, 122001-184000, and 184001-245506. The segment 1-61000 is not needed because it doesn't contain any repository elements. For each case, Columns A through AN are sorted on Column T in descending order. This brings all of the repository footprint cells to the top of the list. The cells not in the footprint are deleted. The data in Columns A through AN are then sorted on the fracture capillary pressure in Column E in descending order. Cells with fracture capillary pressure less than zero are deleted. The matrix data and layer properties are also deleted. The fracture bulk volume is given in Column L and fracture porosity in Column R.

The product of the bulk volume times the porosity gives the volume of water in the fracture cells (because the cell is saturated). This is computed as follows (here capital letters refer to columns and rn refers to any row number):

$\mathrm{Vrn}=\mathrm{Lrn} * \mathrm{Rrn}$

The data are sorted in descending order, based on the permeability in Column S. The total fracture volume is computed as follows:

$\mathrm{AC} 1=\mathrm{SUM}(\mathrm{V}: \mathrm{V})$

The total fracture volume in high-permeability fractures (permeability greater than $10^{-15} \mathrm{~m}^{2}$ ) is found by first assigning the volumes of high-permeability fractures as follows:

$\mathrm{Wrn}=\mathrm{IF}\left(\operatorname{Srn}>10^{\wedge}-15, \operatorname{Vrn}, 0\right)$

Then the volumes are summed:

$\mathrm{AC} 2=\mathrm{SUM}(\mathrm{W}: \mathrm{W})$

These calculations are given in the following files:

gt upper perched 61001-122000.xls

gt upper perched 122001-184000.xls

gt upper perched 184001-245506.xls 
gt mean perched 61001-122000.xls

gt mean perched 122001-184000.xls

gt mean perched 184001-245506.xls

gt lower perched 61001-122000.xls

gt lower perched 122001-184000.xls

gt lower perched 184001-245506.xls

ms upper perched 61001-122000.xls

ms upper perched 122001-184000.xls

ms upper perched 184001-245506.xls

ms mean perched 61001-122000.xls

ms mean perched 122001-184000.xls

ms mean perched 184001-245506.xls

pd lower perched 61001-122000.xls

pd lower perched 122001-184000.xls

pd lower perched 184001-245506.xls

pd upper perched 61001-122000.xls

pd upper perched 122001-184000.xls

pd upper perched 184001-245506.xls

pd mean perched 61001-122000.xls

pd mean perched 122001-184000.xls

pd mean perched 184001-245506.xls

pd lower perched 61001-122000.xls

pd lower perched 122001-184000.xls

pd lower perched 184001-245506.xls

The results of these extractions are summarized in Table A-1. Flux years are the total perched water volume in high permeability fractures divided by the total flow through the repository. This represents the amount of time needed through the percolation flux to generate the same volume of water as in the high-permeability fractures of the perched water zones. 
Table A-1. Extraction Results

\begin{tabular}{|l|c|c|c|}
\hline \multicolumn{1}{|c|}{ Scenario } & $\begin{array}{c}\text { Total Volume of Perched } \\
\text { Water in High-Permeability } \\
\text { Fractures } \mathbf{~ ( ~}^{\mathbf{3}} \mathbf{)}\end{array}$ & $\begin{array}{c}\text { Total Flow through } \\
\text { Repository } \\
\text { Footprint } \mathbf{m}^{\mathbf{3}} \text { /yr) }\end{array}$ & $\begin{array}{c}\text { Flux } \\
\text { Years }\end{array}$ \\
\hline Present day, Lower Infiltration & $4.66 \mathrm{E}+02$ & $2.00 \mathrm{E}+03$ & $2.33 \mathrm{E}-01$ \\
\hline Present day, Mean Infiltration & $4.66 \mathrm{E}+02$ & $2.07 \mathrm{E}+04$ & $2.25 \mathrm{E}-02$ \\
\hline Present day, Upper Infiltration & $6.50 \mathrm{E}+02$ & $6.03 \mathrm{E}+04$ & $1.08 \mathrm{E}-02$ \\
\hline Monsoon, Lower Infiltration & $6.50 \mathrm{E}+02$ & $2.31 \mathrm{E}+04$ & $2.81 \mathrm{E}-02$ \\
\hline Monsoon, Mean Infiltration & $6.50 \mathrm{E}+02$ & $6.18 \mathrm{E}+04$ & $1.05 \mathrm{E}-02$ \\
\hline Monsoon, Upper Infiltration & $6.50 \mathrm{E}+02$ & $1.58 \mathrm{E}+05$ & $4.12 \mathrm{E}-03$ \\
\hline Glacial transition, Lower Infiltration & $6.50 \mathrm{E}+02$ & $1.04 \mathrm{E}+04$ & $6.25 \mathrm{E}-02$ \\
\hline Glacial transition, Mean Infiltration & $6.50 \mathrm{E}+02$ & $9.75 \mathrm{E}+04$ & $6.67 \mathrm{E}-03$ \\
\hline Glacial transition, Upper Infiltration & $1.19 \mathrm{E}+03$ & $1.92 \mathrm{E}+05$ & $6.22 \mathrm{E}-03$ \\
\hline
\end{tabular}

Output DTN: LB0310FEPS0170.001.

\section{A2. EXTRACTING OUTPUT FROM UZ FLOW MODEL FOR SATURATION AND RELATIVE PERMEABILITY}

Each of nine flow fields contains data for saturation and relative permeability. The flow field output is given in DTN: LB03023DSSCP9I.001 [DIRS 163044]. For each flow field, the output for cells 1-61000, 61001-122000, 122001-184000, and 184001-245506 were copied as text from text files downloaded from the DTN and pasted into Microsoft Excel as text. The text was then converted to Columns (A through $\mathrm{H}$ ) in the spreadsheet using the Excel function "text to columns." The spreadsheet was sorted by cell name in ascending order, and the header information was deleted. Columns $A$ through $\mathrm{G}$ of the mesh files for the same range of cells were copied into Columns $\mathrm{J}$ through $\mathrm{P}$ and Column $\mathrm{H}$ (with the repository footprint designation) was copied into Column T. The assignment of the footprint designation is discussed in Section A3. All of the matrix elements were cut from the bottom of the file and pasted into Columns V through AN such that the fracture cells in Column A match the matrix cells in Column V.

Data for the porosity and permeability by rock type was extracted from a file in DTN: LB03023DSSCP9I.001 [DIRS 163044] (e.g., glaq_uA.dat). This information was copied into Columns AP through AR, with the rock type designation in Column AP, the porosity of the rock type in Column AQ, and the permeability of the rock type in Column AR. The porosity and permeability for the fractures and matrix were then assigned to each grid.

First, the rock type of the fractures in Column $\mathrm{K}$ and the rock type of the matrix in Column AF were compared with the rock types in Column AP:

Qrn = MATCH(Krn,AP1:AP98,0) for the fractures

$\mathrm{ALrn}=\mathrm{MATCH}(\mathrm{AFrn}, \mathrm{AP1}: \mathrm{AP} 98,0)$ for the rock matrix

The MATCH function returns the array index of the first value in Column AP that matches the value in Columns $\mathrm{K}$ or AF. This index is then used to extract the porosity and permeability as follows:

Rrn $=\operatorname{INDEX}(A Q \$ 1: A Q \$ 98, \$ Q r n)$ for fracture porosity 
Srn = INDEX $(A R \$ 1: A R \$ 98, \$ Q r n)$ for fracture permeability AMrn = INDEX (AQ\$1:AQ\$98,\$ALrn) for matrix porosity ANrn = INDEX $($ AR \$1:AR \$98,\$ALrn $)$ for matrix permeability

The resulting output files are:

gt upper 1-61000.xls gt upper 61001-122000.xls gt upper 122001-184000.xls gt upper 184001-245506.xls

gt mean 1-61000.xls gt mean 61001-122000.xls gt mean 122001-184000.xls gt mean 184001-245506.xls

gt lower 1-61000.xls gt lower 61001-122000.xls gt lower 122001-184000.xls gt lower 184001-245506.xls

ms upper 1-61000.xls ms upper 61001-122000.xls ms upper 122001-184000.xls ms upper 184001-245506.xls

ms mean 1-61000.xls ms mean 61001-122000.xls ms mean 122001-184000.xls ms mean 184001-245506.xls

ms lower 1-61000.xls ms lower 61001-122000.xls ms lower 122001-184000.xls ms lower 184001-245506.xls

pd upper 1-61000.xls pd upper 61001-122000.xls pd upper 122001-184000.xls pd upper 184001-245506.xls pd mean 1-61000.xls pd mean 61001-122000.xls pd mean 122001-184000.xls pd mean 184001-245506.xls 
pd lower 1-61000.xls

pd lower 61001-122000.xls

pd lower 122001-184000.xls

pd lower 184001-245506.xls

\section{A3. EXTRACTION OF REPOSITORY FOOTPRINT FROM MESH FILE}

Extract from the file mesh_2kb.dkm (from DTN: LB03023DSSCP9I.001 [DIRS 163044]) under the ELEM label the mesh in three, 64000-row groups and one 53,506-row group. This comprises the entire listing of cells for the three-dimensional UZ site-scale flow model. Store these in files called the following:

1-64000 1st file.xls

64001-128000 1st file.xls

128001-192000 1st file.xls

192001-245506 1st file.xls

The structure of the grid leads to many cells having the same $x-y$ coordinates. The ELEM file is also structured such that these cells are listed in adjacent rows. The "raw" cell information is trimmed to contain only the cell name and the $\mathrm{x}$ and $\mathrm{y}$ coordinates (Columns $\mathrm{E}$ and $\mathrm{F}$ in the " $1{ }^{\text {st }}$ files"). These are given in Columns A, B, and C. Columns D and E contain a repeat of the contents of $\mathrm{B}$ and $\mathrm{C}$. In Column $\mathrm{F}$, the following formula is applied:

Frn $=\operatorname{IF}($ Drn=Drn-1,IF $($ Ern=Ern-1,Frn-1+1,1) $)$

where Drn $=$ the element of Column D in the same row as in Column F. The exception is in row 1 , where $F 1=1$. This generates a count of the number of consecutive rows with the same $x-y$ coordinates. A "reverse count" is done in Column $\mathrm{G}$ by initiating the count from the last row using the following formula:

Grn $=\operatorname{IF}($ Drn+1=Drn,IF(Ern+1=Ern, $1+$ Grn $+1,1), 1)$

Column $\mathrm{F}$ is used to identify the first (top) grid with the given $\mathrm{x}-\mathrm{y}$ coordinate using the following formula in Column $\mathrm{H}$ :

$\operatorname{Hrn}=\operatorname{IF}(\operatorname{Frn}=1,1,0)$

Column I is used to identify the total number of consecutive rows having the same $\mathrm{x}-\mathrm{y}$ coordinate using the following formula:

$\operatorname{Irn}=\operatorname{IF}(\mathrm{Hrn}=1, \mathrm{Grn}, 0)$

The results of these calculations are stored in the following files:

1-64001 sorting for independent $x-y$ 2nd file.xls

64001-128000 sorting for independent $x-y$ 2nd file.xls

128001-192000 sorting for independent $x-y$ 2nd file.xls

192001-245506 sorting for independent $x-y$ 2nd file.xls 
The results are sorted by Column $\mathrm{H}$, which contains 1 or 0 depending on whether or not the cell is at the top of a column of cells or not. Only cells with a 1 in Column $\mathrm{H}$ are retained. 531 independent columns are identified. Note that the values in Column I give the number of cells in the column having the same $\mathrm{x}-\mathrm{y}$ values. Repository cells are identified in file rep.xls in Output-DTN: LB0310FEPS0170.001. Plots confirm that these cells lie within the proposed repository footprint. The list of repository cells in the UZ grid and the cell coordinates are given in repository cells.xls.

The drift end-point coordinates in meters (Nevada State Plane coordinates) for the repository design are given in Repository Design, Repository/PA IED Subsurface Facilities (BSC 2003 [DIRS 161727]).

Plots shown in Figures A-1 and A-2 show the correspondence between the UZ grid coordinates for the repository cells and the design coordinates for the endpoints of the waste emplacement drifts.

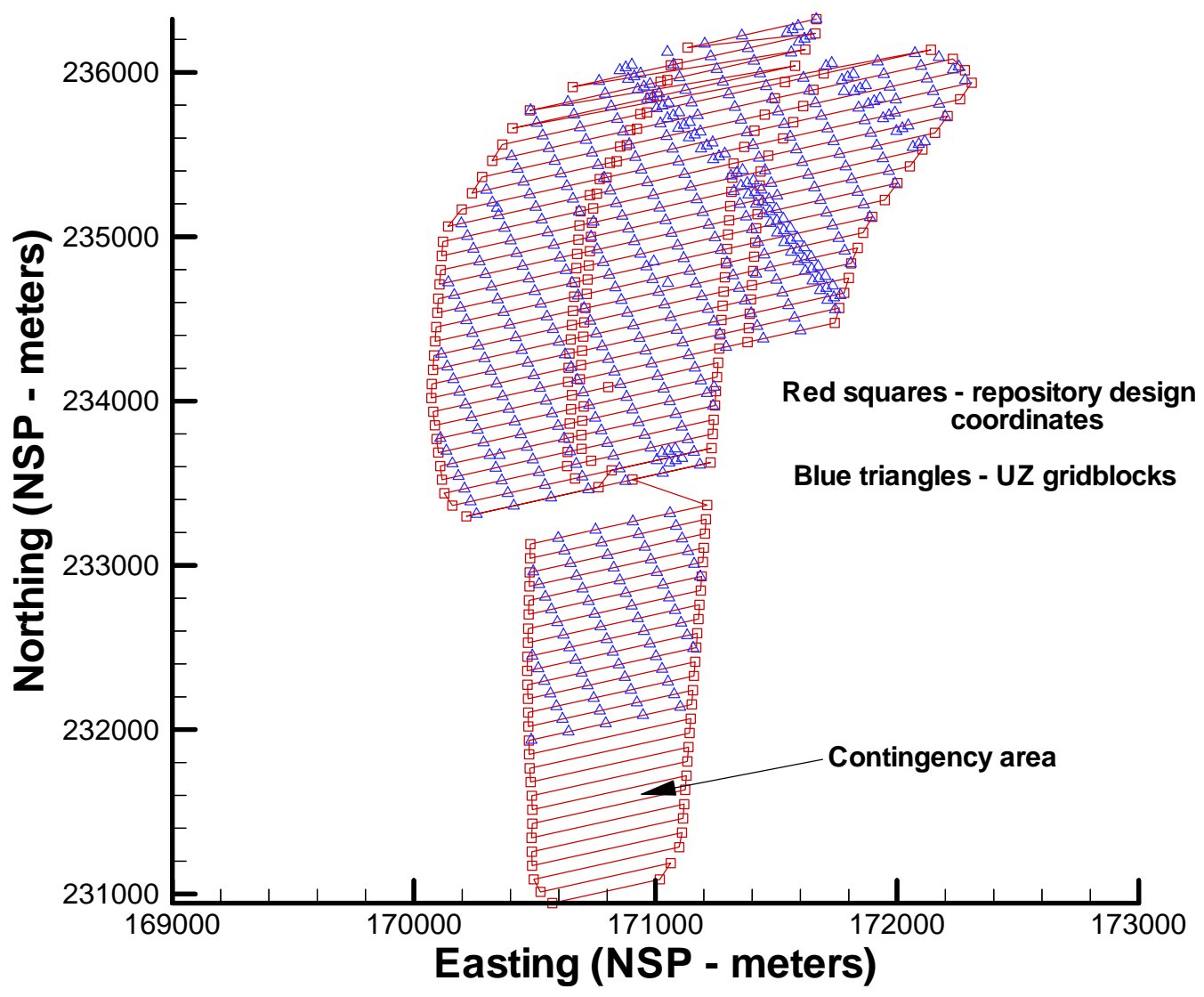

DTNs: LB0310FEPS0170.001 [output]; LB03023DSSCP9I.001 [DIRS 163044].

Figure A-1. Coordinates of UZ Grid Repository Gridblocks Compared with Repository Design Drift Endpoint Coordinates (Plan View) 
The remaining results described here are for processing the cells 64001 to 128000 . The same procedure is applied to the other cell groupings (128001 to 192000 and 192001 to 245506), but the specific number of cells involved changes. The $\mathrm{x}-\mathrm{y}$ coordinates for the $\mathrm{UZ}$ grid in the repository are compared against the $\mathrm{x}-\mathrm{y}$ coordinates of the grid columns identified for "top" cells. Repository easting coordinates are put in row 1 in Columns $\mathrm{K}$ through IK and repository northing coordinates are put in row 2, Columns $\mathrm{K}$ through IK. This accounts for 235 repository $\mathrm{x}-\mathrm{y}$ coordinates. The remaining 234 coordinates are put in rows 534 and 535 following the last identified "top" cell, Columns K through IJ. Then, the $\mathrm{x}-\mathrm{y}$ coordinate for the grid columns in Columns $\mathrm{B}$ and $\mathrm{C}$, rows 3 through 533 , are compared with the repository $\mathrm{x}-\mathrm{y}$ coordinates using the following formula:

$\mathrm{clrn}=\operatorname{IF}(\mathrm{ABS}(\mathrm{cl} \$ 1-\$ \mathrm{Brn})<10,1,0) * \operatorname{IF}(\mathrm{ABS}(\mathrm{cl} \$ 2-\$ \mathrm{Crn})<10,1,0)$

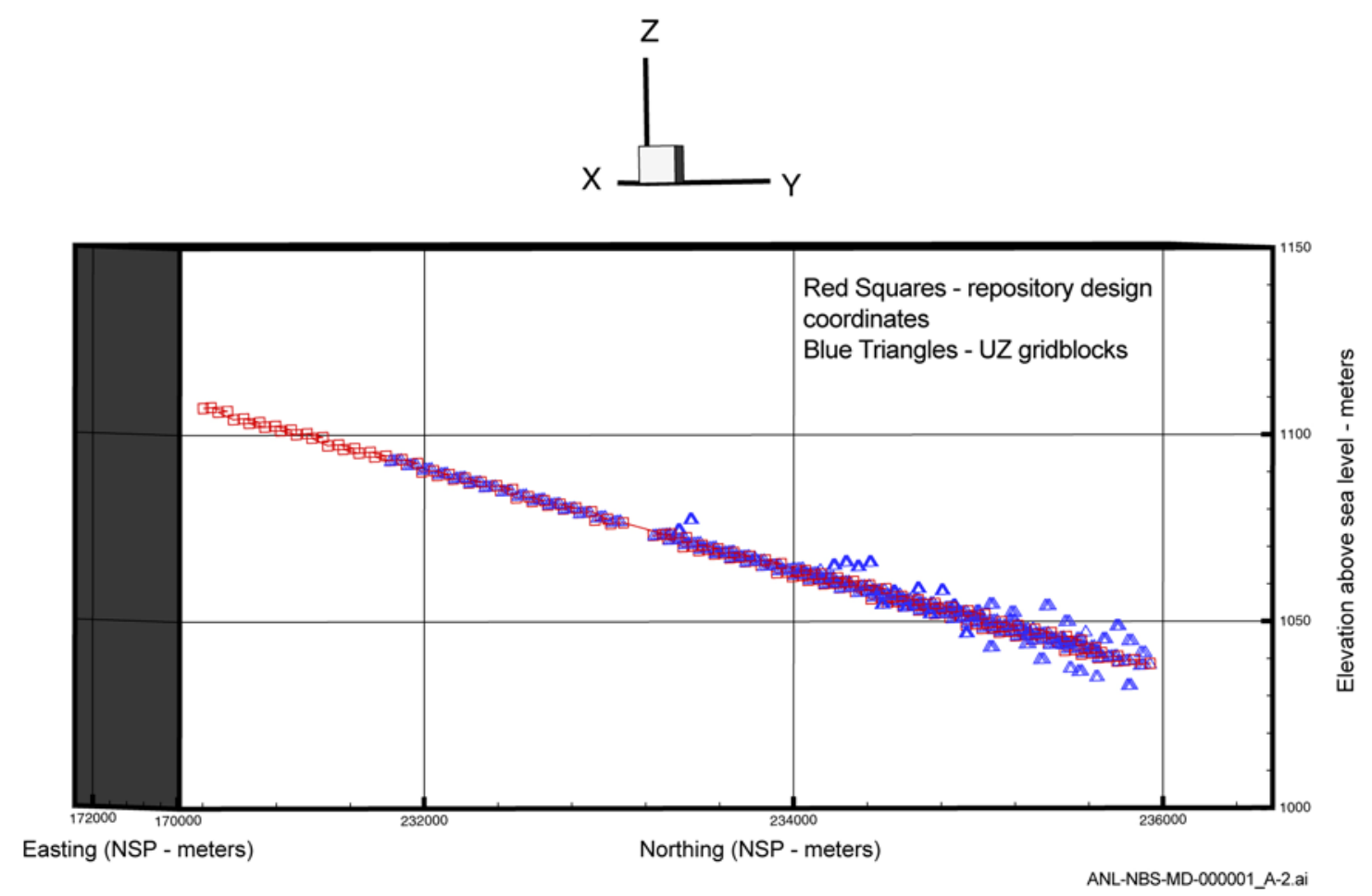

DTN: LB0310FEPS0170.001 [OUTPUT]; DTN: LB03023DSSCP9I.001 [DIRS 163044].

Figure A-2. Coordinates of UZ Grid Repository Gridblocks Compared with Repository Design Drift Endpoint Coordinates (Elevation)

Here, cl\$1 designates a value from row 1 with a variable column letter $(\mathrm{cl})$. This is notation analogous to the use of $\mathrm{rn}$ for a variable row number. This formula identifies if the grid column and the repository cell lie within $10 \mathrm{~m}$ of each other in both the northing and easting directions. If so, a value of one is returned and the column lies within the repository footprint. If not, a value of zero is returned and the cell lies outside the repository footprint. For the repository cells coordinates in rows 534 and 535, an analogous formula is used:

$\mathrm{cl}(\mathrm{rn}+533)=\operatorname{IF}(\mathrm{ABS}(\mathrm{cl} \$ 534-\$ \mathrm{Brn})<10,1,0) * \operatorname{IF}(\mathrm{ABS}(\mathrm{cl} \$ 535-\$ \mathrm{Crn})<10,1,0)$ 
Column $\mathrm{J}$ is used to sum the values across the spreadsheet columns to find if a UZ grid column lies within the footprint:

$\mathrm{Jrn}=\mathrm{SUM}(\mathrm{Krn}: \mathrm{IKrn})$

For $\mathrm{rn}=3$ to 533

and

$\mathrm{Jrn}=\mathrm{SUM}(\mathrm{Krn}: \mathrm{IJrn})$

For $\mathrm{rn}=536$ to 1066 .

These files are saved as:

1-64000 comparison with repository $x$-y 3 rd file.xls

64001-128000 comparison with repository $x-y$ 3rd file.xls

128001-192000 comparison with repository $x-y 3$ rd file.xls

192001-245506 comparison with repository $x-y$ 3rd file.xls

Because of the large number of "top" cells in the first 64,000 cells, the $x-y 3^{\text {rd }}$ file is split into two parts, Part 1 one for the first 235 repository cell comparison and Part 2 for the second 234 repository cell comparison. Note that no cells were found within the footprint for cells 1-64,000. Therefore, further processing for this group is not needed. The results in Column $\mathrm{J}$ from rows 536 to 1,066 are combined with the results for Column J from rows 3 to 533, such that if a "1" is returned from either list, the value of Column $\mathrm{J}$ is " 1 " and " 0 " otherwise. The data from these files are then sorted by Column $J$ to reduce the to spreadsheet entries to the footprint columns in the UZ grid. Then Column A contains the node name for the top of each footprint column in the UZ grid, Columns B and C contain the $\mathrm{x}-\mathrm{y}$ coordinates and Column D contains the number of elements in each UZ grid column. This results in 352 columns in the repository footprint. The top cell names and the number of elements in each grid are transposed into rows 3 and 4, respectively from Columns F through IS (248 cells) and in rows 251 and 252, Columns F through DE (104 cells). These spreadsheets are saved as:

64001-128000 repository footprint top cells 4th file.xls

128001-192000 repository footprint top cells 4th file.xls

192001-245506 repository footprint top cells 4th file.xls

The files containing the ELEM information are then reopened (see " $1{ }^{\text {st }}$ files" discussed above). Rows 1 and 2, Columns F through IS are copied to rows 1 and 2 of the corresponding $1^{\text {st }}$ file in Columns I through IV from the $4^{\text {th }}$ files. The repository footprint top cells for each column are compared with the cells in Column A of the spreadsheet using the formula:

$\operatorname{clrn}=\operatorname{IF}(\mathrm{cl} \$ 1=\$ A r n, \mathrm{cl} \$ 2,0)$

Thus, if the cell name from the ELEM information in Column A equals the top cell of a grid column inside the footprint, the value of the number of cells in that grid column returned. If not, 
a value of zero is returned. Once all columns have been checked, the values for each row are summed using the following formula:

$=\mathrm{SUM}(\mathrm{Irn}: \mathrm{IVrn})$

for rows 3 through the last element in each spreadsheet.

The results are stored in:

64001-128000 construct footprint tag for cells part 1 th file.xls 128001-192000 construct footprint tag for cells part 1 5th file.xls 192001-245506 construct footprint tag for cells part 1 5th file.xls

The same search operation is conducted on the " $1{ }^{\text {st }}$ file" using the repository top cell names and \# of elements from rows 251 and 252, Columns F through DE of the " 4 th file." The results are stored in:

64001-128000 construct footprint tag for cells part 2 5th file.xls 128001-192000 construct footprint tag for cells part 2 5th file.xls 192001-245506 construct footprint tag for cells part 2 5th file.xls

The " 1 st file" is again reopened and the results from Columns $H$ in part 1 and part 2 of the $5^{\text {th }}$ files are copied into Columns $\mathrm{H}$ and I respectively for the $1^{\text {st }}$ file. The combination of columns $\mathrm{H}$ and I give the total number of cells in each column of the footprint and are computed in Column J using the formula:

$\mathrm{Jrn}=\mathrm{Hrn}+\mathrm{Irn}$

The cells are identified in Column $\mathrm{K}$ as to whether or not the corresponding cell lies in the footprint through the following formula:

$\mathrm{Krn}=\mathrm{IF}(\mathrm{K}(\mathrm{rn}-1)>1, \mathrm{~K}(\mathrm{rn}-1)-1,2 * \mathrm{~J} 2)$

This formula initiates a count at the top cell if the previous cell in Column $\mathrm{K}$ is 0 or 1 and if $\mathrm{J}$ in the given row is greater than 0 . The count is initiated as $2 * \mathrm{Jrn}$ because there are fracture and matrix cells in each column. Then each cell is given a designation as being in the repository footprint in Column L using the following formula:

$\operatorname{Lrn}=\operatorname{IF}\left(\mathrm{Krn}>0,{ }^{\prime} \mathrm{RF},, 0\right)$

The results are saved in the following files:

1-64000 cells with footprint tag 6th file.xls 64001-128000 cells with footprint tag 6th file.xls 128001-192000 cells with footprint tag 6th file.xls 192001-245506 cells with footprint tag 6th file.xls 
The file is then consolidated to Columns $A$ through $\mathrm{G}$ and Columns $\mathrm{H}$ through $\mathrm{K}$ are deleted leaving Column G containing either a 0 (outside footprint) or and "RF" denoting inside the footprint. These are saved as:

1-64000 cells with footprint tag summary 7th file.xls 64001-128000 cells with footprint tag summary 7 th file.xls 128001-192000 cells with footprint tag summary 7 th file.xls 192001-245506 cells with footprint tag summary 7 th file.xls

Note that files for steps 4,5 , and 6 for the cells $1-64,000$ were not created because there are no repository footprint cells in these first 64,000 cells.

For subsequent uses, these four sets of files were broken down into the following:

1-61000 cells with footprint tag.xls 61001-122000 cells with footprint tag.xls 122001-184000 cells with footprint tag.xls 184001-245506 cells with footprint tag.xls

In addition, these groupings were ordered (in ascending order) by the cell names in Column A, which segregates the fracture and matrix cells.

File information including all file names, file dates and times, and file sizes are documented in DTN: LB03023DSSCP9I.001 [DIRS 163044] and output DTN: LB0310FEPS0170.001. 


\section{INTENTIONALLY LEFT BLANK}




\section{APPENDIX B}

PTn LOCATIONS RELATIVE TO WASTE EMPLACEMENT 
Figure B-1 shows the PTn coverage over the UZ flow model and waste emplacement areas. The PTn is present over all waste emplacement locations. The coordinates for the PTn are given in the mesh_3dn.dkm file of DTN: LB03023DSSCP9I.001 [DIRS 163044]. The repository coordinates are in file rep.xls in Output-DTN: LB0310FEPS0170.001.

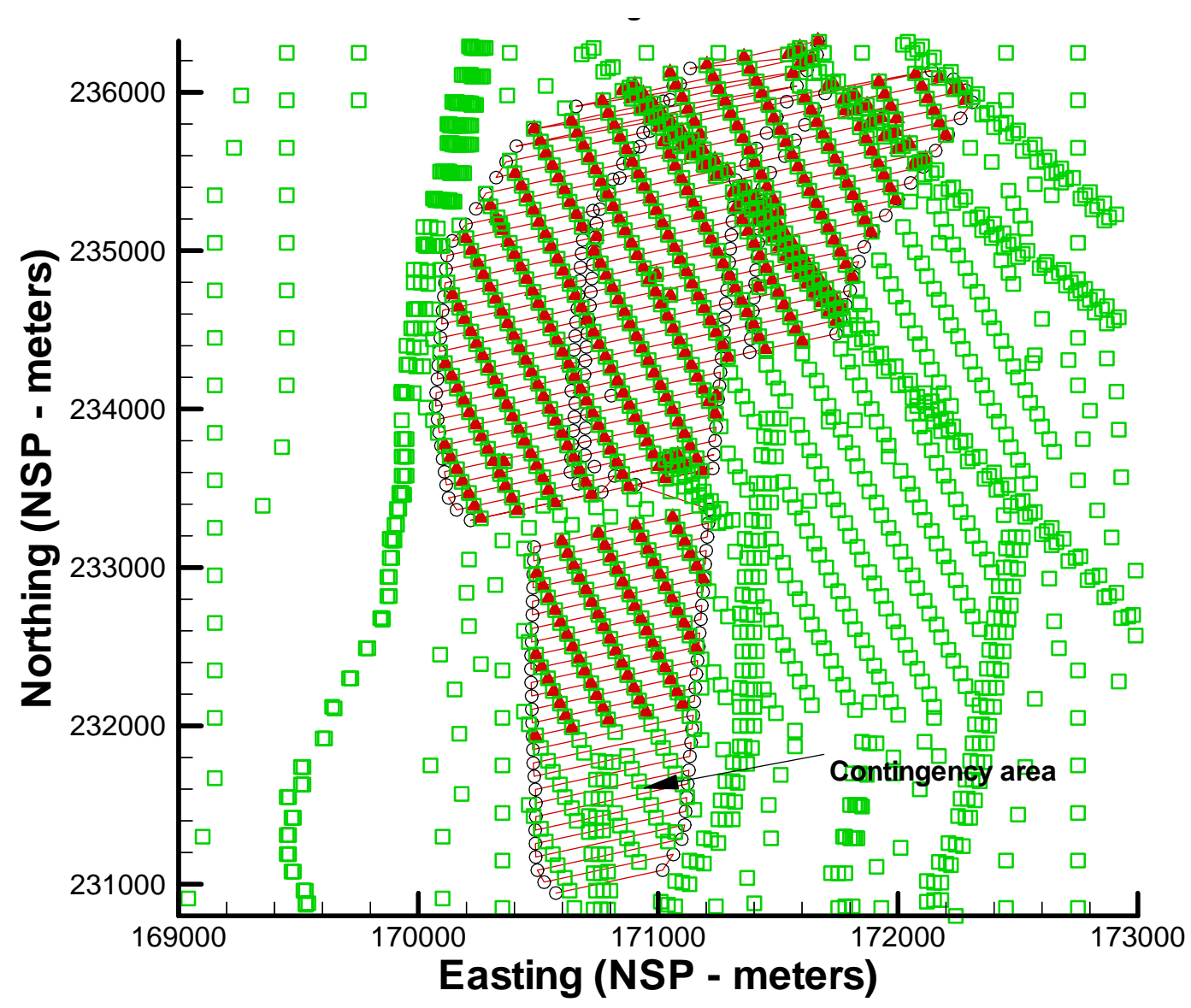

Source: DTN: LB03023DSSCP9I.001 [DIRS 163044] LB0310FEPS0170.001 [output].

NOTE: Green squares - UZ model grid locations with PTn cover; Red triangles - UZ model repository grid locations; Black circles - waste emplacement drift endpoints.

Figure B-1. PTn Coverage over the UZ Flow Model and Waste Emplacement Areas

File information including all file names, file dates and times, and file sizes are documented in DTN: LB03023DSSCP9I.001 [DIRS 163044] and output DTN: LB0310FEPS0170.001. 


\section{INTENTIONALLY LEFT BLANK}




\section{APPENDIX C}

\section{QUALIFICATION OF UNQUALIFIED DATA}


Some data used as direct input (Table 4-2) were acquired during earlier studies sponsored by the DOE Nevada Nuclear Waste Storage Investigation, before the establishment of a 10 CFR 60, Subpart G-compliant quality assurance program. These data have been qualified in Sections C1 through C3, C5 through C11, and C16, in accordance with LP-SIII.2Q-BSC, Qualification of Unqualified Data.

Other data used as direct input were obtained from outside sources. These data are demonstrated in Sections C4 to be suitable for use within this report in accordance with LP-SIII.9Q-BSC, Scientific Analyses.

Other data used as direct input were obtained from the product output of a superseded or cancelled document. These data are demonstrated in Sections C12 through C15 to be suitable for use within this report in accordance with LP-SIII.9Q-BSC. See Appendix D, Section D3.1 for justification for the use of DTNs developed for the TSPA model for Site Recommendation.

All other direct input data are qualified.

\section{C1. STRESS FIELD AT YUCCA MOUNTAIN}

\section{Data sets for qualification:}

Stock, J.M. and Healy, J.H. 1988. "Stress Field at Yucca Mountain, Nevada." Chapter 6 of Geologic and Hydrologic Investigations of a Potential Nuclear Waste Disposal Site at Yucca Mountain, Southern Nevada. Carr, M.D. and Yount, J.C., eds. Bulletin 1790. Denver, Colorado: U.S. Geological Survey. TIC: 203085 [DIRS 101022].

Stock, J.M.; Healy, J.H.; Hickman, S.H.; and Zoback, M.D. 1985. "Hydraulic Fracturing Stress Measurements at Yucca Mountain, Nevada, and Relationship to the Regional Stress Field." Journal of Geophysical Research, 90, (B10), 8691-8706. Washington, D.C.: American Geophysical Union. TIC: 219009 [DIRS 101027].

\section{Description of Use:}

Stock and Healy (1988 [DIRS 101022]) measured in-situ stresses in four boreholes (USW G-1, USW G-2, USW G-3, and UE25p1) and found that in all four boreholes $\mathrm{S}_{\mathrm{v}}>\mathrm{S}_{\mathrm{H}}>\mathrm{S}_{\mathrm{h}}$, where subscripts $\mathrm{v}, \mathrm{H}$, and $\mathrm{h}$ represent the vertical, greatest horizontal, and least horizontal stress, respectively. This corresponds to a normal faulting regime. The direction of least horizontal stress was $\mathrm{N} 60^{\circ} \mathrm{W}$ to $\mathrm{N} 65^{\circ} \mathrm{W}$. Stock et al. (1985 [DIRS 101027]) report the same data. The data are used in Section 6.8.3 to show that USW G-2, north of the repository, is in the same normal-faulting regime as the other boreholes.

Method of qualification: Corroboration with qualified data. No planned method of qualification was abandoned.

Evaluation Criteria: The evaluation criteria, as stated in the Data Qualification Plan (BSC 2004 [DIRS 174775] are that the corroborating data set confirm the relationship $\mathrm{S}_{\mathrm{v}}>\mathrm{S}_{\mathrm{H}}>\mathrm{S}_{\mathrm{h}}$ and that the direction of least horizontal stress reported in the data to be qualified agree within $30^{\circ}$ of the direction reported in the corroborating data. 
Evaluation of the technical correctness of the data to be qualified: In-situ stresses were measured by the hydraulic fracturing method. This method directly measures $\mathrm{S}_{\mathrm{h}}$ by measuring the pressure of injected water needed to open a fracture, and observes the direction of $\mathrm{S}_{\mathrm{h}}$ by acoustic televiewer logging. These are standard methods for measuring $\mathrm{S}_{\mathrm{h}}$. The data are therefore judged to be technically correct.

Evaluation results: These data are qualified by comparison with DTN: SNF37100195002.001 [DIRS 131356], which reports the mean of five hydraulic fracturing in situ stress measurements in a $30 \mathrm{~m}$ borehole drilled from the thermal test facility alcove in the ESF. The values reported there also show $\mathrm{S}_{\mathrm{v}}>\mathrm{S}_{\mathrm{H}}>\mathrm{S}_{\mathrm{h}}$, with $\mathrm{S}_{\mathrm{h}}$ acting in $\mathrm{N} 75^{\circ} \mathrm{W}\left( \pm 14^{\circ}\right)$. DTN: SNF37100195002.001 [DIRS 131356] is qualified, and the values reorted therein agree with those reported in Stock and Healy (1988 [DIRS 101022]) and Stock et al. (1985 [DIRS 101027]). Therefore both evaluation criteria specified in the qualification plan have been satiosfied and the data of Stock and Healy (1988 [DIRS 101022]) and Stock et al. (1985 [DIRS 101027]) are qualified by corroboration.

Limitations on the use of the data: This qualification is limited to use in this report, as described above.

Supporting information used in the qualification: DTN: SNF37100195002.001 [DIRS 131356]

Reference to data qualification plan: BSC 2004 [DIRS 174775].

Qualifications of Personnel or Organizations Generating the Data: Joann M. Stock is Professor of Geology and Geophysics at California Institute of Technology. Her research interests involve a wide range of tectonic problems, including global and regional plate tectonic questions, including Tectonic Evolution of the Gulf of California and Stress Field variations around the Los Angeles region. She holds B.S., M.S., and Ph.D. from Massachusetts Institute of Technology.

\section{C2. WATER TABLE EXCURSIONS INDUCED BY SEISMIC EVENTS}

\section{Data set for qualification:}

Carrigan, C.R.; King, G.C.P.; Barr, G.E.; and Bixler, N.E. 1991. "Potential for Water Table Excursions Induced by Seismic Events at Yucca Mountain, Nevada." Geology, 19, (12), 1157-1160. Boulder, Colorado: Geological Society of America. TIC: 242407 [DIRS 100967].

Description of Use: Numerical simulations by Carrigan et al. (1991 [DIRS 100967]) of tectonohydrological coupling involving earthquakes typical of the Basin and Range province (approximately $1 \mathrm{~m}$ slip) produced 2 to $3 \mathrm{~m}$ excursions of a water table $500 \mathrm{~m}$ below the ground surface. Extrapolation to an event of about $4 \mathrm{~m}$ slip would result in a transient rise of $17 \mathrm{~m}$ near the fault (Carrigan et al. 1991 [DIRS 100967], p. 1,159). These data are used in Section 6.8 .3 as typical examples to exclude FEP 1.2.10.01.0A, Hydrologic response to seismic activity. 
Method of qualification: Corroboration with independent data and independent simulations of seismically induced water table rise. No planned method of qualification was abandoned.

Evaluation Criteria: The evaluation criteria, as stated in the Data Qualification Plan (BSC 2004 [DIRS 174776] are that none of the corroborating data or simulations indicate a water table rise greater than $12 \mathrm{~m}$.

Evaluation of the technical correctness of the data to be qualified: Changes in water level due to seismic activity are identified in the FEP description as being possibly of consequence. Numerical simulations by Carrigan et al. (1991 [DIRS 100967]) of tectonohydrological coupling involving earthquakes typical of the Basin and Range province (approximately $1 \mathrm{~m}$ slip) produced 2 to $3 \mathrm{~m}$ excursions of a water table $500 \mathrm{~m}$ below the ground surface. Extrapolation to an event of about $4 \mathrm{~m}$ slip would result in a transient rise of $17 \mathrm{~m}$ near the fault (Carrigan et al. 1991 [DIRS 100967], p. 1,159). Carrigan et al. (1991 [DIRS 100967]) modeled a 100 m wide fracture zone centered on a vertical fault, with vertical permeability increased by a factor of $10^{3}$. Water level excursions in the fracture zone were twice as great as in the adjacent block. For a fault-fracture zone with $1 \mathrm{~m}$ slip, transient excursions of about $12 \mathrm{~m}$ can occur.

Evaluation results: These simulated water-table rises are qualified by corroboration with observations cited by Carrigan et al. (1991 [DIRS 100967]). The Dixie Valley - Fairview Peak, Nevada, earthquake, magnitude approximately 7, produced water table excursions of 1 to $3 \mathrm{~m}$, as well as long-term changes in the regional hydrology (Raney 1988 [DIRS 147173], p. 44). The 1983 Borah Peak, Idaho earthquake, magnitude approximately 7.3, caused increases of about $4 \mathrm{~m}$, with water levels returning to normal within two weeks to two months (Dudley 1990 [DIRS 147175]). These data serve to qualify the simulation results.

An independent model by Bredehoeft (1992 [DIRS 101122]) calculated a 1-m water table rise due to a magnitude 6 earthquake; this is consistent with the data cited above and the results of Carrigan et al. (1991 [DIRS 100967]).

Limitations on the use of the data: This qualification is limited to use in this report, as described above.

Supporting information used in the qualification: Raney 1988 [DIRS 147173], p. 44; Dudley 1990 [DIRS 147175], Bredehoeft 1992 [DIRS 101122].

Reference to data qualification plan: BSC 2004 [DIRS 174776].

\section{C3. EXTENT OF CONTACT METAMORPHISM RESULTING FROM AN IGNEOUS EVENT}

\section{Data set for qualification:}

Valentine, G.A.; WoldeGabriel, G.; Rosenberg, N.D.; Carter Krogh, K.E.; Crowe, B.M.; Stauffer, P.; Auer, L.H.; Gable, C.W.; Goff, F.; Warren, R.; and Perry, F.V. 1998. "Physical Processes of Magmatism and Effects on the Potential Repository: Synthesis of Technical Work 
Through Fiscal Year 1995." Chapter 5 of Volcanism Studies: Final Report for the Yucca Mountain Project. Perry, F.V.; Crowe, B.M.; Valentine, G.A.; and Bowker, L.M., eds. LA-13478. Los Alamos, New Mexico: Los Alamos National Laboratory. TIC: 247225 [DIRS 119132].

Description of Use: Valentine et al. (1998 [DIRS 119132]) studied two natural analogue sites, Paiute Ridge, Nevada and Grants Ridge, New Mexico, and concluded that contact metamorphism from intrusive dikes is generally confined to distances of a few meters around the dike. These data are used in Section 6.8.1 and 6.8.4 to exclude FEPs 1.2.04.02.0A, Igneous activity changes rock properties, and 1.2.10.02.0A, Hydrologic response to igneous activity. Numerical simulations of flow and transport, which are qualified in Section C11 of the present report, show that hydrologic property changes at this scale would be too small to have a significant effect on the overall hydrologic properties of the UZ.

Method of qualification: Corroborating data.

Evaluation Criterion: The evaluation criterion is that the numerical simulation of an analogue site corroborate the evidence that contact metamorphism from an intrusive dike is limited to within $10 \mathrm{~m}$ from the dike.

Evaluation of the technical correctness of the data to be qualified: Valentine et al. (1998 [DIRS 119132]) used mineral analysis by x-ray diffraction and elemental analysis by neutron activation analysis to determine the extent of contact metamorphism. These are standard analytical techniques and generally accepted scientific practice for these analyses. Depletion of volatile elements near the contact was taken as evidence of metamorphism.

Extent to which the Data Demonstrate the Properties of Interest: The data in Valentine et al. 1998 [DIRS 119132] show that the hydrologic effect of an igneous intrusion into unsaturated tuff is limited in extent. The theoretical basis for this is provided by the corroborating data.

Extent and Quality of Corroborating Data: WoldeGabriel et al. (1999 [DIRS 110071]) studied the effects of a basaltic intrusion at Grants Ridge, New Mexico, on the country rock, consisting of silicic tuffs and volcaniclastic sediments. The field and laboratory data indicate that the physical changes due to the thermal effects of the intruded plug were confined to within $10 \mathrm{~m}$ of the plug. This site was one of the two analogue sites studied by Valentine et al. 1998 [DIRS 119132]. The corroborative power of WoldeGabriel et al. (1999 [DIRS 110071]) lies not in the independence of its chemical analyses, but in the independent analysis by numerical simulation

Evaluation results: WoldeGabriel et al. (1999 [DIRS 110071]) provide not only experimental evidence of limited extent of contact metamorphism, but also a theoretical explanation, supported by results of numerical simulation, of why the effects of igneous intrusion are into unsaturated tuff are localized. A one-dimensional (radial) conductive model was verified against analytical solution and the code FEHM. Results of the numerical simulations are presented in WoldeGabriel et al. (1999 [DIRS 110071], Figures 9 and 13). These show that $10 \mathrm{~m}$ away from the intrusion, the maximum temperature reached was $500^{\circ} \mathrm{C} ; 600^{\circ} \mathrm{C}$ was only reached within $4 \mathrm{~m}$ of the intrusion. This localized effect is explained by the fact that the rock was unsaturated at the 
time of the intrusion: the lack of water prevents fluid-driven convective heat transfer, hydrothermal circulation, and extensive alteration of the country rock. The corroborating numerical simulations presented in WoldeGabriel et al. (1999 [DIRS 110071]), and the evaluation of the qualifications of the personnel and organizations generating the data, provide sufficient confidence that the data of Valentine et al. (1998 [DIRS 119132], p. 5-74) are qualified for the purpose of demonstrating that the hydrologic effect of igneous intrusion effect is limited in extent.

Limitations on the use of the data: This qualification is limited to use in this report, as described above.

Supporting information used in the qualification: WoldeGabriel et al. (1999 [DIRS 110071]).

Reference to data qualification plan: BSC 2004 [DIRS 174777]. Note that the use of Corroborating Data rather than Technical Assessment represents a deviation from the plan.

Qualifications of Personnel or Organizations Generating the Data: Greg A. Valentine leads the Hydrology, Geochemistry, and Geology Group at Los Alamos National Laboratory. He is technical lead for igneous consequences at the Yucca Mountain Project. His fields of research include numerical simulation of flow in porous media, explosive volcanic eruptions and magma chamber dynamics. His field studies are related to volcanic hazards assessment, large-volume pyroclastic eruptions, fossil hydrothermal systems, intrusion mechanisms and dynamics. Dr. Valentine received his Ph.D. in Geological Sciences (1988) from the University of California, Santa Barbara and B.S. in Geological Engineering and Geology (1984) from the New Mexico Institute of Mining and Technology.

\section{C4. LIMITED ENTRAINMENT OF CLAY PARTICLES}

Reference: Vanoni, V.A., ed. 1977. "Sediment Transportation Mechanics.” Sedimentation Engineering. Pages 17-315. New York, New York: American Society of Civil Engineers. Figure 2-51. TIC: 255225 [DIRS 164901].

Description of Use: This Figure shows experimental data on clay erosion caused by entrainment of particles in flowing water. The data show that entrainment of particles ceased after five days, for a variety of experimental conditions. These data are used in Section 6.4.4 to exclude FEP 2.1.09.21.0C Transport of particles larger than colloids in the UZ.

Reliability of Source of the Data: This book was prepared by the Task Committee for the Preparation of the Manual on Sedimentation of the Sedimentation Committee of the Hydraulics Division of the American Society of Civil Engineers. As such, it represents the standard engineering practice under the auspices of the principal professional association concerned with sediment transport. Professor Vito Vanoni (1904-1999) was on the faculty at California Institute of Technology and was a recognized expert in the field of sediment transport and engineering. 


\section{C5. EFFECT OF RADIOACTIVE WASTE HEAT ON SOIL TEMPERATURE}

Data set for qualification:

CRWMS M\&O 1999. Impact of Radioactive Waste Heat on Soil Temperatures. BA0000000-01717-5700-00030 REV 0. Las Vegas, Nevada: CRWMS M\&O. ACC: MOL.19990309.0403 [DIRS 103618].

Description of Use: This is a 1-D simulation of soil temperature for a repository heat load of $900 \mathrm{~mW} / \mathrm{m}^{2}$. It is used in Section 6.9 .9 to demonstrate that the soil will not become so hot as to change the vegetation cover. A change in the vegetation cover would change the hydrologic properties; the results of this simulation show that no such change would occur. This conclusion provides the basis to exclude FEP 2.2.10.01.0A, Repository-induced thermal effects on flow in the UZ.

Extent to which the Data Demonstrate the Properties of Interest: The simulated temperatures show temperature at various depths in the soil. At $2 \mathrm{~m}$ depth, CRWMS M\&O (1999 [DIRS 103618], Figure 30) shows a maximum temperature increase of $0.8^{\circ} \mathrm{C}$ above ambient. This increase would be superimposed on the annual temperature cycle.

Method of qualification: Corroboration with an independent calculation of temperature rise above ambient at $2 \mathrm{~m}$ depth. No planned method of qualification was abandoned.

Evaluation Criteria: The evaluation criterion, as stated in the data qualification plan (BSC 2004 [DIRS 174778] is that the corroborating data set confirm the calculated temperature rise within $0.2^{\circ} \mathrm{C}$.

Evaluation of the technical correctness of the data to be qualified: Three-dimensional coupled TH simulations have been done. The temperature profiles shown in Mountain-Scale Coupled Processes (TH/THC/THM) (BSC 2005 [DIRS 174101], Figure 6.3.1-6) for Column $\mathrm{h} 47$, at $170743.5 \mathrm{~m} \mathrm{E}$ and $235090.3 \mathrm{~m} \mathrm{~N}$ (near the center of the repository) can be taken as representative. The maximum temperature gradient shown in that figure is $0.33^{\circ} \mathrm{C} / \mathrm{m}$. At $2 \mathrm{~m}$ depth, this is $0.66^{\circ} \mathrm{C}$ increase over ambient, which agrees within $0.14^{\circ} \mathrm{C}$ with the value shown in Impact of Radioactive Waste Heat on Soil Temperatures (CRWMS M\&O 1999 [DIRS 103618], Figure 30). This discrepancy is within the evaluation criterion specified in the data qualification plan (BSC 2004 [DIRS 174778]. Note that a slightly cooler temperature would be expected in the case of a three-dimensional model because such a model allows some heat loss in lateral directions, and also because this model includes preclosure ventilation. Both data sets confirm that the soil temperature increase will not be great enough to affect the hydrology through loss of vegetation.

Evaluation results: Because the two simulation results agree within the range specified for the evaluation criterion, the data of CRWMS M\&O 1999 ([DIRS 103618], Figure 30)are qualified by corroboration.

Limitations on the use of the data: This qualification is limited to use in this report, as described above. 
Supporting information used in the qualification: BSC 2005 ([DIRS 174101], Figure 6.3.1-6)

Reference to data qualification plan: BSC 2004 [DIRS 174778].

\section{C6. EFFECTS OF CEMENTITIOUS MATERIAL ON GROUNDWATER QUALITY}

\section{Data sets for qualification:}

DTNs: LB0408CMATUZFT.003 [DIRS 171705]; LB0408CMATUZFT.004 [DIRS 171706]

Description of Use: These data show that leachate from the cementitious materials and their reaction products will be similar in water quality to ambient pore water; therefore, the presence of cementitious materials will not significantly change the transport of radionuclides. They are used in Section 6.9.2 to support the exclusion of FEP 2.2.01.01.0B, Chemical effects of excavation and construction in the near-field.

Extent to which the Data Demonstrate the Properties of Interest: The property of interest is the chemistry of leachate of cementitious materials. This is shown to be similar to the native groundwater.

Method of Qualification: Technical Assessment. No planned method of qualification was abandoned.

Evaluation Criteria: The evaluation criteria, as stated in the Data Qualification Plan (BSC 2004 [DIRS 174779] are that (1) The input data is credible; (2) Qualified software was used for the calculations that produced DTNs: LB0408CMATUZFT.003 [DIRS 171705] and LB0408CMATUZFT.004 [DIRS 171706]; (3) The software was used correctly; (4) The conclusions in Ziegler 2004 ([DIRS 171694], Appendix D) follow logically from the results of the calculations; and that (5) The approach used for the calculations conforms to standard geochemical practice.

Evaluation results: DTNs: LB0408CMATUZFT.003 [DIRS 171705] and LB0408CMATUZFT.004 [DIRS 171706] are judged to be qualified for use described above, based upon the qualified status of their source DTNs, the qualified status of the software used to develop the data, and the following argument that the input data and software were used correctly.

1. DTN: LB0408CMATUZFT.002 [DIRS 172022] presents results of calculations based on the Papadakis (2000 [DIRS 172019]) model of the rates of carbonation of the cementitious materials. This effect is important because it causes subsequent infiltration water to contact calcite rather than the reactive cementitious materials that can generate high $\mathrm{pH}$ values and high calcium concentrations. A water reacting with calcite results in concentrations typical of ambient pore water (circumneutral $\mathrm{pH}$ and moderate cation concentrations). 
2. DTN: LB0408CMATUZFT.003 [DIRS 171705] presents calculations of the horizontal spreading of the plume as a result of hydrodynamic dispersion and molecular diffusion. These calculations show that horizontal spreading is minimal.

3. DTN: LB0408CMATUZFT.004 [DIRS 171706] presents the results of EQ3/6 7.2b calculations on the equilibrium phase assemblage expected after hydrothermal (elevated temperature, in the presence of water) reaction with the cementitious materials. These phase assemblages are presented as a function of the calcium and silica contents of the cement. This is important, since reaction will have the effect of generating new assemblages that produce lower $\mathrm{pH}$ values when leached with water than would be obtained by reaction with a portlandite-based cement.

4. Already-qualified experimental data (DTNs: LL030211423125.005 [DIRS 172020] and LL030211523125.006 [DIRS 172021]) are used to support the argument that $\mathrm{CO}_{2}$ gas present in the drift environment will react with any hyperalkaline plume that is generated, reducing both the solution $\mathrm{pH}$ and the calcium concentration to values close to ambient pore water values.

DTN: LB0408CMATUZFT.002 [DIRS 172022], which presents the results of calculations carried out with the Papadakis (2000 [DIRS 172019]) model. This model provides rates of carbonation of Portland cement as a result of the diffusion of $\mathrm{CO}_{2}$ gas through the pores of the cement, where it reacts with the phases there to form calcite. The model assumes rates are limited by the rate of diffusion of $\mathrm{CO}_{2}$ through the pores - no limitation based on the intrinsic rate of reaction with $\mathrm{CO}_{2}$ is considered. In addition, the process requires that an aqueous film wetting the cementitious grain be present, since the aqueous phase is the medium in which the reaction occurs. It is possible that the Papadakis (2000 [DIRS 172019]) equation will not hold up at very low relative humidities, since in this case the aqueous film wetting the cement grains may be only partly present. Otherwise, the Papadakis (2000 [DIRS 172019]) model is a straightforward implementation of the analytical solution for gas diffusion, which then provides the rate at which the carbonation front (conversion to calcite) occurs. It is implemented here with the software Excel, which is exempt from software qualification requirements. Similar calculations were used to plan carbonation tests over a 100-day period DTN: LL020711323125.001 [DIRS 172026]) — the calculations presented here use the same Papadakis model, but are extended to time scales of 50 years (Ziegler 2004 [DIRS 171694], Table D-5), with data presented in DTN: LB0408CMATUZFT.002 [DIRS 172022]). A range of input values of Portlandite cement, silica fume, and water content in the cement recipe are considered - these control the porosity of the resulting cement, which controls the rate of $\mathrm{CO}_{2}$ gas diffusion through the pores. Also considered in Ziegler (2004 [DIRS 171694], Table D-5) are ranges in the relative humidity, which is the other control besides the porosity on the rate of $\mathrm{CO}_{2}$ diffusion through the pores of the cement. These input parameters cover the range of likely conditions and materials to be used in the drift environment. Since the Papadakis (2000 [DIRS 172019]) model is based on a well known analytical solution to the diffusion equation and it has been calibrated independently for different cement "recipes" (the relative proportions of water, Portland cement, and silica fume), the data produced from the model can be accepted as qualified. 
DTN: LB0408CMATUZFT.003 [DIRS 171705] presents calculations on the horizontal spreading of an aqueous plume as result of both hydrodynamic dispersion and molecular diffusion. The input values for these calculations are based on independently qualified data. These qualified input data are clearly identified. The calculation itself is a straightforward one based on analytical solutions to the diffusion-dispersion equation in which Fick's Law (diffusion and dispersion is proportional to the concentration gradient) is used. The calculations were carried out with the commercial software Microsoft Excel, thus, removing the need to qualify the software.

DTN: LB0408CMATUZFT.004 [DIRS 171706] presents calculations using the qualified code EQ3/6 version 7.2b (database DATA.0) of the equilibrium phase assemblage as a function of differing calcium and silica contents of the cement. These calculations demonstrate that elevated temperatures, as are expected in the drift environment, will convert the primary assemblage of portlandite $\left(\mathrm{Ca}(\mathrm{OH})_{2}\right)$ and silica fume to other phases. These other phases, when reacted with water, will show a lower $\mathrm{pH}$ than would a water reacted with portlandite (Ziegler 2004 [DIRS 171694], Table D-12). This calculation assumes equilibrium conditions will prevail and that kinetic considerations are not important. While this is not universally a reasonable assumption, it is applicable here because of the elevated temperatures, which accelerate reaction rates.

DTNs: LL030211423125.005 [DIRS 172020] and LL030211523125.006 [DIRS 172021] represent data that are already qualified. These data support the argument that $\mathrm{CO}_{2}$ gas present in the atmosphere will diffuse into any hyperalkaline fluid that is formed and neutralize it over time. The neutralization involves lowering of the $\mathrm{pH}\left(\mathrm{CO}_{2}\right.$ is a weak acid that counteracts the high hydroxyl in the cement-reacted water) and reduction of the calcium concentration as a result of the precipitation of calcite. Both of these effects were demonstrated clearly in the experiments described in these two DTNs.

The input data are either already qualified or have been determined by this technical assessment to be suitable for use in this application. The software used to develop DTNs LB0408CMATUZFT.003 [DIRS 171705] and LB0408CMATUZFT.004 [DIRS 171706] is either exempt from qualification requirements or has been qualified. The results of the calculations are reasonable and in agreement with chemical principles. Therefore DTNs LB0408CMATUZFT.003 [DIRS 171705] and LB0408CMATUZFT.004 [DIRS 171706] are qualified for the purpose of simulating the chemistry of leachates of cementitious materials.

Limitations on the use of the data: This qualification is limited to use in this report, as described above.

Supporting information used in the qualification: (Ziegler 2004 [DIRS 171694], Appendix D [DIRS 171694]

\section{Reference to data qualification plan: BSC 2004 [DIRS 174779].}

Qualifications of Personnel or Organizations Generating the Data: John A. Apps is senior scientist emeritus in the Earth Science Division of Lawrence Berkeley National Laboratory. In the past he has served on the Nuclear Regulatory Commission, Advisory Committee on Nuclear 
Waste Isolation (1989-1993) and the Panel on Savannah River Plant Wastes of the National Research Council Committee on Radioactive Waste Management (1979-1982). Dr. Apps received his A.M. and Ph.D. in Geology $(1965,1970)$ from Harvard University and his B.Sc. in Mining Geology (1961) with first-class honors from Imperial College of Science and Technology, London University, England.

\section{C7. CHEMICAL EVIDENCE FOR LONG-TERM TEMPERATURE STABILITY AT YUCCA MOUNTAIN}

\section{Data set for qualification:}

Wilson, N.S.F.; Cline, J.S.; and Amelin, Y.V. 2003. "Origin, Timing, and Temperature of Secondary Calcite-Silica Mineral Formation at Yucca Mountain, Nevada." Geochimica et Cosmochimica Acta, 67, (6), 1145-1176. New York, New York: Pergamon. TIC: 254369 [DIRS 163589].

Description of Use: Studies of secondary minerals at Yucca Mountain using petrography, fluid-inclusion microthermometry, and $\mathrm{U}-\mathrm{Pb}$ dating indicate that temperatures have remained close to the current ambient values over the past two to five million years (Wilson et al. 2003 [DIRS 163589], Section 8). These data are used in Section 6.8.2 to exclude FEP 1.2.06.00.0A, Hydrothermal activity .

Extent to which the Data Demonstrate the Properties of Interest: The property of interest is the long-term stability of the temperature regime at Yucca Mountain, as demonstrated by the relation between the temperatures (inferred from the composition of fluid inclusions) and the age of the inclusions, inferred from the $\mathrm{U}-\mathrm{Pb}$ isotope dating.

Evaluation Criteria: The evaluation criterion, as stated in the Data Qualification Plan (BSC 2004 [DIRS 174780] is that the corroborating data set confirm that no significant hydrothermal alteration has occurred since $10.7 \mathrm{Ma}$ (million years ago).

Evaluation of the technical correctness of the data to be qualified: These data are corroborated by an independent study by Bish and Aronson 1993 [DIRS 100006]. They correlated temperatures of formation of illite-smectite and ages from $\mathrm{K} / \mathrm{Ar}$ dating to conclude that no significant hydrothermal alteration has since $10.7 \mathrm{Ma}$. These are independent data supporting the conclusion of Wilson et al. 2003 [DIRS 163589]. Additional corroborating data are presented by Whelan et al. (2002 [DIRS 160442]).

Evaluation results: The independent study by Bish and Aronson 1993 [DIRS 100006] supports an even longer period of constant temperature in the UZ at Yucca Mountain; thus the data of Wilson et al. (2003) [DIRS 163589] are corroborated and accepted as qualified for the use described above.

Limitations on the use of the data: This qualification is limited to use in this report, as described above. 
Supporting information used in the qualification: Bish and Aronson 1993 [DIRS 100006].

Reference to data qualification plan: BSC 2004 [DIRS 174780].

Reliability of Data Source: Wilson, N.S.F.; Cline, J.S.; and Amelin, Y.V (2003) published their experimental results in the journal Geochimica et Cosmochimica Acta. Published for over 100 years, the Geochimica et Cosmochimica Acta is a professional scientific research journal for geochemistry and cosmochemistry. It is sponsored by The Geochemical Society and The Meteoritical Society and is published by Elsevier Science Ltd. Contributions to the journal are evaluated for scientific merit by thorough professional review. Peer review is an essential and integral aspect of Geochimica et Cosmochimica Acta. The fundamental role of the reviewer is to advise the Associate Editor and the Executive Editor on the virtues, or lack thereof, of a manuscript submitted for publication. Normally the journal requires three "external" reviews. The Associate Editor writes a report summarizing reviewer opinion, presenting his/her overall evaluation based on his/her own reading of the manuscript and the advice of the reviewers.

\section{C8. DEHYDRATION TEMPERATURE OF ZEOLITIC MINERALS}

\section{Data set for qualification:}

Smyth, J.R. 1982. "Zeolite Stability Constraints on Radioactive Waste Isolation in Zeolite-Bearing Volcanic Rocks.” Journal of Geology, 90, (2), 195-201. Chicago, Illinois: University of Chicago Press. TIC: 221104 [DIRS 119483].

Description of Use: Smyth (1982 [DIRS 119483], p. 201) reviewed literature on the thermal stability of clinoptilolite, heulandite, mordenite, and analcime and concluded that dehydration of zeolites below the repository could occur if temperatures in the zeolitic units exceed the estimated minimum alteration temperature of $85^{\circ} \mathrm{C}$ (Smyth 1982 [DIRS 119483], p. 201). These data are used in Section 6.9.16 to exclude FEP 2.2.10.14.0A, Mineralogic dehydration reactions, on the basis of low probability.

Extent to which the Data Demonstrate the Properties of Interest: The property of interest is the dehydration temperature of zeolitic minerals in the $\mathrm{CHn}$ : if the temperature exceeds the dehydration temperature, the permeability of the $\mathrm{CHn}$ would increase, and water would be released below the repository. TH Simulations show that the temperatures in the zeolitic formation do not reach the dehydration temperature.

Method of qualification: Corroboration with independent data. No planned method of qualification was abandoned.

Evaluation Criteria: The evaluation criteria, as stated in the Data Qualification Plan (BSC 2004 [DIRS 174781] is that the corroborating data set confirm that water loss by clinoptilolite at $85^{\circ} \mathrm{C}$ (approximately the maximum temperature simulated for zeolitic rocks in the repository)is less than $5 \%$.

Evaluation Results: These data are corroborated by an independent study by Carey and Bish 1996 ([DIRS 105200], Figure 10). Thermogravimetric analysis was used to monitor dehydration reactions of clinoptilolite. From the data, dehydration curves were presented showing less than 
$5 \%$ water loss was calculated for $85^{\circ} \mathrm{C}$. This amount of water loss is small enough to confirm the findings of Smyth 1982 [DIRS 119483].

Limitations on the use of the data: This qualification is limited to use in this report, as described above.

Supporting information used in the qualification: Carey and Bish 1996 ([DIRS 105200], Figure 10).

Reference to data qualification plan: BSC 2004 [DIRS 174781].

\section{C9. POTENTIAL DOSE FROM GAS-PHASE RELEASE OF CARBON-14}

\section{Data set for qualification:}

DOE (U.S. Department of Energy) 2002. Final Environmental Impact Statement for a Geologic Repository for the Disposal of Spent Nuclear Fuel and High-Level Radioactive Waste at Yucca Mountain, Nye County, Nevada. DOE/EIS-0250. Washington, D.C.: U.S. Department of Energy, Office of Civilian Radioactive Waste Management. ACC: MOL.20020524.0314 through MOL.20020524.0320 [DIRS 155970].

Description of Use: An analysis of the potential dose from gas-phase release of carbon-14 shows that the maximum dose was found to be $1.8 \times 10^{-10}$ mrem per year (DOE 2002 [DIRS 155970], Section I.7). This is based upon a calculation that, of all the ${ }^{14} \mathrm{C}$ in a waste package, $2 \%$ is in the gas phase. This dose estimate is used in Section 6.7.3 to exclude FEP 2.2.11.03.0A, Gas transport in geosphere, on the basis that it is much smaller than the dose from aqueous transport.

Extent to which the Data Demonstrate the Properties of Interest: The property of interest is the amount of ${ }^{14} \mathrm{C}$ that can be rapidly released as gas from each package. The total ${ }^{14} \mathrm{C}$ inventory per package of Commercial Spent Nuclear Fuel is 1.37 g (DTN: SN0310T0505503.004 [DIRS 168761]), the same value as used in DOE 2002 [DIRS 155970], Section I.7, with 2\% distribution to the gas phase.

Method of qualification: Corroboration with independent data. No planned method of qualification was abandoned.

Evaluation Criteria: The evaluation criteria, as stated in the Data Qualification Plan (BSC 2004 [DIRS 174782] is that an independent corroborating data set confirm that less than $2 \%$ of the ${ }^{14} \mathrm{C}$ in a waste package is available to be rapidly released.

Evaluation Results: Two percent was taken as the fraction of ${ }^{14} \mathrm{C}$ in the waste package that is in the gaseous form and therefore available for release as soon as the waste container has failed (Barnard et al. 1992 [DIRS 100309], Section 5.2). Oversby (1987 [DIRS 103446], p. 93) reported rapid release of $0.3 \%$ of the inventory from oxidation testing of a fuel assembly, with 
subsequent releases being orders of magnitude lower. These data support gas-phase rapid release of not more than $2 \%$ of the ${ }^{14} \mathrm{C}$ inventory.

Limitations on the use of the data: This qualification is limited to use in this report, as described above.

Supporting information used in the qualification: Oversby 1987 ([DIRS 103446], p. 93); Barnard et al. 1992 ([DIRS 100309], Section 5.2).

Reference to data qualification plan: BSC 2004 [DIRS 174782].

\section{C10. EROSION RATE AT YUCCA MOUNTAIN}

\section{Data sets for qualification:}

YMP (Yucca Mountain Site Characterization Project) 1993. Evaluation of the Potentially Adverse Condition "Evidence of Extreme Erosion During the Quaternary Period" at Yucca Mountain, Nevada. Topical Report YMP/92-41-TPR. Las Vegas, Nevada: Yucca Mountain Site Characterization Office. Section 3.4. ACC: NNA.19930316.0208 [DIRS 100520].

DOE (U.S. Department of Energy) 1988. Site Characterization Plan Yucca Mountain Site, Nevada Research and Development Area, Nevada. DOE/RW-0199. Nine volumes. Washington, D.C.: U.S. Department of Energy, Office of Civilian Radioactive Waste Management. Section 1.1.3.3.2. ACC: HQO.19881201.0002 [DIRS 100282].

YMP (Yucca Mountain Site Characterization Project) 1995. Technical Basis Report for Surface Characteristics, Preclosure Hydrology, and Erosion. YMP/TBR-001, Rev. 0. Las Vegas, Nevada: Yucca Mountain Site Characterization Office. ACC: MOL.19951201.0049 [DIRS 102215].

Description of Use: These three sources are used to demonstrate that, although erosion processes will be ongoing at Yucca Mountain during the next 10,000 years, the rate of erosion (including mass wasting - e.g., landslides) is too slow to significantly change the hydrologic regime or to expose the repository at the surface. The data are used in Section 6.5.1 to exclude FEP 1.2.07.01.0A, Erosion/Denudation, and in Section 6.5.2 to exclude FEP 1.2.07.02.0A, Deposition.

Prior Use of the Data: Site Characterization Plan Yucca Mountain Site, Nevada Research and Development Area, Nevada (DOE 1988 [DIRS 100282]) is cited in the Yucca Mountain Site Description (BSC 2004 [DIRS 169734]) as indirect input. The text of Site Characterization Plan Yucca Mountain Site, Nevada Research and Development Area, Nevada (DOE 1988 [DIRS 100282], Section 3.4) is quoted verbatim in Technical Basis Report for Surface Characteristics, Preclosure Hydrology, and Erosion (YMP 1995 [DIRS 102215], Section 4.1.2). 
Extent to which the Data Demonstrate the Properties of Interest: The property of interest is the age of colluvial boulder deposits, as determined by the cation ratio of rock varnish (ratio of minor elements that systematically decrease with increasing exposure age).

Method of qualification: Peer review, by a technical assessment team, as documented in (CRWMS M\&O 1992 [DIRS 171834]; YMP 1993 [DIRS 100520], Appendix A; and Hawley et al. 1989 [DIRS 170911].

Evaluation criterion: The judgment of the technical assessment team and peer review panel will be accepted, as planned in BSC 2004 [DIRS 174783].

Evaluation Results: The rock-varnish-cation-ratio method is well established (Harrington and Whitney 1987 [DIRS 106095]; Whitney and Harrington 1993 [DIRS 107303]). Most important, the data used to derive the erosion and canyon downcutting rates and cited in Section 6.5.1 of this report were reviewed by a technical assessment team (CRWMS M\&O 1992 [DIRS 171834]; YMP 1993 [DIRS 100520], Appendix A). The technical assessment team reviewed the scientific notebooks and unanimously concluded that the age determinations were the best being done at that time in the scientific community (Hawley et al. 1989 [DIRS 170911]).

Limitations on the use of the data: This qualification is limited to use in this report, as described above.

Supporting information used in the qualification: Hawley et al. 1989 [DIRS 170911]; CRWMS M\&O 1992 [DIRS 171834]; YMP 1993 [DIRS 100520], Appendix A.

Reference to data qualification plan: BSC 2004 [DIRS 174783].

\section{C11. EFFECT OF LOCAL HETEROGENEITY}

\section{Data sets for qualification:}

Zhou, Q.; Liu, H-H.; Bodvarsson, G.S.; and Oldenburg, C.M. 2003. "Flow and Transport in Unsaturated Fractured Rock: Effects of Multiscale Heterogeneity of Hydrogeologic Properties." Journal of Contaminant Hydrology, 60, [1-2], 1-30. New York, New York: Elsevier. TIC: 253978 [DIRS 162133].

Description of Use: These data are used along with the data of Valentine et al. (1998 [DIRS 119132], p. 5-74) to show that the hydrologic effect of an igneous intrusion would be insignificant because it would be limited in extent. The data of Valentine et al. (1998 [DIRS 119132], p. 5-74) show that igneous activity would change the hydrologic properties of host rock over a limited area (within $10 \mathrm{~m}$ of an intrusion). The data of Zhou et al. (2003 [DIRS 162133]) show that a heterogeneity of fracture permeability at this scale would have a negligible effect on flow. This conclusion is used in Section 6.8.4 to exclude FEP 1.2.10.02.0A, Hydrologic response to igneous activity. 
Extent to which the Data Demonstrate the Properties of Interest: The property of interest is the effect of local heterogeneity on flow. Zhou et al. (2003 [DIRS 162133]) used a two-dimensional mesh, with layer heights the same as in the UZ model, and used the same calibrated layer-scale values for the fracture and matrix hydrologic properties. Case A used uniform fracture permeability; in case B the fracture permeability was varied stochastically. The breakthrough curves for nonsorbing tracers were not significantly different in these two cases.

Method of qualification: Technical assessment.

Evaluation criterion: If the software and input data are found to be essentially equivalent to qualified software and qualified data, the results are to be accepted for the purpose of demonstrating that heterogeneity on a scale of less than $10 \mathrm{~m}$ would have a negligible effect on transport, as planned in BSC 2004 [DIRS 174784].

Evaluation results: Zhou et al. (2003 [DIRS 162133]) is a sensitivity study, in which flow and transport were evaluated for a base case and for sensitivity cases with the hydrologic properties of rock layers varied on different scales. The base case used layer-uniform hydrologic properties taken from CRWMS M\&O 2000 [DIRS 144426], CRWMS M\&O 2000 [DIRS 145771], and Flint 1998 [DIRS 100033]. The two-dimensional grid used for this study (Zhou et al. (2003 [DIRS 162133], Figure 1) was essentially identical to that used in CRWMS-M\&O 2000 ([DIRS 150824], Figure 3.4-7). Thus the model is equivalent to the Site Recommendation (SR) model. As explained in Section D3.1 of this report, the SR model is sufficiently similar to the LA model to justify its use for sensitivity studies. The software used for the simulations was TOUGH2 V. 1.4 (Pruess et al. 1999 [DIRS 160778]) and T2R3D V. 1.4. (Wu and Pruess 2000 [DIRS 153972]). This software has been qualified for the Yucca Mountain project (although for this use the software was not obtained from Software Configuration Management). Therefore both the software and input data are essentially similar to qualified software and data, and the use of the results of a sensitivity study to support the conclusion that heterogeneity at a scale of $10 \mathrm{~m}$ does not have a significant effect on tracer transport to the water table is justified. The data of Zhou et al. (2003 [DIRS 162133]) are therefore qualified.

Limitations on the use of the data: This qualification is limited to use in this report, as described above.

Qualifications of Personnel or Organizations Generating the Data: Quanlin Zhou has B. Eng. and M. Eng. degrees in Hydrology and Water Resources from Hohai University, Nanjing, P.R. China, and Ph.D. in Groundwater Hydrology from Technion-Israel Institute of Technology, Haifa, Israel. While at Technion he was awarded the Miriam and Aaron Gutwirth Prize (1999) and the Irmay Prize (1998). Lawrence Berkeley National Laboratory has been responsible for simulations of UZ flow and transport since the inception of the Yucca Mountain Project.

Limitations on the use of the data: This qualification is limited to use in this report, as described above.

Reference to data qualification plan: BSC 2004 [DIRS 174784]. 


\section{C12. FLOW AND TRANSPORT SIMULATIONS WITH ALTERNATIVE PERCHED-WATER MODELS}

Reference: BSC 2001. UZ Flow Models and Submodels. MDL-NBS-HS-000006 REV 00 ICN 01. Las Vegas, Nevada: Bechtel SAIC Company. ACC: MOL.20020417.0382. [DIRS 158726].

Use of the Data: Simulations of transport of sorbing and nonsorbing radionuclides under various perched water regimes are presented in UZ Flow Models and Submodels (BSC 2001 [DIRS 158726], Section 6.7.2). The perched water models represent the effects of undetected features that might be present in the UZ. Simulation results show that breakthrough curves are only slightly different under the various models. This insensitivity to the perched-water model is used in Section 6.8.9 to support the argument for exclusion of FEP 2.2.12.00.0A, Undetected features in the UZ . It is also used in Section 6.9.14 to support the argument for exclusion of FEP 2.2.10.07.0A, Thermo-chemical alteration of the Calico Hills unit, and in Section 6.9.15 to support the argument for exclusion of FEP 2.2.10.09.0A, Thermo-chemical alteration of the Topopah Spring basal vitrophyre.

Reason for Supersession: The report (BSC 2001 [DIRS 158726]) was revised to comply with AP-SIII.10Q and to generate flow fields with revised input data and a revised grid. In this revision, the alternative perched-water models were not included, only the primary model, which is used for TSPA-LA.

Reliability of Input Source: The source is a model report that was produced under the then-current revision of AP-SIII.10Q. The input data (rock properties, mesh, and infiltration map) were qualified and have since been superseded, but they are qualitatively similar to the corresponding data that are now qualified. This is shown by the fact that both BSC 2001 [DIRS 158726] and the current controlled version, BSC 2004 [DIRS 169861], produce flow fields that contain perched water bodies. The software used in UZ Flow Models and Submodels (BSC 2001 [DIRS 158726]), T2R3D V. 1.4 (LBNL 1999 [DIRS 146654]), and TOUGH2 V. 1.4 (LBNL 2000 [DIRS 146496]), is still on the SCM baseline.

Qualifications of Personnel or Organizations Generating the Input: Lawrence Berkeley National Laboratory has been responsible for simulations of UZ flow since the inception of the Yucca Mountain Project. The same personnel and organization are responsible for the present controlled version of the model report and for the flow fields used in TSPA. Yu-Shu Wu has a Ph.D. in Mineral Engineering from the University of California Berkeley and is group leader at Lawrence Berkeley National Laboratory. Now (2005) he is associate editor of Water Resources Research.

Corroborating Input: These data (flow fields and transport simulations for various perched water models) are output from the UZ Flow model documented in BSC 2001 [DIRS 158726]. The model was validated (BSC 2001 [DIRS 158726], Section 6.8.3) by comparison with data, including perched water data. 


\title{
C13. EFFECT OF PRECLOSURE DRYOUT ON POSTCLOSURE TEMPERATURE
}

\author{
Reference: BSC (Bechtel SAIC Company) 2001. FY 01 Supplemental Science and \\ Performance Analyses, Volume 1: Scientific Bases and Analyses. \\ TDR-MGR-MD-000007 REV 00 ICN 01. Las Vegas, Nevada: Bechtel SAIC \\ Company. ACC: MOL.20010801.0404; MOL.20010712.0062; \\ MOL.20010815.0001., Section 5.3.2.4.4 [DIRS 155950].
}

Use of the Data: The sensitivity studies in FY 01 Supplemental Science and Performance Analyses, Volume 1: Scientific Bases and Analyses (BSC 2001 [DIRS 155950], Section 5.3.2.4.4) indicate that inclusion of preclosure dryout gives rise to slightly higher temperatures during the heating period compared to a model that ignores the influence of preclosure dryout. These data are used in Section 6.9.4 to exclude the effects of dryout occurring during excavation and operation.

Reason for Cancellation: These data are based on the design for TSPA-SR. TSPA-SR has been superseded because changes in models, input data, and design require that the TSPA be recalculated for LA. However, the basic repository design and the treatment of precipitation in TSPA have not changed.

Reliability of Input Source: The calculations presented in FY 01 Supplemental Science and Performance Analyses, Volume 1: Scientific Bases and Analyses (BSC 2001 [DIRS 155950], Section 5.3.2.4.4) are adequate for the intended use regarding this FEP because these were performed using a qualified thermal-hydrologic model (NUFT V3.0 [DIRS 127906]); see BSC 2001 [DIRS 155950], Table 1-2, Sections 5.3.2.4.1 and 5.3.2.4.4) for a similar design thermal load (BSC 2001 [DIRS 155950], Table 2-1; BSC 2005 [DIRS 174101], Section 4.1.5).

Qualifications of Personnel or Organizations Generating the Input: Lawrence Livermore National Laboratory developed the NUFT model. The same personnel and organization are responsible for the present controlled version of the model report that is used in TSPA.

\section{C14. DOSE RATES INCREASING OVER TIME}

Reference: CRWMS M\&O 2000. Total System Performance Assessment for the Site Recommendation. TDR-WIS-PA-000001 REV 00 ICN 01. Las Vegas, Nevada: CRWMS M\&O. ACC: MOL.20001220.0045 [DIRS 153246], Sections 3.5.5 and 4.1.3; Figures 4.1-5, 4.1-7, 4.1-9, 4.1-19a, and 4.1-20

Use of the Data: In the latest total-system performance assessment, dose rates for all radionuclides are predicted to increase over tens of thousands of years (CRWMS M\&O 2000 [DIRS 153246], Figures 4.1-5 and 4.1-7). This is a result of the spread of waste package failures over time (CRWMS M\&O 2000 [DIRS 153246], Figures 4.1-9) and the slow release of radionuclides from the waste emplacement drifts. Therefore, during the 10,000-year period, the highest concentration for any radionuclide at the receptor is expected to occur under conditions giving the greatest transport rates. Reduced solubilities for neptunium americium, plutonium, thorium, and uranium were investigated as a sensitivity in TSPA-SR (CRWMS M\&O 2000 
[DIRS 153246], Sections 3.5.5, 4.1.3, and Figures 4.1-19a and 4.1-20). The dose rates for radionuclides affected by the lower solubilities (including decay products such as ${ }^{226} \mathrm{Ra}$ ) were found to be lower in the reduced-solubility case. These data are used in Section 6.9.6 to support the argument that precipitation of radionuclides has no adverse affect on repository performance, and to support exclusion of FEP 2.2.01.05.0A, Radionuclide transport in the excavation disturbed zone.

Reason for Cancellation: TSPA-SR has been canceled because changes models, input data, and design require that the TSPA be recalculated for LA. However, the basic repository design and the treatment of precipitation in TSPA have not changed.

Reliability of Input Source: The total-system performance assessment for Site Recommendation (CRWMS M\&O 2000 [DIRS 153246], Sections 3.5 .5 and 4.1.3) was performed using qualified software for a repository design, engineered system design, and, waste inventory that is similar to that used for license application. Therefore, the qualitative trends cited for total system performance should be sufficiently representative for its intended use regarding this FEP.

\section{C15. ENDPOINT COORDINATES OF REPOSITORY DRIFTS}

Reference: BSC (Bechtel SAIC Company) 2003. Repository Design, Repository/PA IED Subsurface Facilities. 800-IED-EBS0-00402-000-00B. Las Vegas, Nevada: Bechtel SAIC Company. ACC: MOL.20030109.0146. [DIRS 161727].

Use of the Data: These data define the areal extent and elevation of the repository (Figures A-1 and A-2). They are used in Appendix A, Section A1 to calculate the volume of perched water in the repository and to compare it to the flux through the repository (Table A-1). This comparison is used in Section 6.8.8 to exclude FEP 2.2.06.03.0A, Seismic activity alters perched water zones.

The data are also used in Appendix B to determine that the PTn hydrogeologic unit overlies the entire repository (Figure B-1). This fact is used in Section 6.4.5 to exclude FEP 2.2.07.05.0A, Flow in the UZ from episodic infiltration.

Reason for Supersession: To accommodate rail haulage, the length of drift turnout was increased. This required two more emplacement drifts to accommodate the same total drift length. The drift-to-drift spacing was not changed.

Justification for Use: The differences between the superseded design (BSC 2003 [DIRS 161727]) and the present design (BSC 2004 [DIRS 172801]) is not significant for the purposes of these calculations. Comparison of the map in Figures A-1 and B-1 with the map in D\&E/RIT IED Subsurface Facilities [Sheet 1 of 4] (BSC 2004 [DIRS 172801]) shows that the footprint of the repository is unchanged. Also, the repository is still located in the Tptpmn and Tptpll hydrogeologic units. Therefore, it is still completely overlain by the PTn and the volume of perched water is the same as calculated in Table A-1. 


\section{C16. EFFECT OF TRANSIENT INFILTRATION ON UZ FLOW}

\section{Data set for qualification:}

Wu, Y. S.; Zhang, W.; Pan, L.; Hinds, J.; Bodvarsson, G.S. "Capillary Barriers in Unsaturated Fractured Rocks of Yucca Mountain, Nevada" LBNL-46876. Berkeley, California: Lawrence Berkeley National Laboratory. TIC: 249912. [DIRS 154918].

Description of Use: These data are used to show that the hydrologic effect of episodic infiltration is temporally damped after passing through the PTn. This results in relatively steady flow at the repository horizon and below to the water table. This behavior is used to justify a steady-state UZ flow model that uses temporally averaged infiltration maps as the upper boundary condition. This conclusion is used in Section 6.4.5 to exclude FEP 2.2.07.05.0A, Flow in the UZ from Episodic Infiltration.

Extent to which the Data Demonstrate the Properties of Interest: The property of interest is the effect of transient infiltration on flow. Wu et al. (2000 [DIRS 154918]) used twodimensional and one-dimensional meshes, with layer heights the same as in the base-case UZ model for site recommendation, and used the same calibrated layer-scale values for the fracture and matrix hydrologic properties (CRWMS M\&O 2000 [DIRS 122797]). The two-dimensional model consists of a 50-m long, east-west cross section lying above the waste emplacement areas near borehole UZ-14; the one-dimensional model is located along and a one-dimensional model lying along the cross-sectional model just east of borehole UZ-14. Surface infiltration pulses are assumed to be uniformly distributed spatially with a one-week infiltration cycle of 50 years (i.e., the model top boundary is subject to nonzero infiltration for only one week every 50 years, infiltration rate for the week is about $13,045 \mathrm{~mm} / \mathrm{year}$ ). The net infiltration value of the week averaged over the 50 years is also $5 \mathrm{~mm} /$ year. The initial conditions for both the two-dimensional and one-dimensional models correspond to steady-state status under $5 \mathrm{~mm} /$ year infiltration. The resulting flow from the PTn is shown to have fluctuations of less than $1 \mathrm{~mm} / \mathrm{yr}$.

Method of qualification: Technical assessment.

Evaluation criterion: If the software and input data are found to be essentially equivalent to qualified software and qualified data, then results are to be accepted for the purpose of demonstrating that the flow field below the PTn is not affected by episodicity of infiltration at the ground surface, as planned in BSC 2004 [DIRS 174791].

Technical Adequacy of Equipment and Procedures Used to Collect and Analyze the Data: The software codes used for the simulations was TOUGH2 V1.4, which has been qualified for use on the Yucca Mountain project.

Limitations on the use of the data: This qualification is limited to use in this report, as described above.

Supporting information used in the qualification: Hawley et al. 1989 [DIRS 170911]; CRWMS M\&O 1992 [DIRS 171834]; YMP 1993 [DIRS 100520], Appendix A .

Reference to data qualification plan: BSC 2005 [DIRS 174791]. 
Qualifications of Personnel or Organizations Generating the Data: Yu-Shu Wu has a B.S. in Reservoir Eng. from Daqing Petroleum Inst., China; an M.S. in Flow in Porous Media from Southwest Petroleum Inst., China, and a Ph.D. in Reservoir Engineering/Hydrogeology from the University of California at Berkeley. He has contributed to the Yucca Mountain Project since 1995 as a Staff Geological Scientist with the Earth Sciences Division of Lawrence Berkeley National Laboratory. Lawrence Berkeley National Laboratory has been responsible for simulations of UZ flow since the inception of the Yucca Mountain Project. 


\section{APPENDIX D}

\section{ANALYSIS OF SENSITIVITY OF TRANSPORT TO CHANGES IN FRACTURE APERTURE}




\section{D1. INTRODUCTION}

This appendix documents a recalculation of a portion of the complete sensitivity analysis documented in Fault Displacement Effects on Transport in the Unsaturated Zone (CRWMS M\&O 2000 [DIRS 151953], Sections 6.1, 6.2). The reason for the recalculation is that the original analysis was conducted using software for transport calculations on a platform not approved for use in the software baseline. This analysis is repeated here for the most important three-dimensional site scale model results using qualified software for transport, on an approved platform.

The technical purpose of this Appendix is to evaluate the potential for changes to the hydrogeologic system caused by fault displacement to affect radionuclide transport in the UZ at Yucca Mountain. The repository is bounded on the west by the Solitario Canyon fault and on the east by the Bow Ridge fault. The northern boundary of this structural block is bounded by the Drill Hole Wash fault. There are also three intrablock faults: the Ghost Dance, Sundance, and Dune Wash faults. For the purposes of this analysis, the focus is on two possible effects of fault displacement along the bounding faults: (1) uniform change in fracture properties throughout the UZ flow model domain and (2) change in fracture properties within the faults only. These two hypothetical end-member cases model the bounding cases of mechanical strain being either uniformly distributed throughout the strata bounded by the faults or localized to the individual fault zones. In the physical system, the strain would be spatially distributed in some manner that lies between these end-member cases. This evaluation used the bounding case estimates to determine whether FEPs 2.2.06.02.0A (Seismic activity changes porosity and permeability of faults) and 2.2.06.02.0B (Seismic activity changes porosity and permeability of fractures) can be excluded.

These two end-member cases were evaluated by simulating the flow and transport in the UZ for a pulse input tracer at the repository location. For a specific cross-section, computer simulations were performed assuming (1) a change in fracture properties throughout the UZ models (which assumes all fracture apertures are uniformly altered), and (2) a change in fracture properties in the fault zones only. Simulations were performed for the present-day climate and a wetter, glacial-transition climate case. Tracer breakthrough curves computed at the water table were used to examine the potential impact induced on transport in the UZ.

The effects of fault displacement on UZ transport encompasses four FEPS:

1.2.02.02.0A Faults

1.2.10.01.0A Hydrologic response to seismic activity

2.2.06.02.0A Seismic activity changes to porosity and permeability of faults

2.2.06.02.0B Seismic activity changes to porosity and permeability of fractures.

\section{D2. SENSITIVITY ANALYSES}

As stated in Section D1, the purpose of this report is to describe the potential for fault displacement events during the postclosure period that affect performance through changes in radionuclide transport in the UZ at Yucca Mountain. In particular, the effects of fault 
displacement on repository performance will be addressed in terms of changes in the simulated breakthrough at the water table of a pulse input of tracer at the repository.

The approach for the analysis of fault displacement effects on transport in the UZ is divided into two distinct components: a review of site description information which provides a basis for defining bounding conditions and for understanding the physical significance of the results (Section D2); and a modeling component to provide quantitative analysis of the sensitivity of the UZ flow system to changes in hydrologic parameters (Section D3).

\section{D2.1 SITE DESCRIPTION INFORMATION}

The spatial and temporal patterns of faulting and fracturing of the volcanic bedrock are the fundamental elements of the structural geology of the repository for high-level radioactive wastes at Yucca Mountain. To document and discuss these patterns, a comprehensive program of geologic mapping and fractured rock mass studies has been conducted as an integral part of the site characterization. Of particular importance to this analysis are geologic observations related to displacement in fault zones and observations of the characteristics of the faults zones made during the excavation of the ESF and in the enhanced characterization of the repository block (ECRB) Cross Drift. The observations are briefly described in Section D2.1.1. These observations provide a basis for determining the reasonableness and appropriateness of the range of inputs used in the modeling analysis in Section D3 and for interpreting the level of conservatism represented by the models.

However, the primary controlling factor for amount of flux through the UZ is the amount of precipitation available to infiltrate and percolate through the UZ. This variable is highly dependent on climate conditions. To address this variable, present day average and glacial-transition climate conditions (CRWMS M\&O 1998 [DIRS 100356], Section 2.4.1.1) were used as bounding conditions. The differences in these climate states are briefly explained in Section D2.1.2.

\section{D2.1.1 Geologic Setting}

The Yucca Mountain area is cut by steeply dipping, north-south-striking normal faults which separate the Tertiary volcanics into blocks one to four kilometers wide (Scott 1990 [DIRS 106751]). The repository lies in the central block of the central Yucca Mountain structural domain. The central block is bounded on the west by the Solitario Canyon fault, on the east by the Bow Ridge fault, and on the north by the northwest-striking Drill Hole Wash fault. The southern boundary is marked by a transition to structural styles that accompany greater magnitudes of extension and continue south. Intrablock faults include the Ghost Dance, Sundance, and the Dune Wash faults.

The repository area is bounded by the Solitario Canyon fault to the west and the Ghost Dance fault to the east. Both faults dip steeply toward the west, and displacement, amount of brecciation, and number of associated splays vary considerably along their trace (Scott and Bonk 1984 [DIRS 104181]; Day et al. 1998 [DIRS 101557]).

Surface geologic mapping (Scott and Bonk 1984 [DIRS 104181]; Day et al. 1998 [DIRS 101557]), underground mapping of the ESF, geophysical surveys, and borehole studies 
show that the Yucca Crest subblock is little deformed, and cut only by widely spaced intrablock faults (Ghost Dance and Dune Wash). Within structural blocks, small amounts of strain are accommodated along intrablock faults. In many cases, intrablock faults appear to represent local structural adjustments in response to displacements on the block-bounding faults. Many of the intrablock faults within this part of Yucca Mountain are short, discontinuous, have minor cumulative displacement ( 1 to $10 \mathrm{~m}$ ), and represent the localization of slip along pervasive preexisting weaknesses in the rock mass (Potter et al. 1996 [DIRS 106582], 1996 [DIRS 106583]). In some cases, intrablock faults are expressions of hanging wall or footwall deformation that affect the block within a few hundred meters of the block-bounding faults. The eastern and southern edges of the central block, however, are cut by numerous faults associated with block margin deformation (Solitario Canyon and Bow Ridge faults).

\section{D2.1.1.1 Fracture Attributes}

The fracture network acts as a significant preexisting weakness in the rock mass that can accommodate extensional strain through distributed slip along many reactivated joints. Evidence for reactivation of joints includes the presence of thin breccia zones along cooling joints and observable slip lineations along joint surfaces (Sweetkind et al. 1996 [DIRS 106957]). Cooling joints originally formed as tensional openings, having only face separation, not shear. However, thin selvages of tectonic breccia are often present along the trace of cooling joints, indicating later slip. Subsequent analyses performed here (see Section D3.2) will consider the dilation or compression of any hydraulically connected fractures at Yucca Mountain, regardless of whether the fractures originated as tensional openings during cooling of the rock or from past seismic activity and regardless of distance from the fault.

There are a number of primary controls on fracture characteristics within the Paintbrush Group that are related to stratigraphy, upon which any later tectonic signature (such as fault displacement) is superimposed. Fracture characteristics in the pyroclastic flows at Yucca Mountain are primarily controlled by variations in the degree of welding (CRWMS M\&O 1998 [DIRS 100126], Section 3.6). The intensity of fracturing increases with degree of welding within the welded pyroclastic flows because of the presence of cooling joints, and because increasing brittleness of the rock favors an increase in the number of tectonic joints. Lithophysal development, alteration, and pumice content are secondary controls important in specific stratigraphic intervals. These lithostratigraphic controls affect fracture spacing, type, number of sets, continuity of individual fractures within each lithostratigraphic zone, and they also affect the fracture connectivity of the network as a whole (Sweetkind and Williams-Stroud 1996 [DIRS 100182], pp. 60 to 66; Sweetkind et al. 1997 [DIRS 100183], pp. 62 to 67).

Each lithostratigraphic zone at Yucca Mountain has characteristic fracture attributes, including predominant orientations, spacing, trace length, and joint type (Sweetkind et al. 1997 [DIRS 100183], p. 76); each is unique in its ability to deform by distributed slip. The result is stratigraphic control of structural geometry-what may be a discrete break in one lithostratigraphic unit may be a broad zone of distributed deformation in another.

An analysis of fracture apertures is available from the ECRB Cross Drift Study (DTN: GS990408314224.001 [DIRS 108396] and GS990408314224.002 [DIRS 105625]). The largest aperture recorded was $520 \mathrm{~mm}$. Approximately $64 \%$ of the observed fractures exhibited 
zero aperture. Of the over 1800 fractures measured, only 40 apertures were measured as greater than $20 \mathrm{~mm}$, or about $2 \%$ to $3 \%$. The remaining apertures were less than $20 \mathrm{~mm}$.

The relationship of fractures smaller than $1 \mathrm{~m}$ in length to faults was evaluated by visual examination of every fault in the ESF (Sweetkind et al. 1997 [DIRS 100183], p. 68) that could be correlated with a fault mapped at the surface (Day et al. 1998 [DIRS 101557]). Four principal conclusions were reached, based on observations in the ESF (Sweetkind et al. 1997 [DIRS 100183], pp. 68, 71).

The first conclusion is that the width of the zone of influence on fracture frequency in the immediate vicinity of a fault is, in general, quite narrow, ranging from less than $1 \mathrm{~m}$ to about $7 \mathrm{~m}$ from the fault.

The second conclusion regarding the relationship between faults and fracture attributes is that the width of the zone of influence in the immediate vicinity of a fault correlates, in a general way, with the amount of cumulative fault offset. Therefore, faults with the largest potential future displacement are the most likely to influence the repository block. Intrablock faults with very small amounts of cumulative offset ( 1 to $5 \mathrm{~m}$ ) have zones of influence that are 1 to $2 \mathrm{~m}$ in width. Block-margin faults with tens of meters of cumulative offset (faults at ESF Stations $11+20$ and $70+58$ ) have zones of influence that range up to 6 to $7 \mathrm{~m}$ wide. The limited available data from block-bounding faults are not definitive regarding the nature of attendant fracturing.

The third conclusion is that the width of the zone of influence around a fault does not appear to be related to depth, at least within the ESF. The width of the zones of influence is similar for small faults observed along the North Ramp, where overburden is 50 to $60 \mathrm{~m}$ thick, as it is for small faults observed elsewhere in the ESF, where overburden thickness is two to three times greater. However, upward-splaying faults can result in apparent broad zones of influence at the surface because of the overlap of fractured zones surrounding individual fault splays.

The fourth conclusion is that the amount of deformation associated with faults appears, in part, to be dependent upon which lithologic unit is involved in the faulting. In the ESF, overall variability in the frequency of fractures $1 \mathrm{~m}$ long or longer is primarily a function of lithology, not proximity to faults (Sweetkind et al. 1997 [DIRS 100183], p. 68). Fracture intensity correlates to lithologic differences, lowest in lithophysal units and nonwelded to partially-welded tuffs, and highest in densely welded, nonlithophysal rock. Faults within nonwelded to partly welded portions of the crystal-poor vitric zone of the Tiva Canyon Tuff are generally sharp, discrete breaks with minimal fault gouge or secondary shear surfaces. Individual pumice clasts along some faults can be traced to the fault surface without visible sign of breakage, and wall rocks show little evidence of deformation. In comparison to brittle, welded rocks, nonwelded units apparently can accommodate a greater amount of extensional strain before failing by fracture.

\section{D2.1.1.2 Fault Attributes}

In the following descriptions, fault length refers to the maximum length of a given fault or fault zone as reported or shown on maps in published references (e.g., Piety 1996 [DIRS 106540]). Unless otherwise indicated, the following descriptions for regional faults, including temporal and 
behavioral data, are from Piety (1996 [DIRS 106540]), and the field reconnaissance work is from Anderson et al. (1995 [DIRS 101422]). Piety's report (1996 [DIRS 106540]) is an excellent synthesis of most of the data available for characterizing regional faults, and contains an extensive list of published references.

The Solitario Canyon Fault Zone: The Solitario Canyon Fault Zone is the most laterally continuous fault and displays the most total offset of any structure in the immediate vicinity of Yucca Mountain. Day et al. (1998 [DIRS 101557], p. 6) consider the Solitario Canyon Fault Zone to be one in a series of major north-south trending, block-bounding faults. The fault has been extensively investigated by trenching at the surface in Solitario Canyon (Ramelli et al. 1996 [DIRS 101106]). The Solitario Canyon fault has normal down-to-the-west displacement of about $260 \mathrm{~m}$ near the repository block and is the most significant of the faults involved in this analysis.

The main trace of this fault extends southward from Yucca Wash for about $18 \mathrm{~km}$. It is located about $1 \mathrm{~km}$ from the western boundary of the repository site (Simonds et al. 1995 [DIRS 101929]). Total bedrock displacement varies from $61 \mathrm{~m}$ down-to-the-east at the northern end, to more than $500 \mathrm{~m}$ down-to-the-west at the southern end (Scott and Bonk 1984 [DIRS 104181]). Average dip of the fault plane is $72^{\circ} \mathrm{W}$. Slickensides indicate a component of left-lateral slip.

Map patterns demonstrate that tectonic mixing of various Paintbrush Group lithologies has occurred within the most intensely deformed parts of block-bounding fault systems. This is most apparent in the Solitario Canyon fault system (Scott and Bonk 1984 [DIRS 104181]; Day et al. 1998 [DIRS 101557]). In this system, which is up to $400 \mathrm{~m}$ wide, there are domains in which lenses from stratigraphically diverse parts of the Tiva Canyon Tuff are juxtaposed; similar zones in which slices of Topopah Spring Tuff are mixed; and several areas where lenses from more than one Paintbrush Group formation are tectonically mixed (Day et al. 1998 [DIRS 101557]). Individual fault strands within these tectonically-mixed zones are highly brecciated, and in some cases, the fault-bounded lenses have a high degree of internal brecciation.

The SCFZ was not crossed during the ESF excavation. In the ECRB Cross Drift, the SCFZ was expected to be composed of two major normal fault strands; the first (eastern strand) was projected as the "main splay" with a predicted total offset of about $230 \mathrm{~m}$. The second (western strand) was projected with a predicted cumulative offset of about $165 \mathrm{~m}$ (CRWMS 1998 [DIRS 103731]). Between these two larger strands, several smaller faults were expected to be associated with the SCFZ faulting. The tunnel boring for the ECRB Cross Drift was stopped between the two strands based on programmatic considerations, and the western strand was not intersected.

The as-built geologic cross-section for the ECRB Cross Drift (DTN: GS990408314224.006 [DIRS 108409]) shows that the eastern strand was encountered at Station $25+85$ (that is, $2,585 \mathrm{~m}$ from the start of the survey line) and has approximately $260 \mathrm{~m}$ of cumulative normal offset. Shears and small faults increase in intensity prior to (east of) of Station $25+00$. The Solitario Canyon Fault Zone influences rock in the footwall of the fault to about Station 25+00 (or approximately $85 \mathrm{~m}$ from the fault proper) in the form of increased shear intensity. Spacing of 
faults and shears decreases, while continuity and amount of cumulative offset increases with proximity to the eastern strand of the Solitario Canyon Fault Zone. At Station 25+30, a small fault oriented 200/83 is intercepted by the tunnel. Although the cumulative offset along the fault is approximately $1 \mathrm{~m}$ or less, the rock is intensely fractured after (west of) Station $25+40$. The rock from Station $25+80$ to $25+82$ (between 3 and $5 \mathrm{~m}$ from the fault) is a clast-supported breccia. The rock is shattered to the point of not having recognizable structure. From Station $25+82$ to $25+85$, the rock is a clast-supported breccia. The main plane of displacement along the eastern strand of the Solitario Canyon Fault Zone is at Station 25+85, (left wall, springline). The fault plane is defined by an 8 to $12 \mathrm{~cm}$ thick zone of fault gouge composed of about $85 \%$ clay and about $15 \%$ fine to medium sand. The gouge is firm and was slightly damp at the time of excavation in October 1998, but dry by February 1999. On the west (hanging wall) side of the fault plane described above, there is a zone of matrix-supported breccia that extends along the left wall from Station $25+85.5$ to $25+89.90$. The farthest western zone along the eastern strand of the Solitario Canyon Fault Zone is composed of a clast-supported breccia extending along the left wall from Station 25+89.9 to $25+99.15$ (or a distance of approximately $14 \mathrm{~m}$ west of the fault). This zone is bounded on the west side by a thin, discontinuous, matrix-supported breccia about 10 - to 20 -cm thick.

Ghost Dance Fault Zone-The Ghost Dance fault is in the central part of the repository block. It is mapped for approximately $3 \mathrm{~km}$ as a zone of numerous splays that not only parallel the main north-trending trace of the zone, but locally branch away from the main trace. In general, it is a north-striking normal fault zone, dipping steeply west $\left(75^{\circ}\right.$ to $\left.85^{\circ}\right)$ with down-to-the-west displacement. The Ghost Dance fault bifurcates; one branch connects with the Abandoned Wash fault to the southwest (Scott and Bonk 1984 [DIRS 104181]; Day et al. 1996 [DIRS 124302]), and a second branch trends southeast, but does not appear to connect with the Dune Wash fault (Day et al. 1996 [DIRS 124302]) subdivided the fault into three sections on the basis of cumulative offset and brecciation.

Along the northern segment, north of Split Wash, the fault is a relatively narrow zone (2 to $4 \mathrm{~m}$ wide) with as much as $6 \mathrm{~m}$ of down-to-the-west total displacement.

The central segment of the Ghost Dance fault zone has greater down-to-the-west displacement than the northern segment, and extends from Split Wash to Broken Limb Ridge. On Antler Ridge, there is 13 to $20 \mathrm{~m}$ of cumulative displacement across several splays of the Ghost Dance that are distributed over a map width of approximately 100 to $150 \mathrm{~m}$ (Day et al. 1998 [DIRS 101557], p. 9). Individual splays are characterized by 1 to 2 m-wide breccia zones.

To the south on Whale Back Ridge, the fault zone is about $55 \mathrm{~m}$ wide and has about $30 \mathrm{~m}$ cumulative down-to-the-west offset. There, the zone is bounded by two north-striking faults. The eastern fault is the main trace of the Ghost Dance. Locally, the immediate hanging wall of the principal splay of the Ghost Dance fault is highly fractured. On the south-facing slope of Broken Limb Ridge, the cumulative offset is less than $6 \mathrm{~m}$, and intense fracturing in the hanging wall extends about $15 \mathrm{~m}$ to the west.

The amounts of displacement and brecciation along the southwestern projection of the Ghost Dance fault across Highway Ridge are considerably less than those preserved along the central segment. Cumulative offset on the fault increases to the southwest from Ghost Dance Wash, 
becoming about $17 \mathrm{~m}$ down-to-the-west in Abandoned Wash on the eastern splay of the Abandoned Wash fault (Day et al. 1998 [DIRS 101557], p. 10).

In the Ghost Dance Wash area (near the southern bend in the ESF), displacement on the fault is less than $3 \mathrm{~m}$ both on the surface and in the ESF, and deformation is also confined to a relatively narrow zone $(2 \mathrm{~m})$ of intense fracturing and brecciation.

The geotechnical baseline report (CRWMS M\&O 1998 [DIRS 109848], p. 4-15) stated that the Ghost Dance fault might be encountered in the ECRB Cross Drift, but the fault should have minimal cumulative offset. The geologic cross section from the baseline report accurately predicted the fault in the vicinity of Station 4+80. A shear (that is, less than $0.1 \mathrm{~m}$ displacement) was encountered at Station 4+99 (left wall, springline) which has been identified as the northern distal end of the Ghost Dance fault. This feature is the only north-trending, conspicuous discontinuity in this portion of the tunnel. The feature consists primarily of a 1 to $10-\mathrm{cm}$ thick zone of silty/sandy gouge with clasts. The gouge thickens slightly in the crown to $10 \mathrm{~cm}$, but is only 2 to 4 -cm thick elsewhere. The gouge is surrounded by a zone of intensely fractured and crushed rock. On the right wall, this fractured zone is approximately $0.4 \mathrm{~m}$ thick on the east side of the feature, and $0.6 \mathrm{~m}$ thick on the west side of the feature (DTN: GS990408314224.003 [DIRS 108404]) .

Dune Wash Fault-This south- and southeast-trending fault is mapped along the eastern side of the repository site for a distance of $3 \mathrm{~km}$. It is mapped in exposures of bedrock as a west-dipping normal fault with down-to-the-west displacement. Toward the northern end of the fault, Tertiary volcanic rocks are displaced a total of 50 to $100 \mathrm{~m}$ (Day et al. 1996 [DIRS 124302], 1998 [DIRS 100027]; Scott and Bonk 1984 [DIRS 104181]). However, no evidence of Quaternary movement has been found in surficial deposits that bury the fault toward the south, and no per-event displacement data are available.

The Dune Wash fault is exposed in the ESF near Station $67+88$, where the cumulative offset is $65 \mathrm{~m}$ (Sweetkind et al. 1997 [DIRS 100183], Table 21), and the zone of increased fracture frequency in the vicinity of the fault is 6 to $7 \mathrm{~m}$ wide. This fault was not encountered in the Cross Drift.

Sundance Fault-The Sundance fault is located in the north-central portion of the repository block.

A detailed investigation of the Sundance fault has been conducted by Potter et al. (1999 [DIRS 107259]). The maximum width of the Sundance fault zone is about $75 \mathrm{~m}$, and the cumulative down-to-the-northeast vertical displacement across the fault zone does not exceed $11 \mathrm{~m}$. The faults in this zone are almost exclusively characterized by down-to-the-northeast displacement (Potter et al. 1999 [DIRS 107259], pp. 5 to 6). Even though some horizontal slickensides have been observed, significant strike-slip displacement along the Sundance fault zone is not evident. Potter et al. (1999 [DIRS 107259], p. 9) concluded that the Sundance fault zone has a significantly smaller along-strike extent than had been suggested by previous workers.

Individual faults in the Sundance fault zone and elsewhere at Yucca Mountain are vertically and laterally discontinuous; one or more mechanisms of strain accommodation must operate in the 
Tiva Canyon Tuff to accommodate displacements in the rock volume between the discontinuous discrete fault segments. Two probable mechanisms are: distributed brittle deformation associated with diffuse breccia bodies, and minor cumulative offsets along numerous preexisting cooling joints (Potter et al. 1999 [DIRS 107259], pp. 13 to 14).

The ESF passes beneath the southeastern end of the Sundance fault zone, as mapped by Potter et al. (1999 [DIRS 107259]), where displacement is minimal on the south flank of Live Yucca Ridge. In the ESF, the fault is identified within a broad zone of discontinuous minor northwest-striking faults and joints in the middle nonlithophysal zone of the Topopah Spring Tuff. The exposure in the ESF is similar in character to the fault zone mapped at the surface near its southeastern termination on the south-facing slope of Live Yucca Ridge (Potter et al. 1999 [DIRS 107259], p. 8; Day et al. 1998 [DIRS 101557]).

The Geotechnical Baseline Report (CRWMS 1998 [DIRS 103731]) predicted the Sundance fault to be near Station $10+70$ to $11+00$. The Sundance fault was encountered along the left wall at Station $11+35.40$ to $11+36.70$ (DTN: GS990408314224.003 [DIRS 108404]). The fault intercepts the right wall at Station $11+35$ to $11+36.2$, approximately $35 \mathrm{~m}$ southwest of the location predicted. The amount of displacement is thought to be on the order of several meters, but is indeterminate. The margins of the fault zone were unaltered except in the immediate area of the fault, which exhibits some iron oxide stainings along the right wall. All portions of the Sundance fault were dry at the time of excavation.

The fault zone is composed of three distinct zones along the left wall. Zone 1 is adjacent to the footwall plane, and is a matrix-supported, uncemented breccia. Zone 1 is approximately $20 \mathrm{~cm}$ thick on the left wall, thinning to $4 \mathrm{~cm}$ on the right wall. Zone 2 along the exposure of the Sundance fault is approximately $0.7 \mathrm{~m}$ thick and is a matrix-supported breccia. Zone 3 varies in thickness from $0.3 \mathrm{~m}$ on the left wall, to zero on the right wall. Despite the very sharp and distinct plane of the fault at the footwall, distinct slickensides are not evident. Faint, low-angle slickensides can be interpreted on the left wall, and undulations in the fault plane with low-angle plunges occur at the boundary between Zones 1 and 2. The footwall rock is intact, even within $10 \mathrm{~cm}$ of the fault plane. The hanging wall is slightly more fractured, with an intensely fractured zone about $1 \mathrm{~m}$ thick.

Bow Ridge Fault-This fault is a prominent north-striking, west-dipping, normal-oblique (sinistral) slip fault. It is about $10 \mathrm{~km}$ long and lies along the east side of the repository area. The fault is buried beneath alluvium and colluvium for most of its extent along the western margin of Midway Valley. The best topographic expression of the fault occurs where a 760-m-long section follows the base of the west side of Exile Hill (Simonds et al. 1995 [DIRS 101929]; Menges and Whitney (1996 [DIRS 106343], p. 2-3); Menges et al. 1997 [DIRS 105139]). Tertiary volcanics are displaced at least $125 \mathrm{~m}$ down-to-the-west at this locality. The fault dips $65^{\circ} \mathrm{E}$ to $75^{\circ} \mathrm{E}$.

Trenches on the surface and the ESF expose a complex fault zone in highly-fractured Tertiary volcanic bedrock and colluvial deposits that have been subjected to multiple Quaternary faulting events. At least two and possibly three surface-rupture events are evident in late to middle Pleistocene colluvial deposits at trench 14D (Menges and Whitney 1996 [DIRS 106343]; Menges et al. 1997 [DIRS 105139]). A minimum age of $48 \pm 20$ thousand years is established 
for the most recent surface-rupture event. Displacements range from 14 to $44 \mathrm{~cm}$ for individual faulting events, and cumulative displacement is from 30 to $70 \mathrm{~cm}$ for all events younger than 500 thousand years. Average recurrence intervals vary from 70 to 215 thousand years. Recurrence intervals for individual events vary more widely from 40 to 350 thousand years. Average slip rates are 0.002 to $0.007 \mathrm{~mm} / \mathrm{yr}$ (Menges and Whitney 1996 [DIRS 106343]; Menges et al. 1997 [DIRS 105139]).

The Bow Ridge fault has very little attendant fracturing despite the $100 \mathrm{~m}$ cumulative offset and its exposure near the surface (approximately $35 \mathrm{~m}$ of overburden). Lack of deformation around the fault zone probably results from the presence of nonwelded pre-Rainier Mesa Tuff in the hanging wall of the fault.

\section{D2.1.1.3 Significance of Geologic Setting to the Analysis}

The descriptions in Sections D2.1.1.1 and D2.1.1.2 suggest that an analysis of fault displacement effects needs to be considered from two perspectives: the impact on fractures throughout the repository as a whole, and the effect on fractures in the immediate vicinity of the faults only. Furthermore, the range of fault characteristics that was described supports the idea that movement on the Solitario Canyon fault may be considered the bounding scenario.

As stated in Section D2.1.1.1, the fracture network at Yucca Mountain acts as a significant preexisting weakness in the rock mass that can accommodate extensional strain through distributed slip along many reactivated joints. Evidence for reactivation of joints includes the presence of thin breccia zones along cooling joints and observable slip lineations along joint surfaces (Sweetkind, Potter, and Verbeek 1996 [DIRS 106957]). There are a number of primary controls on fracture characteristics within the Paintbrush Group that are related to stratigraphy, upon which any later tectonic signature (such as fault displacement) is superimposed. The existence of distributed slip suggests that changes in strain (such as would be associated with a significant fault displacement) are likely to be propagated throughout the repository area. Also, some fault zones (such as the Ghost Dance and Solitario Canyon) may be on the order of 100 to $400 \mathrm{~m}$ wide. Although strain is expected to diminish with distance from the fault, these observations suggest that the effect of strain distributed in the fractures throughout the repository should be considered.

The presence of gouge and brecciated zones only in limited proximity to the fault planes, however, suggests that much of the strain will be mechanically dissipated within or near the fault plane itself. For instance, as described in Section D2.1.1.2, in the Solitario Canyon fault zone in the ECRB Cross Drift, the total displacement is approximately $260 \mathrm{~m}$, but the gouge and brecciated zones are limited to less than $20 \mathrm{~m}$. Similarly, the Dune Wash fault as exposed in the ESF exhibits a cumulative offset of $65 \mathrm{~m}$ (Sweetkind et al. 1997 [DIRS 100183], Table 21), but the zone of increased fracture frequency in the vicinity of the fault is only 6 to $7 \mathrm{~m}$ wide. A third example is the observation of the Sundance fault in the ECRB Cross Drift; with an assumed, though indeterminate displacement of several meters, the footwall rock is intact, even within the $10 \mathrm{~cm}$ of the fault plane. The hanging wall is slightly more fractured, with an intensely fractured zone about $1 \mathrm{~m}$ thick. Consequently, an analysis of fault displacement should also consider a case where the effects of strain are limited to the immediate vicinity of the fault zone (Section D3.3.2). 


\section{D2.1.2 Fault Displacement Hazards}

Fault displacement hazards at Yucca Mountain have been investigated in detail in the report "Probabilistic Seismic Hazard Analyses for Fault Displacement and Vibratory Ground Motion at Yucca Mountain, Nevada" (CRWMS 1998 [DIRS 103731]). Several original approaches to characterizing the fault displacement potential were developed by the seismic source expert teams. The approaches were based primarily on empirical observations of the pattern of faulting at the site during past earthquakes (determined from data collected during fault studies at Yucca Mountain). Empirical data were fit by statistical models to allow use by the experts. The results of this analysis were curves representing probabilistic predictions of fault displacements.

Nine locations within the preclosure controlled area were identified to demonstrate the fault displacement methodology. The term "preclosure controlled area" is defined in DOE's Interim Guidance (Dyer 1999 [DIRS 105655]). These locations were chosen to represent the range of potential faulting conditions. Two of the nine sites each had four identified faulting conditions. Some of these locations lie on faults that may experience both principal faulting and distributed faulting. The other points are sites only of potential distributed faulting.

With the exception of the block-bounding Bow Ridge and Solitario Canyon faults (sites 1 and 2, respectively), the mean displacements are $0.1 \mathrm{~cm}$ or less at a $10^{-5}$ annual exceedance probability, and on the order of $1 \mathrm{~m}$ or less at $10^{-8}$ annual exceedance probability (CRWMS 1998 [DIRS 103731], Figures 8-4 through 8-14). For the Ghost Dance fault, the range of displacements per event is $0.6 \mathrm{~m}$ to about $1.5 \mathrm{~m}$ at $10^{-8}$ mean annual exceedance probability (CRWMS 1998 [DIRS 103731], Figure 8-5). Thus, sites not located on a block-bounding fault, such as sites on the intrablock faults, other small faults, shear fractures, and intact rock, are estimated to have displacements significantly less than $0.1 \mathrm{~cm}$ for mean annual exceedance probabilities of $10^{-5}$.

For Solitario Canyon fault and Bow Ridge fault (CRWMS 1998 [DIRS 103731], Figures 8-2 and 8-3; DTN: MO0401MWDRPSHA.000 [DIRS 166962]), the mean displacements are 7.8 and 32 $\mathrm{cm}$, respectively, for these two faults at a $10^{-5}$ annual exceedance probability. At lower annual exceedance probabilities, the fault displacement hazard results are driven by the upper tails of uncertainty distributions and are close to $10 \mathrm{~m}$.

For purposes of determining the appropriateness of the chosen bounding conditions based on the Probabilistic Seismic Hazard Assessment, per-event displacements can be used as a comparison. As described in Section D2.1.1 above, the largest estimate of per event displacement for the faults intersected by the two-dimensional cross section used for the analysis is $1.4 \mathrm{~m}$ along the Solitario Canyon fault. A displacement of $1.2 \mathrm{~m}$ corresponds to the 15 th percentile curve at a $10^{-8}$ annual exceedance probability (CRWMS 1998 [DIRS 103731], Figure 8-3). As described in Section D3.2.6, strains associated with a displacement of $10 \mathrm{~m}$ are used as bounding conditions. Given that the assumed bounding condition is about a factor of 10 greater than measured displacement and the probabilistic displacement event suggested by the 15th percentile curve, the values used in this analysis are judged to be extremely conservative. 


\section{D2.1.3 Climate Data}

The primary controlling factor for flow through the UZ is the amount of infiltration through the system. This variable is highly dependent on precipitation and climate conditions. To address this constraint, present-day average and long-term average conditions were used as bounding conditions.

Present day climate conditions represent relatively dry, interglacial conditions, while the glacial transition conditions represent typical conditions at Yucca Mountain between the wet and dry extremes based on available paleoclimate data (CRWMS M\&O 1998 [DIRS 100356], Section 2.4.1.1). Because these two sets of conditions represent relatively stable (that is, long-term conditions) rather than extreme conditions (that is, short-duration climatic states such as superpluvial periods), they were chosen as representative conditions for this analysis.

\section{D3. EFFECTS OF FAULT DISPLACEMENTS ON UZ FLOW AND TRANSPORT}

As discussed in Section D2, fault displacements are expected to occur along existing faults in the vicinity of Yucca Mountain. The movement produced by a fault displacement will result in changes in the rock stress in the vicinity of the fault. Obviously, the change in rock stress will decrease with distance from any given fault that does move. However, the magnitude of the changes in rock stress as a function of distance from the fault depends on the specific details of the fault displacement (e.g., magnitude of fault motion, direction of fault movement, extent of the fault that participates in the movement) and the mechanical properties of the surrounding rock (e.g., fracture spacing, fracture stiffness, geomechanical properties of the rock matrix). Given some change in rock stress, the fractured rock mass will respond to the change in stress through deformation, or strain, in the rock. Of particular importance is the fact that this induced strain can affect the geometry of fractures in the rock. The effects of changes in properties of the rock matrix (as opposed to the fractures) are assumed to have a negligible effect on UZ flow and transport. Several fracture properties (permeability, capillary pressure, porosity) are a function of fracture aperture, which can be changed significantly by small strains if these strains are allocated entirely to the fracture apertures. The sensitivity of fracture aperture to mechanical strain is due to the small porosity of the fracture continuum. The matrix, on the other hand, has much greater porosity than the fractures in general, and its properties are not expected to be as sensitive to mechanical strain. This approximation is reasonable given the fact that fracture porosity is much less than matrix porosity at Yucca Mountain.

In theory, the effects of a given fault displacement could be evaluated using process-level calculations for the effects of the induced stress and strain on fracture geometry. Then the effects of this change in fracture geometry on the fluid-flow properties of the fracture network could be evaluated. However, this method was not used in this analysis due to the large uncertainty and complexity of the problem.

Some of the effects of previous fault displacements at Yucca Mountain can be examined directly. Previous fault displacements have resulted in observable changes to the structure of the surrounding rock (Section D2.1.1). However, geologic observations are not adequate to assess the effects of some of the changes caused by fault displacements that could be important to UZ flow and transport. In particular, the effects of previous fault displacements on the present-day 
fracture apertures at Yucca Mountain are difficult to determine by observation. For example, it is difficult to determine by geologic observation that a given fracture with an effective hydraulic aperture of, approximately $200 \mu \mathrm{m}$, may have had an effective hydraulic aperture of $150 \mu \mathrm{m}$ at some point in the past before to a fault displacement event. In fact, it is difficult to determine the effective hydraulic apertures of the present-day fractures at Yucca Mountain by direct observation (Sonnenthal et al. 1997 [DIRS 101296], Section 7.5.4). Fracture apertures at Yucca Mountain are determined through pneumatic flow tests (giving the fracture permeability) and a theoretical model relating fracture frequency (determined by observation of fractures), fracture permeability, and fracture aperture (Sonnenthal et al. 1997 [DIRS 101296], Section 7.5.4).

\section{D3.1 USE OF SR MODEL}

In this work, steady state flow fields with fracture apertures undisturbed or changed (to represent the effects of seismic activity) were first calculated, and then used to run transport simulations. A steady state flow field had previously been calculated for the SR model (CRWMS M\&O 2000 [DIRS 151953], Section 6.2.1), and this result provided a flow field that could be used as an initial guess to determine the steady state flow fields for these calculations. For this reason these calculations were done using the SR model. The SR and LA models are similar enough that use of the SR model instead of the LA model is appropriate for the purpose of determining the sensitivity of transport to fracture aperture. The SR and LA flow and transport models are based on the same dual-permeability/active fracture conceptual model and numerical implementation. The main differences in the model set-up are the nonlocal connections introduced for the PTn/TSw interface between fractures and rock matrix. However, these lie above the repository and should have negligible effect on flow and transport below the repository. The most significant differences between the models is the shift in repository footprint to the north for the LA case compared with the SR design and some limited changes in parameterization based on new calibrations for the LA case.

Transport results for present-day and glacial-transition climate scenarios are compared in Figures D-1 and D-2. The transport results are for a uniform, instantaneous release of tracer mass from all repository locations at time zero. The tracer is nonsorbing, but can diffuse into the matrix. The present-day scenarios are shown in Figures D-1a and D-1b, which present the fractional cumulative breakthrough curves and normalized mass arrival rate curves, respectively. (For a unit tracer released at the repository at time zero, the fractional breakthrough curve represents the tracer cumulative arrival at the water table as a function of time. The normalized mass arrival rate is the time-derivative of the breakthrough curve.) These curves show that differences between SR and LA are small in comparison with the uncertainty represented by the lower, mean, and upper infiltration scenarios for this climate. The glacial-transition scenarios are shown in Figures D-2a and D-2b, which present the fractional cumulative breakthrough curves and normalized mass arrival rate curves, respectively. Although differences between the SR and LA cases are more pronounced for the glacial-transition case, these differences are still small in comparison with the uncertainty for this climate. Furthermore, the goal of the present analysis is to compare the relative effects of changes in fracture aperture on UZ transport behavior. Because the conceptual and numerical models for the SR and LA models are nearly the same, the SR model is suitable for its intended use of assessing transport sensitivity to seismic-induced changes in fracture properties. 


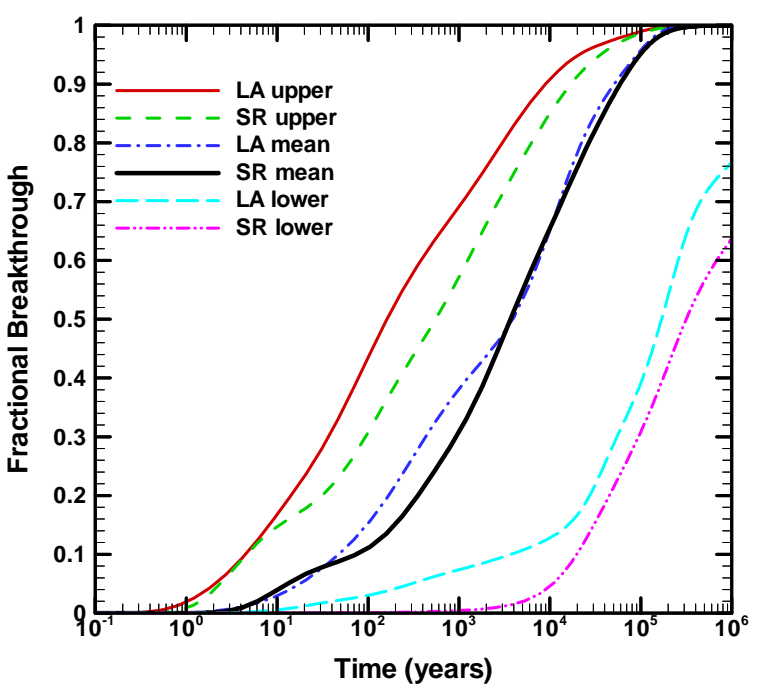

D-1a

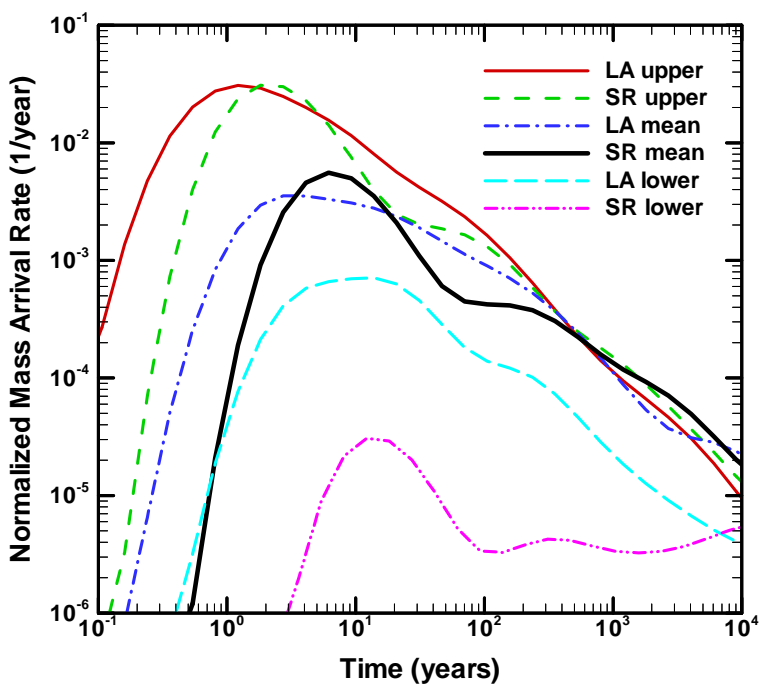

D-1b

DTNs: LB03033DUZTRAN.001 [DIRS 170372] LA transport breakthrough curves. LB9908T1233129.001 [DIRS 147115] SR transport breakthrough curves.

Figure D-1. Comparison of SR and LA Transport Results for an Instantaneous Release of (Nonsorbing) Tracer Mass at the Repository Horizon at Time Zero under Present-Day Climate. a) Cumulative Fractional Breakthrough, b) Normalized Mass Arrival Rate

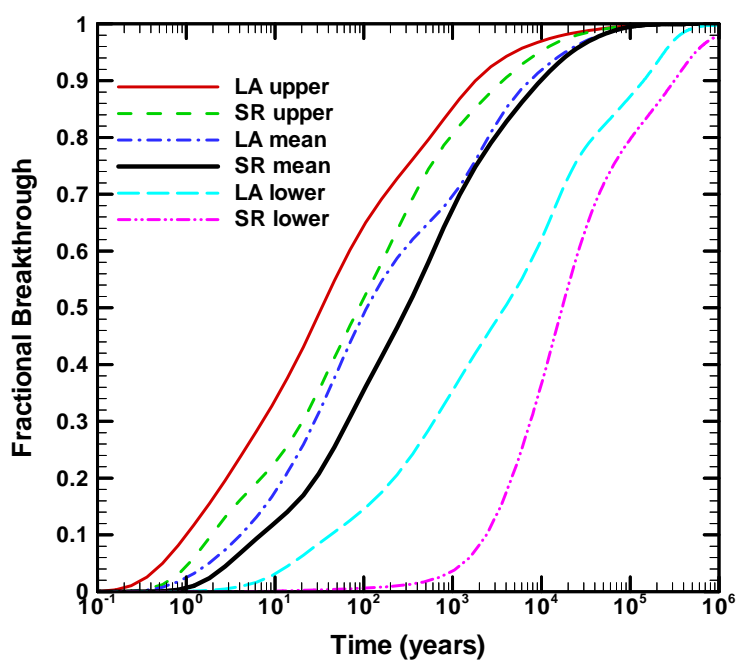

D-2a

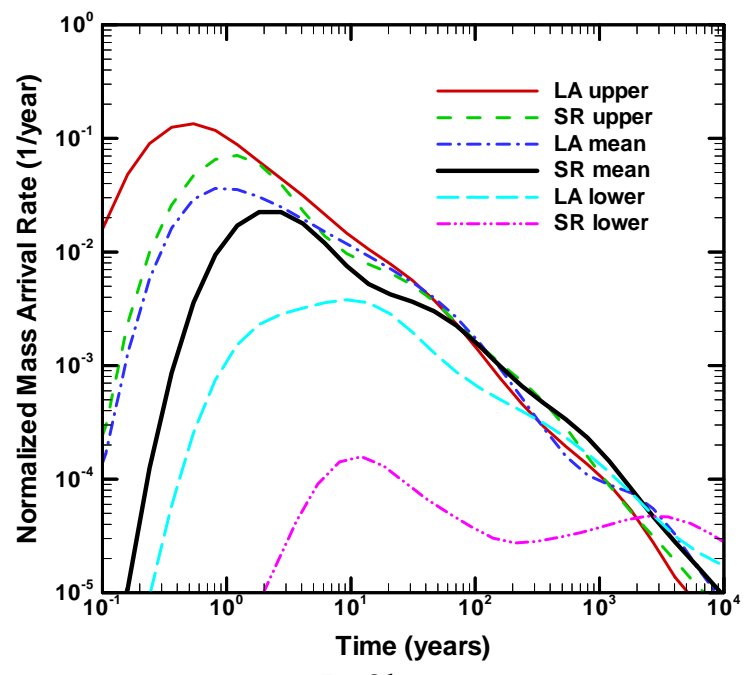

D-2b

DTNs: LB03033DUZTRAN.001 [DIRS 170372] LA transport breakthrough curves. LB9908T1233129.001 [DIRS 147115] SR transport breakthrough curves.

Figure D-2. Comparison of SR and LA Transport Results for an Instantaneous Release of (Nonsorbing) Tracer Mass at the Repository Horizon at Time Zero under Glacial-Transition Climate. a) Cumulative Fractional Breakthrough, b) Normalized Mass Arrival Rate 


\section{D3.2 ANALYSIS APPROACH}

In the absence of definitive, predictive process modeling or definitive geologic observational evidence, a bounding approach is used to assess the potential effects of fault displacement on repository performance. The problem is bounded if large enough changes in fracture aperture are evaluated. Here, "large enough changes" are defined to be changes that can be justified as larger than any expected changes resulting from any fault displacements (near Yucca Mountain) that have an annual exceedance probability greater than $10^{-8}$ (Section 5, Assumption 5.1). Given an assumed change in aperture, it is possible to estimate the change in fracture hydraulic properties using theoretical models that relate the changes in fracture properties to the changes in fracture aperture (Section D3.2.7). The effects of the modified fracture properties on transport behavior between the repository and the water table can be evaluated using the UZ site-scale flow and transport models. Changes in transport are identified through the use of breakthrough curves for a simulated nonsorbing tracer. Transport of a nonsorbing tracer is used because this is expected to be more sensitive to changes in fracture aperture, because the effects of fracture aperture dominate fracture/matrix interaction for such a tracer (given fixed matrix properties).

If the identified changes in transport are small, then it can be concluded that the effects of fault displacement on potential radionuclide transport are negligible and can be excluded from further consideration in TSPA.

For such a method to be valid, the assumed changes in fracture aperture must be shown to represent a bounding change in fracture aperture for the effects of any fault displacement near Yucca Mountain. The justification that the assumed changes in fracture aperture bound the range of expected changes is given in Section D3.2.6.

The spatial distribution of changes to fracture aperture within the modeling domain is treated using two end-member scenarios:

1. All fracture apertures are altered uniformly throughout the UZ model domain (both fault zones and fractured rock).

2. Only fracture apertures in the faults zones are altered.

Isolating the effects of fault displacement to the fault zones provides the most reasonable expected case, which emphasizes the effects of property contrasts between the fault zones and the fractured rock. A large change in fracture properties over the entire UZ domain (fault zones and fractured rock) is an extreme bound for the possible effects of fault displacement. These cases bound the expected extremes for the spatial distribution of changes to fracture properties as a result of fault displacement.

Sensitivity calculations are performed for both the present-day (dry) climate and the long-term, glacial-transition (wetter) climate. The average infiltration rates used in the TSPA-SR UZ flow model for the present-day mean climate is about $4.6 \mathrm{~mm} /$ year and for the glacial-transition mean climate is about $18 \mathrm{~mm} /$ year (BSC 2001 [DIRS 158726], Table 6-3). The water table elevation remains unchanged in this analysis as a result of fault displacement or climate change. Maintaining a fixed water table provides a reference point for comparisons of the effects of fault 
displacements on radionuclide transport. This is reasonable as a basis for comparison of the effects of fault displacement.

Fault displacements may result in changes to perched water. However, the effects of these changes in perched water on potential radionuclide transport are assumed to be negligible. The sensitivity of radionuclide transport to different perched water models has been shown to be small (CRWMS M\&O 2000 [DIRS 134732]). Furthermore, the potential release of the perched water (and associated radionuclides) due to some disruptive event is expected to have a negligible effect on radionuclide releases at the water table (Section 6.8.8). Therefore, any additional changes in perched water, except for those changes caused by changes in fracture properties, are not expected to have significant consequences.

Thermal-hydrologic processes due to waste heat from the repository will affect UZ flow and transport. However, the effects of thermal-hydrologic processes are expected to be negligible with respect to this sensitivity study on the effects of fault displacements on mountain-scale UZ transport (Section 6.8.9).

\section{D3.2.1 Dual-Permeability Concept}

The conceptual model for unsaturated flow and transport used in this analysis is called the dual-permeability model. In the version of the dual permeability model used in this analysis, there are two continua representing the fracture and matrix that overlap in the macroscopic flow continuum. At every macroscopic "point" there are separate hydrologic conditions, properties, and other factors, for the fracture continuum and for the matrix continuum. Therefore, at every macroscopic "point" there is also a defined flux of water (flow rate of water per unit area) in the fracture continuum and in the matrix continuum. Practically speaking, the macroscopic point (or length scale) is defined by the grid discretization. At the microscopic (or sub-grid) scale, the fractures and matrix are spatially distinct, with length scales that define the microscopic geometric arrangement of the fracture and matrix continua. Given this microscopic geometry of the continua and the properties and conditions defined in each continuum, a flux of fluid at each macroscopic point between the fracture and matrix continua is also defined. In other words, there is also an exchange of flow between the fracture and matrix continua as well as flow through each continuum at each macroscopic point.

Although the dual-permeability model has been described above in terms of a flow model, an analogous description can also be made for the transport model. That is, transport takes place at each macroscopic point in both the fracture and matrix continua (each continuum having its own transport properties and conditions), and there is, likewise, a transport exchange between the fracture and matrix continua.

The dual-permeability model for flow and transport can be used in three, two, or one dimension. For example, a one-dimensional problem would have flow and transport in one linear direction only. This is easiest to understand for a problem in which flow occurs along one axis, say the $z$-axis. Assume that the rock properties and conditions at the boundaries of the model are independent of the remaining two spatial coordinates, $x$ and $y$. Then the only spatial variations that could possibly occur in the problem are in the $z$ direction. The spatial evolution of the problem can be completely described in terms of $z$. The $x$ and $y$ dimensions only enter the 
problem in a trivial sense to scale the total quantity of flow and transport that take place in the real three-dimensional domain. This simple scaling can be done after analyzing the spatial (and temporal) variations in the problem. Numerically, the one-dimensional dual-permeability model is configured using a stack of paired grid cells as shown in the one-dimensional connection diagram give in Figure D-3. One stack represents the fracture continuum and one stack represents the matrix continuum. The dual-permeability connection diagram can be extended to two dimensions as shown in Figure D-4. In three dimensions, the conceptual nature of the dual-permeability model (with overlapping continua) becomes more apparent in so far as a connection diagram is concerned. In this case, there is no "extra" dimension for the fracture/matrix node pairing, so the fracture/matrix node pairs must overlap spatially in a three-dimensional connection diagram.

\section{D3.2.2 Active Fracture Concept}

The dual-permeability model used in these calculations employs the active fracture concept. The active-fracture-dual-permeability model (Liu et al. 1998 [DIRS 105729]; BSC 2004 [DIRS 170035]) takes into account that only a portion of the fracture network (conceptualized as a continuum in the dual-permeability model) is actively involved in conducting water, while other fractures are bypassed. It conjectures that only a portion of the fracture network is hydraulically active and only this active portion is in hydraulic contact with the rock matrix. As a result of such conceptualization, capillary pressure and relative permeability for the entire fracture network are treated as equal to those for the active portion, and the geometric fracture-matrix interface area is scaled down to define an active fracture-matrix interface area for use in fracture-matrix interaction. Therefore, the mechanism of the active fracture model hinges upon how the active fracture network is defined. In the UZ flow model used here, the fraction of active fractures is defined as an exponential function of the effective water saturation for the entire fracture network, with the exponent being treated as a fitting parameter. Subsequently, the capillary pressure and the relative permeability functions for the entire fracture network are defined by using the effective water saturation of active fractures. In addition, the active fracture-matrix interface area is defined as the geometric fracture-matrix interface area multiplied by a power function of the effective water saturation of the active fractures. 


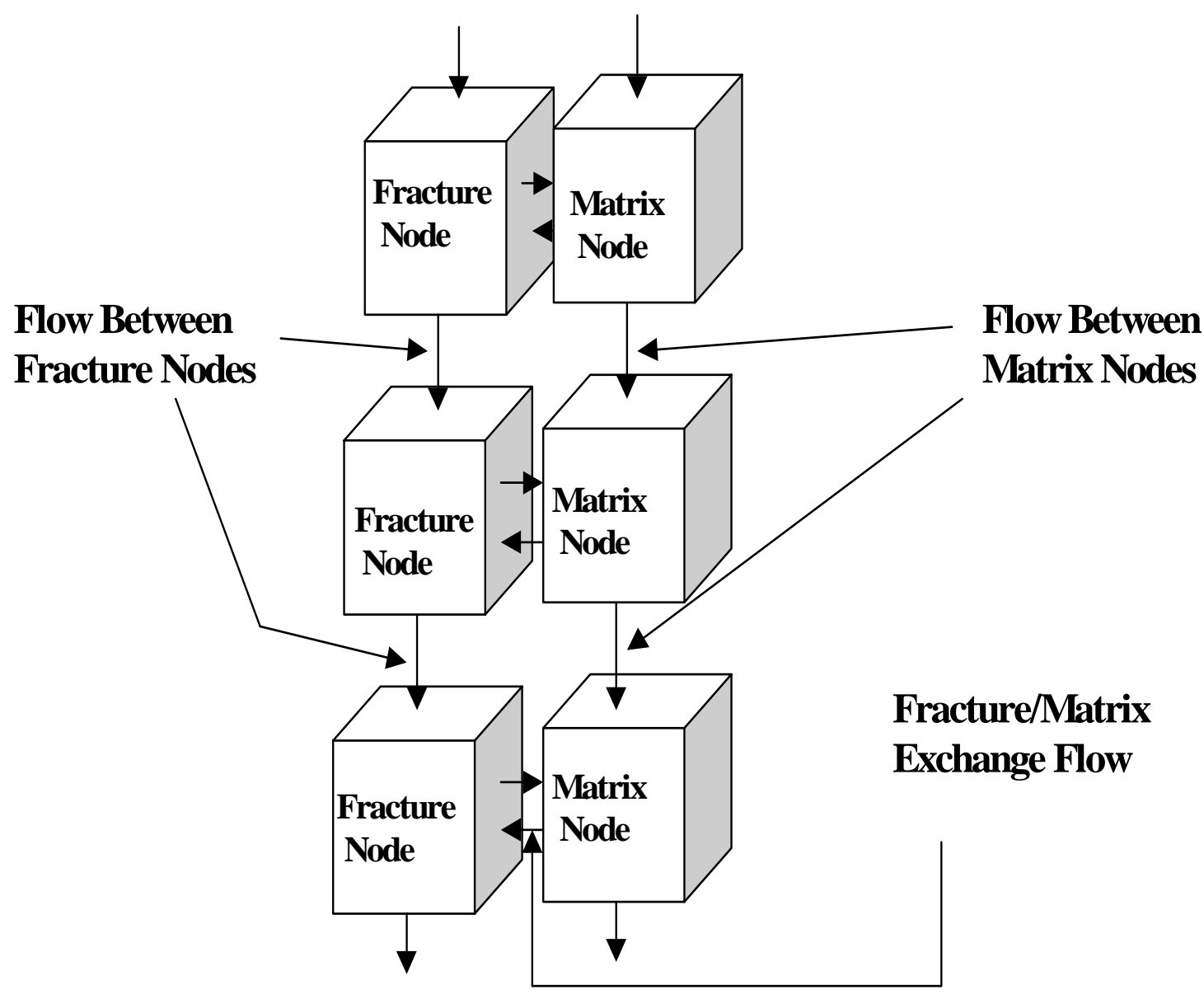

Figure D-3. Conceptual Connection Diagram for a One-Dimensional Dual-Permeability Model 


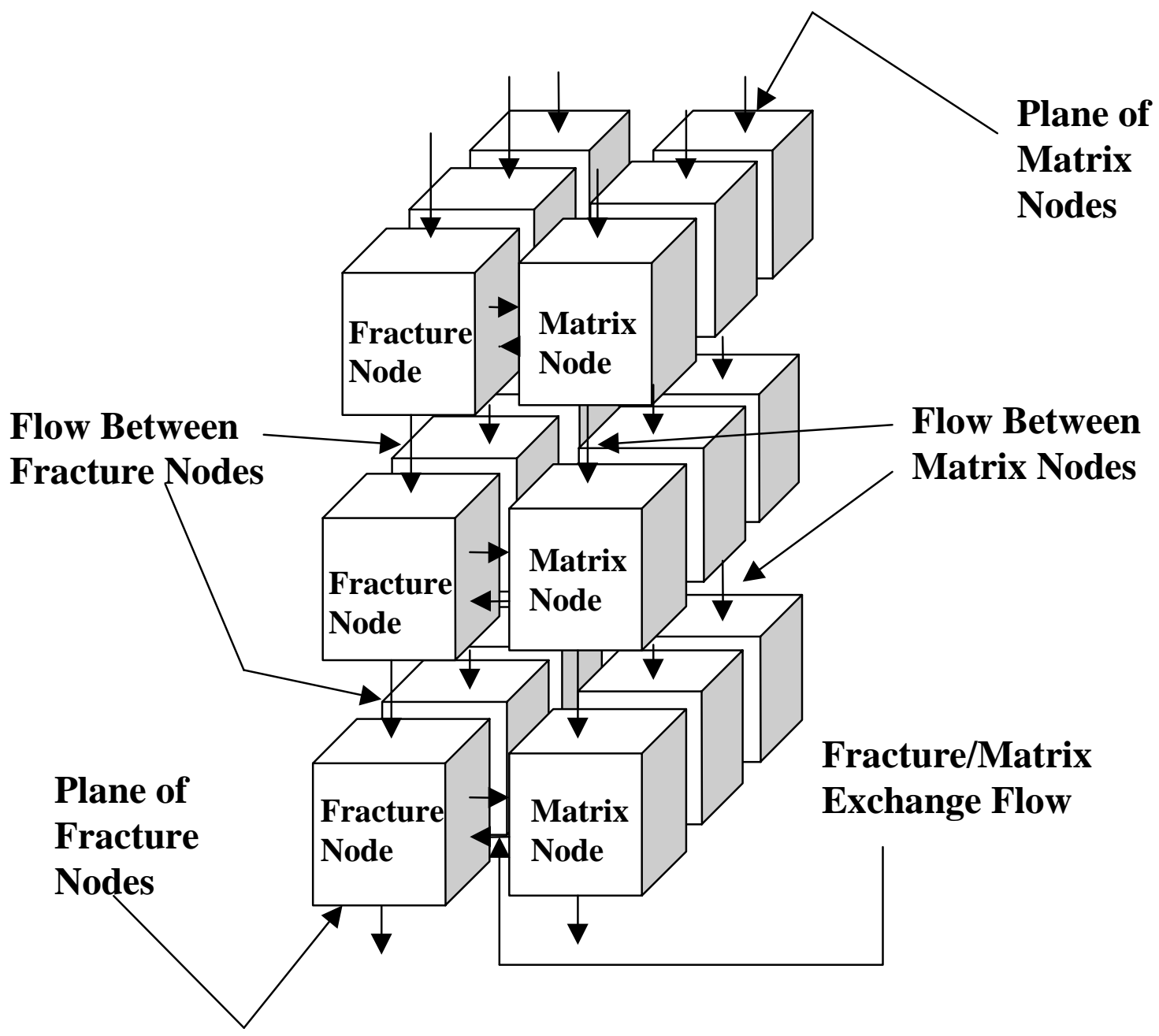

Figure D-4. Conceptual Connection Diagram for a Two-Dimensional Dual-Permeability Model

\section{D3.2.3 Site-Scale Models for UZ Flow and Transport}

The site-scale model for UZ flow uses the software TOUGH2 V1.4 (LBNL 2000 [DIRS 146496]). TOUGH2 is a multipurpose numerical model that, among other problems, can solve fluid flow problems in geologic materials (Pruess 1991 [DIRS 100413]). The standard differential conservation equations describing flow are cast in an integrated form for the numerical solution methods used in TOUGH2. The solution to these conservation equations is obtained by discretization of problem in space and time. In this analysis, TOUGH2 is used to solve the equations for unsaturated flow in a fractured rock domain representative of Yucca Mountain. Unsaturated flow is defined to be the flow of water only in a geologic material with pore spaces partially filled with water and partially filled with air. In an unsaturated flow model (as opposed to a two-phase flow model), the air is assumed to be at static equilibrium. As discussed in Section D3.2.1, fractured rock is represented using an active-fracture-dual-permeability conceptual model.

Transport simulations in this appendix are based on transport studies of conservative tracers using the T2R3D V1.4 code (LBNL 1999 [DIRS 146654]). The dual-permeability modeling 
approach with the three-dimensional TSPA-SR grid, as discussed in Section D3.1, is used in the transport simulations. T2R3D is an integrated finite-difference transport model that is intended to solve mass transport problems in geologic materials. The fracture-continuum permeability and van Genuchten $\alpha$ values for these simulations were obtained from DTN: LB990801233129.009 [DIRS 118717] and LB990801233129.003 [DIRS 122757], and the grid was obtained from LB990701233129.001 [DIRS 106785]. The use of these SR rock properties and grid is justified for their intended use in section D3.1.

\section{D3.2.4 Breakthrough Curves}

Breakthrough curves are used in this analysis to describe the behavior of radionuclide transport in the unsaturated zone. A breakthrough curve is generated by releasing particles uniformly over the fracture nodes of all the grid cells within the repository. Particles are only released to the fracture nodes because fractures are expected to be the main transport pathway at the repository horizon. Particles are released over some period (short relative to the transport time of the problem), approximating an "instantaneous" release of the particles. For this analysis, the particles are released uniformly over a period of one year. The breakthrough curve shows the total mass that has arrived at the water table (over the entire model domain) relative to the total mass released as a function of time, as shown in Figure D-5.

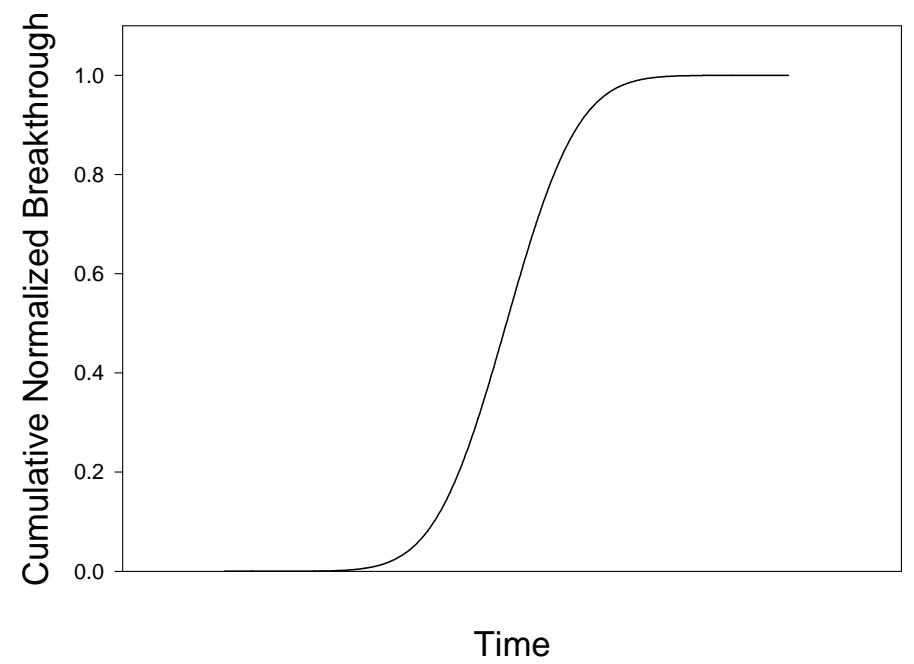

NOTE: Time axis is arbitrary.

Figure D-5. Schematic Diagram of a Breakthrough Curve

\section{D3.2.5 Problem Domain}

The TSPA-SR site-scale UZ flow and transport model is shown in plan view in Figure D-6 (BSC 2001 [DIRS 158726], Figure 6-2). An east-west vertical cross-section and a one-dimensional column are extracted from this three-dimensional model for some subdimensional calculations. 


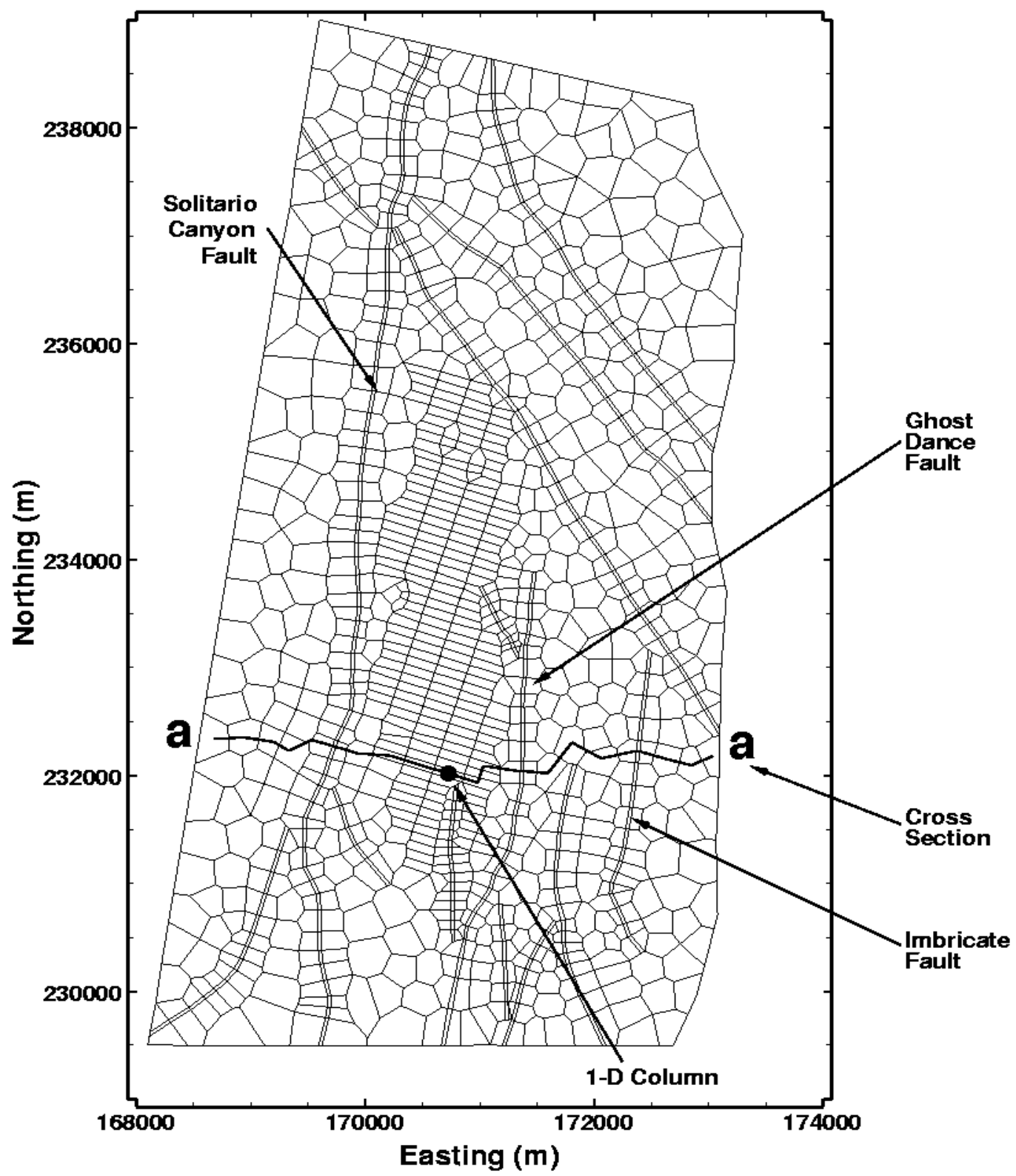

mView 2.200 21 Jun 2000

NOTE: The location of the one-dimensional column is shown by a ' $\bullet$ ' symbol and the two-dimensional cross section by line 'a-a' (added to this figure from BSC 2001 [DIRS 158726], Figure 6-2.

Figure D-6. Plan View of the Locations of the Two-Dimensional Cross Section and the Nearby Faults within the TSPA-SR UZ Grid. 


\section{D3.2.6 Bounds on the Change in Fracture Aperture}

The approach used to investigate the effects of fault displacements is to evaluate the sensitivity of radionuclide transport in the UZ to changes in fracture apertures. This is investigated over a wide enough range to bound the potential changes in fracture aperture that could result from any fault displacement at Yucca Mountain with an annual exceeding probability of greater than $10^{-8}$. The largest fault movement close to the repository is likely to be along Solitario Canyon fault. The general topic of seismic hazard at Yucca Mountain has been investigated in detail in the report "Probabilistic Seismic Hazard Analyses for Fault Displacement and Vibratory Ground Motion at Yucca Mountain, Nevada" (CRWMS 1998 [DIRS 103731]). For Solitario Canyon fault, the hazard analysis shows fault displacement of about $10 \mathrm{~m}$ (CRWMS 1998 [DIRS 103731], Figure 8-3) at an annual exceedance probability of $10^{-8}$.

Geomechanical models used to investigate the amount of strain induced by fault movements in the rock at Yucca Mountain show that changes in strain extend several kilometers from a fault movement (Gauthier et al. 1995 [DIRS 103258]; National Research Council 1992 [DIRS 105162], Appendix D). Using a three-dimensional elastic boundary element model of Yucca Mountain, Gauthier et al. (1995 [DIRS 103258]) investigated the effects of a right-lateral, strike-slip fault displacement on a fault dipping $60^{\circ} \mathrm{E}$. The fault movement was $1 \mathrm{~m}$ along a $30 \mathrm{~km}$ section of the fault. The results show strains of 10 microns per meter (10 micro-strain, or $10 \mu \mathrm{s}$ ) up to $8 \mathrm{~km}$ from the fault. Geomechanics calculations were also performed in the National Research Council (1992 [DIRS 105162], Appendix D) report. This calculation was for a normal displacement along a fault dipping $60^{\circ} \mathrm{E}$ to the vertical. The simulated fault movement was 1 meter along $30 \mathrm{~km}$ section from the surface to a depth of $10 \mathrm{~km}$. The results of this calculation show $50 \mu$ s two kilometers from the fault plane and $10 \mu \mathrm{s}$ about $6 \mathrm{~km}$ from the fault plane. If these models were used for a $10 \mathrm{~m}$ fault movement instead of $1 \mathrm{~m}$, the strains would be amplified proportionally because of the linearity of the elastic model. Therefore, for a bounding fault movement of 10 meters along Solitario Canyon fault, an elastic model would predict strains up to $500 \mu$ s two kilometers from the fault and $100 \mu \mathrm{s}$ six kilometers from the fault. If the conservative approach is taken that all the strain accumulates in the fractures, then an estimate of the change in aperture can be made. First, assume a lower bound aperture of $100 \mu \mathrm{m}$ in the present-day system (Sonnenthal et al. 1997 [DIRS 101296], Table 7.12) and a fracture spacing of approximately $1 \mathrm{~m}$ (Sonnenthal et al. 1997 [DIRS 101296], Table 7.7). Then a tensile strain of $500 \mu \mathrm{s}$ would result in a new fracture aperture of about $600 \mu \mathrm{m}$. For a compressive strain of $500 \mu \mathrm{s}$, then the fractures would essentially be closed and the rock matrix would necessarily be compressed.

Changes in fracture properties are related to dilation or compression of existing fractures rather than the generation of new fractures. This approximation relies on the fact that the rock at Yucca Mountain is highly fractured and that fractured rock is mechanically weaker along existing fractures than intact rock. This assumption is supported by the results of the Probabilistic Seismic Hazard Analysis, which show that the probability for fault displacement to occur along existing fractures is more likely than for intact rock (CRWMS 1998 [DIRS 103731], Section 8.2.1). Therefore, strain due to fault displacement is likely to occur along existing fractures rather than initiate new fractures. 
These results suggest that a factor of 10 change in aperture would bound the effects of tensile strain. In fact, because the average aperture at Yucca Mountain is approximately $200 \mu \mathrm{m}$ (Sonnenthal et al. 1997 [DIRS 101296], Table 7.12), a factor of 10 change would result in fractures with an average aperture of $2,000 \mu \mathrm{m}$, or $2 \mathrm{~mm}$. With regard to the reduction in aperture under compressive strain, other limitations constrain the change in fracture aperture. Attempts were made to use a factor of 10 reduction in aperture; however, convergence problems were encountered with the flow model. This is likely the result of insufficient bulk permeability in the system to accommodate the imposed infiltration flow conditions. Therefore, reductions in aperture were limited to factors of 0.2 .

\section{D3.2.7 Affected Parameters}

Given a change in aperture, theoretical models are available to quantitatively model the associated changes in fracture permeability, fracture capillary pressure, and fracture porosity. Fracture aperture enters flow and transport modeling in different ways. Aperture affects the permeability and capillary pressure used for steady-state unsaturated flow calculations. For radionuclide transport calculations, the fracture aperture affects the fracture porosity. Fracture aperture also affects matrix diffusion for radionuclide transport, but for these simulations the matrix diffusion coefficient was set to zero. The fracture apertures used in these different parameters are not necessarily the same because the theoretical models strictly apply to idealized "parallel plate" fractures. Therefore, the aperture for permeability, capillary pressure, and porosity are generally different values. However, it is assumed that an increase or decrease in aperture will affect these physical characteristics in proportion to the functional dependence on aperture in the theoretical models.

The relationship for permeability, known as the cubic law, (Freeze and Cherry 1979 [DIRS 101173], Section 2.12; Sonnenthal et al., 1997 [DIRS 101296], Section 7.5.4) is the following:

$$
k=\bar{f} \frac{b^{3}}{12}
$$

where $\bar{f}$ is the average fracture spatial frequency, $k$ is the permeability, and $b$ is the fracture aperture. As can be seen, the permeability is proportional to the cube of the fracture aperture.

The relationship between capillary pressure and saturation is derived from van Genuchten (1980 [DIRS 100610]), noting that $S_{\boldsymbol{e}}=\Theta$ in van Genuchten's notation:

$$
P_{c}=\frac{2 \tau \cos \theta}{b \rho g}\left[S_{e}^{-1 / m}-1\right]^{(1-m)}
$$

where $P_{c}$ is the capillary pressure (expressed as elevation above the water table by inclusion of $\rho$ and $g$ terms), $\tau$ is the surface tension of an air/water interface, $\theta$ is the contact angle between the air/water interface and the mineral surface, $\rho$ is the density of water, $g$ is the acceleration of gravity, $S_{e}$ is the effective water saturation (normalized for the residual and maximum 
saturations), and $m$ is a parameter describing the variation in capillary pressure with water saturation.

The collection of terms, $\frac{b \rho g}{2 \tau \cos \theta}$, is known as the van Genuchten $\alpha$ parameter. The van Genuchten $\alpha$ parameter scales the overall capillary pressure in the system. The parameter $m$ accounts for the distribution of fracture apertures that the air-water interface encounters as a function of water saturation. The van Genuchten $\alpha$ parameter is directly proportional to fracture aperture.

The relationship for porosity, $\phi_{f}$, is the following:

$$
\phi_{f}=\bar{f} b
$$

The porosity is also found to be proportional to the fracture aperture.

Now, let $b$ be changed to $b^{*}$; then correspondingly $k, \alpha$, and $\phi_{f}$, are changed to $k^{*}, \alpha^{*}$, and $\phi_{f}^{*}$. These variables can be used to express the following relationships:

$$
\begin{aligned}
& k^{*}=\left(b^{*} / b\right)^{3} k \\
& \alpha^{*}=\left(b^{*} / b\right) \alpha \\
& \phi_{f}^{*}=\left(b^{*} / b\right) \phi_{f}
\end{aligned}
$$

The factor of change in fracture aperture $\left(b^{*} / b\right)$ is then used to directly assign the new values of permeability, capillary pressure $(\alpha)$, and porosity.

In addition, the volumes for fracture and matrix elements should also be varied. Assume $V_{f}$ and $V_{m}$ as the original fracture and matrix element volumes, then the fracture and matrix element volumes varied due to fracture aperture change can be calculated as

$$
\begin{gathered}
V_{f}^{*}=V_{f}\left(\phi_{f}^{*} / \phi_{f}\right) \\
V_{m}^{*}=V_{m}\left(1-\phi_{f}^{*}\right) /\left(1-\phi_{f}\right)
\end{gathered}
$$

Such variation in fracture and matrix element volumes only changes the partition of the bulk grid-cell volume (into either $V_{f}$ and $V_{m}$ or $V_{f}^{*}$ and $V_{m}{ }^{*}$ ) which itself remains as a constant.

\section{D3.2.8 Calculation Procedures}

Each calculation involves two major computer programs: TOUGH2 version 1.4 (Pruess 1987 [DIRS 100684], 1991 [DIRS 100413]) and T2R3D version 1.4 (LBNL 1999 [DIRS 146654]). TOUGH2 with its EOS9 module (for single-phase unsaturated flow) is used for computing unsaturated flow fields. Through transient simulations, steady-state flow fields are obtained and used in subsequent transport simulations. T2R3D performs transport calculations using the flow field calculated by TOUGH2. 
The matrix and fracture parameter values both for the hydrogeologic units and the faults are taken from the TSPA-SR base-case UZ flow model (BSC 2001 [DIRS 158726]) and treated as the base case for this study. Sensitivity cases are conducted using fracture apertures modified as discussed in Sections D3.2, D3.2.6 and D3.2.7. Flow and transport modeling calculations are performed for present-day and glacial-transition climates. The UZ flow results from the base-case UZ flow calculation are processed to obtain the initial condition for calculations involving cases affected by fault displacement.

The input and output files for the calculations presented in Section D3.3 (output from this report) are available from the technical database under DTN: LB0408U0170FEP.001 [output] and DTN: LB0408U0170FEP.002 [output].

UZ flow properties affected by fracture aperture were varied for the sensitivity study reported in this analysis. For the UZ transport calculations, diffusivity was given a nominal value of $3.2 \times 10^{-11} \mathrm{~m}^{2} / \mathrm{s}$, with a tortuosity of 0.7 , for an effective diffusivity of $2.24 \times 10^{-11} \mathrm{~m}^{2} / \mathrm{s}$, as discussed in UZ Flow Models and Submodels (BSC 2004 [DIRS 169861], Sections 6.5.2 and 6.7.1). Only nonsorbing transport is investigated here. Dispersion has been shown to have little effect on transport results in the UZ over a wide range of dispersivities investigated (CRWMS M\&O 1998 [DIRS 100364], Section 7.6.1.2.6), therefore, a dispersivity of zero was assigned.

\section{D3.3 RESULTS}

The next two subsections describe the effects of fracture aperture changes on flow in the UZ and on mass releases at the water table. Results for cases in which the fracture apertures are varied are compared with the corresponding base cases. The first subsection, D3.3.1, considers a three-dimensional model when fracture apertures are only changed in the fault zones, not in the fractured rock. The second subsection, D3.3.2, describes the results for transport in a three-dimensional model with fracture apertures changed both in the fault zones and in the fractured rock. These three-dimensional calculations are performed for present-day and the glacial-transition climates. Mass transport calculations correspond to the instantaneous release of tracer mass at the repository at time zero.

\section{D3.3.1 Fracture Apertures Altered in Fault Zones Only; Three-Dimensional Calculations for Present-Day and Glacial-Transition Climates}

In this set of calculations, only the fracture apertures for the fault zones are changed by given factors. This is a reasonable case, although some effects on fracture properties may extend beyond the fault zone. The flow and transport calculations results shown in this section were performed as described in Section D3.2.8.

As shown in Figures D-7 and D-8 respectively for the present-day climate and the glacial-transition climate, the breakthroughs for the altered cases remain essentially unchanged from the base case. This indicates that if only the fault fracture apertures are affected by factors of 0.2 to 10 , there would be virtually no impact to UZ flow and transport. 

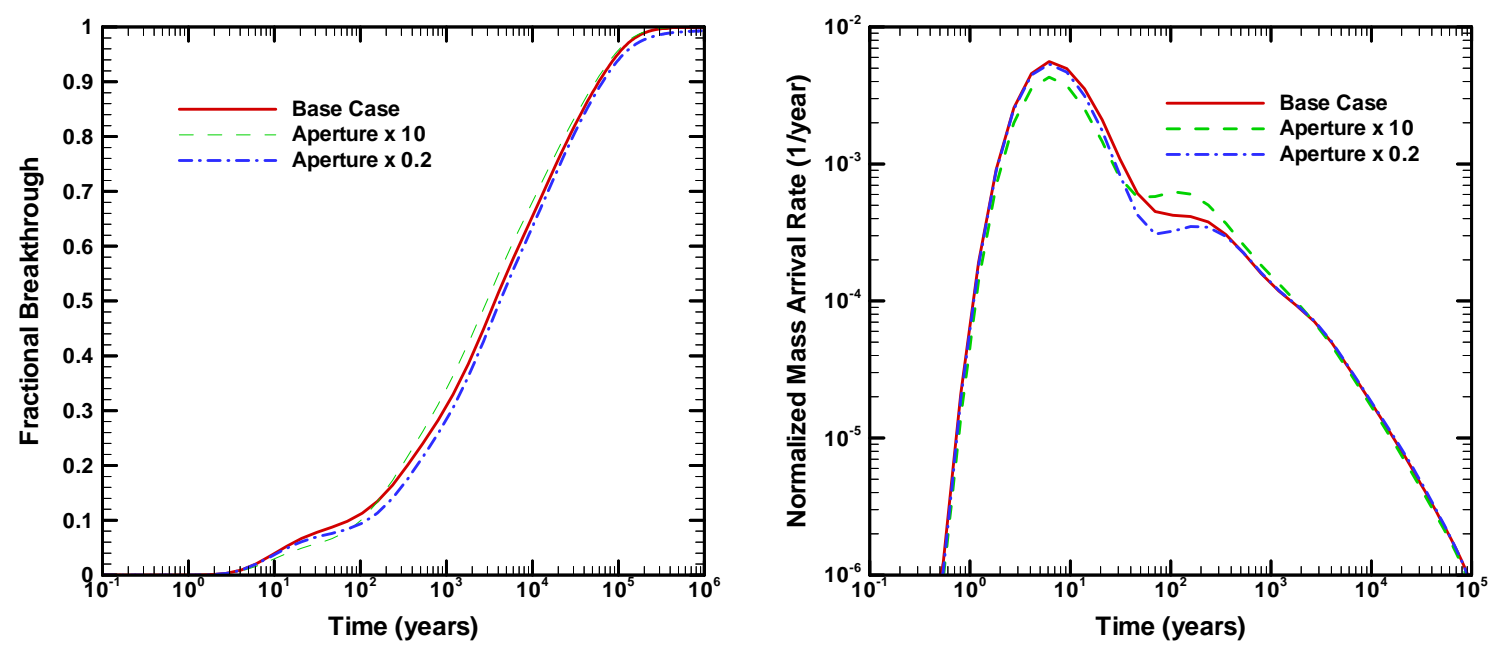

Output DTN: LB0408U0170FEP.002.

Figure D-7. Breakthrough Curves under Present-day Infiltration when Fracture Property Changes are Limited to the Fault Fractures.
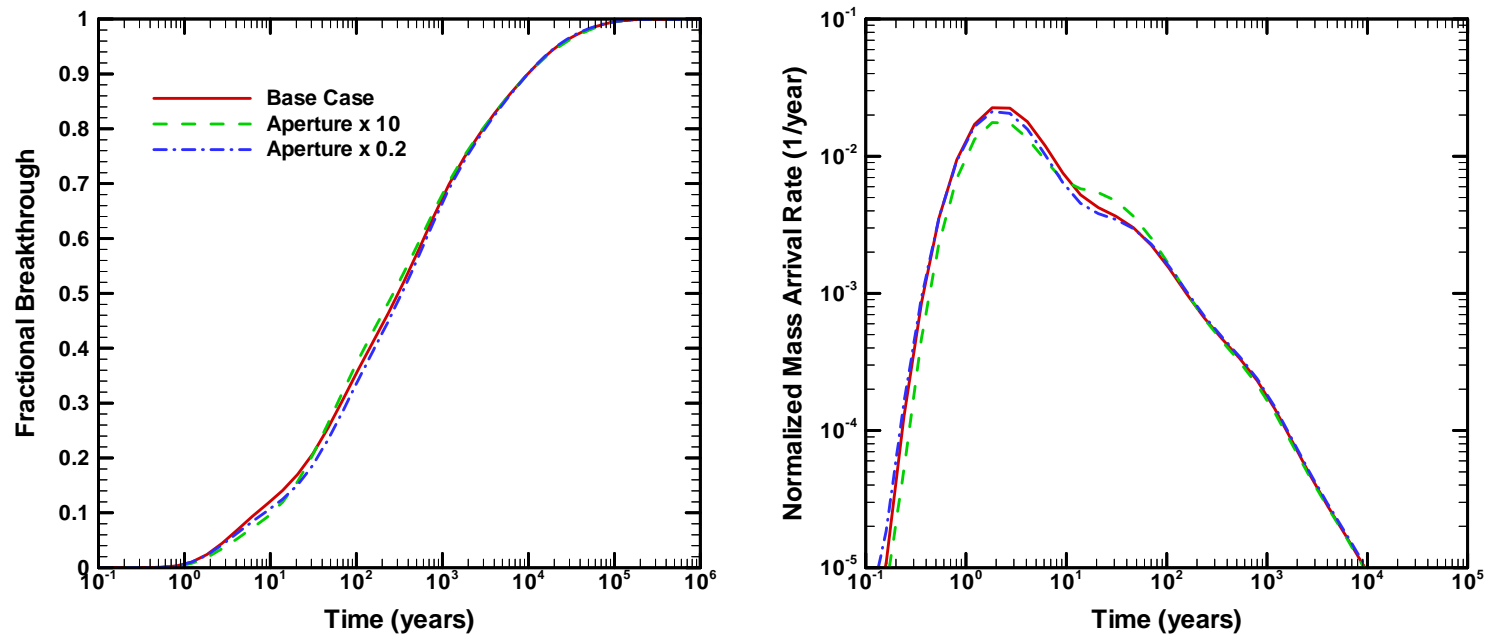

Output DTN: LB0408U0170FEP.002.

Figure D-8. Breakthrough Curves under Glacial-Transition Infiltration when Fracture Property Changes are Limited to the Fault Fractures.

\section{D3.3.2 Fracture Apertures Altered Uniformly Across the Repository Block; Three-dimensional Calculations for Present-Day and Glacial-Transition Climates}

The three-dimensional flow and transport calculations described in this section were performed as described in Section D3.2.8. The breakthrough curves for the present-day and the glacial-transition climates are shown in Figures D-9 and D-10, respectively. The results exhibit much greater influence compared with the case in which fracture property changes are confined to the fault zones. For the factor-of-10 case, travel time (for 0.5 fractional breakthrough) is found to decrease by about a factor of 25 for the present-day case and a factor of 11 for the 
glacial-transition climate. On the other hand, the normalized mass arrival rates are likely to be more significant for dose due because the rate of radionuclide mass arrival at the accessible environment is what controls dose rates. Comparisons between peak mass arrival rates for present-day and glacial-transition show that the effects of fault displacement are about a factor of 1.4 and 1.3, respectively. Furthermore, the peak doses occur slightly later for the $\times 10$ aperture case. For the $\times 0.2$ aperture case, the breakthrough curves are significantly delayed relative to the base case and the peak mass arrival rate is reduced by substantially more than one order of magnitude.
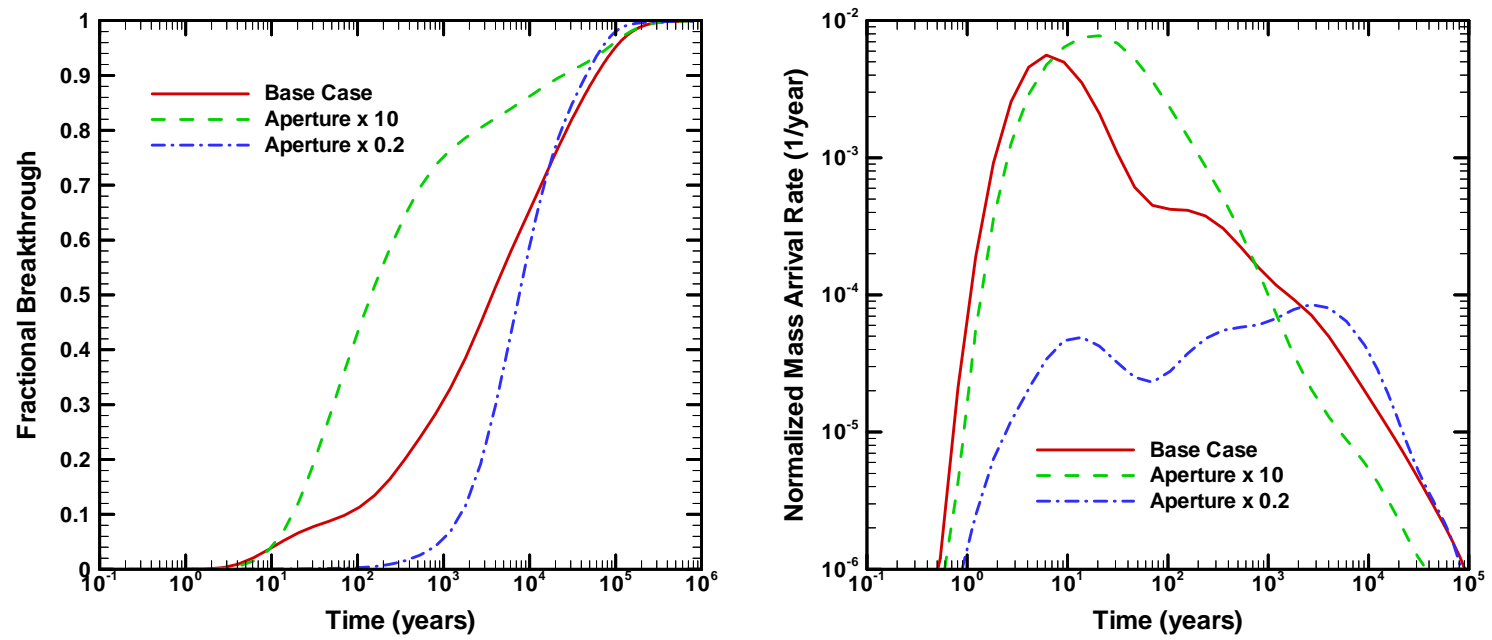

Output. DTN: LB0408U0170FEP.002.

Figure D-9. Breakthrough Curves under Present-Day Infiltration with Change in Fracture Properties Throughout the Entire Model Domain.
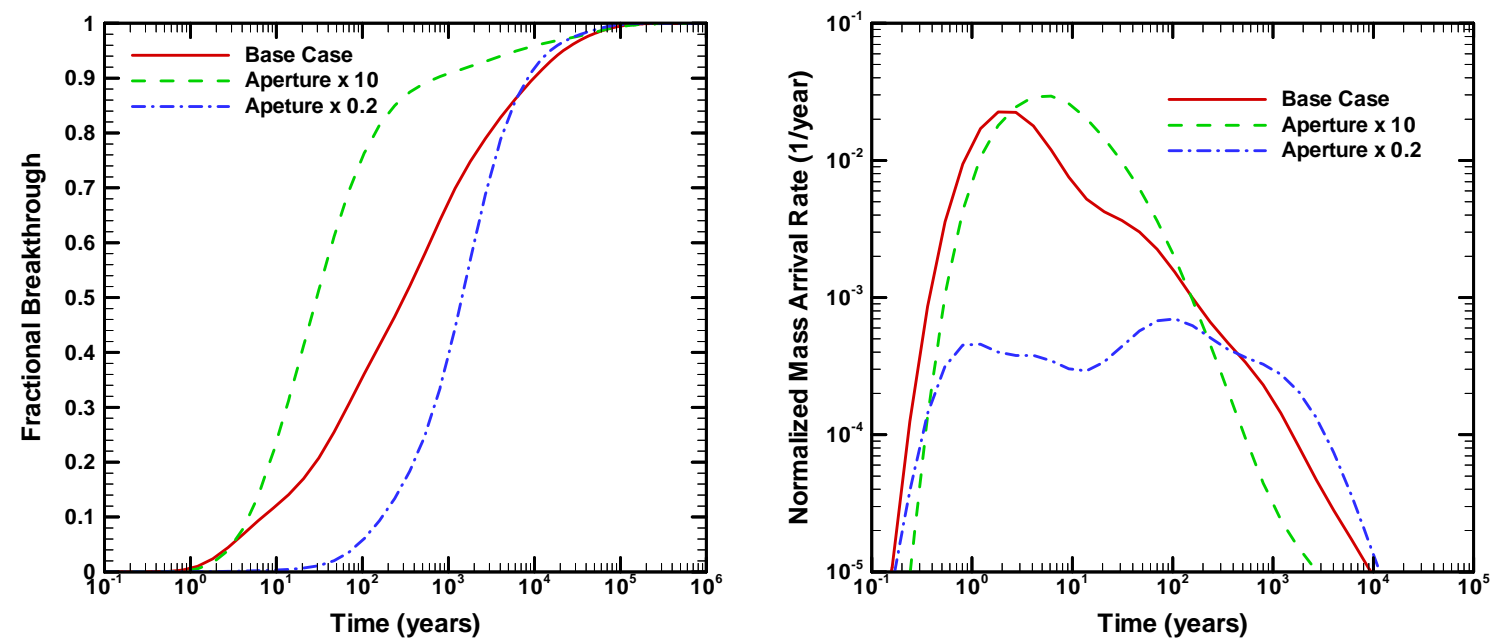

Output DTN: LB0408U0170FEP.002.

Figure D-10. Breakthrough Curves under Glacial-Transition Infiltration with Change in Fracture Properties Throughout the Entire Model Domain. 


\section{D3.4 Discussion}

The effect of changing fracture apertures on mass transport reflects the trend observed in the effect on flow; increased aperture leads to greater transport in fractures and shorter travel time to the water table. This leads to a consistent trend for simulated tracer breakthrough profiles at the water table. If the fracture apertures are decreased (increased), the travel times of the majority of the particles are increased (decreased), causing delayed (earlier) breakthrough. In particular, when fracture apertures are increased, the travel times of some particles are decreased due to enhanced transport in the fractures.

Capillary and gravity forces in the fractures of the dual-permeability model tend to work against fracture-matrix inter-flow and keep water flowing in the fractures. Note that fracture-matrix inter-flow is driven by the matrix-fracture capillary pressure difference. Assuming the inter-flow is from the fractures to the matrix, larger fracture apertures tend to promote fracture-to-matrix flow due to decreased fracture capillary pressure and increased matrix capillary pressure (that is, increased matrix-fracture capillary pressure differential). On the other hand, as fracture aperture is increased, gravity exerts more effect to keep flow within the fractures. The decreased capillary pressure in the fractures is roughly inversely proportional to the fracture aperture. In addition, due to the use of upstream weighting of the relative permeability in the numerical scheme of TOUGH2, the fracture relative permeability is used with the matrix absolute permeability to estimate the effective permeability of the fracture/matrix interface for fracture to matrix flow. The fracture relative permeability is the effective permeability for the fracture system at the given flow rate divided by the absolute permeability of the fracture system (i.e., a saturated fracture system). Thus, when the fracture apertures are increased, the fracture relative permeability (for about the same amount of fracture flow) decreases roughly in proportion to the cube of the aperture ratio. This is due to the fact that the effective permeability is roughly set by the amount of flow and the saturated permeability is proportional to the cube of the fracture aperture (Equation D-1). Therefore, the fracture/matrix interface effective permeability is also reduced by this ratio. This reduction of the fracture/matrix interface effective permeability leads toward greater flow and transport in the fractures when fracture apertures are increased. The above mechanism for enhanced fracture transport when fracture aperture is increased can be further promoted by the use of active-fracture-dual permeability model. The active-fracture-dual-permeability model, among other things, scales the fracture-matrix interface areas using a function of water saturation in the fractures, and thus can further reduce fracture-to-matrix transport because fracture-matrix interface areas are reduced as a result of the generally reduced water saturation in the fractures.

\section{D4. CONCLUSIONS}

This study attempts to address the potential effects of fault displacement on transport in the UZ using sensitivity analysis that is conducted by perturbing fracture parameters. The degree of such perturbations are conservatively based on phenomenological assessment of the geological information of the site.

The SR UZ flow and transport models have been found to be substantially the same as the LA UZ flow and transport models. Differences in cumulative fractional breakthrough and mass arrival rates for the SR and LA models are found to be less than uncertainties in these models. Thus, use of the SR model for this sensitivity study is adequate for its intended purpose. 
In the context of the TSPA-SR three-dimensional UZ flow and transport model, sensitivity studies for UZ flow and transport presented in this analysis suggest that transport between the repository and the water table is only weakly coupled to changes in fracture aperture. Overall, insignificant changes in transport behavior are found for large changes in fracture aperture. Changes in fracture aperture confined to the fault zones show virtually no effect on transport behavior. Breakthrough is found to be at most about 25 times earlier than the base case (under the present-day or the glacial-transition climate), for an extremely conservative ten-fold increase in fracture aperture applied over the entire UZ domain. Nevertheless, changes in the peak mass arrival rate at the water table are much smaller, factors of 1.4 and 1.3 for present-day and glacial-transition climates, respectively. Effects of such magnitude on travel time and mass arrival rates are no more significant than those caused by uncertainties in infiltration (CRWMS M\&O 2000 [DIRS 134732]). Given that the more realistic case where fracture changes are confined to the fault zones and the relatively limited changes found for the extremely conservative change in properties over the entire domain, the effects of fault displacement on UZ transport is expected to be negligible. Therefore, models for TSPA-LA may exclude the effects of fault displacement on UZ transport. 


\section{APPENDIX E}

\section{ANALYSIS OF LATERAL DISPERSION OF PLUMES}




\section{E1. INTRODUCTION}

Given the spatial separation of waste packages in the emplacement drifts and shotcrete support structures in the main drift turnout intersections and in the exhaust drift intersections, the question arises as to the probability that leachate plumes from a failed waste package and from the degrading shotcrete might intersect and mix at depth. The likelihood that this would occur depends on the extent of lateral spreading of the plume due to transverse dispersion with increasing depth in the unsaturated zone. There are three mechanisms that could lead to plume lateral dispersion: hydrodynamic dispersion due to heterogeneities in the host rocks, molecular diffusion through the rock matrix, and capillary dispersion. The last process could occur to a significant degree only in the event of leaching of either cementitious material or the waste package by a focused plume percolating into the dryout zone surrounding the repository prior to rehydration, such as might occur during episodic events. Rehydration of the repository horizon and underlying formations would be accompanied by equilibration of capillary pressure, and, therefore, capillary dispersion would no longer be operative.

\section{E2. PLUME DISPERSION RESULTING FROM HETEROGENEITY}

Transverse plume spreading due to intrinsic heterogeneities in the vitroclastic tuffs could be a significant factor in inducing lateral dispersion in a migrating plume. This process is essentially Fickian in nature and can be treated in the manner described by Pruess (1996 [DIRS 173821]). The effective transverse dispersivity, $\alpha_{T}$, is

$$
\alpha_{T}=\frac{1}{2} \frac{d}{d z}\left(\sigma_{T}^{2}\right)
$$

where $\sigma_{T}^{2}$ is the variance of the transverse distribution of solute concentration in the plume, and $z$ is the vertical distance of migration. Consider a hydrologically unsaturated rock consisting of separate idealized cubic matrix blocks of length $d$, bounded by continuous fractures, such that each block is in contact with its neighbors. The contacts (asperities) represent only a fraction of the total surface area of the bounding fracture surfaces. It is assumed that the fracture surfaces represent impermeable capillary barriers, that the pore waters percolate under gravity, and that they only flow across blocks through the fracture asperities. Consider a point source contaminant originating in one block as the source of the contaminant plume and that this plume migrates vertically downward within the block. When the flow encounters the impermeable barrier at the bottom of the block, it is assumed to split into two separate equal flows at $x=+d_{x} / 2$ and $x=-d_{x} / 2$ in underlying contiguous blocks, where $d_{x}$ is the horizontal dimension of the block. The increase in the variance due to this process, $\Delta \sigma_{T}^{2}$, is:

$$
\Delta \sigma_{T}^{2}=1 / 2\left\{\left(+d_{x} / 2\right)^{2}+\left(-d_{x} / 2\right)^{2}\right\}=d_{x}^{2} / 4
$$

Given that the matrix blocks are assumed to be of uniform size, the impermeable barriers occur in the vertical direction with a separation, $d_{z}$, the vertical dimension of the block, then the transverse dispersivity can be expressed as:

$$
\alpha_{T}=1 / 2\left(\Omega / d_{z}\right)\left(d_{x}^{2} / 4\right)
$$


where $\Omega$ is the probability of encountering a capillary barrier at the block intersection. If it is assumed that the asperities represent one-third of the block in contact, then $\Omega=1-1 / 3=2 / 3$. For a typical value of $d_{z}=d_{x}=0.377 \mathrm{~m}$ (Liu et al. 2003 [DIRS 162470]), then $\alpha_{T}=0.0314 \mathrm{~m}$.

The plume half-width, $x$, can be approximated by $\left(D_{d} t\right)^{1 / 2}$, where $D_{d}$ is the dispersion coefficient and equals $\alpha_{T} v, t$ is time, and $v$ is the percolation velocity. Given that $z=v t, x$ can be expressed as:

$$
x=\left(\alpha_{T} Z\right)^{1 / 2}
$$

Using Eq. E-4 with $\alpha_{T}=0.0314 \mathrm{~m}$, value of $x$, at the 300 -m depth of the water table below the repository horizon, is approximately $3.1 \mathrm{~m}$, giving a plume width of $6.2 \mathrm{~m}$.

\section{E3. PLUME DISPERSION RESULTING FROM MOLECULAR DIFFUSION}

Dispersivity arising from molecular diffusion, $\alpha_{m d}$, can be calculated from the effective molecular diffusion coefficient, $D_{e}$, and infiltration rate, $v$ :

$$
\alpha_{m d}=D_{e} / v
$$

Using an average molecular diffusion coefficient of $10^{-9} \mathrm{~m}^{2} / \mathrm{s}$ (Sonnenthal and Bodvarsson 1999 [DIRS 117127]), and correcting for a tortuosity factor of 0.5 (Liu et al. 2003 [DIRS 162470]), and a porosity of 0.16 (Liu et al. 2003 [DIRS 162470]), $D_{e}$ is $8 \times 10^{-11} \mathrm{~m}^{2} / \mathrm{s}$. An infiltration rate of $5 \mathrm{~mm} / \mathrm{yr}$ (Sonnenthal and Bodvarsson 1999 [DIRS 117127]), or $1.6 \times 10^{-10} \mathrm{~m} / \mathrm{s}$, gives a $\alpha_{m d}$ value approximately equal to $0.50 \mathrm{~m}$. Dispersion due to molecular diffusion will, therefore, dominate the plume lateral dispersion, and this effect will lead to a plume half-width of $12.25 \mathrm{~m}$ at the water table. The total estimated plume width at the water table $300 \mathrm{~m}$ below the repository horizon is the sum of the full plume widths due to molecular diffusion $(24.5 \mathrm{~m})$ and heterogeneity $(6.2 \mathrm{~m})$, or $30.7 \mathrm{~m}$. These results are comparable with chloride lateral diffusion illustrated by Sonnenthal and Bodvarsson (1999 [DIRS 117127]).

\section{E4. INTERSECTION OF PLUMES}

An alkaline leachate plume could mix with a water-borne radionuclide plume from a failed waste package if the distance between the cementitious material and a failed waste package at the repository horizon is less than the plume width. No cementitious material will be used in the emplacement drifts (BSC 2005 [DIRS 173498]), and in nonemplacement drifts all cementitious material (concrete invert and shotcrete used in shafts) will be removed prior to closure except that necessary for ground support (BSC 2005 [DIRS 174514], Section 3.1.1.15.1). Grout associated with rock bolt supports will remain, but this grout would be effectively carbonated prior to rehydration and would have negligible effect on repository performance. Therefore of greatest concern is failure of the waste packages nearest the shotcrete at the intersection of the emplacement drift and the access or exhaust drift; that is, the first- or last-emplaced package in the emplacement drift. These distances are found by reference to design documents.

The emplacement and storage drifts meet through a curved section (BSC 2004 [DIRS 167736]), which is typically $73 \mathrm{~m}$ (238 ft) long, of which $36 \mathrm{~m}$ (118 ft) is shotcreted (BSC 2004 
[DIRS 166102], Section 4.9 and Figure 5). This leaves $37 \mathrm{~m} \mathrm{(121} \mathrm{ft)} \mathrm{without} \mathrm{shotcrete.} \mathrm{An}$ additional $24 \mathrm{~m}(80 \mathrm{ft})$ of turnout drift dock segment has no shotcrete (BSC 2004

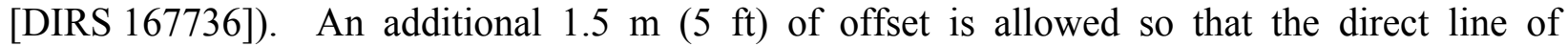
radiation from the last emplaced waste package is intercepted by the curved emplacement drift wall (BSC 2003 [DIRS 165572], Section 6.3; BSC 2004 [DIRS 166102], Table 2 and Figure 3). Therefore, the separation of the last emplaced waste package and the remaining committed cementitious support material (i.e., shotcrete) in the main access drift turnout intersection would be approximately $61 \mathrm{~m}$ (BSC 2004 [DIRS 167736]). This separation would be sufficient to prevent the intersection of cementitious leachate plume with that of a plume transporting radionuclides from the last emplaced waste package if it were to fail.

The situation is somewhat different with respect to the first-emplaced waste package on the exhaust drift side, where a minimum standoff of $15 \mathrm{~m}$ would be maintained between the end of the first emplaced waste package and the centerline of the exhaust main (BSC 2003 [DIRS 165572], Section 6.3). The exhaust and emplacement drifts are not perpendicular; they typically form an angle of $57^{\circ}$ as determined from drift azimuths (BSC 2004 [DIRS 167736]) and the turnout drift departure angle (BSC 2004 [DIRS 166102], Table 1). This intersection is shotcreted for $5.5 \mathrm{~m}$ on one side and for a longer distance on the other side as shown in IED Subsurface Facilities Ground Support Configuration (BSC 2005 ([DIRS 173498], Figure 3). Along the centerline of the emplacement drift, this additional length is approximately $3.3 \mathrm{~m}$, so that approximately $8.8 \mathrm{~m}$ of $15 \mathrm{~m}$ offset would be shotcreted (BSC 2004 [DIRS 166102]). Therefore, the separation between the start of an emplacement drift and the shotcreted intersection would be a little over $6 \mathrm{~m}$. Thus, a potential exists for the intersection of cementitious leachate plume with a radionuclide-containing plume from the first-emplaced waste package. The nature and extent of predicted plume overlap from a hypothetical initiation of concurrent alkaline and radionuclide-bearing plumes is illustrated in Figure E-1 (Note horizontal exaggeration). 


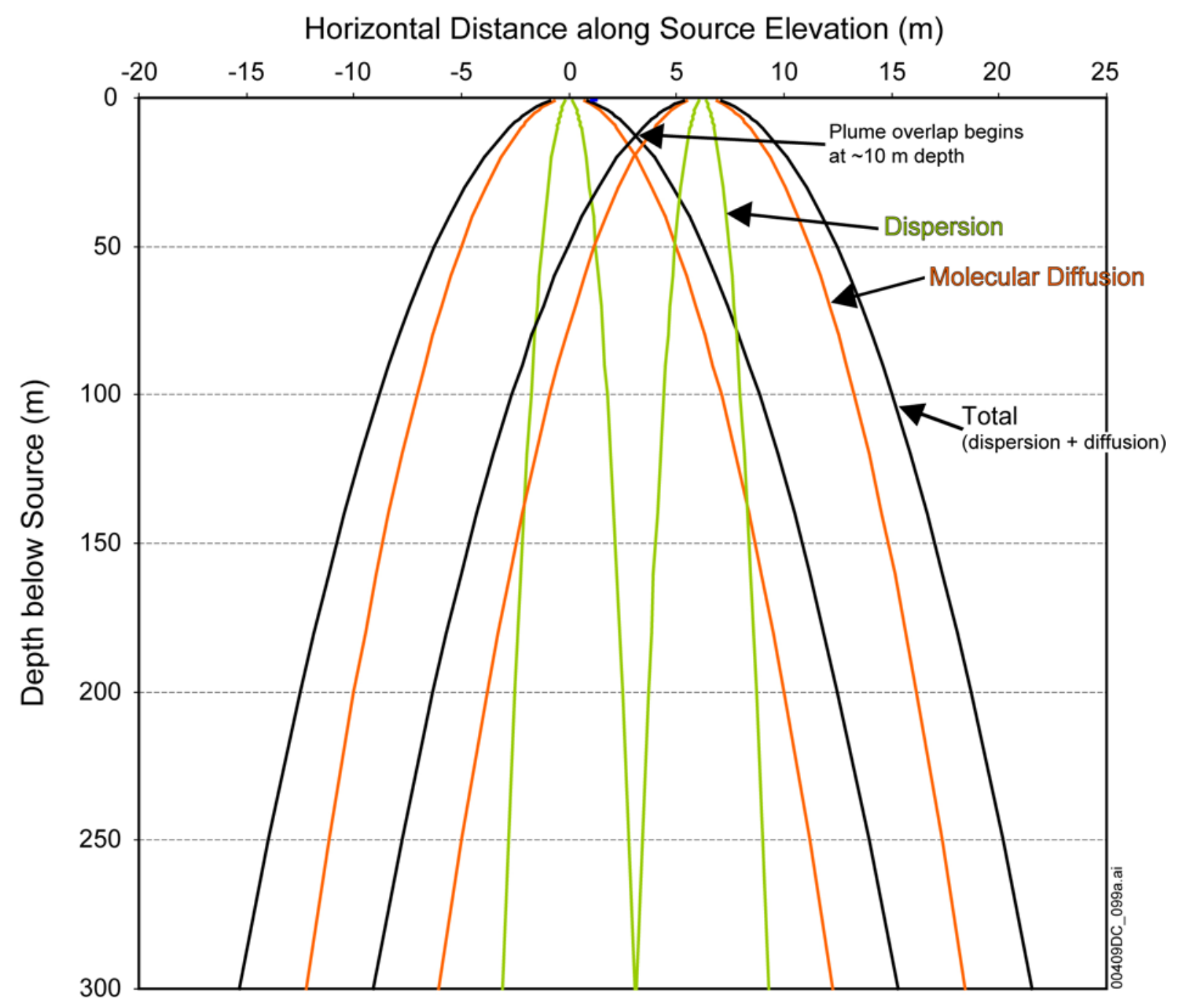

Source: DTN: LB0408CMATUZFT.003.

NOTE: Horizontal scale is exaggerated.

Figure E-1. Plume Spreading with Depth Due to Lateral Dispersion and Molecular Diffusion 